$$
\text { ORNL/M-1 } 3763
$$

\title{
Ecological Risks of DOE's Programmatic Environmental Restoration Alternatives
}

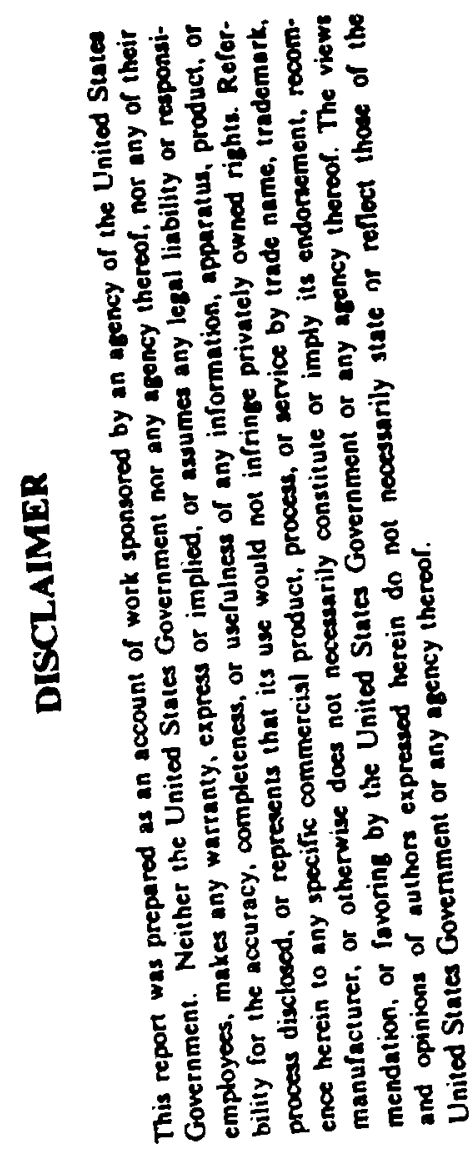

\author{
Environmental Sciences Division \\ Oak Ridge National Laboratory \\ Advanced Sciences, Incorporated
}

June 1994

Prepared for

META/Berger, Inc.

Gaithersburg, Maryland

Sponsored $\mathrm{b}_{j}$ the Office of Environmental Restoration and Waste Management, U.S. Department of Energy, unde: Contract No. DE-AC05-84OR2 1400 with Martin Marietta Energy Systems, Inc. 


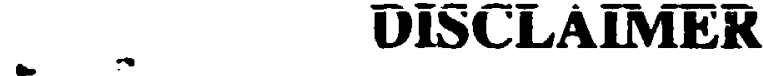

The results contained in this report are based on source term data that are incomplete because none of the facilities evaluated have been fully characterized. We assume that the information given to us is representative of the number, size, and kinds of contaminated sites present. An assessment based on this kind of data should be sufficient for comparing relative risks and benefits of broad program altematives (e.g., cleanup to Applicable and/or Relevent and Appropriate Requirements (ARARS) vs. use of land-use restrictions). This assessment is not, however, intended to accurately characterize the true ecological risks of contaminated sites present at the facilities described in this report. This level of detail can be achieved only through site-specific assessments performed to satisfy facility-level Comprehensive Environmental Response Compensation and Liaility Act (CERCLA) and National Environmental Protection Agency (NEPA) requirements. 
LIST OF FIGURES

LIST OF TABLES

EXECUTIVE SUMMARY

Chapter 1: INTRODUCTION

Chapter 2: ECOLOGICAL ENDPOINTS

Chapter 3: INTEGRATION AND EVALUATION

Chapter 4: IDAHO NATIONAL ENGINEERING LABORATORY

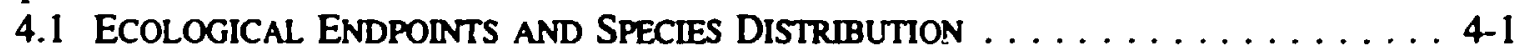

4.2 Contaminants of Potential Concern $\ldots \ldots \ldots \ldots \ldots \ldots \ldots \ldots \ldots .4$

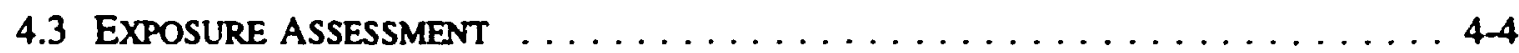

4.4 Contaminant EfFects AsSessment $\ldots \ldots \ldots \ldots \ldots \ldots \ldots \ldots \ldots \ldots .6 \ldots \ldots$

4.5 Contaminant HaZARd AsSessment $\ldots \ldots \ldots \ldots \ldots \ldots \ldots \ldots \ldots .4 .9 \ldots$

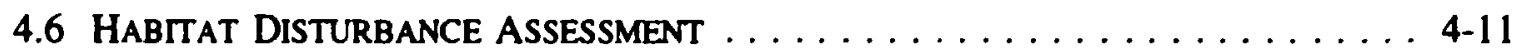

4.7 Cumulattve assessment $\ldots \ldots \ldots \ldots \ldots \ldots \ldots \ldots \ldots \ldots \ldots \ldots \ldots \ldots \ldots .12$

Chapter 5: HANFORD RESERVATION

5.1 ECOLOGICAL ENDPOINTS AND SPECIES DISTRIBUTION $\ldots \ldots \ldots \ldots \ldots \ldots .5-2$

5.2 Coniaminants of Potential Concern $\ldots \ldots \ldots \ldots \ldots \ldots \ldots \ldots .4$

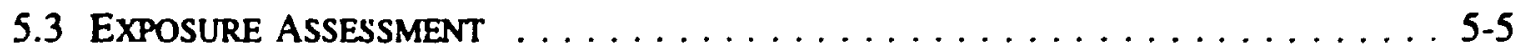

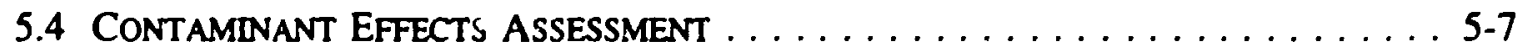

5.5 Contaminant Hazard AsSesSment $\ldots \ldots \ldots \ldots \ldots \ldots \ldots \ldots \ldots \ldots$

5.6 HabtTat Disturbance AsSESSMent $\ldots \ldots \ldots \ldots \ldots \ldots \ldots \ldots \ldots$ 5-11

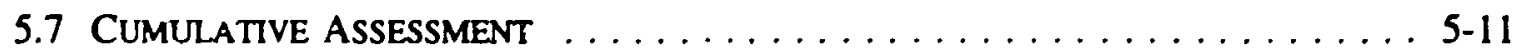

Chapter 6: FERNALD ENVIRONMENTAL MANAGEMENT PROJECT

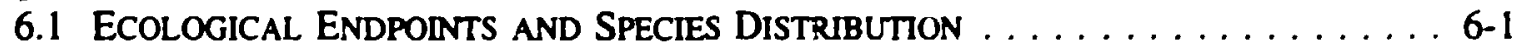

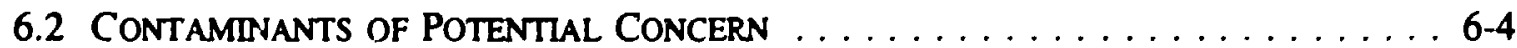

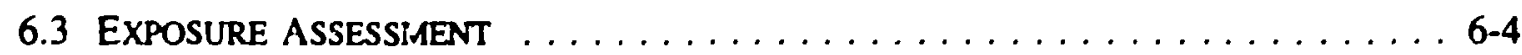

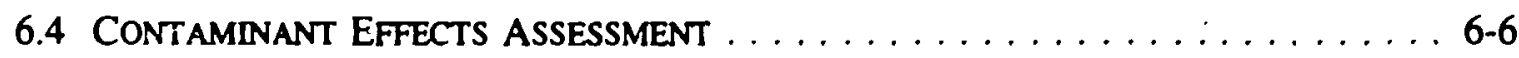

6.5 CONTAMINANT HaZARD ASSESSMENT $\ldots \ldots \ldots \ldots \ldots \ldots \ldots \ldots \ldots$ 6-10

6.6 HABITAT DISTURBANCE ASSESSMENT $\ldots \ldots \ldots \ldots \ldots \ldots \ldots \ldots \ldots .6 \ldots \ldots$

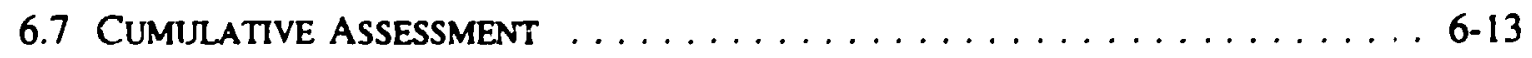

Chapter 7: OAK RIDGE RESERVATION

7.1 ECOLOGICAL ENDPOINTS AND SPECIES DISTRIBUTION

7.2 CONTAMINANTS OF POTENTIAL CONCERN

7.3 EXPOSURE ASSESSN 'ENT

7.4 CONTAMARAANT EFFECTS ASSESSMENT

7.5 CONTAMINANT Hazard ASSESSMENT 
Chapter 8: ROCKY FLATS PLANT RESERVATION

8.1 Ecological ENDPOINTS aNd SPECIES Distribution $\ldots \ldots \ldots \ldots \ldots \ldots .8$ 8-2

8.2 Contammnants of Potential Concern $\ldots \ldots \ldots \ldots \ldots \ldots \ldots \ldots \ldots .5$

8.3 EXPOSURE ASSESSMENT $\ldots \ldots \ldots \ldots \ldots \ldots \ldots \ldots \ldots \ldots \ldots$ 8-5

8.4 Contaminant EFFECTS ASSESSMENT $\ldots \ldots \ldots \ldots \ldots \ldots \ldots \ldots \ldots \ldots$ 8-7

8.5 Contammint HaZARD ASSESSMENT $\ldots \ldots \ldots \ldots \ldots \ldots \ldots \ldots \ldots$ 8-10

8.6 HABITAT DisturbancE ASSESSMENT $\ldots \ldots \ldots \ldots \ldots \ldots \ldots \ldots \ldots$ 8-14

8.7 Cumulattve ASSESSMent $\ldots \ldots \ldots \ldots \ldots \ldots \ldots \ldots \ldots \ldots .8 \ldots \ldots \ldots$

Chapter 9: PORTSMOUTH GASEOUS DIFFUSION PLANT

9.1 ECOLOGICAL ENDPOINTS AND SPECIES DISTRIBUTION $\ldots \ldots \ldots \ldots \ldots \ldots .9 .2$

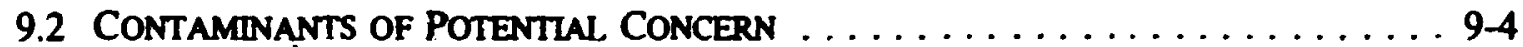

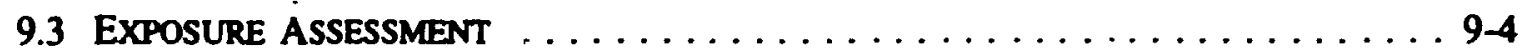

9.4 Contaminant EFFECTS ASSESSMENT $\ldots \ldots \ldots \ldots \ldots \ldots \ldots \ldots \ldots \ldots .6 \ldots$

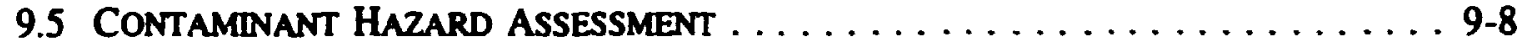

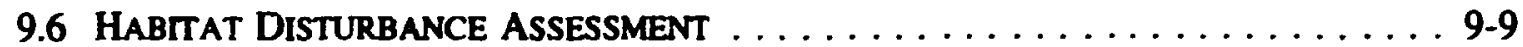

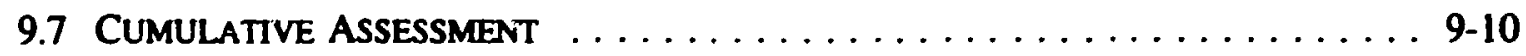

Chapter 10: REFERENCES

APPENDIX A: EXPOSURE AND EFFECTS ASSESSMENT METHODOLOGY $\ldots \ldots \ldots \ldots \ldots$

APPENDIX B: GeNERATION OF SOURCE TERMS, HoMe RANGE Est'MIATES, EXPOSURE CORRECTION Factors, and Habitat Disturbance Estimates . . . . . . 


\section{LIST OF ȦCRONYMS AND INITIALISMS}

$\begin{array}{ll}\text { ARARS } & \text { Appropriate, Relevant, and Applicable Requirements } \\ \text { BLM } & \text { Bureau of Land Management } \\ \text { CEQ } & \text { Council on Environmental Quality } \\ \text { CERCLA } & \text { Comprehensive Environmental Response Compensation and Liability Act } \\ \text { DOE } & \text { U.S. Department of Energy } \\ \text { EIS } & \text { Environmental Impact Statement } \\ \text { ER } & \text { Environmental Restoration } \\ \text { FEMP } & \text { Fernald Environmental Management Project } \\ \text { HI } & \text { Hazard Index } \\ \text { INEL } & \text { Idaho National Engineering Laboratory } \\ \text { MEPAS } & \text { Multimedia Environmeotal Pathways Assessment System } \\ \text { NEPA } & \text { National Environmental Protection Agency } \\ \text { NOAEL } & \text { no-observable-adverse-effects level } \\ \text { NWI } & \text { National Wetland Inventory } \\ \text { ORNL } & \text { Oak Ridge National Laboratory } \\ \text { ORR } & \text { Oak Ridge Reservation } \\ \text { PEIS } & \text { Programmatic Environmental Impact Statement } \\ \text { PNL } & \text { Pacific Northwest Laboratory } \\ \text { TWRA } & \text { Tennessee Wildlife Resources Agency } \\ \text { WM } & \text { Waste Management }\end{array}$




\section{LIST OF TABLES}

Table

ES-1 Summary of Ecological Risk and Benefits

4-1 Distribution of Endpoints on the Idaho National Engineering Laboratory

4-2 Rare Species on the Idaho National Engineering Laboratory

4-3 Maximum and Average Soil Concentrations on the Idaho National Engineering Laboratory

4-4 Maximum and Average Water Corcentrations on the Idatho National Engineering Laboratory

4-5 Maximum and Average Sediment Coacentrations on the Idaho National Engineering Laboratory

4-6 Body Weights and Consumption Rates for Terrestrial Species on the Idaho National Engiateering Laboratory

4-7 Soil to Jegetation and Plamt to Beef Transfer Factors for the Constiarents of Concem on the Idaho National Engineering Laboratory

4-8 Criteria Benchmarks for Terrestrial and Aquatic Species on the Idaho National Engineering Laboratory

4-9 Territory Sizes and Receptors Chosen for Analysis on the Idaho National Engineering Laboratory

4-10 Baseline Hazand Indices for Terrestrial Organisms on the Idaho National Engineering Laboratory

4-11 Baseline Chemical Hazard Indices for Aquatic Organisms on the Idaho National Engineering Laboratory

4-12 Average Internal and Extemal Radiological Doses to Aquatic Organisms on the Idaho National Engineering Laboratory

412a Baseline Maximum Potential Risks to Threatened, Endangered, and Candidate Species that Ocrupy Waste Sites

4-13b Baseline Maximum Potential Rists to Wetlands that are Waste Sites

4-13c Baseline Maximum Potential Risks to Recreational Wildlife that occupy Waste Sites

4-13d Baseline Maximum Potential Risks to Cantle that occupy Waste Sites

4-13e Baseline Maximum Potential Risks to Other Important Food Web Components that occupy Waste Sites

4-14 Land Use in the Five-County Area Surrounding but not including the Idaho National Engineering Laboratory Reservation, which is considered to be All in Native Vegetation, except for 14,000 ha in facilities, roads, and rights-of-ways

4-15 Comparative Summary of Porential On-Site Cumulative Risks to Ecological Endpoints from the Baseline Altemative on the Idaho National Engineering Laboratory

4-16 Comparison of Source-Term Concentrations of Contaminants with Naturally Occurring Concentrations in Parts per Million

5-1 Distribution of Ecolngical Endpoints and Receptors at the Hanford Reservation

5-2 Rare Species on the Hanford Reservation

5-3 Maximum and Average Concentrations of Organic, Inorganic, and Radionuclide Contaminants in Soil at the Hanford Reservation

5-4 Maximum and Average Concentrations of Organic, Inorganic, and Radionuclide Contaminants in Water at the Hanford Reservation

5.5 Maximum and Average Concentrations of Organic. Inorganic, and Radionuclide Contaminants in Sediment at the Hanford Reservation 


\section{LIST OF TABLES}

Table

5-6 Body Weights and Consumption Rates for Terrestrial Species on the Hanford Reservation

5-7 Allometric Equations for Estimating Inhalation Rates Water Consumption and Food Consumption from Data on Body Weight

5-7 Fish Bioconcentration Factors and Soil to Vegetation, Soil to Fruit, and Plant to Beef Transfer Factors, for Contaminants of Concem on the Hanford Reservation

5-8 Criteria Benchmarks for Terrestrial and Aquatic Species on the Hanford Reservation

5-9 Home Ranges of and Hazard Index Correction Factors for Terrestrial Receptor Species at the Hanford Reservation

5-10 Baseline Hazand Indices for Terrestrial Organisms on the Hanford Reservation

5-11 Baseline Average Radiological Doses for Terrestrial Organisms on the Hanford Reservation.

5-12 Baseline Average Internal and External Radiological Doses for Aquatic Organisms on the Hanford Reservation

5-132 Baseline Potential Risks to Federally Listed Threatened, Endangered, or Candidate Receptor Species That Occupy Waste Sites on the Hanford Reservation

5-13b Baseline Porential Risks to Recreational Wildlife Recepuors That Occupy Waste Sites on the Hanford Yeservation

5-13c Baseline Potential Risks to Receptor Species That Are Important Food Web Components on Waste Sites on the Hanford Reservation

5-13d Baseline Potential Risks to Receptor Species That Are Important for the Conservation of Biodiversity on the Hanford Reservation

5-14 Comparative Summary of Potential Onsite Cumulative Risł. to Ecological Endpoints on the Hanford Reservation

6-1 Distribution of Endpoints and Receptors at Fernald Environmental Management Project

6-2 Constituents of Potential Concem with Maximum and A verage Soil Concentrations on the Fetnald Environmental Management Project

6-3 Maximum and Average Fernald Water Concentrations on the Fernald Environmental Management Project

6-4 Maximum and Average Fernald Sediment Concentrations on the Femald Environmental Maragement Project

6-5 Body Weights and Consumption Rates for Terrestrial Species on the Femald Environmental Management Project

6-6 Soil-to-Vegetation and Plant-10-Beef Transfer Factors for the Constituents of Concern on the Fernald Environmental Management Project

6-7 Criteria Benchmarks for Terrestrial and Aquatic Species on the Femald Environmental Management Project

6-8 Home Ranges of and Hazard Index Correction Factors for Terrestrial Receptor Species at the Femald Environmental Management Proj.ct

6-9 Baseline Hazard Indices for Terrestrial Organisms on the Fernajis Environmental Management Project

6-10 Baseline Average and Maximum Chemical Hazard Indices for Aquatic Organisms on the Fernald Environmental Management Project 


\section{LIST OF TABLES}

Table

6-11 Average Intemal and External Radiological Doses to Aquatic Organisms on the Femald Environmental Management Project

6-12a Baseline Potential Risks to the Endangered Indiana bat, the only endangered species that may reside, feed, $\mathrm{Cr}$, rink in the immediate vicinity of the waste sites or contaminated waters on the Fernald Environmental Management Project

6-12b Baseline potential rists to wetlands adjecent to waste sites

6-12c Baseline potential rists to recreationsl wildife that occupy or inclucle waste sites or contaminated waters in their home ranges at the Fernald Environmental Management Project

6-12d Baseline potential risks to vegetation

6-12e Baseline potential risks to other important food web components that occupy waste sites on the Fernald Environmental Management Project

6-13 Comparative summary of potential risks to ecological endpoints from baseline and ARAR alternatives on the Fernald Environmental Management

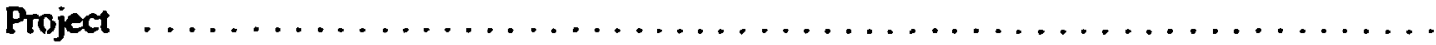

7-1 Rare species on the Oak Ridge Reservation $\ldots \ldots \ldots \ldots \ldots \ldots \ldots \ldots \ldots \ldots$

7-2 Distribution of Endpoints on the Oak Ridge Reservation . . . . . . . . . . . . . . .

7-3a Maximum and Average the Y-12 Plant Soil Concentrations

7-3b Maximum and Average the K-25 Site Soil Concentrations

7-3c Maximum and Average X-10 Soil Concentrations

7-4a Maximum and Ayerage the Y-12 Plant Water Concentrations

7-4b Maximum and Average X-10 Water Concentrations

7-5a Maximum and Average the Y-12 Plant Sediment Concentrations

7-5b Maximum and Average the K-25 Site Sediment Concentrations

7-5c Maximum and Average X-10 Sediment Concentrations .

7-6 Body Weights and Compumption Rates for Oak Ridge Terrestrial Species

7-7 Soil to Vegetation, Soil to Fruit and Plant to Beef Transfer Factors, and Fish Bioconcentration Factors for the Oak Ridge Reservation Constituents of Concem Criteria Benchmarks for

7-9a Home Rangers of and Hazard Index (HI) Correction Factors (CF) for Receptor Species at the Y-12 Plant on the ORR

7-9b Home Rangers of and Hazard Index (HI) Correction Factors (CF) for Receptor Species at the K-25 Site on the ORR

7-9c Home Rangers of and Hazard Index (HI) Correction Factors (CF) for Receptor Species at X-10 on the ORR

7-10a Baseline A verage Hazard Indices for the $Y-12$ Plant Terrestrial Organisms

7-106 Baseline Average Hazard Indices for the K-25 Site Terrestrial Organisms

7-10c Baseline Average Hazand Indices for X-10 Terrestrial Organisms .

7-11a Baseline Average Hazand Indices for the Y-12 Plant Aquatic Organisms

7-11b Baseline Average Hazard Indices for the K-25 Site Aquatic Organisms

7-11c Baseline Average Hazare Indices for X-10 Aquatic Organisms

7-12a Baseline Average Intemal and Extemal Radiological Doses for the Y-12 Plant Aquatic Organisms (rad/d)

7-12b Baseline Average Intemal and Extemal Radiological Doses for the K-25 Sit: Aquatic Organisms (rad/d) .

7-12c Baseline Average Intemal and Extemal Radiological Doses for X-10 Aquatic Organisms (rad/d) 


\section{LIST OF TABLES}

Table

7-13a Baseline potential risk to threatened, endangered and candidate species that occupy waste sites and contaminated areas of the Y12

Site. Risks to individuals that do not occupy waste sites are negligible. Waste and contaminated areas associated with the Y-12 Plant account for less than $1.5 \%$ of the land area and one third to one half of the streams and ponds on the ORR

7-13b Baseline potential risk to wetlands that are waste sites or contaminated streams and sediments on the Y-12 Plant. Source terms were not available for cetiver wetlands; therefore we assume risks to ocher wetlanis are negligible

7-13c Baseline maximum potential risks to recreational wildlife that occupy waste sites or contaminated areas on the Y-12 Plant. Risks to individuas that do not occupy waste sites or contamintaed areas are negligible

7-13d Baseline potential risks to hay and timber that grow on waste sites or contaminated areas on the Y-12 Plant. No hay is harvested from contaminated areas, and timber is not grown on the ORR for commercial harvest. Therefore, baseline risks to agriculture and timber production are negligible

7-13e Baseline maximum potential risks to other important food web components that occupy waste sites or contaminated areas on the Y12 Sites. Risk to individuals that do not occupy waste sites and contaminated areas are negligible

7-14a Baseline potential risk to threatened, endangered and candidate species that occupy waste sites and contaminated areas of the K25 Site. Risks to individuals that do not occupy waste sites are negligible. Waste sites and contaminated areas associated with the K-25 Site account for less than 1.5\% of the ORR

7-14b Baseline potential risk to wetlands that are waste sites or contaminated streams and sediments on the K25 Site. Source terms were not available for water at the K-25 Site ir other wetlands on the ORR. We assume risks to other wetland on the ORR are negligible

7-14c Baseline potential risks to recreational wildlife that occupy waste sites or contaminated areas on the K25 Site. Risks to individuals that do not occupy waste sites or contamintaed areas are negligible

7-14d Baseline potential risks to hay and timber that grow on waste sites or contaminated areas on the K25 Sites. No hay is harvested from contaminated areas, and timber is not grown on the ORR for commercial harvest. Therfore, baseline risks to agriculture and timber production are negligible $\ldots \ldots \ldots \ldots \ldots \ldots \ldots \ldots$

7.14e Baseline maximum potential risks to other important food web components that occupy waste sites or contaminated areas on the K25 Sites. Risk to individuals that do not occupy waste sites and contaminated areas are negligible

7-15a Baseline potential risk to threatened, endangered and candidate species that occupy waste sites and contaminated areas of the $X-1 C$ Site. Ridks to indiviluals that do not occupy waste sites 


\section{LIST OF TÁBLES}

Table

are negligible. Waste and contaminated areas associated with $\mathrm{X}-10$ account for less than $1.5 \%$ of the ORR

7-15b Baseline potential risk to wetlands that are sites or contaminated streams and sediments at X-10 Site. Source terms were not available for other wetlands; therefore we assume risks to other wetlands ire negligible

7-15c Baseline maximum potential risks to recreational wildlife that occupy waste sites or contaminated areas at X-10. Ristes to individuals that do not occupy waste sites or contamintaed areas are negligible

7-15d Baseline potential risk to other important food web components that occupy waste sites or contaminated areas at X-10. RIsk to individuals that do not occupy waste sites and contaminated areas are negligible

7-15e Baseline maximum potential risks to other important food web components that occupy waste sites or contaminated areas on the X-10 Sites. Risk to individua's that do not occupy waste sites and contarninated areas are negligible

7-16 Comparative summary of porential on-site cumulative risks to ecological endpoints from baseline on the ORR. Risks are for endpoints which occupy waste sites and contaminated areas ior which source terms were available

7-17 Comparison of Source Term Concentrations of Elements in Soil with Naturally Occuring Concentrations (ppm) .

7-18 Land use in the four county area surrounding but not including the ORR, which is considered to be $80 \%$ in native forest vegetation with the remainder in facilities, roads, and rights-of-way .

8-1 Distribution of Endpoints and Receptors on the Rocky Flats Plant Reservation

8-2 Federally Listed Threatened, Endangered, and Candidate Species on the Rocky Flats Plant

8-3 Maximum and Average Soil Concentrations on the Rocky Flats Plant

8-4 Maximum and Average Water Concentrations on the Rocky Flats Plant

8-5 Maximum and Average Sediment Concentrations on the Rocky Flats Plant

8-6 Body Weights and Consumption Rates for Terrestrial Species on the Rocky Flats Plant . . . . . . . . . . . . . . . . .

8-7 Soil to Vegetation, Soil to Fruit and Plant to Beef Transfer Factors, and Fish Bioconcentration Factors for Constituenis of Concem at the Rocky Flats Plant.

8-8 Criteria Benchmarks for Terrestrial and Aquatic Species at the Rocky Flats Plant

8-9 Home Ranges of and Hazard Index Correction Factors for Terrestrial Receptor Species on the Rocky Flats Plant

8-10 Baseline hiazard Indices for Terrestial Organisms on the Rocky Flats Plant

8-11 Baseline Average Radiological Doses for Terrestrial Organisms on the Rocky Flats Plant

8-12 Baseline Hazard Indices for Aquatic Organisms on the Rocky Flats Plant

8-13 Baseline Average Internal and Extemal Radiological Doses for 


\section{LIST ÖF TABLES}

Table

Page

Aquatic Organisms on the Rocky Flats Plant

8-14a Baseline Potential Risks to Federally Listed Threatened, Endangered, and Candidate Species That May Reside. Feed, or Drink in the Immediate Vicinity of Contaminated Soils, Sediments, or Waters on Rocky Flats Plant

8-14b Baseline Potential Risks to Wetlands on the Ra ky Flats Plant

8-14c Baseline Maximum Potential Risks to Recreational Wildlife that Occupy or Include Waste Sites or Contaminated Waters in Their Home Ranges on the Rocky Flats Plant

8-14d Baseline Potential Risks to Other Important Food Web Components that Occupy Contaminated Sites on the Rocky Flats Plan

8-15 Comparative Summary of Potential Risks to Ecological Endpoints From Baseline and ARAR Alternatives on the Rocky Flats Plant

9-1 Distribution of Ecological Endpoints and Receptors at the Portsmouth Reservation

9-2 Maximum and Average Concentrations of Organic, L:organic, and Ragionuclide Contaminants in Soil on the Portsmouth Reservation

9-3 Maximum and Average Concentrations of Organic, Inorganic, and Radionuclide Contaminants in Water at the Portsmouth Reservation

9-4 Maximum and Average Concentrations of Organic, Inorganic, and Radionuclide Contaminants in Sediment at the Portsmouth Reservation

9-5 Body Weights and Consumption Rates for Terrestrial Receptor Species on the Portsmouth Reservation

9-6 Soil to Vegetation, Soil to Fruit, and Plant to Beef Transfer Factors, and Fish Bioconcentration Factors for Constituents of Concern at the Portsmouth Reservation

9-7 Criteria Benchmarks for $\mathrm{T}$. restrial and Aquatic Receptor Species at the

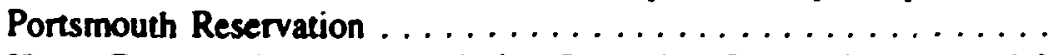

9-8 Home Ranges of and Hazard Index Correction Factors for Terrestrial Receptor Species at the Portsmouth Gaseous Diffusion Plant . . . . . . . . . . . . .

9-9 Baseline Hazard Indices for Tertestrial Organisms on the Portsmouth Reservation

9-10 Baseline Average Radiological Doses for Terrestrial Organisms on the Portsmouth Reservation

9-11 Baseline Hazard Indices for Aquatic (rganisms on the Portsmouth Reservation

9-12 Baseline Average Internal and External Radiological Doses for Aquatic Organisms on the Portsmouth Reservation.

9-1 3a Baseline Potential Risks to Federally Listed Threatened, Endangered, or Candidate Receptor Species that Occupy Waste Sites on the Portsmouth Reservation

9-13b Baseline Potential Risks to Wetlands Associated with Waste Sites on the Portsmouth Reservation

9-13c Baseline Potential Risks to Recreaticnal Wildlife That Occupy Waste Sites on the Portsmouth Reservation

9-13d Baseline Potential Risks to Vegetation on the Portsmouth Reservation

9-13e Baseline Potential Risks to Important Food Web and Biodiversity Components That Occupy Waste Sites on the Postsmouth Reservation

9-14 Comparative Summary of Altematives for Onsite Risks to Ecological 


\section{LIST OF TABLES}

Table

Endpoints on the Portsmou.h Reservation

10-1 Ecologiccal Risk and Eenefits of ER Altematives

A-1 Allometric Equations for Estimating Inhalation Rates, Water

Consumption, and Food Consumption frorn Data on Bodv Weight

B-1 Assumptions Made in the First Stage of Source Term Ceneration

B-2 Home Range Data and References for Bird and Mammal Receptor Species

at the Six DOF Reservations 


\title{
ECOLOGICAL RISK ASSESSIMENT FOR THE: ENVIRONMENTAL RESTORATION PROGRAMMATIC ENVIRONMENTAL IMPACT STATEMENT
}

\section{EXECUTIVE SUMMARY}

\author{
L.W. Barnthouse, G.K. Eddlemon, L.K. Mann, and L.L. Sigal
}

This report assesses the ecological risks of the Department of Energy's (DOE) Environmental Restoration Program. The assessment is programmatic in that it is directed at evaluation of the broad programmatic alternatives outlined in the DOE Implementation Plan. It attempts to (1) characterize the ecological resources present on DOE facilities, (2) describe the occurrence and importance of ecologically significant contamination at major DOE facilities, (3) evaluate the adverse ecological impacts of habitat disturbance caused by remedial activities, and (4) determine whether one or another of the programmatic alternatives is clearly ecologically superior to the others.

\section{Methodology Overview}

The assessment focuses on six representative facilities: the Idaho National Engineering Laboratory (INEL); the Femald Environmental Management Project (FEMP); the Oak Ridge Reservation (CRR), including the Oak Ridge National Laboratory (ORNL), Y-12 plant, and K25 plant; the Rocky Flats Plant; the Hunford Reservation; and the Portsmouth Gaseous Diffusion Plant. Six generic categories of ecological resources of concern were evaluated for each facility: threatened and endangered species, wetlands, recreational fish and wildlife, agriculture and timber production, parks and public lands, and general biodiversity. Specific resources (e.g., receptor species and communities) belonging to these categories were identified for each. facility and, where possible, the spatial patterns of occurrence of these resources were described.

Information on the types, quantities, and distributions of contaminants on the six facilities was obtained from the Pacific Northwest Laboratory (PNL) Source Term Database; concentrations in soil, water, and sediment were obtained from the human exposure and risk assessment team in ORNL's Health Sciences Division. Estimates of the ioxicity of radionuclides and chemical contaminants to aquatic biota, wildlife, and terrestrial plants were obtained from the published literature. These three kinds of information were used to perform a screening-level ecological risk assessment. The objectives of this assessment were (1) to separate those contaminants that clearly pose no risk at levels believed to be present from those contaminants that might be ecologically hazardous, and (2) to dr celop a rough rank ordering of the importance of different contaminants and the vulnerability of different biological resources. Risk assessments of this type are termed "screening-level" assessments because they do not include enough site or species-specific information to permit firm conclusions about the actual magnitude of risk present.

Finally, the significance of the potential risks identified in the screening-level risk assessment performed for each facility was addressed in a cumulative impact assessment. In this assessment 
an aicmpi was maic to provide an ecoiogicai context for the contaminant risks by compaing the home rages of individual organisms and the distribution of species to the area believed (based on PNL's source-term data) to be contaminated. For the two most extreme of the altematives identified in the Programmatic Environmental Impact Statement (PEIS) Implementation Plan [the Appropriate, Relevant, and Applicable Requirements (ARAR) altemative and the Restricted Land Use alternative], relative degrees of contaminant risk reduction and habitat disturbance impact were evaluated and compared.

Below is a summary of major findings and conclusions.

\section{Ecological Resources at Risk}

The DOE facilities collectively represent an important reservoir of biological diversity. The three largest reservations examined (Oak Ridge, INEL, and Hanford) occupy up to several hindred square miles of land. Only small fractions of these reservations are occupied by developed facilities; most of the undeveloped land has been isolated from majoi human intrusions (except for grazing at INEL and forestry at Oak Ridge) for up to 50 years. All three of these reservations are large enough to support substantial populations of wildlife and all contain species (including federal and state-listed species) and ecosyrtem types that are becoming rare in surrounding regions due to rapid increases in agricultural industrial, and residential deveiopment. All three reservations are included in DOE's National Environmental Research Park system.

The three smaller facilities examined (Rocky Flats, Femaid, and Portsm(uth) were more variable in terms of ecologicai :alue but all contain some ecolcgical resources. Rocky Flats, the most diverse and least disturbed of the three, contains many small, perennial wetlands and is utilized hy the bald eagle, peregrine falcon, and several other endangered species. Femald and Portsmouth were heavily disturbed by agricultural activities pnor to acquisition by DOE; they nevertheless contain small areas of wetland and hardwood forest and provide habitat for a variety of wildilifo -
Aithough they were not specifically examized in this study, available information suggests that other large DOE reservations such as the Savannah River Site, Los Alamos National Laboratory, and Nevada Test Site are probably as ecologically rich as are Oak Ridge, INEL, and Hanford. Smaller facilities may contain significant ecological resources in buffer zones surrounding developed plant areas.

\section{Ecological Risks of Existing Contamination}

The screening-level risk assessments showed that potentially ecologically significant contamination exists at all of the facilities examined. Although radionuclides are the most widespread envisonmertal contaminants, heavy metals. PCBs, and other organic contaminants appear to be present in potentially toxic quantities on most facilities. Both aquatic and terrestrial biota were found to be at risk.

Although the most contaminated sites appear, based on PNL's data, to be highly hazardous to biota, the areal extent of these sites appear to be quite small. The spatial extent of contamination appears limited to relatively small fractions ( 1 to 25\%, including developed plant areas) of most facilities. Mnst of these contaminated areas are waste disposal sites (trenches, burial grounds, etc.) or developed plant areas that are already highly disturted ard provide poor habitat for most biota. Surface water and sediment, including waste ponds, are important exceptions to this generalization. These habitats, some of which are relatively undisturbed streams, are far more important ecologically than is indicated by there surface area relative to the area of an entire reservution. Aquatic habitats such as streans, ponds, and wetlands are utilized by a wide variety of biota, including fish and terrestrial vertebrates (waterfowl, deer, fish-eating birds and mammals). Sediment and flood-plain soil are major sinks for many radionuclides and toxic chemicals, especially in regions were rainfall is abundant (e.g., Oak Ridge). Waste ponds themselves can be important ecological resources, especially in tne arid West where they may be the only available surface water during large parts of the year. 
Fraluation of Alternatives

Remedial actions taken to reduce human and erological exposure to contaminants often involve removal of large quantities of soil or sediment. Koads and support facilities are also required. These activities cause adverse ecological impacts that must be balanced against the benefits of contaminant reduction. The alternatives described in the PEIS Implementation Plan differ significantly in terms of the degree of contaminant removal and soncomitant habitat disturbance. The ES-1 summariezes result of a bounding analysis of the three most extreme alternatives included in the PEIS: the No Action altemative, th C ARAR altemative, and the Restricted Lan' Use alternative. Only radioncuclides were examined. but the results of the anaysis probsbly are representative of other contaminants as well. The ARAR altemative involves the greatest contaminant removal and also the greatest habitat disturbance. The Restricted Land Use altemative involves little or no contaminant reduction but also little or no habit disturbance. The land use restricitions associated with this altemative would presumably preserve existing ecological resources and might also permit recovery of resources affected by past DOE activities. The No Action alternative would similarly minimize habitat disturbance, however, in the absence of land use restriction future development could lead in modification or destruction of existing ecosystems.

None of the altematives appeared clearly preferable from an ecological perspective. Remediation alternatives focused on human health risk reduction, so that ecclogical risks are reduced only if they invole significant human exposures. In general, for extremely large reservations such as Hanford and INEL, the fraction of the total reservation area contaminated oy past DOE activities is small enough that habitat disturbance impact appear negligible as well. For small facilities such as
Rocky Flats and Ferr.sld relatively large (up to 25\%) fractions of the total reservation arcas could be disturbed under the ARAR altemative. The benefit gained from contaminant removal at these sites could be relatively large, if the areas remediated are restored to a natural or seminatural condition. For either alternative, the resources most likely to be at risk are (1) endangered and threatened species (because even very small impacts on the species have regulatory significance) and (2) wetlands and aquatic ecosystems. The optimal approach for minimizing ecological risks is probably an intermediate strategy in which remediation activities are focused on sites of highest contamination, where the degree of habitat disturbance per unit contaminant removed is the smallest. Specific remedial pricrity decisions would be made at the level of the individual facility's Environmental Restoration Program.

\section{Uncertainties}

Key uncertainties limiting this assessment include the (1) validity of source-term estimates, (2) the actual distribution of receptor species on the facilities relative to sites where contamination is present, and (3) the unknown degree of conservatism of the transfer coefficients and toxicity benchmarks used in the hazand assessment. The first two uncertainties can be addressed in facility-specific assessments that focus on optimizing the balance between remediation and habitat preservation based on reservation-wide distributions of contaminants and ecological resources. The third uncertainty is a function of the state-of-the-science of environmental toxicology; it can be reduced by performing (1) periodic updating of the toxicological data base as new information becomes available from the scientific community, and (2) field studies at the DOE fa. Ities to generate site-specific exposure and effects data. 
TABUS FS-1 - Summany of Ecological Rists and Benefits of ER Alterrutiviti

\begin{tabular}{|c|c|c|c|c|c|}
\hline Factiny & $\begin{array}{l}\text { Towel Area } \\
\text { (ocres) }\end{array}$ & $\begin{array}{l}\text { Resources at } \\
\text { Ritt }\end{array}$ & Atermattres & Reduction & $\begin{array}{l}\text { Dracilits } \\
\text { Deturbeds }\end{array}$ \\
\hline \multirow[t]{3}{*}{ INE!' } & 570.000 & $\begin{array}{l}\text { Soil: none } \\
\text { Wret (waste ponds): } \\
\text { wildife, endangered } \\
\text { species }\end{array}$ & No Action & $\begin{array}{l}\text { Soil: NR } \\
\text { Water. } 0\end{array}$ & 0 \\
\hline & & & ARAR & $\begin{array}{l}\text { Soil: NR } \\
\text { water. } 0\end{array}$ & 0.03 \\
\hline & & & Restricted land use & $\begin{array}{l}\text { Soil: NR } \\
\text { Waer: } 0\end{array}$ & 0 \\
\hline \multirow[t]{3}{*}{ Hanford } & 365.700 & $\begin{array}{l}\text { Soil: none } \\
\text { Water (waste ponds): } \\
\text { wildife. endingered } \\
\text { species }\end{array}$ & No Action & $\begin{array}{l}\text { Soil: NR } \\
\text { Water: } 0\end{array}$ & 0 \\
\hline & & & ARAR & $\begin{array}{l}\text { Soil: NR } \\
\text { Wert } 98\end{array}$ & 0.1 \\
\hline & & & Restricted land use & $\begin{array}{l}\text { Soil: NR } \\
\text { Wwer: } 0\end{array}$ & 0.02 \\
\hline \multirow[t]{3}{*}{ Fermald ${ }^{7}$} & 1050 & $\begin{array}{l}\text { Soil: wildlife. encangered } \\
\text { spucies, biodiversity } \\
\text { Water: fish }\end{array}$ & No action & $\begin{array}{l}\text { Soil: } 0 \\
\text { Water: } 0\end{array}$ & 0 \\
\hline & & & ARAR & $\begin{array}{l}\text { Soil: } 99.95 \\
\text { Wwer:0.0 }\end{array}$ & 19 \\
\hline & & & Restricted land use & $\begin{array}{l}\text { Soil: } 0 \\
\text { Vater: } 0\end{array}$ & 19 \\
\hline \multirow[t]{3}{*}{$\begin{array}{l}\text { Dak Ridge } \\
\text { Keservation" }\end{array}$} & 37.500 & $\begin{array}{l}\text { Soil: wildlife, endangered } \\
\text { species, biodiversity } \\
\text { Water: fish, wetlands }\end{array}$ & No action & $\begin{array}{l}\text { Soil: } 0 \\
\text { Water: } 0\end{array}$ & 0 \\
\hline & & & ARAR & $\begin{array}{l}\text { Soil: } 99.99 \\
\text { Waser: } 99.5\end{array}$ & 1.1 \\
\hline & & & Resuricted land use & $\begin{array}{l}\text { Soil: } 0 \\
\text { Wacer: } 0\end{array}$ & 0.8 \\
\hline \multirow[t]{3}{*}{ Rocky flats } & $6350^{-1}$ & $\begin{array}{l}\text { Soil: wildife. encangered } \\
\text { species, biodiversity } \\
\text { Water: wetlands }\end{array}$ & No action & $\begin{array}{l}\text { 3o1: } 0 \\
\text { Waer: } 0\end{array}$ & 0 \\
\hline & & & ARAR & $\begin{array}{l}\text { Sol:99.99 } \\
\text { Wwer.>99.99 }\end{array}$ & 26 \\
\hline & & & Resticted and use & $\begin{array}{l}\text { Sol: } 0 \\
\text { Water: } 0\end{array}$ & 6 \\
\hline
\end{tabular}


'Kesources at risic are der̂ned separateiy, by principai exposure medium. Resources were determined to be "at risk" if (1) the are present on the facility and possibly present in known contaminated areas, and (2) comparison of estimated contaminant concentrations to regulatory criteria or other toxicological benchmarks indicates a moderate or severe risk to organisms inhabiting contaminated areas.

${ }^{2}$ Altematives are defined in the PEIS Implementation Plan.

'Percentage reduction in contaminant exposure, as approximated by $\%$ reduction in risk to on-site farmers. Radionuclides were used ans reference contaminants.

4\% of total facility area either temporarily or permanently disturbed by remedial activities. Estimates include adjustments for access roads and soil borrow areas.

'Major areas of INEL containing contaminated soil (e.g., the Radioactive Waste Management Complex) are already heavily disturbed and provide poor habitat for terrestrial bicta, hence, terrestrial resources are not at risk. Contaminated waste ponds are utilized by wildlife, hence these resnurces are considered to be at nsk for purposes of the PEIS. None of the remeaiation alternatives for INEL include remediation of waste ponds.

Tajor areas of Hanford containing contaminated soil are already heavily disturbed and provide poor habitat for terrestrial biota, hence, terrestrial resources are not at risk. Contaminated waste ponds are utilized by wildlife, hence these resources are considered to be at risik for purposes of the PEIS.

'Wildlife have free access to contaminated areas; aquatic resources at risk include waste ponds and statutory wetlands. None of the remediation alternatives for Femald include remediation of waste ponds or wetlands.

'This facility has many widely-dispersed contaminated areas; wildlife have free access to many of these. Contaminated aquatic resources include both on-site waste ponds and on- and off-site streams.

Wildlife have free access to some contaminated areas. Small wetlands are widely dispersed over the site.

${ }^{10} \mathrm{NR}=$ no resources at risk 


\section{CHAPTER 1: INTRODUCTION}

This report presents an assessment of impacts of environmental restoration and (ER) altematives to be included in the Programmatic Environmental Impact Statement for Implementation (PEIS) of an Integrated Environmental Restoration and Waste Managemerit Program (ER PEIS) by the U.S. Department of Energy (DOE). Impacts addressed in this report include current contamination, residual contamination following remecial action, and adverse ecological impacts of remediation and new facility construction.

The impacts assessment focuses on cumulative impacts of ER activities on reservation-wide ecological resources. Of the 30 facilities discussed in the ER PEIS, eight are singled out for detailed ecological risk assessments: the Idaho National Engineering Laboratory (INEL), the Hanford Reservation, the Fernald Environmental Management Project (FEMP), the Rocky Flats Plant (RFP), the Portsmouth Gaseous Diffusion Plant (PORT), and the three facilities [Oak Ridge National Laboratory (ORNL), Y-12 Plant, and K-25 Sitel occupying the Oak Ridge Reservation (ORR).

The assessment process consists of the following five tasks:

1. Description of climatic regime and ecosystem types, drawn from environmental data available for each reservation. This information includes metcornlogy, surface and subsurface hydrology, topography, soil and vegetation types, land use, and ecology 'aquatic and terrestrial). Locations of ecological resources falling into the six endpoint categories identified in chapter 2 were identified from site maps. Site maps were also used to identify areas for which ER activities are planned.

2. Specification of exposure pathways linking ER activities to ecological endpoints. Exposures considered include exposures to contaminants and physical disturbances caused by the remedial actions themselves.
3. Estimation of the exposure of ecological resources to habitat disturbance associated with site remediation.

4. Assessment of the ecological effects associated with contaminant exposure and physical disturbance. This task draws on current information on acute toxicity. chronic toxicity, and bicaccurmulation of contaminants included in the source-tertm inventories developed for the ER PEIS.

5. Fivaluation of the cumulative ecological impact of remedial activities on ecological resources on or near the reservations included in the assessment.

The general procedure for the ecological risk assessment is shown in figure $1-1$. First, the specific ecological resources falling into each of the six endpoint categories defined in chapter 2 are identified from documents, maps, and contacts with resource management personnel at each site. The distribution of each resource on and near the facilities is mapped. These resource distributions are overiaid on the distributions of ER activities at each facility. General locations of activities are available from the site ER programs. For contaminant exposures, transport media are identified and exposures are quantified from (1) existing environmental characterization reports and (2) cutput from the Multimedia Environmental Pathways Assessment System (MEPAS) (Droppo et al. 1989). For habitat alteration, disturbed areas are estimated for each remedial action or construction activity including both the actual contamination site and the surrounding area expected to be disturbed by road construction, dust, erosion, or noise.

The programmatic altematives for both the ER and the waste management (WM) components of the PEIS consist of many individual remedial actions or waste types. The exposure assessment for each altemative consists of (1) estimates of the types and, if possible. quantities of contaminants to which each endpoint is exposed; and (2) the total area of habitat disturbed by restoration or construction activities (figure 1-1). 


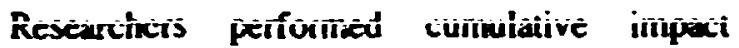
assessments (figure 1-1) for each endpoint by (1) using information on ecological effects of the identified contaminants to evaluate the likelithood of adverse impacts due to contaminant toxicity or bioaccumulation. and (2) comparing the area disturbed with the total area occupied by the resource.
Cisapiet 2 of this repori describes the generai classes of ecological resources for which impacts are addressed. These are often termed assessinent endpoints in the ecological risk assessment licerature (Suter and Barnthouse 1993). Chapter 3 describes the method to be used for cumulative impact assessment. Chapt $s$ 4-9 present the results obtained for the six reservations addressed in this report. appendices $A$ and $B$ present detailed documentation of the methods and data used for the assessments. 


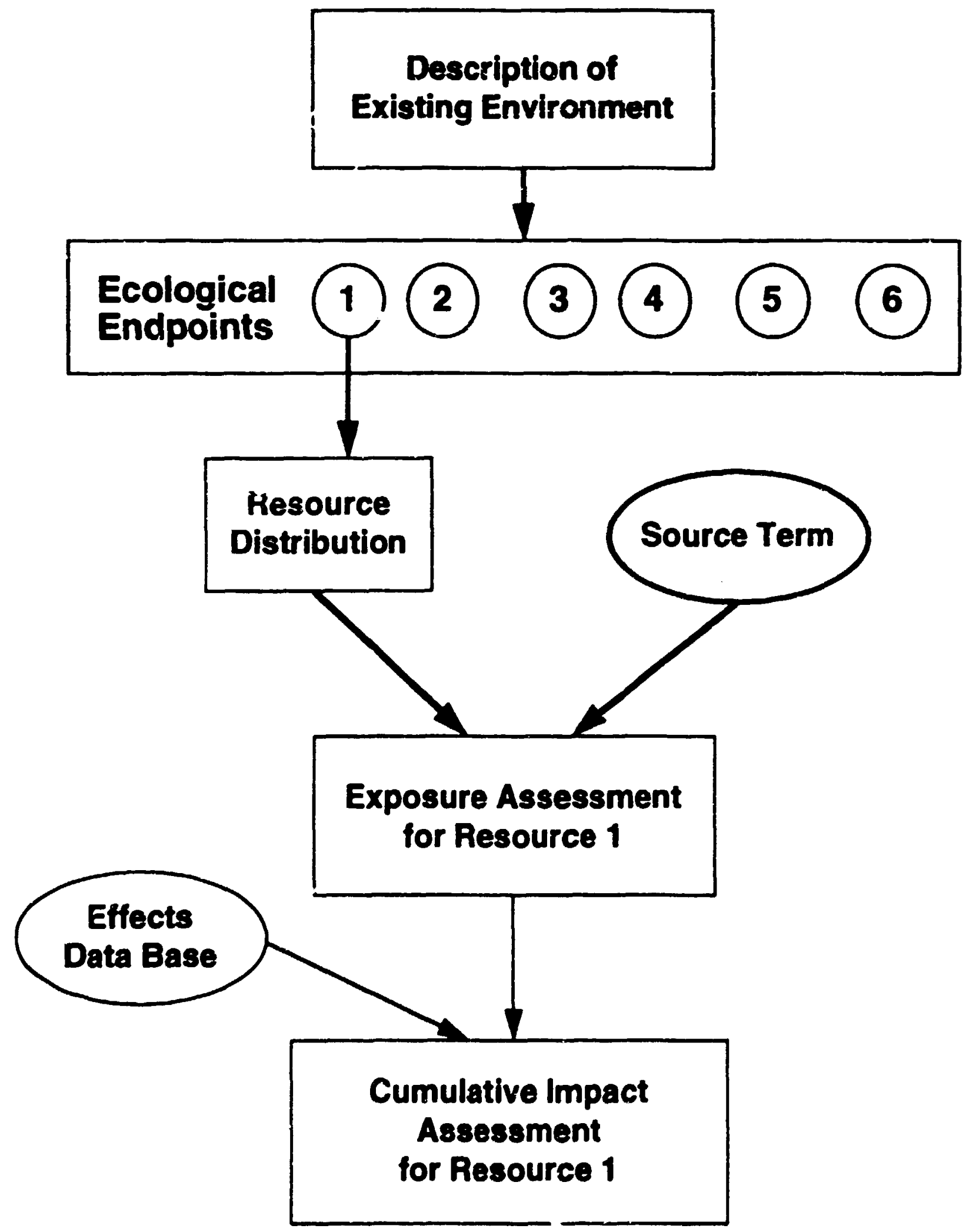




\section{CHAPTER 2: ECOLOGIC}

This chapter describes the ecological resources to be adtressed in the ecological impact sections of the ER PEIS. Once identified, these resources will serve as endpoints for the ecological risk assessment components of the PEIS, in the same way that cancerous and noncancerous health effects serve as endpoints for health risk assessments.

Any assessment must have defined endpoints. An endpoirt is a formal expression of an environmental valuse to be protected during and after the action for which the assessment is being performed (Suter and Barnthouse 1993). A clear statement of an endpoint is as important to an assessment as a clear statement of a hypothesis is to an experimental research project. Defining an endpoint involves two steps: (1) identifying valued attriburtes of the environment that are considered to be at risk and (2) defining these attributes in operational terms. Suter and Bamthouse (1993) described five criteria that any endpoint should satisfy:

1. Societal relevance. The endpoint should be understood and valued by the public and the decision maker.

2. Blological relevance. The endpoint must represent important population or ecosystem characteristics.

3. Unambizuous operntional definition. The endpoint must be explicitly defined.

4. Accessibility to prediction and measurement. The endpoint must be empirically measured or estimated: otherwise, an assessment of impacts on that endpoint is impossible.

5. Suscepedble to the hazardous agent. The endpoint must be susceptible to exposure to the stress being c aluated; otherwise, there is no point in performing an assessment.

For the ER PEIS, selection of endpoints involved identification of (1) general categories of ecological resources that meet the criteria of
Suter and Bamthouse (1993) and are inclusive of the ecological resources present on DOE facilities, and (2) for each facility, the specific resources (i.e., receptors) falling into those categories. Following are the descriptions of the six ecological endpoints used in this assessment.

1. Threatenad and endangered species. Species that are legally protected under foderal or state endangered species acts have by definition societal relevance. Because of the rarity of the endangered species, losses of even a small amoum of habita or a few individual organisms can have potentially adverse impacts on populations of those species. Population characteristics are amenable to study with the use of standard field rechniques and hence meet the criteria of unambiguous operational definition and accessibility to prediction and measurement. Contaminants related to DOE operations or adverse impacts of remedial actions, including construction activities related to the ER/WM Program, may affect organisms or habitats ax DOE facilities. Federally or state-listed and candidate species are known to occur at each of the facilities.

2. Wetiands. Wetlands are also legally protected and hence by definition have societal relevance. They are important for flood control and natural biodegradation of pollutants, and as spawning and nursery habitat for many fish and wildlife species. Methods for assessing wetland status are well developed, and data on wetlands are available for each of the DOE facilities.

3. Recreational fiah and willfe. Many species of fish and wildlife valued for recreation flourish on and in the immediate vicinity of DDE facilities. Methods for study of fish and wildlife populations are well developed, and some of the facilities with wildlife management programs have conducted wildlife population studies.

4. Apricultural or dimber production. Portions of some DOE reservations are managed for timber. livestock, or crop 
protiction. Altitionght DOE actirities do în threaten the survival of managed crops or forests, reducticas in the productivity or marketability of these resources constitute valid endpoints for ecological risk assessment.

5. Partes and other pablic lands. Severai of the DOE reservations border state parks. national forests, or other public lands. Contaminants migrating off DOE property may affect these other public lands; moreover, many wildlife species migrate freely between DOE and non-DOE lands so that actions having adverse impacts on LOEresident populaticns can have impacts on wildlife inhabiting non-DOE land as well.

6. Biodiversity. The worldwide decline and disappearance of species and communities. generally termed loss of biodiversity, is attracting both scientific debate (Wilson 1988) and public attention (May 1992). As a result, special consideration of impacts to biodiversity is now part of the National Environmental Policy Act (NEPA) process (CEQ 1993). Generally, biological diversity is considered from the perspective of regional or local ecosystem diversity, species diversity. genetic diversity, and relationships and interactions among species (CEQ 1993).

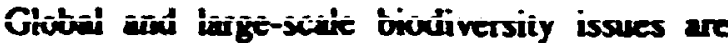
more difficult to translate into exdpoints, but assessment is possible if specifi. taxonomic groups or well-defined community types can be identified as being "a risk." For purposes of this assessment, species or communities that do not otherwise have explicit legal protection are defined as a rist if (1) they belong to a taronomic group known or suspected to be declining worddwide, (2) they are rare outside areas that are protected from disturbance or development, or (3) they are a critical component of a larger landscape. Because of their long isolation from human influence, many DOE reservations provide refuge for such species and cormmunities. Examples of the worldwide loss of biodiversity include the worldwide decline of amphibians, bats, and neotropizal migratory birds (McCracken 1988; Blaustein and Wake 1990; Terborgh 1989). Wild stocks of anadromous salmonid fishes are also declining in rnany regions (Nehisen et al. 1991); mos of the wild stocks in the upper Columbia River basin in the northwestern United States are being considered for protection under the Endangered Species Act. Some types of plant communities are susceptible to invasion by nonnative species, especially after disturbance (Cheater 1992), and other oncecommon plant communities have become rare because land has been converted for agricultural use or urban/sulurban development. 


\section{CHAFTER 3: ANTEGRATHON AND EVALUATION}

\section{BACKGround}

Action-forcing requirements in the National Environmental Policy Act of 1969 (NEPA) (Sect. 102) and Council on Environmental Quality (CEQ) regulations that implement NEPA require analysis of potential cumulative impacts in environmental impact statements (EISs) [40 (CFR) Pts. 1509.7 and i508.8j. Cumulative impact is defined as "... the impact on the environment which results from the incremental impact of the action when added to other past, present, and reasonably foreseeable future actions regardless of what agency (Federal oi nonFederal) or person undertakes such other actions. Cumulative impacts can result from individually minor but collectively significant actions taking place over a period of time."

The concept of cumulative ecological impacts is still evolving, and researchers, regulators, and managers may differ in the emphasis placed on various aspects. However, there is a general agreement that cumu'ative impact assessment examines the consequences of multiple sources of environmental disturbance that impinge on the same set of valued environmental components. The characteristic "multiple" nature of the sources of cumulative impacts may arise in three ways: (1) the same kind of source recurs sufficiently frequently through time; (2) the same kind of soure recurs sefficiently densely through space; and (3) different kinds of sources impose similar consequences on a valued environmental component, such that the individual disturbances cannot be assimilated by the natural environment. The key components of an analysis should (1) identify a threshold of acceptable effert (i.e., within a regulatory standard or by public perception) and (2) determine the extent to which the proposed action or actions add to effects from other actions in approaching or exceeding that threshold.

The cumulative effects analysis for the PEISs differs from those in most site-specific EISs in that it is an analysis of proposed actions to remediate unacceptable conditions at existing waste sites. Thus, for some of the ecological endpoints, the cumulative effects of the proposed action(s), when added to ocher past, present, and reasonably foresecable future actions, might be beneficial in the long term, whereas short-term impacts might be expected from habitat alteration during remediation. Specifically, the proposed ER alternatives would tend to reduce contaminant exposure risk to ecological endpoints while tending to simultaneously increase risks from construction activities.

The objective of the programmatic cumulative risk assessment is to compare the ecological benefits of remedial activities with the ecological impacts of those activities.

\section{APPROACH}

Cumulative risks to ecological endpoints should be considered within the context of well-defined spatial and temporal scales; otherwise, there are endless possibilities that trivialize the effort. The barriers to effective cumulative risk analysis at the programmatic level include a lack of both data and models, particularly at the regional level, and more fundamentally, the limited understanding of environmental processes and how biological effects occur. Chances for success rely on recognition of the important connections on which we need to concentrate. For purposes of this analysis, the relevant spatial scales are local and regional. Relevant temporal scales range from shon to long term or permanent. For these analyses, cumulative risks are believed to occur at the local level (e.g., within the reservation) and at the regional level as defined by the region of influence for the human health analyses. Traditionally, cumulative risks at the local level would include risks from existing and planned sources other than those of the proposed actions. In this analyses. cumulative risks at the local level are considered to be the aggregate risks from all restoration or WM activities for each alternative.

Existing sources of contaminants subject to remediation within each reservation are included in the analyses here, and any contaminant releases from future developments would be 
subject to current Anpmpiate. Relevant, and Applicable Requirements (ARARs). Although source terms were not available for the reservations in areas not currently considered for remediation, this is believed to be a reasonable approach to assessment of cumulative risks from contaminant exposure for each reservation and will provide adequate information for comparing proposed alternatives.

Construction could result in habitat alteration that would pose direct and indirect risks to the ecological endpoints. Such risks are assumed to be proportional to the amount of habitat altered (i.e.. the total area affected on each reservation) as a result of remediation of the contaminated site, soil borrow areas, new roads, and newly constructed waste treatment or storage areas. Risk from construction of current and future projects other than ERWM projects was excluded from these cumulative analyses because of uncertainty in predicting habitat alteration.

Furthermore, quantitative assessment of cumulative risks to ecological endpoints from regional (i.e., off-site) activities that result in habitat alteration (i.e., urban development. forestry, agriculture) is precluded because of financial constraints and data availability. For regional cumulative analysis of habitat loss, natural ecosystems within the DOE reservations are compared with similar ecosystems in the surrounding regions for cach alternative.

Analysis of cumulative risks for the purposes of the PEIS will include on-site and off-site risks to the six ecological endpoints defined in chapter 2. Ecological risks associated with remediation of the three facilities located on ORR are aggregated because they lie or exist within a single contiguous ecosystem. Further aggregation (i.e.. across all DOE reservations) is unnecessary because the geographic distances

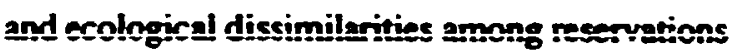
are large enough to ensure independence of impacts.

On-site cumulative construction risks consist of the total areas fisturbed by capping, soil sediment removal, and constnuction (i.e., roads, waste treatment facilities, and storage areas). Methods used to calculate the total disturbed area for each remediation alternative are described in appendix $B$.

For on-site cumulative contaminant exposure risks, base-line exposure concentrations were derived from source terms provided by Pacific Northwest Laboratory (PNL) (see appendix B).

There are no scientifically defensible methods for directly comparing or combining habitat disturbance risks and contaminant risks. Thus, these two kinds of risks were addressed separately, and results were summarized in tabular form. A qualitative comparison of these sources of risk was performed by establishing scales of relative severity. For contaminants, a cumulative hazard index (HI) (appendix A) of less than I was assumed to indicate no long-term contaminant risk; an $\mathrm{HI}$ from 1 to 10 was assumed to indicate a moderate risk, and an $\mathrm{HI}$ of 10 or greater was assumed to indicate a potentially severe contaminant risk. A negligible habitat disturbance risk was assumed to exist for a given alternative if less than 3\% of the total area of the reservation (or of the habitat occupied by a particular endpoint) was expected to be disturbed; a moderate habitat disturbance risk was assumed to exist if 3-10\% of the total reservation (habitat) area was expected to be disturbed; and a severe habitat disturbance risk was assumed to exist if more than 10\% of the reservation (habitat) was expected to be disturbed. 


\section{CHAPTER 4: DAHO NATIONAL ENGINEERING LABORATORY}

The Idaho National Engineering Laboratory (INEL) reservation covers 230,500 ha $(570,000$ acres) in Idaho, and elevations range from 1,400 $m(4,770 \mathrm{ft})$ to more than $2,000 \mathrm{~m}(6,570 \mathrm{ft})$ at the top of several extinct volcanoes (figure 4-1). All of the reservation was Bureau of Land Management (BLM) land prior to acquisition, and sheep or cattle currently graze on $60 \%$ of the reservation (Reynolds 1993). The Little Lost River, Lemhi, Bitterroot, and Beavertead mountain ranges border INEL on the north and northwest. The Big Lost River, the Little Lost River, and Birch Creek originate in the mountains to the north and west of INEL. These rivers do not usually extend onto the INEL reservation. When flow is adequate, they end in playas within the site boundaries (Tkachyk et al. 1990). Vegetation is principally shrub-steppe; and sagebrush-grassland, juniper-grassland, crested wheatgrass, and giant wild rye are the dominant plant communities. Trees are found in juniper-grassland communities in the foothills to the northwest and southeast and in the riparian communities along the Big Lost River (Arthur et al. 1984). McBride et al. (1978) describe the vegetation in detail, and Adams et al. (1979) describe vegetation and wildlife at the waste management (WM) complex of INEL.

Contaminated sites are associared with facilitips that lie mostly in the southwesterm portion of the INEL reservation. Additional facilities and associated waste sites are in the southeastern and northern portions of the reservation. No contaminated sites are known to exist in the central region of INEL. According to the ER PEIS source-term data base (appendix A), 4,500 ha $(11,000$ acres) of the 230,500 -ha $(570,000$ acre) INEL reservation are cortaminated, including 15 ha (36 acres) of buried waste and 10 ha ( 24 acres) of waste ponds. The ER PEIS data base contains data on surface areas of $20 \%$ of the waste areas on the INEL reservation. We assumed that these were a representative sample of the surface areas of all waste sites at INEL.

\section{Ecological ENDPoints and Srzcies Distrabution}

The dominant ecosystem type on the INEL reservation is shrub-steppe, and there are some trees in the surrounding foothills and riparian areas. Nine federally listed or candidate species are known to visit, breed, winter, or stay yearround (table 4-1). Waste ponds are important wetlands on the reservation, and natural ephemeral wetlands are found along the rivers and in depressions in lava flows. Recreational fish are found in the rivers on the reservation when they contain water, but flow is intermittent on-site. Although hunting is not allowed on most of the site, several recreational wildlife species are present. Sheep or cattle currently graze $60 \%$ of the reservation, and the reservation is surrounded ty Bureau of Land Manas. ment (BLM) and national forest lands. The INEL reservation is a very large, relatively undisturtred, and protected block of native sagebrush-steppe ecosystem. Important species groups of concern for conservation of biodiversity at INEL include bats, raptors, and wintering/migratory wildlife: sensitive habitats include lava tube caves, wintering grounds for wildlife, and wetlands.

Determining risks to endpoints requires (1) defining distribution and composition of endpoints and (2) selecting receptor species. The distribution of endpoints must be known in order to determine both exposure pathways for contaminants and risks to endpoints from construction.

For purposes of determining risk of exposure to contaminants, distribution of endpoints is considered to be either ubiquitous (i.e., more or less uniformly distributed throughout the reservation or region), discrete (i.e., located in one clearly ideritified location), or discontinuous (i.e., found in several locations within a limited area or areas). Risks to ubiquitous endpoints are assumed to be related to the total surface area 

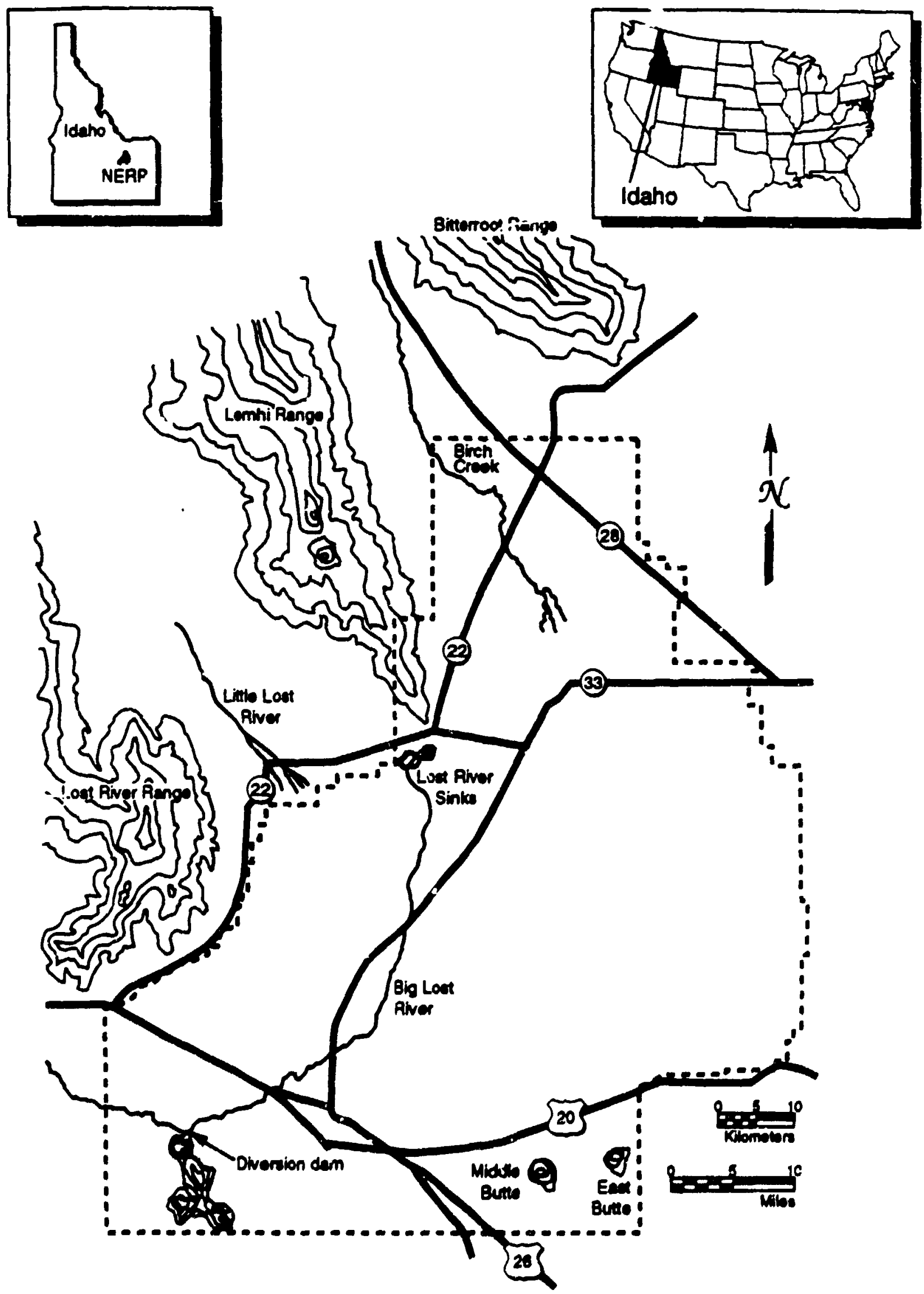

Idaho National Engineoring Laboratory 
TABLE 4-1-Distribution of Endpoints on the Idaho National Engineering Laboratory

\begin{tabular}{|l|l|l|}
\hline \multicolumn{1}{|c|}{ Ubiquitous } & \multicolumn{1}{|c|}{ Discontinuous } & \multicolumn{1}{|c|}{ Discrete } \\
\hline $\begin{array}{l}\text { Resident, breeding, and } \\
\text { wintering federally listed } \\
\text { and candidate species }\end{array}$ & $\begin{array}{l}\text { Wetlonds and riparian } \\
\text { vegetation along rivers } \\
\text { Waste pond wetlands and } \\
\text { associated migratory waterfowl } \\
\text { (biodiversity, recreational } \\
\text { wildlife) }\end{array}$ & $\begin{array}{l}\text { Grazing land for sheep and } \\
\text { cattle (agricultural } \\
\text { production) }\end{array}$ \\
$\begin{array}{l}\text { Lava tube caves' } \\
\text { (biodiversity) } \\
\text { Public lands surrounding the } \\
\text { reservation }\end{array}$ \\
$\begin{array}{l}\text { Small playa wetlands in } \\
\text { lava flows } \\
\text { lecreational wildlife } \\
\text { flow in rivers is sufficient }\end{array}$ & \\
$\begin{array}{l}\text { Important components of } \\
\text { blodiversity not included in } \\
\text { the above (bats, food } \\
\text { sources for protected } \\
\text { species, sagebrush } \\
\text { communities) }\end{array}$ & &
\end{tabular}

I The distribution of all lava tube caves at INEL is not documented, and we assume they are found throughout the reservation.

affected by contaminant exposure or by disturbance from remediation. Risks to discontinuous and discrete endpoints are determined if their locations are known to be within contaminated areas or within areas affected by remedial activities or contaminant exposures.

As a result of the relative ecological uniformity of the INEL reservation, most endpoints are ubiquitous (table 4-1). Exceptions are wetlands and associated species, which are discontinuous along the rivers and waste ponds, and grazing areas on the reservation and surrounding public lands, which are discrete. Locations of endpoints were determined from existing maps and publications, as well as personal communications with ecologists at INEL (Reynolds 1993).

\subsubsection{Threatened and Endangered Species}

\subsubsection{Receptors}

There are nine federally listed or candidate birds and mammals at INEL but no known federally listed or candidate plants (table 42) and no known designated or proposed critical habitats. Of the nine species, four birds (the endangered peregrine falcon and the candidate white-faced ibis, northern goshawk, and black tern) are present only for a few days during migration (Reynoids 1993) and were, therefore, not included in our risk analysis.

The endangered bald eagle is usually present from November through March, mostly in the northern part of the reservation (Reynolds 1993; Arthur et al. 1984). This 
species roosts off-site. Although nomally a Iisi eater, the baid eagie teeds almost exclusively on carrion at INEL, and it may occasionally kill a jackrabbit. The candidate ferruginous hawk breeds on the reservation and is usually present from March through September (Reynolds 1993). It is found throughout INEL and feeds almost exclusively on jackrabbits. There is also a breeding population of the candidate loggerhead shrike on the reservation, which we assume is present from March through September (Reynolds 1979). Shrikes eat mostly insects and small mammals; although small birds are a minor component of the shrike's diet. they were not included in our analyses. The candidate pygmy rabbit lives in sagebrush, which is its food source, but little is known about the abundance or distribution of the rabbit on the reservation (Reynolds 1993). The candidate Townsend's big-eared bat is a colonial hibemating species that roosts and hibernates in lava tube caves (Reynolds 1993). It eats flying insects. Both of these mammals are on the reservation year-round.

\subsubsection{Distribution}

Except for the pygmy rabbit, all of the federally listed or candidate species are known to occur throughout the INEL reservation. Although many species of concern are likely to be unevenly distributed rather than uniformly dispersed over the entire reservation (Morris 1992), for this programmatic analysis, we assume all listed and candidate species are uniformly distributed.

\subsubsection{Wetlands}

\subsubsection{Receptors}

Benthic macroinvertebrates, fish, muskrats, and aquatic plants are representative wetland species for which some toxicity benchmark data are available. Although these biota do not necessarily occur in all wetlands on the reservation, they were selected as receptors in our risk analysis because they cover the range of wetland ecosystem components that could be present. We therefore calculate risks to these receptors in all wetlands.

\subsubsection{Distribution}

The only perennial wetlands on the reservation are the waste ponds, which are a source of drinicing water for wildlife, a rest area for migratory waterfowl, and habitat for breeding and summer resident waterfowl (Arthur et al. 1984; Reynolds 1993). Most of the waste ponds are in the southwest corner of the reservation. Ephemeral wetlands along the Big Lost River and the Little Lost River, especially near the sinks. and in many small playas [mostly less than 2 ha (5 acres)] on old lava beds primarily in the central portion of the reservation are also water sources for wildlife and livestock and rest areas for migratory birds (Arthur et al. 1984).

National Wetland Inventory (NWI) maps (USFWS 1980 and 1984) were us:d to identify locations of waste ponds and wetlands along the Big Lost River. Major wetlands on the INEL reservation total 800 ha (2000 acres) (Arthur et al. 1984). Because most of the small ephemeral playa wetlands on the NWI maps are in lava flows, which are mainly in the central part of the INEL reservation, we assume none are located in currently contaminated areas. However, these playa wetlands could occur in areas where treatment facilities might be located in the future. Although the NWI maps probably underrepresent these sniall wetlands, for our analyses we assump these small ephemeral wetlands are found throughout the reservation at a density comparable to that of a representative sample area of INEL fiom the NWI quad maps. We estimate that at least $0.2 \%$ of the 
TABLE 4-2-Rare Species on the Idaho National Engineering Laboratory

\begin{tabular}{|c|c|c|}
\hline Species & Common Name & Status ${ }^{2}$ \\
\hline \multicolumn{3}{|l|}{ Birds } \\
\hline Halioeetus leucocephalus & Bald eagle & $\mathbf{E}$ \\
\hline Falco peregrinus & Peregrine falcon & $\mathbf{E}$ \\
\hline Accipiter gentilis & Northem goshawk & $\mathrm{C2}$ \\
\hline Buteo regalis & Fernuginous hawk & C2 \\
\hline Chlidonias niger & Black tem & C2 \\
\hline Lanius Iudovicianus & Loggerhead shrike & C2 \\
\hline Plegadis chihi & White-faced ibis & $\mathrm{C2}$ \\
\hline \multicolumn{3}{|l|}{ Mammals } \\
\hline Brachylagus idahoensis & Pygmy rabbit & $\mathrm{C}_{2}$ \\
\hline Plectotus ownsendii & Townsend's big-eared bat & C2 \\
\hline
\end{tabular}

' Compiled from Markham 1987: DOE 1985; Arthur et al. 1984; Cholewa and Henderson 1984; Moseley and Groves 1992; and Reynolds 1993.

2 Endangered and threatened wikdlife and plants. S0 CFR 17.11 \& 17.12. July 15. 1991: endangered and threatened wildlife and plants: animal candidate review, 56 FR 58804-58836, November 21, 1991. E=endangered, C2=candidate under review.

reservation is in small ephemeral wetlands in any given area.

\subsubsection{Recreational Fish and Wildlife}

\subsubsection{Receptors}

Determining contaminant risks to aquatic species, including recreational fish, does not require the use of specific receptor species. We determined risks to fish in general to represent recreational fish in the Big Lost River (e.g., the rainbow trout). The sage grouse, mallard, pronghom antelope, jackrabbit, and coyote were selected as common species representative of recreational wildlife, which are also important components of the food web on the reservation. Except for the mallard, all of these species are year-round residents on the reservation, although some of the sage grouse and antelope populations corne from surrounding areas to winter in the northem part of the reservation (Rope and Stahly 1993). To be conservative in our analyses, we assume that all populations are year-round residents, except for the mallard, which we assume to be present when ponds are not frozen, from March through October. Thus, our analysis estimates potential risks to populations continuously exposed to contaminants. Exposure risks to sage grouse and ancelope populations that winter off the reservation would be lower than to resident populations.

\subsubsection{Distribution}

Recreational fish are present on the reservation only when the Big Lost River contains enough water for them to survive. Although the reservation is closed to public access. many wildlife species suitable for recreational use are present, including resident bird species, migratory waterfowl, ruminants, furbearers, and large predatcrs (Arthur et al. 1984). 


\subsubsection{Agricultural or Timber Production}

\subsubsection{Receptors}

Sheep and cattle are ecologically similar. both are grazing livestock. Exposure and uptake data were available only for cattle; therefore, cattle were chosen to represent the agricultural endpoint. For calculating maximum potential risk, assume that livestock would be exposed to contaminants year-round.

\subsubsection{Distribution}

Sheep or cattle graze approximately $60 \%$ of the reservation. (Rope and Stahly 1993; Reynolds 1993).

\subsubsection{Parks and Other Public Lands}

\subsubsection{Receptors}

Risks to these endpoints were determined by calculating risks to food web components at reservation boundaries adjacent to public lands. We assume that risks are maximal closest to the reservation.

\subsubsection{Distribution}

Public lands (national forest and BLM lands) surround most of the reservation.

\subsubsection{Blodiversity}

\subsubsection{Receptors}

The candidate Townsend's big-eared bat, which is ecologically similar to most bats found or, the reservation and is a large year-round resident, was chosen as a conservative representative of bat species. Raptors are well represented in our analyses by federally listed or candidate species (e.g., endangered bald eagle and candidates ferruginous hawk and shrike), and migratory waterfowl are represented by the $n$ iard. The robin, which is a common sitewide, summer breeding migrant, was chosen as a representative songbird. Other important food web components (figure 4-2) include major food organisms of receptors chosen to represent other endpoints (i.e., small marnmals exten by rapiors and coyotes, and insects eaten by loggerhead strikes and bats) and other endpoints discussed in the preceding paragraphs. Although very important to ecosystem function and as food for other species, invertebrates were not included in our analyses because there was a lack of benchmark data for them. Benchmark data were generally not available for reptiles, sother important species group at the site.

\subsubsection{Distribution}

All of the reservation may be classified as sagebrush-steppe (Morris 1992). Its existence as a large block of relatively undisturbed sagebrushsteppe ecosystem is its greatest value to biodiversity. The surrounding counties contain extensive BLM and national forest lands, which also support native sagebrush-steppe rangeland and lava flows comparable to most of the DNEL reservation. The northern portion of the INEL reservation is an important wintering ground for pronghom and sage grouse from surrounding mountains, and the reservation is an important nesting and wintering ground for raptors (Reynolds et al. 1986). The large undisturbed expanse of sagebrush-steppe provides protected habitat for several species groups whose populations are in general decline. These groups include 22 species of raptors (e.g. bald and golden eagles, American kestrels, owls, and vultures), 6 species of bats, 6 species of camivores, and 11 species of reptiles and amphibians (e.g., the Great Basin spadefoot toad, snakes, and lizards) (Reynolds et al. 1986).

Within the sagebrush-steppe ecosystem on the INEL reservation lava tube cave habitats and associated lava flows are important sensitive habitats, providing sheiter for bats, snakes, owls, and camivores (Rope and Stahly 1993). The distribution of all lava tute caves on the reservation is not documented. We therefore made the conservative assumption that the caves are ubiquitous.

Invasion of sagebrush-steppe communities by nonnative chealgrass on the reservation is an increasing threat to native biodiversity on the reservation (Markham and Morris 1991). Cheatgrass invades disturbed areas, crowding out native species and inhibiting or preventing their 
estublishrment on fresh disturbances. We assume tine the sounciance of this species is inverseiy proportional to the quality of native sagebrushsteppe habitat and that cheargrass is most abundant in and adjacent to disturbed sites.

\section{Contammants of potentul Concern}

The constituents of potential concern on INEL include radionuclides, inorganic, and organic contaminants. The primary radionuclides, according to relative average concentrations, are ${ }^{137} \mathrm{Cs}$ and ${ }^{60} \mathrm{Co}$; the primary inorganics are $\mathrm{Ba}$, $\mathrm{Cr}, \mathrm{Pb}, \mathrm{Ni}$, and $\mathrm{Zr}$. The concentrations of organic chemicals on the site are relatively low and thus are not expected to pose a potential hazard.

Maximum and average concentrations of chemical and radiological constituents in soil, surface water, and sediment were determined from the source terms provided by PNL (tables 4-3, 4-4, and 4-5, respectively). Determination of these average and maximum concentrations required that certain assumptions be made with regard to data interpretation and compensation for data gaps. Appendix A describes the methodology used to develop the source terms for input into the exposure and risk assessment.

\subsection{EXPOSURE ASSESSMENT}

Estimating contaminant exposure for representative species on the INEL reservation depends on knowing the amount of time spent in waste areas, and the amount of contaminants ingested. Since specific home ranges and habits of many of the representative species on INEL are not well known, and only a few species with small home ranges (e.g., small mammals, birds) would reside within contaminated areas for most of their lives, and very few individuals would contact areas of maximum concentrations (see Appendix B for discussion of home ranges), an initial screening assessment for contaminant exposure was conducted. Where available for INEL, the maximum concentrations of each contaminant in each medium (i.e., soil, water, and sediment) were used to identify the worstcase potential contaminants. Contaminants that did not pose a risk to any of the receptor species from exposure to the maximum values were not considiered furuier. if exposure to the maximum concentrations of contaminants posed a rist to organisms, then the average concentrations of those contaminants were used in the assessment to estimate the most probable and reasonable exposure and rist.

The risk assessment considers chronic exposures of vegetation, terrestrial wildlife, and aquatic organisms to radiological and nonradiological contaminants. Die to limited availability of sensitivity data for many species (e.g. threatened and endangered species) and to similarities in exposure (e.g., similarly sized raprors feeding on the same prey), representative organisms for each endpoint were chosen for evaluation. A food web showing relationships among these representative receptors is presented in figure 42. Conservative estimates of exposure and risk were made by selecting receptors most sensitive to contaminants or habitat alteration, most likely to experience additional risk due to bioaccumulation or larger body size, or at greatest risk due to rarity. Other abundant species on the reservation were included as important prey components $c i$ the food web, such as mice and insects (risk estimates were not determined for insects).

The primary exposure routes for terrestrial wildlife species are exposure to extemal radiation, ingestion of food (including soils for some species) and water. Table 4-6 lists the body weights and consumption rates for the representative species. The rabbits, pronghorn, cow, and sage grouse are assumed to feed exclusively on the vegetative parts of plants. The mouse and malland duck are assumed to feed exclusively on the fruiting bodies of plants (i.e., seeds). On the basis of a review of the literature, the percentage of prey items consumed by omnivores and predators was estimated (table 4-6; figure 4-2). The robin is assumed to eat $70 \%$ fruit/seeds and $30 \%$ insects; the loggertead shrike eats $60 \%$ insects and $40 \%$ mice; the ferruginous hawk eats $100 \%$ jackrabbits; the coyote cats $45 \%$ mice. $45 \%$ jackrabbits, and $10 \%$ sage grouse; and the bald eagle is assumed to eat only carrion, consisting of $50 \%$ jackrabbits and $50 \%$ pronghom. The bat is assumed to eat $100 \%$ insects, and the insects are assumed to eat 100\% vegetative plant parts. 


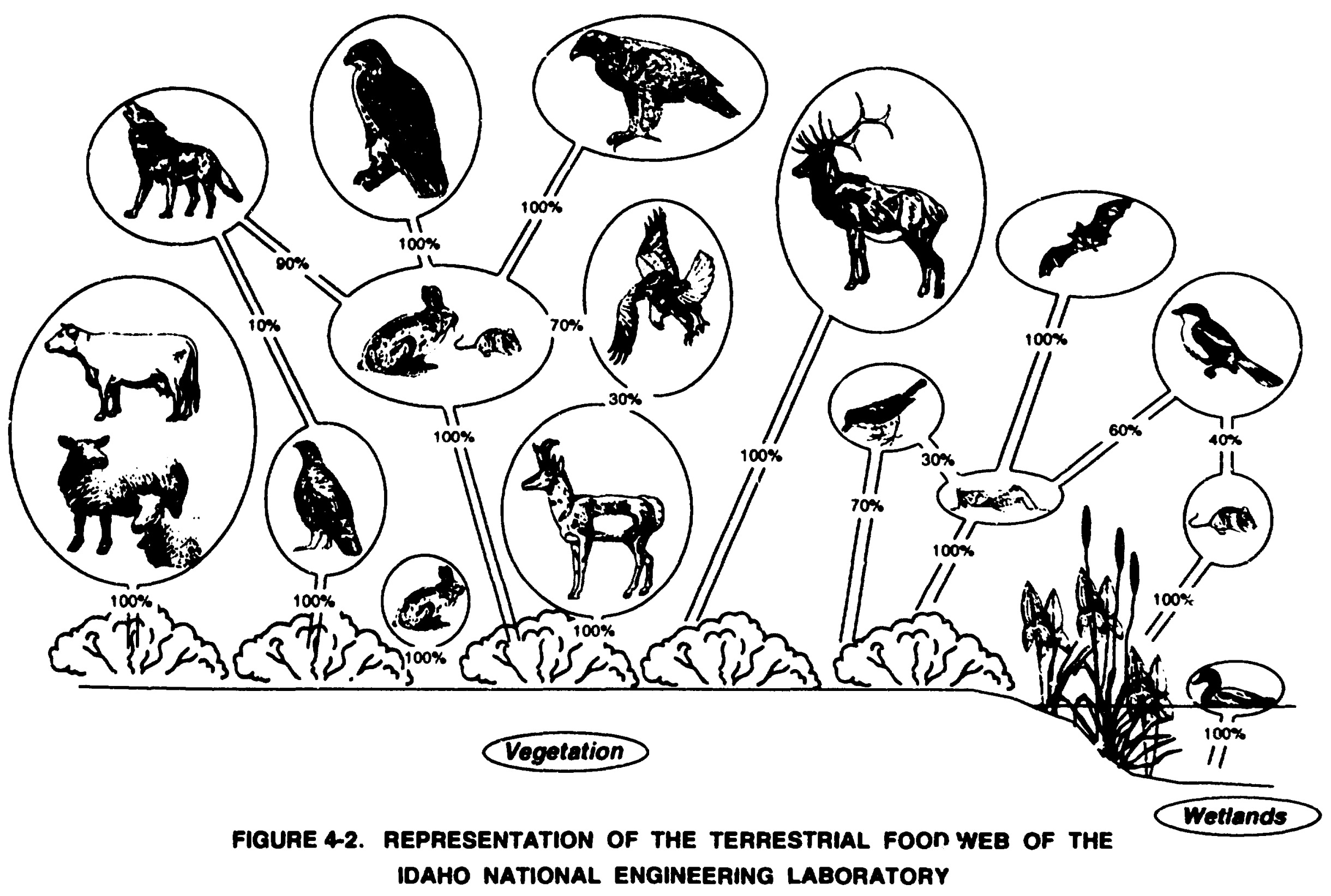




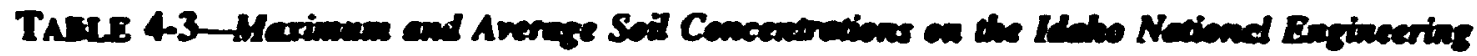

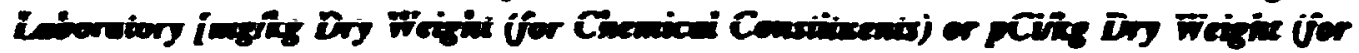
Rectionuctistes)]

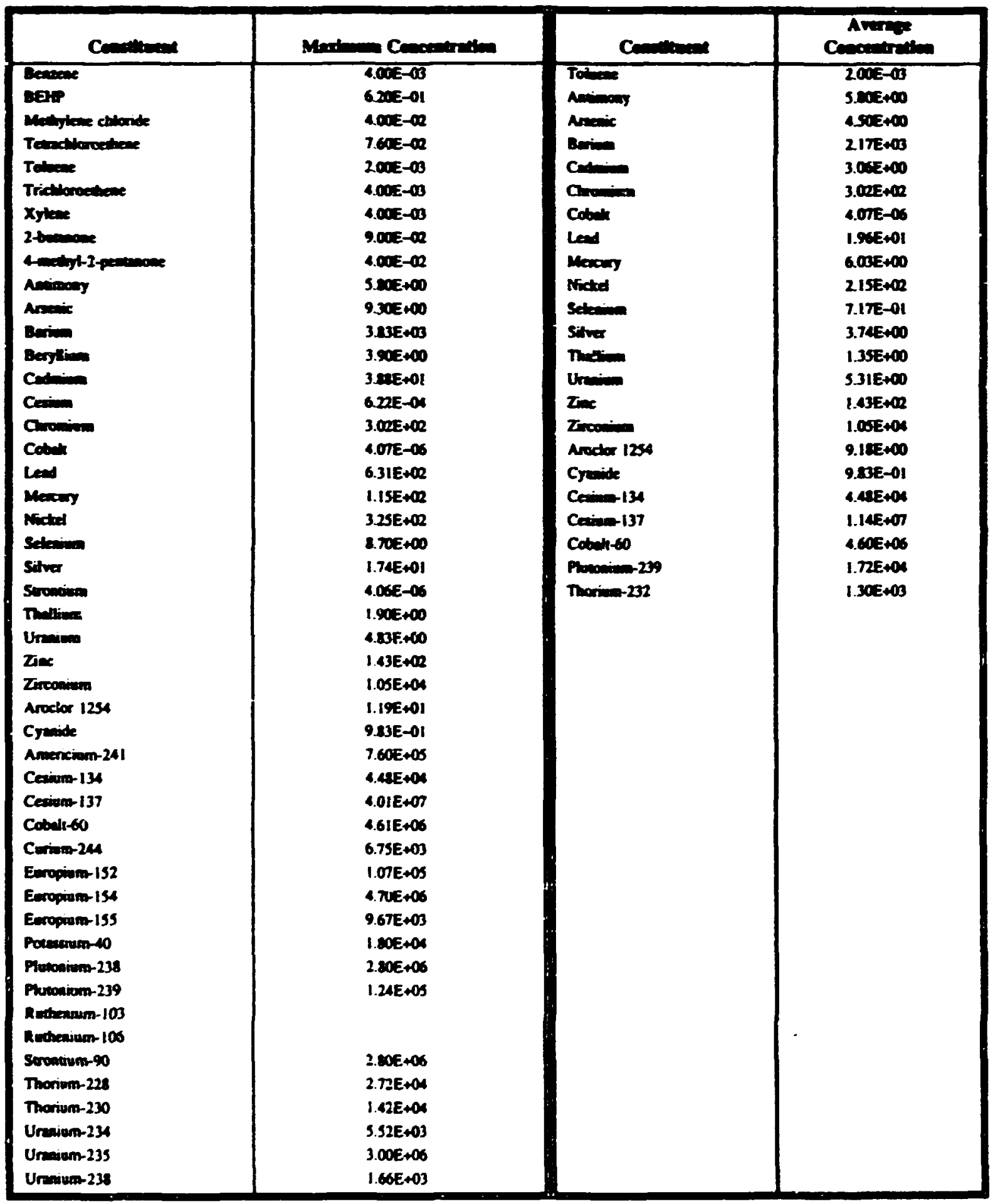

NA = no measured soil concentration available. 


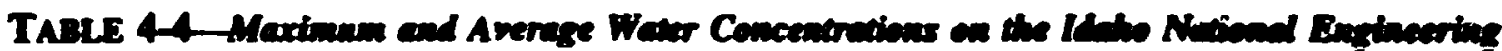

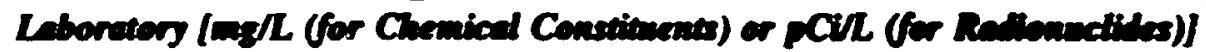

\begin{tabular}{|c|c|c|c|}
\hline Constituent & Mndinen Concentrotion & Compinent & Avarate Concentruien \\
\hline Cesium & $3.33 E-12$ & Cobaht & $2.29 \mathrm{E}-12$ \\
\hline Cobalt & $2.29 \mathrm{E}-12$ & Cesium-137 & $2.90 \Sigma-01$ \\
\hline Cesium-137 & 2.90E-01 & Cobalt -60 & $2.59 E+00$ \\
\hline Cobalt -60 & $2.59 E+00$ & & \\
\hline
\end{tabular}

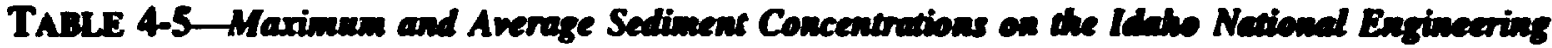
Laboratory [mg/le (for Chemicals) or pCilig (for Radiannclites)]

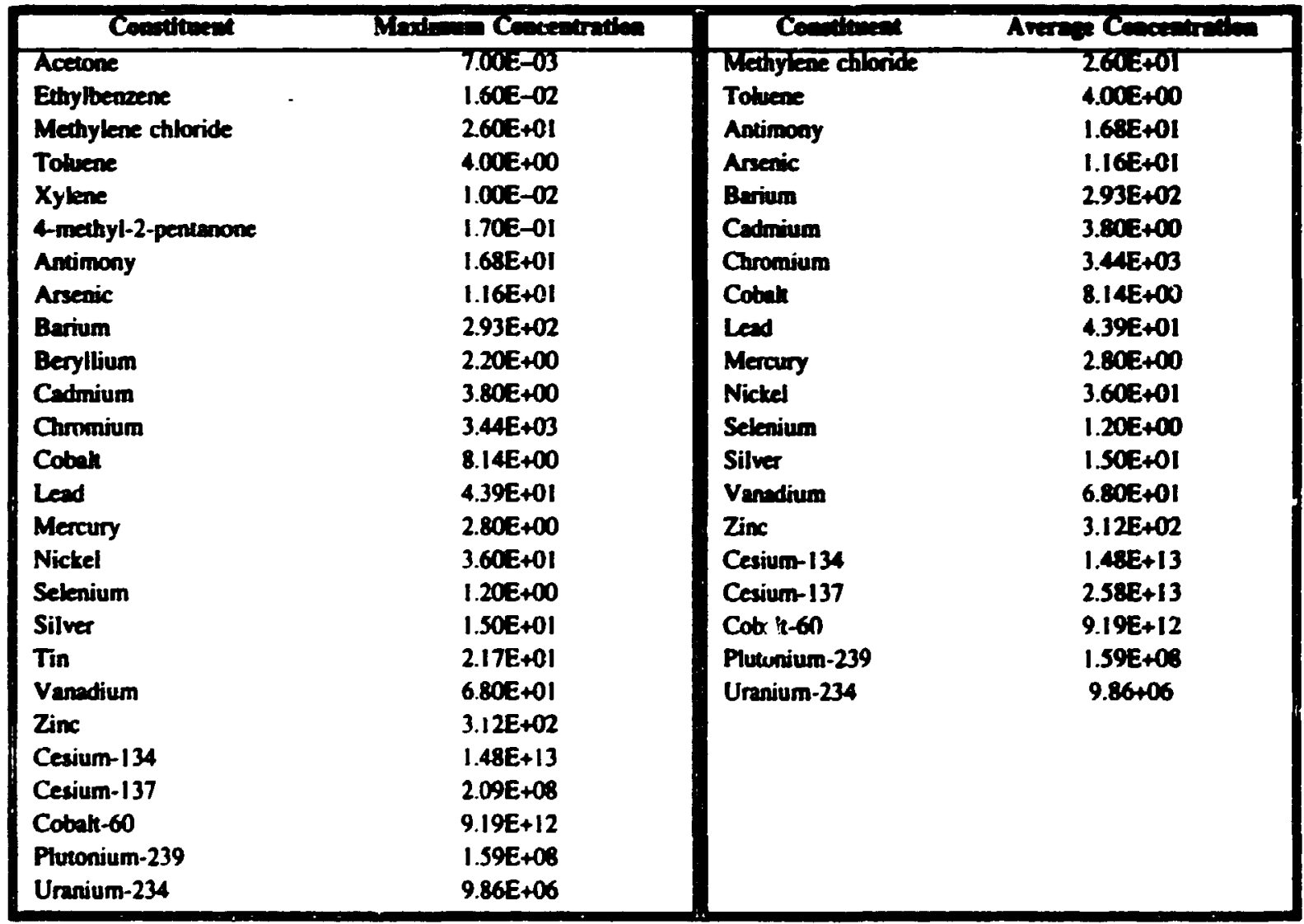

All species are assumed to purposely or incidentally ingest soil while eating, grooming. or preening except for the shrike and other raptors, bat, and coynte for which soil ingestion was assumed to be negligible. Soil ingestion rates $\left(Q_{\mathcal{L}}\right)$ were obtained from the literature for the jackrabbit $(6.3 \%$ of the dry-matter intake; Arthur and Gates 1988), pronghom (5.4\% of the dry-matter intake; Arthur and Gates 1988), cow (7\% of the dry-matter intake; Mayland et. al. 1977), mallard duck (8.2\% of the dry-matter intake: Beyer et al. 1991), and the mouse (Beyer et al. 1991) (table 4-6). Since published values of soil ingestion rates were not found for the robin or sage grouse, it was conservatively estimated to be $10 \%$ of the dry-matter intake. The soil ingestion rate for pygmy rabbits was assumed to be the same as that reported for black-tailed jackrabbits.

The estimated daily rates of food and water consumption $\left(Q_{,}\right.$or $Q_{\text {, }}$ and $Q_{\text {n, respectively) for }}$ each representative species were calculated from allometric regression equations that are based on 


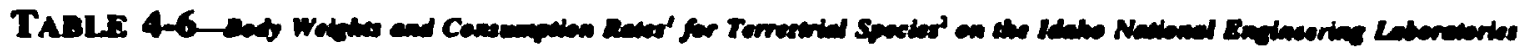

\begin{tabular}{|c|c|c|c|c|c|c|c|c|c|c|c|c|c|}
\hline 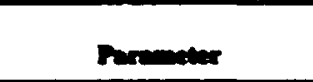 & Mane & rengy & Jecturnisile & Preanghers & Cow & (Roling) & Snemen & Menns & Storitere & Then & D. Newn & & Consus \\
\hline Das win ow & $22 \pi 0^{2}$ & 4. पE-O1 & $2.27 \mathrm{E} \times 00$ & $4.666+01$ & $4.005 \times 02$ & $7560-02$ & 2.00300 & $0.110 \times 6$ & 7.SS:Fon" & T.6i: & T.Sinditin & 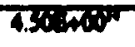 & T.Tinoln \\
\hline 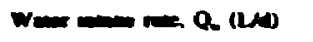 & $6.00 E-03$ & $3765-\infty 2$ & $1.83 E-01$ & $2.268+\infty 00$ & $1.238+01$ & $1.43 E-02$ & $1.908-01$ & $1.258-01$ & $1.002-02$ & $2.902-03$ & $1.438-01$ & $3.392-01$ & $770-01$ \\
\hline 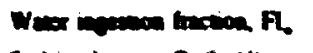 & $1000+\infty$ & $1.000+00$ & $1.000+00$ & $1.006+\infty$ & $1.00 \varepsilon+\infty$ & $1.000+00$ & $1.000+\infty 00$ & $7.000-01$ & $0.008-01$ & $1.00: 400$ & $0.008-01$ & $3.000-01$ & $10 \sin 00$ \\
\hline seal & $136 E-05$ & $125 E-0.31$ & $9.32 E-03^{10}$ & $4.60 E-02 "$ & $4.200-01=$ & 9.46E-0.1" & $1.056-02^{\prime \prime}$ & $9.645-03^{2}$ & 0.00 & 0.00 & 0.00 & 0.00 & 0.00 \\
\hline 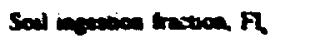 & $1000+\infty 0$ & $1.00 E+\infty 0$ & $1.00 E+00$ & $1.00 c+00$ & $1.005+\infty 0$ & $1.00 E+\infty 0$ & $1.006+\infty 0$ & $7.00 \mathrm{a}-01$ & 0.00 & 0.00 & 000 & 0.00 & 0.00 \\
\hline 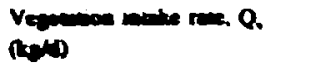 & 0.00 & $2.14 E-02$ & $\begin{array}{l}\text { (596-0] } \\
(A \times 43)\end{array}$ & $\begin{array}{l}\text { 9.3AE-01 } \\
\text { (Sets) }\end{array}$ & $7.47 E+\infty 0$ & 0.00 & $|| 3 E-0 \mid$. & 0.00 & 0.00 & 0.00 & 0.00 & 0.00 & 0.00 \\
\hline 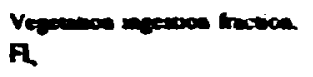 & 0.00 & $100 E+\infty$ & $100 E+\infty$ & $100 E+\infty 0$ & $1.00 E+\infty 0$ & 0.00 & $1.00 E+\infty 0$ & 0.00 & 0.00 & 0.00 & 0.00 & 0.00 & 0.00 \\
\hline 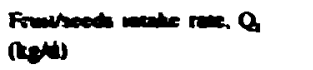 & $+\operatorname{soc}-03$ & 000 & 000 & 0.00 & 0.00 & $5.28 E-03^{4}$ & 0.00 & $7.416-02$ & 0.00 & 0.00 & 000 & 0.00 & 0.00 \\
\hline 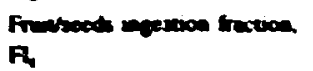 & $100 E+\infty$ & 0.00 & 000 & 0.00 & 0.00 & $1.006+\infty 0$ & 0.00 & $7.002-01$ & 0.00 & 0.00 & 0.00 & 0.00 & 0.00 \\
\hline 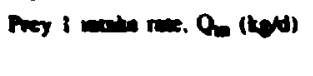 & 0.00 & 0.00 & 0.00 & 0.00 & 0.00 & $\begin{array}{l}2.52 E-03 \\
(\text { inesectus) }\end{array}$ & 0.00 & 0.00 & $\begin{array}{l}3.660-03^{85} \\
\text { (1nsects) }\end{array}$ & $\begin{array}{c}1.200-03 \\
\text { (Inecte) }\end{array}$ & 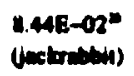 & $\begin{array}{l}1.300-0)^{n} \\
\text { (jectentuns) }\end{array}$ & $\begin{array}{c}2.638-0)^{\circ} \\
(m \infty 0)\end{array}$ \\
\hline 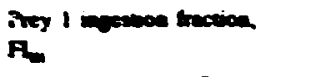 & 0.00 & 000 & 000 & 0.00 & 0.00 & $1.00 \mathrm{E}+00$ & 0.00 & 0.00 & $6.00 \mathrm{e}-01$ & $1.0004+\infty 0$ & $0.000-01$ & $1.000-01$ & $100 \sin 00$ \\
\hline 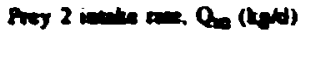 & 0.00 & 0.00 & 0.00 & 0.00 & 0.00 & 0.00 & 0.00 & 0.00 & $\begin{array}{c}2.440-03 \\
(n+\infty)\end{array}$ & 0.00 & 0.00 & $\begin{array}{l}6.4210-02 \\
(\text { mengenteon })\end{array}$ & $\begin{array}{l}2.638-01 \\
\text { (vickencuatu) }\end{array}$ \\
\hline 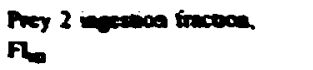 & 0.00 & 0.00 & 000 & 0.00 & 0.00 & 0.00 & 0.00 & 0.00 & $6.0003-01$ & 0.00 & 0.00 & $5.005-01$ & $100 \sin 0$ \\
\hline 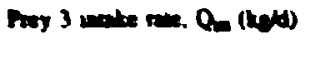 & 000 & 0.00 & 000 & 000 & 0.00 & 0.00 & 0.00 & 0.00 & 0.00 & 0.00 & 0.00 & 0.00 & s.mpen \\
\hline $\begin{array}{l}\text { Mny } 3 \text { in } \\
\text { Re }\end{array}$ & 000 & $a \times 0$ & 0.00 & 0.00 & 0.00 & 0.00 & 0.00 & 0.00 & 0.00 & 0.00 & 0.00 & 0.00 & 100000 \\
\hline
\end{tabular}

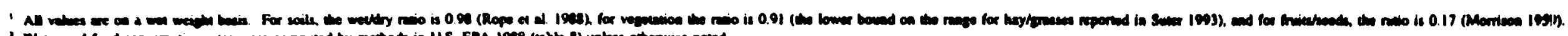

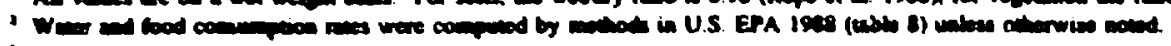

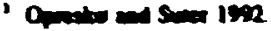

- Omina a

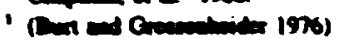

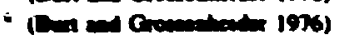

U.S. EPA igat

- Tures isca

Them isea

"Tom ision

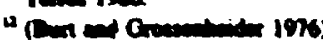

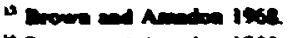

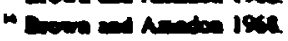

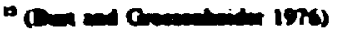

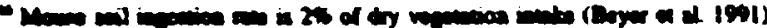

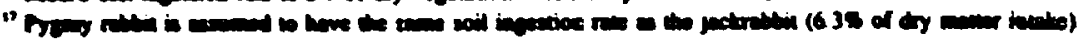

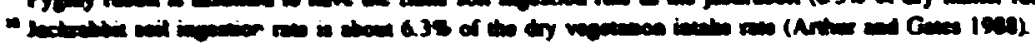

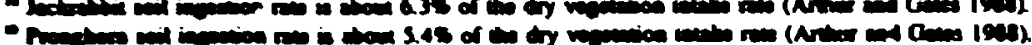

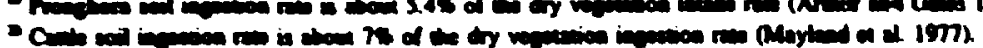

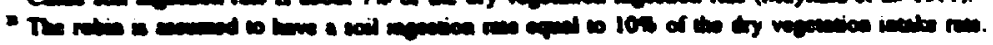

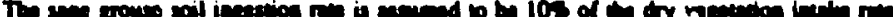

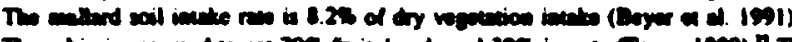

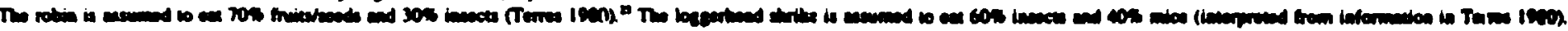

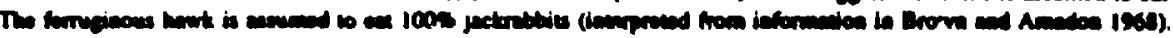

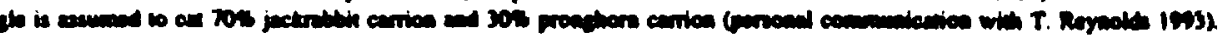

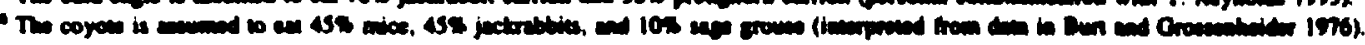


the weight of the organism (EPA 1988)

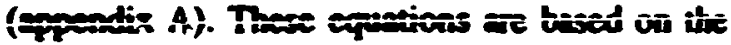
combined measurements for laborstory animals. livestock, and selected wildilife and bird species. Measured values for some rates were obtained from the litermure for several species and are noted in appendix $A$.

Besanse information on the specific hrbits and behaviors of most of the representative wildlife species is not well known, it is assumed that all species spend 100\% of their time on the reservation. The exceptions are the reptors, the mallend duck, and the loggenhead shrike (see discussion in chpper 4.1), whose specific time spent or the INEL reservation has been documented by site ecologists (Reynolds 1993). Therefore. the fraction of contamiroted veaptaion, fruit, prey, soil, and water consumed (FI, FI, FL, F, and FI, respectively) is set at 100\%, except for those species noted above, for which the FI values are set accordingly. The bald eagle, for instance, is present 6 months out of the year, so values are set $250 \%$ (table 4-6).

Contaminant concentrations in vegetation, the first kevel in the food chain, are estimated from source-term concentrations in the soils using published soil-to-plant element- or chemicalspecific transfer factors (Baes et al. 1984; Travis and Arms 1988) (table 4-7). Transfer factors for inorganic chemicals are available for both the vegetative and fruiting parts of plants (Baes et al. 1984); however, the transfer factors for organic chemicals do not make this distinction (Travis and Arms 1988). The methodology used to predict contaminant concentrations in vegetation does not make a distinction between different plant types or species. Therefore, all species ingest "generic" vegetation containing contaminant concentrations derived from soil concentrations by the use of transfer factors.

Transfer fuctors for contaminants of concem are applied to predict concentrations in the tissues of terrestrial mammalian receptors from consumption of vegetation, soil, and water (collectively termed Ba) (Baes et al. 1984; Travis and Arms 1988) (table 4-7). Data on transfer factors from vegetation or soil to insects and earthworms are very limited in the literature. Therefore, the concentration in insects was derived from vegetation concentrations, and a defouk, conservative one-to-0ise trender betweed vefciacion and insects wes soumed. The retionale and limitutions for aphying these transfer factors are discussed in eppendix $A$.

The consumption nes and the beachmatk limit or no-observable-edverze-efiect leved (NOAEI) values are typically reported in wet weights, whereas the vequtaion and soil concentruions are typically reported in dy weighes. Therefore. conversion fectors were applied to eccound for this difference. The wet- to dy-meight conversion factor for the vegetrive pats of plants on INEL was sorumed to be 0.91 [the lower end of the range of the percen ase of water content for hay and grasees (Suter 1993)]. The wet- 10 dry-weight conversion factor for the fruiting parts of planes on INEL was assumed to be 0.17 (Morrison 1959). The dy- to wet-weight conversion fector for soils is 0.98 ; it is the mean for 16 sampling locacions in the southwest portion of INEL (Rope a al. 1988).

For the baseline ascessment of INEI, the concentrations of radionuclides in animal tisstres and the resulting doses were not decay-corrected. The doses are estimated for the current simation and not at some point in the future. The primary radionuclides of concem, "Cs and "Co, have relatively long half-lives, so this assumption is reasonable. PNL decay-corrected the radionuclide concentrations in the source terms to the time of disposal or release. To estimate dose to terrestrial receptors, all short-lived daughter products were included.

Aquatic organisms considered in the asseasment included benthis macroinvertebrates and, for radiological analyses, emergent vegetation (i.e., cattails) and muskrats. All equaic organisms, except tor benthic macroinvertebretes, are exposed to con'vminants in surfece water. Benthic macroinvertebrates are assumed to be exposed only to sediment pore-water for calculation of internal ridiation dose and exposure to chemicals. The external radiation dose from exposure to surface water was calculated for all organisms. 
TAme 47-Soil to Vegetution and Plant to Beof Trenefer Foetors for the Condinuents of Concen on dhe

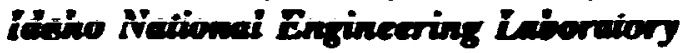

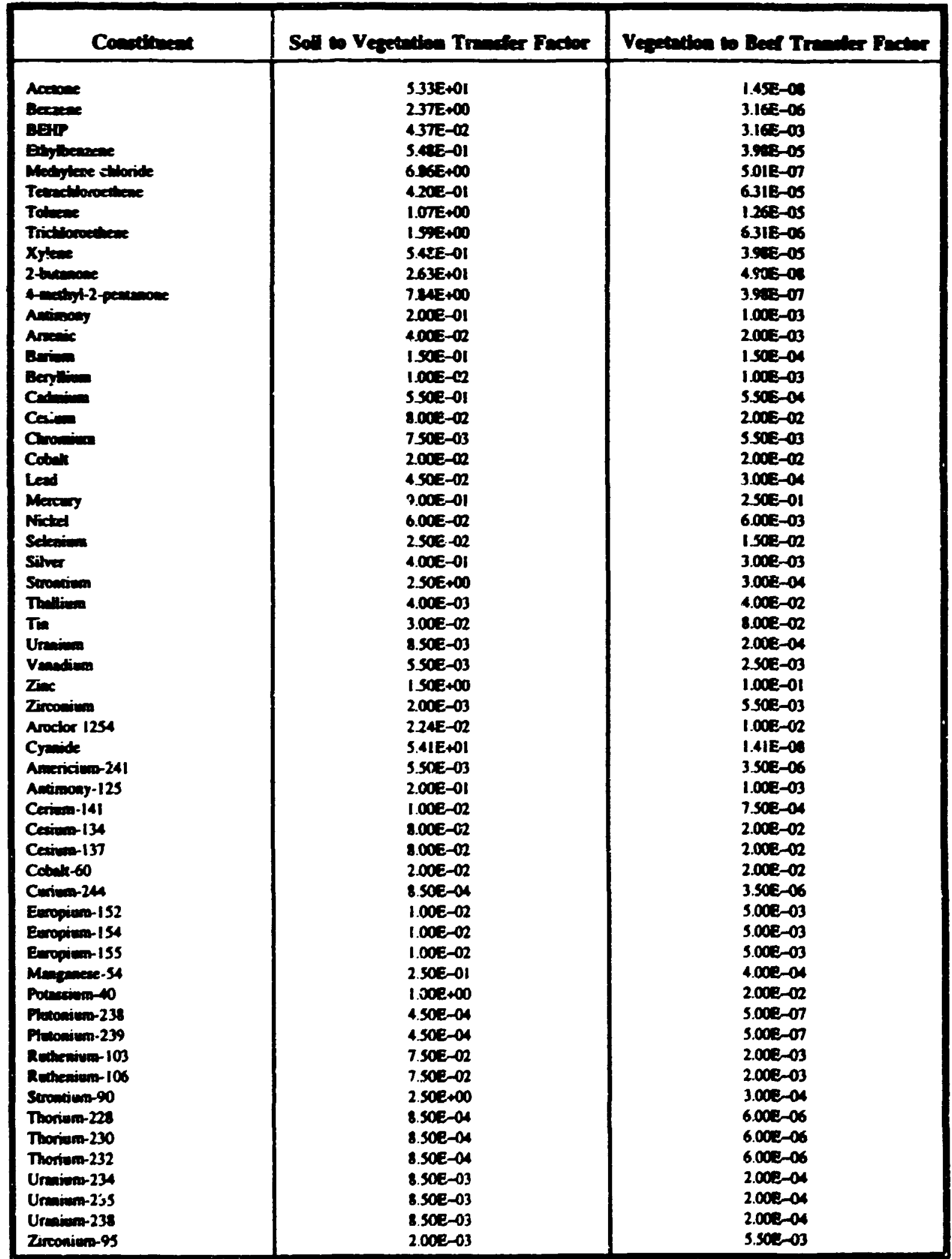

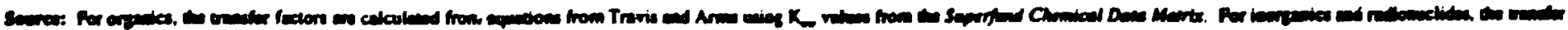

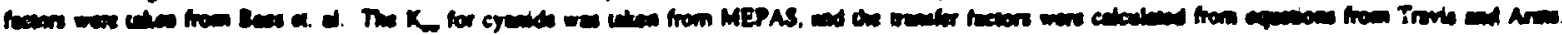




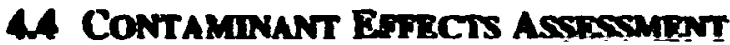

To quantify risk to terrestrial receptors exposed to organic and inorganic contaminants, the daily consumption rate of contaminated food and water, normalized to body weight (in units of me/kg/d), was compared with the NOAEL benchmark (mg/kg/d). Ratios more than 1 are considered to pose a potential risk to organisms but do not necessarily indicate the severity of the effect(s). However, it is reasconable to assume thin the higher the ratio, the greater the risk of adverse effects. Dose to terrestrial receptors, including vegetation. from internal and external exposure to redionuclides was also determined from calculated tissue concentrations and soil concentrations, respectively. Doses that exceeded $0.1 \mathrm{rad} / \mathrm{d}$ were considered to pose a potential risk to terrestrial organisms (IAEA 1992). Methods used tc uculate exposure and risk are described in apf :ndix $A$.

Toxicological benchmarks for terrestrial organisms, excluding vegetation, were obtained from Opresko and Suter (1992) (table 4-8). For representative receptor species that were not listed in the data base, extrapolation techniques were employed to obtain the chronic NOAEL by adjusting for differences in body weight between the receptor and a test organism. If a NOAEL was available for a laboratory test species, the NOAEL for a receptor species could be calculated. Many of the NOAEL benchmarks were derived by extrapolation from smallmammal laboratory data (Opresko and Suter 1992). No wildlife toxicity data were found for a few contaminants. For these cases, wildlife NOAELs were extrapolated from human noscarcinogenic toxicity data (i.e., RfDs) listed in the MEPAS constituent data base, normalized to the "standard man" body weight of $70 \mathrm{~kg}$. Thus, for our purposes. wildlife species that weigh less than $70 \mathrm{~kg}$ would have a higher benchmark than humans, and the opposite would be true for wildlife species weighing more than $70 \mathrm{~kg}$.

Literature sources for inorganic terrestrial phytotoxicity benchmarks were summarized and reported by Suter and Futrell ( $10 ; j)$ (table 4-8). Where applicable, the lowest source concentration in a soil medium that produced phytotoxically excessive effects was chosen from the data hase. Several henchmorts yese derived from experiments using outrient solutions. However, uncertainty values were not applied to these data to account for differences in growth media.

As cited in the MMR Air National Gmard Rist Assessment Handboot (1992), Eskew and Babb developed a methodology for deriving phytotoxicity beachmarts for organic constituents (table 4-8). Estimned critical concentrations (me/kg wet weight) for soil were calculeted from experimental dation on the uptike of compounds from nutrient solution or vapor phase by determining the distribution of a compound between the soil solution and absorption to organic maner with the use of a $K_{\alpha c}$ value. The $K_{\infty}$ value was estimuted from the chemical-specific $\mathbf{K}_{\mathrm{ow}}$. Ascumptions used to derive toxicity beachmerts were (1) a soil organic content of 1\%, (2) a bulk soil density of $1.3 \mathrm{~g}^{\prime} \mathrm{cm}^{3}$, and (3) a soil water content of $18 \%$. The organic fraction of the soil is the primary factor in determining bioavailability of organic compounds to plant rooks. Use of these assumptions was determined to be applicable since the average soil organic matter at INEL is 1.7\% (0.8 - 2.4\%) (Rope et al. 1988). Uncertainty factors were applied to adjust the data from acute to chronic effects and from $50 \%$ inhibition of growth to lowest toxic effect levels.

Riske to aquatic organisms from exposure to organic and inorganic contaminants in water and sediments (pore water) were calculated through comparison of the water or sediment pore-water concentrations with the chemical-specific aquatic benchmark (Suter et al. 1992) (table 4-8). To determine internal dose to aquatic plants, fish, and muskrats from exposure to radionuclides, the surface-water concentrations were multiplied by radionuclide and organism-specific aquatic (internal) dose conversion factors to produce a daily dose in rads (Killough and McKay 1976). To determine the internal dose to benthic macroinvertebrates and cther bottom-dwelling organisms (e.g., fish larvae) from exposure to radionuclides, the sediment pore-water concentrations were multiplied by radionuclide and organism-specific aquatic (internal) dose conversion factors to produce a daily dose. The extemal dose to all organisms was determined by 


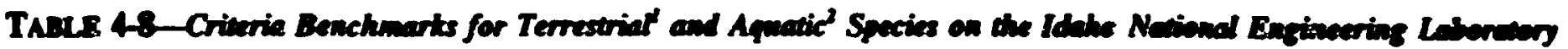

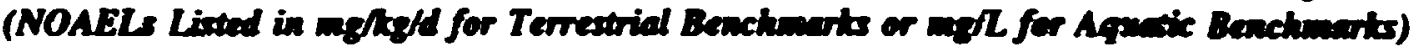

\begin{tabular}{|c|c|c|c|c|c|c|c|c|}
\hline Conسm & Mese & Mrs rath & Jadoriben & Procenters & $\mathrm{Com}_{\mathrm{m}}$ & somplund & 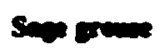 & Mand \\
\hline Acentere & $2.52 E+01$ & $927 \mathrm{E}+00$ & $5.36 E+\infty 0$ & $1.96 E+\infty 0$ & 9S6E-OI & 1.67E+01 & SSSE +00 & $6.67 \varepsilon+\infty 0$ \\
\hline Deareare & $6.29 E+\infty 0$ & $2.32 E+\infty 0$ & $1.34 E+00$ & $4.90 E-01$ & $2.39 E-01$ & $4.12 E+\infty 0$ & $1.40 E+\infty 0$ & $1.67 E+\infty 0$ \\
\hline BerP & NA & NA & NA & NA & NA & NA & MA & MA \\
\hline Burbeanase & NA & NA & NA & NA & Ni & MA & NA & $\mathrm{NA}$ \\
\hline Methyleme cillonite & 1,4TEڤOI & $5.42 E+100$ & $3.14 E+00$ & $1.15 E+\infty 0$ & $560 E-01$ & $9.78 x+\infty$ & $32 \pi E+\infty 0$ & $3.90=+\infty 0$ \\
\hline Terectlonoctiene & $1.5 S E+00$ & $5.72 E-01$ & $3.31 E-01$ & $1.21 E-01$ & $5.900-02$ & $1.036+\infty 0$ & $3.45 E-01$ & $4.12 E-01$ \\
\hline Taluese & $5.61 E+01$ & $2.07 E+01$ & $120 E+01$ & $437 E+\infty 0$ & $2.13 E+\infty 0$ & 3.73E+01 & $1.25 E+01$ & $1.496+01$ \\
\hline 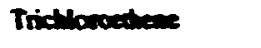 & $1.66 E+02$ & $6.13 E+01$ & 3.55E+01 & $1.30 E+01$ & $6.33 \mathrm{E}+60$ & $125 E+\infty$ & $420 E+01$ & $5.00 E+01$ \\
\hline Xstere & $1.26 E+03$ & $4.63 E+02$ & $2.608+02$ & $9.79 E+01$ & $4.78 E+01$ & $836 E+00$ & $2.00 E+02$ & $3.33 E+\infty 0$ \\
\hline 2tater & $2.31 E+01$ & $8.52 E+\infty 0$ & $4.93 E+100$ & $1.80 E+\infty 0$ & $8.00 z-01$ & |SAE+01 & $5.15 E+00$ & $6.14 E+\infty 0$ \\
\hline 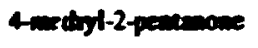 & $|26 E+0|$ & $4.63 E+00$ & $2.60 E+\infty 00$ & $79 E-01$ & $4.78 E-01$ & $8362+\infty 0$ & $2800 E+100$ & $3.33 E+\infty 0$ \\
\hline Ansiosony & $1.25 E+04$ & $4.61 E+03$ & $2.67 E+03$ & $9.73 E+02$ & 4.75E+02 & $8.31 E+03$ & $278 E+03$ & $3.31 E+03$ \\
\hline Ansmix & $1.05 E-01$ & $2.26 E+00$ & $1.31 E+00$ & $8.10 E-01$ & $3.96 E-01$ & $700=-02$ & $1.36 E+100$ & $1.63 E+\infty 0$ \\
\hline Briven & $1.28 E+00$ & $4.73 E-01$ & $2.73 E-01$ & $9.99 E-02$ & $4.8 x E-02$ & B.52E-01 & 2.85E-01 & $3.40 E-01$ \\
\hline Benglitien & $1.36 E+00$ & $5.00 E-01$ & $2.90 E-01$ & $1.06 E-01$ & $5.16 E-02$ & $9.028-01$ & $3.02 E-01$ & $3.60 E-c 1$ \\
\hline Consinan & $2.42 E-02$ & $8.92 E-03$ & $5.16 E-03$ & $1.896-03$ & $9.21 \mathrm{E}-04$ & $1.44 t-01$ & $1.96 E-03$ & $1.260-02$ \\
\hline Cerives & NA & NA & NA & NA & NA & NA & NA & NA \\
\hline Cronimen & $6 . C 4 E+\infty 0$ & $2.22 E+00$ & $1.29 E+00$ & $4.708-01$ & $2.30 \mathrm{e}-01$ & $4.01 E+00$ & $1.34 E+00$ & $1.60 E+\infty 0$ \\
\hline Cotan & NA & NA & NA & NA & NA & NA & NA & MA \\
\hline Lead & $7.29 E-03$ & 2.69E-03 & $1.56 E-03$ & $3.682-04$ & $2.77 E-04$ & I.SSE- 02 & $9.858+00$ & $1.17 E+01$ \\
\hline Merewy & $|47 E+0|$ & $2.22 E-02$ & $5.58 E-03$ & $2.296-02$ & $1.12 E-02$ & $3.19 E+00$ & $5.096-01$ & $2.83 E-02$ \\
\hline Nicket & $6.07 E+01$ & $2.24 E+01$ & $1.29 E+01$ & $4.73 E+00$ & $2.31 E+00$ & $4.1 T E+\infty 0$ & $1.40 z+00$ & $1.6 \pi t+\infty 0$ \\
\hline Setenium & $0.32 E-02$ & $2.33 E-02$ & $1.35 E-02$ & $4.92 E-03$ & $2.40 e-03$ & $2.51 E-01$ & $8.392-02$ & $1.00 E-01$ \\
\hline Silver & NA & NA & NA & NA & NA & NA. & NA & NA \\
\hline Scroescium & $6.62 E+02$ & 2. $40 E+02$ & $1.41 E+02$ & S 15E+01 & $2.52 E+01$ & $4.40 E+02$ & 1.47E+02 & $1.75 E+02$ \\
\hline Thallium & $2.52 E-02$ & $9.2 \pi E-03$ & $3.36 \mathrm{E}-03$ & $1.96 \mathrm{E}-03$ & $956 E-04$ & $1.6 \pi-02$ & $5.59 e-03$ & $6.67 E-03$ \\
\hline Tin & NA & NA & NA & NA & NA & NA & NA & NA \\
\hline Uraium & $1.56 \mathrm{E}-01$ & $3.74 E-02$ & $3.32 \mathrm{E}-0$ ? & $121 E-02$ & $5.93 \mathrm{E}-03$ & $2.20 e_{+01}$ & $7.35 \mathrm{E}+100$ & s. $m E+\infty$ \\
\hline Vmadiun & $2.37 \mathrm{E}-\mathrm{O} \mathrm{I}$ & $8.73 E-02$ & S.05E-C2 & $1.84 E-02$ & $9.01 E-03$ & $1.57 E-01$ & $5.27 \mathrm{E}-02$ & $6.28 \mathrm{E}-02$ \\
\hline Zixc & $2.44 \mathrm{E}+01$ & $8.99 E+00$ & $3.20 E+\infty 0$ & $1.90 \mathrm{e}+00$ & $9.28 \mathrm{e}-01$ & $1.62 \mathrm{E}+01$ & $5.43 E+100$ & $6.47 \mathrm{E}+00$ \\
\hline Zirconium & $7.76 \mathrm{e}-02$ & $286 \mathrm{E}-02$ & $1.65 \mathrm{E}-02$ & $6.04 E-03$ & 2.95e-03 & $3.160-02$ & $1.73 E-02$ & $2.06 e-02$ \\
\hline Aroctor 1254? & $1.45 E-01$ & $6.03 E-02$ & $3.50 e-12$ & $1.7 r E-02$ & $8.63 \mathrm{E}-03$ & $3.19 \pi+\infty 0$ & $1.30 E+\infty 0$ & $1.55 \mathrm{E}+\infty 0$ \\
\hline Cyenidetion & $2.72 E+01$ & $1.00 E+01$ & $3.79 E+00$ & $2.30 R-02$ & $1.37 z-02$ & $1.800+01$ & $6.01 E+00$ & $7.20 e+00$ \\
\hline
\end{tabular}

NA a Benctur te not avilable.

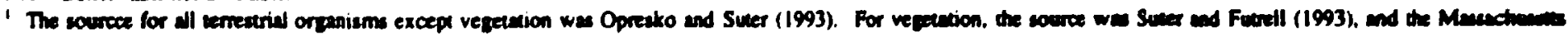
Milien Reservecion Rick Ascesement Handbook (1992).

2 The source for equetic benchmerts was Suter a d. (1992). 


\begin{tabular}{|c|c|c|c|c|c|c|c|}
\hline Concturest & Surthe & TAE ba & F. Anwt & Baid enters & Cogneste & Apunde & Veonition \\
\hline Aatwose & $1.97 E+01$ & $3.27 E+01$ & $6.31 E+00$ & $4.27 \Xi+00$ & $2.80 E+\infty$ & $2.3 \pi E+01$ & $9.65 \mathrm{E}+01$ \\
\hline Benteare & 4.94E+00 & $8.18 E+00$ & $1.58 E+00$ & $1.07 E+\infty$ & $6.99 E-01$ & $2.10 E-12$ & NA \\
\hline BEHP & NA & NA & NA & NA & NA & $3.00 E-04$ & $1.40 \mathrm{E}+01$ \\
\hline Ethylbenzene & NA & NA & NA & NA & NA & 4.40E-01 & NA \\
\hline Methylene chibride & $1 .|S E+0|$ & $1.91 E+01$ & $3.69 E+00$ & $2.50 E+\infty 0$ & $1.64 E+00$ & $4.10 \mathrm{E}-01$ & $5.602+00$ \\
\hline Tetrachloroethene & $1.22 E+00$ & $2.02 E+00$ & $3 x E-01$ & $2.63 E-01$ & $1.73 E-01$ & $5.00 E-01$ & $1.57 E+01$ \\
\hline Tolvene & $4.40 E+01$ & $7.29 E+01$ & $|.41 E+0|$ & $9.52 \varepsilon+00$ & $6.24 E+100$ & $2.60 E-02$ & $9.702+00$ \\
\hline Trichloroethene & $1.48 E+02$ & $2.16 E+02$ & $4.74 E+01$ & $3.20 E+01$ & $1.85 E+01$ & $5.76 E+00$ & $6.702-01$ \\
\hline Xylene & $9.87 E+02$ & $1.64 E+03$ & $3.16 E+02$ & $2.13 E+02$ & $1.40 E+02$ & $2.68 E+\infty 0$ & $2.40 \sum+01$ \\
\hline 2-bucenose & $1.82 E+01$ & $3.01 E+01$ & $5.81 E+00$ & $3.93 E+00$ & $2.57 E+\infty$ & $1.78 E+01$ & NA \\
\hline 4-owechyl-2-pentinone & $9.87 E+00$ & $1.64 E+01$ & $3.16 E+00$ & $2.13 E+\infty 0$ & $1.40 \mathrm{E}+\infty 0$ & $1.59 E+00$ & NA \\
\hline Antinday & $9.81 E+03$ & $1.63 \mathrm{E} \nrightarrow 04$ & $3.14 E+03$ & $2.12 E+03$ & $1.39 E+03$ & $1.908+00$ & $5.00 E+00$ \\
\hline Armonic & $8.27 E-02$ & $1.37 \mathrm{E}-01$ & $2.61 E+\infty 0$ & $1.77 E+\infty$ & $1.16 E+\infty 0$ & $9.32 E-01$ & $1.508+01$ \\
\hline Berium & $1.01 E+\infty$ & $1.67 E+\infty 0$ & $3.22 \mathrm{E}-01$ & $2.18 E-01$ & $1.43 \mathrm{E}-01$ & $2.03 E+01$ & $5.00 \mathrm{E}+02$ \\
\hline Beryllium & $1.07 E+00$ & $1.77 E+00$ & $3.41 E-01$ & $2.31 E-01$ & $1.51 \mathrm{E}-01$ & $3.80 \mathrm{E}-03$ & $1.00 \varepsilon+01$ \\
\hline Codmium & $|.70 \varepsilon-0|$ & $3.15 E-02$ & $2.24 E-03$ & $1.51 E-03$ & $2.69 \mathrm{E}-03$ & $1.10 E-03$ & $3.002+00$ \\
\hline Cerion & NA & NA & NA & NA & NA & NA & NA \\
\hline Chronium & $4.74 E+00$ & $7.85 E+\infty 0$ & $1.52 E+\infty 0$ & $1.02 E+00$ & $6.71 E-01$ & $1.10 E-02$ & $7.50 \Sigma+01$ \\
\hline Cobent & NA & NA & NA & NA & NA & $4.40 E-03$ & $2.502+01$ \\
\hline Lead & $1.88 E-02$ & $9.49 E-03$ & $|| 1 E+0 \mid$. & $7.51 E+00$ & $8.11 \mathrm{E}-04$ & $3.20 \varepsilon-03$ & $1.002+02$ \\
\hline Mercury & $3.77 E+00$ & $1.92 E+01$ & $5.74 E-01$ & $3.88 E-01$ & $2.91 E-03$ & $1.30 E-03$ & $3.00 \mathrm{E}-01$ \\
\hline Nickel & $4.93 E+00$ & $7.90 E+01$ & $1.58 E+00$ & $1.07 E+00$ & $6.75 E+00$ & $\mid .60 \varepsilon-0]$ & $1.002+02$ \\
\hline Selenium & $2.96 E-01$ & $8.22 E-02$ & $9.47 \mathrm{E}-02$ & $6.40 E-02$ & $7.03 E-03$ & $3.50 z-02$ & $5.00 \pm+00$ \\
\hline Silver & NA & NA & NA & NA & NA & $2.00 \varepsilon-04$ & $2.002+00$ \\
\hline Strontium & $5.19 E+02$ & $8.61 E+02$ & $1.66 \mathrm{E}+02$ & $1.12 E+02$ & $7.36 \mathrm{E}+01$ & NA & NA \\
\hline Thallium & $1.97 \varepsilon-02$ & $3.27 E-02$ & $6.31 E-03$ & $4.27 E-03$ & $2.80 E-03$ & $6.40 z-02$ & $1.008+00$ \\
\hline $\operatorname{Tin}$ & NA & NA & NA & NA & NA & NA & NA \\
\hline Urmium & $2.59 \mathrm{E}+01$ & $2.03 E-01$ & $8.30 E+00$ & $5.61 E+00$ & $1.73 \mathrm{E}-02$ & $2.708-02$ & NA \\
\hline Venadium & $1.86 E-01$ & $3.08 E-01$ & S.95E-02 & $4.02 E-02$ & $2.63 \mathrm{E}-02$ & $4.10=-02$ & NA \\
\hline Ziac & $1.91 \mathrm{E}+01$ & $3.17 E+01$ & $6.13 E+00$ & $4.14 E+\infty 0$ & $2.718+\infty 0$ & $1.100-01$ & $7.008+01$ \\
\hline Zirconium & $6.09 E-02$ & $1.01 E-01$ & $1.95 \mathrm{E}-02$ & $1.32 \mathrm{E}-02$ & $8.63 \mathrm{E} \sim 03$ & $2.51 \mathrm{E}-01$ & NA \\
\hline Aroclor 1254 & $3.77 \mathrm{E}+\infty 0$ & $\mid .89 E-01$ & $1.47 E+00$ & $9.92 E-01$ & $2.52 \mathrm{E}-02$ & $5.202-04$ & $1.002+01$ \\
\hline Cyanideion & $2.13 \mathrm{E}+01$ & $3.53 \mathrm{E}+01$ & $6.82 E+00$ & $6.11 E-62$ & $4.00 E-02$ & $5.20 \mathrm{E}-03$ & NA \\
\hline
\end{tabular}


multiplying the surface-water concentration by the extemal radionuclide-specific dose conversion factor. Combined internal and external doses more than $1 \mathrm{rad} / \mathrm{d}$ are considered to pose a potential risk to aquatic organisms (NCRP 1991).

For contaminants and receptors that did not pass the average concentratior: screening (section 4.3), an attempt was made to further define exposure risks by comparing receptor species' home range sizes with the potential fraction of the home range occupied by contaminants in food and water from waste sites.

Receptor species at INEL have home ranges or territories that range from small [e.g., less than ] ha ( 1 acre) for aquatic species in waste ponds] to large [e.g., thousands of hectares (acres) for bald eagles and coyotes (table 4-9)]. Some small species have home ranges small enough to be completely within individual waste sites. Other species have such large home ranges that the waste sites would represent only a small part of the arra they would occupy, if the waste sites were used at all. To further interpret the results of the risk analysis, the following assumptions were made about the contaminant exposure to receptors.

1. Burrowing small mammals, insects, and vegetation are known to move radiological contaminants from buried waste where it is presumably redistributed on the surface through the food chain, excrement, and soil dust (Arthur 1982; Markham 1987; Arthur and Markham 1982). The same is probably true for nonradiological contaminants. Because the waste sites are the original sources of contaminants, and data were not provided by PNL for contaminant levels outside the waste sites, the assumption was made that source terms outside waste sites are negligible.

2. The assumption was made that small species with home ranges of 2 ha $(5$ acres) or less (table 4-9) could receive as much exposure as our average screening indicates.
The assurnotion was mide thet wide. ranging species with home ranges more th 42 ha (5 acres) but less than the total area within the waste complexes on the reservation could receive at most 25\% of the exposure cakulated by the average screening if their home range includes as much contaminated area as possible. This assumption is based on the $\mathbf{3 6 0 0}$ ha (8800 acres) of waste sites contained within the 14,000-ha $(35,000$-acre) block where most of the waste sites are located (figure 4-3) (see appendix B). Exposures could be higher if, for instance. the sole source of contaminants is a waste pond used as the only source of drinking water.

4. The assumption was made that species with very large home ranges, greater than the largest waste complex of 14,000 ha ( 35,000 acres) could receive at most a fraction of exposure comparable to the fraction of its home range contained in the total area of waste sites.

5. Only 4500 ha $(11,000$ acres) or $2 \%$ of the surface area of the DNEL reservation is waste sites, which is the only part of the reservation considered for remediation. Biota living in the remaining $98 \%$ of the reservation are exposed only to contaminants that have moved from waste sites by dust and by contaminated wildlife and plants. Although this contamination may be measurable, source terms do not exist for them and assume they are negligible compared with the contamination in the waste sites. Because the assumption was made that the entire INEL reservation is similar habitat, only $2 \%$ of the area supporting ecological endpoints would be affected by contaminants from the waste sites.

6. Except for threatened and endangered species, for which the loss of an individual is considered a 
TABLE 4-9-Territory Sizes of Receptors Chosen for Analysts on the Idaho National Engineering Laboratory Reservation'

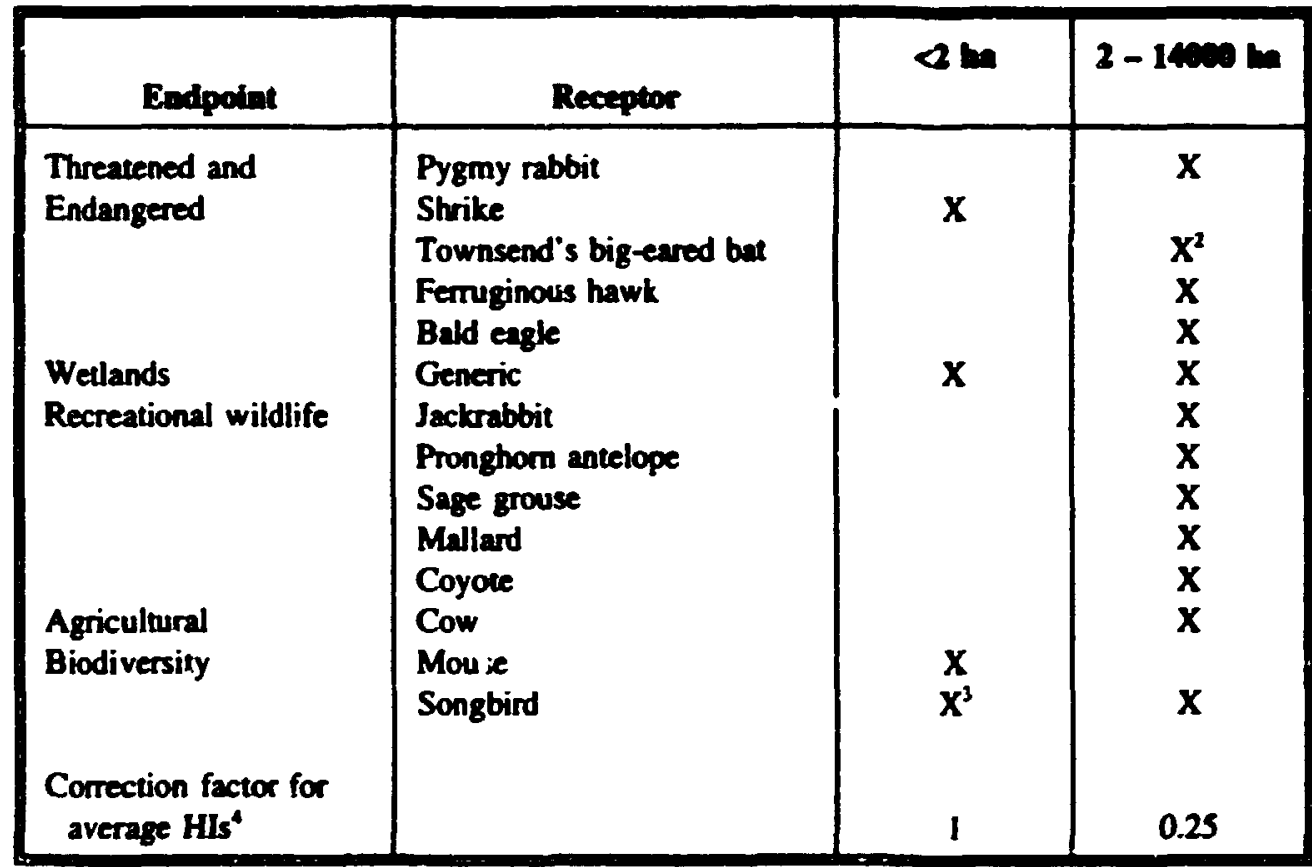

' Data sources are discussed in appendix B.

2 Sizes of feeding territories of bets in general are not known. We assume that Townsend's bigeared bats a INEL have feeding areas of more than 5 acres.

'The songbird selected for our risk analyses was the robin, which generaily has a territory size of more than 2 ha, bun smaller birds can have territories nf less than 2 ha.

- We assume that this will result in HIs for less than 2\% of the populacions on the INEL reservation. See appendix B for discussion of correction factors.

significant risk to the population, the assumption was made that other endpoints are at risk only at the small scale represented by the $2 \%$ of the INEL reservation that is in waste sites.

7. All contaminated wetlands are waste ponds. The assumption was made thatall aquatic biota receive the average exposure to contaminants if they occur in waste ponds. Similarly. the assumption was made that biota in other wetlands are not exposed to contaminants.

8. Grazing livestock are not allowed into contaminated sites. Risks to livestock would be applicable only if livestock were allowed to graze in waste areas.

\subsection{Contaminant hazard Assessments}

\subsubsection{Comparison of Modeled Doses with On-Site Measurements}

To validate the model assumptions and calculations used in determining contaminant exposure and risk to INEL receptors occupying waste sites, site-measured data were compared with modeled values of risk from exposure to the maximum contaminant concentrations. A literature search of the INEL data provided radiological contaminant concentrations in water and selected organisms and nonradiological concentrations in soils and vegetation. Several comparisons were made to validate different aspects of the model. Contaminant concentrations were measured in mice. cottontail and Nuttall's rabbits, pronghom, 3wallows, ducks, coots, arthropods, mourning doves, invertebrates, and sage grouse. Comparisons were made between the modeled hazard indices (HIs) for chemical contaminants or dores for radiological contaminants for the pygmy rabbit and 
jackrabbit, and the calculated HIs (or doses) for cottontail rabbits; between the modeled vsives

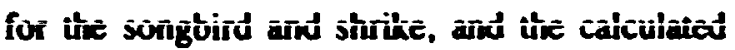
HIs (or doses) for swallows and doves; and between the modeled values for the mallard and the calculated Hls for ducks and coots.

Doses were calculated for receptor species using (1) measured water concentrations for drinking water only, (2) measured soil and vegetation values, (3) measured water and applicable prey tissue concentrations, and (4) measured tissue concentrations in the organism. External dose from exposure to radionuclides was also applied, using measured soil concentrations.

Results of the comparisons indicated that the modeled His or doses were similar to the measured values. With few exceptions, the modeled values were generally within one to two orders of magnitude of the measured values. Most modeled values were greater than the measured values, indicating that the model is not underestimating risk. This was to be expected. since the comparison was made with the modeled maximum contaminant concentrations. In general, the model tended to overestimate the risk from exposure to mercury, ${ }^{17} \mathrm{Cs}$, and ${ }^{60} \mathrm{Co}$ and underestimate the risk from strontium and ${ }^{20}$ sr.

\subsubsection{Baseline}

Baseline HIs for terrestrial receptors exposed to the maximum source concentrations were greater than the criteria limit of 1 for 15 out of 21 inorganic contaminants. There were no exposures to organic contaminants that resulted in HIs greater than 1. Exposure to the maximum concentrations of radionuclides resulted in HIs for all receptors of 30 . Radiological exposure was dominated by external exposure $10{ }^{137} \mathrm{Cs}$ in soils.

Exposures to average soil concentrations at the waste sites were calculated for those contaminants whose maximum concentrations resulted in HIs greater than I (table 4-10). Compared with the maximum HIs, exposure to the average concentrations at INEL waste sites resulted in a $28 \%$ decrease in the number of contaminants with HIs greater than I. In other words, $72 \%$ of the contaminants the resulted in HIs greater than 1 from exposure to the

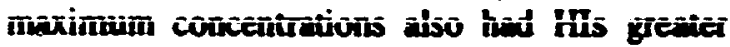
than I from exposure to average concentrations.

About $90 \%$ of the $\mathrm{HI}$ values were less than 10, 8\% were above 10 but less than 1000 , and $2 \%$ were still greater than 1000 . Exposure to zirconium was responsible for those HIs that exceeded 1000.

Exposure of aquatic organisms to maximum concentrations of nonradiological contaminants in surface water did not result in any HIs over 1 (cesium and cobalt were the only constituents with measured concentrations in surface water). Exposure of benthic macroinvertebrates to the maximum sediment pore-water concentrations (calculated from sediment concentrations) resulted in many His greater than 1. Plazard indices resulting from exposure to the average pore-water concentrations were identical to the maximum HIs (table 4-11); this is because there was only one value given in the source terms, and it was not clear whether it represented the maximum or the average concentration

Exposure to boch the maximum and average concentrations of radionuclides in the surface water or in the sediment pore water (macroinvertebrates only) resulted in HIs (or doses) greater than 1 for only benthic macroinvertebrates (table 4-12). The primary contributing radionuclide was the gamma emitter ${ }^{134} \mathrm{Cs}$.

The initial screening using average contaminant values indicated 21 contaminants resulting in HI values greater than 10 (i.e., severe risk from contaminants) or HI values greater than 1 (i.e., moderate risk from contaminants) for various endpoints (tables 4-10, 4-11). Following the assumptions cutlined in section 4.4, the approximate home range or territory size of receptors was used to determine the proportion that could potentially be contained within waste sites. Of the receptors included in the analyses, only the shrike and the deer mouse occupy a srrall enough area (table 4-9) to potentially live entirely within contaminated areas [(e.g., less than 2 ha (5 acres)]. Some small wetlands are less than 2 ha ( 5 acres) in extent, and vegetation and small songbirds can occupy smal areas. All 
other receptors included in the analyses had territories or horne renges grester then 2 he (9 actes) and less than the largest waste complex [1400 ha (35,000 acres)] (appendix B). The basis of the assumptions discussed in section 4.3 and appendix B, appropriate correction factors were applied to His in table 4-10, 4-11 and 4-12 to determine potential severity of risks to endpoints. For species with home ranges or territories less than 2 ha (5 acres) (e.g., the shrike and the deer mouse), no correction factor was used. For species with home ranges or territories more than 2 ha (5 acres) but less than 1400 ha $(35,000$ acres), a correction factor of 0.25 was used. No species had home ranges or territories more than 1400 ha $(35,000$ acres).

Some contaminants may be highly localized, but data bo not exist for their areal distribution. Of the contaminants which analyses indicate result in moderate to severe risks, source terms for $\mathbf{Z r}$ represent less than 0.004 ha (0.01 acres), and Sb, $\mathrm{Ni}$, and $\mathrm{Tl}$ represent less than 0.2 ha (0.5 acres) of contaminated land (appendix A). Except for total radiological contaminants, for which our source terms represent more than 120 ha (300 acres), source terms for all other contaminants represent 1 to 40 ha (3 to 100 acres). Although data for most contaminants were mported for only a small fraction of the total area in waste sites, the data were assumed to be representative. All source terms used in our risk analysis are. therefore, assumed to be present in all $\mathbf{4 5 0 0}$ ha (11,000 acres) of waste sites (appendix B). Although this may not be a realistic assumption for all contaminants, it is acceptable for comparison of risks from remediation altematives.

\subsubsection{Threatened and Endangered Species}

- Risks to some threatened and endangered species would be moderate or severe if individuals a small songbird can occupy waste sites. Potentially severe risks would be present for shrikes (sum of radiosctive contaminants) and pygmy rabbits (zirconium). Potentially moderate risks would be present from these and other contaminants to all threatened and endangered species (cable 4-13a). Although the analyses indicate potential risks to these species, a sitespecific survey of individual waste sites for occurrences of threatened and endagered species

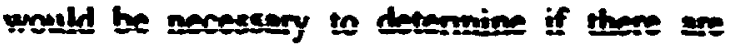
actual risks.

\subsubsection{Wetlands}

Risks to wetlands receptors (e.g., benthic macroinvertebrates) would be severe from tea contaminants in waste ponds and moderate from nickel and vanadium (table 4-13b). However, because it was assumed that non-waste-pond wetlands are not contaminated, risks to receptors in natural wetands from contaminants would be negligible.

\subsubsection{Recreational Species}

For some recreational species occupying waste sites, risks from $\mathrm{Ba}_{2} \mathrm{Zr}$, and $\mathrm{Pb}$ would be severe (table 4-13c). Additional moderate risks would also be possible from $\mathrm{Cd}$, cyanide, $\mathrm{H}_{\mathrm{g}}$, and tocal radioactive contaminants. Risks to individualsthat do not occupy waste sites would be negligible, and because less than 25 of the reservation is waste sites, overall risks to populations of wildlife on the reservation would be negligible.

\subsubsection{Agriculture}

Barium. $\mathrm{Pb}$, and $\mathrm{Zr}$ would pose severe risks to cattle if waste sites were used for grazing (table 4-13d). Similariy, cadmium, cyanide, and total radiological contaminants would pose moderate risks to cattle. However, catte do not graze in waste areas; therefore, potential risks to livestock are negligible.

\subsubsection{Public Lands}

Because risks to receptor spucies in the food web would be negligible unless receptors occupy waste sites and because the reservation boundaries adjacent to public lands are more than $10 \mathrm{~km}$ ( 6 miles) from waste sites, risks to public lands would be negligible. Although wide-ranging species (e.g., coyote, hawks, eagles, sage grouse, migratory waterfowl, and pronghom) are capable of transporting contaminants to public lands, risks to populations of these species would be negligible. 
TABLE 4-10_Baseline Hazand Indices for Terrestrial Organisms on the Idako National Engineering Laboratory

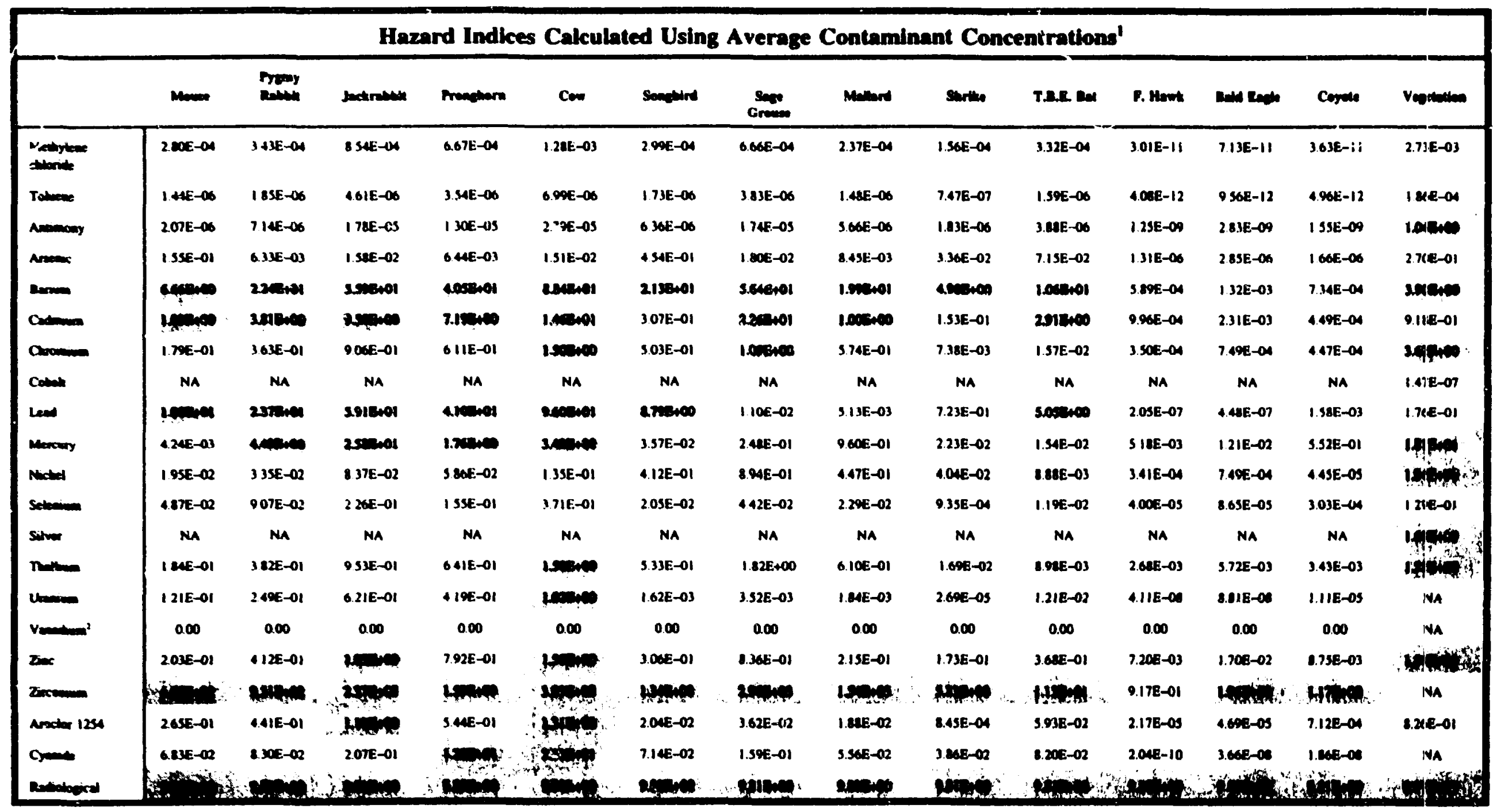

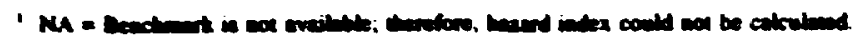

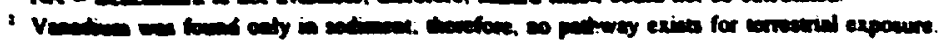


TAeuE 4-11-Baseline Chemical Barand Indices for Aqmatic Ongonisons

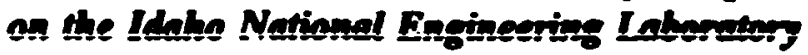

\begin{tabular}{|c|c|c|}
\hline Consthent & 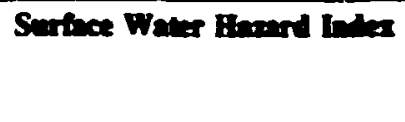 & 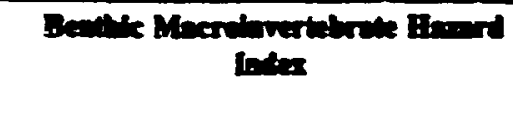 \\
\hline Methylene chloride & 0.00 & \\
\hline Totwene & 0.00 & \\
\hline Antimony & 0.00 & $1.96 E-01$ \\
\hline Arsenic & 0.00 & $6.22 \mathrm{E}-02$ \\
\hline Barium & 0.00 & $240 E-01$ \\
\hline Codmium & 0.00 & \\
\hline Chromium & 0.00 & \\
\hline Coban & $5.20 E-10$ & \\
\hline Lead & 0.00 & \\
\hline Mercury & 0.00 & \\
\hline Nickel & 0.00 & \\
\hline Selenium & 0.00 & $1.14 E-01$ \\
\hline Silver & 0.00 & \\
\hline Thallium & 0.00 & 0.00 \\
\hline Unnium & 0.00 & 0.00 \\
\hline Vanadium & 0.00 & 3 \\
\hline Zinc & 0.00 & $i$ \\
\hline Zirconium & 0.00 & 0.00 \\
\hline Aroctor 1254 & 0.00 & 0.00 \\
\hline Cyanide ion & 0.00 & 0.00 \\
\hline
\end{tabular}

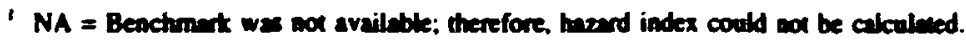

TABLE 4-12-Average Internal and External Radiological Doses to Aguatic Onganisms (radd) on the Idaho National Engineering Laboratory

\begin{tabular}{|c|c|c|c|c|c|}
\hline & $\begin{array}{c}\text { External Beta and } \\
\text { Gamma }\end{array}$ & Interanl Plants & $\begin{array}{l}\text { Internal Beotilic } \\
\text { Macroiavertebrates }\end{array}$ & Internal Piah & $\begin{array}{l}\text { Interned } \\
\text { Modarats }\end{array}$ \\
\hline Cesium-134 & 0.00 & 0.00 & 8.53E+04 & 0.00 & 0.00 \\
\hline Cesium-137 & $9.53 \mathrm{E}-09$ & $6.99 E-07$ & $7.79 E+04$ & $3.50 E-06$ & $4.93 E-06$ \\
\hline Cobalit 60 & $3.41 \mathrm{E}-07$ & $3.97 \mathrm{E}-05$ & $3.13 E+06$ & $3.97 E-06$ & $7.81 E-06$ \\
\hline Pluronium-239 & 0.00 & 0.00 & $9.61 E+00$ & 0.00 & 0.00 \\
\hline Thorium-232 & 0.00 & 0.00 & 0.00 & 0.00 & 0.00 \\
\hline Uranium-234 & 0.00 & 0.00 & $5.52 \mathrm{E}+00$ & 0.00 & 0.00 \\
\hline Total dose & $3.50 \mathrm{E}-07$ & 4.04E-OS & $3.30 E+06$ & $7.47 E-06$ & $1.2 \pi \mathrm{E}-05$ \\
\hline
\end{tabular}

1 The benchmark for aquatic organisms is 1 :ad/d, therefore the tocal dose equals the hazard index. 


\subsubsection{Biadiversity}

Rists to overall biodiversity of the sagebrushsteppe ecosystem on the reservation would be negligible because waste sites occupy caly $2 \%$ of the tool land area However, as discussed for other entroints, there would be potential risks to some receptors important to biodiversity in waste sites. In addition to the receptor species discussed previously. Pb. Zr, and total radiological contaminants pose potentially severe risks, and Ba and Cd pose potentially moderate rists to mice or songtirds tha could occupy waste sites (table 4-13e). In addition to these contaminants, vegetaxion is also potentially at severe risk from $\mathrm{H}_{\mathrm{g}}$ and at moderate risk from $\mathrm{Sb}, \mathrm{Cr}, \mathrm{Ni}, \mathrm{Ag}, \mathrm{M}$, and $\mathrm{Zn}$ in waste sites. $\mathrm{On}$ the basis of calculated risks to Townsend's bigeared bat (table 4-9), risks to bats inhabiting lava tube caves and feeding within waste sites would be moderate for $\mathrm{Ba}, \mathrm{Pb}, \mathrm{Zr}$, and total radiological contaminents table (4-13a).

\subsection{Fhattat Disturbance Asstassment}

As urban and agricultural development increasingly fragments the nation's ratural landscape large, undisturted, and protected blocks of natural landscape are becoming more important for the protection of biodiversity. The INEL reservation is a large block of relatively undisturbed native sagebrush-steppe grassland. Rangeland and lava flow areas in the surrounding counties are similar ecologically. As is clearly seen on acrial photos, much of the surrounding area (table 414) is in agricultural use (i e., farm or rangeland), especially to the north and west of the reservation.

The nine major facilities on the reservation occupy 150 ha (370 acres), and public roads, utility, and railroed rights-of-way occupy an additional 13,349 ha $(33,480$ acres $)$ (predecisional draft EIS for INEL, September

\subsubsection{Baseline}

Because no additional disturbasce resulting from restoration activities is included in the baseline altemative, no additional disturbance beyond the current $6 \%$ of the reservation is expected.

\subsection{Cumurative Assessuigert}

\subsubsection{On-Site}

\subsubsection{Baseline}

For 17 contaminants, His sugest potentil risks to orgenisms inhubiting waste sites (cable 4-15). Of these contaminants, 4 pose potential rists only to waste pond wetiands and two (antimony and thallium) pose potential istes only to other elements of biodiversity (e.g., vigetation growing on waste sites; table 4-13e). Brium, Cd, Cr, Po, Hs. Zr. and total radiological contamianmes pose potertial rists to many endpoints occupying waste sites. Most of the waste sites are highly developed areas the do not provide suitable habita for most organisms. Actual risks associnted with these sites are probably lower than indicated by the H. Wis. Wife and waterfowl probably use waste ponds; therefore. for these organisms current exposures may be substantial. For all of the sites, a future scenario involving closure of the INEL facility without restoration would result in reoccupation of all waste sites by plants and animals; risks similar to those indicated in table 4-15 would then be expected.

Determining cumulative risks to endpoints that do not occupy waste sites is more problematic. Data were not adequate to determine facilitywide contaminant levels. Moreover, many of the inorganic contaminants (e.g., metals) included in our analyses are known to occur in soils throughout the United States at concentrations greater than or equal to concentrations in the INEl source-term data base (table 4-16). For some of these substances, it is possible that the source lerms reflect naturally occurring concentrations rather than contamination. Even when background levels are known, interpretation of Hls for inorganic substances is often difficult because most analytical rechniques do not distinguish between chemical forms that are available for uprake by organisms (e.g.. dissolved in soil pore water or loosely bound to particles) and those that are biologically unavailable (e.g., insoluble salts). 
TAare 413A-Baseline Potential Rists' to Threatened, Endangered, and Candirate Specios abot

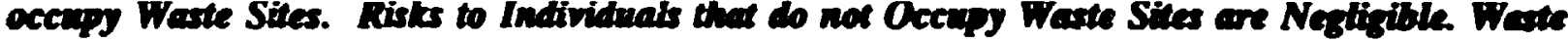
Sites Account for 2\% of the Surface Area of the Idaho National Engineering Laboratory Reservation

\begin{tabular}{|c|c|c|c|c|c|}
\hline & Pyemy Rabbin & Strilke & $\begin{array}{c}\text { Townead is } \\
\text { Bit-Eared } \\
B \times x\end{array}$ & Perrutinoens Hint & Bald Focke \\
\hline $\begin{array}{l}\text { Barium } \\
\text { Cadmium } \\
\text { Lead } \\
\text { Mercury } \\
\text { Zirconium } \\
\text { Radiological }\end{array}$ & $\begin{array}{l}\mathbf{M}^{2} \\
\mathbf{M} \\
\mathbf{M} \\
\mathbf{M} \\
\mathbf{S} \\
\mathbf{M}\end{array}$ & $\begin{array}{l}\text { M } \\
\text { M } \\
\text { M }\end{array}$ & $\begin{array}{l}\mathbf{M} \\
\mathbf{M} \\
\mathbf{M} \\
\mathbf{M}\end{array}$ & $\mathbf{M}$ & $\mathbf{M}$ \\
\hline
\end{tabular}

'Potential risks based on assumptions discussed in Section 4.4.3.

${ }^{2} \mathrm{M}=$ moderate, $\mathrm{S}=$ severe.

TABLE 4-13B-Baseline Potential Rists to Wetlands that are Waste Sites. Risks to Wettands that are not Waste Ponds are Negligible

\begin{tabular}{|l|c|}
\hline Contaminants & Benthic Invertebrates \\
\hline Cadmium & S \\
Chromium & S \\
Cobalt & S \\
Lead & S \\
Methylene chloride & S \\
Mercury & S \\
Nickel & M \\
Silver & S \\
Toluene & S \\
Vanadium & M \\
Zinc & S \\
Radiclogical & S \\
\hline
\end{tabular}

'Based on Environmental Protection Agency Water Quality Criteria (Suter et al. 1992). It is assumed that benthic invertebrates are exposed to porewater concentrations, whereas other wetland (aquatic) organisms are exposed to surface water. 
TARrs 4-13C-Beseline Potential Rishs to Recreational Widnife that occupy Weste Sites. Rislor to Individeals that do not Occapy Weste Sites are Negligille, and Ovenull Rists to Populations of Wildife on the Resernation are Negtigible

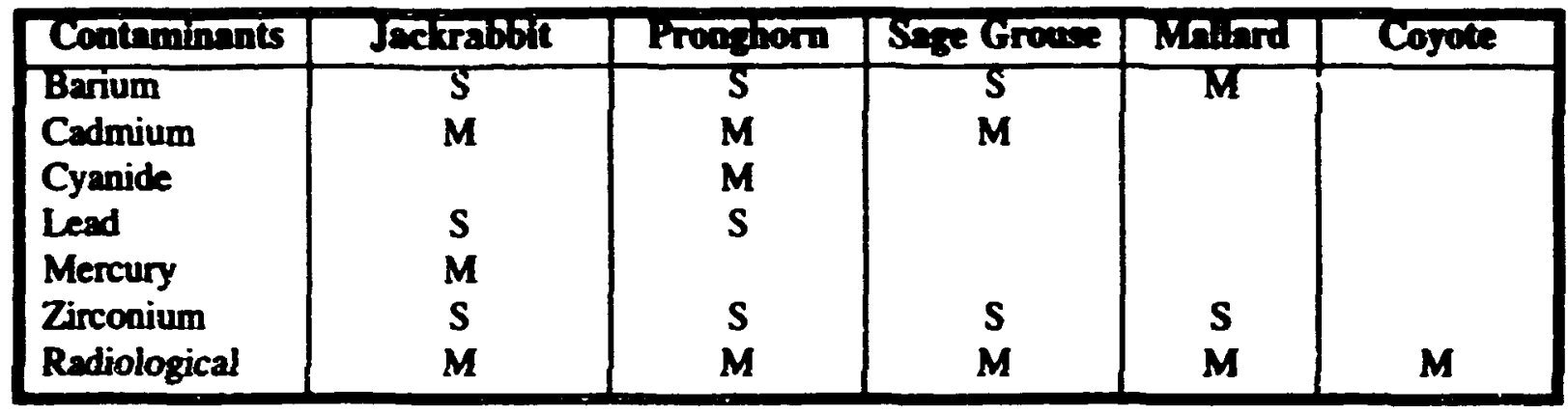

TABLE 4-13D-Baseline Potertial Risks to Cautle that Occripy Waste Sites. Risks to Individuals that do not occupy waste sites are negligible; hence, rists to cattle are negligible in the areas currently used for livestock greaing

\begin{tabular}{|l|c|}
\hline Contaminants & Catte \\
\hline Barium & $\mathbf{S}$ \\
Cadmium & $\mathbf{M}$ \\
Chromium & $\mathbf{M}$ \\
Cyanide & $\mathbf{M}$ \\
Lead & $\mathbf{S}$ \\
Zirconium & $\mathrm{S}$ \\
Radiological & $\mathbf{M}$ \\
\hline
\end{tabular}




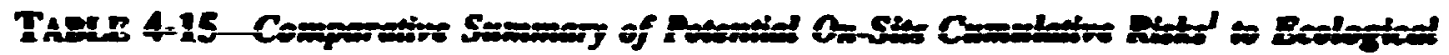

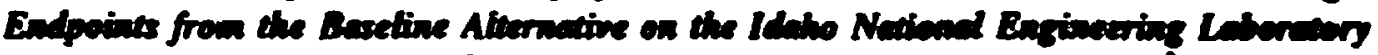

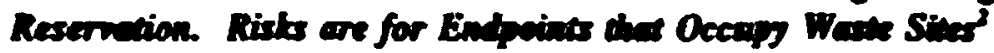

\begin{tabular}{|c|c|}
\hline Contenimat & berely \\
\hline Constructions & \\
\hline Antimoay & $\mathbf{B}^{4}$ \\
\hline Barium & ERB \\
\hline Codnium & E.WR,FB \\
\hline Chroxium & W.F,B \\
\hline Cobalt & $\mathbf{w}$ \\
\hline Cyenide & $\mathbf{R} \mathbf{F}$ \\
\hline Lead & EWR.FB \\
\hline Mercury & EWRB \\
\hline Methylene chloride & $\mathbf{w}$ \\
\hline Nicked & $\mathbf{W}, \mathbf{B}$ \\
\hline Silver & W.B \\
\hline Thallium & B \\
\hline Tolvene & $\mathbf{w}$ \\
\hline Vanadium & $\mathbf{w}$ \\
\hline Zinc & $\mathbf{W}, \mathbf{B}$ \\
\hline Zirconium & E.R.F.B \\
\hline Radiological & EW,R,FB \\
\hline
\end{tabular}

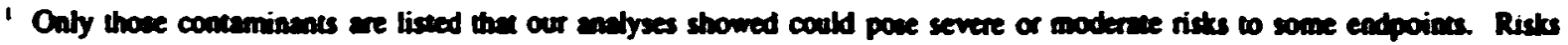
could be severe from a beat one conteminat for each andpoind (sec toble 4).

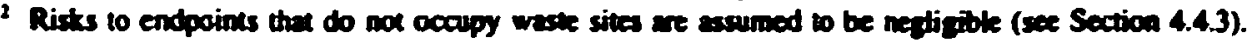

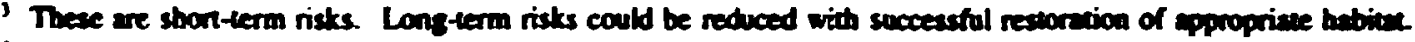

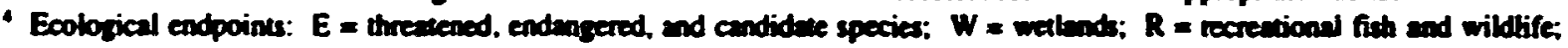
$F=$ apriculure and forestry: $P$ = public land; $B=$ biodiversity (oaly for receptors ax included under other exdpoins).

TABLE 4-16-Comparison of Source-Term Concentrations of Contaninants with Naturadly Occuring Concententions in Parts per Million

\begin{tabular}{|c|c|c|c|c|}
\hline Contaminnt & $\begin{array}{c}\text { Source-Term } \\
\text { Conc. }\end{array}$ & $\begin{array}{l}\text { Ave. Bectroround } \\
\text { Conc. at INEL' }\end{array}$ & $\begin{array}{l}\text { Are. Cone for } \\
\text { Weatern US }\end{array}$ & Necuredly \\
\hline $\begin{array}{l}\text { Antimony } \\
\text { Barium } \\
\text { Cadmium } \\
\text { Chromium } \\
\text { Lead } \\
\text { Metcury } \\
\text { Nickel } \\
\text { Silver } \\
\text { Thallium } \\
\text { Zinc } \\
\text { Zirconium }\end{array}$ & $\begin{array}{c}3.8 \\
2170 \\
3.1 \\
302 \\
19.6 \\
6.0 \\
215 \\
3.7 \\
1.4 \\
143 \\
10500\end{array}$ & $\begin{array}{l}\text { NA } \\
298 \\
0.6 \\
18 \\
12 \\
0.24 \\
18 \\
\text { NA } \\
\text { NA } \\
68 \\
\text { Ni }\end{array}$ & $\begin{array}{c}0.5 \\
580 \\
N A \\
41 \\
17 \\
0.05 \\
15 \\
N A \\
N A \\
55 \\
160\end{array}$ & $\begin{array}{c}<1-2.6 \\
70-5000 \\
N A \\
3-2000 \\
<10-700 \\
<.01-4.6 \\
S-700 \\
\text { NA } \\
\text { NA } \\
<10-2100 \\
20-1500\end{array}$ \\
\hline
\end{tabular}

- Prom Rope a al. (1988).

1 NA = not avaibble.

1 Prom Sheckleuce and Boerngen (1994). 
It wes not possible to definitively determine either the fraction of inorpanic suibstances in the source verm dita base actually anriburable to conconinimation or the fraction of those substances biologically available to organisms living on the reservation. However, evaluation of existing datn on regional background levels permits some tenture conclusions. Ranges of concentran 3 m for thallium throughout the United Stmes are higher then our average source-term den for thit elemen (table 4-16). Therefore, ristes from thallium due to waste sites are probebly eegligible. At present, no den chnreterizing renges of concentrations of cadmium, thallium. and silver are available. All other inorganics for which data were available range in concentrations from less than those given in source terms to much greater than source terms. However, gecmetri means for the western United States were nuch less (e.g- generally less than $1 / 10$ ) than source terms for Sb, $\mathrm{Ba}, \mathrm{Cr} . \mathrm{Hg}$. $\mathrm{Ni}$, and $\mathrm{Zr}$. Lead and zixc source term concentrations were somewhat higher than average background concentrations. Because of the high toxicity of lead, and the uncertainty associated with background variability, risks from lead in waste sites ma; be present. Zinc. however, is an essential element for iife, and source-term concentrations were only about three times the average concentration for the western United States. Risks from zinc, which were found to be present only in wetlands and in vegetation growing on waste sites, are probably negligible.
Despite difficulies in interpremion of the HIs, cumularive rists from aviliblic source-term and benchmat dat are adequate to compere afternatives. Becanse of the relntively small fraction of the WNE reservation the is contuminsted, potential rists to all endpoints except for (1) endangered and threatened species and (2) wildlife using waste ponds appen negligible. Because no reatoraion activities are included in the beceline case hobiton disturbencefirgmenteion risks wonld also be negligible.

\section{7 .2 Onsile}

The only curreaty known mechenism for transport of contuminants from waste sites off the reservation is through ingestion by wideranging wildlife (e.g., migntory waterfowl or prongthom antelope). Of the three classes of contaminants in waste sites (i.e., organics, inorganics, and radionuclides), the only sourree of radionuclides in the region would be DNEL reservation waste sites. Therefore, regional (offsite) cumulative risks for radionuclides would be the same as on-site risks. At the time of our analyses no regional data for organics or inorganics were available, and cumulative risks for the region of influence could not be estimated. 


\section{CHAPTER 5: HANFORD RESERVATION}

The Hanford Reservation in south-central Washington Sute is about 148,000 ba $(365,700$ acres; 560 miles $^{2}$ ) of semiarid sagebrush-steppe vegetaition located just inorth of the confluences of the Snake and Yakima rivers with the Columbia River (figure 5-1). About 6\% of the Ind area has been disturbed and is actively used. Public access to the reservation is restricted (Woodruff and Hanf 1992). The reservation is bordered on the north by the Saddle Mountains. The Columbia River flows through the northern part of the site, and turning south, forms part of the eastern boundary. The Yakima River nus along part of the southem bourdary. Rattlesnake Mountain, Yakima Ridge, and Umtanum Ridge form the southwestern and westem boundary. Two small east-west ridges, Gable Bute and Gable Mountain, rise above the plateat of the central part of the reservation (Cushing 1991). The Arid Lands Ecology (ALE) Reserve, a protected environmental research area, occupies the sounhwestern edge of the reservation. Saddle Mountain National Wildlife Refuge and Wahluke Slope Widdlife Refuge Area occupy the portion of the reservation north of the Columbia River.

This semiarid reservation is one of the largest undisturbed tracts of native sagebrush-steppe remaining in the state of Washington. Big sagebrush is the most common shrub species. Additional shrubs include other species of sagebrush, antelope bittertrush, gray rabbitbrush, greasewood, spiny hopsage, and winterfat. Common grasses are bluebunch wheatgrass, Sandberg's bluegrass, and cheatgrass. In the past, trees were planted for windbreaks and shade. and some have persisted at abandoned farmsteads on the reservation. Wildlife includes 12 species of repriles and amphibians, almost 187 species of birds, 40 species of mammals, including 6 species of bats (Fitzner and Gray 1991), and 43 species of fish. Most species are chancteristic of the semiarid shrub-steppe and river environments of the region. Ecology of the Hanford Reservation is described in detail in Cushing (1991) and Sackschewsky ef al. (1992); information is taken from these reports unless noted otherwise.
Contaminated sites are associnted with facilities in major operational areas and have been grouped into four aggregated areas using identifiable geographic boundaries (figure 5-1). The four aggregated areas, which have been placed on the U.S. Environmental Protection Agency's (EPA) National Priorities List, are as follows:

- The 100 Area occupies sbout $11 \mathrm{~km}^{2}\left(4 \mathrm{mi}^{-2}\right)$. It lies along the Columbia River in the northern portion of the Hanford Reservation and is the site of eight retired plutonium production reactors and the N Reactor (currently in retired status).

- The 200 West and 200 East Areas cover about $16 \mathrm{~km}^{2}$ $\left(6 \mathrm{mi}^{2}\right)$. They lie in the center of the Hanford Reservation near the basalt outcmps of Gable Mountain and Gable Butte. These areas historically were dedicated to fuel reprocessing and waste processing management and disposal activities.

- The 300 Area covers $1.5 \mathrm{~km}^{2}$ $\left(0.6 \mathrm{mi}^{2}\right)$. It is near the south border of the Hanford Reservation and is the site of nuclear research and development.

- The 1100 Area is a corridor northwest of the city of Richland used for vehicle maintenance and other support activities.

On the basis of information from the Environmental Restoration PEIS source term data base (appendix A), about 870 ha (2150 acres) of the 148,000 ha $(365,700$ acres) Hanford Reservation are contaminated, including about 
OPNL-DWG 94N-5261

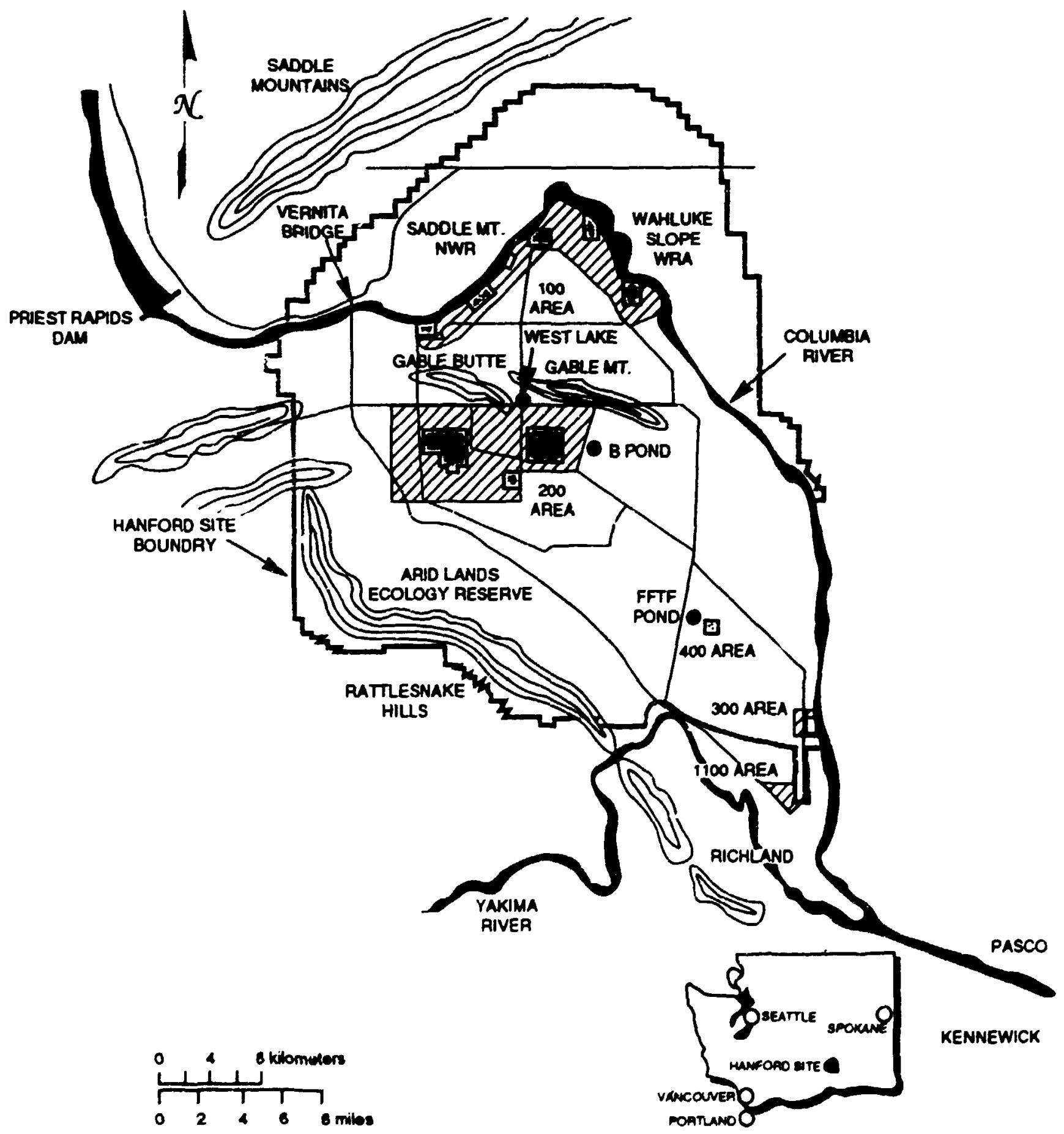


820 ha (2030 acres) of contaminated soil and 45 ha (110 acres) of waste ponds. This is about 0.6\% of the total area of the Hanford Reservation and about $10 \%$ of the disturbed areas. It was assumed that this is a representative sample of the surface area of all waste sites at Hanford.

\subsection{ECOLOGICAl Endpoints and SPECIES Distreibution}

Erupoints can be represented by many different receptors. The ecological endpoints and receptors chosen for the Hanford Reservation ecological risk assessment are described in this section of the report. In summary, 11 federally listed threatened and endangered or candidate species of plants and animals occur, visit, or nest on the reservation; wellands are found along the Cciumbia River, in the Rattlesnake Hills, at West Lake, and in surface ponds and ditches associated with fuel and waste processing activities; recreational wildlife species are present but hunting is not allowed; no grazing or agricultural activities are allowed, although the reservation is surrounded by range and agricultural land; several public areas lie within the reservation but access is restricted; and finally, the Hanford Reservation is one of the largest relatively undisturbed and protected tracts of sagebrush-steppe in the state of Washington. Because of these important ecological endpoints, the reservation has value for the conseryation of biodiversity. Important groups of species include raptors, salmonids, large mammals, and wintering/migratory wildlife.

Determining risks to endpoints requires (1) defining distribution and composition of endpoints and (2) selecting receptor species. The distribution of endpoints must be known in order to determine both exposure pathways for contarrinants and risks to endpoints from construction (i.e., habitat disturbance).

For purposes of determining risk of exposure to contaminants, distribution of endpoints is considered to be either ubiquitous (i.e., more or less uniformly distributed through.out the reservation or region), discontinuous (i.e., found in several locations within a limited area or areas), or discrete (i.e., located in one clearly identified location). Risks to ubiquitous endpoints are assumed to be related to the total surface area affected by contaminant exposure or by disturbance from remediation. Risks tc discontinuous and discrete endpoints are determined if their locations are known to be within contaminated areas or within areas affected by remedial activities or contaminant exposures.

Although the terrestrial ecology of the reservation is generally uniform, the wetland areas (i.e., rivers, ponds, seeps, and springs) are scattered. Thus, endpoints (e.g., biodiversity) can be both ubiquitous (e.g., shrub-steppe vegetation) and discontinuous (e.g., pelicans) depending on the receptors (table 5-1). Locations of endpoints were determined from existing maps and publications, supplemented by personal communications with ecologists at the Hanford Reservation.

\subsubsection{Threatened and Endangered Species}

\section{I.I.I Receptors}

There are 11 federally listed or candida $\%$ species of plants, birds, and mollusks at the Hanford Reservation (table 5-2). Of the federally listed species of birds, the Aleutian Canada goose is a rare visitor, the peregrine falcon is known to reside full-time on the reservation but is listed as rare, and the bald eagle is found during the fall and winter. Of the candidate species of birds, the wt stem sage grouse and loggerhead shrike are year-round residents, and the ferruginous hawk winters off-site (Fitzner and Gray 1991). The plants and mollusk are, of course, full-time residents.

The peregrine falcon feeds almost exclusively on birds, and the Canada goose and bald eagle feed exclusively on vegetation and salmon, respectively. The ferruginous hawk feeds almost exclusively on jackrabbits. The sage grouse has not been observed since the mid-1980s and probably no longer resides at the Hanford site (Fitzner and Gray 1991). The loggerhead shrike eats mostly insects and small mammals. Exposure risk to populations that migrate would be less than to resident populations. 
TABLE 5-1-Distribution of Ecological Endpoints and Receptors

at the Hanford Reservation

\begin{tabular}{|l|l|l|}
\hline \multicolumn{1}{|c|}{ Ubiquitoos } & \multicolumn{1}{|c|}{ Disconthous } & \multicolumn{1}{|c|}{ Discrete } \\
\hline $\begin{array}{l}\text { Resident, breeding federally } \\
\text { listed and candidate species } \\
\text { (peregrine falcon. western sage } \\
\text { grouse, loggertead shrike) }\end{array}$ & $\begin{array}{l}\text { Wetlands (vegetation, benthic } \\
\text { invertebrates, fish, mustrats, } \\
\text { and migratory waterfowl) }\end{array}$ & $\begin{array}{l}\text { Public lands (Arid Lands } \\
\text { Ecology Reserve. Saddle } \\
\text { Mountain Wildlife Refuge. } \\
\text { Wahluke Slope Wildlife } \\
\text { Refuge Area) }\end{array}$ \\
$\begin{array}{l}\text { Recreational wildlife (deer, } \\
\text { elk, jackrabbits, ard upland } \\
\text { gamebirds) }\end{array}$ & Recreational wildlife (salmon) \\
$\begin{array}{l}\text { Biodiversity (important } \\
\text { components not included } \\
\text { above- bats, food sources for } \\
\text { protected species, sag-hrush } \\
\text { communities) }\end{array}$ & $\begin{array}{l}\text { Biodiversity (pelican, bald } \\
\text { eagle) }\end{array}$ & \\
\hline
\end{tabular}

TABLE 5-2-Rare Species on the Hanford Reservation

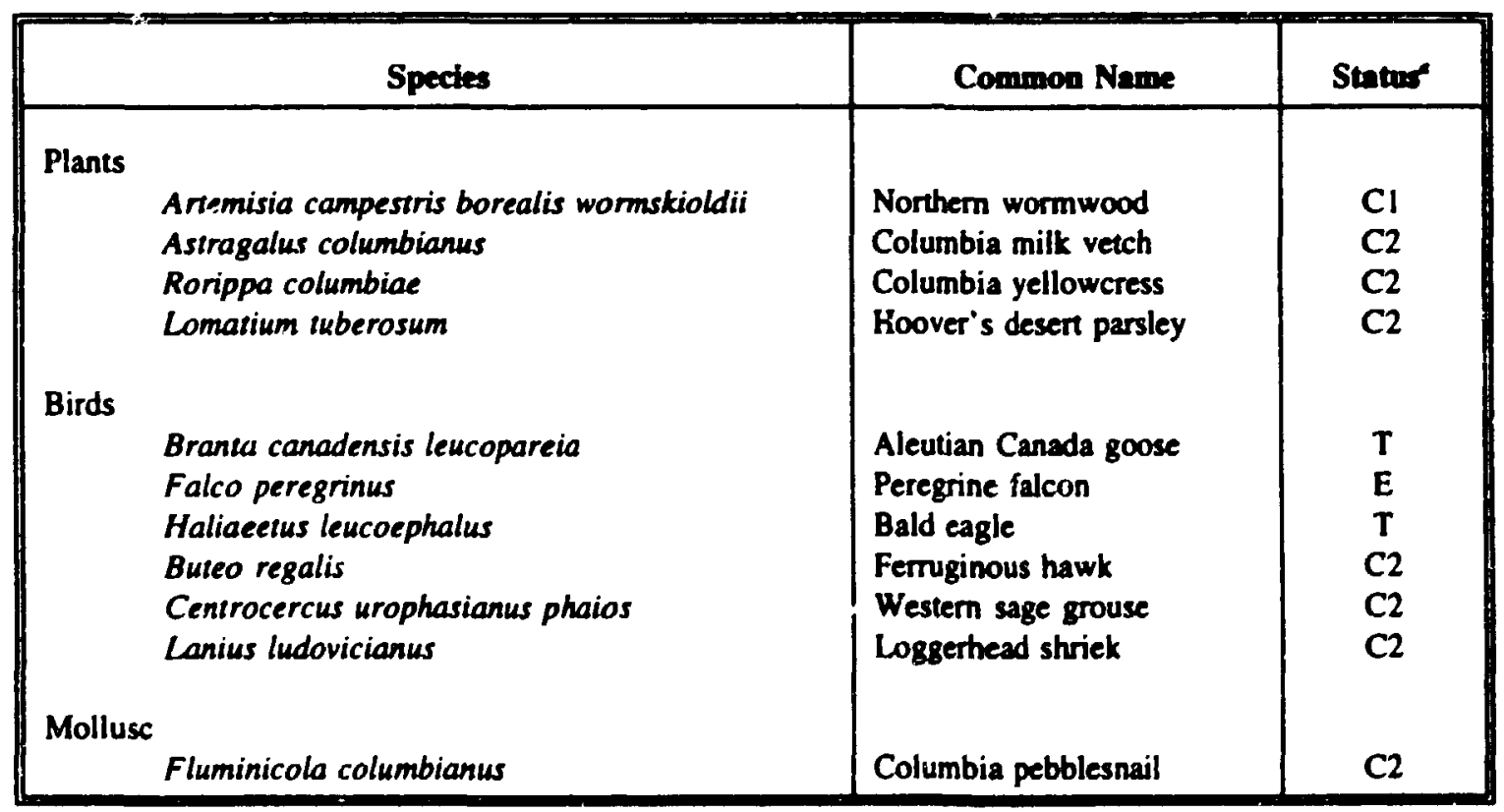

${ }^{\circ}$ Endangered and threatened wildlife and plants, Fed. Regist. 50 CFR $17.11 \& 17.12$, August 29. 1992: endangered and threatened wildlife and plants: animal candidate review, Fed. Regist. 50 CFR part 17. Nov. 21, 1991; endangered and threatened wildlife and plants: review of plant taxa. Fed. Regist. 50 CFR part 17, August 29, 1992. E = endangered, T = threatened, C1, C2 = under review. 


\subsubsection{Distribution}

Most of the fecieraily iisted or candidate species are known to have patchy distributions rather than uniform dispersal over the entire reservation. There is no known designated or proposed critical habitat. The plant species are generally found near the Columbia River (Sackschewsky et al. 1992). The mollusk. Aleutian Canada goose, and bald eagle are found in or near the Hanford Reach of the river. For this programmatic analysis, the falcon, hawk. grouse, and shrike - - assumed to be uniformly distributed in ... Hanford shrub-steppe environment.

\subsubsection{Wetlands}

\subsubsection{Receptors}

Although the Hanford Reservation is located in a semiarid region, various types of wetlands are on reservation. Benthic macroinvertebrates, fish, muskrats, and aquatic plants are representative species of wetlands for which some toxicity benchmark data are available. Although these biota do not necessarily occur in all wetlands on the reservation, they were selected as receptors in our risk analysis because they cover the range of wetland ecosystem components that could be present. Thus, risks are calculated to these receptors in all wetlands (excluding West Lake which is recharged from groundwater and has not received direct effluents from site activities).

\subsubsection{Distribution}

Wetlands on the Hanford Reservation include the Columbia River; on-site ponds (i.e., West Lake, B Pond, and FFTF Pond); small spring streams and seeps, located mainly on the Arid Lands Ecology Reserve in the Rattlesnake Hills, that disappear into the ground before reaching any major water bodies; artificial ponds and ditches. formed as a result of wastewater disposal practices associated with the operation of the reactors and separation facilities that support aquatic and emergent flora and fauna (Gray and Rickard 1989); and ponds resulting from irrigation nunoff in the Saddle Mountain Wildlife
Refuge and the Wahluke Slope Wildlife Refuge Area (Cushing 1992).

\subsubsection{Recreational Fth and Wildife}

\section{S.1.3.1 Receplors}

Many wildlife species having recreational, aesthetic, or commercial importance are present on the reservation, although access to the Hanford Reservation is restricted and the site is closed to hunting and fishing. Determining contaminant risks to aquatic species, including recreational fish, does not require the use of specific receptor species. Risks to fish in general were determined to represent recreational fish in the Columbia River (e.g., salmon). The mule deer. jackrabbit, and coyote were selected as common terrestrial species representative of recreational wildife that are also important components of the food web on the reservation. All of these species are year-round residents on the reservation. Thus, our analysis estimates potential risks to populations continuously exposed to contaminants. However, it is highly unlikely that Hanford populations of fish, birds. or animals are continuously exposed to contaminants throughout their lifetimes.

\subsubsection{Distribution}

Game animals including deer, elk, jackrabbits, and upland gamebirds were considered to be common and found throughout the Hanford Reservation. Recreational fish are found in the Hanford Reach of the Columbia River which provides valuable spawning habitat for salmon and steelhead trout and is a major resting and feeding area for migratory waterfowl and shorebirds (Fitzner and Gray 1991).

\subsubsection{Agricultural or Timber Production}

Because of arid conditions, natural productivity on the Hanford Resirvation is low. Although closed to agricultural activity, data are available on productivity of native vegetation (see references in (ushing 1991). The reservation is surrounded by range and agricultural land to the west, north, and east. 


\subsubsection{Parks and Other Public Lands}

\subsubsection{Receptors}

Within the Hanford Reservation, there are several public areas with restricted access (figure 5-1). Risks to these receptors were determined by calculating risks to food web components at reservation boundaries. Risks are assumed to be maximal closest to the reservation.

\subsubsection{Distribution}

The Arid Lands Ecology Reserve (ALE) occupies the southwestern section of the reservation, and the Saddle Mountain National Wildlife Rsiuge and the Washington State Department of Game Wahluke Slope Wildlife Refuge Are: occupy the portion of the reservation north of the Columbia River (figure 5-1). Other public lands include the Priest Rapids Wildlife Area on the Columbia River to the northwest, the Columbia National Wildlife Refuge to the north, and the Sacajawea State Park and McNary National Wildlife Refuge to the southeast of the reservation.

\subsubsection{Biodiversity}

\subsubsection{Receptors}

The Hanford Reservation is a very large, relatively undisturbed, native sagebrush-steppe ecosystem; most of the plant and animal species are characteristic of semiarid and river environments of the region. Conservation of such a large area of natural sagebrush-steppe vegetation contributes to the conservation of biodiversity. Raptors are well represented in our analyses by federally listed or candidate species (e.g. the endangered peregrine falcon, threatened bald eagle, and candidace ferruginous hawk and loggerhead shrike). The common pallid bat (Anzroznus pallidus), which is ecologically similar to most bats found on the reservation, is a year-round resident and was chosen as a conservative representative of bat species. The robin, which is abundant site-wide and yearround, was chosen as a representative songbird. Other important food web components (figure 5-2) include major food organisms of receptors (e.g., small mammals eaten by raptors and coyotes, and insects eaten by loggethead shrikes and hats) which wete chnoen in represent other endpuints. Although very important to ecosystem function and to other species as food. invencbrates were not included in our analyses due to lack of benchmark data for them. Benchmark data were generally not available for reptiles, another important species group at the reservation.

\subsubsection{Distribution}

Rocky Mountain elk inhabit the Arid Lands Ecology Reserve. Mule deer, hawks, upland gamebirds, and other shrub-steppe birds (e.g., sage sparrows, sage thrashers, loggerticad shrikes, and long-billed curlews) find refuge on the reservation from expanding agriculture and urbanization. Eagles, pelicans, and geese benefit from riverine management practices that restrict public access and ensure critical resources such as food, perches, and cover for broods. This large undisturted expanse of sagebrush-steppe with its associated wetlands provides protected habitat for several species groups whose populations are in general decline. These species groups found on the Hanford Reservation include raptors (26 species), bats (seven species), reptiles and amphibians (12 species), and native Pacific salmonid populations (four species). In adcition. the reservation is an important resting area for migrant waterfowl and is within a major sandhill crane flyway.

Invasion of sagebrush-steppe communities on the reservation by nonnative plant species (e.g.. cheatgrass. Russian thistle) is an increasing threat to biodiversity. Nonnative species invade disturbed a.eas, crowd out native species, and inhibit or prevent their reestablishment on fresh disturbances. The abundance of these species is assumed to be inversely proportional to the quality of native sagebrush-steppe habitat and most abundant in and adjacent to disturbed sites and old cultivated fields.

\subsection{Contaminants of Potential. CONCERN}

The contaminants of potential concerm at the Hanford Reservation include radionuclides and inorganic and organic contaminants (table 5-3). 
TABLE 5-3-Maximm and Average Concenthations of Organic, Inerganic, and Rationuclide Combuinants in Soll at the Banford Reservecion

[mg/kg dry weight (for chemical constituents) or pCikg dry weight (for radionuclides)]

\begin{tabular}{|c|c|c|c|}
\hline Constlunest & Concentriation & Cosothent & $\begin{array}{c}\text { Averase } \\
\text { Coscentration }\end{array}$ \\
\hline $\begin{array}{l}\text { Ammonia (cartonate) } \\
\text { Benzo(a)pyrene } \\
\text { 4-methyl-2-pentanone } \\
\text { Tributyl phosphnte (TBP) } \\
\text { Trichloroethene } \\
\text { Aluminum (fluoronitrate) } \\
\text { Beryllium } \\
\text { Cadmium } \\
\text { Chromium } \\
\text { Copper } \\
\text { Cyanide (iron) } \\
\text { Fluoride } \\
\text { Iron (nitrate) } \\
\text { Lead } \\
\text { Magnesium (nitrate) } \\
\text { Mercury } \\
\text { Nickel } \\
\text { Nitrate } \\
\text { Nitric acid } \\
\text { Nitrite } \\
\text { Phosphate } \\
\text { Potassium (borate) } \\
\text { Sodium } \\
\text { Sulfate } \\
\text { Sulfuric acid } \\
\text { Zinc } \\
\text { Americium-241 } \\
\text { Carbon-14 } \\
\text { Cobalt-60 } \\
\text { Cesium-134 } \\
\text { Cesium-137 } \\
\text { Eurnpium-152 } \\
\text { Europium-154 } \\
\text { Europium-155 } \\
\text { lodine-129 } \\
\text { Nickel-63 } \\
\text { Plutonium-238 } \\
\text { Plutonium-239 } \\
\text { Plutonium-240 } \\
\text { Plutonium-241 } \\
\text { Promethium-147 } \\
\text { Ruthenium-106 } \\
\text { Strontium-90 } \\
\text { Tin-113 } \\
\text { Tritium } \\
\text { Uranium-235 } \\
\text { Uranium-238 }\end{array}$ & $\begin{array}{l}4.43 E+04 \\
1.80 E+04 \\
1.35 E+05 \\
2.35 E+06 \\
1.05 E+03 \\
2.75 E+05 \\
3.92 E+00 \\
7.85 E+00 \\
3.92 E+02 \\
7.85 E+03 \\
1.57 E+04 \\
1.08 E+06 \\
5.23 E+04 \\
2.35 E+02 \\
2.35 E+05 \\
2.94 E+04 \\
1.18 E+03 \\
4.04 E+06 \\
1.18 E+05 \\
2.88 E+05 \\
6.02 E+05 \\
2.82 E+05 \\
2.72 E+06 \\
1.31 E+05 \\
3.00 E+03 \\
3.92 E+02 \\
1.57 E+05 \\
1.62 E+08 \\
4.96 E+08 \\
1.56 E+05 \\
5.05 E+09 \\
3.32 E+07 \\
5.81 E+06 \\
1.36 E+07 \\
2.04 E+04 \\
1.84 E+06 \\
7.16 E+05 \\
3.07 E+12 \\
8.33 E+06 \\
8.05 E+06 \\
8.52 E+05 \\
1.36 E+06 \\
2.09 E+09 \\
8.41 E+02 \\
3.52 E+09 \\
6.59 E+02 \\
4.90 E+07\end{array}$ & $\begin{array}{l}\text { Benzo(a)pyrene } \\
\text { 4-methyl-2-pentanone } \\
\text { Trichloroethene } \\
\text { Cadmium } \\
\text { Chromium } \\
\text { Copper } \\
\text { Cyanide (iron) } \\
\text { Iron (nitrate) } \\
\text { Lead } \\
\text { Magnesium (nitrate) } \\
\text { Mercury } \\
\text { Nickel } \\
\text { Zinc } \\
\text { Cobalt-60 } \\
\text { Cesium-137 } \\
\text { Europium-152 } \\
\text { Plutonium-239 } \\
\text { Strontium-90 } \\
\text { Uranium-238 }\end{array}$ & $\begin{array}{l}1.15 e+04 \\
2.65 e+04 \\
7.89 e+02 \\
6.25 E-01 \\
3.51 e+01 \\
5.07 e+02 \\
1.12 e+03 \\
5.23 e+04 \\
4.69 e+01 \\
2.35 e+05 \\
3.94 e+00 \\
8.20 e+01 \\
3.51 e+01 \\
5.82 e+05 \\
1.58 e+07 \\
4.91 e+06 \\
3.77 e+09 \\
1.19 e+07 \\
3.96 e+04\end{array}$ \\
\hline
\end{tabular}


The primary radionuclides, according to relative avernge concentralions, are ${ }^{10} \mathrm{Co},{ }^{14} \mathrm{C},{ }^{159} \mathrm{Cs},{ }^{29} \mathrm{Pu}$.

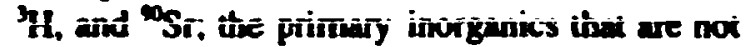
escentiai nutrients (i.e.. sodium) are Al, cyanide. $\mathrm{Pb}, \mathrm{Hg}$. $\mathrm{Ni}$, and $\mathrm{Zn}$; the primary organics are ammonia, benzo(a)pyrene, triburyl phosphate, trichloroethene, and 4-methyl-2-pentanone.

Maximum and average concentrations of chemical and radiological constituents in soil, surface water, and sediment were determined from the source terms provided by PNL (tables 5-3, 5-4, and 5-5, respectively). Determination of these average and maximum concentrations required that certain assumptions be made with regard to data interpretation and compensation for data gaps.

Appendix B describes the methodology used to develop the source terms for input into the exposure and risk assessment.

\subsection{Exposure ASSESSMENT}

Where available for Hanford, the maximum concentrations of each contaminant in each medium (i.e., soil, water, and sediment) were used to identify the worst-case potential contaminants. Contaminants that did not pose a risk to any of the receptor species from exposure to the maximum values were not considered further. If exposure to the maximum concentrations of contaminants posed a risk to organisms, then the average concentrations of those contaminants were used in the assessment to estimate the most probable and reasonable exposure and risk.

Estimating contaminant exposure for receptor species on the reservation also depends on knowing the amount of time species spend in waste areas and the amount of contaminants ingested. Because specific home ranges and habits of many of the representative species on the Hanford Reservation are not well known, an initial screening assessment for contaminant exposure was conducted using conservative assumptions. Even though only a few species with small home ranges (e.g., small mammals and birds) could reside within contaminated areas for most of their lives and even fewer individuals could contact areas of maximum concentrations (see chapter 5.4 for discussion of home ranges). the conservative assumptions were applied rouineiy.

The ecological risk assessment (appendix B) estimates the risk to vegetation, terrestrial wildife, and aquatic orgarisms from chronic exposure to radiological and nonradiological contaminants. In our exposure andyses. the ecological endpoints and their receptor species were considered. However, due to limited availability of sensitivity data for many species (e.g., threatened and endangered species) and to ecological similarities in exposure risk (e.g., similarly sized raptors feeding on the same prey). a representative organism for each endpoint was chosen for evaluation. A food web was developed which includes receptor species representing the endpoints (figure 5-2). In all cases where data were available, conservative estimates of exposure and risk were made by selecting receptors most sensitive to contaminants or habitat alteration, most likely to experience additional risk due to bioaccumulation or larget body size, or at greatest risk due to rarity. Oher abundant species on the reservation were included as important prey components of the foodweb, such as mice and insects (risk estimates were not determined for insects).

The primary exposure routes for terrestrial wildlife species are exposure to extemal radiation, and ingestion of food (including soils for some species), and water. Table 5-6 lists the body weights and consumption rates for the receptor species. The jackrabbit, sage grouse, and Canada goose are assumed to feed exclusively on the vegetative parts of plants. The mule deer is assumed to eat $80 \%$ vegetation and $20 \%$ fruits and seeds. On the basis of a review of the literature, the percentage of prey items consumed by omnivores and predators was estimated (table 5-6; figure 5-2). The mouse is assumed to eat $80 \%$ fruits and seeds and $20 \%$ insects; the robin is assumed to cat $70 \%$ fruits and seeds and $30 \%$ insects; and the coyore eats $35 \%$ mice, 35\% jackrabbits, $20 \%$ sage grouse, and $10 \%$ fisil. The loggerhead shrike is assumed to eat $60 \%$ insects and $40 \%$ mice, the ferruginous hawk eats $100 \%$ jacksabbits, and the bald eagle eats $100 \%$ fish. The pallid bat is assumed to eat $100 \%$ insects, and the insects eat $100 \%$ vegetative plant parts. 


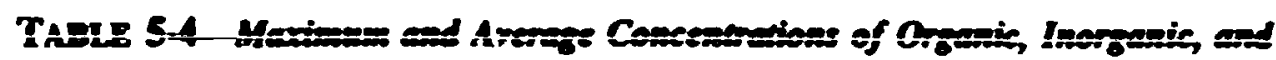

Rationactide Commininats in Mater at the Hanforl Reservetion

[mgl (for chemical constituents) or pCiL (for radionuclides)]

\begin{tabular}{|c|c|c|c|}
\hline Conctionerat & $\underset{\text { Coscontration }}{\text { Maximan }}$ & Contineat & $\begin{array}{c}\text { Average } \\
\text { Concentration }\end{array}$ \\
\hline $\begin{array}{l}\text { Antianony-125 } \\
\text { Beryllium-7 } \\
\text { Cobalt-60 } \\
\text { Cerium-144 } \\
\text { Cesium-134 } \\
\text { Cesium-137 } \\
\text { Europium-154 } \\
\text { Potussium-40 } \\
\text { Ruthenium-106 } \\
\text { Strontium-90 } \\
\text { Technetium-99 } \\
\text { Tritium } \\
\text { Uranium-234 } \\
\text { Zirconium-95 }\end{array}$ & $\begin{array}{l}1.99 e+00 \\
6.82 e+01 \\
2.64 e+00 \\
8.35 e+00 \\
7.33 e-01 \\
9.64 e-01 \\
3.47 e+00 \\
7.14 e+01 \\
8.34 e+00 \\
5.10 e+03 \\
9.87 e+12 \\
7.33 e+03 \\
3.10 e-01 \\
1.86 e+01\end{array}$ & $\begin{array}{l}\text { Cobali-60 } \\
\text { Cesium-137 } \\
\text { Strontium-90 } \\
\text { Technetium-99 }\end{array}$ & $\begin{array}{l}1.22 e+00 \\
9.64 e-01 \\
5.10 e+03 \\
6.49 e+12\end{array}$ \\
\hline
\end{tabular}

TABLE 5.5-Maximum and Average Concentrations of Onganic, Inorganic, and Radionuctide Contaminants in Sediment at the Hanford Reservation [mg/kg (for chemicals) or pCi/kg (for radionuclides)]

\begin{tabular}{|c|c|c|c|}
\hline Constifuesen & $\begin{array}{l}\text { Maxionam } \\
\text { Concentration }\end{array}$ & Conetifmeat & $\begin{array}{c}\text { Averase } \\
\text { Conceatration }\end{array}$ \\
\hline $\begin{array}{l}\text { Cesium-137 } \\
\text { Plutonium-239 } \\
\text { Potassium-40 } \\
\text { Strontium-90 } \\
\text { Uranium-235 } \\
\text { Uranium-238 }\end{array}$ & $\begin{array}{l}2.45 E+03 \\
5.40 E+04 \\
2.19 E+04 \\
1.57 E+03 \\
1.91 E+02 \\
5.13 E+03\end{array}$ & $\begin{array}{l}\text { Cesium-137 } \\
\text { Plutonium-239 } \\
\text { Strontium-90 } \\
\text { Uranium-238 }\end{array}$ & $\begin{array}{l}2.45 e+03 \\
5.40 e+04 \\
2.94 e+02 \\
5.13 e+03\end{array}$ \\
\hline
\end{tabular}


TABLE 5-6-Body Weights and Consumption Rates' for Terrestrial Species' on the Hanford Reservation

\begin{tabular}{|c|c|c|c|c|c|c|c|c|c|c|c|}
\hline Parameter & Grex Rom & 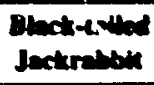 & Pand An & Muke Dore & Robian & sege Groune & $\begin{array}{l}\text { Caneata } \\
\text { Goome }\end{array}$ & $\begin{array}{l}\text { Lopprtwead } \\
\text { surtine }\end{array}$ & $\begin{array}{l}\text { Perropleneen } \\
\text { Hownk }\end{array}$ & Dabl Eophe & Cogen \\
\hline Body meitite, BW (te) & $2.38 E-02^{\prime}$ & $2.27 E+\infty 0^{4}$ & $3.30 E-02^{3}$ & $1.10 E+02$ & $7.50 \mathrm{E}-02^{1}$ & $2.008+00^{2}$ & $2.76 E+00^{\circ}$ & $4.55 \mathrm{E}-02^{10}$ & $1.39 E+00^{11}$ & $4.50 \mathrm{E}+00^{12}$ & $1.600+01^{11}$ \\
\hline 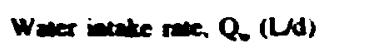 & 6. 30E-03 & $1.83 \mathrm{E}-01$ & $7.505-03$ & 4.45E+40 & $1.43 E-02$ & $1.90 \mathrm{e}-01$ & $2.800-01$ & $9.70 \mathrm{E}-0.3$ & $1.67 \mathrm{E}-0 \mid$ & $4.05 E-01$ & $773 \mathrm{E}-01$ \\
\hline Werer inersion frection, Fl. & $1.00 \varepsilon+\infty$ & $1.00 E+\infty$ & $1.00 E+\infty 0$ & $1.00 E+\infty 0$ & $1.00 E+\infty 0$ & $1.00 E+00$ & $1.00 E+00$ & $7.000-01$ & $7.00 E-01$ & $3.002-01$ & $1,000++\infty$ \\
\hline Soil inente rexc. Q (teds) & $3.22 E-05^{\omega}$ & $9.32 \mathrm{E}-03^{\prime \prime}$ & 0.00 & $2.79 E-02^{\omega}$ & $3.56 \notin-04^{4}$ & $1.05 \mathrm{E}-02^{14}$ & $1.35 E-02^{10}$ & 0.00 & 0.00 & 0.00 & 0.00 \\
\hline Soul ingestion fraction, $\boldsymbol{F}_{1}$ & $1.00 E+\infty$ & $1.00 E+\infty$ & 0.00 & $1.00 \varepsilon+\infty$ & $1.00 E+\infty 0$ & $1.008+\infty 0$ & $1.00 E+\infty 0$ & 0.00 & 0.00 & 0.00 & 0.00 \\
\hline 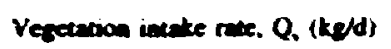 & 0.00 & $|.59 E-0|=$ & 0.00 & $2.13 \mathrm{E}+00^{21}$ & 0.00 & $1.13 \mathrm{E}-01$ & $|.77 \mathrm{E}-0|$ & 0.00 & 0.00 & 0.00 & 0.00 \\
\hline 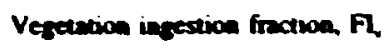 & 0.00 & $1.00 E+100$ & 0.00 & $1.00 E+\infty 0$ & 0.00 & $1.008+\infty$ & $1.00 E+\infty 0$ & 0.00 & 0.00 & 0.00 & 0.00 \\
\hline 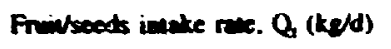 & $3.76 E-03^{22}$ & 0.00 & 0.00 & $5.32 E-01$ & $5.806-03^{2}$ & 0.00 & 0.00 & 0.00 & 0.00 & 0.00 & 0.00 \\
\hline Frinsects ingesticen fraction. Fr, & $1.00 E+\infty 0$ & 0.00 & 0.00 & $1.00 E+\infty 0$ & $1.00 E+00$ & 0.00 & 0.00 & 0.00 & 0.00 & 0.00 & 0.00 \\
\hline Prey I ineste rase. $Q_{m,}$ (keds) & 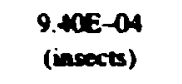 & 0.00 & $\begin{array}{l}4.40 E-03 \\
\text { (insects) }\end{array}$ & 0.00 & $\begin{array}{l}2.50 E-03 \\
\text { (insects) }\end{array}$ & 0.00 & 0.00 & $\begin{array}{c}3.36 \mathrm{E}-03^{24} \\
\text { (insocts) }\end{array}$ & $\begin{array}{l}9.91 \mathrm{E}-02 \\
\text { (mabtics) }\end{array}$ & $\begin{array}{c}2.67 \mathrm{E} .01 \\
\text { (Aish) }\end{array}$ & $\begin{array}{c}\text { 2.cue-01 } \\
\text { (mice) }\end{array}$ \\
\hline Prey I ingescion fraction, $\mathbf{F l}_{\text {qI }}$ & $1.00 E+\infty 0$ & 0.00 & $1.00 E+\infty 0$ & 0.00 & $1.00 E+\infty 0$ & 0.00 & 0.00 & $7.00 \mathrm{E}-01$ & $7.000-01$ & $3.000-01$ & $1,1008+\infty 0$ \\
\hline 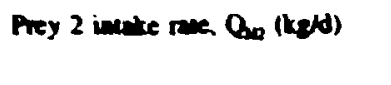 & 0.00 & 0.00 & 0.00 & 0.00 & 0.00 & 0.00 & 0.00 & $\begin{array}{c}2.20 \mathrm{E}-03 \\
\text { (mice) }\end{array}$ & 0.00 & 0.00 & $\begin{array}{l}2.000-01 \\
(12 b 001\end{array}$ \\
\hline Prey 2 ingestion frection. $F_{W L}$ & 0.00 & 0.00 & 0.00 & 0.00 & 0.00 & 0.00 & 0.00 & $7.00 \mathrm{e}-01$ & 0.00 & 0.00 & $1.1000+\infty$ \\
\hline Prey 3 intake race, $Q_{w}$ (kg/d) & 0.00 & 0.00 & 0.00 & 0.00 & 0.00 & 0.00 & 0.00 & 0.00 & 0.00 & 0.00 & $\begin{array}{l}1.17 \mathrm{E}-01 \\
\text { (17rower) }\end{array}$ \\
\hline Prey 3 ingestion tirection. Fho & $0 . \infty$ & 0.00 & 0.00 & 0.00 & 0.00 & 0.00 & 0.00 & 0.00 & 0.00 & 0.00 & $1,100 e+\infty$ \\
\hline Prey 4 incule race. On (ketd) & 0.00 & 0.00 & 0.00 & 0.00 & 0.00 & 0.00 & 0.00 & 0.00 & 0.00 & 0.00 & $\begin{array}{l}\text { S.ME-O2 } \\
\text { (nes) }\end{array}$ \\
\hline Prey \& ingetion frection, Fly & 0.00 & 0.00 & 0.00 & 0.00 & 0.00 & 0.00 & 0.00 & 0.00 & 0.00 & 0.00 & $1.1000+\infty$ \\
\hline
\end{tabular}

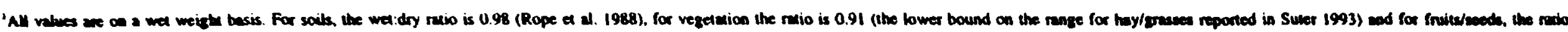
0.11 (Merriocen 1959).

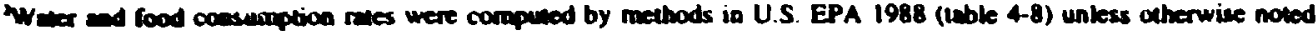

Wrienter lisas.

Ben and Grocencubider 1976

'Anderson and Wallon 1984.

Anderson and Watton 1984.

'Tertes 1900.

Tences 1900

Weatom Bnd Birdine Associntion 1984.

Tenses 1900.

"Browe and Amedoa 1968

"Brom and Amadoe 1968.

"Ben and Crovecabelder 1976.

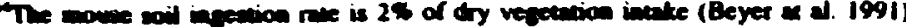

'The soil ingestiva race of the jectrabbis is 6.39 (Arthur and Gaves 1988)

The mule deer noil ingestion rule is $1.35 \%$ of dry mener incake (Arture and Alloredge 1979).

"The soil ingextion rate of the robin is assurned 10 be $10 \%$ of dry matrex iatale.

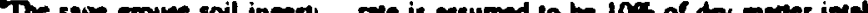

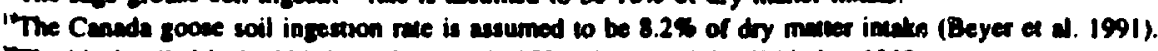

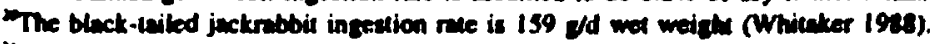

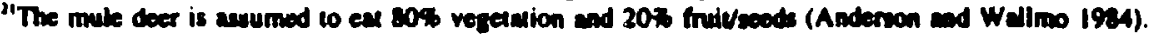

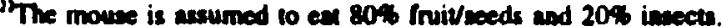

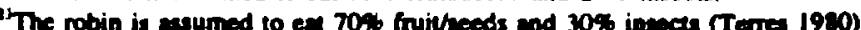

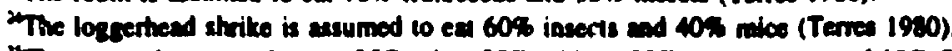

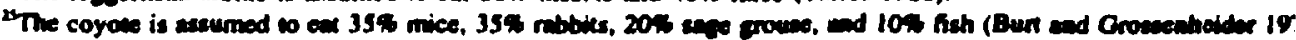


All species are assumed to purposely or incidentally ingest soil while exting, grooming. or preening except for the bat, raptors, and coyote (table 5-6). The soil ingestion rate (Q) for black-tailed jackrabbits is said to be 6.3\% of the dry matter intake (Arthur and Gates 1988); for mule deer, $1.35 \%$ of the dry matter intake (Arthur and Alldredge 1979); and for the mouse and goose, 2\% and 8.2\% of the dry-mater intake, respectively (Beyer et al. 1991). Since published values of soil ingestion rates were not found for the robin and the sage grouse, they were conservatively estimated to be $10 \%$ of the dry matter intake.

The estimated daily rates of food and water consumption ( $Q_{1}, Q_{4}$ or $Q_{H}$, and $Q_{m}$, respectively) for each receptor species were calculated from allometric regression equations that are based on the weight of the organism (EPA 1988) (Appendix A). These equations are based on the combined measurements for laboratory animals, livestock. and selected wildlife and bird species. Measured values for some rates were obtained from the literature for several species and are noted in appendix $A$.

Because information on the specific habits and behaviors of some of the receptors is not well known, it is assumed that all species, except the loggertead shrike. the ferruginous hawk, and the bald eagle spend $100 \%$ of their time on the reservation. Therefore, the fraction of contaminated vegetation, fruit, prey, soil, and water consumed $\left(\mathrm{FL}_{1}, \mathrm{FL}_{4}, \mathrm{FL}_{\mathrm{H}}, \mathrm{FL}_{\text {, }}\right.$ and $\mathrm{FL}_{\text {, }}$. respectively) is set at $100 \%$ (table 5-6). The loggertead shrike and the ferruginous hawk are assumed to winter off the reservation; thus, their FI values are set at $70 \%$. The bald eagie is present on the reservation approximately 6 months or less each year (Fitzner and Gray 1991), and its FI value is set at 50\%.

Contaminant concentrations in vegetation, the first level in the foodchain, are estimated from source-term concentrations in soils using published element-, or chemical-specific soil-to-plant transfer factors (Baes et al. 1984; Travis and Arms 1988) (Lable 5-7). Transfer factors for inorganic chemicals are available for both vegetative and fruiting parts of plants (Baes et al. 1984); however, transfer factors for organic chemicals apply only to "vegetation" in generai
(Travis and Ams 1988). The methodology used to predict contaminant concentrations in vegetation does not distinguish between different plant types or species. Therefore, all species ingest "generic" vegetation containing contaminant concentrations derived from soil concentrations via transfer factors.

Contaminant concentrations in the tissues of terrestrial mammalian receptors are based on transfer factors for consumption of vegetation. soil, and water by beef (collectively termed B, (Baes et al. 1984; Travis and Arms 1988) (table 5-7). Data on transfer factors from regetation or soil to insects and earthworms are very limited in the literature. Therefore, the concentration in insects was derived from vegetation concentrations, and a default, conservative oneto-one transfer between vegetation and insects was assumed. Fish bioconcentration factors (BCF) were applied to estimate the concentrations of contaminants in fish tissue for consumption by the bald eagle (Droppo et al. 1989) (table 5-7). The rationale and limitations for applying these transfer factors are discussed in appendix B.

The consumption rates and the benchmark limit or no-observable-adverse-effect level (NOAEL) values are typically reporsd in wet weights, whereas the vegetation and soil concentrations are typically reported in dry weights. Therefore. conversion factors were applied to account for this difference. The wet- to dry-weight concentration conversion factor for the vegetative parts of plants on the Hanford Reservation was assumed to be 0.91 [the lower end of the range of percent water content for hay and grasses (Suter 1993)]. The wet- to dry-weight concentration conversion factor for the fruiting parts of plants on the reservation was assumed to be 0.17 (Morrison 1959). The wet-to dry-weight concentration conversion factor for soils was assumed to be 0.98 [this factor is based on the mean for 16 sampling locations in southwest Idaho (Rope et at. 1988)].

For the baseline assessment of the Hanford Reservation, the concentrations of radionuclides in animal tissues and the resulting doses were not decay-corrected. The doses are estimated for the current situation and not at some point in the future. The primary radionuclides of concem 


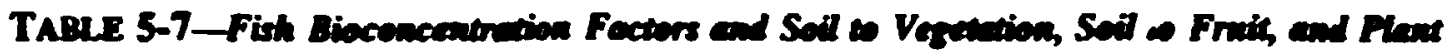

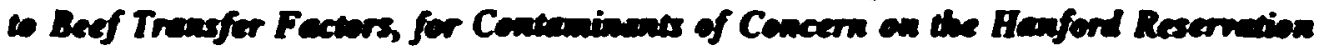

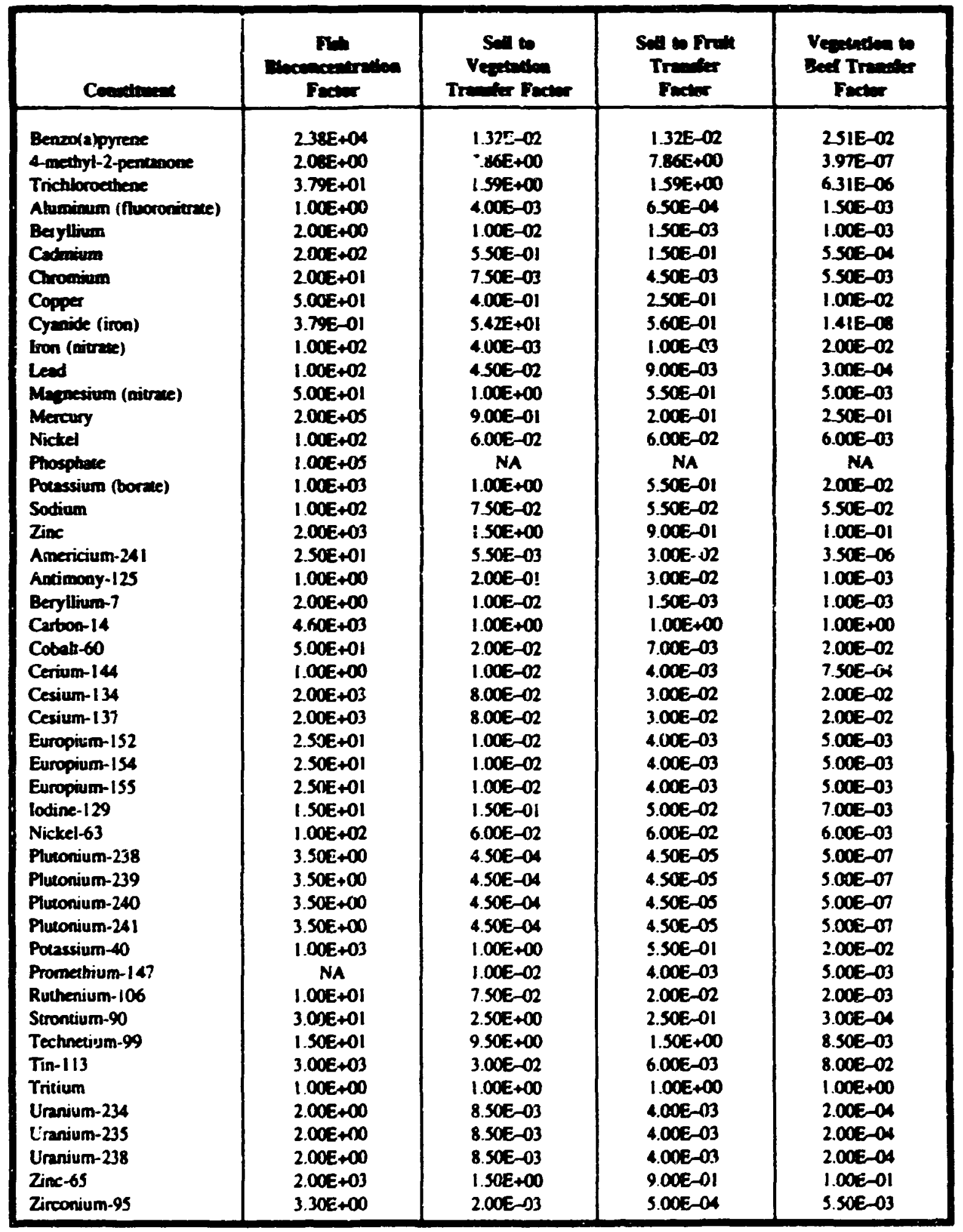

NA = Transfer factor could not be calculated.

Soures: For organics. the transfer factors were calculated from equations in Travis and Arms (1988) using $K$. values from the Supertund Chemical Date Marrix (1991). For inorganics and radionuclidet, the transfer fectors were taken from Bees et al. (1994). The $K_{m}$ for cyanide was taken from MEPAS and the transfer factors were calculwed from equations in Travis and Arms (1988). 
huve relatively long balf fives, so this assumption is reasonsble. The radionuclide concentrions in the source terms were decay-corrected by PNL to the time of disposal or release. To estimate dose to terrestrial receptors. all short-lived daughter products were included.

Aquatic organisms considered in the assessment included benthic macroinvertebrates and a generic fish species. For radiotogical analyses. emergent vegetation (i.e., cattails) and muskrats were included as well. All aquatic organisms, are exposed to contaminants in surface water. However. for this analysis, benthic macroinvertebrates are assumed to be exposed only to the sediment pore water for calculation of internal radiation dose and exposure to chemicals. The external radiation dose from exposure to surface water was calculated for all organisms.

\subsection{Contaminamt Eptects Assessment}

Two pathways are used to determine the effects of contaminant exposure (chaprer 5.3) on ecological endpoint receptors. For terrestrial receptors. consumption rates of contaminated food and water are compared with toxicological benchmarks. For aquatic receptors, contaminant concentrations in water or sediment pore water are compared with chemical-specific aquatic benchmarks.

To quantify risk to terrestrial receptors exposed to organic and inorganic contaminants, the daily consumption rate of contaminated food and water, normalized to body weight (in units of mg/kg/d), was compared with the NOAEL benchmark (mg/kg/d). Ratios greater than 1 are considered to pose a potential risk to organisms but do not necessarily indicate the severity of the effect(s). However, it is reasonable to assume that the higher the ratio, the greater the ris.. of adverse effects. Doses to terrestrial receptors, including vegetation, from intemal and extemal exposure to radionuclides was also determined from calculated tissue concentrations and soil concentrations, respectively. Doses that exceeded $0.1 \mathrm{rad} / \mathrm{d}$ were considered to pose a potential risk to terrestrial organisms (IAEA 1992). Methods used to calculate exposure and risk are described in appendix $A$.
Toxicological benchmerks for tertestrial organismk exchuding vegetuinon. were attaines from Opresto et al. (1993) (table 5-8). For representative receptor species that were nor listed in the data base. extrapolation techniques were employed to obtain the chroaic NOAEI by adjusting for differences in body weight between the receptor and a test organism. If a NOAEL was available for a laboratory test species, the NOAEL for a receptor species could be calculated. Many of the NOAEL benchmarks were derived by extrapolation from small mammal laboratory dxa (Opresko et al. 1993). There were a few comtaminants for which no wildlife toxicity data were found. For these cases, wildlife NOAELs were extrapolated from human noncarcinogenic toxicity data (i.e., RfDs) listed in the MEPAS constiment data base, normalized to the "standard man" body weight of $70 \mathrm{~kg}$. Thus, for our purposes, wildlife species that weigh less than $70 \mathrm{~kg}$ would have a higher benchmark than humans and the opposite would be true for wildlife species weighing more than $70 \mathrm{~kg}$.

Literature sources for inorganic terrestrial phytotoxicity benchmarks were summarized and reported by Suter and Futrell (1993) (table 5-8). Where applicable, the lowest source concentration in a soil medium that produced phytotoxically excessive effects was chosen from the data base. Several benchmarks were derived from experiments using nutrient solutions. However, uncertainty values were not applied to these data to account for differences in growth media. A methodology for deriving phytoroxicity benchmarks for organic constiuents was de veloped by Eskew and Babb [as cited in the MMR Air National Guard Risk Assessment Handbook (1992)] (table 5-8).

Risks to aquatic organisms from exposure to organic and inorganic contaminants in water and sediments (pore water) were calculated by comparing the water or sediment pore-water concentrations with the chemical-specifis aquatic benchmark (Suter et al. 1992) (table 5-8). To determine internal dose to aquatic plants, fish. and muskrats from exposure to radionuclides, the surface-water concentrations were multiplied by radionuclide and organism-specific aquatic (intemal) dose conversion factors to produce a daily dose in rads (Killough and McKay 1976). 
TABLE 5-8-Criteria Benchmarks for Terrestrial' and Aquatic ${ }^{2}$ Species on the Hanford Reser sation

(NOAELs listed in milligrams per killogram per day for terrestrial benchmarks or milligrams per liter for aquatic benchmarks)

\begin{tabular}{|c|c|c|c|c|c|c|c|c|c|c|c|c|c|}
\hline Consinacent & $\begin{array}{l}\text { Gas. } \\
\text { Mense }\end{array}$ & $\begin{array}{l}\text { Deactivilad } \\
\text { Jacturinuic }\end{array}$ & $\begin{array}{l}\text { Palld } \\
\text { nax }\end{array}$ & Rebla & $\begin{array}{l}\text { Sage } \\
\text { Grense }\end{array}$ & $\begin{array}{l}\text { Loppertwend } \\
\text { shrites }\end{array}$ & $\begin{array}{l}\text { Canado } \\
\text { Gumer }\end{array}$ & $\begin{array}{l}\text { Mule } \\
\text { Denr }\end{array}$ & P. Howk & Dald & Coyole & Vequention & Apmante \\
\hline Bearor(u)pyneac & $2.456-12$ & $5.36 \mathrm{E}-03$ & $2.208-02$ & $1.67 \mathrm{E}-02$ & $5.59 E-03$ & $1.97 E-02$ & $5.02 E-03$ & $1.47 E-03$ & $6.31 E-03$ & $4.27 \mathrm{e}-03$ & $2.002-03$ & $1.288-02$ & $2.998-03$ \\
\hline 4- bethyl-2-penuanose & $1.22 E+01$ & $2.62 E+00$ & $1.108+01$ & $8.36 E+\infty 0$ & $2.808+\infty 0$ & $9.87 E+00$ & $2.518+00$ & 7.35E-01 & $3.16 E+00$ & $2.138+00$ & $1.40 \mathrm{E}+00$ & NA & $1.598+00$ \\
\hline Trictloroctionese & $1.62 E+02$ & $4.02 E+01$ & $1.65 E \cdot .02$ & $1.11 E+02$ & $4.20 E+01$ & $1.31 E+02$ & $3.778+01$ & $1.108+01$ & $4.74 E+01$ & $3.20 \mathrm{E}+01$ & $2.108+01$ & $6.702-01$ & $5.768+00$ \\
\hline Almoinum & NA & NA & NA & NA. & NA & NA & NA & NA & NA & NA & NA & $8.00 \mathrm{E}+00$ & $8.700-02$ \\
\hline Benglingon & $1.32 E+00$ & $2.908-01$ & $1.19 E+00$ & $9.02 E-01$ & $3.02 \mathrm{E}-01$ & $1,07 E+00$ & $2.71 \mathrm{E}-0 \mathrm{t}$ & $7.94 \mathrm{E}-02$ & $3.41 E-01$ & $2.318-01$ & $|.51 \mathrm{E}-0|$ & $1.00 \mathrm{E}+01$ & $3.208-03$ \\
\hline Cadnium & $2.36 \varepsilon-02$ & $5.168-03$ & $2.12 E-02$ & $1.4 \mathrm{E}-01$ & $1.06 \mathrm{e}-02$ & $1.702-01$ & $1.783-03$ & $1.42 E-03$ & $2.24 E-03$ & I. $51 E-03$ & $2.69 \mathrm{e}-03$ & $3.008+\infty$ & $1.108-03$ \\
\hline Orrominos & $588 E+00$ & $1.29 \varepsilon+\infty$ & $5.27 E+\infty$ & 4.011:.(x) & $1.34 E+00$ & $4.74 E+00$ & $1.21 E+\infty 0$ & $3.53 \mathrm{E}-01$ & $1.52 E+00$ & $1.02 \mathrm{E}+00$ & $6.71 \mathrm{E}-01$ & $7.508+01$ & $1.108-02$ \\
\hline Copper & $|84 E-0|$ & $7.51 \mathrm{E}-01$ & $1.65 E-01$ & $6.88 E+01$ & $1.86 E+01$ & 8. $12 \mathrm{E}+01$ & $\mid .67 E+01$ & $2.06 \mathrm{E}-01$ & $2.108+01$ & $1.42 \mathrm{E}+01$ & $3.928-01$ & $6.002+01$ & $1.208-02$ \\
\hline Cyanide (irow) & $1.65 E+01$ & $5.79 a+00$ & $2.37 E+01$ & $1.80 \varepsilon+01$ & $6.04 E+00$ & $2.13 E+01$ & $5.43 E+\infty 0$ & $2.10 \mathrm{E}-02$ & $6.82 E+00$ & $0.11 E-02$ & $4,000-02$ & NA & $5.20=03$ \\
\hline brow (nimeres) & NA & NA & NA & NA & NA & NA & NA & NA & NA & NA & NA & $1.000+104$ & $1.008+\infty$ \\
\hline Lead & $7.10 E-03$ & $1.565-03$ & $6.37 E-03$ & 1.59E-02 & $9.85 E+00$ & $1.88 E-02$ & 8. $84 E+\infty 0$ & 4.27E-04 & $1.118+01$ & $7.518+00$ & $8.11 E-04$ & $1.008+02$ & $3.202-03$ \\
\hline Mapresiun (nitrate) & $4.31 E+01$ & $9.46 E+00$ & $3.87 E+01$ & $2.94 E+01$ & $9.85 E+C 0$ & $3.47 E+01$ & $8.84 \mathrm{E}+00$ & $2.598+00$ & $1.118+01$ & $7.31 \mathrm{~B}+00$ & $4.92 \mathrm{E}+00$ & NA & $1600-04$ \\
\hline Mercury & $1.44 \dot{1}+01$ & $5.5 x E-03$ & $1.29 E+01$ & 3. $19 E++00$ & $5.09 E-01$ & $3.77 E+00$ & $4.57 \mathrm{E}-01$ & $1.72 \mathrm{E}-02$ & $3.748-01$ & $3.888-01$ & $3.27 \mathrm{E}-02$ & $3.000: \cdots$ & 1.3002-03 \\
\hline Nicted & $5.92 E+01$ & | 29E+01 & S.31E+01 & $4.17 E+00$ & $1.40 E+00$ & $4.938+\infty 0$ & $1.25 \mathrm{E}+00$ & $3.5 S E+00$ & $1.58 E+00$ & $1.07 E+\infty 0$ & $6.75 E+00$ & $1.002+02$ & $1.602-01$ \\
\hline Potension (barac) & NA & NA & NA & NA & NA & NA & NA & NA & NA & NA & NA & NA & $1.30 \mathrm{e}-04$ \\
\hline Sodinos & NA & NA & NA & NA & NA & NA & NA & NA & NA & NA & NA & NA & $4.808-01$ \\
\hline $\sin$ & $2.38 E+01$ & $5.20 \mathrm{E}+00$ & 2.13E+01 & $1.62 \mathrm{E}+01$ & $5.43 \mathrm{E}+00$ & $1.91 E+01$ & $4.87 E+\infty 0$ & $1.43 E+00$ & $6.13 E+00$ & 4.145 .00 & $2.71 E+\infty 0$ & $1.002+01$ & $1.108-01$ \\
\hline
\end{tabular}

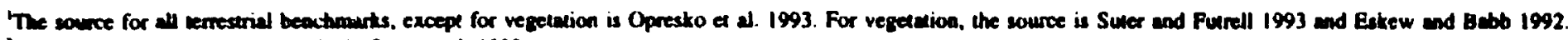

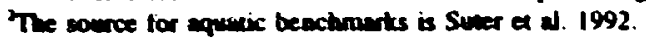

NA = Beactumat col available. 
To determine the intermal dose to generic benthic macroinvertebrates and other bottom-dwelling organisms (e.g., fish larvae) from exposure to radionuclides, the sediment pore-water concentrations were multiplied by radionuclide and organism-specific aquatic (internal) dose conversion factors to produce a daily dose. The external dose to all organisms was determined by multiplying the surface-water concentration by the external radionuclide-specific dose conversion factor. Combined internal and extemal doses greater than $1 \mathrm{rad} / \mathrm{d}$ are considered to pose a potential risk to aquatic organisms (NCRP 1991).

For contaminants and receptors that did not pass the average concentration screening (chapter 5.3), an anempt was made to further define exposure risks by comparing receptor species' home range sizes with the potential fraction of the home range occupied by contaminants in food and water from waste sites.

Receptor species at the Hanford Reservation have home ranges or territories that range from small [e.g., less than one hectare ( 2.5 acres) for mice and robins] to large [e.g., thcusands of hectares (acres) for bats and coyotes (table 5-9)]. Some small species have home ranges small enough to be completely within individual waste sites. Other species have such large home ranges that the waste sites would comprise only a small part of the area they would occupy, if the waste sites were used at all. To further interpret the results of this risk analysis, the following assumptions are made about contaminant exposure to receptors.

1. Burrowing small mammals, insects, and vegetation are known to move radiological contaminants from buried waste to the surface where it is presumably redistributed through the food chain, excrement, and soil dust (Arthur 1982; Markham 1987; Arthur and Markhar: 1983). The same is probably true for nonradiological contaminants. Because the waste sites are the original sources of contaminants, and data are lacking for contaminant levels
Outside the waste sites, soune terms outside waste sites are assumed to be negligible.

2. It is assumed that small species with home ranges of about 5 ha (12 acres) or less (table 5-9) could receive as much exposure as our average screening indicates.

3. It is assumed that wider ranging species could receive at most $30 \%$ of the exposure calculated by our average screening. This assumption is based on the approximately 800 ha (2,000 acres) of waste sites contained within the two major waste areas [i.e., 100 and 200 Areas; total area of 2700 ha (6670 acres)]. Exposure could be greater if, for instance, the sole source of contaminants is a waste pond used as the only source of drinking water. Or exposure could be less if the species home range or territory is very large.

4. Waste sites occupy about 800 ha $(2,000$ acres) or $0.6 \%$ of the surface area of the Hanford Reservation; this is the only part of the reservation considered for remediation. Biota living in the remaining $99.4 \%$ of the reservation may be exposed to contaminants that have moved from waste sites in dust and that exist in contaminated wildlife and plants. Although this contamination may be measurable, source terms for it are not available and contamination is assumed to be negligible compared with the contamination in the waste sites. Because we assume that the overall habitat at the Hanford Reservation is similar, it is also assumed that only $0.6 \%$ of the area supforting ecological 
TABLE 5-9_Home Ranges' of Hazard Index (HI) Correction Factors (CF)

for Terrestrial Receptor Species at the Hanford Reservation

\begin{tabular}{|c|c|c|c|c|}
\hline \multirow[b]{2}{*}{ Receptor Species } & \multicolumn{3}{|c|}{ Home Range (ha) } & \multirow[b]{2}{*}{ Correction Factior } \\
\hline & $<5$ & $5-800$ & $>800$ & \\
\hline $\begin{array}{l}\text { Bald eagle } \\
\text { Aleutian Canada goose } \\
\text { Generic vegetation } \\
\text { Black-tailed jackrabbit } \\
\text { Mule deer } \\
\text { Sage grnuse } \\
\text { Canada goose } \\
\text { Coyote } \\
\text { Great Basin pocket mouse } \\
\text { Pallid bat } \\
\text { Robin } \\
\text { Loggerhead shrike } \\
\text { Ferruginous hawk }\end{array}$ & $\mathbf{X}$ & $\begin{array}{l}\mathbf{X} \\
\mathbf{X}\end{array}$ & $\begin{array}{l}\mathrm{X} \\
\mathrm{X} \\
\mathrm{X} \\
\mathrm{X} \\
\mathrm{X} \\
\mathrm{X}^{4}\end{array}$ & $\begin{array}{c}1.0^{3} \\
0.30 \\
1.0 \\
6.15 \\
0.27 \\
0.15 \\
0.30 \\
0.09 \\
1.0^{4} \\
0.004 \\
1.0 \\
0.15 \\
0.11\end{array}$ \\
\hline
\end{tabular}

'Data are from Schoener (1968), Terres (1980), Chapman and Feldhamer (1982), Nowak and Paradiso (1983), Anderson and Wallmo (1984), and Fitzner and Gray (1991).

${ }^{2} \mathrm{~A}$ CF of 1.0 was applied to HIs for each contaminant for each species having a home range $55 \mathrm{ha}$ (12 acres); other CFs are based on the ratio of contaminated land and water to the area of the waste complex; CFs for wide-ranging species are based on the ratio of contaminated land and water to the area of their home ranges (see text for discussion of CFs).

${ }^{3} \mathrm{~A}$ CF of 1.0 was applied to the bald eagle because it is assumed to feed exclusively in the Columbia River.

'Sizes of home ranges for bats are generally unknown. Foraging distance ranges between 25 to $97 \mathrm{~km}$. The CF is based on the area of a circle with a $25 \mathrm{~km}$ radius.

endpoints is affected by contaminants from the waste sites.

5. Except for threatened and endangered species, for which the loss of an individual is considered a significant risk to the population, it is assumed that other endpoints are at risk only at the small scale represented by the $0.6 \%$ of the Hanford Reservation that is in waste sites.

6. Contaminated wetlands are found in B Pond and the FFTF Pond. It is assumed that all aquatic biota receive the average exposure to contaminants if they occur in these waste ponds. Similarly, it is assumed that biota feeding exclusively on fish from the Hanford Reach of the Columbia River recrive the average exposure to contaminants.

\subsection{Contaminant Hazard Assessment}

Risk to terrestrial and aquatic receptors from contamination at the Hanford Reservation was modeled. For terrestrial receptors, hazard indices (HIs) were generated for maximum and average contaminant concentrations for chemical constituents, and maximum and average doses were generated for radiological constituents. For aquatic receptors, maximum and average internal and extemal doses were generated for radiological constituents. 


\subsubsection{Baseline}

The next step in the ecological risk assessment generates HIs that are representative of potential risk and that estimate the level of effects from exposure to contaminants. Baseline HIs for terrestrial receptors exposed to the maximum source concentrations were greater than the criteria limit of 1 for 11 out of 12 inorganic contaminants and for 3 out of 3 organic contaminants for which we had benchmarks. Benchmarks for many of the contaminants could not be cbtaineci. Exposure to the total maximum concentrations of radionuclides resulted in HIs for all receptors of about $2 \mathrm{E}+04$. Radiological exposure was dominated by exposure to ${ }^{20} \mathrm{Pu}$, ${ }^{9} \mathrm{Sr},{ }^{9} \mathrm{Tc},{ }^{\infty} \mathrm{Co}$, and ${ }^{17} \mathrm{Cs}$ in soils.

Exposures of terrestrial species to average soil and water concentrations at the site were calculated for those contaminants whose maximum concentrations resulted in HIs greater than 1 (table 5-10). About 18\% of the HI values were above 1 but below $10,61 \%$ were above 10 but below 1000, and about $21 \%$ were still above 1000. The HIs for all species exposed to the average concentrations of radionuclides were still over 1, as a result of ${ }^{20 u}$ and ${ }^{M} \mathrm{Tc}$ exposure (table 5-11).

Concentrations of nonradiological contaminants in surface water and sediment at the Hanford Reservation were not provided in the source terms obtained from PNL. Therefore, risks to aquatic organisms from nonradiological contaminants could not be calculated. Exposure to meximum concentrations of radionuclides in the surface water or in the sediment pore water resulted in HIs (or doses) greater than I for all aquatic organisms (except benthic macroinvertebrates) as the result of internal and external exposure to $\mathrm{Tc}$ in surface water. Exposure to average concentrations did not substantially reduce the Hls because the concentratio., of $\mathrm{Tc}$ in the water did not change significantly (table 5-12).

Or the receptors included in these analyses, the Great Basin pocket mouse and robin occupy small enough areas (table 5-9) to potentially live entirely within contaminated areas (e.g., less than 5 ha ( 12 acres)]. The black-tailed jackrabbit, sage grouse, and loggerhead shrike have home ranges or territories greater than 5 ha (12 acres) and less than the treal estimated contaminated areas (i.e., 800 ha (2000 acres)]. Of the remaining receptors, the home territory of the Canada goose was less than the total area of the waste complex (i.e., 2700 ba (6670 acres) for Areas 100 and 200), whereas the horme ranges or territories of the pallid bat, mule deer, fernginous hawk, bald eagle, and coyote exceoded the area of the waste complexes.

On the basis of assumptions discussed in chapter 5.3, appropriate correction factors were applied to the HIs for chemical constituents and radionuclides in tables 5-10, 5-11, and 5-12 to determine potential severity of risks to roceptors. (Information for concentrations of nonradiological contaminants in surface water was unavailable; therefore, HIs for aquatic organisms could not be calculated.) For biota with home ranges or territories less than 5 ha (12 acres), no correction factor was applied to the hazard index. For species with home ranges or territories greater than 5 ha (12 acres) but less than 800 ha (2000 acres), a correction factor of 0.15 was used. It was assumed that species with home ranges up to 800 ha (2000 acres) would spend half of their time in one or the other of the aggregated areas but not in both because the 200 Area is about $10 \mathrm{~km}(6$ miles) south of the 100 Area. Thus, the ratio of contaminated area to the area of the waste complex was divided by 2 for a correction factor of 0.15 (i.e., $800 / 2700=$ $0.3012=0.15$ ). For species with home ranges or territories greater than 2700 ha (6670 acres), the correction factor is determined by dividing the total estimated contaminated area by the area the species home range or territory in hectares (i.e., 800 home rarige].

Some contaminants on the Hanford Reservation may be highly localized; however, there are no data for their areal distribution. Of the contaminants that result in moderate to severe risks (i.e., HI from I to 10 and $\mathrm{Hl}$ greater than 10. respectively), source terms for $\mathrm{Mg}$ represent about 0.02 ha 0.6 .5 acre), cyanide and $\mathrm{Pb}$ represent about 2 ha ( 5 acres), and $\mathrm{Cd}, \mathrm{Cu}$, and $\mathrm{Hg}$ represent about 6 ha (15 acres) of contaminated land (appendix B). Source terms for radionuclides range from 0.4 ha (1 acre) to 36 ha (90 acres). Source terms for all other contaminants range from $0.0 \mathrm{CO} 2$ ha ( 0.0005 acre) 
TABLE 5-10_Basoline Hecand Indices for Torrestrial Organtems on the Fanford Reservation

\begin{tabular}{|c|c|c|c|c|c|c|c|c|c|c|c|c|}
\hline & $\begin{array}{l}\text { Grese Inds } \\
\text { nocter Monese }\end{array}$ & $\begin{array}{l}\text { Deck-Trilod } \\
\text { Jecturabult }\end{array}$ & Pridu nat & Male Daer & Robita & Gemp & Coman & Iecortiond & 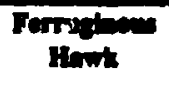 & Dadd & Copele & $v_{\boldsymbol{m}}$ \\
\hline Benzo(a)pyrease & $7.362+02$ & $.563+03$ & $2.948+\infty 8$ & $2518+a$ & 3.16000 & 56 & $100 \mathrm{nim}$ & $15 x+94$ & $2000+01$ & 0.00 & 1.85401 & 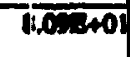 \\
\hline 4-methyl-2-pencianone & $4.598+02$ & $1.2 x+183$ & $20 s+60$ & $1.998+00$ & comentens. & $13 \sin$ & $180=403$ & $3.4+\infty$ & 6.78E-0S & 0.00 & $5.578-05$ & NA \\
\hline Trichboroethene & $2.14 E-01$ & $7.71 E-01$ & $3.248-01$ & 8.13E-01 & $3.00 \mathrm{~B}-01$ & $6.26 \mathrm{e}-01$ & 7.760401 & $1.39 \mathrm{e}-01$ & $4.688-07$ & 0.00 & $3.89 \mathrm{e}-07$ & $1.008+00$ \\
\hline Cudmium & $1.39 E-01$ & $1.94 E+00$ & $6.938-01$ & $1.608 \times 100$ & $5.26 \mathrm{~B}-02$ & $8.658-01$ & $\operatorname{sen}$ & $3.348-02$ & $2.79 \mathrm{e}-0 \mathrm{~A}$ & 0.00 & $8.608-05$ & $1.808-01$ \\
\hline Cromium & $7.996-03$ & $1.05 E-01$ & $2.13 n-03$ & $2.77 \mathrm{E}-02$ & $3.66 \mathrm{~B}-02$ & $1.278-01$ & $1.338-01$ & $9.196-04$ & 5.5TE-05 & 0.00 & $5.28 \mathrm{ag}-0 \mathrm{~s}$ & $4.21 \mathrm{E}-01$ \\
\hline Copper & $2.198+01$ & $8.538+00$ & 5.258 .01 & 7.17000 & $8.72 B-02$ & $3.26 \mathrm{~B}-01$ & 3.83 .01 & 4.13B-02 & 3.47E-04 & 0.00 & $7,040-03$ & 7.618:00 \\
\hline Cyanice (iroa) & $6.806-01$ & $2.36 \mathrm{~B}+02$ & $1.098+08$ & $1.7 \mathrm{~min}$ & 2xomen & & $2 \operatorname{sunat}$ & Amanor. & $3.208-07$ & 0.00 & $1.262-05$ & NA \\
\hline Iroen (nitrane) & NA & NA & NA & NA & NA & NA & NA & NA & NA & NA & NA & $4.718+00$ \\
\hline Lead & $9.638+\infty 0$ & $1.428+00$ & $1.41 \mathrm{~B}+01$ & $x$ & $14=01$ & $2.64 E-02$ & $2.828-02$ & 1.0000000 & $6.75 E-07$ & 0.00 & $3.78 \mathrm{e}-03$ & $422 \mathrm{E}-01$ \\
\hline Matresium (nitrate) & $8.718+01$ & $6.508+02$ & $25 s a+c e$ & & 12 inden & frane & $6.000+000$ & 1.820400 & 3.13E-01 & 0.00 & $2.61 e-01$ & NA \\
\hline Mercury & $1.81 E-03$ & $1.688+01$ & $1.178-02$ & Wa & $2.048-02$ & $1.62 \mathrm{~B}-01$ & $1.97 \mathrm{~B}-01$ & $1.568-02$ & 4.64E-03 & 0.00 & $3.018-02$ & $1.188+01$ \\
\hline Nickel & $3.92 E-03$ & $3.19 E-02$ & $3.96 \mathrm{~B}-03$ & $1.508-02$ & $1.12 \mathrm{~B}-01$ & $3.418-01$ & $3.68 \mathrm{E}-01$ & $1.65 B-02$ & 1.78E-04 & 0.00 & $1.69 \mathrm{e}-05$ & 7.38E-01 \\
\hline Zinc & 3.75E-02 & 2.52E-01 & $1.058-01$ & $2.328-01$ & $6.958-02$ & $2.058-01$ & $2.53 \mathrm{~B}-01$ & $4.558-02$ & $2.42 E-03$ & 0.00 & $2.018-03$ & 4.S18-01 \\
\hline
\end{tabular}

NA = Beachanert not available, therefore haverd index could sot he calculabed.

TABLE 5-11-Baseline Average Radiological Doses for Terrestrial Organisms on the Hanford Reservation

\begin{tabular}{|c|c|c|c|c|c|c|c|c|c|c|c|c|}
\hline & $\begin{array}{l}\text { Greed Desho } \\
\text { Pretet Moure }\end{array}$ & $\begin{array}{l}\text { Dack-talled } \\
\text { Jackirabin }\end{array}$ & Pallid Bet & Mubs Deer & Robla & Seper & Cande & $\begin{array}{l}\text { Lapitiead } \\
\text { Shritio }\end{array}$ & $\begin{array}{c}\text { Permideoes } \\
\text { Hawl }\end{array}$ & Bald teape & Cospese & Versiction \\
\hline Cobuh-60 & $6.97 \mathrm{E}-02$ & $6.978-02$ & $6.97 \mathrm{E}-02$ & $6.97 \mathrm{~B}-02$ & $6.978-02$ & $6.978-02$ & $6.97 \mathrm{E}-02$ & $6.97 \mathrm{~B}-02$ & $6.97 \mathrm{E}-02$ & $6.97 \mathrm{E}-02$ & $6.97 \mathrm{e}-02$ & $6.815-04$ \\
\hline Cesiumb-137 & $5.91 E-01$ & $5.918-01$ & $5.91 \mathrm{E}-01$ & $5.928-01$ & $5.918-01$ & $5.918-01$ & $5.91 \mathrm{E}-01$ & $5.918-01$ & $5.91 \mathrm{E}-01$ & $5.91 \mathrm{E}-01$ & $5.918-01$ & 0.00 \\
\hline Europium-152 & $2.888-01$ & $2.828-01$ & $2.888-01$ & $2.888-01$ & $2.888-01$ & $2.888-01$ & $2.848-01$ & 288B-01 & $2.848-01$ & $2.848-01$ & $2.828-01$ & 0.00 \\
\hline Plutoniurar-239 & $1.29 E+00$ & $1.29 e+00$ & $1.298+\infty$ & $1.298+00$ & $1.29 \mathrm{E}+00$ & $1.298 \times 00$ & $1.298+\infty 0$ & $1.298+00$ & $1.29 \%+\infty 0$ & $1.298+\infty 0$ & $1.298+00$ & $5.00 E-01$ \\
\hline Stroncium-90 & 6.19E-01 & 6.19E-01 & $6.19 \mathrm{~B}-01$ & $6.198-01$ & $6.19 \mathrm{~B}-01$ & $6.19 \mathrm{~B}-01$ & $6.198-01$ & $6.19 \mathrm{E}-01$ & $6.198-01$ & $6.19 \mathrm{e}-01$ & $6.198-01$ & $5.908+01$ \\
\hline Technetium-99 & $1.80 \varepsilon+00$ & $5.22 E+01$ & $2.14 E+\infty 0$ & $1.27 z+03$ & $4.08 E+\infty 0$ & $3.412+01$ & $7.928+01$ & $1.948+\infty$ & $3.33 \mathrm{R}+01$ & $6.292+02$ & $5.221+02$ & 0.00 \\
\hline Uranium-238 & $1.668-03$ & $1.66 E-03$ & $1.668-03$ & $1.668-03$ & $1.668-03$ & $1.668-03$ & $1.668-03$ & $1.668-03$ & $1.668-03$ & $1.668-03$ & $1.66 \mathrm{E}-03$ & $1.2 \%-02$ \\
\hline Tow doex & $4.66 E+00$ & $5.502+01$ & $5.008+\infty 0$ & $1.27 \mathrm{E}+03$ & $6.948+00$ & $5.70 E+01$ & $8.268+01$ & $4.802+00$ & $3.618+01$ & $6.32 \mathrm{R}+02$ & $5.318+02$ & $3.598+\infty 0$ \\
\hline Ratiological HI & $4660+01$ & $5.509+00$ & $5.003+01$ & $127 \mathrm{BaC}$ & acinin & $5.74 \times 10$ & 200100 & Anten & $3.61 \mathrm{man}$ & $6.92,40$ & $5.312+03$ & $3.5914+01$ \\
\hline
\end{tabular}


TABLE 5.12 - Baseline Average Intermal and External Radiological Doses for Agratic Onganions (ruld) on the Hanford Reservation

\begin{tabular}{|c|c|c|c|c|c|}
\hline & Externd & $\begin{array}{l}\text { Internal } \\
\text { Plands }\end{array}$ & $\begin{array}{l}\text { Internad } \\
\text { Invertebrates }\end{array}$ & $\begin{array}{l}\text { Internal } \\
\text { Ptat }\end{array}$ & $\begin{array}{l}\text { Internal } \\
\text { Moderats }\end{array}$ \\
\hline Cobalt -60 & $1.60 \mathrm{E}-07$ & $1.87 E-05$ & 0.00 & $1.87 \mathrm{E}-06$ & $3.68 E-06$ \\
\hline Cesium-137 & $3.17 \mathrm{E}-08$ & $2.32 E-06$ & $7.38 E-06$ & $1.16 E-05$ & $1.64 E-05$ \\
\hline Europium-152 & 0.00 & 0.00 & 0.00 & 0.00 & 0.00 \\
\hline Plutonium-239 & 0.00 & 0.00 & $3.25 E-03$ & 0.00 & 0.00 \\
\hline Strontium-90 & $1.40 \mathrm{E}-04$ & $1.40 E-01$ & $4.83 \mathrm{E}-\mathrm{OS}$ & $1.40 E-03$ & $6.15 \mathrm{E}-01$ \\
\hline Technetium-99 & I.60E +04 & $1.24 E+06$ & 0.00 & $4.62 E+05$ & $9.07 E+04$ \\
\hline Uranium-238 & 0.00 & 0.00 & $2.50 E-03$ & 0.00 & 0.00 \\
\hline Total dose & $1.60 E+04$ & $1.24 E+06$ & $5.81 E-03$ & $4.625+05$ & 9.07ita4 \\
\hline
\end{tabular}
dose.

The benchmark for aquatic organisms is $1 \mathrm{rad} / \mathrm{d}$; thus the hazard index is equal to the total

to 32 ha (80 acres). Although data for most contaminants were reported for only a small fraction of the total area in waste sites, it is assumed that the data are representative. All source terms used in this risk analysis are. therefore, assumed to be present in all 800 ha (2000 acres) of waste sites (appendix B).

Threatened and Endangered Species. Risks to some threatened and endangered species would be severe or moderate if individuals occupy waste sites. Potentially severe risks would be present for geese, eagles, and hawks from total radioactive contaminants and for geese from organic contaminants and cyanide and magnesium (table 5-13a). Potentially moderate risks also would be present for the goose (cadmium) and the hawk [benzo(a)pyrene]. Although these analyses indicate potential risks to these species, a site-specific survey of individual waste sites for occurrences of threatened and endangered species would be necessary to determine if there are actual risks.

\subsubsection{Wetlands}

Risks from total radionuclides to wetlands receptors (e.g., plants, invertebrates, fish and muskrats) if present in waste ponds would be severe based entirely on an elevated source term for "Tc (table 5-12; the benchmark for aquatic organisms is $1 \mathrm{rad} / \mathrm{d}$; thus for radioactive contaminants the $\mathrm{HI}$ equals the total dose). Risks to wetland receptors from nonradiological contaminants were not estimated because source term data were lacking. However, because it is assumed that wetlands that are not waste ponds are free of contamination, risks to receptors in natural wetlands from contaminants would be negligible.

\subsubsection{Recreational Wildife}

For some recreational species occupying waste sites, risks from organic contaminants, cyanide, lead, magnesium, and total radioactive contaminants would be severe (table 5-13b). Additional moderate risks would also be possible from copper and mercury. Risks to individuals that do not occupy waste sites would be negligible, ind because less than $0.6 \%$ of the reservation is waste sites, overall risks to populations of wildlife on the reservation would be negligible.

\subsubsection{Public Lands}

The size, geography, and restricted access to the Hanford Reservation provide buffers to the contaminated waste sites. The Columbia River in particular is a barrier that inhibits wide-ranging wildlife (e.g., deer and elk) from transporting contaminants to public lands north and east of the reservation, whereas the Yakima River and 
TABLE 5-13A - Baseline Pocential Risto' to Federally Listed Threutened, Endangered or Candidate Receptor Species' That Occups Weste

Sites on the Hanford Resernation

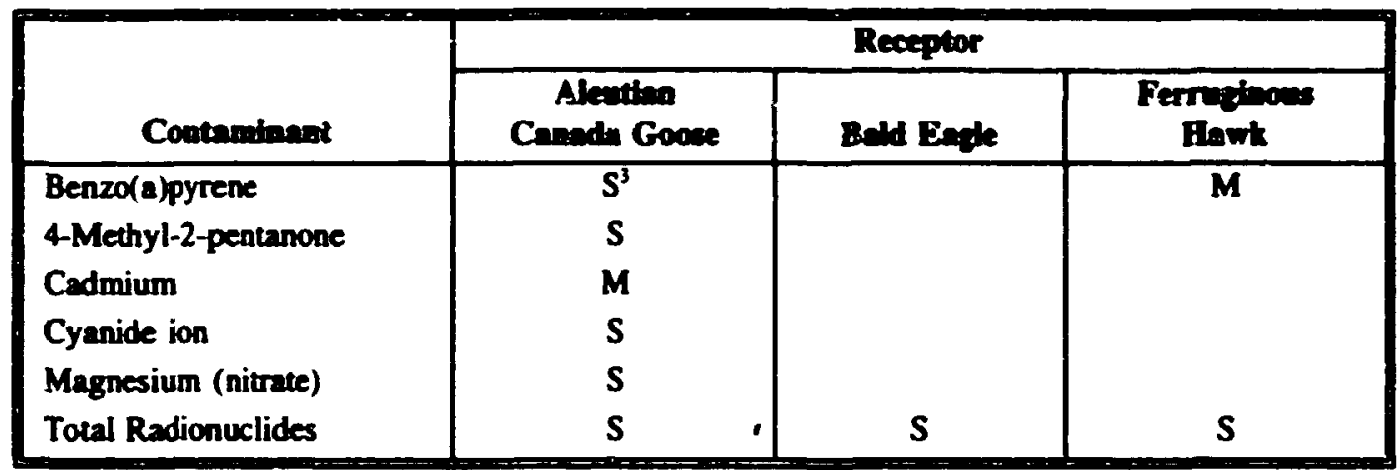

'Potential risks based on assumptions described in Section 5.4. Risks to individuals that do not occupy waste sites are negligible. Waste sites account for about $0.6 \%$ of the surface area of the Hanford Reservation.

${ }^{2}$ See Table S-2 for complete list of federally listed endangered, threatened, and candidate species.

${ }^{3} M=$ moderate risk, where $H I$ is equal to or greater than 1.0 , but less than $10 ; S=$ severe risk. where $\mathrm{HI}$ is equal to or greater than 10.

TABLe 5-138-Baseline Potential Rists' to Recreational Wildife Receptors That Occupy Waste Siles on the Hanford Reservation

\begin{tabular}{||l|c|c|c|c||}
\hline \multicolumn{1}{|c|}{ Contaminant } & \multicolumn{3}{|c|}{ Receptor } \\
\cline { 2 - 5 } & $\begin{array}{c}\text { Black-Talled } \\
\text { Jacknabbit }\end{array}$ & Mule Deer & $\begin{array}{c}\text { Sage } \\
\text { Grouse }\end{array}$ & Coyote \\
\hline Benzo(a)pyrene & $\mathbf{S}^{2}$ & S & S & M \\
4-Methyl-2-pentanone & S & S & S & \\
Copper & M & M & & \\
Cyanide ion & & S & S & \\
Lead & S & S & & \\
Magnesium & S & S & S & \\
Mercury & M & & & \\
Total Radionuclides & S & S & S & S \\
\hline
\end{tabular}

'Potential risks based on assumptions described in Section 5.4. Risks to individuals that do not occupy waste sites are negligible, and overall risks to populations of wildlife on the reservation are negligible. Waste sites occupy about $0.6 \%$ of the surface area of the Hanford Reservation.

${ }^{2} M=$ moderate risk, where $H I$ is equal to or mreater than 1.0, but less than $10 ; S=$ severe risk. where $\mathrm{HI}$ is equal io or greater than 10. 
and west. Although other wide-ranging species (c.s. coyote) are capable of transporting contaminants, the risk to public lands would be negligible because of the size of home ranges or territories in relation to the size of the reservation. Risks from receptor species in the food web (table 5-13c) would be negligible because the home ranges or territories of these species are small, they are limited by geographic barriers from access to public lands, and/or individuals do not occupy waste sites and thus pose no risk to public lands.

\subsubsection{Biodiversity}

Risk to overall biodiversity of the sagebrushsteppe ecosystem on the reservation would be negligible because waste sites $\propto$ ccupy only about $0.6 \%$ of the total land area. However, as discussed for other endpoints, there would be potential risks to some receptors which are important to biodiversity in waste sites (e.g.. the mouse as a food source or the robin as an indicator for risk to songbirds). Total radiological contaminants, organic contaminants, and cyanide and magnesium pose putential risks to raptors (e.g., shrikes and hawks) and bats that could feed on prey that occupy waste sites (table 5-13d). In addition to these receptors, vegetation is also potentially at severe risk from uptake of benzo(a)pyrene, trichloroethene, $\mathbf{M g}$, and total radiological contaminants in waste sites (table 5-13c). Copper and Fe pose moderate risks to vegetation.

\subsection{Habitat Disturbance assessment}

As our national natural landscape is increasingly fragmented by agricultural and urban development, large, undisturbed, and protected blocks of natural landscape are becoming more important for protection of biodiversity. The Hanford Reservation is a large block of relatively undisturbed native sagebrush-steppe. Adjoining lands to the west, north, and east are principally range and agricultural land. The cities of Richland, Kennewick, and Pasco (Tri-Cities) located southwest of the reservation are the nearest urban areas.
$1450 \mathrm{~km}^{2}$ (about $560 \mathrm{mi}^{2}$ ). Of this thout $665 \mathrm{~km}^{2}$

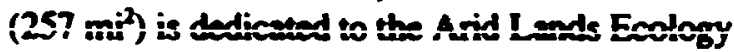
(ALE) Reserve, the U.S. Fish and Widdlife Service Saddle Mountain National Widdlife Refuge, and the Washington State Department of Game Reserve area (Wahluke Slope). About $90 \mathrm{~km}^{2}$ (36 mi ) is actively used for facilities operations including roads, utilities, and railroad rights-of-way. These disturbed areas, which are about $6 \%$ of the total reservation, are dominated by introduced plant species such as cheatgrass (Bromus tectorum), tumble mustard (Sisymbriwn altissimum), and Russian thistle (Salsola kali) that also intrude into surrounding native sagebrush-steppe.

\subsubsection{Baseline}

Because no additional disturbance due to restoration activities is included in the baseline alternative, no additional habitat disturbance or fragmentation beyond the current $6 \%$ of the reservation is expected.

\subsection{Cumulattve Assessment}

\subsubsection{On-Site}

\subsubsection{Baseline}

For 11 contaminants, including organic and inorganic chemicals and radionuclides, HIs suggest potential risks to organisms inhabiting waste sites (table 5-14). Of these contaminants. six pose potential risks to federally listed threatened. endangered, or candidate species (table 5-13a); only one ("Tc) poses a potential risk to species in wetlands, (no data are available for organic and inorganic contaminants in wetlands); eight pose potential risks to recreational wildlife species (table 5-13b); and ten pose potential risks to important food web components (table 5-13c) and species important to biodiversity (table 5-13d). The waste sites are mostly in highly developed areas that do not provide suitable habitat for many organisms. Thus, actual risks associated with these sites are probably lower than indicated by the HIs. Waste ponds, however, are utilized by wildlife and waterfowl; consequently, exposure may be 


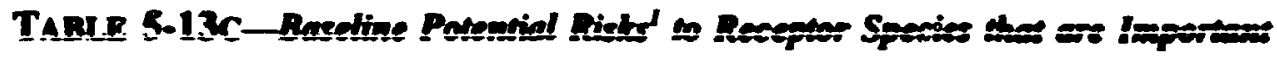
Food $W_{E}$ i Components on Waste Silas on the Hanforl Rosernition

\begin{tabular}{|c|c|c|c|}
\hline \multirow[b]{2}{*}{ Coutheninent } & \multicolumn{3}{|c|}{ Recepter } \\
\hline & $\begin{array}{l}\text { Great Bade } \\
\text { Pockiet Mowse }\end{array}$ & Robla & Vequation \\
\hline Benzo(a)pyrene & $S^{2}$ & $\bar{S}$ & $\bar{S}$ \\
\hline 4-Methyl-2-pentanone & $\mathbf{S}$ & $\mathbf{S}$ & \\
\hline Trichloroethene & & & $\mathbf{S}$ \\
\hline Copper & $\mathbf{S}$ & & $\mathbf{M}$ \\
\hline Cyanide ion & & $\mathbf{S}$ & \\
\hline Iron (nitrate) & & & $\mathbf{M}$ \\
\hline Lead & $\mathbf{M}$ & $\mathbf{S}$ & \\
\hline Magnesium (nitrate) & $\mathbf{S}$ & $\mathbf{S}$ & \\
\hline Mencury & & & $\mathbf{S}$ \\
\hline Total Radionuclides & $\mathbf{S}$ & $\mathbf{S}$ & $\mathbf{S}$ \\
\hline
\end{tabular}

'Potential risks based on assumptions described in Section 5.4. Risks to individuals that do not occupy waste sites are negligible and overall risks to populations of wildlife on the reservation are negligible.

${ }^{3} \mathrm{M}=$ moderate risk, where $\mathrm{HI}$ is equal to or greater than 1.0. but less than $101 \mathrm{~S}=$ severe risk. where $\mathrm{HI}$ is equal to or greater than 10 .

TABLE 5-13D-Baseline Potential Risks' to Receptor Species that are Important for the Conservation of Biodiversity on the Hanford Reservation

\begin{tabular}{|c|c|c|c|}
\hline \multirow[b]{2}{*}{ Contaminant } & \multicolumn{3}{|c|}{ Receplor } \\
\hline & $\begin{array}{l}\text { Palld } \\
\text { Bat }\end{array}$ & $\begin{array}{l}\text { Logsertiead } \\
\text { Shrike }\end{array}$ & $\begin{array}{c}\text { Perrughons } \\
\text { Hank }\end{array}$ \\
\hline $\begin{array}{l}\text { Benzo(a)pyrene } \\
\text { 4-Methyl-2-pentanone } \\
\text { Cyanide ion } \\
\text { Magnesium } \\
\text { Total Radionuclides }\end{array}$ & $\begin{array}{l}\mathbf{M}^{3} \\
\mathbf{M} \\
\mathbf{M}\end{array}$ & $\begin{array}{l}S \\
S \\
M \\
S \\
M\end{array}$ & $\mathbf{M}$ \\
\hline
\end{tabular}

'Potential risks based on assumptions described in Section 5.4. Risks to individuals that do not occupy waste sites are negligible and cverall risks to populations on the reservation are negligible.

${ }^{2}$ See Tabie 5-18c for potential risk to other receptors important for the conservation of biodiversity (e.g.. Great Basin pocket mouse, robin, and vegetation).

${ }^{3} M=$ moderate risk, where $\mathrm{HI}$ is equal to or greater than 1.0, but less than $10 ; \mathrm{S}=$ severe risk. where $\mathrm{HI}$ is equal to or greater than 10 . 


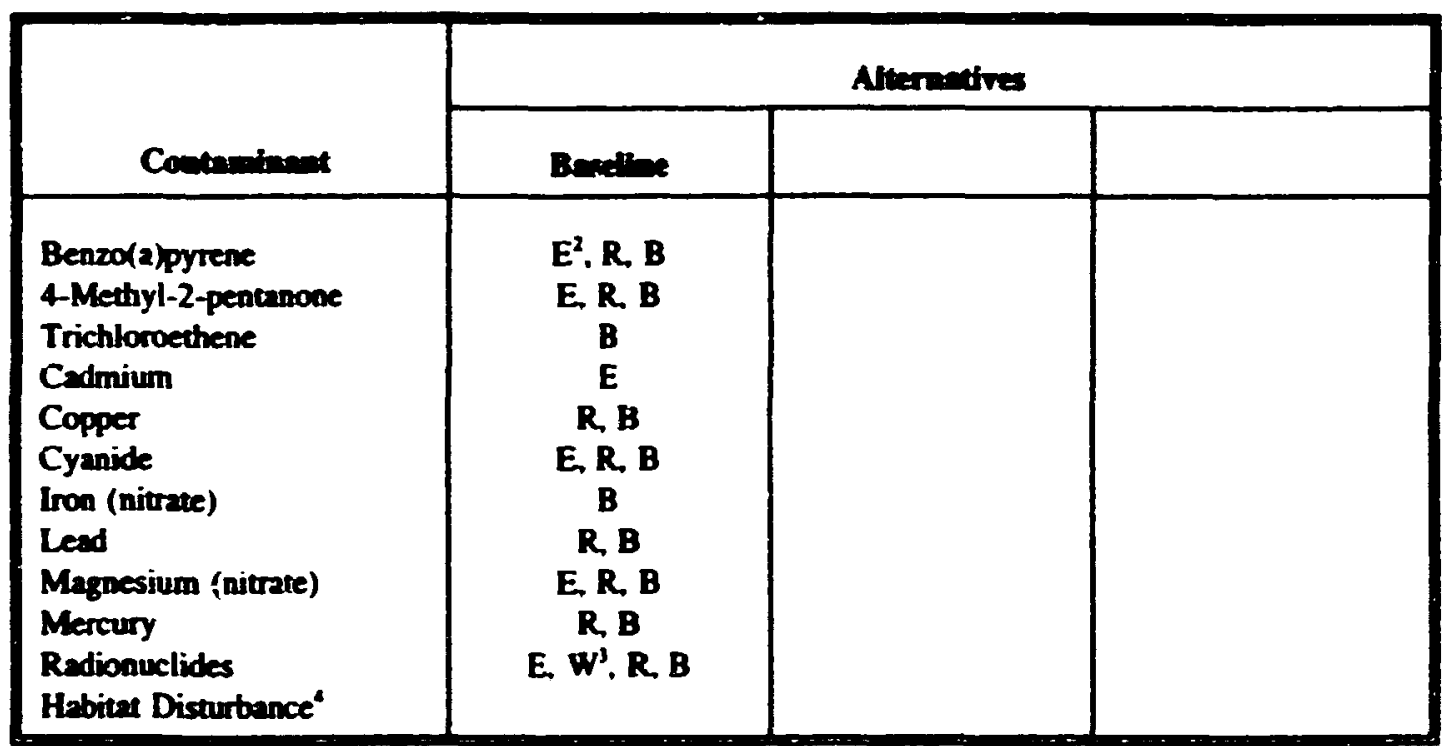

'Only those contaminants are listed for which our analyses showed potential moderate or severe risk to endpoint receptors.

${ }^{2}$ Ecological endpoints: $E=$ federally listed threatened, endangered, and candidate species:

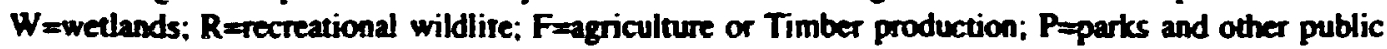
land: and B=biodiversity.

'Risk to aquatic resources from organic and inorganic contaminants is unknown; source terms were provided for radienuclides only.

These are short-term risks; long-term risks could be redused by successful restoration of appropriate habitat.

substantial for these organisms. For all of the sites. a future scenario involving closure of the Hanford facility without restoration might result in reoccupation of the waste sites by plants and animals; risks similar to those indicated in tables 5-13a, b, c, and d would then be expected.

Determining cumulative risks to receptors and endpoints that do not occur at waste sites is more problematic. Data were not adequate to determine facility-wide contaminant levels. Moreover, many of the inorganic contaminants (e.g., metals) included in our analyses are known to occur in soils throughout the United States at concentrations greater than or equal to concentrations in the Hanford source-term data base (e.g., Fe, Pb, Mg: Shacklette and Boemgen 1984). For some of the substances, it is possible that the source terms reflect naturally occurring concentrations rather than contamination. Even when background levels are known, interpretation of HIs for inorganic substances is often difficult because most analytical techniques do not distinguish between chemical forms that are available for uptake by organisms (e.g., dissolved in soil pore water or loosely bound to particles) and those that are biologically unavailable (e.g., insoluble salts).

Despite difficulties in interpreting the HIs, cumulative risks from available source term and benchmark data are adequate to compare altematives. Because of the relatively small fraction of the Hanford Reservation that is contarninated, potential risks to all endpoints except for (1) endangered and threatened species and (2) wildlife utilizing waste ponds appear negligible. Because no restoration activities are included in the baseline case, habitat disturbance/fragmentation risks would also be negligible. 


\subsubsection{Ox-Site}

The only currently known mechanism for transport of coniaminants from waste sites off the reservation is through ingestion of contaminants by wide- ranging wildlife (e.g., migratory waterfowl or mule deer). Of the three classes of contaminants in waste sites (i.e., organics, inorganics, and radionuclides), the only counce of radionuclides in the region wonld he the Hanford Reservation waste sites. Therefore. regional (off-site) cumulative rists for redionuclides would be the same as for on-site risks. At the time of our analyses no regional data for organics or inorganics were available. and cumulative risks for the region of influence could not be estimated. 


\section{CHAPTER 6: FERNALD ENVIRONMENTAL MANAGEMENT PROJECT (FEMP) ECOLOGICAL RISK ASSESSMENT}

The 425 ha (1050 acres) of the Fermald Environmental Management Project (EEMP) reservation lie in a transition zone where the mixed mesophytic forests of the east give way to oak-hickory forests to the west. Very little of the natural vegetation communities that dominated the region prior to clearing by settlers of European origin, however, survives. The site and immediate environs, moreover, have no virgin forests at all. Most of the remaining reservation area outside the industrial and waste storage areas is dominated by grasses, particularly red fescue, that are regularly mowed or grazed. Agriculture (especially pasture and croplands) is the primary land use in the environs near the reservation. followed by heavy and light industries, and a scattering of individual residences and small villages.

The Great Miami River flows within $1.2 \mathrm{~km}$ ( 0.75 mile) of the eastem boundary of the reservation on its way io the Ohio River, approximately 39 river $\mathrm{km}$ ( 24 river miles) to the southwest. This river averages about I m (3 ft) in depth and ranges in width from 40 to $120 \mathrm{~m}$ (130-390 ft). Average flow is about $94 \mathrm{~m}^{3} / \mathrm{s}$ ( $3200 \mathrm{cfs}$ ), whereas the maximum and minimum discharges were about $3100 \mathrm{~m}^{3} / \mathrm{s}$ (110,000 cfs) and $4.4 \mathrm{~m}^{3} / \mathrm{s}$ (155 cfs), respectively. A much smaller, first-order, intermittent stream, Paddy's Run, flows southward through the reservation along the westem boundary, finally emptying into the Great Miami River about 2.9 river km (1.8 miles) south of the site's southem boundary. Riparian woodland borders most of Paddy's Run and its principal tributary. Both streams support aquatic communities fairly typical of warmwater streams of the region that are slightly to moderately polluted.

The reservation itself (figure 6-1) is characterized by (1) a centrally located (former) production area and waste storage area, totaling only 55 ha (140 acres), that is almost completely devoid of natura! ecological communities, (2) small plantations of pine and spruce planted in 1972 in the vicinity of the northeast and southwest comers of the reservation, (3) fairly extensive areas of introduced grassland currently mowed or used for grazing of cactle. (4) relatively small areas of mature riparion woodlands along Paddy's Run and two of its small tributaries, (5) an area of scrub growth as well as young to mature upland woodlands in the northwestern part of the reservation, and (6) fly ash piles cowards the southeast comer of the reservation. Although the geographic ranges of at least four federally listed threatened and endangered species encompass the reservation, only one, the Indiana bat, is likely to actually occur on the reservation. One forested wetland of approximately 3.8 ha ( 9.5 acres) lies in the north central part of the reservation. Other smaller wetlands of the emergent type occupy certain drainage ditches and swales in the vicinity of the waste storage areas. Recreational fish species may occur occasionally in the reach of Paddy's Run that passes along the westem boundary of the reservation. Although hunting is not allowed on the reservation, several recreational wildlife species are present. Approximately $60 \%$ of the reservation is currently grazed by cattle. Important species groups of concem for conservation of biodiversity at FEMP include songbirds, raptors, deer, fox, other bats, amphibians, fish, and many flowering plants.

\subsection{ECOLOGICAl ENDPOINTS AND SPECTES Distribution}

The ecological endpoints chosen for the Fernald reservation are described in this chapter. In summary, only one federally listed threatened, endangered. or candidate species is likely to occur on the reservation; wetlands are found along swales, ditches, and streams, and in topographic depressions; recreational wildlife from contaninated species are present but hunting is not allowed; grazing is limited to specific non-contaminated areas; no public areas occur in or adjacent to the reservation; and the vegetation and wildlife (i.e.. 


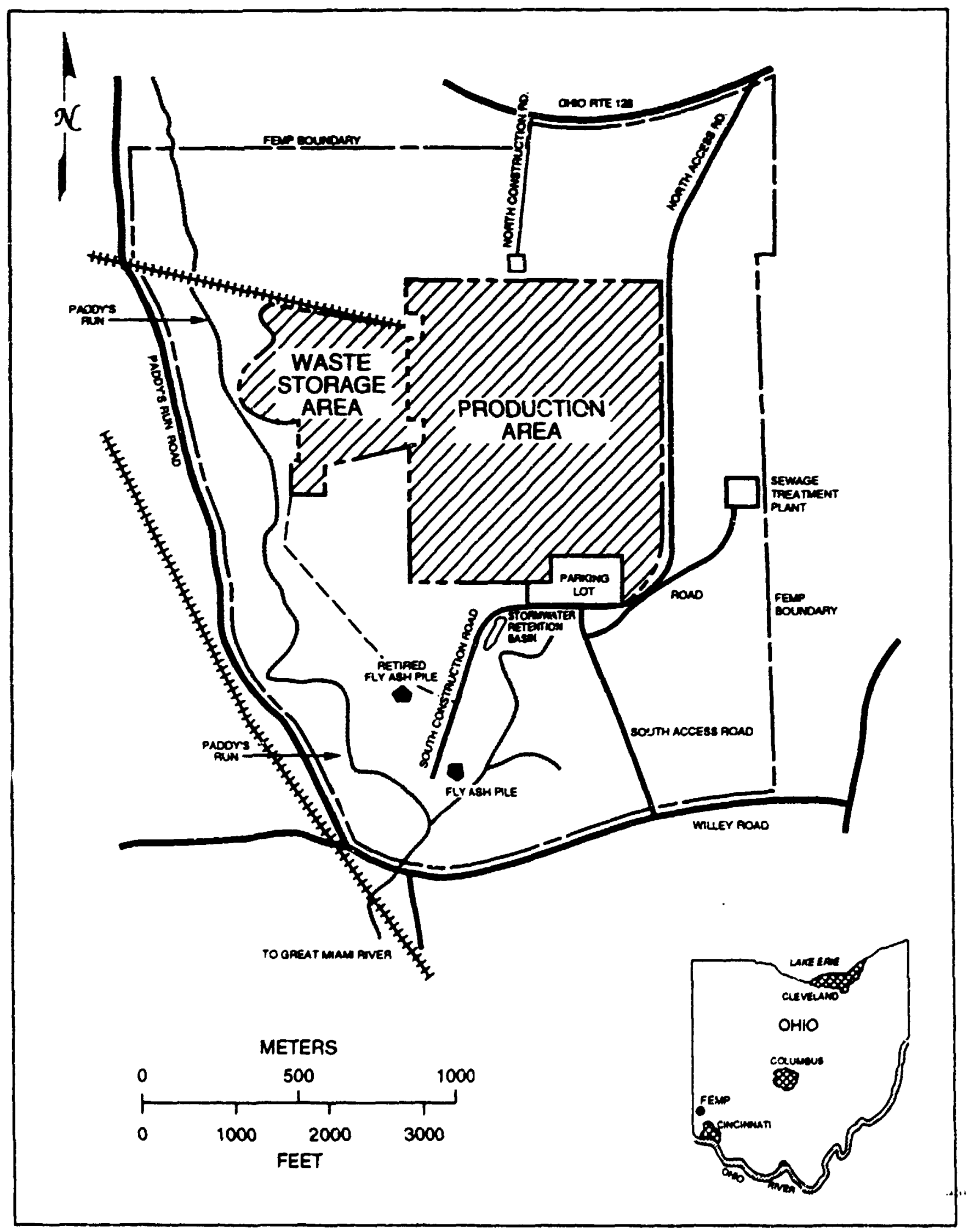


biodiversity) are typical of that found in the surrounding area.

Determining risks to endpoints requires (1) defining distribution and composition of endpoints and (2) selecting representive receptor species. The distribution of endpoints must be known in order to determine both exposure pathways for contaminants and risks to endpoints from construction.

For purposes of determining risk of exposure to contaminants, distribution of endpoints is considered to be either ubiquitous (i.e., more $x$ less uniformly distributed througioun une reservation or region). discrete (i.e., located in one clearly identified location), or discontinuous (i.e., found in several locations within a limited area or areas). Risks to ubiquitous endpoints are assumed to be related to the total surface area affected by contaminant exposure or by disturbance from construction. Risks to discontinuous and discrete endpoints are determined if their locations are known to be within contaminated areas or within areas affected by remediation-related construction or contaminant exposures.

Ubiquitous endpoints on the FEMP reservation include recreational wildlife and certain components of biodiversity (table 6-1). Wetlands, the only federally listed endangered species, and other elements of biodiversity and recreational wildlife, on the other hand, exhibit discontinuous distributions. The distribution of agricultural production and public lands endpoints can best be described as discrete. Locations of endpoints were determined from existing maps and publications.

Endpoints can be represented by many different receptors. The following chapters describe endpoints on the FEMP reservation and endpoint receptors selected for our analyses.

\subsubsection{Threatened and Endangered Species}

\subsubsection{Receptors}

The geographic ranges of several species listed by the U.S. Fish and Wildlife Service as threatened or endangered theoretically encompass the FEMP reservation, including the threatened northern wild monkshood (an herb, Aconituon noveboracense) and the endangered peregrine falcon (Falco peregrinus), bald cagle (Haliacetus leucocephalus), and lndiana bat (Myotis sodalis). The range of one state-listed endangered species, the cave salamander (Eurycea lucifuga), also overiaps the reservation. For reasons state ${ }^{2}$ in the next paragrapins, the Indiana bat was selected as the only receptor representative of federally listed threatened or endangered species on the reservation.

Foraging habitat for one colony of Indiana bats was found to range from 1.5 ha ( 3.6 acres) in early summer to 4.5 ha (11.2 acres) after young bats are flying (Humphrey et al. 1977). In the summer. these bats forage for insects in the upper woodland canopy (Thomson 1982). They prefer mature riparian woodland containing dead trees for shelter, along small- to medium-sized streams. Winters are generally spent hibernating in caves (October-April).

\subsubsection{Distribution}

Although the northem wild monkshood occurs in northeastem Ohio, it does not occur on or near the reservation (McCance and Bums 1984). Individual peregrine falcons and bald eagles might occur rarely as transients along the Great Miami River, but they do not nest in any of the counties surrounding the reservation. Neither have cave salamanders been found on the reservation. For these reasons, none of these four species will be considered further in this assessment. A survey for threatened and endangered species did not find Indiana bats on the reservation, but eight bats of this species were captured about $5.3 \mathrm{~km}$ ( 3.3 miles) northeast of the FEMP boundary along a tribuzary creek to the Creat Miami River. Moreover, potential Indiana bat habitat along Paddy's Run ranges in quality from poor to excellent. Therefore. the Indiana bat was chosen for this assessment as the only representative of a threatened or endangered species under the Endangered Species Act that may actually reside, or at least forage, on the reservation. 
TAELE 6-1-Distribution of Endpoints and Receptors at

Fernald Environmental Management Project

\begin{tabular}{|l|l|l|}
\hline \multicolumn{1}{|c|}{ Ubiquitous } & \multicolumn{1}{|c|}{ Discontinuous } & \multicolumn{1}{c|}{ Discrete } \\
\hline $\begin{array}{l}\text { Recreational wildife } \\
\text { (rabbit, deer) }\end{array}$ & $\begin{array}{l}\text { Resident, breeding, or } \\
\text { foraging Federally listyd } \\
\text { and candidate species } \\
\text { (Indiana bat) }\end{array}$ & $\begin{array}{l}\text { Agricultural production } \\
\text { (pine plantations. grazing } \\
\text { land) }\end{array}$ \\
$\begin{array}{l}\text { Important components of } \\
\text { biodiversity not included in } \\
\text { the above (mice, fox, other } \\
\text { bats, robin, hawk, } \\
\text { vegetation) }\end{array}$ & $\begin{array}{l}\text { Wetlands and riparian } \\
\text { vegetation along rivers } \\
\text { (aquatic plants, benthos) } \\
\text { adjacent to FEMP) }\end{array}$ & \\
& $\begin{array}{l}\text { Biodiversity (aquatic } \\
\text { bentios), recreational } \\
\text { vildife (fish) }\end{array}$ & \\
\hline
\end{tabular}

\subsubsection{Wetlands}

\subsubsection{Receptors}

Representative wetland organisms include minnows and other small fish species, benthic invertebrates, and wetland vegetation such as cattails and rushes. For this assessment, benthic invertebrates and vegetation were selected as the receptors representative of reservation wetlands.

\subsubsection{Distribution}

With the exception of approximately 3.8 ha ( 9.5 acres) of forested wetland near the north-central boundary of the reservation, most ( 8 ha or 20 acres) of the jurisdictional wetlands on the reservation consist of drainage ditches and swales supporting emergent vegetation such as cattail, sedges, and rushes (DOE 1992). For the purposes of this assessment, at least some of the reservation wetlands are also considered to be within or under the influence of the waste sites. These wetlands, and the receptors chosen to represent them, exhibit discontinuous distributions.

\subsubsection{Recreational Fish and Wildlife}

\subsubsection{Receptors}

Several iecreationally desirable wildlife species occur or may occur on the FEMP reservation, although, with the exception of a few dairy farmers who lease land to graze cattle, the reservation is closed to public access. Fish, particularly those of the catfish and sunfish families, the cottontail rabbit, and the white-tailed deer were selected for this assessment as representative of the recreational fish and wildlife on the reservation. The data available for fish are not specific to species of interest; therefore, the assessment is limited to risks to fish in general.

\subsubsection{Distribution}

For the most part, recreationally desirable fish (mostly of the sunfish family) are limited to the Great Miami River to the east and south of the reservation. Occasionally, a few specimens of catchable size may occur in Paddy's Run or its tributaries within the reservation. None are expected to occur in the waste sites themselves. Game mammals 
and birds that occur on the reservation include the eastem cottontail rabbit (Sylvilagus floridanus), white-tailed deer (Odocoileus virgin::Inus), and the bobwhite (Colinus virginianus). The fish have a discontinuous distribution, while both mamn. olian species are considered to be ubiquitous in distribution.

\subsubsection{Agricultural or Timber Production}

\subsubsection{Receptors}

Although cattle are allowed to graze on the FEMP reservation, under normal circumstances they do not have access to contaminated sites. Therefore, vegetation (representing grass and planted pines), but not cattle, were selected for this assessment as the endpoint receptors representative of agricultural and timber production.

\subsubsection{Distribution}

Approximately 170 ha ( 430 acres) of grazing land is leased to local dairy owners for cattle grazing. This land, dominated by introduced red fescue (Festuca rubra) and Kentucky bluegrass (Poa pratensis), exhibits a discontinuous distribution on the reservation. Small pine and spruce plantations have been established in the northeast and southwest corners of the reservation. On the basis of soil classifications, the U.S. Department of Agriculture, has designated much of this land as prime agricultural land. This assessment considers only vegetation on or adjacent to the contaminated sites.

\subsubsection{Parks and Other Public Lands}

\subsubsection{Receptors}

No likely receptors in terms of parks and public lands were identified for this assessment.

\subsubsection{Distribution}

There are no parks or public lands on or adjacent to the reservation. Nearly all of the land adjacent to the reservation is privately owned agricultural or open land. To the southeast, an industrial area has developed along about $0.37 \mathrm{~km}(0.23$ mile) or $4 \%$ of the reservation perimeter's $8.4-\mathrm{km}$ length (5.2 miles). To the northeast lies a Girl Scout camp. Although camp property commences only $0.50 \mathrm{~km}(0.31$ mile) from the nearest reservation boundary, the camp is topographically upgradient of the entire FEMP reservation and consequently is not considered to be subject to contamination from the waste sites.

\subsubsection{Biodiversity}

\subsubsection{Receptors}

As indicated sarlier, the ecosystems of the reservation and its environs began to undergo substantial alterations in structure and function beginning with the arrival of the first European settlers. Virgin forests and the complex plant and animal communities they supported no longer exist in the area. What roodland persists is highly fragmented, and current practices in land management on the reservation, including mowing and grazing, prevent the establishment of trily climax communities. Even so, the frag.nented and disturbed terrestrial systems now dominant on the reservation support a variety of plant and animal communities.

Except for catile, all of the animals and plants used as representative of the other endpoints discussed above are considered as representative elements of area biodiversity and, therefore, are used in this assessment of impacts on biudiversity (i.e., the mouse, rabbit, deer, robin, bat, hawk, fox, vegetation, aquatic invertebrates, and fish). Note that for this assessment aquatic 
organisms are assumed to oce aosent frrom the actual waste sites.

\subsubsection{Distribution}

A!l but two of the selected receptors representative of the area's biodiversity are considered to have ibiquitous distributions. Fish and bentrac invertebrates have discontinuous isstributions.

\subsection{Contaminants of Potential CONCERN}

The contaminants of porential concem at FEMP include numerous inorganic, organic, and radioactive contaminants (table 6-2). The most prevalent radionuclide, according to relative average concentrations, is ${ }^{238} \mathrm{U}$; $\mathrm{Al}, \mathrm{Ba}, \mathrm{Cu}, \mathrm{U}$ and $\mathrm{Zn}$ exhibit the highest concentrations among inorganic contaminants. The concentrations of organic chemicals on the site are fairly low and, thus, are not expected to pose as great a potential hazard as the inorganic and radioactive contamiriants.

Maximum and average suit, surtace water, and sediment concentrations used in the assessment were determined from the source ter-- provided by $f$ L (tables 6-2, 6-3, and 6-. Developnint of average and maximum source terms for use in exposure and risk assessment involves certain assumptions concerning interpretations of and compeusation for data gaps. $/$ ppendix A describes the methodology en upl oyed to develop useable source terms for input into the exposure and risk assessment.

\subsection{EXPOSURE ASSESSMENT}

Estimating exposures for all representative species on the reservation accurately is difficult because of the lack of data for numbers of individuals actually exposed to wastes, the amount of time they spend in waste areas, and the actual amounts of contaminant uptake. Site-specific home ranges, behavior, and habitat requirements of many of the iepresentative species at FEMP are not necessarily well known, and only a few species with small home ranges (e.g., sinall mammals and birds) may reside within contaminated areas for most of their lives. Of these, only a very few individuals may be subject to exposure to maximum concentrations (see chapter 6.4 for discussion of home ranges). Therefore, an initial screening assessment was conducted, using, where available, the maximum concentrations of each contaminant in each medium on-site to identify worst-case potential contaminants. Contaminants that do not pose a risk to any of the receptor species from exposure to the maximum values will not be considered further. If contaminants pose a risk to organisms exposed to the maximum concentrations, however, the average concentrations of those contaminants will be used in the assessment to estimate a more reasonable exposure and risk.

The ecological assessment estimates the risk to vegetation, teriestrial wildlife, and aquatic organisms from chronic exposure to radiological and nonradiological contarninants [appendix A]. It is desirable in exposure analysis $t c$ consider ali possible ecological endpoints and receptor species within each endpoint. However, due to limited availability of exposure sensitivity data for many species (e.g., threatened and endangered species) and ecological similarities in exposure risks (e.g., similarly sized hawks feeding on the same or similar prey), certain organisms considered representative of each endpoint were chosen fo evaluation. A food web was developed that includes terrestrial receptor species tepresenting all endpoints (figure 6-2). Wi.ere data were available, we tried to erisure conservatism in our estimates of expostire and risk by selecting receptors most sensitive to contaminants or habitat 
TABLE 6-2-Constituents of Potential Concern w/Maximum and Average Soil Concentrations ( $\mathrm{mg} / \mathrm{kg}$ dry weight (for chemical constituents) or pCi/kg dry weight (for radionuclides)] on the Fernald Environmental Management Project

\begin{tabular}{|c|c|c|c|}
\hline Constituent & $\begin{array}{c}\text { Madimam } \\
\text { Concentration }\end{array}$ & Conetituent & $\begin{array}{c}\text { Average } \\
\text { Concentration }\end{array}$ \\
\hline 1.4 dioxane & $1.29 \mathrm{E}+01$ & Arocisr 1248 & $5.65 E-01$ \\
\hline 2-butanone & $1.20 E-02$ & Aroclor 1254 & $9.77 \mathrm{E}-01$ \\
\hline 2-methyinapthaiene & $1.10 E+01$ & Di-n-butyl phthalate & $7.30 \mathrm{E}-02$ \\
\hline Acenapthene & $2.80 E+01$ & Alurinum & $5.85 E+03$ \\
\hline Acetone & $2.30 \mathrm{E}-01$ & Antimony & $2.53 E+01$ \\
\hline Aroclor 1242 & $1.60 E+\infty 0$ & Arsenic & $4.50 E+10$ \\
\hline Aroclor 1248 & $5.65 E-01$ & Barium & $5.84 E+01$ \\
\hline Aroclor 1254 & $1.10 E+00$ & Beryllium & $8.00 E-01$ \\
\hline Aroclor 1260 & $6.10 E-01$ & Cadmium & $5.10 E+00$ \\
\hline BEHP & $3.10 \mathrm{E}-01$ & Chromium & $1.45 E+01$ \\
\hline Dibenzofuran & $1.90 \mathrm{E}+00$ & Copper & $1.52 E+02$ \\
\hline Diethyl phthalate & 8. $40 E-02$ & Cyanide ion & $1.70 E+00$ \\
\hline Di-n-butyl phthalate & $7.30 E-02$ & Lead & $1.99 \mathrm{E}+01$ \\
\hline Di-n-octylphthalate & $2.10 \mathrm{E}-01$ & Mercury & $1.00 E-01$ \\
\hline Fluoranthene & $6.10 E-02$ & Molybdenum & $4.80 E+00$ \\
\hline Methylene chloride & $2.40 E-01$ & INickel & $2.62 E+01$ \\
\hline Napthalene & $1.90 \mathrm{E}+01$ & Selenium & $5.00 E-01$ \\
\hline Octachlorodibenzo-p-dioxin & $7.90 E-03$ & Silver & $9.60 \mathrm{E}+00$ \\
\hline Pyrene & $5.00 \mathrm{E}-01$ & Uranium & $2.97 E+03$ \\
\hline Toluene & $1.80 E-01$ & Vanadium & $1.75 E+01$ \\
\hline Aluminum & $1.17 \mathrm{E}+04$ & Zinc & $4.02 E+01$ \\
\hline Antimony & $3.25 E+01$ & Technetium-99 & $8.90 E+03$ \\
\hline Arsenic & $1.54 \mathrm{E}+01$ & Uranium-238 & $9.51 E+05$ \\
\hline Barium & $2.23 E+02$ & & \\
\hline Beryllium & $1.60 \mathrm{E}+00$ & & \\
\hline Cadmium & $7.70 E+00$ & & \\
\hline Chromiun: & $5.18 E+01$ & & \\
\hline Cobalt & $1.70 E+01$ & & \\
\hline Copper & $2.01 E+01$ & & \\
\hline Cyanide ion & $1.70 E+C 0$ & & \\
\hline Lead & $1.47 E+102$ & & \\
\hline Mercury & $2.00 \mathrm{E}-01$ & & \\
\hline Molybdenum & $|.88 E+0|$ & & \\
\hline Nickel & $5.02 \mathrm{E}+01$ & & \\
\hline Selenium & $6.20 \mathrm{E}-01$ & & \\
\hline Silver & $2.17 E+01$ & & \\
\hline Sodium ion & $1.85 E+02$ & & \\
\hline Strontium & $5.00 E-199$ & & \\
\hline Thallium & $6.80 \mathrm{E}-01$ & & \\
\hline Uranium & $1.81 E+05$ & & \\
\hline Vanadium & $2.69 E+01$ & & \\
\hline Zinc & $7.99 \mathrm{E}+01$ & & \\
\hline Cesium-137 & $2.00 \mathrm{E}+102$ & & \\
\hline
\end{tabular}




\begin{tabular}{|c|c|c|c|}
\hline Constitued & Coscentration & Coentitionent & $\begin{array}{c}\text { Averiate } \\
\text { Coucentration }\end{array}$ \\
\hline Lead-210 & $4.43 E+04$ & & \\
\hline Nepturium-237 & $4.00 E+03$ & & \\
\hline Pluronium-238 & $6.00 E+02$ & & \\
\hline Plutonium-2s9 & $2.00 E+03$ & & \\
\hline Radium-224 & $2.10 E+03$ & & \\
\hline Radium-226 & 8.76E+05 & & \\
\hline Radium-228 & $1.30 E+03$ & & \\
\hline Strontium-90 & $8.00 E+02$ & & \\
\hline Technetium-99 & $3.70 E+04$ & & \\
\hline Thorium-228 & $1.70 E+04$ & & \\
\hline Thorium-230 & 4.42E+05 & & \\
\hline Thorium-232 & $1.80 E+04$ & & \\
\hline Uranium-234 & $1.30 E+05$ & & \\
\hline Uranium-235 & $4.20 E+04$ & & \\
\hline Uranium-236 & $7.60 E+02$ & & \\
\hline Uranium-238 & $6.04 E+07$ & & \\
\hline
\end{tabular}


TABLE 6-3-Maximum and Average Fernald Water Concentrations (mg/L (for chemical constisuents) or pCH/L (for madionuclides)) on the Fernald Environmental Management Project

\begin{tabular}{|c|c|c|c|c|c|c|c|}
\hline \multicolumn{4}{|c|}{ Drivilas Water } & \multicolumn{4}{|c|}{ Aquatk Water } \\
\hline Cantivened & Mardaum Conc. & Constituent & Average Conc. & Constituent & Maxdmum Conc. & Comativent & Average Conc. \\
\hline 2butreanes & $5.00 E-02$ & Aroclor 1248 & $3.28 E-01$ & Cedmium & $5.00 E-03$ & Cadmium & $2.808-03$ \\
\hline Acetione & $1.92 E+00$ & Aroclar 1254 & $6.15 E-01$ & Copper & $1.47 \mathrm{E}-02$ & Copper & $1.03 E-02$ \\
\hline Ambracene & 4.7TE-01 & Benzo(a)pyrene & $7.12 E-01$ & Lead & $1.40 E-02$ & Uranium-234 & $3.43 \mathrm{E}+03$ \\
\hline Arockor 1248 & $3.28 E-01$ & Di-n-butyl phthalaee & $1.81 E+00$ & Mencury & $1.00 E-03$ & & \\
\hline Aroctor 1254 & $3.28 \mathrm{E}-01$ & Aluminum & $1.00 E-01$ & Uranium & $1.90 E-02$ & & \\
\hline Beanda)mehricence & $9.46 \mathrm{E}-01$ & Ancimony & $3.70 E-02$ & & & & \\
\hline Benzodupyreac & $7.12 E-01$ & Arsenic & 9.2SE+00 & & & & \\
\hline Beazo(b)Avoranchene & $7.54 E-01$ & Barium & $3.32 \mathrm{E} \times 0.3$ & & & & \\
\hline 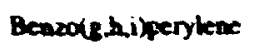 & $2.45 E-01$ & Beryllium & $9.67 E+00$ & & & & \\
\hline Beazo(k Muoraenthene & $7.96 E-01$ & Cadmium & $1.90 E+00$ & & & & \\
\hline BEHP & $5.95 E-01$ & Chronisum & $3.69 \mathrm{E}+01$ & & & & \\
\hline Ongsene & $1.0 \times E+\infty$ & Copper & $3.97 \mathrm{E}+02$ & & & & \\
\hline Di-a-buagl phenalute & $1.81 \mathrm{E}+\infty$ & Cyanide ion & $9.76 E+\infty 0$ & & & & \\
\hline Fhoramlene & $3.29 \mathrm{E}+\infty 0$ & Lend & $199 E+01$ & & & & \\
\hline indemo(1,2,3-cd)pyreac & $2.29 \mathrm{E}-01$ & Mercury & $1.55 E+00$ & & & & \\
\hline Mathylene chlande & $6.80 E-01$ & Molybatenum & $1.80 E-02$ & & & & \\
\hline Pheasonthere & $2.24 E+00$ & Nickel & $712 E+01$ & & & & \\
\hline Pyrexe & $1.49 E+00$ & Sckensum & $3.95 E+00$ & & & & \\
\hline Ancimonay & $3.69 E-02$ & Uranium & $7.27 \mathrm{E}+02$ & & & & \\
\hline Arseanc & $1.85 E+01$ & Vanadium & $1.72 E+03$ & & & & \\
\hline Barivan & $664 E+03$ & Zine & $9.16 E+01$ & & & & \\
\hline Beryltium & $9.67 \mathrm{E}+\infty 0$ & Technetium. 99 & $3.28 E+05$ & & & & \\
\hline Borom & $2.43 \mathrm{E}-0.1$ & Uranium-238 & $2.34 E+05$ & & & & \\
\hline Condrium & $7.59 E+\infty 0$ & & & & & & \\
\hline Cakium (ande) & $4.79 E+01$ & & & & & & \\
\hline Oromiura & $7.38 E+01$ & & & & & & \\
\hline Cobeh & $1.96 E+01$ & & & & & & \\
\hline Copper & 1. $19 \mathrm{E}+03$ & & & & & & \\
\hline Cyankt ion & $9.76 E+\infty 0$ & & & & & & \\
\hline Irom & $3.33 E-02$ & & & & & & \\
\hline Lead & $7.75 E+01$ & & & & & & \\
\hline Magnesium & $4.78 E+01$ & & & & & & \\
\hline Mangavese & $1.14 \mathrm{E}-01$ & & & & & & \\
\hline ivercury & $4.05 E+00$ & & & & & & \\
\hline Malyouteoun & 8. $13 E-02$ & & & & & & \\
\hline Nixtel & $7.12 \mathrm{E}+01$ & & & & & & \\
\hline
\end{tabular}




\begin{tabular}{|c|c|c|c|c|c|c|c|}
\hline 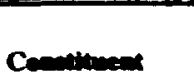 & $\begin{array}{l}\text { Driation Wo } \\
\text { Maximase Canc. }\end{array}$ & Comentwent & Avernge Coos. & Comatituent & $\begin{array}{l}\text { Aquele Woler } \\
\text { Maximum Ceac. }\end{array}$ & Comalitued & Averneg Case. \\
\hline Poressium & $1.32 \mathrm{E}+01$ & & & & & & \\
\hline Seteninger & $395 E+\infty$ & & & & & & \\
\hline Silieren & $1.04 E+00$ & & & & & & \\
\hline Sillver & $1.13 E-02$ & & & & & & \\
\hline Soctiven ina & $272 E+02$ & & & & & & \\
\hline Uranium & $2.1 .3 E+03$ & & & & & & \\
\hline Vamidum & $1.72 E+03$ & & & & & & \\
\hline Cesiuar-137 & 4.79E+05 & & & & & & \\
\hline Neppluaium-237 & $2.85 E+03$ & & & & & & \\
\hline Phwomiun-238 & $9.59 E+01$ & & & & & & \\
\hline Radiun-226 & 3.24E+0S & & & & & & \\
\hline Reativen-228 & $1.20 E+00$ & & & & & & \\
\hline Tectroctivin-99 & $349 E+10 S$ & & & & & & \\
\hline 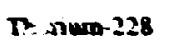 & $5.37 E+04$ & & & & & & \\
\hline Tharium-230 & $.61 E+06$ & & & & & & \\
\hline Tharium-232 & 4. $11 E+04$ & & & & & & \\
\hline Unave-235 & $516 E+04$ & & & & & & \\
\hline Urammon-238 & 7.03E+05 & & & & & & \\
\hline
\end{tabular}

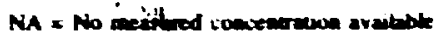

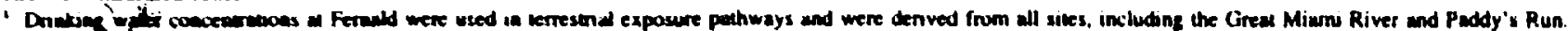

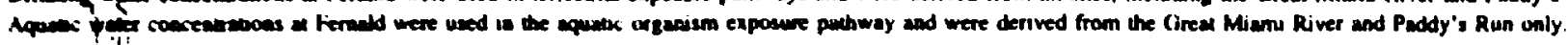

'...

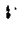




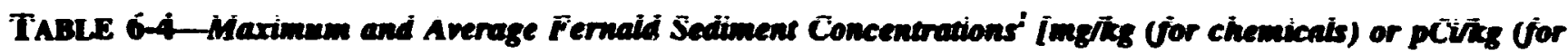
radionuclides)] on the Fermald Environmented Managewent Project

\begin{tabular}{|c|c|c|c|}
\hline Constituent & $\begin{array}{c}\text { Maximanam } \\
\text { Concentration }\end{array}$ & Constituent & $\begin{array}{c}\text { Averase } \\
\text { Coucentration }\end{array}$ \\
\hline Aluminum & $5.46 E+03$ & \multirow[t]{8}{*}{ Aluminum } & \multirow[t]{8}{*}{$3.82 E+03$} \\
\hline Radium-226 & $3.70 E+03$ & & \\
\hline Radium-228 & $8.20 E+02$ & & \\
\hline Thorium-228 & $1.50 E+03$ & & \\
\hline Thorium-230 & $1.30 E+03$ & & \\
\hline Thorium-232 & $6.20 E+02$ & & \\
\hline Uranium-234 & $2.90 \mathrm{E}+04$ & & \\
\hline Uranium-238 & $3.00 E+04$ & & \\
\hline
\end{tabular}

' Sediment concentrations were used only in the aquatic pathway and were derived from the Great Miami River and Paddy's Run values only.

alteration, most likely to experience additional risk due to bioaccumulation or larger body size, or at greatest risk due to rarity. Other abundant species on the reservation were included as important components of the foodweb, such as mice and insects (exposure and risk estimates were not determined for insects).

The primary exposure routes for terrestrial wildlife species at FEMP are ingestion of water (including soils for some species) and food. Table 6-5 lists the body weights and consumption rates for the selected representative species. Cattle are assumed to feed exc.'isively on the vegetative parts of plants. The cottontail rabbit and white-tailed deer are assurned to eat $50 \%$ vegetation and $50 \%$ fruits and seeos. Based on a review of the literature, the percentage of prey items consumed by omnivores and predators was estimated (table 6-5; figure 6-1). The mouse and robin are assumed to eat $70 \%$ fruit/seeds and $30 \%$ insects; the red-tailed hawk to eal $80 \%$ mice and $20 \%$ rabbits; and the red fox to eat $70 \%$ mice and $30 \%$ rabbits. Bats are assumed to eat $100 \%$ insects, and insects to eat $100 \%$ plant material.

All species are assumed to purposely or incidentally ingest soil while eating, grooming, or preening except for the bat, hawk, and red fox (table 6-5). The soil ingestation rate $\left(Q_{1}\right)$ for cottontail rabbits was assumed to be the same as that reported for the jackrabbit (6.3\% of the dry-matter intake) (Arthur and Gates 1988). The white-tailed deer soil ingestion rate is assump \& :, be the same as that reported for the mule deer [1.35\% of the dry-matter intake (Arthur and Alldredge 1979)]. The soil ingestion rates for the cow and mouse are $7 \%$ and $2 \%$ of the drymatter intake, respectively (Mayland et al. 1977 and Beyer et al. 1991). Because published values of soil ingestion rates were not found for the robin, the rate was conservatively estimated to be $10 \%$ of the dry-matter intake.

The estimated daily rates of food and water consumption ( $Q_{v}$ or $Q_{n}$, and $Q_{n}$, respectively) for each representative species were calculated from allometric regression equations that are based on the weight of the organism (EPA 1988) (table 65). These weights, in tum, are based on combined measurements for laboratory animals, livestock, and selected wildlife and bird species (EPA 1988) (appendix A).

Because details of the behavior and habitat requirements of most of the representative wildlife species are not well known, it is assumed that all species spend $100 \%$ of their time on the reservation. Thus, all selected representative species are considered to be yearround re sidents at FEMP. Therefore, the fraction of confaminated food, soil, and water consumed $\left(F I_{1}\right.$; is set at $100 \%$ (table 6-5).

Contaminant concentrations in vegetation, the first level in the food clain, are estimated from concentrations measured in suils using published 
TABLE 6-5-Body Weights and Consumption Rates' for Terrestrial Species' on the Fernald

Environmetmal Management Project

\begin{tabular}{|c|c|c|c|c|c|c|c|c|}
\hline Faremeiter & $\begin{array}{l}\text { White-foeted } \\
\text { Mouse }\end{array}$ & $\begin{array}{c}\text { Eestern } \\
\text { Coctiondall rabeun }\end{array}$ & Deer & $\operatorname{Con}$ & Rowin & Indiana bat & Bed-Tallad howli & Red Par \\
\hline Body weighte. BW (kg) & $2.40 E-02$ & $1.19 E+00^{2}$ & $5.65 E+01^{3}$ & $4.00 E+02^{\circ}$ & $7.30 \mathrm{E}-02^{\prime}$ & $7.30 \mathrm{E}-03 \mathrm{~T}$ & $1.39 E+10$ & $6.002+00^{5}$ \\
\hline 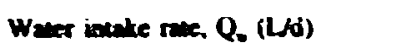 & $6.40 E-03$ & $1.14 E-01$ & $2.63 E+\infty 0$ & $1.23 \mathrm{E}+01$ & $1.43 \mathrm{E}-02$ & $2.30 E-03$ & $|43 E-0|$ & $4.51 \mathrm{E}-01$ \\
\hline Werer inesation fraction, $F I$. & $1.00 E+\infty 0$ & $1.00 E+\infty$ & $1.00 \varepsilon+\infty$ & $1.00 E+\infty$ & $1.00 E+00$ & $1.00 \mathrm{E}+\infty$ & $1.00 E+\infty$ & $1.00 \mathrm{E} \times 00$ \\
\hline Soil inutake rme, Q, (kg/d) & $438 E-05 "$ & $1.28 E \cdot 03^{12}$ & $5.83 \mathrm{E}-03^{13}$ & $1.86 E-01^{14}$ & $3.87 E-0413$ & 0.00 & 0.00 & 0.00 \\
\hline Soil ingestion fraction Fl, & $1.00 E+100$ & $1.00 E+\infty$ & $1.00 E+\infty$ & $1.00 E+00$ & $1.00 E+100$ & 0.00 & 0.00 & 0.00 \\
\hline 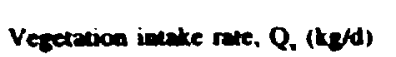 & 0.00 & $3.73 \mathrm{E}-0^{10}$ & $7.93 E-01 "$ & $7.47 E+00$ & 0.00 & 0.00 & 0.00 & 0.00 \\
\hline Vegersion ingestion frection. $F$, & 0.00 & $1.008+\infty$ & $1.00 E+00$ & $1.00 E+00$ & 0.00 & 0.00 & 0.00 & 0.00 \\
\hline Fnielseeds incate rake, $Q_{1}(k g / d)$ & $3.366-0.3^{4}$ & $3.73 E-02$ & $2.93 E-01$ & 0.00 & $5.80 E-03^{10}$ & 0.00 & 0.00 & 0.00 \\
\hline Frivescedb ingestion frection. FY & $1.00 E+\infty 0$ & $1.00 E+\infty$ & $1.00 \mathrm{E}+00$ & 0.00 & $1.00 E+00$ & 0.00 & 0.00 & 0.00 \\
\hline Prey 1 incuke rave. $Q_{n 1}$ (kef) & $1.0 E-03$ & 0.00 & 0.00 & 0.00 & $2.50 \mathrm{E}-03$ & $1.30 \mathrm{E}-03$ & $7.92 \mathrm{E}-02^{\circ}$ & $1.880-01^{11}$ \\
\hline Prey I incestion frection $\mathbf{F}_{\text {w }}$ & $\begin{array}{l}\text { (insects) } \\
1.00 E+\infty 0\end{array}$ & 0.00 & 0.00 & 0.00 & $\begin{array}{l}\text { (insecls) } \\
1.00 \mathrm{E}+00\end{array}$ & $\begin{array}{l}\text { (insects) } \\
1.00 \mathrm{E}+00\end{array}$ & $\begin{array}{l}\text { (mice) } \\
1.00 E+\infty 0\end{array}$ & $\operatorname{lmices}_{1.002+0(1)}$ \\
\hline Prey 2 inesike rowe, $Q_{a}$ (kp/d) & $0 . \infty 0$ & 0.00 & 0.00 & 0.00 & 0.00 & 0.00 & $1.98 E-02$ & $8.068-02$ \\
\hline Prey 2 ingestion frection, $F_{\text {wo }}$ & 0.00 & 0.00 & 0.00 & 0.00 & 0.00 & 0.00 & $1.008+00$ & $1.008+00$ \\
\hline Prey 3 inste race, $Q_{x,}$ (ke/d) & $0 . \infty 0$ & 0.00 & 0.00 & 0.00 & 0.00 & 0.00 & 0.00 & 0.00 \\
\hline Prey 3 inpestion frection. Fho & 0.00 & 0.00 & 0.00 & 0.00 & 0.00 & 0.00 & 0.00 & 0.00 \\
\hline
\end{tabular}

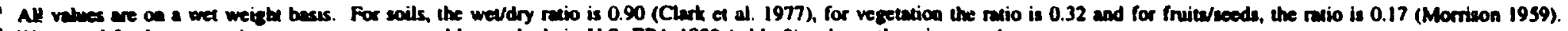

Werer and food consumption mes were compunod by methods in U.S. EPA 1988 (Lable 8) unless otherwise noted.

Lartey a al 1985

Cxpona a 1900

STich 1991

U.S. EPA 1948

Teriso 1940.

- Tnomerom 1902.

- Brom and Aloudoa 1968

- Opreato and Sinc 1992.

11 Mouse soil ingestion rate is $2 \%$ of dry vegetation intake (Beyer et al. 1991)

is The rotin soil ingeation rale is assumed to be 105 of dry maner intuke.

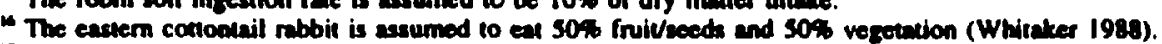

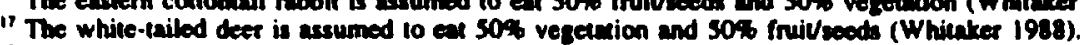

10 The mouse is ascumed to ea $70 \%$ initureeds and $30 \%$ insects (Leckey et 4 . 1983).

The robin is assumed to eat 705 fruivseeds and $30 \%$ insects (Terrea 1980).

the red-lailed hawk is assumed to en $80 \%$ mice and 20\% nubbits (Terros (960)

13 The white-tail deer is assumed to have a soil ingestion rate of $135 \%$ of dry matter intake (Anthur and Alldredge 1979 )

14 Cattle soil ingestion rate is about 7\% of dry matter intake (Mayland et al. 1977). 


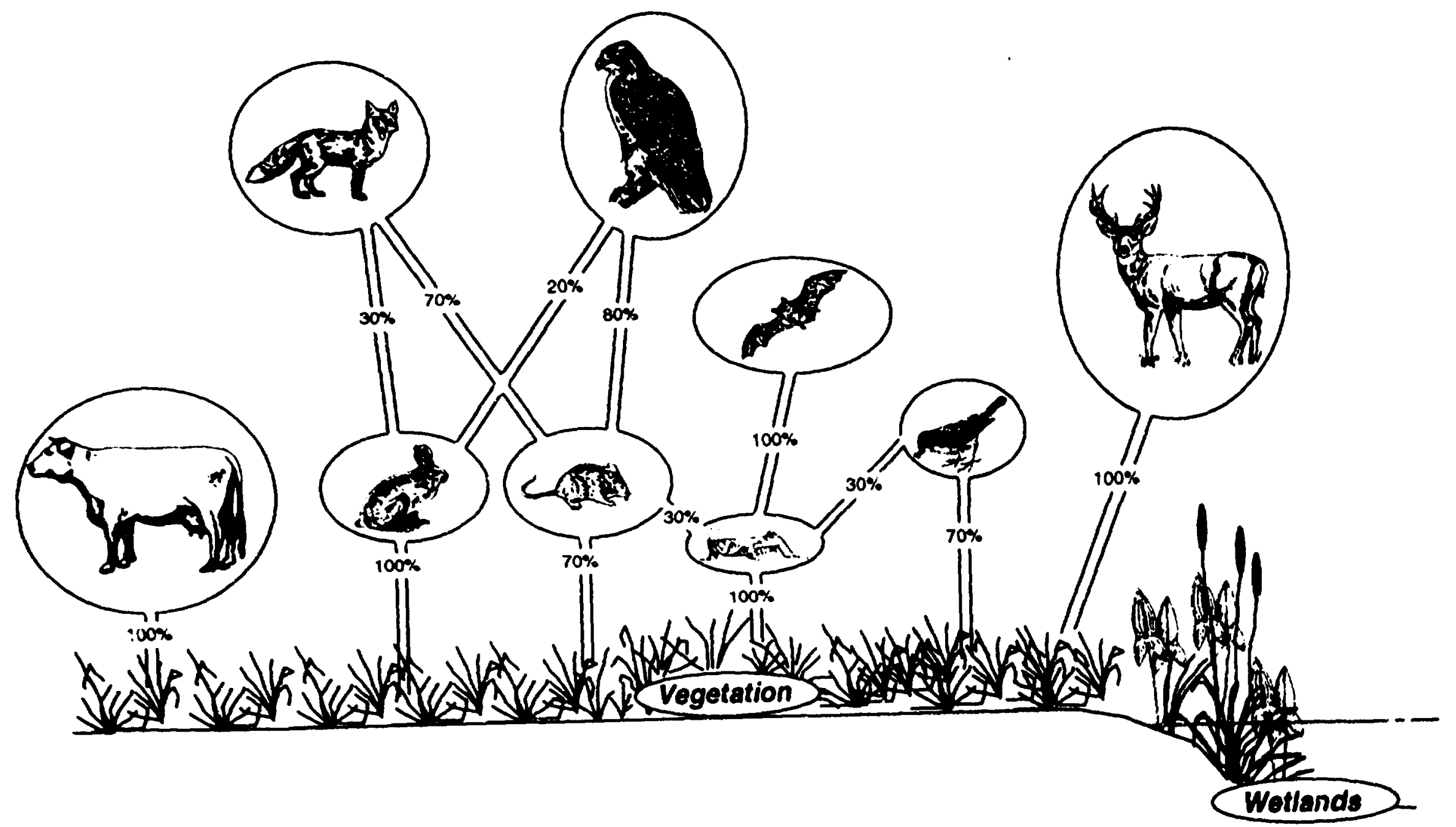

FIGURE 6-2. REPRESENTATION OF THE TERRESTRIAL FOOD WEB OF THE FERNALD RESERVATION 
element-specifis. soil-to-plant tansfer factors (Baes et al. 1984; Travis and Arms 1988) (table 6-6). Transfer factors for inorganic chemicals are available for both the vegetative and fruiting parts of plants (Baes et al. 1984); published transfer factors for organic chemicals, however. do not make this distinction (Travis and Arms 1988). The methodology used to predict contaminant concentrations in vegetation does not make a distinction between different plant types or species. It is assumed, therefore, all species ingest "generic" regetation containing contaminant concentrations derived from soil concentrations by the use of published transfer factors.

Transfer factors for contaminants of concem are used to predict concentrations in the tissues of terrestrial mammalian receptors from consumption of vegetation, soil, and water (collectively termed $B_{b}$ ) (Baes et al. 1984; Travis and Arms 1988) (table 6-6). The rationale and limitations for applying these transfer factors are discussed in appendix A. Data on transfer factors from vegetation or soil to insects and earthworms are very limited in the literature. Therefore, the concentration in insects was derived from vegetation concentrations, and a default, conservative one-to-one transfer between vegetation and insects was assumed.

The consumption rates and the benchmark limits or no-observable-adverse-effect level (NOAEL) values are typically reported in wet weights, whereas the vegetation and soil concentrations are typically reported in dry weights. Therefore, conversion factors were applied to account for this difference. The wet- to dry-weight conversion factor for the vegetative parts of plants at FEMP was assumed to be 0.32 [the average for meadow fescue, Kentucky bluegrass, wild bromegrass, and orchard grass (Morrison 1959)]. The wet- to dry-weight conversion factor for the fruiting parts of plants on Femald was assumed to be 0.17 (Momison 1959). The wet- to dry-weight conversion factor for soils is 0.90 .

For the base-line assessment of FEMP, the concentrations of radionuclides in animal tissues and the resulting doses were not decay-corrected. The doses are estimated for the existing conditions and not as some point in the future.
The primary rationiuchites of concem, nut and ${ }^{23} \mathrm{U}$, have a very long half-lives, so this assumption is reasonable. The radionuclide concentrations in the source terms have been decay-corrected by PNL back to the time of disposal or release. Estimated dose to terrestrial receptors was based not only on the radionuclide itself, but on all radioactivity of the short-lived daughter products as well.

Aquatic organisms considered in the assessment include benthic macroinvertebrates and a generic fish species. For radiological analyses, emergent vegetation (i.e., cattails) and muskrats are included as well. All aquatic organisms, except for benthic macroinvertebrates, are assumed to be exposed to contaminants in the surface waters of the Great Miami River and Paddys Run only. For this analysis, benthic macroinvertebrates are assumed to be exposed only to the sediment pore water in the Great Miami River and Paddys Run for calculation of internal radiation dose and exposure to chemicals. The external radiation dose from exposure to surface water was calculated for all organisms. Although contaminant concentration source terms in surface water and sediments were provided by PNL for all sites at FEMP, only those maximun and average source terms corresponding to the Great Miami River and Paddys Run were included in the aquatic exposure scenarios. Surveys indicate there are no year-round aquatic communities living in waste ponds or streams (e.g., lime sludge ponds, the clearwell, or the storm sewer outfall ditch). For the terrestrial drinking water exposure pathway, however. maximum and average source-term concentrations were derived from all sites. including waste ponds and the Great Miami River and Paddys Run.

\subsection{Contamnant Effects Assessment}

Two pathways are used to determine the effects of contaminant exposure (chapter 6.3) on ecological endpoint receptors. For terrestrial receptors, consumption rates of contaminated food and water are compared with toxicological benchmarks. For aquatic receptors, contaninant concentrations in water or sediment pore water are compared with chemical-specific aquatic benchmarks. To quintify risk to terrestrial 


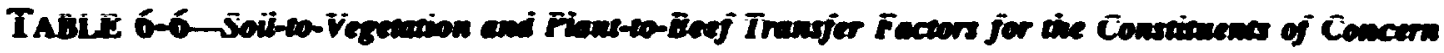
on the Fermall Environmenal Mansemene Project

\begin{tabular}{|c|c|c|}
\hline Constibuent & $\begin{array}{l}\text { Sol to Vegeteition Trander } \\
\text { Factor }\end{array}$ & 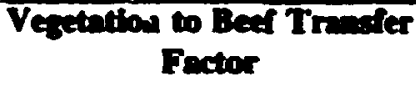 \\
\hline 1,4 dioxane & 5.55E+01 & $1.35 \mathrm{E}-08$ \\
\hline 2-butanone & $2.63 E+01$ & $4.90 E-08$ \\
\hline 2-methylnapthalene & $2.27 E-01$ & $1.82 E-04$ \\
\hline Acenapthene & $2.16 E-01$ & 2.00E-04 \\
\hline Acetone & $5.33 \mathrm{E}+01$ & $1.45 E-08$ \\
\hline Aroclor 1242 & $2.24 E-02$ & $1.00 E-02$ \\
\hline Aroclor 1248 & $2.24 E-02$ & $1.00 E-02$ \\
\hline Aroclor 1254 & $2.24 \mathrm{E}-02$ & $1.00 E-02$ \\
\hline Aroclor 1260 & $2.24 \mathrm{E}-02$ & $1.00 E-02$ \\
\hline BEHP & $4.37 \mathrm{E}-02$ & $3.16 E-03$ \\
\hline Diethyl phthalate & $5.48 E-01$ & $3.98 E-05$ \\
\hline Di-n-butyl phthalate & $3.82 \mathrm{E}-02$ & $3.98 E-03$ \\
\hline Di-n-octylphthalare & $1.86 \mathrm{E}-04$ & $3.98 \mathrm{E}+01$ \\
\hline Fluoranthene & $5.72 \mathrm{E}-02$ & $1.98 \mathrm{E}-03$ \\
\hline Methylene chloride & $6.86 \mathrm{E}+00$ & $5.01 E-07$ \\
\hline Napthalene & $3.22 \mathrm{E}-01$ & $1.00 E-04$ \\
\hline Pyrene & $3.35 E-02$ & $5.01 E-03$ \\
\hline Toluene & $1.07 \mathrm{E}+00$ & $1.26 \mathrm{E}-05$ \\
\hline Aluminum & $4.00 E-03$ & $1.50 E-03$ \\
\hline Antimony & $2.00 \mathrm{E}-01$ & $1.00 \mathrm{E}-03$ \\
\hline Arsenic & $4.00 \mathrm{E}-02$ & $2.00 E-03$ \\
\hline Barium & $1.50 \mathrm{E}-01$ & $1.50 E-04$ \\
\hline Beryllium & $1.00 \mathrm{E}-02$ & $1.00 \mathrm{E}-03$ \\
\hline Cadmium & $5.50 \mathrm{E}-0 \mathrm{I}$ & $5.50 \mathrm{E}-04$ \\
\hline Chromium & $7.50 \mathrm{E}-03$ & $5.50 \mathrm{E}-03$ \\
\hline Cobalt & $2.00 \mathrm{E}-02$ & $2.00 \mathrm{E}-02$ \\
\hline Copper & $4.00 \mathrm{E}-01$ & $1.00 \mathrm{E}-02$ \\
\hline Cyanide ion & $5.42 E+01$ & $1.41 \mathrm{E}-08$ \\
\hline Lead & $4.50 \mathrm{E}-02$ & $3.00 \mathrm{E}-0.4$ \\
\hline Magnesium & $1.00 \mathrm{E}+00$ & $5.00 E-03$ \\
\hline Manganese & $2.50 \mathrm{E}-01$ & $4.00 \mathrm{E}-04$ \\
\hline Mercury & $9.00 \mathrm{E}-01$ & $2.50 \mathrm{E}-01$ \\
\hline Radium-226 & $1.50 \mathrm{E}-02$ & $2.50 \mathrm{E}-0.4$ \\
\hline Radium-228 & $1.50 \mathrm{E}-02$ & $2.50 \mathrm{E}-04$ \\
\hline Thorium-228 & $8.50 E-04$ & $6.00 \mathrm{E}-06$ \\
\hline Thorium-230 & $8.50 \mathrm{E}-04$ & $6.00 \mathrm{E}-06$ \\
\hline Thorium-232 & $8.50 \mathrm{E}-04$ & $6.00 \mathrm{E}-06$ \\
\hline Uranium-234 & $8.50 E-03$ & $2.00 \mathrm{E}-04$ \\
\hline Uranium-238 & $8.50 E-03$ & $2.00 \mathrm{E}-04$ \\
\hline
\end{tabular}

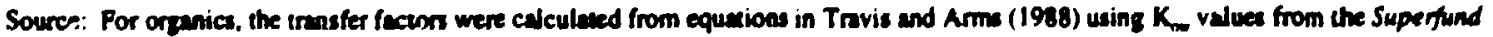
Chemical Dala Marrix (1991). For inorganics and radionuclides, the transfer factors were taken from Bas et al. (1984). The K for cyanide wa caken from MEPAS and the inater fecton were calculated from equations in Travis and Arms (1988). 
receptors exposed to organic and inorganic contaminants, the daily comsumption rates of contaminated food and water, normalized to body weight (in units of $\mathrm{mg} / \mathrm{kg} / \mathrm{d}$ ), is compared to the NOAEL benchmarks (mg/kg/d). These ratios are termed hazard indices (HIs). Ratios greater than 1 are considered to pose a potentially unacceptable risk to organisms but do not necessarily indicate the severity of the effects. However, it is reasonable to assume that the higher the ratio, the greater the risk of adverse effects. Dose to terrestrial receptors, including vegetation, from internal and external exposure to radionuclides was also determined from calculated tissue concentrations and soil concentrations, respectively. Doses that exceed $0.1 \mathrm{rad} / \mathrm{d}$ are considered to pose a potentially unacceptable risk (i.e., an HI greater than 1) to terrestrial organisms (IAEA 1992). The "Ecological Risk Assessment Methodology for the PEIS" (1993) and appendix A describes in mone detail methods used to calculate exposure and risk.

Toxicological benchmarks for terrestrial organisms, excluding vegetation, were obtained from Opresko et al. (1993) (tabie 6-7). For representative receptor species that are not specifically listed in the data base, extrapolation techniques were employed to obtain the chronic NOAEL by adjusting for differences in body weight between the receptor and a test organism. If a NOAEL is available for a laboratory test species, a NOAEL for a receptor species can be derived by extrapolation. Many of the NOAEL benchmarks were derived by extrapolation from small-mammal laboratory data, where available (Opresko et al. 1993). There were a few contaminants, however, for which no animal toxicity data was found. For these cases, wildlife NOAELs were extrapolated from human noncarcinogenic toxicity data listed in the EPA IRIS data base based on the "standard man" body weight of $70 \mathrm{~kg}$. In relation to human toxicity values, the wildlife species that weigh less than $70 \mathrm{~kg}$ have higher benchmarks than humans; wildlife species weighing more than 70 kg have lower benchmarks.

Literature sources for inorganic terrestrial phytotoxicity benchmarks were summarized and reported by Suler and Futrell (1993) (eable 6-7). Where available. the lowest concentrations in a soil medium the produced phytotoxically excessive effects were chosen from the data base. Several benchmarks were derived from experiments using nutrient solutions as the experimental medium. Uncertainty values were not applied to this data to account for differences in experimental growth medium. A methodology for deriving phytotoxicity benchmarks for organic constituents has been developed by Eskew and Babb (in preparation, as cited in the MMR Air National Guard Rist Assessment Handbook (1992)] (table 6-7).

Risks to aquatic organisms from exposure to organic and inorganic contaminants in water and sediments (pore water) were calculated by comparing the water or sediment pore-water concentrations with the chemical-specific aquatic benchmark (Suter et al. 1992) (table 6-7). To determine internal dose to aquatic plants, fish, and muskrats from exposure to radionuclides, the su face water concentrations were multiplied by aquatic (internal), radionuclide-specific dose conversion factors to produce a daily dose in rads (Killough and McKay 1976). To determine the internal dose to benthic macroinvertebrates and other bottom-dwelling organisms (e.g., fish larvae) from exposure to radionuclides, the sediment pore-water concentrations were multiplied by radionuclide and organism-specific aquatic (intemal) dose conversion factors to produce a daily dose. The external dose to all organisms was determined by multiplying the surface water concentrations by the external radionuclide-specific dose conversion factors. Combined internal and external doses greater than $1 \mathrm{rad} / \mathrm{d}$ are considered to pose a potential risk to aquatic organisms (i.e., HI is equal to or greater than 1) (NCRP 1991).

Although it is reasonable to assume that most species are exposed to contaminants only some of the time and that contaminant concentrations are not as high as maximum values, an initial screening assessment was conducted using the maximum concentrations of each contaminant on-site to identify worst-case potential contaminants. Following this initial screening. average concentrations were used for a more realistic maximum exposure for contaminants and receptors that did not pass the initial screening. 
TABLE 6.7-Crite:ia Benchmarts for Terrestrial' and Aquatic ${ }^{2}$ Species (NOAELs listed in mg/kg/d for terrestrial benchmants or $\mathrm{mg} / \mathrm{L}$ for aquatic benchmarks) on the Fernald Environmental Management Project

\begin{tabular}{|c|c|c|c|c|c|c|c|c|c|c|}
\hline Comonarear & $\begin{array}{l}\text { Pribe- } \\
\text { Focted } \\
\text { Mouse }\end{array}$ & $\begin{array}{c}\text { Badern } \\
\text { Cottentall } \\
\text { Rabblt }\end{array}$ & Indlana Bat & $\begin{array}{l}\text { American } \\
\text { Robin }\end{array}$ & $\begin{array}{l}\text { Red.Talled } \\
\text { Hawk }\end{array}$ & $\begin{array}{l}\text { White-Talled } \\
\text { Deer }\end{array}$ & Cow & Red Fox & Aqualk & Verectaden \\
\hline $\begin{array}{l}\text { 1.1.2-Trictibro-1,2.2 } \\
\text { inimoroetione }\end{array}$ & $\mathbf{N A}$ & NA & NA & NA & NA & $\overline{N A}$ & NA & NA & NA & $2.602+\infty 0$ \\
\hline 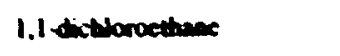 & NA & NA & NA & NA & NA & NA & NA & NA & $1.59 \mathrm{E}+00$ & $8.602-01$ \\
\hline 2-busmose & $2.23 E+01$ & $6.12 E+00$ & $3.34 E+01$ & $1.54 E+01$ & $5.81 E+00$ & $1.69 \mathrm{E}+00$ & $8.80 \mathrm{E}-01$ & $3.57 \mathrm{E}+00$ & $1.78 \mathrm{E}+01$ & NA \\
\hline 2- Wethylanpethakene & $\mathrm{NA}$ & NA & NA & NA & NA & NA & NA & NA & NA & $2.108+01$ \\
\hline Acemepoticot & $\mathrm{Ni}$ & NA & NA & NA & NA & NA & NA & NA & $1.97 \mathrm{E}-01$ & $1.28 E+02$ \\
\hline Acetone & $2.44 E+01$ & $6.65 E+00$ & $3.63 E+01$ & $1.67 E+01$ & $6.31 E+\infty 0$ & $1.84 \mathrm{E}+00$ & $9.56 \mathrm{E}-01$ & $3.88 \mathrm{E}+00$ & $2.37 \mathrm{E}+01$ & $9.65 E+01$ \\
\hline Anuctor 1242 & $1.16 E-01$ & $3.16 E-02$ & $1.73 E-01$ & $1.59 E-01$ & $6.02 E-02$ & $8.74 E-03$ & 4.5SE-03 & $1.85 E-m$ & $2.908-03$ & $1.00 \mathrm{e}+01$ \\
\hline Aructor 1248 & $6.22 \mathrm{E}-01$ & $0.05 E-\infty$ & $9.25 \mathrm{E}-01$ & $4.25 E-01$ & $5.75 E-02$ & $1.67 E-02$ & $8.70 E-0.3$ & $3.53 \mathrm{E}-02$ & $4.00 \mathrm{e}-04$ & NA \\
\hline Arockux 1254 & $1.41 E-01$ & $4.34 \mathrm{E}-02$ & $2.10 E-01$ & $3.19 E+00$ & $1.47 E+00$ & $1.73 \mathrm{E}-02$ & $9.03 \mathrm{E}-03$ & $3.50 \mathrm{E}-02$ & $3.20 \mathrm{e}-04$ & $1.002+01$ \\
\hline Aroctor 1250 & $1.46 E+00$ & $2.92 \mathrm{E}-03$ & $2.17 \mathrm{E}+00$ & $9.96 E-01$ & $2.77 E-0.3$ & 8.06E-04 & $4.20 E-04$ & $1.70 \mathrm{E}-03$ & $2.10 E-03$ & NA \\
\hline Benzia)matracese & NA & NA & NA & NA & NA & NA & NA & NA & $6.50 z-04$ & $1.288+02$ \\
\hline Benzo(a)pyrese & $2.44 E-02$ & $6.65 \mathrm{E}-03$ & $3.63 E-02$ & $1.67 \mathrm{E}-02$ & $6.31 E-03$ & $1.84 E-03$ & $9.56 E-04$ & $3.88 E-03$ & $2.99 E-03$ & $1.28 E+02$ \\
\hline Beazof b) Aworsenthene & NA & NA & NA & NA & NA & NA & NA & NA & NA & $1.28 \mathrm{E}+02$ \\
\hline Bearolshipherylese & NA & NA & NA & NA & NA & NA & NA & NA & NA & $1.28 \mathrm{E}+02$ \\
\hline Bearad (K) Nuranchene & NA & NA & NA & NA & NA & NA & NA & NA & NA & $1.2 \mathrm{nE}+02$ \\
\hline Onyseax & NA & NA & NA & NA & NA & NA & NA & NA & NA & $1.20 \mathrm{E}+02$ \\
\hline Culontane & $1.72 E-03$ & 4.69E-04 & $2.56 E-03$ & $3.98 E-01$ & $|.51 \mathrm{E}-0|$ & $1.30 E-04$ & $6.75 E-05$ & $2.74 E-04$ & $1.70 e-04$ & $1.99 \mathrm{E}+04$ \\
\hline Dideasofuran & NA & NA & NA & NA & NA & NA & NA & NA & $2.00 \mathrm{E}-03$ & NA \\
\hline Diecthyl phubabace & NA & NA & NA & NA & NA & NA & NA & NA & $1.00 E+00$ & NA \\
\hline Di-a bucyl phathalate & $4.56 E+01$ & $1.24 \mathrm{E}+0 !$ & $6.78 E+01$ & $1.41 E-02$ & $5.34 \mathrm{E}-03$ & $3.43 \mathrm{E}+00$ & $1.78 E+\infty 0$ & $7.23 \mathrm{E}+00$ & $2.70 \mathrm{e}-01$ & $1.48 \mathrm{E}+04$ \\
\hline Di-a-acty phatabiane & NA & NA & NA & NA & NA & NA & NA & NA & $3.10 \mathrm{e}-01$ & NA \\
\hline Fuarandicare & NA & NA & NA & NA & NA & NA & NA & NA & $3.20 \mathrm{e}-02$ & $1.28 \mathrm{E}+02$ \\
\hline indema(1.2,3-odpyreac & NA & NA & NA & NA & NA & NA & NA & NA & NA & $1.288+\infty 8$ \\
\hline Methyleoe ctibride & $1.43 E+01$ & $3.89 E+00$ & $2.13 E+01$ & $9.78 E+00$ & $3.69 \mathrm{E}+00$ & $1.07 E+\infty 0$ & $5.60 E-01$ & $2.27 E+\infty$ & $4.10 e-01$ & $5.00 E+\infty 0$ \\
\hline Nupthalesere & NA & NA & NA & NA & NA & NA & NA & NA & $4.50 e-01$ & $1.12 \mathrm{E}+02$ \\
\hline Octutborodibenzo-p- dioxis & $2.44 E-02$ & $6.65 E-03$ & $3.63 E-02$ & $1.678-02$ & $6.31 \mathrm{E}-03$ & $1.84 E-03$ & $9.36 \mathrm{E}-04$ & $3.88 E-03$ & NA & NA \\
\hline Premunaticese & NA & NA & NA & NA & NA & NA & NA & NA & $1.10 e-01$ & $1.28 \mathrm{E}+02$ \\
\hline Pyene & NA & NA & NA & NA & NA & NA & NA & NA & NA & $1.28 E+02$ \\
\hline Tahese & S.4SE+01 & $1.48 E+01$ & 8. $10 E+01$ & $3.73 \mathrm{E}+01$ & $1.41 E+01$ & $4.108+\infty 0$ & $2.13 \mathrm{E}+\infty$ & $8.65 E+\infty 0$ & $2.60 \mathrm{E}-02$ & $9.700+10$ \\
\hline Nhmioum & NA & NA & NA & NA & NA & NA & NA & NA & $8.70 z-02$ & $8.008+\infty 0$ \\
\hline Amimony & $1.21 E+04$ & $3.31 E+03$ & $1.81 E+04$ & $8.31 E+03$ & $3.14 E+03$ & $9.13 E+02$ & $4.75 E+02$ & $1.93 \mathrm{E}+03$ & $1.908+\infty 0$ & $5.000+00$ \\
\hline
\end{tabular}


Table 6-7 (cont'd)

\begin{tabular}{|c|c|c|c|c|c|c|c|c|c|c|}
\hline Cometibueas & $\begin{array}{l}\text { Monic } \\
\text { Fented } \\
\text { Mener }\end{array}$ & 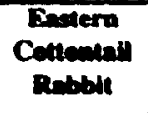 & Indiana Bal & $\begin{array}{l}\text { American } \\
\text { Roble }\end{array}$ & $\begin{array}{l}\text { Red-Talled } \\
\text { Howk }\end{array}$ & $\begin{array}{l}\text { Whilte-Tallod } \\
\text { Deer }\end{array}$ & Cow & Red Pox & Aquetle & Veroution \\
\hline Arseaic & $1.02 \mathrm{E}-01$ & $1.62 E+00$ & $152 \mathrm{E}-0 \mid$ & $7.00 \mathrm{E}-02$ & $2.61 E+00$ & $7.60 \mathrm{E}-01$ & $3,968-01$ & $1.60 \mathrm{E}+00$ & $9.3^{\prime} \mathrm{E}-01$ & T.502001 \\
\hline Barium & $1.25 E+\infty 0$ & $3.39 \mathrm{E}-01$ & $1.85 E+\infty 0$ & 8.52E-01 & $3.22 \mathrm{E}-01$ & $9.37 E-02$ & $4.88 E-02$ & $1.98 \mathrm{E}-01$ & $2.03 E+01$ & $3.002+02$ \\
\hline Beryllium & 1. $32 \mathrm{E}+00$ & $3.59 \mathrm{E}-01$ & $1.96 E+00$ & $9.02 \mathrm{E}-01$ & $3.41 \mathrm{E}-01$ & $9.92 \mathrm{E}-02$ & $5.16 E-02$ & $2.09 \mathrm{E}-01$ & $3.80 \mathrm{E}-03$ & $1.008+0.1$ \\
\hline Boron & NA & NA & NA & NA & NA & NA & NA & NA & $7.00 \mathrm{E}-03$ & NA \\
\hline Catmium & $2.35 E-0^{\circ}$ & $6.41 E-0.3$ & 3.50E-02 & $1.44 E-01$ & $2.24 \mathrm{E}-03$ & $1.77 E-03$ & $9.21 \mathrm{E}-04$ & $3.73 \mathrm{E}-03$ & $1.108-03$ & $3.008+00$ \\
\hline Calcium (axide) & NA & NA & NA & NA & NA & NA & NA & NA & NA & NA \\
\hline Cromium & $5.86 E+00$ & $1.60 E+00$ & $8.72 E+00$ & $4.01 E+00$ & $1.52 \mathrm{E}+00$ & $4.41 \mathrm{E}-01$ & $2.30 \varepsilon-01$ & $9.31 \mathrm{E}-01$ & $1.10 E-02$ & $7.502+01$ \\
\hline Cabah & NA & NA & NA & NA & NA & NA & NA & NA & $4.40 E-03$ & $2.502+01$ \\
\hline Copper & $1.83 \mathrm{E}-01$ & $9.31 \mathrm{E}-01$ & $2.72 \mathrm{E}-01$ & $6.88 E+01$ & 2.10E+01 & 2.57E-0I & $1.34 \mathrm{E}-01$ & $5.43 \mathrm{E}-01$ & $1.20 \mathrm{E}-02$ & $6.002+01$ \\
\hline Cymave ion & $2.64 E+01$ & $7.18 E+\infty 0$ & $3.92 \mathrm{E}+01$ & 1. $.10 E+01$ & $6.82 \mathrm{E}+00$ & $2.63 \mathrm{E}-02$ & $1.37 \mathrm{E}-02$ & S.53E-02 & $3.20 \mathrm{E}-03$ & NA \\
\hline thon & NA & NA & NA & NA & NA & NA & NA & NA & $1.002+\infty 0$ & $1.008+04$ \\
\hline Lead & $7.09 E-03$ & $1.93 \mathrm{E}-03$ & $1.05 E-02$ & $1.59 \mathrm{E}-02$ & $|| 1 E+0 \mid$. & $5.33 \mathrm{E}-04$ & $2.77 \mathrm{E}-0.4$ & $1.12 \mathrm{E}-03$ & $3.20 \mathrm{E}-03$ & $1.008+02$ \\
\hline Magnesium & 2.33E+02 & $6.34 E+01$ & $3.46 E+02$ & 1.59E+02 & $6.02 E+01$ & $1.75 E+01$ & $9.12 E+00$ & $3.70 \mathrm{E}+01$ & $1.60 \mathrm{E}-0.4$ & NA \\
\hline Marganese & $2.00 E+00$ & S.4SE-01 & $2.97 E+\infty 0$ & $1.37 E+\infty 0$ & $5.17 E-01$ & $1.50 \mathrm{E}-01$ & $7.83 \mathrm{E}-02$ & $3.18 \mathrm{E}-01$ & $1.10 E+00$ & $1.502+03$ \\
\hline Mercary & $1.43 E+01$ & $6.92 \mathrm{E}-0.3$ & $2.13 \mathrm{E}+01$ & $3.19 E+00$ & $5.74 \mathrm{E}-01$ & $2.15 E-02$ & $1.12 E-02$ & $4.04 E-03$ & $1.300-03$ & $3.00 \mathrm{e}-01$ \\
\hline Molybdeaum & NA & NA & NA & NA & NA & NA & NA & NA & $3.60 \mathrm{E}-01$ & $2.002+00$ \\
\hline Nicked & $5.90 E+01$ & $1.61 E+01$ & $8.77 E+01$ & $4.17 \mathrm{E}+00$ & $1.58 E+\infty 0$ & $4.44 E+00$ & $2.31 E+\infty 0$ & $9.37 \mathrm{E}+00$ & $1.60 \mathrm{e}-01$ & $1.002+02$ \\
\hline Ponassion & NA & NA & NA & NA & NA & NA & NA & NA & $1.30 \mathrm{E}-04$ & NA \\
\hline Selcaiman & $6.14 E-02$ & $1.67 E-02$ & 9. $13 \mathrm{E}-02$ & $2.51 E-0 \mid$ & $9.47 \mathrm{E}-02$ & $4.62 \mathrm{E}-03$ & $2.4 \mathrm{EE}-03$ & $9.75 \mathrm{E}-03$ & $3,50 \mathrm{E}-02$ & $5.002+01)$ \\
\hline Silver & NA & NA & NA & NA & NA & NA & NA & NA & $2.00 \mathrm{e}-04$ & $2.008+01$ \\
\hline Sodinam ion & NA & NA & NA & NA & NA & NA & NA & NA & $4.80 \mathrm{E}-01$ & NA \\
\hline Strominem & $6.43 E+02$ & 1.75Eस ? & 9.56E.02 & $4.40 E+02$ & $1.66 E+02$ & $4.83 E+01$ & $2.52 \mathrm{E}+01$ & $1.02 E+02$ & NA & NA \\
\hline Theltien & $2.44 E-02$ & $6.65 E-03$ & $3.63 \mathrm{E}-02$ & $1.67 E-02$ & $6.31 E-03$ & $1.84 E-03$ & $9.56 \mathrm{E}-04$ & $3.88 \mathrm{E}-03$ & $6.40 z-02$ & $(1.004+0,1)$ \\
\hline Utraminas & $1.51 E-01$ & $4.12 E-02$ & $2.25 E-01$ & $2.20 E+01$ & $8.30 E+00$ & $1.14 \mathrm{E}-02$ & $5.93 \mathrm{E}-03$ & $2,40 \mathrm{E}-02$ & $2.70 \mathrm{E}-02$ & NA \\
\hline Vandiun & $2.30 \mathrm{E}-0.1$ & $6.26 \varepsilon-02$ & $3.42 E-01$ & $1.57 \mathrm{E}-01$ & $5.95 E-02$ & $1.73 \mathrm{E}-02$ & $9.01 \mathrm{E}-03$ & $3.65 E-02$ & $4.10 \mathrm{E}-02$ & $5.002+0$ \\
\hline $\operatorname{Iinc}$ & 2.37E+01 & $6.45 E+00$ & $3.52 \mathrm{E}+01$ & $1.62 \mathrm{E}+01$ & $6.13 E+\infty 00$ & $1.78 E+\infty 0$ & $9.28 \mathrm{E}-01$ & $3.762+\infty 0$ & $1.10 \mathrm{e}-01$ & $7.002+0 \mathrm{~K}$ \\
\hline
\end{tabular}

NA $=$ Beachant nol available.

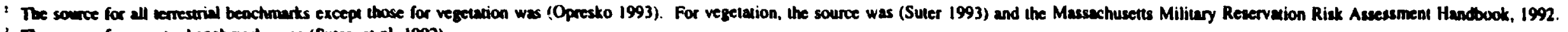

i $T$ e cource for aquatic beachmarts was (Sver, et al. 1992). 
Estimating realistic axpostires for all exdpoints on the reservation is impossible because data for numbers of individuals actually exposed to wastes, amount of time spent in waste areas, and axtual amounts of tontaminants ingested are lacking or incomplete. In some cases, for example, benchmarks were lacking; consequently, hazard indices (HIs) could not be calculated and risks could not be assessed. Specific home ranges and habits of many of the representative species at FEMP are not well known or vary widely, and only a few species with small home ranges (e.g., very small mammals and small birds) may reside within a contaminated area for most of their lives.

For contaminants and receptors that did not pass the average concentration screening (see above discussion), an attempt was made to further define exposure risks by comparing the home range sizes of receptor species with the potential fraction of the home range that is contaminated.

Receptor species at FEMP have home ranges or territories that range from small [e.g., 1 ha (about $\mathbf{2 . 5}$ acres) or less for very small animals such as the robin, mouse, and certain aquatic species)] to hundreds of hectares for hawks and foxes. Some small species have home ranges small enough to be contained within individual waste sites. Some other species have suck large home ranges that the waste sites would comprise only a part of the area they would occupy, if the waste sites were used at all. To further interpret results of this risk analysis, the following assumptions about the contribution of waste sources to receptor exposure are made.

1. For most of the DOE sites assessed in this PEIS, correction factors based on the ratio of the tutal contaminated area to the home range of terrestrial receptors were developed and applied to the Hls calculated for the average concentrations screening. This is appropriate where contaminant uptake pathways other than drinking water predominate. For most tertestrial endpoint receptors at FEMP, however, results of the exposure assessments indicate that nearly all of the exposure of a receptor to a particular contaminant results from to trinking watei pathway (typically $97 \%$ or more), although in a very few instances (e.g., uptake of cyanide ion by deer), ingestion of contaminated soil, insects, and/or vegetation rivaled the drinking water pathway in importance. With the exceptions of $\mathrm{Cd}, \mathrm{Cu}, \mathrm{Pb}, \mathrm{Hg}$, and $\mathrm{U}$, ail waterborne contaminants for which concentration data are available appear to be associated with the small clear well and sludge ponds of the waste storage area in the northwest quadrant of the reservation. Many contaminants in these waste facilities occur at extremely high levels. Therefore, where the drinking pathway dominates (except for the five metals identified above), it is assumed that the ratio of the length of shoreline of contaminated waters within an animal's home range to the total shoreline of waters available to that animal is the more appropriate correction factor (table 6-8) to apply to the calculated HIs in tables 6-9 through 6-11) to determine the effective HIs used to characterize risk in (tables 6-12a through 6-12c.). Shoreline was determined by measuring the length of streams and the circumference of ponds (including waste ponds) circumscribed by a circle equal in area to the minimum reported range of a given receptor species, and centered on the contaminated sites.

2. Drinking water concentrations of $\mathrm{Cd}$, $\mathrm{Cu}, \mathrm{Pb}, \mathrm{Hg}$, and $\mathrm{U}$, on the other hand, are based on the average concentrations for a total of 77 ha (190 acres) of surface waters (all water bodies on the reservation including Paddy's Run as well as a reach of the Great Miami River offsite). The resulting HIs for these metals therefore require no correction (i.e., the correction factor is 1.0) since none of the receptor species under consideration have 


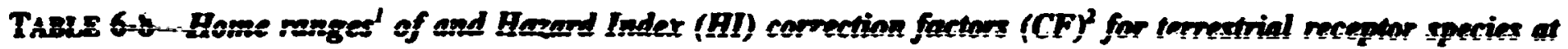
Fermald Environmental Management Project

\begin{tabular}{|c|c|c|c|}
\hline \multirow[t]{2}{*}{ Receptor Species } & \multicolumn{2}{|c|}{ Howe Rongthe } & \multirow[t]{2}{*}{ Correction Tactor } \\
\hline & $<22 \mathrm{ha}$ & $>22 \mathrm{ha}$ & \\
\hline White-footed mouse & $\begin{array}{c}X \\
(0.2-0.6)\end{array}$ & & 1.0 \\
\hline Eastern cottontail rabbit & $\frac{X}{(1.0-2.8)}$ & & 1.0 \\
\hline Indian bat & $\begin{array}{c}x \\
(1.5-4.5)\end{array}$ & & $1.0,0.56$ \\
\hline Red fox & & $\begin{array}{c}x \\
260-520\end{array}$ & $1.0,0.35$ \\
\hline White-tailed deer & & $\begin{array}{c}x \\
60-520)\end{array}$ & $1.0 ; 0.55$ \\
\hline American robin & $\frac{x}{(0.1-2.0)}$ & & 1.0 \\
\hline Red-tailed hawk & & $\begin{array}{c}x \\
(130-420)\end{array}$ & $1.0 ; 0.42$ \\
\hline Vegetation & $\begin{array}{c}x \\
(<0.1)\end{array}$ & & 1.0 \\
\hline
\end{tabular}

I Burt and Grossenheider 1976; Chapman et al. 1980; Smith 1991; Schoener 1966.

2 A CF of 1.0 was applied to HIs for each contaminan for each species having home range $\leq 1.0$ ha. Other CFs based m ratio of circumference of contaminated water bodies te total length (shoreline) of water bodies available within home range, except for cadmium, copper, lead, mercury. and uranium, which require a correction factor of 1.0 because of their extensive distribution throughour reservation $u$ face waters.

${ }^{3}$ Where ternestrial sources of contaminant are most imporant 10 exposure. 37 ha should be used as the maximim territory size that can result in a correction factor of 1.0 . 
TABLE 6-9-Baseline Hezand Indices for Terresuidi Onganivons: on the Fesmald Environmested Mangerwent Project

\begin{tabular}{|c|c|c|c|c|c|c|c|c|c|}
\hline & Menes & Ininit & Deer & Com & Denin & Ind Ben & ET Rint & Ded Pex & Veated \\
\hline Aroctor 1248 & $1.43 E-01$ & $5.30 E-01$ & $9.22 E-01$ & $1.19 E+\infty 0$ & $|S 4 E-0|$ & $1.12 \mathrm{E}-01$ & $5.868-01$ & $6.98 E-01$ & $\mathbf{N} / \mathbf{A}$ \\
\hline Arodor I2S4 & $1.188+00$ & $1388+10$ & $1805+00$ & $2.158+00$ & $3.845-02$ & $928 E-01$ & $4.30 \varepsilon-02$ & 1324300 & $\mathbf{N} / \mathbf{A}$ \\
\hline Benzo(a)pyreax & $7.77 E+\infty 0$ & $100 \mathrm{men}$ & IOLS+0| & $2293+01$ & $8.12 E+00$ & $6.178+10$ & 1.16301 & $1.303+01$ & 0.00 \\
\hline Crondiane & 0.00 & 0.00 & 0.00 & 0.00 & 0.00 & 0.00 & 0.00 & 0.00 & 0.00 \\
\hline Di-abuyi phthalare & $1.06 E-02$ & $139 E-02$ & $2.46 E-02$ & $3.12 E-02$ & $2448+01$ & $8.42 E-03$ & $3.4 \times 3+01$ & $1.88 E-02$ & $4.43 E-06$ \\
\hline Alwoningen & $\mathbf{N} / \mathbf{A}$ & NA & NA & $\mathbf{N A}$ & NA & NA & NA & $\mathbf{N A}$ & $6 \sec 5+10$ \\
\hline Antionony & $9.92 \varepsilon-06$ & 2. $i 1 E-0 S$ & $3.13 E-05$ & 8.83E- $x$ & $1.97 \mathrm{E}-0 \mathrm{~S}$ & $9.27 \mathrm{E}-06$ & $121 E-06$ & $1.44 E-06$ & $45 s: 40$ \\
\hline Ansecic & $2.428+01$ & $5.43 E-01$ & $5.68 E-01$ & $7265-01$ & $2558+01$ & $1.925+01$ & $3.63 E-01$ & $4.33 E-01$ & $2.70 \Sigma-01$ \\
\hline Burisun & $7.11 E+C 2$ & 9.35E+02 & $1658+03$ & $2098+03$ & $7.438+02$ & $5.650+02$ & $1.005+10$ & $1.263+00$ & $1.05 E-01$ \\
\hline Berylliom & $1.908+00$ & $257 \mathrm{E} \times 00$ & $4542+00$ & $5.263+00$ & $20013+00$ & $1.558+00$ & $2915+00$ & $3.47 \mathrm{E}+00$ & $720 E-02$ \\
\hline Cadiniman & $2.403+01$ & $3.422+01$ & $5.855+01$ & $8.403 * 01$ & $2878+00$ & $1.97 \mathrm{~B}+01$ & LTIE*01 & $3.018+01$ & $1538+00$ \\
\hline Aronivon & $1.608+00$ & $2228 \times 100$ & $3.902+00$ & $4.978+00$ & $1.7 m+\infty 00$ & $1338+00$ & $2505 \times 00$ & $290+00$ & $1.74 E-01$ \\
\hline Copper & $5.818+02$ & 4.ITE+01 & $7338+01$ & $9.43 E+01$ & $1.12 E+00$ & $46 \pi+2$ & $1.945+00$ & $\operatorname{S.ASB}+01$ & $2288+00$ \\
\hline Cymaide ion & $2.32 E-01$ & $3.27 \mathrm{E}-0 \mathrm{I}$ & $4.14 E+01$ & $6.228+01$ & $2.12 E-01$ & $|.81 E-0|$ & $1.47 E-08$ & $1.328+01$ & N/A \\
\hline Lead & $7368+02$ & $9.758 \times 0$ & $1.712+\infty$ & $2203+03$ & $2393+\infty 2$ & $5202+02$ & $1.79 E-0 E-$ & $1242+03$ & $1.79 \varepsilon-01$ \\
\hline Mercury & $2.90 E-102$ & $2.152+01$ & $3.36 \mathrm{e}+00$ & $4318+00$ & $931 E-02$ & $2.31 E-02$ & $2.78 E-01$ & $2.908+01$ & $3.00 E-01$ \\
\hline Molybdeaum & $\mathbf{N} / \mathbf{A}$ & $N / A$ & N/A & N/A & NA & NA & NA & N/A & $2.168+00$ \\
\hline Nictel & $3.24 E-01$ & $426 E-01$ & $7.50 E-01$ & $9.57 E-01$ & $3.298+00$ & $2.56 E-01$ & $4.638+00$ & S.7IE-0I & $2.36 E-01$ \\
\hline Seleaium & $1.72 E+01$ & $2.26 \mathrm{E}+01$ & $3.9 \% 2+01$ & $5.008 \times 01$ & $3.02 \mathrm{E}+00$ & $1.363+01$ & $428 E+\infty 0$ & $3.05 \mathrm{se}+01$ & $9.00 E-02$ \\
\hline Silver & N/A & NA & NA & NA & N/A & NA & N/A & N/A & $4.32 E+00$ \\
\hline Urmiurn & $1.328+03$ & $1.76 z+03$ & 301EACB & $4.018+03$ & $6.358+00$ & $1.028+03$ & $8.998+00$ & $2278+03$ & NA \\
\hline Vandium & $1.992+03$ & $2628+03$ & $463 E+03$ & $5.87 E+103$ & $2.088+03$ & $1.56 B+0 B$ & $2.97 E+03$ & $3.542+03$ & $3.15 E-01$ \\
\hline Zinc & $1.10=+00$ & $1 / 49+00$ & $2602+00$ & $3,44 Z+\infty$ & $1.148+10$ & $8.83 E-01$ & 1S4EH00 & $1.832+00$ & $5.17 E-01$ \\
\hline Rediological & $3.99 E-01$ & $3.99 \mathrm{E}-01$ & $4.00 E-01$ & $4.03 E-01$ & $3.99 \mathrm{E}-0 \mathrm{~J}$ & $3.99 \mathrm{E}-01$ & $1.26 \mathrm{E}-01$ & $|26 \mathrm{E}-0|$ & $4.09 E-01$ \\
\hline
\end{tabular}

NA = Benctunat not available, therefore hazand index could nor be calculared.

1 Shaded numbers are Hls > 1.0. 


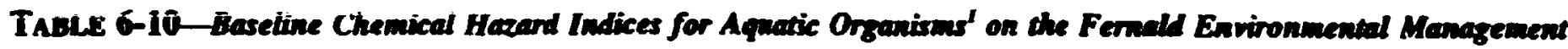
Project

\begin{tabular}{|lcc|}
\hline \multicolumn{1}{|c|}{ Constituent } & Average & \\
\hline Aluminum & Surfece Water HI & Sediment Water HI \\
Cadmium & 0.00 & $2.93 E+01$ \\
Copper & $2.55 E+00$ & 0.00 \\
Lead & $8.54 \mathrm{E}-01$ & 0.00 \\
& $2.09 \mathrm{E}+00$ & 0.00 \\
\hline
\end{tabular}

I Shaded numbers are Hls $>1.0$.

TABLE 6-11-Average Internal and External Radiological Doses to Aquatic Organisms (radld) on the Fermald Environmental Management Project

\begin{tabular}{|c|c|c|c|c|c|}
\hline & External Beth and Gaman & Internal rions & 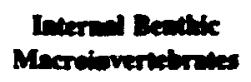 & Interiol Fith & Internel Molores \\
\hline Uraium-234 & $1.50 E-06$ & 8c:anos & $4.87 E-04$ & $8.64 E-02$ & $1.22 E-02$ \\
\hline Tool doese & $1.50 \varepsilon-06$ & cr:an & $4.87 \mathrm{E}-04$ & $8.64 E-02$ & $1.22 E-02$ \\
\hline
\end{tabular}

The benchmet for aquatic organisms is I rede, therefore the tonl doce equals the hazard index.

I Shaded waibers are Hls > 1.0 .

TABLE 6-12A-Baseline potential risks, 2 to the endangered Indiana bat, the only endangered species that may reside, feed, or drink in the inmediate vicinity of the waste sites or contaminated waters on the Fernald Environmetnal Management Project.

\begin{tabular}{|l|c|}
\hline \multicolumn{1}{|c|}{ Contaminant } & Risk \\
\hline arsenic & S \\
benzo(a)pyrene & M \\
barium & S \\
cadmium & S \\
copper & S \\
lead & S \\
selenium & M \\
vanadium & S \\
uranium & S \\
\hline
\end{tabular}

1 Potential risks based on assumptions discussed in Section 4.4.3: $\mathrm{M}=$ moderate risk, where 1.0 SHI $<10 ; \mathrm{S}=$ severe risk. where HI $\geq 10$.

1 Risks to individuals that are not in the immediate vicinity of the waste sites are negligible. Waste sites and contaminated waters accoum for less than 17\% of the surface area of the Fernald Environmental Management Project. 
TADLE 6-120-Baseline potential risks to wetlands adjacent to waste sites. Rists to wethonds that are not adjacent to waste ponds are negligible at the Fermald Environmental Management Project

\begin{tabular}{|l|c|c|}
\hline \multicolumn{1}{|c|}{ Contaminant } & Benthos & Plants \\
\hline Aluminum & $\mathbf{S}$ & - \\
Cadmium & $\mathbf{M}$ & - \\
Lead & $\mathbf{M}$ & - \\
Radiological dose & - & $\mathbf{M}$ \\
\hline
\end{tabular}

' $M=$ moderate risk. where $\mathrm{HI}$ is equal to or greater then 1.0, but less than 10; $S=$ severe risk, where HI is equal to or greater than 10 .

2 Based on EPA Water Quality Criteria (Suter et al. 1992). We assume that benthic inventebretes are exposed to surface water or sediment pore water concenarations, whichever are higher (see Section 6.6.2) while otber wetand (aquatic) organisms are exposed to surface water.

TABLE 6-12C-Baseline potential risks' to recreational wildiffe that occupy or include waste sites or contaminated waters in their home nanges at the Fernald Environmental Management Project

\begin{tabular}{|c|c|c|c|}
\hline Contaminant & Cottontal Rabbit & White-inted Deer & Fah \\
\hline Benzo(a)pyrene & $\mathbf{S}$ & $\mathbf{M}$ & \\
\hline Aroclor 1254 & $\mathbf{M}$ & & \\
\hline Barium & $\mathbf{S}$ & $\mathbf{S}$ & \\
\hline Beryllium & $\mathbf{M}$ & $\mathbf{M}$ & \\
\hline Caomium & $\mathbf{S}$ & $\mathbf{S}$ & M \\
\hline Chromium & $\mathbf{M}$ & $\mathbf{M}$ & \\
\hline Copper & $\mathbf{S}$ & $\mathbf{S}$ & \\
\hline Lead & $\mathbf{S}$ & $\mathbf{S}$ & $\mathbf{M}$ \\
\hline Mercury & $\mathbf{S}$ & $\mathbf{M}$ & \\
\hline Seleniunı & $\mathbf{S}$ & $\mathbf{S}$ & \\
\hline Uranium & $\mathbf{S}$ & $s$ & \\
\hline Vanadium & $\mathbf{s}$ & $\mathbf{S}$ & \\
\hline Zinc & $\mathbf{M}$ & $\mathbf{M}$ & \\
\hline Cyanide ion & & $\mathbf{S}$ & \\
\hline
\end{tabular}

' $M=$ moderace risk. where $H I$ is equal to or greater than 1.0. bus less than 10; $\mathrm{S}=$ severe risk. where HI is equal to or greater than 10 . 


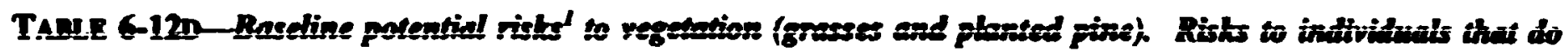
not greze or drink in waste sites are negtigible; hence, risls to cuttle are negligible in the areas currently used for livestock grazing at the Femald Environmental Management Project

\begin{tabular}{|l|c|}
\hline \multicolumn{1}{|c|}{ Contaminant } & Vegetation \\
\hline Aluminum & $\mathrm{S}$ \\
\hline Antimony & $\mathbf{M}$ \\
\hline Cadmium & $\mathbf{M}$ \\
\hline Copper & $\mathbf{M}$ \\
\hline Molybdenum & $\mathbf{M}$ \\
\hline Silver & $\mathbf{M}$ \\
\hline
\end{tabular}

I $M=$ moderate risk, where HI is equal to or grearer than 1.0, but less then 10, S = severe rist, where HI is equal to or greater thre 10 .

TABLE 6-12E-Baseline potential risk's' to other important food web (biodiversity) components that occupy waste sites on the Fernald Environmental Management Project

\begin{tabular}{|c|c|c|c|c|c|c|c|}
\hline Contamitant & Moune & $\begin{array}{l}\text { Red } \\
\text { Fox }\end{array}$ & $\begin{array}{l}\text { Other } \\
\text { Bats }\end{array}$ & Robla & $\begin{array}{c}\text { RT } \\
\text { Hawt }\end{array}$ & Vequetition & $\begin{array}{l}\text { Aquadic } \\
\text { Bendion }\end{array}$ \\
\hline Aroctor 1254 & $M$ & & & & & & \\
\hline Benzo(a)-pyrene & M & $\mathbf{M}$ & M & M & $\mathbf{M}$ & & \\
\hline Cyanide ion & & $\mathbf{M}$ & & & & & \\
\hline di-n-butyl phthalate & & & & $\mathbf{S}$ & $\mathbf{S}$ & & \\
\hline Aluminum & & & & & & $\mathbf{S}$ & $\mathbf{s}$ \\
\hline Antimony & & & & & & $\mathbf{M}$ & \\
\hline Arsenic & $\mathbf{S}$ & & $\mathbf{S}$ & $\mathbf{S}$ & & & \\
\hline Barium & $\mathbf{s}$ & $\mathbf{S}$ & $\mathbf{S}$ & $\mathbf{S}$ & $\mathbf{S}$ & & \\
\hline Beryllium & M & $M$ & & M & M & & \\
\hline Cadmium & $\mathbf{S}$ & $\mathbf{S}$ & $\mathbf{S}$ & M & $\mathbf{s}$ & $\mathbf{M}$ & \\
\hline Chromium & $\mathbf{M}$ & $\mathbf{M}$ & & M & $\mathbf{M}$ & & \\
\hline Copper & $\mathbf{S}$ & $\mathbf{s}$ & $\mathbf{s}$ & M & $\mathbf{M}$ & $\mathbf{M}$ & \\
\hline Lead & $\mathbf{S}$ & $\mathbf{S}$ & $\mathbf{S}$ & $\mathbf{S}$ & & & \\
\hline Mercury & & $\mathbf{S}$ & & & & & \\
\hline Molybdenum & & & & & & $\mathbf{M}$ & \\
\hline Nickel & & & & M & $\mathbf{M}$ & & \\
\hline Selenium & $\mathbf{s}$ & $\mathbf{S}$ & M & $\mathbf{M}$ & $\mathbf{M}$ & & \\
\hline Silver & & & & & & $\mathbf{M}$ & \\
\hline Uranium & $\mathbf{S}$ & $\mathbf{S}$ & $\mathbf{S}$ & M & $\mathbf{M}$ & & \\
\hline Vanadium & $\mathbf{S}$ & s & $\mathbf{S}$ & $\mathbf{S}$ & $\mathbf{S}$ & & \\
\hline Zinc & M & & & $\mathbf{M}$ & & & \\
\hline
\end{tabular}

' $M=$ moderate risk. where $H I$ is equal to or greater than 1.0, but less than $10 ; S=$ severe risk, where HI is equal to or greater than 10 . 
home ranges that woitd circunzstite incte surface water than 77 ha in the vicinity of the reservation. The correction factors as represented by the ratios calculated for each endpoint receptor are presented in table 6-8.

3. The maximum home range (idealized as a circle) that would circumscribe contaminated site waters is only about 22 ha (55 acres). It is assumed, therefore, that small receptor species with minimum home ranges of about 22 ha or less (table 6-8) could receive as much exposure as our average screening indicates. Thus no correction factor was applied to the HIs for these species.

4. For the very few instances in which other (non-drinking water) contaninant uptake pathways are important, the effective HI was determined as follows. It is assumed that the effective exposure (and hence HI) for a given contaminant for wide ranging receptors species with home ranges greater than the total contaminated land area of 37 ha [(92 acres; $9 \%$ of the total reservation area of 425 ha (1050 acres)] is proportional to the ratio of the contaminated area to the minimum home range of an individual animal whose range is centered on the contaminated area. As described above for the drinking water pathway, this ratio was then applied as a correction factor to the calculated His presented in tables 6 9 through 6-11 to determine the effective HI. The contaminated area actually varies with different contaminant species, but lacking sufficient contaminant-specific distribution data, an area of $37 \mathrm{ha}$ is assumed for each contaminant. Exposure of biota living completely outside the $9 \%$ of the reservation that is contaminated is limited to contaminants that have moved from waste sites in dust and by contaminated villtife and plants. Although some contaminants possibly occur in measurable concentrations outside waste sites, for the most part, source terms or measurement data for them are not available, and it is assumed they are minor compared to the concentrations in the waste sites.

5. Although the endangered Indiana bat has not been observed on the reservation itself, its known proximity lapproximately $5 \mathrm{~km}$ (3 miles) from the northeast boundary] and the identification of potentially suitable habitat along Paddy's Run prompted its inclusion in this assessment.

6. Most wetlands, particularly the wooded wetlands, are probably not subject to contamination by waste sites. For this assessment, it is assumed that only those small emergent wetlands immediately adjacent to or downgradient of waste areas are subject to exposure to contaminants. All aquatic biota receive the average exposure to contaminants if they occur in these small wetiands. Conversely, it is assumed that biota in other wetlands are not exposed to contaminants.

7. Aquatic receptors (fish, invertebrates, and plants) are assumed to be fully exposed to contaminants measured in aquatic habitat (i.e., Paddy's Run and the Great Miami River) outside the primary waste areas, but not in the waste areas themselves, because reported contaminant concentrations and other water quality and habitat conditions in the very small waste ponds would be unlikely to support most aquatic life.

8. Grazing livestock are not allowed into contaminated sites. Risks to livestock, therefore, would only be 
appiicabie if caurie were aifowed io graze in waste areas.

\subsection{Contaminant Hazard assessment}

\subsubsection{Baseline}

The next step in the ecological risk assessment generates HIs that are representative of potential risk and that estimate the level of effects from exposure to contaminants. Baseline hazard indices (HIs) for terrestrial receptors exposed to the maximum source concentrations were gremer than the criteria limit of 1 for 18 our of 29 inorganic contaminants and 4 out of 33 organic contaminants. Exposure to the maximum concentrations of radionuclides resulted in HIIs of about for all receptors 27. Radiological exposure was dominated by exposure to ${ }^{20} \mathrm{U}$ in soils.

Exposure of terrestrial species to average soil and water concentrations at the site were calculated for those contaminants whose maximum concentrations resulted in $\mathrm{HIs}>1$ (table 6-9). About $48 \%$ of the HII values for non-radioactive contaminants were above I but below 10, 38\% were above 10 but below 1000 , and about 19\% were still above 1000 .

Exposure of aquatic organisms to the maximum concentrations of nonradiological contaminants in surface water resulted in HIs over 1, but less than 10, for $\mathrm{Cd}, \mathrm{Cu}$, and $\mathrm{Pb}$. Exposure of benthic macroinvertebrates to the maximum sediment pore-water concentrations (calculated from sediment concentrations) resulted in an $\mathrm{HI}$ over $I$ (41.8) for aluminum only. Hazand indices resulting from exposure to the average surface water concentrations remained over 1 for cadmium and lead (table 6-10). The $\mathrm{HI}$ for benthic macroinvertebrates exposed to the average aluminum pore-water concentration was 29.

Exposure to the maximum concentrations of radionuclides in surface water or sediment pire. water (macroinvertebrates only) resulted in HIs (or doses) greater than 1 (about 30) only for aquatic plants exposed to ${ }^{23} \mathrm{U}$. Exposure to the average concentrations in the same media reduced the HI for aquatic plants to about 9 (table 6-11).
Frūu its inititi suite of 80 corstituents of concern, the two-stage screening process using maximum and then average contaminant values yielded 22 contaminants producing HI values equal to or greater than 1 (i.e., representing at least an intermediate risk from contaminants) for at least one endpoint receptor, as shown in tables 6-9, 6-10, and 6-11). Of these, 13 contaminants produce $\mathrm{HI}$ values of 10 or greater (i.e., severe risk) for one or more endpoint receptors. For nearly all combinations of receptor species and contaminants, ingestion of contaminated water accounted for almost 100\% of exposure and consequently almost $100 \%$ of the calculated $\mathrm{HI}$ values. Hazand indices for inorganics (primarily trace elements) most commonly exceeded vahues of 1 , followed by organic compounds, and lastly radionuclides. Following the assumptions outlined in chapter 6.4, the approximate home ranges or territory sizes of receptors were calculated to estimate the proportion of their range that could potentially encompass contaminated lands or surface waters.

Three of the endpoint receptors included in our analyses (the white-for ed mouse, the contontail rabbit, and the American robin) occupy small enough areas (table 6-8) to potentially live their lives entirely within contaminated areas (e.g.) less than 37 ha (92 acres)]. The Indiana bat may have home (foraging) areas less than 2 ha (5 acres), but wooded riparian habitat preferences make it likely that only part of the waste areas near Paddy's Run (the clear well area in particular) would be readily accessible to these bats. All of the small wetlands are also less than 37 ha in extent and are considered here because of their proximity downgradient from the waste areas, not because they are immediately within the known contaminated areas. Vegetation selfevidently occupies small areas.

The remaining selected terrestrial receptor species, i.e., the red fox, the white-tailed deer. and the red-tailed hawk, have home ranges generally larget than the waste areas and therefore require application of a correction factor to their average HIs to produce a more meaningful. effective HI. Aquatic receptors (fish, macroinvertebrates, invertebrates, and plants) are assumed to be fully exposed to contaminants measured in sipuatic habitat outside the primary waste areas (i.e., Paddy's Run and 
the Great Miami Kiver) ont not in the waste areas themselves. Based on the assumptions discussed here and in chapter 6.4, appropriate correction factors were applied to HIs in table 6-9 to determine potential severity of risks to endpoints. For receptor species with home ranges or territories less than 37 ha (e.g., the mouse), no correction factor was used. For species with larger home ranges or serritories, the correction factors shown in table 6-8 were applied to the average HIs to produce an effective HI for each receptor speciescontaminant combination.

Note that some contaminants may be fairly localized. Of the contaminants which these analyses indicate present moderate to severe risks, source terms for benzo(a)pyrene, for example, probably represent only 0.28 ha (0.70 acres), and $\mathrm{V}, \mathrm{Cr}$, and $\mathrm{Ba}$ probably represent less than 10 ha (23 acres) of contaminated land (see appendix B). The qualifier "probably" is used here because, as explained in appendix $B$, it cannot be certain that larger areas are not contamirated, even though some contaminants such as benzo(a)pyrene almost certainly occur in high concentrations in only a few very small waste sites such as the clear well and sludge ponds. Uranium contaminates the largest area of both land and water at FEMP, 37 ha (92 acres) and 77 ha (190 acres), respectively.

\subsubsection{Threatened and Endangered Species}

As shown in table 6-12a, no less than nine contaminants pose moderate in severe risks to any Indiana bats that may live or forage near the contaminated sites. All but one contaminant, benzo(a)pyrene, are inorganics. Uptake through ingestion of contaminated water accounts for at least 98\% of the exposure and $\mathrm{HI}$ fur each contaminant except cadmium, for which $87 \%$ of the $\mathrm{HI}$ for this contaminant is due to water ingestion. Ingestion of contaminzted insect prey accounts fur nearly all of the remaining exposure for these bats. The HIs for five contaminants (Ba, $\mathrm{Pb}, \mathrm{Cu}, \mathrm{V}$, and $\mathrm{U}$ ) are each more than 300. Although by these analyses, individuals of this species utilizing contaminated areas face a severe risk, it must remembered that the HI's incorporate a number of conservative assumptions. A site-specific assessment will be required to cetermine more reaiistic exposure levels.

\subsubsection{Wedands}

Rists to wetlands receptors (e.g., benthic macroinvertebrates and aquatic plants) that might receive contamination from the waste sites are shown in tible 6-12b. As jiscussed eartier, wetlands do not occur within the waste site area, but a few small emergent wetlends [probably no more than 3.5 ha (8.5 acres)] occur along drainage ditches and swales immediately downstream of the waste sites. If these small wetlands are comtaminated, then wetland plants would incur a moderate risk (doses greater than $1 \mathrm{rd} / \mathrm{d}$ ) from radionuclides (nearly all of the dose atributable to $\left.{ }^{23} \mathrm{U}\right)$. Aquatic plants were the only receptors included in the FEMP assessment for which the radiological HI exceeded I $(H I=8.7)$.

Because many benthic invertebrates are exposed to overlying (surface) waters as well as sediment pore water, the HIs are calculated on the basis of either surface water concentrations or sediment water concentrations, whichever are greater. Thus, these calculations indicate that benthic invertebrates would incur moderate risks from $\mathrm{Cd}$ and $\mathrm{Pb}$ concentrations and severe risks from AJ.

\subsubsection{Recreational Species}

Table 6-12e summarizes risks to recreationally desirable species at FEMP. Baseline average HIs for recreational terrestrial species as represented by the cottontail rabbit and white-tailed deer exceeded unity for 14 different contaminants, including trace metals, cyanide ion, benzo(a)pyrene, and Aroclor 1254 la polychlorinated biphenyl (PCB)]. Moreover, on the basis of this assessment, nine of the contaminants pose severe risks to contontail rabbits, whereas each of eight contaminants would put deer at severe risk. Fish in contaminated waters would incur moderate risks from cadmium and lead only.

\subsubsection{Agriculture}

Cattle are not allowed to graze in waste areas: therefore, potential risks to livestocis are 
negligible. Vegetation, in the form of grass and planted pines and spruce, would incur a severe risk from exposure to $\mathrm{Al}$ and moderate risks from Sb, Cd, Cu, Mo, and Ig (lable 6-12d). Potentially adverse effects, however, would be limited to the relatively small areas (totaling less than $37 \mathrm{ha}$ ) (92 acres) within and around the waste sites. Some of these values may well be artifects caused by the analytical techniques used to measure metal concentrationals in soil. With respect to ahminum, it should be noted that the geometric mean concentration for soils in the eastern United States $(33,000 \mathrm{mg} / \mathrm{kg})$ reported by Shacklette and Boerngen (1984) is far greater than the $5850-\mathrm{mg} / \mathrm{kg}$ average concentration used in this assessment. It is quite likely that the extremely low benchmark $(8.0 \mathrm{mg} / \mathrm{kg}$ ) used in this assessment represents an experimental artifact

\subsubsection{Public Lands}

There are no parks or public lands on or adjacent to the FEMP reservation. A Girl Scout camp lies about $1 \mathrm{~km}$ northeast of the reservation boundary, but it is upgradient from the reservation and is therefore unlikely to receive any contamination beyond negligible quantities in the form of occasionally contaminated droppings and scats from birds and wildlife that may encompass both camp and waste sites within their ranges.

\subsubsection{Biodiversity}

As noted earlier, biodiversity on and around the FEMP reservation has suffered under the heavy impact of human activities at least since the arrival of the first European settlers. The original forests have given way to agriculture (crops and cattle), industry, residential developments, a wide variety of introduced organisms, and. here and there, small to mediumsized woodland areas. What is left, nevertheless. supports desirable ecological communities that could be adversely affected by the availability of harmful contaminants on the reservation as indicated in table 6-12e. The mouse, fox, bat, robin, and hawk all would incur moderate or severe risks from each of several contaminants if they inhabited waste sites. Most of the severe risks to these important elements of ecosystem structure and function arise from exposure to As.
$\mathrm{Ba}$, and several beavy metals (i.e., $\mathrm{Cd}, \mathrm{Cu}, \mathrm{Pb}$, $U$, and $V$ ). Both bird species included in this assessment incur severe risks from di-n-butylphthalate as well. Aluminum may pose severe risk to vegetation (sec discussion under wetlands above), whereas the beavy metais generally pose moderate risks to vegetation. Aluminum is the only contaminant that produces an $\mathrm{HI}$ greater than 1 for aquatic invertebrates, but it is sufficiently high that the risk must be rated severe.

\subsubsection{Conclusions}

On the basis of the assumptions and calculations used in this assessment, certain contaminants at a few locations pose modernte to severe risks to selected receptor species. Table 6-13 shows which individual contaminants pose risks to one or more receptor species in the six endpoints.

With respect to the agricultural endpoint, if the contaminated sites were to be uspd for grazing cante or planting trees, then those canle or trees actually using these sites would also incur severe to moderate risks. Otherwise, no adverse effects on agricultural receptor species would be expected.

Most wetlands on the reservarion would not be affected under the no-action alternative; however, a few small wetlands in the immediate vicinity of the waste sites could be affected. These analyses indicate that risks to benthic invertebrates and plants in these few wetlands could be severe and moderate, respectively. Finally, public lands and parks do not occur in or adjacent to the reservation; hence, no adverse effects on this endpoint would be expected.

\subsection{Habitat Disturbance Assessment}

Agricultural, residential, and industrial development long ago began transforming the natural mesophytic and oak-hickory forests (and the ecological communities they supported) that dominated the region around FEMP before the arrival of Europeans. Thus, from a historical perspective, nearly all of the FEMP sice and environs already existed in a considerably altered or ecologically "disturbed" state before FEMP was built. The site and environs nevertheless 
TABuE 6-13 - Comparative subumary of potential risks' to ecological endpoists from beseline and ARAR alternatives on the Fernald Environmental Mancgement Project. Risls are for endpoints which occupy or use waste sites or contaninated waters?

\begin{tabular}{|c|c|}
\hline Source of Rist & $\begin{array}{l}\text { Eodpolats' - No-action } \\
\text { (Besellac) }\end{array}$ \\
\hline Construction & \\
\hline Aroclor 1254 & R, B \\
\hline Benzo(a)pyrene & E, R, B \\
\hline Cyanide ion & R, B \\
\hline Di-n-butyl phthalate & B \\
\hline Alumisum & W. F, B \\
\hline Antimony & F, B \\
\hline Arsenic & E, B \\
\hline Barium & E, R, B \\
\hline Beryllium & $\mathbf{R}, \mathbf{B}$ \\
\hline Cadmium & E, W, R, F, B \\
\hline Chromium & R, B \\
\hline Copper & E, R, F, B \\
\hline Lead & $\mathbf{E}, \mathbf{W}, \mathbf{R}, \mathbf{B}$ \\
\hline Mercury & R, B \\
\hline Molybdenum & F. B \\
\hline Nickel & $\mathbf{B}$ \\
\hline Selenium & E. R, B \\
\hline Silver & F, B \\
\hline Uranium & E, R, B \\
\hline Vanadium & E. R, B \\
\hline Zine & R, B \\
\hline Radiological & $\mathbf{w}$ \\
\hline
\end{tabular}

' Only those contaminants are listed which our analyses showed could pose severe or moderate risks to some endpoints.

2 Risks to endpoints which do not include known conkaminated areas within their manges are assumed to be negligible (see Section 4.4.3).

3 These are short-term risks. Long-term risks could be reduced with successful restoration of appropriate habitat.

- Ecological endpoins: $E=$ threatened, endangered, and candidate species; $W=$ wetlands; $R=$ recreational fish and wildlife; $F=$ agriculture or timber production: $P=$ parks and other public lands: $B=$ biodiversity (only for receptors not included under other endpoints) 
support faify tich, if substmoially sluesed, ecosystems typical of this disturbed state. ecosystems that have perhaps come to represent what the layman would characterize today as "normal" in much of Ohio and Kentucky.

\subsubsection{Baseline}

Outside the 55-ha (136-acres) central production area, another approximately $35-40$ ha (90-100 acres), about $9 \%$ of the esservation, is highly disturbed physically and therefore possesses little or no habitat $\mathbf{v}$-hue, primarily due to the presence of waste sites and ancillary facilities. The baseline altemative under consideration here does not, by definition, include additional disturbances by restoration activities beyond the $9 \%$ of the reservation already disturbed.

\subsection{Cumulative AsSESSMent}

\subsubsection{On-Site}

As many as 22 contaminants present at FEMP have been identified on the basis of this analysis as potential hazards (HIs zreater than or equal to 1) to the well-beir.g of certain receptor species of local ecosystems, including an endangered bat, recreationally desirable fish and wildlife, and other elements of biodiversity. Moreover, five of these contaminants $(\mathrm{Cd}, \mathrm{Cu}, \mathrm{Pb}, \mathrm{Hg}$, and $\mathrm{U}$ ) may adversely affect off-site terrestrial and aquatic receptor species that use contaminated reaches of Paddy's Run and the Great Miami River. Some studies of Paddy's Run have reported higher species richness and diversity above the FEMP than adjacent to the FEMP (Facemire et al. 1990; Bauer et al. 1978). Other confounding factors, however, conceivably are the most important canses of fedpred species richness and divesiny. These factors include the intermittent nature of the stream adjacent to and downstream of the FEMP; natural differences in substrate and other habitat characteristics; past physical disturbances such as stream straightening and dredging; and other sources of pollutants such as agricultural runoff, a small chemical plant, and a steel plant. Although FEMP releases, runoff, or groundwater recharge may have had alverse effects on aquatic comminities of Paddy's Run, none of the studies of Patdy's Run to date are adequate for demonstrating cause and effect.

\subsubsection{On-Site}

The Great Miami River has a long history of water quality problems related to municipel sewage and industrial outfalls, especially low dissolved oxygen, thermal discharges, and high levels of ammonia and nitrates. Several urban and industrial areas upstream (e.g., the cities of Dayton and Hamiltun-Fairfield) discharge pollutants th the river. The Mound Laboratory near Miamisburg, Ohio may release small zmounts of radionuclides to the river. Agricultural practices in the watershed have also contributed to problems related to nutrient enrichment, increased suspended solids, and lowered dissolved oxygen. It is not possible to separate the impact of FEMP -derived contaminants from up stream industrial/urhan impacts. It should be noted that the reach from the FEMP outfall to well below the confluence with Paddy's Run was described by the Ohio Environmental P otection Agency (OEPA 1982). on the basis of community abundance and diversity, as supporting one of the healthiest fish comrisunities in the lower $150 \mathrm{~km}$ (93 miles) of the ril er. 


\section{CHAPTER 7: OAK RIDGE RESERVATION}

The CRR is a 15,000 -ha $(37,500$-acre!, relatively undisturbed and protected block of mostly native forest ecosystem. It is located in the Ridge and Valley Physiographic Province of east Tennessee, bounded on the south and west by the impounded Clinch River (Melton Hill and Watts Bar reservoirs) (figure 7-1). The Federal government acquired the ORR property, which was primarily in agricultural use, in 1942 for the wartisne Manhattan Project (Fielder et al. 1977). At that time, public access to the ORR was restricied exuept at the Three developed facilities (the Y-12 Plant, the K-25 Site, and X-10). The upper slopes were mostly forested, but the re were some clearings for orchards, pastures, and crops. T:llage crops were primarily restricted to lower slopes and bottomlands (Dale et al. 1990). Most of the forest was cut for timber, though not necessarily cleared.

In the late 1940s and early 1950s, extensive loblolly, shortleaf, and white pine plantations were planted in many of the old field areas (Bradbum 1977). Some of these areas were severely eroded prior to establishment of these plantations. From 1965 to 1986 , there was an active timber management program. During that time, much of the area was selectively logged. Natural plant communities or pine plantations currently occupy most of the ORR. Within the ORR, 5000 ha (12,500 acres) are desig lated as the Oak Ridge Research Paik. All of the undeveloped area of the. ORR is currently under a wildlife management agreement with the Tennessee Wildlife Resources Agency (TWRA) (Parr and Evans 1992). The agreement was initiated in 1984 to reduce deer/vehicle collisions by permitting deer hunting, thus lowering the deer population.

The terrestrial ecology of the ORR has teen described in many documents (e.g., Boyle et al. 1982; Saylor et al. 1990; Cunninghaun et al. 1993). Plant communities are characteristic of those found in the intermountain regions of Appalachia, from the Allegheny Mountains in southem Pennsylvania to the southern extension of the Cumberland Mountains in nonhern
Alabama. The most common forest types are either mixed oak-hickory, pine-hardwood, or pine. In addition to these major forest types, northem hardwoous are found in coves and ravines that are interspersed along the dissected ridge system and on bluffs along Poplar Creek and the impounded river which border ORR. Cedar barrens are also fairly common in small areas on limestone substrate.

The ORR provides habitat for a large number of animal species, including about 60 reptilian and amphibian species, more than 120 species of ierrestrial birds (plus 32 species of waterfowl, wading birds: and shorebirds), and about $\mathbf{4 0}$ mamnialian species (Boyle et al. 1982, Parr and Evans 1992). Habitats dominated support the greatest number of wildlife species. Few wildlife species are found in pine plantations (Parr and Evans 1992).

Contaminated sites are associated with the three main facilities on the ORR. These facilities are ORNL (Oak Ridge National Laboratory, also known as X-10), ORGDP (Oak Ridge Gaseous Diffusion Plant, also known as the K-25 Site), and the the $Y-12$ Plant weapons production facility. Source terms were provided separately for these three main facilities. According to the Environmental Restoration PEIS source term data base (Appendix B), abo:It 220 ha (550 acres) of the ORR are contaminateci areas subject to remediation. This does not include contaminated streams, for which estimates of area were not provided. It was assumed that waste sites and contaminated areas in the source term dato base were a representative sample of the surface areas of all waste sites on ORR.

\subsection{ECOLOGical ENDPonts and SPECTES Distribution}

The dominant ecosystem type on the ORR is eastem deciduous forest, some pine plantations and natural pine stands are locaued primarily in the valleys. Nine federally listed or candidate species are known to visit, breed, winter, or stay 
5
$\vdots$
$\vdots$
0
0
5
$\vdots$
$\vdots$
$\frac{1}{5}$
0
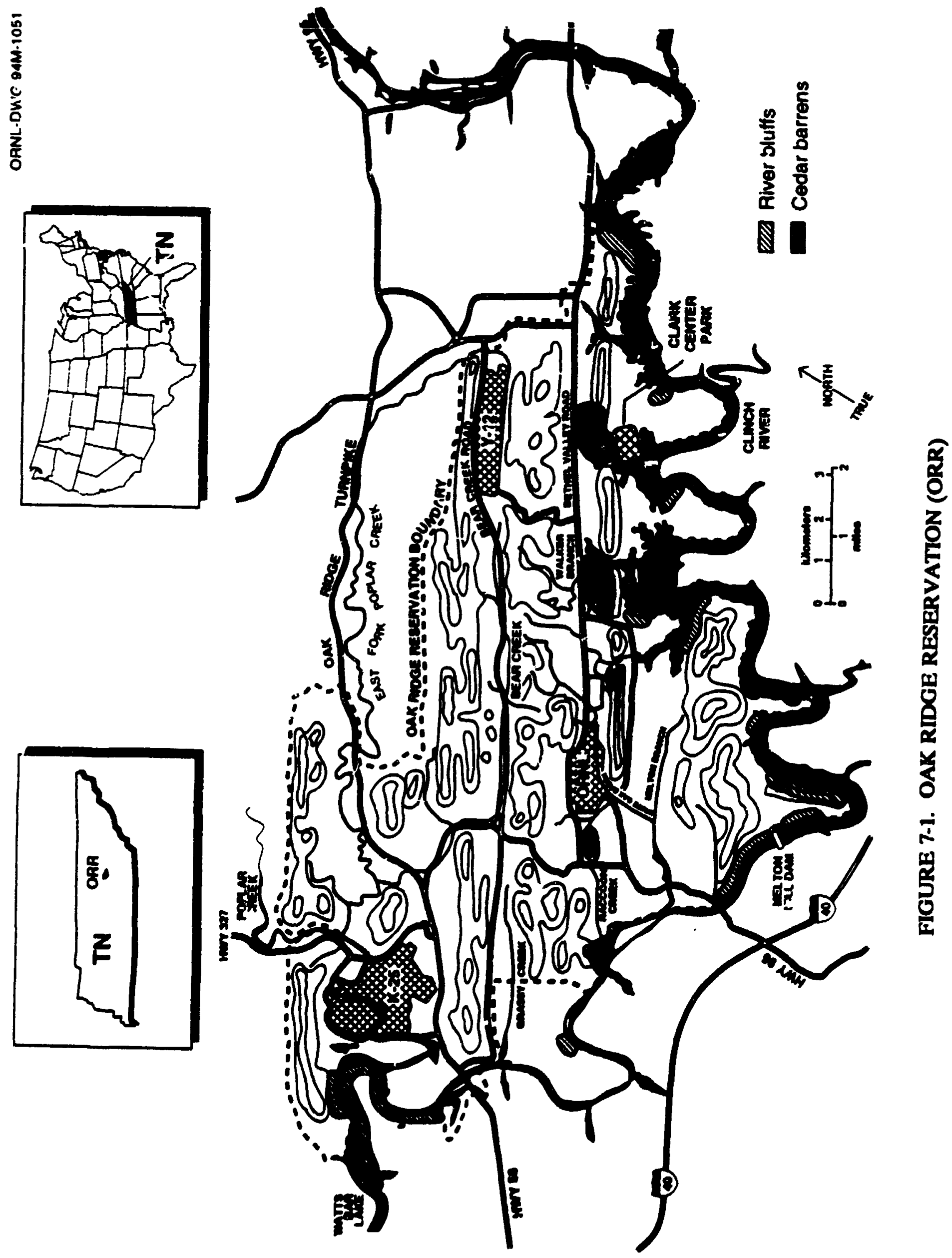

,

3 妾

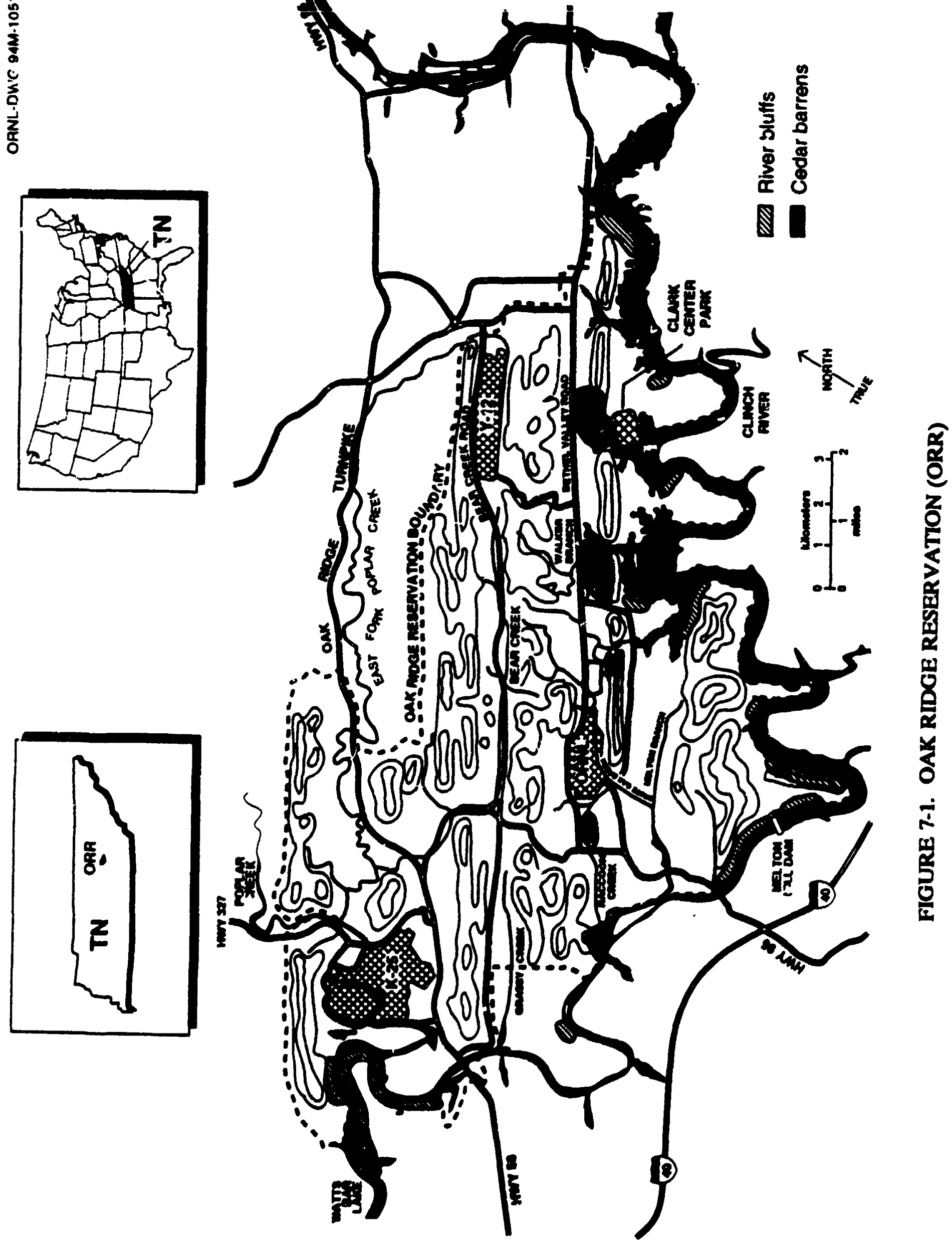

30

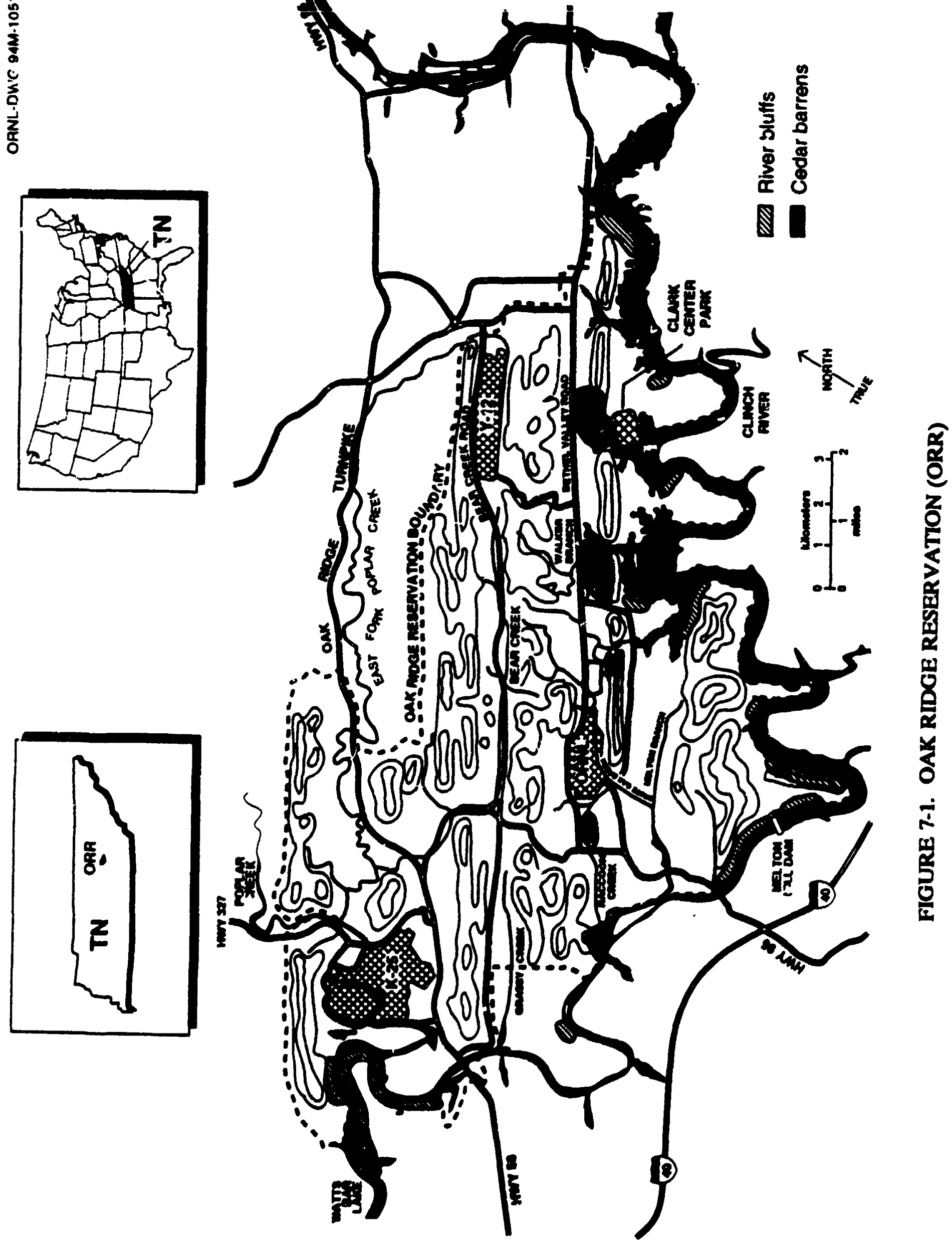

(e)

.

筮

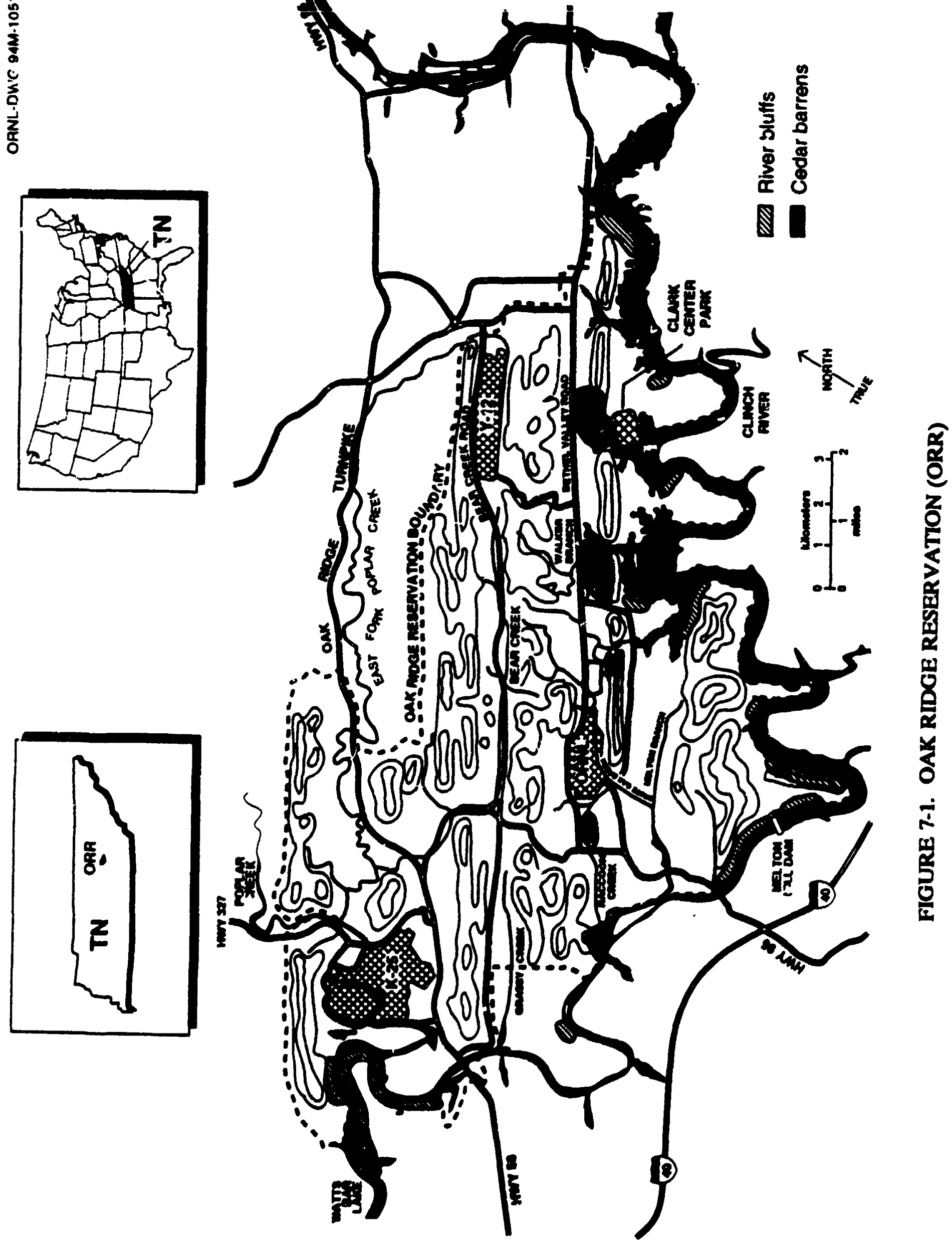

( 0 
year-round (table 7-1). Natu' al wetlands are common along the impounded river and along streams. Recreational fish are found in the river and major streams on the reservation. Although only deer hunting is currently allowed, miny recreational wildlife species are present. None of the reservation is used for agriculture or commercial forestry, but surrounding lands are used for various forms of agriculture and timber production. Important species groups of concern for conservation of biodiversity on the ORR include bats, raptors, predators, and wintering/migratory viloilife. Sensitive habitats include wetlands providing habitat for state-listed plants and ariinals, cedar bartens, and river bluffs.

As discussed in Section 4.1, determining risks to endpoints requires (1) selecting receptor species and (2) defining distribution and composition of endpoints. Although ORR is not ecologically homogeneous, it is more or less uniformly reterogeneous so that. for purposes of the analyses, most endpoints are ubiquitous (table 7-2). Exceptions are wetlands and associated species found along the impounded river. recreational fish found in the impounded river and large streams, cedar barrens, and river bluffs, which are discontinuous; and public lands, which are discrete. Locations of endpoints were determined from existing maps and publications, suppleriented by personal cois:nunications with ecologists at the ORR.

Endpoints cari ce represented by many different receptors. The following sections describe endpoints on the ORR and receptors selected for the analyses.

\subsubsection{Threatened and Endangered Speciass}

Numerous species of plants and animals of special concem have ranges that include the Oak Ridge area, and several occur on the ORR (Kroodsma 1987a; Kroodsma 1992; Cunningham et al. 1993). These species are found in many different habitats throughout the ORR. All federally listed or candidate species were evalusted: state-listed species or species of speciv concem were beyond the scope of this assessment and were included in discussions of sensitive habitats, wetlands, and biodiversity as only appropriate.

\subsubsection{Receptors}

Nine federally listed or candidate species of rlants and animals are known to occur on the ORR (table 7-1). The only listed species known to occur on the ORR, the endangered bald eagle, is an occasional visitor, rarely seen. Although never proven to be present, the endangered eastern sougar has beein repeatedly reported on the ORR (Kroodsma 1987a; Parr and Evans 1992). The ORR is also within the range of the endangered Indiana bat, and suitable habitat for this species is present, although the animal is not currently known to be present. Because the Indiana bat is the only listed species that is likely to reside on the ORR, it was the only listed species chosen as a receptor in the analyses.

The candidate Bewick's wren and Bachman's sparrow were represented by a generic songbird receptor (e.g., robin). Because of a lack of benchmark data, vegetation in general serves as a receptor representing the three candidate plant species. Similarly, a generic aquatic receptor represents the aquatic hellbender and paddlefish. The candidate green salaniander was not represented by a receptor in the analyses because there were no benchmark data, and this cliff dwelling species was assumed to be unaffected by contaminants.

\subsubsection{Distribution}

Hardwoxd forest corridors overhanging Poplar Creek and East Fork Poplar Creek are suitable foraging habitut for the endangered Indiana bat (figure 7-1). This species preys on insects as it flies under the forest canopy above streams or rivers. 


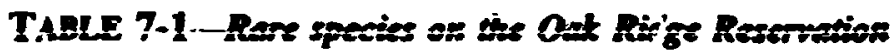

\begin{tabular}{|c|c|c|}
\hline Species & Common Name & Status' \\
\hline \multicolumn{3}{|c|}{ PLANTS } \\
\hline Aureolaria patula & Spreading false foxglove & $\mathrm{Cl}$ \\
\hline Cimicifuga rubifolia & Appalachian bugbane & $\mathrm{C2}$ \\
\hline Delphinium exaltatum & Tall larkspur & $\mathrm{C} 2$ \\
\hline \multicolumn{3}{|c|}{ BIRDS } \\
\hline Haliaeetus leucocephalus & Bald eag!e & $\mathbf{E}$ \\
\hline Thryomanes bewickii & Bewick's wren & $\mathrm{C2}$ \\
\hline Aimophila aestivalis & Bachman's sparrow & $\mathrm{C2}$ \\
\hline \multicolumn{3}{|c|}{ REPTILES AND AMPHIBIANS } \\
\hline Cryptobranchus alleganiensis & Hellbender & $\mathrm{C2}$ \\
\hline Aneides aeneus & Green salamander & $\mathrm{C2}$ \\
\hline \multicolumn{3}{|c|}{ FISII } \\
\hline Polyodon spathula & Paddlefish & $\mathrm{C2}$ \\
\hline
\end{tabular}

1 Endangered and threatened wildlife and plants, 50 CFR 17.11 \& 17.12, July 15, 1991; Endangered and threatened wildlife and plants: animal candidate review. Fed Reg SO CFR part 17. Nov. 21. 1991: Endangered and threatened wildife and plants: review of plant taxa, Fed Reg 50 CFR part 17. Feb. 21. 1990. E=endangered, T=threatened, CI, C2=under review.

Source: Cunningham et al. 1993, Kroodsma 1987a. Kroodsma 1992. Part and Evans 1992)

\section{TABLE 7-2-Distribution of Endpoints on the Oak Ridge Reservation}

\begin{tabular}{|c|c|c|}
\hline Ubiquitous & Discontinuous & Discrete \\
\hline $\begin{array}{l}\text { Resident, breeding, and } \\
\text { wintering federal candidate } \\
\text { species' } \\
\text { Wetlands along streams } \\
\text { Recreational wiblufe } \\
\text { Important components of } \\
\text { blodiversity not included in } \\
\text { the above (bats. food sources } \\
\text { for other species. interior } \\
\text { deciduous forest communities) }\end{array}$ & $\begin{array}{l}\text { Wetlands and riparian vegetation } \\
\text { along the impounded river } \\
\text { Recreational fish in major streams } \\
\text { and the impounded river } \\
\text { Sensitive ecosystems important " } \\
\text { blodiveraity and federally listed } \\
\text { and candidate species" (river bluffs, } \\
\text { cedar barrens, and Indiana bat } \\
\text { foraging habitat) }\end{array}$ & $\begin{array}{l}\text { Public lands within the } \\
\text { reservation }\end{array}$ \\
\hline
\end{tabular}

1 Birds

2 Indiana bat and plants 
Candidate species (tahle 7-1) are found on river bluffs and slopes, in cedar barrens, on or near wetlands, in forests, and in old fields(Kroodsma 1987a; Cunningham et al. 1993; Part and Evans 1992). Species of concem are likely to have patchy distribution rather than uniform distribution over the entire reservation. The hellbender and padulefish are known only from the impounded river, and the green salamander is known only from une cliff near the river. Appalachian bugbane and spreading false foxglove are known only from bluffs and slopes on the river or major embayments. The tall larkspur is found only in cedar barrens, primarily along Bethel Valley Road (figure 7-1). These species are considered to have discontinuous distribution. The candidate birds could be found in suitable habitat throughout the ORR and are considered ubiquitous.

\subsubsection{Wetlands}

\subsubsection{Receptors.}

Benthic macroinvertebrates, fish, muskrats, and aquatic plants are representative wetland species for which some toxicity benchmark data are available. Although these biota do not include all wetland species on the reservation, they were selected as receptors in the risk analysis because they cover the range of wetland ecosystem components that could be present. Therefore risks were calculated to these receptors in all wetlands.

\subsubsection{Distribution.}

Wetlands on the ORR include emergent communities in shallow embayments on the impounded river, emergent and aquatic communities in ponds, forested wetlands on low ground along major streams, and wet meadows and marshes associated with streams and seeps (Cunningham and Pounds 1991). Small headwater wetlands, not shown on National Wetland Inventory (NWI) maps, are found throughout the ORR bordering minor stream channels that dissect the hilly terrain. These headwater wetlands are often less than $6 \mathrm{~m}$ (20 ft) wide but are often found in and near waste sites. Some provide habitat for sensitive species (e.g. statg-listed orchids) (Cunningham et al.

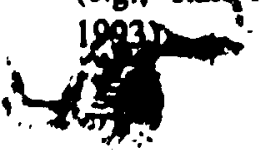

\subsection{Recreatoral Fat and Whatffe}

\subsubsection{Receptors.}

Fish and wildlife suitable for recreational use are abundant on the ORR (Boyle et al. 1982; Parr and Evans 1592). Fish suitable for recreational use include gizzard shad; large-mouth, white. striped, and yellow bass; several species of sunfish; sauger; and several species of catfish (Boyle et al. 1982; Parr and Evans 1992). Determining contaminant risks to aquatic species. including recreational fish, doss not require the use of specific receptor species. Risks were determined to nonbenthic aquatic biota in general to represent recreational fish in the impounded river and Poplar Creek.

Recreational wildlife include white-tailed deer, which are ronted annually, and wild turkey, which are tray,ed for release off-site. Other recreational wildlife include coyote, beaver, foxes, bobcat, raccoon, cr wntail rabbit, groundhog. opossum, eastem gray squirrel, weasel, mink, woodcock, bobwhite quail, ruffed grouse, mourning and rock dove, and waterfowl. The white-tailed deer, cottontail rabbit, Canada goose, and coyote were selected as common species representative of recreational wildlife which are also important components of the food web on the reservation.

\subsubsection{Distribution.}

Although fish large and abundant enough to be used for recreational purposes are mainly present in the impounded river and its embayments. Poplar Creek, and East Fork Poplar Creek, some recreational species are found in all streams on the ORR. Most recreational wildlife species are year-round residents throughout the ORR. Canada geese, which are also year-round residents on the ORR, are abundant near facilities, especially in grassy areas near ponds.

\subsubsection{Agricultural Production}

Portions of ORR have been used experimentally for swine, poultry, beef, and dairy caule; for pasture: for hay production; and for pine and hardwood timber production (Bradbum and Roserubalm 1984). Timber sales are limited to salvage sales in areas being cleared for other 
purposes, and agriculfusal axtivity is limited to occasional hay harvest in small areas in various locations.

\subsubsection{Receptors.}

Generic vegetation was the receptor chosen to represent hay, the agricultural exdpoint, and trees, the forestry endpoint in the analyses.

\subsubsection{Distribution.}

Most of the ORR is forested, except for facilities, roads and rights-of-way, cedar barrens, sorke wetlands, very young pine plantations, and fields previously used as pasture, primarily on the eastem end of the ORR.

\subsubsection{Parks and Other Public Lends}

\subsubsection{Receptors.}

Risks to this endpoint were determined by estimating risks to food web components at reservation boundaries adjacent to public access areas. Aquatic receptors are generally the most important ecological components of interest in these public areas (e.g., fishing access), but all food web components were considered.

\subsubsection{Distribution.}

Although no parks or public lands are adjacent to the ORR, several public access and recreational areas are located along the impounded river bordering the ORR. Clark Center Park, an employee recreational area located on the ORR on the impounded river upstream from most potential sources of contaminants from the ORR, is also open to the public.

There are several state natural areas on the ORR registered with the state to provide protection to habitat of rare species (Pounds et al. 1993), but these areas are not open to the public and are not considered part of this endpoint.

Because the source term data base does not include source terms for the reservoirs, for purposes of discussion, all public access areas along the impounded rivers, including Clark Center Park, wil! be considered comparable.

\subsubsection{Blodiversity, Inciuding Sensitive Habitats Other Than Wethads}

\subsubsection{Receptors.}

The food web developed for the risk assessment was assumed to adequately represent critical components of biodiversity in the mixed forest ecosystems on the ORR. The endangered Indiana bat, whose inabitat is restricted to forested large streams, is otherwise similar ecologically to most bats found on the reservation and was chosen as a conservative representative of bat species. Raptors are represented in the analyses by the state eadangered Cooper's hawk, and osprey and migratory waterfowl are represented by the resident Canada goose. The robin, which is common across the site was chosen as a representative songbind. Other important food web components (figure 7-2) include inajor foud organisms of receptors chosen to represent other endpoints (i.e., small mammals eaten by coyore. and insects eaten by small mammals, birds, and bats) and other endpoints discussed in the preceding sections. Although very important to ecosystem function and as food for other species, invertebrates were not included in the analyses because of benchmark data were lacking for them. Benchmark data were generally nor available for amphibians, a: ther important species group at the site.

\subsubsection{Distribution.}

ORR is a large block of relatively natural mixed hardwood and pine forest surrounded by a greatly fragmented urban, suburban, woodlot. and farm landscape. The existence of ORR as a large block of relatively undisturted forest habitat is a major contribution to its value to biodiversity. In this heterogencous mixture of upland hardwoods, coves, pine stands, streams, impounded river, and wetlands, amphibians are widespread and diverse (Parr and Evans 1992) as are breeding populations of neotropical migratory warblers (Kroodsma 1987b; Anderson and Shugart 1974), predators, waterfowl, and raptors (Part and Evans 1992). The ORR is also used as a feeding and resting area by migrating warblers 


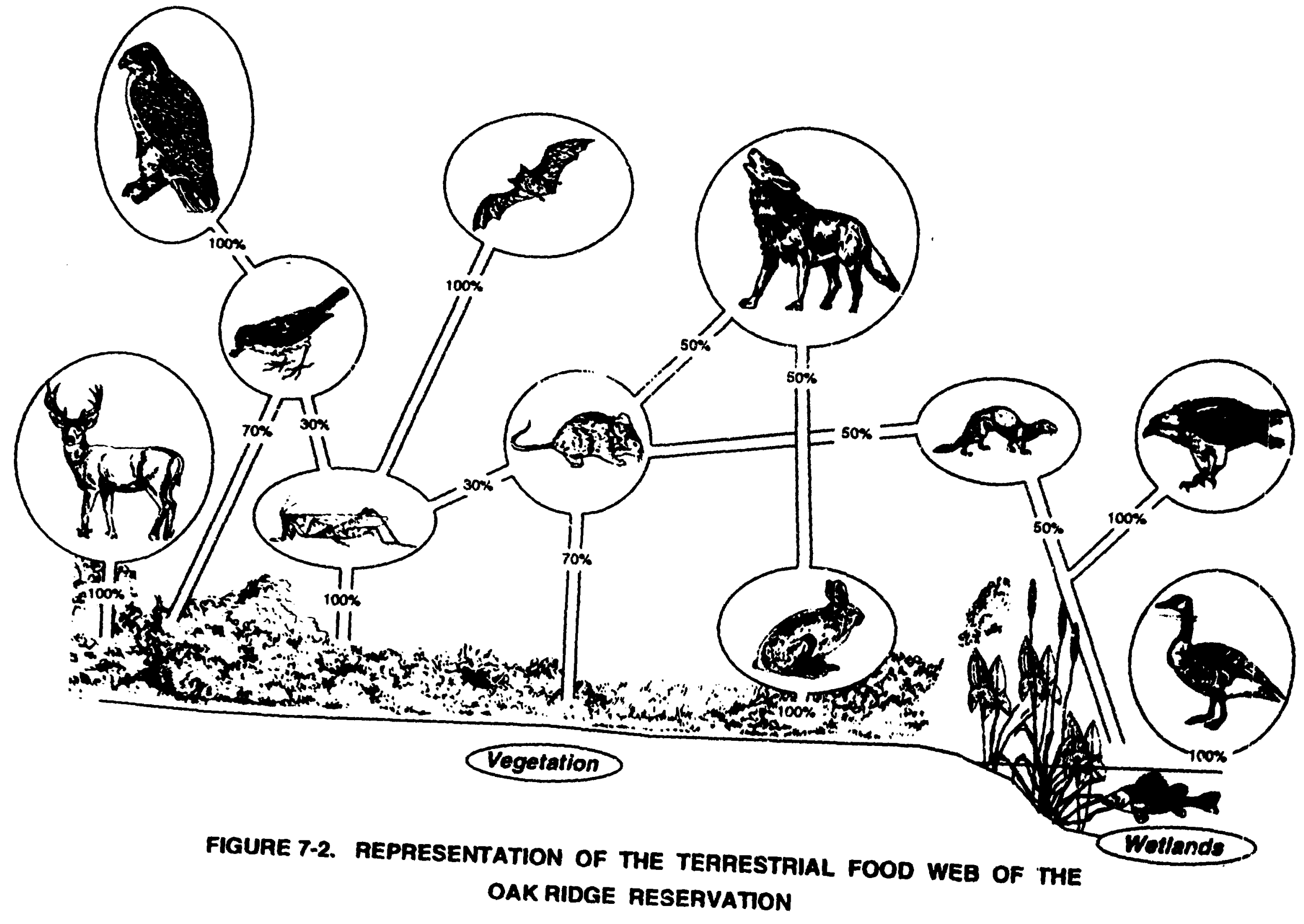


in the spring and fall and is an important source of wildlife for surrounding areas (e.g., white-tailed deer and turkey).

Within the forests of the ORR, sensitive habitats include river bluffs, found in several locations along the impounded river, and cedar barrens, fourd on shallow limestone soils, mostly in Bethel Valley (figure 7-1). Both of these habitats support federal candidate plant species, and stare-protected plant and animal species are found throughout the reservation (Cunningham et al. 1993). Abundant relatively pristire reaches of streams on the ORR are also an important component of bicdiversity and centrast with streams in the surrounding area, which are affected by agriculture and urbanization. Although chemical and radiological contaminants are present in some streams, sediment resulting from human activity, which is a great threat to biodiversityin aquatic environments, does not affect most streams on the ORR. Some of these streams are habita for sensitive species [e.g.. the state-listed red-bellied dace).

Because they are found only in certain areas of the ORR, cedar barrens and river bluffs are considered to be discontinuous, and endpoints in these areas would be at risk from contaminants cnly if located in waste sites or known areas of contamination. Because streams are abundant and found throughout the ORR, they and their associated receptors (e.g., aquatic organisms, mink) were assumed to be uniformly distributed and ubiquitous. Terrestrial receptors (e.g., mouse, rabbit, coyoce, bats other than the Indiana bat, and other species not explicitly included in the analyses) are ubiquitous.

Two nonnative plant species dominate certain areas of the ORR. Several hundred acres. primarily along roads in the valleys, have been planted in nonnative loblolly pine (Pinus taeda), which is very poor habitat for most native species of plants and animals. Many disturbed areas (e.g., roadsides and rights-of-way) have been planted in fescue (Festuca elatior), a nonnative perennial grass. for erosion control. This species is a vigorous cool season grass. which can monopolize terrestrial sites, crowding out native species. Other nonnative plant species are aggressive invaders: kudzu smothers native vegetation in a few areas where it was originally planted for erosion control, Japmese bone; suckle (Lonicera japanica) is invasive thrcughout the ORR. Japanese grass (Microstegium viminewm) often blankets the ground in moist woods and headwater wetlends, and water milfoil (Myriophyllum spp.) poses problems in reservoir waters. Only abundance of the planted species (fescue and loblolly pine) would be assumed to be related to restoration attivities. and these spocies were assumed to be most abundant in and adjacent to disturbed sites where these agressively competitive species could crowd out matives.

\subsection{Constituents of Potenmal CONCERN}

The constituents of potential and concem on the ORR include radionuclides incoganic and organic contaminants. The primary radionuclides, according to relative average concentrations, are

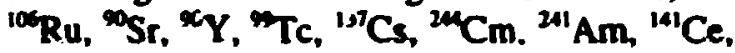

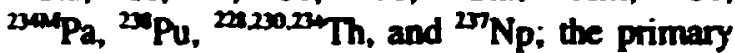
inorganics are $\mathrm{AL}, \mathrm{AS}, \mathrm{BA}, \mathrm{B}, \mathrm{Cd}, \mathrm{Cn}, \mathrm{Cu}, \mathrm{Cr}$. $\mathrm{Fe}, \mathrm{Mg}, \mathrm{Mn}, \mathrm{Ni}, \mathrm{Si}, \mathrm{Pb}, \mathrm{Hg}, \mathrm{Zn}$, and $\mathrm{V}$. The primary organic contaminants are (PCBs). flouranthene, phenanthrene, and phenol.

Maximum and average concentrations of chemical and radiological constituents in soil, surface water, and sediment were determined from the source terms provided by PNL (tables 7-3, 7-4, and 7-5.). Determination of these average and maximum concentrations required that certain assumptions be made with regard to data interpretation and compensation for data gaps. Appendix A describes the methodology used to develop the source terms for input into the exposure and risk assessment.

\subsection{Exposure ASSESSMENT}

Where available for the ORR, the maximum concentrations of each contaminant in each medium (i.e soil, water, and sediment) were used to identify the worst case potential contaminants. Contaminants that did not pose a risk to any of the receptor species from exposure to the maximum values were not considered further. If exposure " the maximum concentrations of contaminants posed a risk to organisms, then the average concentrations of those contaminants 


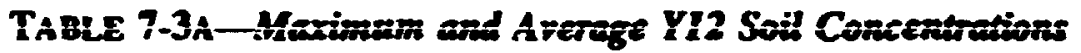

\begin{tabular}{|c|c|c|c|}
\hline Constituen & $\begin{array}{c}\text { Madinam } \\
\text { Concentiration }\end{array}$ & Constiveres & $\begin{array}{c}\text { Averag: } \\
\text { Coucenteretion }\end{array}$ \\
\hline Aroctor 1248 & 2SEE+02 & Aroclor 1248 & $5.24 E+00$ \\
\hline Benzene & $3.80 e-12$ & Methylene chloride & $1.64 F+00$ \\
\hline Trans-1.2-dichloroethylene & $2 \pi E+\infty 0$ & Phenol & $290 E+01$ \\
\hline 2.4-dimethylphenol & $240 E+\infty 0$ & Tohene & $1.60 E+\infty 0$ \\
\hline Fivorenthene & $1.40 t+02$ & Aluminum & $1.68 E+04$ \\
\hline Freon 113 & $7.74 E+\infty 0$ & Antimony & $1.35 E+01$ \\
\hline Methytene chioride & $! .64 E+00$ & Atsenic & $9.0 \% E+\infty 0$ \\
\hline Phenamabrene & $1.30 E+01$ & Barium & $1.32 \mathrm{E}+02$ \\
\hline Phenol & $290 E+01$ & Beryllium & $1.01 E+00$ \\
\hline Tetrachloroethene & $9.1 \pi+\infty 0$ & Codmium & $9.69 E+01$ \\
\hline Tetsene & $1.60 E+00$ & Chrourium & 243E+01 \\
\hline 1.1.1.-Arichloroethane & $4.27 e-02$ & Cobaln & I.68E+0I \\
\hline Xylene & $5.37 e-01$ & Copper & $2.00 E+00$ \\
\hline Aluminam & $8.62+04$ & Cyanide & $1.60=-01$ \\
\hline Antimony & $1.35+01$ & Iren & $1.65+04$ \\
\hline Arsenic & $7.30 E+01$ & Lead & 3.01E+01 \\
\hline Barium & $6.84 E+02$ & Lithium & $5.16 E+01$ \\
\hline Berllium & $2.90 E+02$ & Manpanese & $9.08 E+02$ \\
\hline Boron & $1.89 E+02$ & Mercury & $3.43 E+02$ \\
\hline Cadmium & $6.95 E+103$ & Molybdenum & $1.12 \varepsilon+\infty$ \\
\hline Cakcitm & 2.04E +05 & Nickle & $2.1 \pi E+01$ \\
\hline Chromium & $8.80 \mathrm{E}+01$ & Potassium & $3.16 E+03$ \\
\hline Cobah & $2.50 E+01$ & Selenium & $1.68 E+01$ \\
\hline Copper & $2.40 \mathrm{E}+01$ & Silver & $3.05 E+01$ \\
\hline Cyanide ion & $1.60 x-01$ & Sodium ian & $8.09 E+01$ \\
\hline Gailium & $2.13 E+01$ & Thallium & 7.55E+01 \\
\hline Hafnium & $8.15 E+00$ & Vanadium & $2.39 \varepsilon+01$ \\
\hline Iron & $6.43 E+04$ & Zinc & $4.11 E+01$ \\
\hline Lanthanum & $3.00 E+00$ & Zirconium & $4.25 E+\infty 0$ \\
\hline Lead & S.SOE+02 & Cerium-141 & $1.9 \pi \mathrm{E}+15$ \\
\hline Lichium & $3.70 E+01$ & Curium-244 & $1.530 \varepsilon+12$ \\
\hline Magnesium & $7.93 E+03$ & Scontium-90 & $9.17 e-01$ \\
\hline Manganese & $9.08 E+02$ & Yttrium-90 & $6.53 E+15$ \\
\hline Mercury & $3.73 E+02$ & & \\
\hline Molybdenum & $6.00 E+00$ & & \\
\hline Nickle & 3 OSE +02 & & \\
\hline Niobium & $2.00 E+01$ & & \\
\hline Nitrate & $2.00 E+0 \mathrm{I}$ & & \\
\hline Phosphorus & $2.18 E+03$ & & \\
\hline Potassium & $3.87 E+04$ & & \\
\hline Scandium & $1.26 E+01$ & & \\
\hline Selenium & $1.71 E+01$ & & \\
\hline Silver & $3.05 E+01$ & & \\
\hline Sodium ion & $3.84 E+02$ & & \\
\hline Thallium & $7.55 \mathrm{E}+01$ & & \\
\hline Titanium & $2.12 E+03$ & & \\
\hline
\end{tabular}




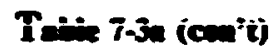

\begin{tabular}{|c|c|c|c|}
\hline Condituent & $\begin{array}{l}\text { Maribian } \\
\text { Concesination }\end{array}$ & Constuse= & $\begin{array}{c}\text { Averax } \\
\text { Comcontinetion }\end{array}$ \\
\hline Vanadium & $2.12 \varepsilon+03$ & & \\
\hline Zinc & $7.60 \varepsilon+01$ & & \\
\hline Zirconium & $5.70 E+01$ & & \\
\hline Cerium- $|4|$ & $1.97 E+15$ & & \\
\hline Cesium-137 & $3.36 E+02$ & & \\
\hline Curium-244 & $6.04 E+12$ & & \\
\hline Pocassium-40 & $1.12 E+04$ & & \\
\hline Strontium-9x & $8.21 E+12$ & & \\
\hline Thorium-232 & 2.18E+03 & & \\
\hline Uranium-23s & $2.25 E+03$ & & \\
\hline Uranium-238 & $9.09 E+04$ & & \\
\hline Yurium-90 & $6.53 E+15$ & & \\
\hline
\end{tabular}

Note: Measurements for chemical constituents given in milligrems per kilogrum. dry weight, metsourements for radionuclides given in picocuries per kilogram. dry weighte. 


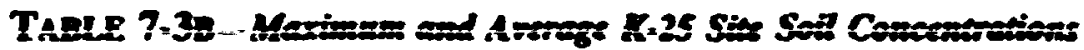

\begin{tabular}{|c|c|c|c|}
\hline Coosulitines & 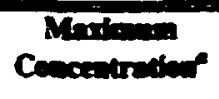 & Contivent & Avery \\
\hline Acentphylene & $2.00 E+00$ & Benzo(a)pyrene & $1.15 E+\infty 0$ \\
\hline Antracene & $6.70 E+00$ & BEHP & $1.24 \mathrm{E}+00$ \\
\hline Aroclor 1016 & $1.00 \varepsilon-01$ & Di-n-buxyl phithatace & $132 \varepsilon+00$ \\
\hline Aroclor 1232 & $1.00 E-01$ & Abminum & 1.90E+04 \\
\hline Arocior 1242 & $1.00 \varepsilon-01$ & Antimony & $4.65 E+01$ \\
\hline Arocior 1248 & $1.00 E-01$ & Arsenic & $1.03 x+01$ \\
\hline Aroclor 1254 & $6.70 E+00$ & Brium & $1.92 E+02$ \\
\hline Arocior 1260 & $280 \varepsilon-01$ & Beryllium & $6.41 E-01$ \\
\hline Benzo(a)enthracene & $250 \varepsilon+\infty$ & Boron & $2.01 E+C D$ \\
\hline Benoo(a)pyrene & $4.70 E+00$ & Caduinim & $1.75 E+\infty 0$ \\
\hline Benzo(b)floorathen & $4.20 E+00$ & Chomium & 7.94E+01 \\
\hline Benoodgh,i)perylene & $3.50 E+00$ & Cobel & $9.72 E+00$ \\
\hline Benzo(k)fluoranthene & $4.50 E+00$ & Copper & $1.07 E+02$ \\
\hline Benowic acid & $9.60 E+00$ & Inon & $4.91 E+04$ \\
\hline BEHF & $3.80 c+00$ & Lead & 3.84E+01 \\
\hline Chloride IC & $1.00 \varepsilon+03$ & Lithium & $2.04 E+01$ \\
\hline Chlorofcrm & $8.00 E+00$ & Mequasium & 2.10E+03 \\
\hline Chrysene & $2.70 E+\infty 0$ & Manganese & $5.63 E+02$ \\
\hline Dibenzoía.benthracene & $1.90 \varepsilon+00$ & Mercury & $1.20 E+\infty 0$ \\
\hline 3.3-dicinlorobenzidine & $4.00 E+\infty 0$ & Molybdentem & $2.22 E+\infty 0$ \\
\hline Diethyl phutalate & $\mid .30 \varepsilon+n)$ & Nictel & $3.13 E+01$ \\
\hline Dimethyi phathalate & $200 E+00$ & Porassium & i. $5 \mathbb{T E}+03$ \\
\hline Di-n-butyl phthalate & $5.30 E+00$ & Selenium & $0.95 E+00$ \\
\hline Di-n-actylphthalate & $2.00 E+00$ & Silver & $1.63 E+\infty$ \\
\hline 2.4-dinitrophenol & $9.60 c+\infty 0$ & Vanadium & $6.44 E+01$ \\
\hline Floornthene & $4.00 E+\infty 0$ & Zins & $1.06 \varepsilon+02$ \\
\hline Fhooride & $3.96 E+02$ & Zircosium & $9.59 E+\infty 0$ \\
\hline indeno(1.2.3-cd)pyrene & $3.50 E+00$ & Americium-241 & $1.96 E+09$ \\
\hline 2-methylnapthalese & $2.00 E+\infty 0$ & Cesium-137 & $1.54 E+10$ \\
\hline Naphbylene & $2.00 E+\infty 0$ & Plutonium-238 & $5.33 E+09$ \\
\hline 2-nitroaniline & $9.60 E+00$ & Procactinium-234M & $1.900 E+19$ \\
\hline 3-nitroaniline & $9.60 E+\infty 0$ & Strontium-90 & $1.10 \varepsilon_{+}+12$ \\
\hline A-nitroaniline & $9.60 \varepsilon+\infty 0$ & Technecium-99 & $1.20 E+05$ \\
\hline 4-nitrophenol & $9.60 E+\infty 0$ & Thorium-228 & $1.79 E+12$ \\
\hline a-nitrosodium-n-propylamine & $1.20 E+\infty 0$ & Thorium-230 & $1.46 E+07$ \\
\hline Peritachlorophenol & $9.60 \varepsilon+00$ & Thorium-234 & $1.710 \varepsilon+14$ \\
\hline Phenankhrexe & 2. $10 \varepsilon+00$ & & \\
\hline Pyrene & $4.60 E+00$ & & \\
\hline Sulphare & $5.43 E+03$ & & \\
\hline 2,4.5-erichlorophenol & $9.602+00$ & & \\
\hline Aluminum & $2.40 E+04$ & & \\
\hline Antimony & $5.002+01$ & & \\
\hline Arsenic & $1.77 E+02$ & & \\
\hline Barium & $7.202+02$ & & \\
\hline Beryllium & $1.00 E+02$ & & \\
\hline
\end{tabular}


Table 7-3b $\left(\cos ^{2} t\right)$

\begin{tabular}{|c|c|c|c|}
\hline Consethen & Compentretione & Coosituneat & $\begin{array}{c}\text { Avernige } \\
\text { Concesitration }\end{array}$ \\
\hline Boron & $8.90 E+00$ & & \\
\hline Cadmium & $290 E+01$ & & \\
\hline Cakcium & $3.10 E+05$ & & \\
\hline Chromium & $3.70 E+02$ & & \\
\hline Cobak & $5.90 E+01$ & & \\
\hline Copper & $3.00 E+03$ & & \\
\hline Iron & $1.24 E+05$ & & \\
\hline Lead & $4.20 E+02$ & & \\
\hline Lithium & $250 E+01$ & & \\
\hline Magnesium & $270 E+04$ & & \\
\hline Manganese & $2.70 E+04$ & & \\
\hline Mercury & $2.90 \mathrm{E}+01$ & & \\
\hline Molybdenem & $1.00 E+01$ & & \\
\hline Nickel & $1.90 E+03$ & & \\
\hline Niobium & $3.60 E+\infty 0$ & & \\
\hline Nitrate & $8.56 \mathrm{E}+01$ & & \\
\hline Phosphores & $3.10 E+02$ & & \\
\hline Poenssium & $5.70 E+03$ & & \\
\hline Selenium & $1.45 E+02$ & & \\
\hline Silicon & $1.10 E+03$ & & \\
\hline Silver & $6.75 E+02$ & & \\
\hline Sodium & $1.30 E+02$ & & \\
\hline Thallium & $1.00 E+\infty 0$ & & \\
\hline Titanium & $1.00 E+02$ & & \\
\hline Vanadium & $3.25 E+02$ & & \\
\hline Zinc & $1.31 E+03$ & & \\
\hline Zirconium & $1.10 \varepsilon+01$ & & \\
\hline Americium-24! & $2.29 E+09$ & & \\
\hline Cesium- 137 & $1.37 E+11$ & & \\
\hline Neptunium-237 & $1.04 E+106$ & & \\
\hline Plutonium-238 & $2.59 E+10$ & & \\
\hline Plutonium-239 & 4.86E $\div 04$ & & \\
\hline Procectinium-234M & $4.83 E+19$ & & \\
\hline Strontium-90 & $2.04 E+13$ & & \\
\hline Technecium-99 & $3.79 E+08$ & & \\
\hline Thorium-228 & $6.65 E+12$ & & \\
\hline Thorium-230 & $6.54 E+07$ & & \\
\hline Thorium-232 & $2.19 E+04$ & & \\
\hline Thorium-234 & $4.710 E+14$ & & \\
\hline Uranium-239 & $6.21 E+04$ & & \\
\hline Uranium-238 & 4.32E+05 & & \\
\hline
\end{tabular}

"Chemical constituents mesuured in millierams per kilogram; radionuclides in picocuries per kilogram. NA = No measured soil concentration available. 
TABLE 7-3C-Marimum and Average XI0 Soil Concentrutions

\begin{tabular}{|c|c|c|c|}
\hline Constibuent & Maximatem & Conthentent & $\begin{array}{c}\text { Averas: } \\
\text { Concentratione }\end{array}$ \\
\hline Aroctor 1248 & $1.31 E-01$ & Ahumiaum & NA \\
\hline Aluminnm & $5.88 E+04$ & Barium & $5.24 E+\infty 0$ \\
\hline Barium & $2.62 E+02$ & Lead & $1.64 E+\infty 0$ \\
\hline Cadmium & $1.13 E+01$ & Litnium & $2.90 E+01$ \\
\hline Calcium & 4.04E +04 & Manganese & $1.60 E+\infty 0$ \\
\hline Chromium & $2.72 \mathrm{E}+02$ & Nickel & $1.68 E+04$ \\
\hline Hafnium & $6.33 \mathrm{E}+01$ & Pocassium & 1.35E+01 \\
\hline Lithium & $5.88 E+01$ & Selenium & $9.09 E+\infty 0$ \\
\hline Magnesium & $5.21 E+03$ & Silver & $1.32 E+02$ \\
\hline Manganese & $3.41 E+02$ & Sodium ion & $1.01 E+\infty 0$ \\
\hline Mercury & $3.20 E+02$ & Ziac & $9.69 E+01$ \\
\hline Nickel & $2.83 E+02$ & Zirconium & $2.43 E+01$ \\
\hline Phosphorus & $2.23 E+\infty 2$ & Cerium-141 & $2.22 E+08$ \\
\hline Potassium & $1.72 E+04$ & Curium-244 & $2.30 E+26$ \\
\hline Soctium ion & $2.60 \varepsilon+03$ & Strontium-90 & $1.35 E+09$ \\
\hline Titanium & $3.11 E+03$ & Yrtrium-90 & $7.69 E+07$ \\
\hline Vanadium & $6.07 E+01$ & & \\
\hline Zinc & $6.00 E+01$ & & \\
\hline Zirconium & 9.15E+0! & & \\
\hline Americium-241 & $4.47 E+05$ & & \\
\hline Carbon-14 & $1.39 \mathrm{E}+05$ & & \\
\hline Cerium- $|4|$ & $3.47 E+06$ & & \\
\hline Cesium-134 & $8.36 E+04$ & & \\
\hline Cesium-137 & $3.73 \mathrm{E}+11$ & & \\
\hline Chromium-51 & $3.83 \mathrm{E}+02$ & & \\
\hline Cobalt-60 & $2.43 E+09$ & & \\
\hline Curium-244 & $4.47 E+05$ & & \\
\hline Europium-152 & $1.39 \mathrm{E}+101$ & & \\
\hline Europium-154 & $4.47 E+05$ & & \\
\hline Europium-1ss & $1.39 E+01$ & & \\
\hline IodinE-|3| & $3.79 E+03$ & & \\
\hline Neptunium-237 & $4.02 E+03$ & & \\
\hline Plutonium-238 & $4.47 \mathrm{E}+0 \mathrm{~S}$ & & \\
\hline Plutonium-239 & 4.47E+05 & & \\
\hline Radium-226 & $1.70 E+03$ & & \\
\hline Ruchenium-106 & $6.31 E+09$ & & \\
\hline
\end{tabular}


Trale ije (con't)

\begin{tabular}{|c|c|c|c|}
\hline Constibuent & 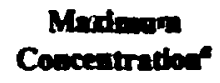 & Condtureat & $\begin{array}{c}\text { Averase } \\
\text { Coscemtirationa }\end{array}$ \\
\hline Strontium-90 & $7.76 E+C 9$ & & \\
\hline Technecium-95 & $8.45 E+03$ & & \\
\hline Technecium-99 & $2.01 E+03$ & & \\
\hline Thorium-228 & $7.90 \mathrm{E}+03$ & & \\
\hline Thorium-232 & $1.50 E+113$ & & \\
\hline Uranium-234 & $1.13 \mathrm{E}+00$ & & \\
\hline Uranium-235 & $1.77 E-01$ & & \\
\hline Uranium-238 & $1.20 \mathrm{E}+03$ & & \\
\hline
\end{tabular}

"Chemical conssiturents measured in milligrams per kilogram: radionuclides in picocuries per tilogram. NA = No measured soil concentration available. 
TABLE 7-4A-Maximun and Average Y12 Woter Concentrations

\begin{tabular}{|c|c|c|c|}
\hline Constituent & Marimom Conc- & Constituent & $\begin{array}{l}\text { Average } \\
\text { Coac: }\end{array}$ \\
\hline Arocior 1016 & $2.50 \mathrm{E}-03$ & Aroclor 1016 & $250 \mathrm{E}-03$ \\
\hline Aroclor 1232 & $2.50 E-03$ & Arocior 1242 & $2.50 E-03$ \\
\hline Aroclor 1242 & $2.50 E-03$ & Aroctor 1248 & $2.50 \mathrm{E}-03$ \\
\hline Aroclor 1248 & $2.50 E-03$ & Arocior 1254 & $2.50 \varepsilon-03$ \\
\hline Aroclor 1254 & $2.50 \mathrm{E}-03$ & Aroctor 1260 & $2.50 E-03$ \\
\hline Aroclor 1260 & $2.50 E-03$ & $\begin{array}{l}\text { Benzene bexachloride } \\
\text { (gamma) }\end{array}$ & $2.50 E-04$ \\
\hline Benzene & $1.20 E-02$ & $4.4^{\circ}-\mathrm{DDE}$ & $2.50 E-04$ \\
\hline Benzene hexachloride (gamma) & $2.50 E-04$ & $4,4^{\circ} \cdot \mathrm{DDT}$ & $2.50 \mathrm{E}-04$ \\
\hline Carton tetrachloride & $1.10 E-M 2$ & Methylene chioride & $4.10 E-03$ \\
\hline Chloroform & $2.50 E-02$ & Phenol & $3.00 E-02$ \\
\hline Chioromethane & $5.00 E-03$ & Tetrachloroethene & 4.81E-03 \\
\hline 2.4-D & $2.50 E-03$ & Toivene & $1.10 \mathrm{E}-03$ \\
\hline 4.4'-DDD & $2.50 E-04$ & Vinyl chloride & $3.16 \mathrm{E}-03$ \\
\hline 4.4'-DDE & $2.50 E-04$ & Aluminum & $2.69 \mathrm{E}-02$ \\
\hline $4.4^{\circ} \cdot \mathrm{DDT}$ & $2.50 \mathrm{E}-04$ & Arsenic & $2.10 E-93$ \\
\hline 1,1-dichloroethane & $5.00 E-02$ & Barium & $1.30 \mathrm{E}-03$ \\
\hline 1.2-dichloroethane & $1.00 E-02$ & Copper & $8.90 E-03$ \\
\hline 1,1-dichloroethene & $2.50 E-02$ & Iron & $1.36 E-03$ \\
\hline Trans-1,2-dichloroethylene & $8.31 E-01$ & Lead & $8.00 E-04$ \\
\hline Dieldrin & $2.00 \mathrm{E}-04$ & Magnesium & $1.47 \mathrm{E}+01$ \\
\hline Di-n-octylphthalate & $2.70 E-02$ & Manganese & $1.09 \mathrm{E}+00$ \\
\hline Endosulfan & $7.50 \mathrm{E}-04$ & Potassium & $4.94 \varepsilon-03$ \\
\hline Endosulfan II & $2.50 E-0.4$ & Sodium ion & $3.16 E+00$ \\
\hline Endrin & $2.50 \mathrm{E}-04$ & Zinc & $1.53 \mathrm{E}-02$ \\
\hline Endrin ketone & $2.50 \mathrm{E}-04$ & & \\
\hline Methoxychlor & 2.50E-04 & & \\
\hline Methy.ene risinmate & $6.50 E-02$ & & \\
\hline Phenol & $3.00 E-02$ & & \\
\hline $2.4 .5-\mathrm{T}$ & $5.00 \mathrm{E}-04$ & & \\
\hline 2.4.5-TP (Silvex) & $5.00 \mathrm{E}-04$ & & \\
\hline Tetrachloroethere & $1.02 E-01$ & & \\
\hline Toluene & $6.30 E-02$ & & \\
\hline Toxaphene & $5.00 E-04$ & & \\
\hline 1.1.1-trichloroethane & $6.80 \mathrm{E}-02$ & & \\
\hline 1.1.2-trichloroethane & $5.00 E-03$ & & \\
\hline Tric.: 'oroethene & 4.43E-03 & & \\
\hline Vinyl chloride & $9.20 \mathrm{E}-02$ & & \\
\hline Aluminum & $2.69 \mathrm{E}-02$ & & \\
\hline Arsenic & $2.105-C 3$ & & \\
\hline Barium & $1.30 E-03$ & & \\
\hline Calcium & $9.36 \mathrm{E}-02$ & & \\
\hline Copper & $8.90 \mathrm{e}-03$ & & \\
\hline Iron & $5.80 \mathrm{E}-03$ & & \\
\hline Lead & $8.00 E-04$ & & \\
\hline Magnesium & $1.47 E_{4}+01$ & & \\
\hline
\end{tabular}


Table 7-4e (con't)

\begin{tabular}{|c|c|c|c|}
\hline Constituent & Mardmem Conce" & Condituent & $\begin{array}{l}\text { Average } \\
\text { Cosec: }\end{array}$ \\
\hline Manganese & $1.09 E+00$ & & \\
\hline Niobium & $9.50 E-03$ & & \\
\hline Nitrate & $1.00 E+\infty 0$ & & \\
\hline Potassium & $2.00 E+\infty 0$ & & \\
\hline Sodium ion & $3.16 E+\infty 0$ & & \\
\hline Zinc & $1.53 \mathrm{E}-02$ & & \\
\hline Americium-241 & $8.80 E-02$ & & \\
\hline Nepeunium-237 & $6.41 E-01$ & & \\
\hline Radium-226 & $5.68 \mathrm{E}-01$ & & \\
\hline Thorium-230 & $3.90 E-01$ & & \\
\hline Uranium-2.34 & $1.11 \mathrm{E}+02$ & & \\
\hline Uranium-235 & $1.65 E+01$ & & \\
\hline Uranium-232' & $2.35 E+02$ & & \\
\hline
\end{tabular}

"Chemical constituents measured in milligrams per kilogram: radionuclides in picocuries per kilogram. NA $=$ No measured concentration available. 
TABLE 7-4B-Maximum and Average X10 Water Concenduations

Measurements in miiligrams per iiter (for chemicai constiments) or picocuries per iiter (for radionuclides)

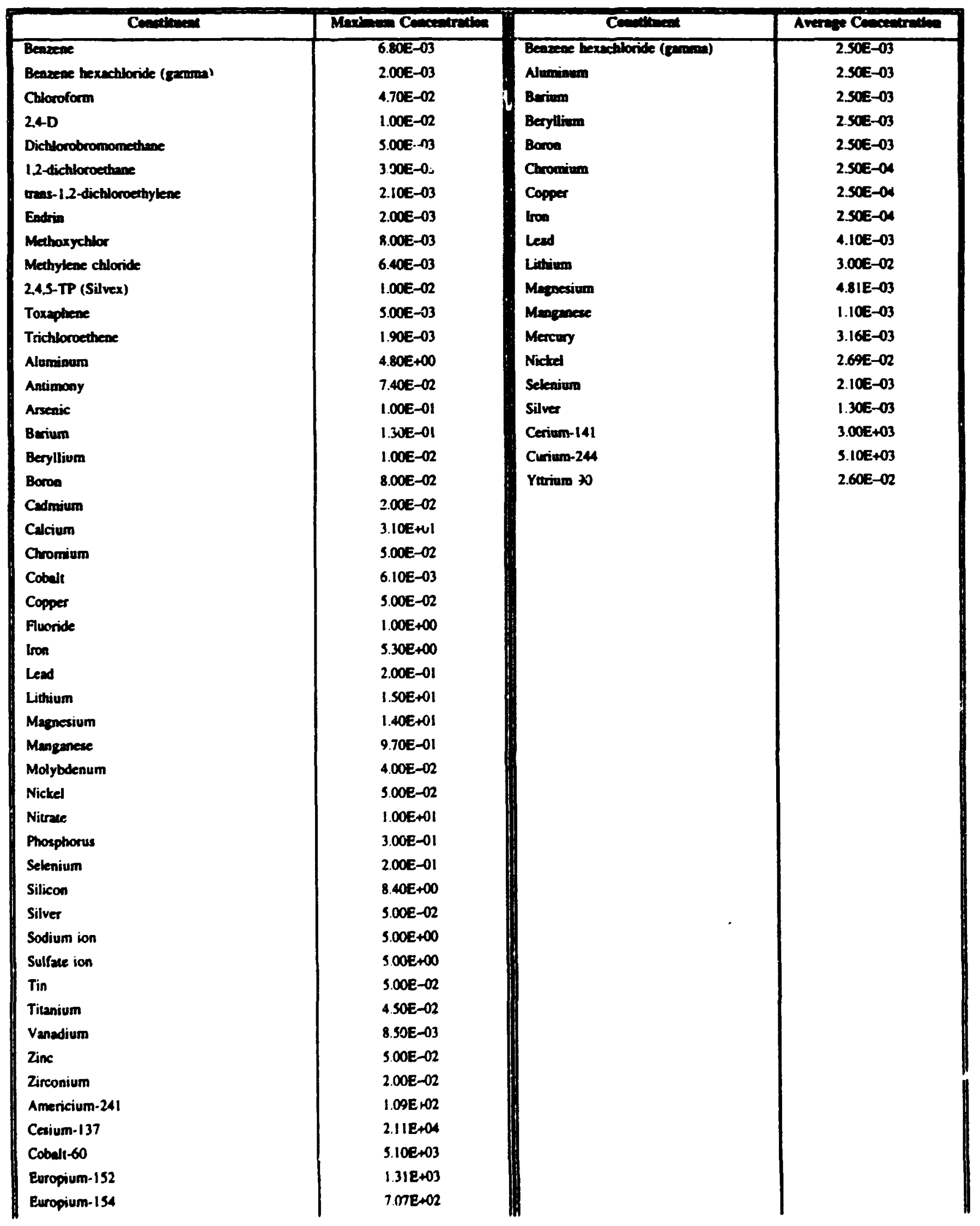


Talle 7-4b'con't)

\begin{tabular}{|c|c|c|c|}
\hline Complasen & Mnidon Concentretion & Conolinent & Alurep Conserindion \\
\hline Enropien-155 & $2.692+02$ & & \\
\hline Prenowivar-258 & $1.85 E+\infty$ & & \\
\hline Phtucium-240 & $2.92 E+02$ & & \\
\hline Stroution-90 & $1.00 E+03$ & & \\
\hline
\end{tabular}

NA $=$ No measened water concenoration availuble. 


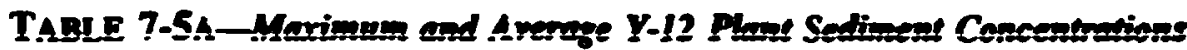
Measurements in milligrams per kilogram (for chemicals) or pCi/kg (for radionuclides)

\begin{tabular}{|c|c|c|c|}
\hline Continest & Mroing Concentrotian & Conotisat & 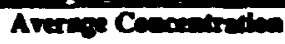 \\
\hline Aceseppticne & $7.90 E-02$ & Aroctor 1254 & $8.52 E-02$ \\
\hline Aceaspthylease & $1.60 E-01$ & Arocker 1260 & $220 E-02$ \\
\hline Altrin & $1.10 E-03$ & Beaso(a) durcene & $4.145-01$ \\
\hline Anthrecene & $8.505-01$ & Beanese bexnchloride (orame) & $4.67 \varepsilon-04$ \\
\hline Aroctar 1254 & $+20 \varepsilon-01$ & BEHP & $1.7 I E-0 I$ \\
\hline Anocior 1260 & $2.70 E-01$ & 4.4.-DDE & $3.75 E-04$ \\
\hline Benor(a)materese & $3.90 E+\infty 0$ & 4.4'-DDT & $9.74 E-04$ \\
\hline Benaene & 1.55E-02 & Methylene ctionide & $1.66 \bar{E}-02$ \\
\hline Benzene bexachloride (alphe) & $2.00 E-04$ & Fhead & NA \\
\hline Bensene bexectloride (ben) & $1.60 E-03$ & Tetrectionothene & $8.81 E-03$ \\
\hline Beasease hexechloride (Fanm) & $1.00 \mathrm{E}-03$ & Tolvewe & $1.04 E-03$ \\
\hline Bensene bexachloride (delon) & $2.70 E-03$ & Viayl chloride & $4.62 E-04$ \\
\hline 3.4benzfluornathese & $5.00 E-04$ & Alasuivan & $8.10 E+03$ \\
\hline Benzo(a)gyreace & $350 E+00$ & Anciunony & $7.39 E+01$ \\
\hline Benzo(ghi)perylene & $5.00 E-0.04$ & Arsacis & $1.66 E+01$ \\
\hline Benzo(k) Aluoranthene & $4.60 E-01$ & Britam & $1.20 E+02$ \\
\hline Benzoic acid & $1.80 E-01$ & Berylliom & I.78E++01 \\
\hline BERP & $1.20 E+\infty 0$ & Baroa & $3.16 E+03$ \\
\hline Buryl benzyl phathatae & $230 E-01$ & Codmium & $5.32 E+\infty 0$ \\
\hline Catezol & $7.80 E-02$ & Chromiun & 4.95E+01 \\
\hline Chioriane (alpta) & $4.60 E-03$ & Coban & $1.76 E+01$ \\
\hline Chlordase (Eamma) & $7.80 E-03$ & Copper & $2.45 E+01$ \\
\hline Chlorobenzene & $1.55 E-02$ & Iroa & $3.79 E+04$ \\
\hline Chloroethane & $5.00 E-03$ & Lead & $6.56 E+01$ \\
\hline Chloride IC & $2.00 E+00$ & Lithium & NA \\
\hline Chloroform & $2.10 E-02$ & Magnesium & $5.10 E+03$ \\
\hline Chloromethone & $2.90 \varepsilon-02$ & Mangenese & $1.24 E+03$ \\
\hline Chrysene & $3.70 E+\infty 0$ & Mercury & 1.31E+01 \\
\hline $4.4^{\circ} \cdot \mathrm{DDD}$ & $4.80 E-03$ & Molybdenum & $1.69 E+01$ \\
\hline $4.4^{\circ} \cdot \mathrm{DDE}$ & $6.00 E-03$ & Nicked & $3.26 E+01$ \\
\hline 4.4'-DDT & $4.702-03$ & Potrassiom & $6.80 \varepsilon+02$ \\
\hline Dibenzo(2h)andhracene & $5.802-01$ & Selenium & $1.26 \varepsilon+02$ \\
\hline 1.1-dichloroethune & $1.60 E-02$ & Silver & 1.65E+01 \\
\hline 1.2-dichloroethane & $9.002-03$ & Sodium ion & $3.19 E+03$ \\
\hline 1.1-dichloroethene & $120 E-02$ & Thallium & $1.59 E+03$ \\
\hline Trans-1,2-dichloroethylene & $4.20 \varepsilon-01$ & Vanedium & $3.30 \varepsilon+01$ \\
\hline Dieldrin & $1.20 \varepsilon-03$ & Zinc & $9.62 E+01$ \\
\hline Diethyl phchalase & $6.002-02$ & Zirconium & $6.40 E+00$ \\
\hline Di-n-butyl phahalate & $9.702-01$ & Curium-244 & $3.03 \mathrm{E}+01$ \\
\hline Di-n-octylphehalue & $2.502-01$ & Strontium-90 & $4.77 E+100$ \\
\hline Endosulfan & $1.002-03$ & & \\
\hline Endosultan II & $1.30 E-03$ & & \\
\hline Fluoranthene & $7.108+00$ & & \\
\hline Flworene & 1.40E-n' & & \\
\hline Fleorotrichloromethane & $2.108-0$ & & \\
\hline Heptectlor & $3.00 E-04$ & & \\
\hline Hepexhior epoxide & $8.002-05$ & & \\
\hline indeno(1.2.3-cd)pyrene & $2.208+\infty 0$ & & \\
\hline Methylene chloride & $1.308-01$ & & \\
\hline
\end{tabular}




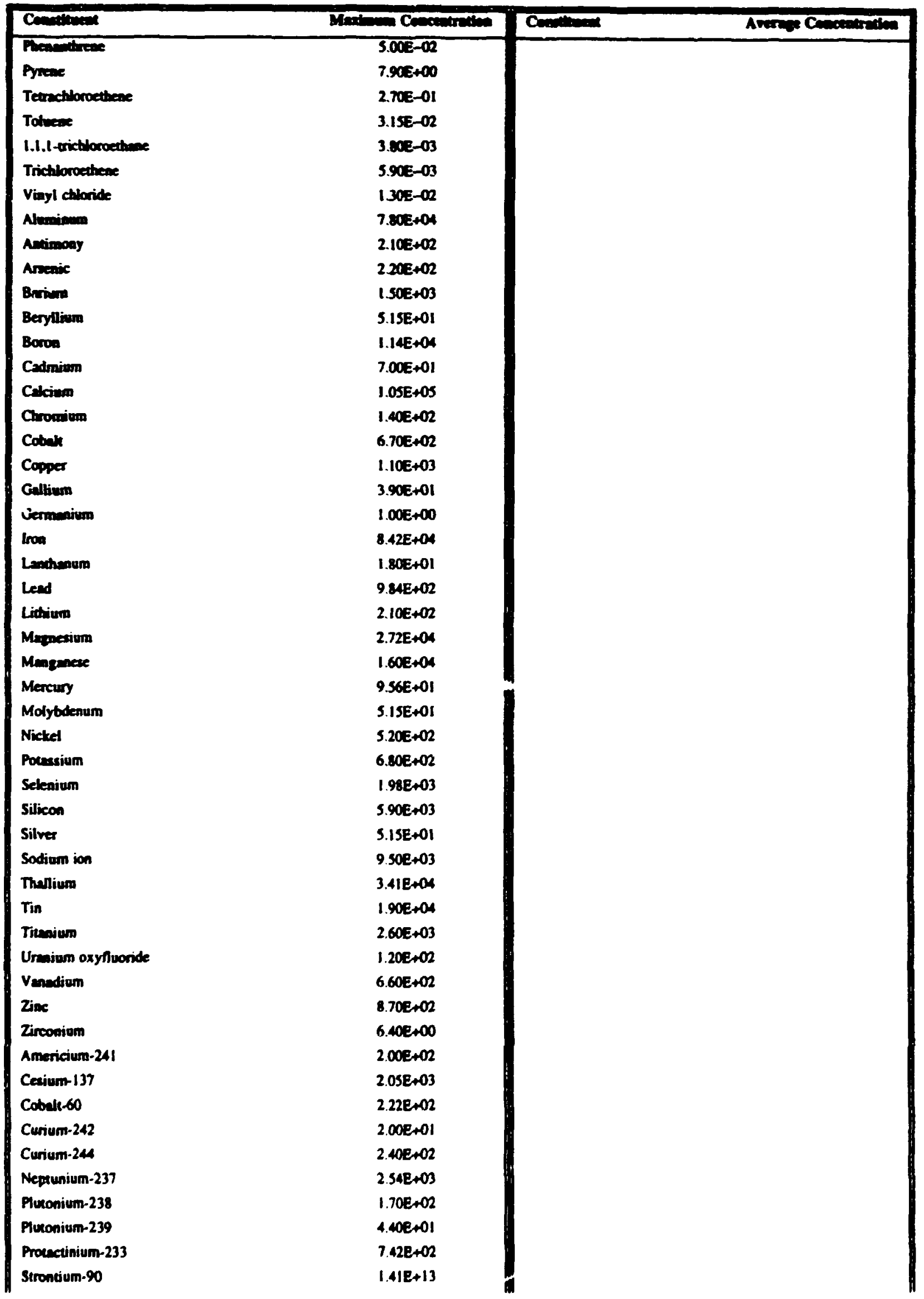




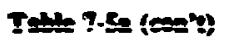

\begin{tabular}{|c|c|c|}
\hline Cenopitusen & Minton Cencentiration & Avares Conosination \\
\hline Thonivan-228 & I.1TE+03 & \\
\hline Thorium-230 & $1.21 E+03$ & \\
\hline Thorivor-232 & I.4SE+03 & \\
\hline Uranium-234 & $3.85 E+04$ & \\
\hline Uranivm-235 & $3.565+03$ & \\
\hline Uraivin-238 & I.05E+05 & \\
\hline
\end{tabular}

NA = No measoued sedimeon concentratica aveilable 


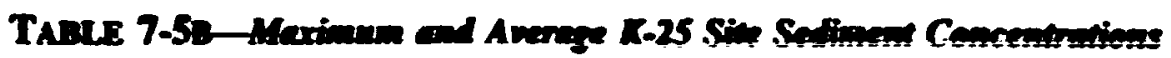
Measurements in milligrams per kilogram (for chernicals) of PCikg (for rationuclides)

\begin{tabular}{|c|c|c|c|}
\hline 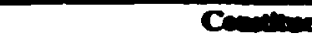 & 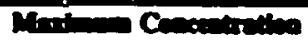 & Cons: & Andere \\
\hline Acoupe & $1.000-03$ & BEHP & $3202+00$ \\
\hline Arodor 1254 & $1.00=+\infty 0$ & Alarinas & $363 E+04$ \\
\hline Arocior 1260 & $1.00 \sum+\infty 0$ & Anseric & $1.398+01$ \\
\hline BEAP & $3.50 E+\infty 0$ & Brian & $3.232+01$ \\
\hline Bromoforsa & $1.00 E-03$ & Bensivien & $120 E+\infty$ \\
\hline Crtoo verelboride & $300 \mathrm{E}-03$ & Bance & $800 E+01$ \\
\hline Chlondendere & $1.05 E-03$ & Caniman & $4.46 E-01$ \\
\hline 1,1-ischlarietiene & $100 \varepsilon-03$ & Aromine & $1.31 E+03$ \\
\hline 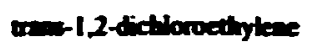 & $300 E-03$ & Coth & $250 E+01$ \\
\hline 1,2-1ichiberipropene & $1.00 E-03$ & Copper & $1.2 \pi \mathrm{E}+02$ \\
\hline cir-13-didloxopopere & $1.00 E-03$ & thon & 4.94E+04 \\
\hline unes-1.3-dichlosopropeace & $1.00 E-03$ & Lead & $2385+01$ \\
\hline Eisfl bencese & $1.00 E-03$ & Lintiven & $2.90 E+01$ \\
\hline Froordatere & $160 \sum+\infty 0$ & Mngaxim & S.0TE+03 \\
\hline Freon 113 & $1.00 E-03$ & Maranex & $8.12 E+02$ \\
\hline Fineon 114 & $1.00 E-03$ & Mexemy & $7.74 E-01$ \\
\hline Freon 123 & $1.00=-03$ & Mabyldeanan & $1.002+01$ \\
\hline Methyl chloroform & $2.50 E-02$ & Nicted & $4.50 E+02$ \\
\hline Methyl ethyl ketome & $1.00 E-03$ & Pociscien & $4.75 E+03$ \\
\hline Preanchese & $1.10 E+\infty 00$ & Selexien & $6.00 E+01$ \\
\hline Phocephese & $8.40 E+02$ & Silver & $1.25 E+00$ \\
\hline Pyrexe & $1.40 E+00$ & Veandion & $4.40 \varepsilon+01$ \\
\hline $1.1,2.2$ eterachilaroediaxe & $1.00 E-03$ & Zine & $4.32 E+02$ \\
\hline Tolneave & $1.00 E-03$ & Cesium-137 & $6.63 E+03$ \\
\hline Toxpoptexe & $3.005-03$ & Plutonimin-238 & $2.16 E+03$ \\
\hline 1,1,2-trictloroethase & $1.00 E-03$ & Stromien-90 & $7.50 \mathrm{E}+12$ \\
\hline Trichloroedhene & $6.90 E-02$ & Technecing-99 & $2.38 \mathrm{E}+06$ \\
\hline Trictsorofluoromethane & $1.00 E-03$ & Thoriem-234 & NA \\
\hline Alemisoun & $3.63 E+04$ & & \\
\hline Arreaic & $2.505+02$ & & \\
\hline Beriug & $6.30 \varepsilon+02$ & & \\
\hline Berylliun & $3.10 E+40$ & & \\
\hline Doros & 1.902402 & & \\
\hline Codriven & $5605+00$ & & \\
\hline Calcium & $2.28 E+04$ & & \\
\hline Crromium & $3.308+03$ & & \\
\hline Cobals & $6.10 e+01$ & & \\
\hline Copper & $1.70 E+03$ & & \\
\hline 1200 & 4.94E+04 & & \\
\hline Lead & $2.202+02$ & & \\
\hline Liduium & $5.302+01$ & & \\
\hline Mropeciom & $1.602+05$ & & \\
\hline Menpasece & $5,408+03$ & & \\
\hline Mercury & $9.508+00$ & & \\
\hline
\end{tabular}


Tante $7.50\left(\cos ^{2} 1\right)$

\begin{tabular}{|c|c|c|c|}
\hline Complowent & 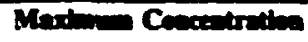 & 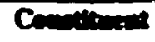 & 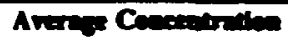 \\
\hline Motyodeand & 4.90E+01 & & \\
\hline Nicted & $9.70 E+03$ & & \\
\hline Niobiom & $7.00 E-01$ & & \\
\hline Phoepporos & $2.10 E+0 \mathrm{~J}$ & & \\
\hline Potaxion & $1.10 E+0$. & & \\
\hline Seteriving & $2.00 E+02$ & & \\
\hline silver & 8.90E +01 & & \\
\hline Sodivem & $3.10 E+0]$ & & \\
\hline Tomingen & $4.60 E+02$ & & \\
\hline Venadion & $1.60 \mathrm{E}+01$ & & \\
\hline $\operatorname{zin}$ & $1.30 E+03$ & & \\
\hline Cescium-137 & $9.01 E+03$ & & \\
\hline Cobuh -60 & 2.1JE+02 & & \\
\hline Neppenieun-237 & $7.66 E+013$ & & \\
\hline Plictonicum-238 & 8.56E+03 & & \\
\hline Seroutium-90 & $2.58 E+13$ & & \\
\hline Technocium-99 & $6.76 E+06$ & & \\
\hline Thorium-232 & 6.34E+03 & & \\
\hline Urmimm-235 & 8.5AE+04 & & \\
\hline Urmium-238 & 4.74E.OS & & \\
\hline
\end{tabular}

NA $=$ No messured sediment concentration available. 


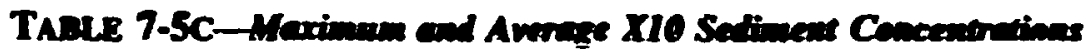
Measurements in milligrams per kilogram (for chemicals) or pCilsg (for radionuclides)

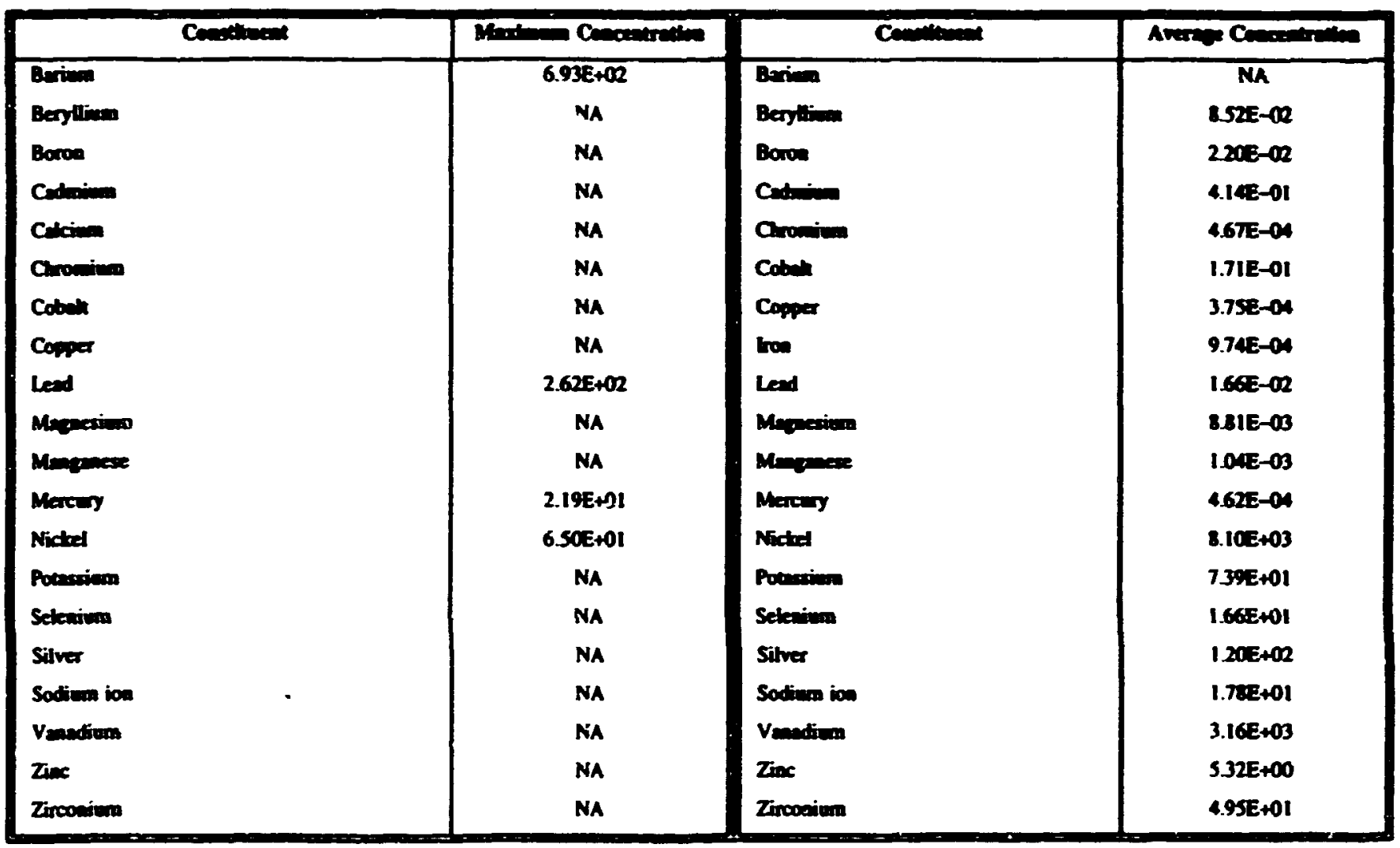

NA $=$ No measured sediment concentraion available. 
were uod in the accossment to estimate the rost probable and reasonable exposure and risk.

Contaminant exposure of species on the reservation depends on the amount of time spent in waste areas and the amount of contaminants ingested. Only species with small home range such as small mammals and birds would reside within contaminated areas for most of their lives, and very few individuals would contact ireas of maximum concentrations (see Appendix B for discussion of home ranges).

The risk assessment estimates the risk to vegetation, terrestrial wildife, and aquatic organisms from chronic exposure to radiological and nonradiological contaminants. In the exposure analyses, the ecological endpoints and their corresponding species were considered. However, because the availability of sensitivity data for many species (e.g., threatened and endangered species) is limited and because those are similarities in exposure risk (e.g., similarly sized raptors feeding on the same prey), representative organisms for each endpoint were chosen for evaluation. A food web was developed which included receptor species representing the endpoints (figure 7-2). In all cases where data were available, conservative estimaies of exposure and risk were made by selecting receptors most sensitive to contaminants or habitat alteration, most likely to experience additional risk due to bioaccumulation or larger body size. or at greatest risk due to rarity. Other abundant species on the reservation were included as important prey components of the food web, such as mice and insects (risk estimates were not determined for insects).

The primary exposure routes for terrestrial wildlife species are exposure to external radiation, ingestion of food (including soils for some species), and water. Table 7.6 lists the body weights and consumption rates for the representative species on the ORR. The Canada goose feeds exclusively on the vegetative parts of plants. The cottontail rabbit and white-tailed deer were assumed to eat $50 \%$ vegetation and $50 \%$ fruits and seeds. On the basis of on a review of the literature, the percentage of prey items consumed by omnivores and predators was estimated (table 7-6; Figure 7-2). The mouse and robin were assumed to eat $70 \%$ fnuit and seeds

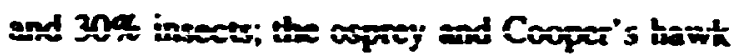
to feed exclusively on fish and songbirds (robin). respectively; the mink to eat 50\% fish and 50\% mice; and the coyote to ea $50 \%$ mice and $50 \%$ rabbits. The bat was assumed to eat 100\% insects, and the insects were assumed to eat $100 \%$ vegetative plant parts.

All species were assumed to purposely or incidentally ingest soil while eating, grooming. or preening except for the bat, mink, coyole, and the rapeors for which soil ingestion was assumed to be negligible (table 7-6). The soil ingestion rate (Q) for cottontnil rabbits was assumed to be the same as that reported for the jackrabbit. 6.3\% of the dry matter intake (Arthur and Gates 1988). The white-tailed deer soil ingestion rate was assumed to be the same as that reported for the mule deer, 1.35\% of the dry matter intake (Arthur and Alldredge 1979). The soil ingestion rate for the mouse was assumed to be 2\% of the dry matter intake (Beyer et. al., 1991). The soil ingestion rate of the Canada gocse was assumed to be the same as that for the mallard. 8.2\% (OHEA 1991). Since published values of soil ingestion rates were not found for the robin, it was conservatively estimated to be $10 \%$ of the dry matter intake.

The estimated daily rates of food and water consumption ( $Q_{.}, Q_{i}$ or $Q_{H}$, and $Q_{\text {.. }}$ respectively) for each representative species were calculated from allometric regression equations that were based on the weight of the organism (EPA 1988) (appendix A). These equations are based on the combined measurements for laboratory animals, livestock, and selected wildlife and bird species.

Because information on the specific habits and behaviors of most of the representative wildlife species is not well known, it is assumed that all species spend $100 \%$ of their time on the reservation or within the vicinity of contaminated areas. Therefore, the fraction of contaminated vegetation, fruit, prey, soil, and water consumed $\left(\mathrm{FI}_{v}, \mathrm{FI}_{\mathrm{r}}, \mathrm{FI}_{\mathrm{H}}, \mathrm{FI}_{\mathrm{r}}\right.$ and $\mathrm{FI}$, respectively) is set at 100\% (table 7-6).

Contaminant concentrations in vegetation, the first level in the food chain, are estimated from source tem concentrations in the soils using published soil-10-plant element- or chemical- 
specific transfer factors (Baes et al. 1984; Travis and Arms i 980 ) (ivioie $7-7$ ). Transier factors for inorganic chemicals are available for both the vegetative and fruiting parts of plants (Baes et 2 !. 1984); however, the transfer factors for organic chemicals do not make this distinction (Travis and Arms 1988). The methodology used to predict contaminant concentrations in vegetation does nor make a distinction between different plant types or species. Therefore. all species ingest "generic" vegetation containing contaminant concentrations derived from soil concentrations by the use of transfer factors (appendix A).

Transfer factors for contaminants of concem were applied to predict concentrations in the tissues of terrestrial mammalian receptors from consumption of vegetation, soil, and water (collectively termed $B_{b}$ ) (Baes et al. 1984; Travis and Arms 1988) (table 7-7). Data on transfer fxtors from vegetation or soil to insects and earthworms are very limited in the literature. Therefore, the concentration in insects was derivel from vegetation concentrations, and a default, conservative one-to-one transfer between vegetation and insects was assumed. Fish bioconcentration factors (BCF) were applied to estimate the concentrations of contaminants in fish tissue for consumption by the osprey and mink (Droppo et al., 1989) (table 7-7). The rationale and limitations for applying these transfer factors are discussed in Appendix A.

The consumption rates and the benchmark iimit or no-observable-adverse-effect level (NOAEL) values are typically reported in wet weights, whereas the vegetation and soil concentrations are typically reponted in dry weights. Therefore, conversion factors were applied to account for this difference. The wet- to dry-weight concentration conversion factor for the vegetative parts of plants on the ORR was assumed to be 0.32 [the average for meadow fescue. Kentucky bluegrass, wild bromegrass, and orchand grass (Morrison 1959)]. The wet- to dry-weight concentration conversion factor for the fruiting parts of plants on the ORR was assumed to be 0.17 (Morrison 1959). The wet- to dry-weight concentration conversion factor for soils was assumed to be 0.90 (Clark and Maisel 1977).
For tive baseline assessment of the ORR, the concentations of radionuciides in animal tussues and the issulting doses were not decay-corrected. The doser are estimated for the current situation and not at some point in the future. The primery radionuclides of concern (except for ${ }^{\circ} \mathrm{Y}$ ) have sufficiently long half-lives, so this assumption was reasonable. PNL decay-corrected the radionuclide concentrations in the source terms to the time of disposal or release. To estimate dose to terrestrial receptors, all short-lived daughter products were included.

Aquatic organisms considered in the assessment included benthic macroinvertebrates and generic aquatic bicta. For radiological analyses, emergent vegetation (i.e., catails) and muskrats were included as well. All aquatic organisms, except for benthic macroinvertebrates, were assumed to be exposed to contaminants in surface water. Benthic macroinvertebrates were assumed to be exposed only to contarninants in the sediment pore water for calculation of internal radiation dose and exposure to chemicals. The external radiation dose from exposure to surface water was calculared for all organisms.

\subsection{Contammant Emects Assessment}

Two pathways were used to determine the effects of contaminant expousure on ecological endpoint receptors. For terrestrial receptors, consumption rates of contarninated food and water were compared with toxicological benchmark. For aquatic receptorscontaminanat concentrations in water and sediment pore water were compared with chemical-specific aquatic benchmarks.

To quantify risk to terrestrial receptors exposed to organic and inorganic contaminants, the daily consumption rate of contaminated food and water, normalized to body weight (in units of $\mathrm{mg} / \mathrm{kg} / \mathrm{d}$ ), was compared with the NOAEL benchmark (mg/kg/d). Ratios greater than I were considered to pose a potential risk to organisms but do not necessarily indicate the severity of the effect(s). However, it is reasonable to assume that the higher the ratio, the \& reater the risk of adverse effects. Dose to terrestrial receptors. including vegetation, from intemal and 
TABLE 7-6-Body Weights and Consumption Rabes' for Oak Ridge Terroserial Species"

\begin{tabular}{|c|c|c|c|c|c|c|c|c|c|c|}
\hline Parameter & $\begin{array}{l}\text { While-footed } \\
\text { Mome }\end{array}$ & $\begin{array}{l}\text { Enstern } \\
\text { Coctontall } \\
\text { Rablut }\end{array}$ & $\begin{array}{l}\text { Whlle- } \\
\text { colled } \\
\text { Deer }\end{array}$ & $\begin{array}{l}\text { Indlana } \\
\text { Bet }\end{array}$ & Robia & $\begin{array}{l}\text { Canadh } \\
\text { Goane }\end{array}$ & $\begin{array}{l}\text { Cooper's } \\
\text { Hawk }\end{array}$ & Orprey & Mlak & Coyote \\
\hline Sody weidta 8W (ke) & $2+0 E-02$ & $196+00^{2}$ & $5.63 E+01$ & $7.30 \mathrm{E}-03^{2}$ & $7.50 E-02$ & $2.76 E+\infty 0^{\circ}$ & $4.398 \mathrm{E}-01$ & $1.498+00^{5}$ & T.13E+Co" & $1.602 \times 51 \%$ \\
\hline Wear inate me. Q. (LA) & $6.40 E-03$ & $1.14 E-01$ & $2.63 \mathrm{E}+00$ & $2.305-03$ & $1.43 \mathrm{~B}-02$ & $2.80 \mathrm{~B}-01$ & $5.758-02$ & $1.758-01$ & $1.23 \mathrm{E}-01$ & $9.768-01$ \\
\hline Wuer insection frection Fl & $1.00 E+\infty$ & $1.00 E+00$ & $1.00 \mathrm{E}+00$ & $1.00 E+\infty 0$ & $1.008+\infty$ & $1.008+\infty$ & $1.008+\infty$ & $1.002+00$ & $1.002+00$ & $1.002+\infty$ \\
\hline Soil inatere rme. Q (ked) & $4.38 E-0{ }^{\prime \prime}$ & $1,20 E-03^{14}$ & $5.83 E-0.3 "$ & 0.00 & $3.87 \mathrm{e}-04^{m}$ & $C .29 \mathrm{E}-0.3^{\prime \prime}$ & 0.00 & 0.00 & 0.00 & 0.00 \\
\hline Soil ingession frection $F$ & $100 E+\infty 0$ & $1.00 E+00$ & $100 E+\infty 0$ & $1.00 E+00$ & $1.002+\infty 0$ & $1.000+\infty$ & 0.00 & 0.00 & 0.00 & 0.00 \\
\hline 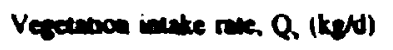 & 0.00 & $37 \mathrm{JE}-02^{10}$ & $7.93 \mathrm{~B}-01^{10}$ & 0.00 & 0.00 & $1.77 \mathrm{E}-01$ & 0.00 & 0.00 & $0 . \infty 0$ & 0.00 \\
\hline 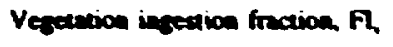 & 0.00 & $100 E+\infty 0$ & $1.008+00$ & 0.00 & 0.00 & $1.002+\infty 0$ & 0.00 & 000 & 0.00 & 0.00 \\
\hline 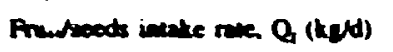 & $36 E-03^{\circ}$ & $3.73 \mathrm{E}-02$ & $7.93 \mathrm{E}-01$ & 0.00 & $5.80 \mathrm{E}-03^{\prime \prime}$ & 0.00 & 0.00 & 0.00 & 0.00 & 0.00 \\
\hline Froinseceds insustion frection, Fl, & $1.00 E+\infty 0$ & $1.00 E+\infty$ & $1008+\infty$ & 0.00 & $1.00 \mathrm{E}+\infty$ & 0.00 & 0.00 & 0.00 & 0.00 & 0.00 \\
\hline Prey I watke nuce $Q_{m}$ (kefd) & $\begin{array}{l}\text { 1. } 40 E-03 \\
\text { (insocts) }\end{array}$ & 0.00 & 0.00 & $\begin{array}{l}\text { 1. } .30 E-03 \\
\text { (insects) }\end{array}$ & $\begin{array}{l}2.50 \mathrm{e}-03 \\
\text { (insects) }\end{array}$ & 0.00 & $\begin{array}{c}3.398-02 \\
\text { (madowlates) }\end{array}$ & $\begin{array}{l}\text { |.0se-01 } \\
\text { (fish) }\end{array}$ & $\begin{array}{l}3.63 \mathrm{E}-01^{37} \\
\text { (mice) }\end{array}$ & $\begin{array}{l}\text { 2.92E-01" } \\
\text { (RAd) }\end{array}$ \\
\hline Prey I inession frection Fl w $_{1}$ & $1.00 E+\infty 0$ & 0.00 & $0 \infty 0$ & $1.00 E+00$ & $1.00 \mathrm{E}+\infty 0$ & 0.00 & $1.008+00$ & $1.002+00$ & $1.006+\infty$ & $100 E+\infty 0$ \\
\hline Prsy 2 inathe race, $Q_{w}$ (ked) & $0 . \infty$ & 0.00 & 0.00 & 0.00 & 0.00 & 0.00 & 0.00 & 0.00 & $3.63 \mathrm{E}-01$ & $2.92 \mathrm{E}-01$ \\
\hline Prey 2 inerestion frection. $F_{\text {w }}$ & 0.00 & 0.00 & 0.00 & 0.00 & 0.00 & 0.00 & 0.00 & 0.00 & $1.002+100$ & $1.002+\infty 0$ \\
\hline Poy 3 instie race, $Q_{\text {ul }}$ (hed) & 0.00 & 0.00 & 0.00 & 0.00 & 0.00 & 0.00 & 0.00 & 0.00 & 0.00 & 0.00 \\
\hline 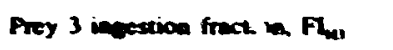 & 0.00 & 0.00 & 0.00 & 000 & 0.00 & 0.00 & $c .00$ & 0.00 & 0.00 & 0.00 \\
\hline
\end{tabular}

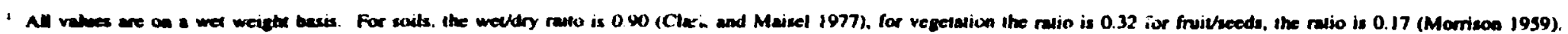

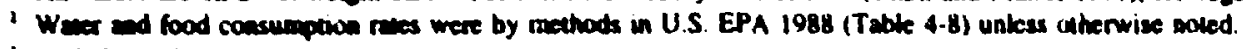

1 Lactely a al. 1903.

- Ompone a al. 19:0

S Sinit 1991.

- Tromean 1982

- Terves 1990

- Ternes 1900

- Teries 1900

Terns 1990.

"Whinter 19.

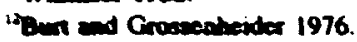

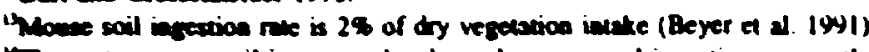

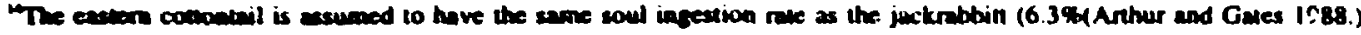

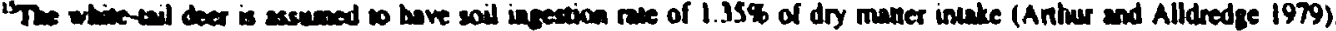

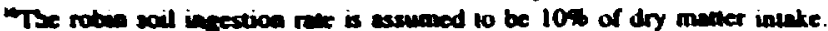

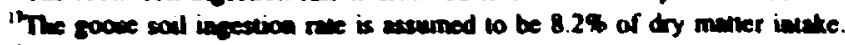

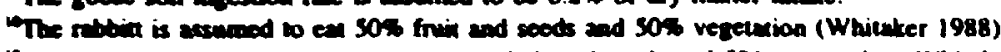

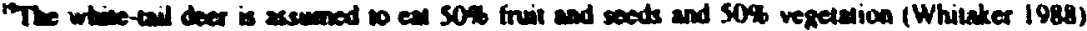

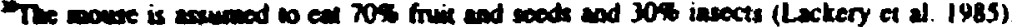

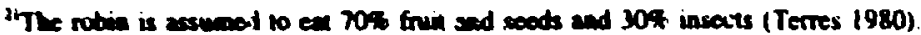

"The mint is asumed to en 300 mice and 500 fieh (Whitater 1988).

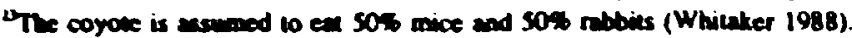




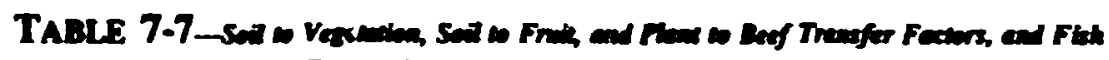

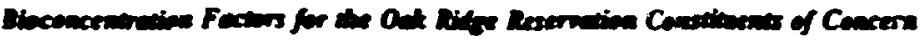

\begin{tabular}{|c|c|c|c|c|}
\hline Constibent & 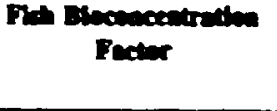 & 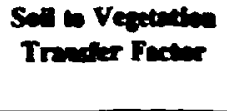 & $\begin{array}{l}\text { Sel to Tru' } \\
\text { Trumer } \\
\text { Pecter }\end{array}$ & 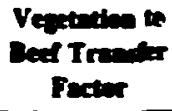 \\
\hline Acenopthene & $6.46 E+02$ & $2.16 E-01$ & $2.16 E-01$ & $2.00 E-04$ \\
\hline Acenoptaylene & 3.01E+02 & $2.16 E-01$ & $2.16 E-01$ & $2.00 E-04$ \\
\hline Aldria & $3.14 E+03$ & $7.14 E-01$ & $7.14 E-01$ & 2.SIE-OS \\
\hline Anthracence & $1.42 E+03$ & $9.7 I E-02$ & $9.71 E-02$ & $7.94 E-04$ \\
\hline Aroctor 1016 & $1.70 E+04$ & $2.24 E-02$ & 2.24E-02 & $1.00 E-02$ \\
\hline Arocior 1232 & I.6DE+02 & 2.24E-02 & $2.24 E-02$ & $1.00 E-02$ \\
\hline Arocior 1242 & $7.84 E+02$ & $2.24 E-02$ & $2.24 E-02$ & $1.00 E-02$ \\
\hline Arocior 1248 & $1.40 \mathrm{E}+04$ & $2.24 E-02$ & $2.24 E-02$ & $1.00 E-02$ \\
\hline Arocher 1254 & $230 E+04$ & $2.24 E-02$ & 2.24E-02 & $1.00 E-02$ \\
\hline Arvator 1260 & $1.60 E+05$ & 2.24E-02 & $2.24 E-02$ & $1.00 E-02$ \\
\hline Benzo(a)tanthracene & $1.17 E+04$ & $1.97 E-02$ & $1.97 \mathrm{E}-02$ & $1.26 E-02$ \\
\hline Benuene & $2.4|E+0|$ & 2.37E+00 & $2.37 E+00$ & $3.16 E-06$ \\
\hline Benso(b)/luor mothene & $2.38+04$ & $2.37+\infty 0$ & $1.19=-02$ & $2.14 e-04$ \\
\hline Benzene hexactiboride (alpha) & $5.17 \mathrm{E}+02$ & $2.46 E-01$ & $2.46 E-01$ & $1.58 E-04$ \\
\hline Benuene he rechloride (bets) & $5.42 E+02$ & $2.16 E-01$ & $2.16 \mathrm{E}-01$ & $1.98 E-04$ \\
\hline Bensene hexechioride (garman) & $1.80 E+02$ & $1.65 E-01$ & $1.65 \mathrm{~S}-01$ & $3.16 E-04$ \\
\hline Bendene bexactsoride (detu) & $7.70 E+02$ & $1.62 E-01$ & $1.62 E-01$ & $3.27 E-04$ \\
\hline 3.4-benzfluorwathene & $6.94 E+04$ & $5.93 E-03$ & $5.93 E-03$ & $1.00 E-01$ \\
\hline Benzola)pyrene & $2.38 E+04$ & $1.32 E-02$ & $1.32 E-02$ & $2.51 E-02$ \\
\hline Benow(eb.i)perylene & $6.70 E+04$ & $6.09 E-03$ & $6.09 \mathrm{E}-03$ & $7.55 E-02$ \\
\hline Benxo(k) Nluorenthene & $2.38 E+04$ & I.19E-02 & $1.19 \mathrm{E}-02$ & $3.02 E-02$ \\
\hline Benzoic acid & $1.55 E+01$ & $3.09 E+\infty 0$ & $3.09 E+00$ & $2.00 F-06$ \\
\hline BEHP & $1.19 E+07$ & 4.37E-02 & $4.37 E-02$ & $3.16 E-03$ \\
\hline Rutyl benzyl phathalate & $3.54 E+03$ & $5.70 E-02$ & $5.70 E-02$ & $2.00 E-03$ \\
\hline Carbon tetrachloride & $1.70 E+01$ & $9.32 E-01$ & $9.32 \mathrm{E}-01$ & $1.58 E-05$ \\
\hline Cinlordane (alpha) & $3.22 \mathrm{E}+02$ & $2.56 \mathrm{E}-02$ & $2.56 \mathrm{E}-02$ & $7.94 E-03$ \\
\hline Chlordane (gamma) & $3.22 E+02$ & $2.56 E-02$ & $2.56 \mathrm{E}-02$ & 7.94E-03 \\
\hline Chloride IC & NA & $1.19 \pi-02$ & NA & $8.00=-04$ \\
\hline Chlorobenzene & 6.45E+02 & $9.32 E-01$ & $9.32 \mathrm{E}-01$ & $1.58 E-05$ \\
\hline Chloroetinane & $7.19 E+\infty 0$ & $3.76 E+00$ & $5.76 E+00$ & $6.78 E-07$ \\
\hline Chiorolorm & $1.85 \mathrm{E}+01$ & $2.70 E+\infty 0$ & $2.70 E+\infty 0$ & $2.51 E-06$ \\
\hline Chloromethane & $3.106,+00$ & $1.15 E+01$ & $1.15 \mathrm{E}+01$ & 2.04E-07 \\
\hline Chrysene & $1.08 E+04$ & $1.97 \mathrm{E}-02$ & $1.97 \mathrm{E}-02$ & $1.26 \mathrm{E}-02$ \\
\hline 2.4-D & 8.05E $\leftarrow 01$ & $9 . \mid 7 E-01$ & $9 . ! 7 E-01$ & $1.63 \mathrm{E}-0.5$ \\
\hline $4 . \because \cdot D D D$ & $2.71 E+03$ & $1.32 E-02$ & $1.32 E-02$ & $2.51 E-02$ \\
\hline 4.4'-DDE & $8.45 E+03$ & $1.97 E-02$ & $1.97 \mathrm{E}-02$ & $1.26 E-02$ \\
\hline $4,4^{\prime}-D D T$ & $2.98 E+04$ & 7.74E-03 & $7.74 \mathrm{E}-03$ & $6.31 \mathrm{E}-02$ \\
\hline Dibenzo( 2 h) anthrecene & $1.13 E+05$ & $6.78 \mathrm{E}-03$ & $6.78 E-03$ & $7.99 \mathrm{E}-02$ \\
\hline 1.1-dichloroethane & |.35E+n| & $3.53 E+\infty 0$ & $353 E+00$ & $1.58 E-06$ \\
\hline 1,2-dichloroethene & $2.00 e+100$ & $5.26 \mathrm{E}+\infty$ & $5.26 \mathrm{E}+00$ & $794 E-07$ \\
\hline 1.1-dichloroethene & $1.47 E+01$ & $2.37 \mathrm{E}+00$ & $2.37 \mathrm{E}+00$ & $3168-06$ \\
\hline Trans-1.2-dichloroethyline & $1.36 \mathrm{E}+\infty 0$ & $2.37 \mathrm{E}+100$ & 2.37E+00 & $3.16 E-06$ \\
\hline Dieldrin & $4.87 \mathrm{E}+03$ & $8.502-02$ & $8.50 \mathrm{E}-02$ & $1.00 e-03$ \\
\hline Diethyl phohaiate & $4.36 e_{-01}$ & $5482-01$ & $5.48 \mathrm{E}-01$ & $3.98 \mathrm{E}-0 \mathrm{~s}$ \\
\hline 2.4-dimethylphenol & $1.508+02$ & $1.39 e+10$ & $1.39 \mathrm{e}+00$ & $7.94 \mathrm{E}-06$ \\
\hline 3.J-dishlorobenzidine & $2.69 \mathrm{E}+12$ & NA. & $3,65-01$ & $2.00=-02$ \\
\hline Dimethyl phthelete & $5.708+01$ & $2.70,240^{\circ}$ & 1.80400 & $5.00=-03$ \\
\hline
\end{tabular}




\begin{tabular}{|c|c|c|c|c|}
\hline Constivent & 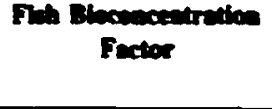 & $\begin{array}{l}\text { Seil bo Vequention } \\
\text { Trenefer Fection }\end{array}$ & $\begin{array}{l}\text { Sul is Trel } \\
\text { Tremer } \\
\text { Fecter }\end{array}$ & 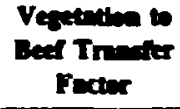 \\
\hline Di-n-buryl phathaline & $1.07 E+04$ & $3.82 E-02$ & $3.82 E-02$ & $3.98 E-03$ \\
\hline Di-n-octylphthelex & $1.87 E+07$ & $1.86 E-04$ & $1.86 E-04$ & $3.98 E+01$ \\
\hline 2.4-dinitorphenol & $8.12 E+00$ & $9.17 e-01$ & $5.22 E+00$ & $6.00=-03$ \\
\hline Endosulfan & $2.94 E+02$ & $3.22 E-01$ & $3.22 E-01$ & $1.00 E-04$ \\
\hline Eadosulfan II & $3.32 E+02$ & $3.22 E-01$ & $3.22 \mathrm{E}-01$ & $1.00 E-04$ \\
\hline Endrin & $1.48 E+03$ & 2.24E-02 & $2.24 E-102$ & $1.00 E-02$ \\
\hline Fiocranticane & $3.12 \mathrm{E}+03$ & $5.70 E-02$ & $5.70 E-02$ & $2.00 \varepsilon-03$ \\
\hline Floorene & $7.13 E+02$ & $1.44 E-01$ & $1.44 E-01$ & $4.02 \mathrm{E}-0.4$ \\
\hline Fuoride & $1.00 E+0 \mid$ & $7.74 c-03$ & NA & $5.50=-02$ \\
\hline Feorourichloconethere & $5.60 E+01$ & $1.34 E+00$ & $1.34 E+00$ & $8.51 E-06$ \\
\hline Freon 113 & $1.90 E+02$ & $4.79 E-01$ & $4.79 \mathrm{E}-01$ & $5.02 E-05$ \\
\hline Heptachlor & $1.30 E+03$ & $|.27 E-0|$ & $1.27 E-01$ & $5.01 E-04$ \\
\hline Hepenchlor epoxide & $6.73 \mathrm{E}+01$ & $1.05 E+00$ & $1.05 E+00$ & $1.28 E-05$ \\
\hline indenot 1.2.3-cd)pyrene & $5.13 E+04$ & $2.37 E+00$ & $6.6 x=-03$ & $3.00=-03$ \\
\hline indenor (1.2.3-cd)pyrene & $5.13 E+04$ & $6.69 E-03$ & $6.69 E-03$ & $8.13 \mathrm{E}-02$ \\
\hline Methoxychior & $8.30 \varepsilon+03$ & $6.51 E-02$ & $6.51 E-02$ & $1.58 \mathrm{E}-03$ \\
\hline Methyiene chloride & $5.74 E+00$ & $6.86 E+00$ & $6.86 E+\infty 0$ & $5.01 E-07$ \\
\hline 2-methylnapthalene & S.OSE+02 & NA & $2.28 e-01$ & $8.00=-02$ \\
\hline Napthylene & $1.68 \mathrm{E}+02$ & $5.48 c-01$ & $5.26 e-01$ & $3.00=-02$ \\
\hline 2-nitrosniline & NA & $1.39 E+\infty 0$ & NA & $2.50=-03$ \\
\hline 3-nitromiline & NA & $3.82 e-02$ & NA & $1.00=-01$ \\
\hline 4-nitroaniline & NA & $1.86 e-04$ & NA & $5.500-03$ \\
\hline 4nituophenol & $1.26 \mathrm{E}+02$ & $3.22 c-01$ & $3.05+00$ & VA \\
\hline a-nitrosodium-0-propylamine & $7.22 E+\infty 0$ & $3.22 e-01$ & $6.34 E+00$ & NA \\
\hline Permachlorophenol & $3.72 E+03$ & $2.24 c-02$ & $4.99-02$ & NA \\
\hline Phenanchrene & $1.44 E+03$ & $9.71 E-02$ & $9.71 E-02$ & $7.94 \mathrm{E}-04$ \\
\hline Phenol & $7.57 E+\infty 0$ & $5.26 E+00$ & $5.26 E+00$ & $7.94 \mathrm{E}-\mathrm{M7}$ \\
\hline Protactinium-234M & $1.10 E+01$ & $2.50=-03$ & $2.50=-04$ & $1.00 e-05$ \\
\hline Pyrene & $2.80 E+03$ & $3.35 E-02$ & $3.35 E-02$ & S.01E-03 \\
\hline Sulphare & NA & $1.34 E+\infty 0$ & NA & NA \\
\hline 2.4.5-T & $1.90 E+03$ & $625 E-01$ & $6.25 E-01$ & $3.16 E-05$ \\
\hline 2.4.5-TP (Silvex) & $\$ 7 \mid E+02$ & $2.07 \mathrm{E}-01$ & $2.07 E-01$ & $2.14 E-04$ \\
\hline Tectunecium-99 & ISOE+101 & $9.50 E+00$ & $1.50 E+00$ & B. $50 \mathrm{e}-\mathrm{C3}$ \\
\hline Tetrachloroethene & $5.57 E+01$ & 4.2JE-01 & $4.20 E-01$ & $6.31 E-05$ \\
\hline Toluene & $6.99 E+01$ & $1.07 E+00$ & $1.07 E+00$ & $1.26 \mathrm{E}-05$ \\
\hline Toxsphene & $1.90 E+02$ & $6.51 E-02$ & $6.51 \mathrm{E}-02$ & $1.58 \mathrm{E}-03$ \\
\hline 1.1.1 erichloroethene & $9.00 E+50$ & $1.35 E+00$ & $1.39 E+00$ & $7.94 \mathrm{E}-06$ \\
\hline 1.1.2 trichlorpethanc & $390 E+01$ & $2.07 E+00$ & $2.07 E+00$ & $3.98 \mathrm{E}-06$ \\
\hline 2.4.5-vichlorophenol & $1.90 E+03$ & $9.71 e-02$ & $2.73 e-01$ & NA \\
\hline Tnchloroethene & $3.79 \mathrm{E}+01$ & $1.59 \mathrm{E}+00$ & $1.59 E+00$ & $6.31 \mathrm{E}-0.06$ \\
\hline Vinyl chlonde & 6.59E +100 & $6.01 E+\infty 0$ & $6.01 E+\infty 0$ & $6.31 E-07$ \\
\hline Xylene & $1.77 E+02$ & $5.48 \mathrm{E}-01$ & $3.48 \mathrm{E}-01$ & $3.98 \mathrm{E}-05$ \\
\hline Aluminum & $1.00 E+\infty$ & $4.00 E-03$ & $6.50 \mathrm{e}-0.4$ & $1.50 e-03$ \\
\hline Antimony & $100 E+\infty 0$ & $2.00 E-01$ & $3.00 \mathrm{e}-02$ & $1.002-03$ \\
\hline Aneanic & $1,00 E+\infty$ & $4.00 \mathrm{E}-02$ & $6.00 E-03$ & $2.00 \mathrm{E}-03$ \\
\hline Berium & $400 E+\infty 0$ & $1.50 E-01$ & $1.50 \mathrm{E}-02$ & $1.50 \mathrm{E}-04$ \\
\hline Beryllium & $1.902+01$ & $1.00-02$ & $1.50 \mathrm{E}-03$ & $1.00 E-03$ \\
\hline Boron & $2.20 \mathrm{e}-0 \mathrm{I}$ & $400 E+00$ & $2.00 E+00$ & $8.00 E-0.4$ \\
\hline
\end{tabular}




\begin{tabular}{|c|c|c|c|c|}
\hline Comitionit & 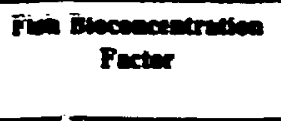 & 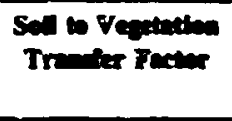 & Suln & 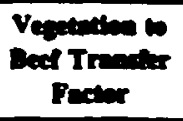 \\
\hline Cadming & $2.00 E+02$ & S.SOE-0I & $1.50 E-01$ & $5.50=-04$ \\
\hline Calcium & 0.00 & $3.50 E+\infty 0$ & $3.50 E-01$ & $7.00 E-04$ \\
\hline Chromium & $2.00 E+01$ & $7.50 E-03$ & $4.50 E-03$ & $5.50 E-03$ \\
\hline Coball & $5.00 E+01$ & $2.00 E-02$ & $7.00 \varepsilon-03$ & $2.00 E-02$ \\
\hline Copper & $5.00 E+01$ & $4.00 E-01$ & $2.50 \Sigma-01$ & $1.00 E-02$ \\
\hline Cyanice ion & $3.79 E-01$ & $5.42 E+01$ & $5.60 E-01$ & $1.41 E-08$ \\
\hline Gallium & $1.00 E+02$ & $4.00 E-03$ & $4.00 E-04$ & $5.00 E-04$ \\
\hline Germanizam & $4.00 E+03$ & $4.00 E-01$ & $8.00 E-02$ & $7.00 E-01$ \\
\hline Hafaium & $4.00 E+01$ & $3.50 E-03$ & $8.50 z-04$ & $1.00 E-03$ \\
\hline Iron & $1.00 E+02$ & $4.00 E-03$ & $1.00 E-03$ & $2.00 \varepsilon-02$ \\
\hline Lancheam & $3.00 E+01$ & $1.00 E-02$ & $1.00 \varepsilon-12$ & $3.00 \varepsilon-04$ \\
\hline Lead & $1.00 E+02$ & $4.50 E-02$ & $9.00 \varepsilon-03$ & $3.00 E-04$ \\
\hline Lithium & $S .00 E-01$ & $2.50 \Sigma-02$ & $4.00 E-03$ & $1.00 E-02$ \\
\hline Magnesium & $S .00 E+01$ & $1.00 E+00$ & S.50E-01 & $5.00 E-03$ \\
\hline Manganese & $4.00 E+02$ & $2.50 E-01$ & $5.00 E-02$ & $4.00 E-04$ \\
\hline Mercury & $2.00 E+05$ & $9.00 E-01$ & $2.00 E-01$ & $2.50 \varepsilon-01$ \\
\hline Molybdenum & $1.00 E+01$ & $2.50 \varepsilon-01$ & $6.00 E-02$ & $6.00 E-03$ \\
\hline Nickel & $1.00 E+02$ & $6.00 E-02$ & $6.00 E-02$ & $600 E-03$ \\
\hline Niobium & $3.00 E+04$ & $2.00 \Sigma-02$ & $5.00 E-03$ & $2.50 E-01$ \\
\hline Phosphonss & $1.00 E+05$ & $3.50 \Sigma+00$ & $3.50 E+00$ & $5.50 E-02$ \\
\hline Potassium & $1.00 E+03$ & $1.00 E+00$ & $5.50 E-01$ & $2.00 \varepsilon-02$ \\
\hline Scandium & $1.00 E+02$ & $6.00 E-03$ & $1.00 E-03$ & $1.50 E-02$ \\
\hline Selenium & $1.70 E+02$ & $2.50 \varepsilon-02$ & $2.50 \mathrm{E}-02$ & $1.50 E-02$ \\
\hline Silicon & $2.00 E+01$ & $3.50 \varepsilon-01$ & $7.00 \mathrm{E}-02$ & $4.00 E-05$ \\
\hline Silver & $2.30 E+00$ & $4.00 \varepsilon-01$ & $|.00 E-0|$ & $3.00 E-03$ \\
\hline Sodium ion & $1.005+02$ & $7.50 E-02$ & S.SOE-02 & $5.50 E-02$ \\
\hline Thallium & $1.00 E+04$ & $4.00 E-03$ & $4.00 E-04$ & $4.00 E-02$ \\
\hline $\operatorname{Tin}$ & $3.00 E+03$ & $3.00 E-02$ & $6.00 E-03$ & $8.00 E-02$ \\
\hline Tilanjum & $1.00 E+03$ & $5.50 E-03$ & $3.00 E-03$ & $3.00 E-02$ \\
\hline Uranium oxyfluoride & $2.00 E+00$ & NA & NA & NA \\
\hline Vansodium & $1.00 E+01$ & $5.50 \mathrm{E}-03$ & $2.50 E-03$ & $2.50 E-03$ \\
\hline Zinc & $2.00 v+03$ & $1.50 E+00$ & $1.00 E-0 \mid$ & $1.00 E-01$ \\
\hline Zireonium & $3.30 E+\infty 00$ & $2.00 E-03$ & $5.00 E-04$ & $5.50 E-03$ \\
\hline Americium-241 & $2.50 E+01$ & $5.50 \mathrm{E}-03$ & $3.00 E-02$ & $3.50 \mathrm{E}-06$ \\
\hline Cerium-141 & $1.00 E+10$ & $1.00 E-02$ & $4.00 \varepsilon-03$ & $7.50 E-04$ \\
\hline Cesiumr 137 & $2.00 E+03$ & $8.002-02$ & $3.00 E-02$ & $2.00 E-02$ \\
\hline Cobalt -60 & $5.00 E+01$ & $2.00 E-02$ & $7.00 E-03$ & $2.00 E-02$ \\
\hline Curium-242 & $2.50 E+01$ & $8.50 z-04$ & $1.50 E-05$ & $3.50 E-06$ \\
\hline Curium-244 & $2.50 \mathrm{E}+01$ & $8.50 E-04$ & $1.50 \mathrm{e}-0 \mathrm{~s}$ & $3.502-06$ \\
\hline Neprunium-237 & $1.00 E+01$ & $1.002-01$ & $1.00 \Omega-02$ & $5.50=-05$ \\
\hline Poenssium-40 & $1.00 E \curvearrowleft 03$ & $1.00 E+\infty$ & $5.50 E-01$ & $2 m n-02$ \\
\hline Putonium-238 & $3.50 \mathrm{E}+00$ & $4.508-04$ & $4.50 \mathrm{E}-0 \mathrm{~S}$ & $5.00 E-07$ \\
\hline Plutonium-239 & $3.50 E+00$ & $4.50 \mathrm{E}-04$ & $4.50 E-05$ & $5.000-07$ \\
\hline Protactinium-233 & $1.10 E+01$ & $2.50 \mathrm{E}-03$ & $2.50 \mathrm{E}-04$ & $1.000-05$ \\
\hline Redium-226 & $5,00 E+01$ & $1.30 \mathrm{E}-02$ & $1.508-03$ & $2.308-04$ \\
\hline Strontium-90 & $3.00 e+01$ & $2.502+00$ & $2.50 E-01$ & $3.00 \mathrm{E}-04$ \\
\hline Thorium-228 & $3.002+01$ & $8.502-04$ & $8.50 E-05$ & $6.000-00$ \\
\hline Thorium-230 & $1002+01$ & $8.50 \mathrm{E}-04$ & $8.502-05$ & $6,04-0$ \\
\hline
\end{tabular}




\begin{tabular}{|c|c|c|c|c|}
\hline Conomineser & 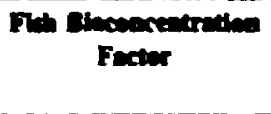 & 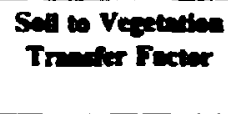 & 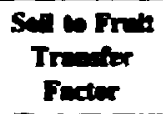 & 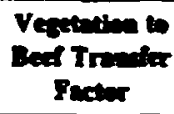 \\
\hline Thorium-232 & $3.00 E+01$ & 8.50E-04 & $8.50 \mathrm{E}-05$ & $6.00 E-06$ \\
\hline Unaium-234 & $2.00 \varepsilon+\infty 0$ & $8.50 E-03$ & $4.00 E-03$ & $2.00 E-04$ \\
\hline Uranium-235 & $2.00 E+00$ & $8.50 E-03$ & $4.00 E-03$ & $2.00 \varepsilon-04$ \\
\hline Uraium-238 & $2.00 E+\infty 0$ & $8.50 E-03$ & $4.00 E-03$ & $2.00 E-04$ \\
\hline Youriam-90 & $2 S 0 E+01$ & $1.50 E-02$ & $6.00 E-03$ & $4.00 E-04$ \\
\hline
\end{tabular}

NA = Transfer factor could not be calculased.

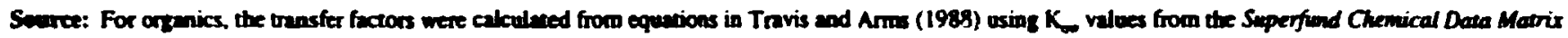

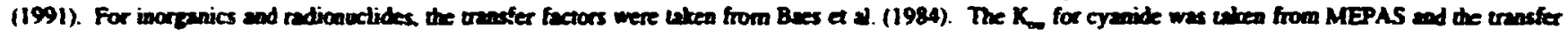
facturs were calculared from equations in Travis and Ams (1938). 
external exposure to radionuclides was also determined from calculated tissue concentrations and soil concentrations, respectively. Doses that exceeded $0.1 \mathrm{rad} / \mathrm{d}$ were considered to pose a potential risk to terrestrial organisms (IAEA 1992). Methods used to calculate exposure and risk are described in Appendix A.

Toxicological benchmarks for terrestrial organisms, excluding vegetation, were obtained from Opresko et al. (1993) (table 78). For representative receptor species that were not listed in the data base, extrapolation techniques were employed to obtain the chronic NOAEL by adjusting for differences in body weight between the receptor and a test organism. If a NOAEL was available for a laboratory test species, the NOAEL for a receptor species could be calculated. Many of the NOAEL benchmarks were derived by extrapolation from small mammal laboratory data (Opresko et al. 1993). There were a few contaminants for which no wildlife toxicity data was found. For these cases, wildlife NOAEL's were extrapolated from human non-carcinogenic toxicity data (i.e. RfD's) listed in the MEPAS constituent database, normalized to the "standard man" body weight of $70 \mathrm{~kg}$. Thus, wildlife species that weigh less than $70 \mathrm{~kg}$ would have a higher benchmark than humans, and the opposite would be true for wildlife species weighing more than $70 \mathrm{~kg}$.

Literature sources for inorganic terrestrial phytotoxicity benchmarks were summarized and reported by Suter and Futrell (1993). Where applicable, the lowest source concentration in a soil medium that produced phytotoxically excessive effects was chosen from the data base. Several benchmarks were derived from experiments using nutrient solutions. However, uncertainty values were not applied to these data to account for differences in growth media. A methodology for deriving phytotoxicity benchmarks for organic constituents was developed by Eskew and Babb (as cited in the MMR Air National Guard Risk Assessment Handbook (1992).
Risics to aquatic organisms from exposure to urganic and inorganic contaminants in water and sediments (pore water) were calculated by comparing the water or sediment porewater concentrations (for benthic macroinvertebrates only) with the chemicalspecific aquatic benchmark (Suter et al. 1992) (table 7-8). To determine intemal dose to aquatic plants, fish, and muskrats from exposure to radionuclides, the surface water concentrations were multiplied by radionuclide and organism-specific aquatic (internal) dose conversion factors to produce a daily dose in rads (Killough and McKay 1976). To determine the internal dose to benthic macroinvertebrates and other bottomdwelling organisms (e.g., fish larvae) from exposure to radionuclides, the sediment pore. water concentrations were multiplied by radionuclide and organism-specific aquatic (intemal) dose conversion factors to produce a daily dose. The external dose to all organisms was determined by multiplying the surface water concentration by the external radionuclide-specific dose conversion factor. Combined internal and external doses greater than $1 \mathrm{rad} / \mathrm{d}$ are considered to pose a potential risk to aquatic organisms (NCRP 1991).

For contaminants and receptors that did not pass the average concentration screening (section 7.3), an attempt was made to further define exposure risks by comparing the home range sizes of receptor species with the potential fraction of the home range occupied by contaminants in food and water from waste sites and other contaminated areas.

Receptor species on the ORR have home ranges or territories that range from small [e.g., less than 1 hectare ( 1 acre) for aquatic species in small wetlands] to large [e.g.. thousands of hectares (acres) for coyotes (appendix B)]. Some small species have home ranges small enough to be completely within individual waste sites. Other species have such large home ranges that the waste sites would represent only a small part of the area the species would occupy, if the waste 
sites were used at all. To further interpret the results of the risk analysis, assumptions similar to those described in section 4.4 were made. Because the ORR is different from the INEL reservation in ecological characteristics and distribution of endpoints/receptors, in distribution and area of waste sites, and in having three sets of source terms (e.g., Y-12, K-25, X-10), some assumptions for the ORR were different from those for the INEL reservation.

1. As for the NEL reservation, it was assumed that source terms outside of contaminated areas in the PNL data base are negligible. Although floodplain soils contain measurable leveis of contaminants along some contaminated streams (SAIC 1994), source terms were assumed to be negligible for the rest of the ORR compared with source terms for waste sites.

2. The average size of terrestrial waste sites is about 4 ha (10 acres)at Y-12; about 20 ha (50 acres)at the K-25 Site; and about 2 ha ( 5 acres) or less at X-10. It was assumed that small terrestrial species with home ranges less than or equal to the area of a typical waste sites at each facility (table 7-9 a, b, c) could receive as much exposure as the average screening indicates (appendix B).

3. It was assumes that wideranging terrestrial species with home ranges greater than the average waste site but less than the total waste complex at each facility could receive at most about $20 \%$ and $15 \%$ for the $Y-12$ Plant and $X-10$, respectively, of the exposure caiculated by the average screening if their home range includes as much contaminated area as possible (see appendix B). This assumption was derived from the approximate proportion of area of waste sites contained within the waste complex or within an area containing a representative group of waste sites at the $Y-12$ Plant (figure $7-3)$ and $X-10$ (figure 7-4). The waste complexes at $Y-12$ and $X-10$ were estimated to occupy about 690 ha 1700 acres) and 445 ha (1100 acres) respectively.

The waste complex at the $\mathrm{K}-25$ Site is very large relative to the total area in waste sites [e.g., 20 ha (50 acres)] more than $80 \%$ of which is in one locacion. Receptor species home ranges were either less than the area in a representative waste site or many times larger than all waste sites (appendix B). Therefore, for the K-25 Site it was assumed that all species with home ranges greater than the representative waste sites could receive at most a fraction of exposure comparable to the fraction of its home range contained in the total of all waste sites. At all three sites, exposures could be higher if, for instance, the sole source of contaminants is a waste pond or contaminated stream used as the only source of drinking water, or if waste sites are preferred feeding areas. 


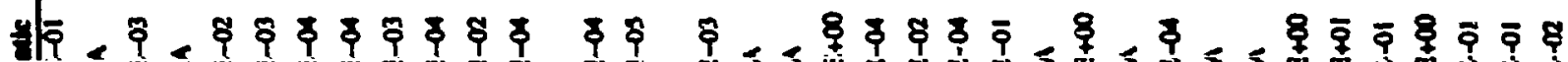

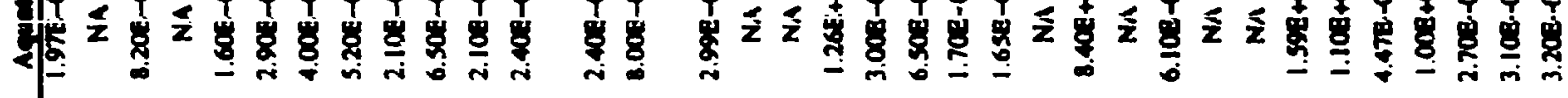

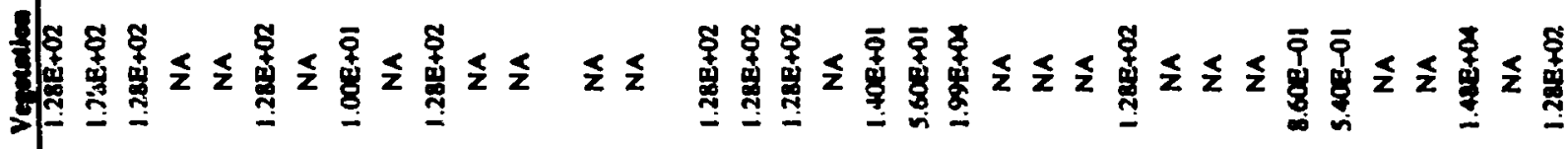

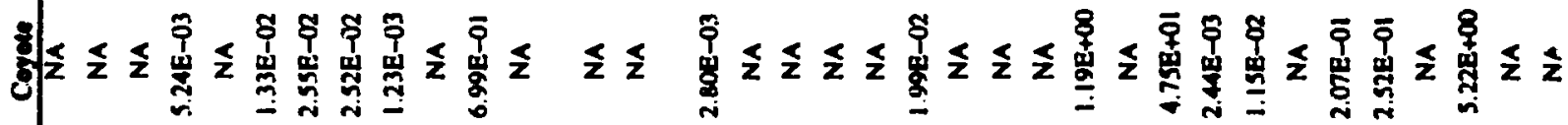
to

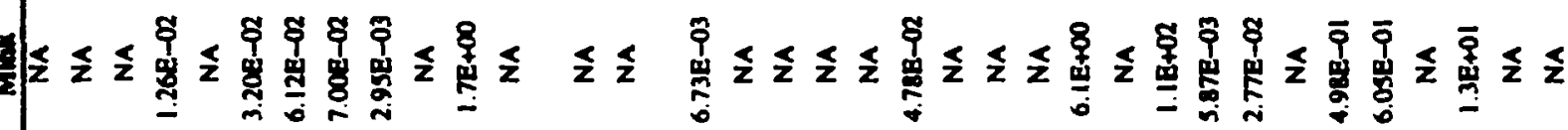

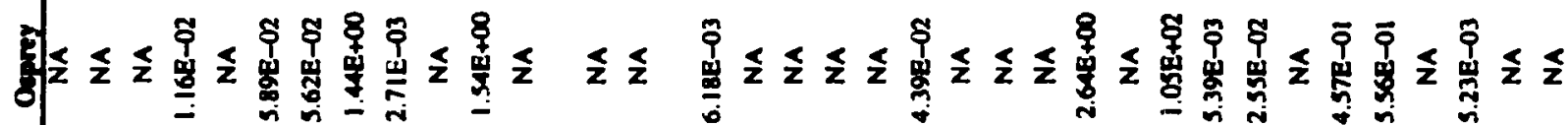

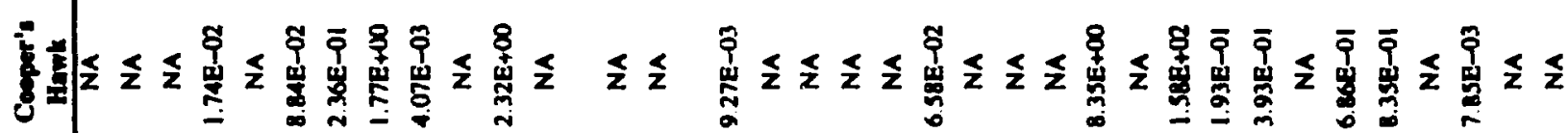
J)

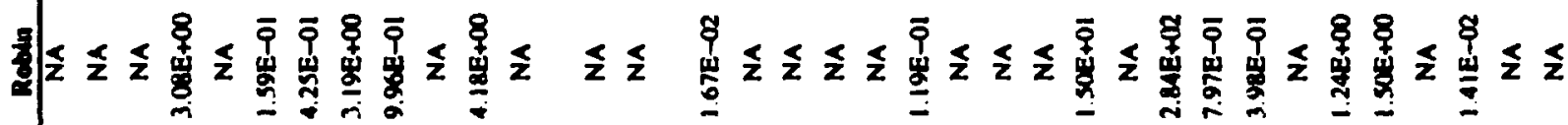

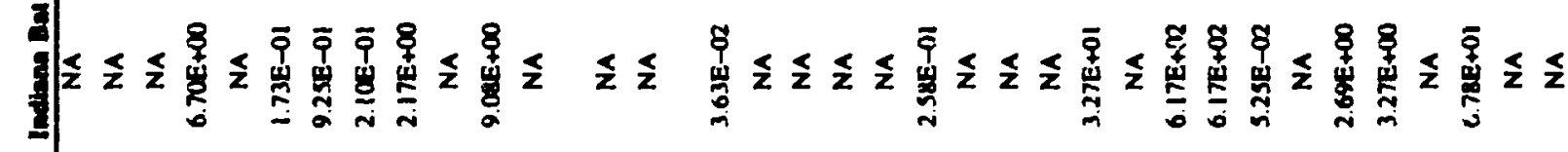

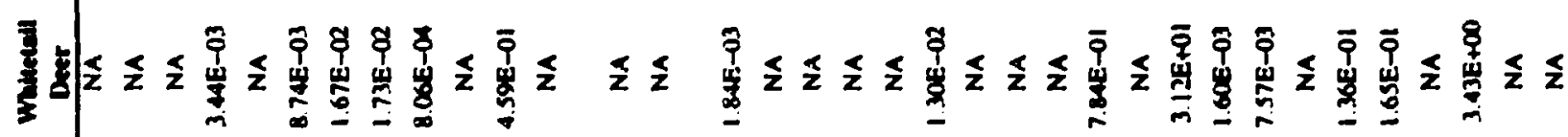

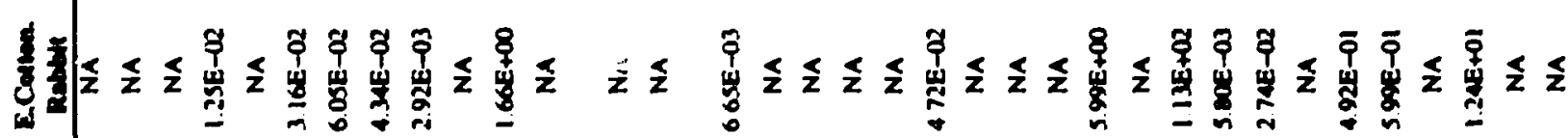

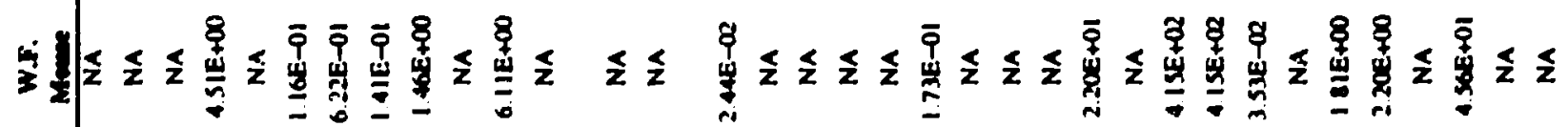
8

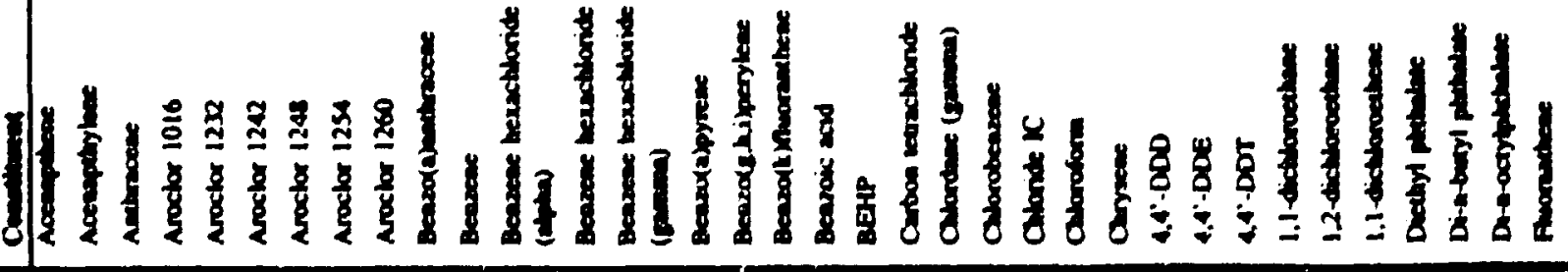




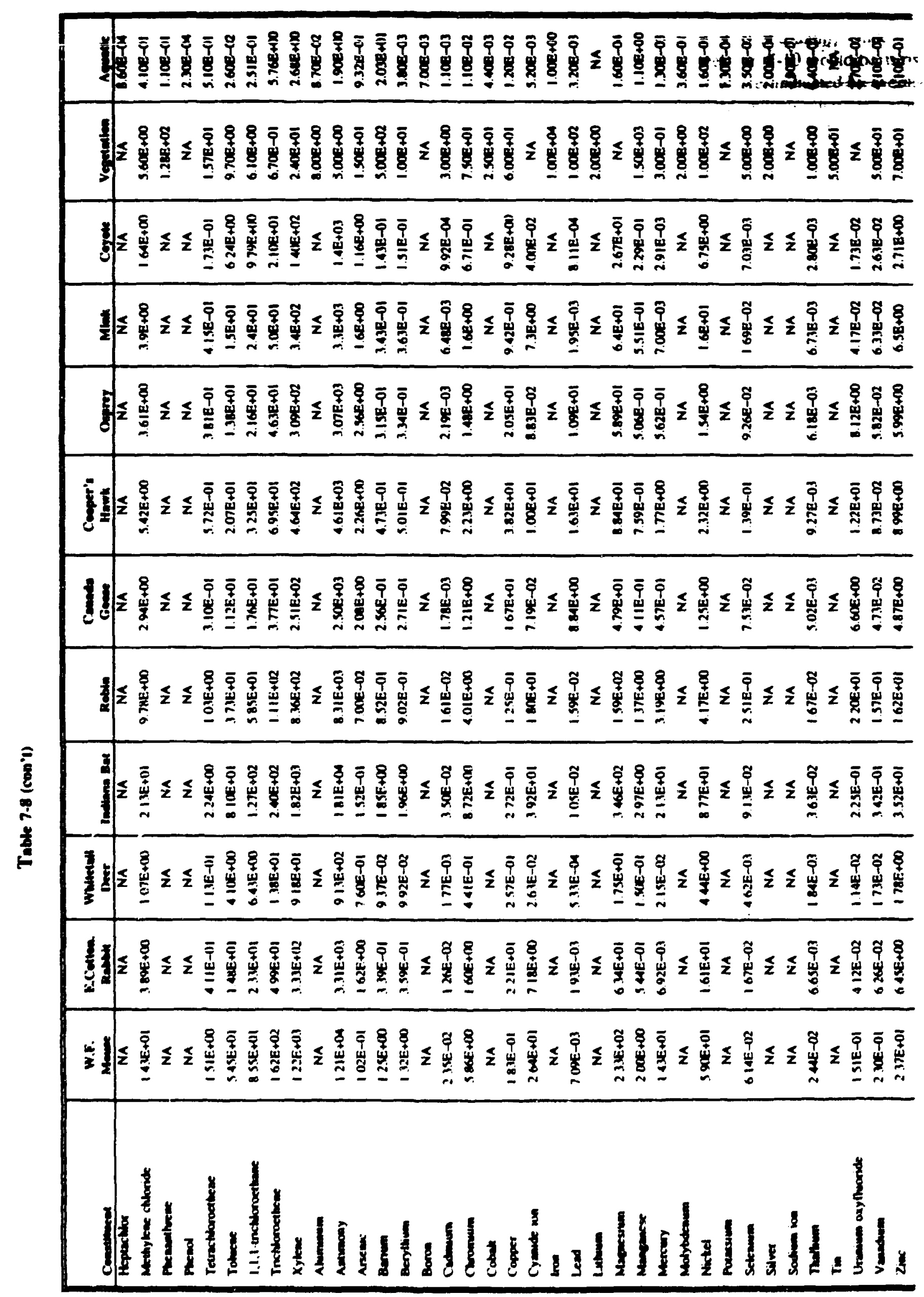


Table 7.8 (con't)

\begin{tabular}{|c|c|c|c|c|c|c|c|c|c|c|c|c|}
\hline 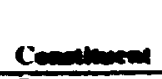 & $\begin{array}{c}\text { W.F. } \\
\text { Mme } \\
\end{array}$ & rective & Mnimetall & Introm Ren & Rcmin & Camede & $\begin{array}{c}\text { Comer's } \\
\text { Hown }\end{array}$ & ons & Mman & : & مس & \\
\hline Znconien & 7S4E- 02 & 20KE-02 & T67E-01 & $|12 E-0|$ & $5.16 \mathrm{E}-01$ & T.33E- 02 & $2.85 E-02$ & T91E-ी2 & $2012=02$ & 8.6.5E-11 & NA & 201 \\
\hline
\end{tabular}

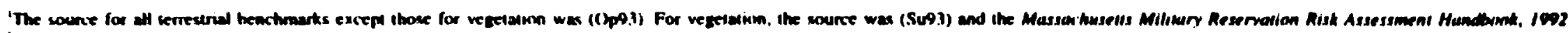

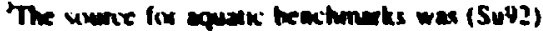

NA = Beachourt mon avalable 
4. As a INEL it was ascumed that terrestrial species with bome ranges grearer inan tine wasic complex of each facility could receive a most a fraction of exposure comparable to the fraction of its home range contained within waste sites included in the source term data base (appendix B). The total area in waste sites was 137 ha (338 acres), 21 ha (53 acres). and 64 ha (158 acres) at Y-12. $K-25$, and $X-10$, respectively.

5. Unlike terrestrial species, which were assumed to have circular or rectangular habitats, species primarily associated with streans were assumed to have more linear habitats. The Indiana bat, if present on the ORR, would be expected to occur only along East Fork Poplar Creek, and Poplar Creek which contain effluents from the Y-12 Plant. The length of these streams with suitable habitat is about $20 \mathrm{~km}$ (12 miles). The estimated foraging habitat of the Indiana bat is less than the total area of contaminated stream (Appendix B). Therefore, it was assumed that the Indiana bat, if present. would be at risk at the level indicated by average hazard indexes determined for the $\mathrm{Y}-12$ Plant.

The mink, which can subsist entirely on aquatic foods (e.g., fish. frogs. etc.). forages along streams, ponds, wetlands, lakes, or rivers. Data for a mink on the ORR indicate a foraging distance of 3 to $5 \mathrm{~km}$ (2 to 3 mile). As is true for the Indiana bat, the mink could forage entirely within habitats containing effluents at the $\mathrm{Y}-12$ Plant and X-10. Unlike the Indiana bat, however, suitable habital is found throughout the ORR. Therefore, it was assumed that mink occuring along East Fork Poplar Creek. Poplar Creek, and Berr Creek

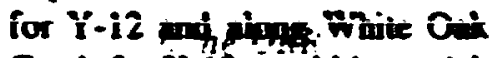
Creek for X-10 would be a rist at the levet intimat byomenge hazard indices, and that mink living aloog werer bodies that do not contain effluents are not at risk. The only water included in the source term data base for the K-25 Site is a small stream. about $1.2 \mathrm{~km}$ (0.75 miles) of which contains contaminated sediment. Tierefore, for the K-25 Site it was assumed that the mink could receive at most about $40 \%$ [e.g., $1.2 \mathrm{~km}(0.75$ miles) divided by $3 \mathrm{~km}$ ( 2 miles)] of the exposure the average screening indicates.

Because osprey generally hunt only in large bodies of water. such as the impounded river. the only source of contaminants from the ORR to osprey is probably from the impounded river. The source term data base does not contain data from the impounded river; therefore. osprey were assumed to feed from smaller streams as well.

The home range for the osprey was assumed to be about 500 acres (see appendix B). Contaminated streams and ponds would be about $30 \%, 10 \%$, and $1 \%$ of the osprey's feeding area for $Y-12, K-25$ and $X-10$ respectively.

Other birds that feed on aquatic life in streams (e.g., the great blue heron and the belted kingfisher) were assumed to be exposed to contaminants similar to those calculated for the osprey.

6. As reported in the source term data base, only about 220 ha ( 550 acres) or about $1.5 \%$ of the surface area (e.g., nonaquatic) of the ORR is waste sites or known 
areas of contamination, which are the oaly pans of the reservation corridered for remodivion. Terrestrial biote living in the remaining 98.5\% of the reservacion are only exposed to contarninants the have moved from waste sites in dust. sediment, contaminated wrter. and by contaminated wildife and plants. As at WEL, although this contamination may be measurable and is known to be of concern in some areas. source terms wete not available except for the Bear Creek floodplain and were assumed to be negligible compared known sources of contamination that are subject to remediation. Because most of the ORR was assumed to be simil-r heterogeneous forest habitat, only about $1.5 \%$ of the area supporting terrestrial ecological endpoints was assumed to be affected by contaminants from the waste sites or contaminated areas reported in the source term data base

7. No estimates of surface area of water or wetlands on the ORR have been documentaed. As determined by ORR staff from the ORR GIS data base, the total surface area of streams, ponds, and embayments is bout 150 to 300 ha (375 to 750 acres). An additional 200 ha (5000 acres) of the impounded river border the ORR.

The surface or streams and ponds reported in the source term data base were 8890 ha (22.225 acres), 2.6 ha (6.5 acres), and 1550 ha (3875 acres for $Y-12, K-25$, and $X-10$, respectively. These surface areas for $\mathrm{Y}-12$ and $\mathrm{X}-10$ were apparently for the entire watershed, including terrestrial habital, of East Fork Poplar Creek and White Oak Creek and are much lerer then sctual aquatic or wethed habita.

More eccurnte estimnes of surface areas of stream habitat affected by effluents from $Y-12$ and $X-10$ were derived from map distances and published data for East Fork Poplar Creek (SAIC 1994), resulting in estimates of 40 to 80 ha (100 to 200 acres) and 5 to $20 \mathrm{ha}$ (12 to SO acres) are for $Y-12$ and $X-10$, respectively.

Therefore, assuming tha the total area of streams is 150 to 300 ha (375 to 750 acres) and 45 to 100 ha (112 to 250 acres) are affected by effluents, about one-thind to one-half of the stream area on the ORR may be affected by effluents included in the source term data base. Popluations of species living in or dependent on streams for food that are on the remaining one-half to two-thinds of the streams of the ORR were assumed not to be at risk.

8. Wetland area associated with streams, ponds, and embayments was assumed to be proportional to the surface area of water. Therefore. the proportion of wetlanc affected would be compar. to the proportion of streams, ponds, and embayments affected.

9. Stream or wetland dependent species habitat is often defined by linear distance. However, habitat (e.g., food supply) was assumed to be related to surface area of water. Therefore. aquatic surface areas were used 10 estimate the proportion of con tam inated and uncontaminated habitat.

10. As at INEL, except for threatened and endangered species (e.g.. candidate species), for which the loss of an 


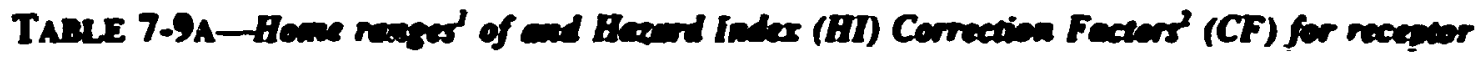
precies at the Y-12 Prine on the ORS

\begin{tabular}{|c|c|c|c|c|c|}
\hline Endpan & Recepter & $\begin{array}{c}\text { <is } \\
\text { (10 exres) }\end{array}$ & 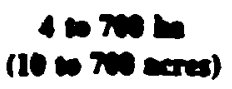 & 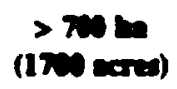 & $\begin{array}{l}\text { Correctiva } \\
\text { Pacter }\end{array}$ \\
\hline \multirow{2}{*}{$\begin{array}{l}\text { Threacened and } \\
\text { Endengered }\end{array}$} & Indiana bat & $x$ & & & 1.0 \\
\hline & $\begin{array}{l}\text { candictare } \\
\text { songationts }\end{array}$ & $\mathbf{x}$ & & & 1.0 \\
\hline Wetands & teneric & $x$ & & & 1.0 \\
\hline \multirow[t]{4}{*}{ Recreational wildife } & white-tailed deer & & $x$ & & 0.2 \\
\hline & cotsontril rabbit & $x$ & & & 1.0 \\
\hline & Canada goose & & $\mathbf{x}$ & & 0.2 \\
\hline & coyoure & & & $x$ & 0.14 \\
\hline Agricultural & regetuition & $\mathbf{x}$ & & & 1.0 \\
\hline \multirow[t]{5}{*}{ Biodiversity } & $\begin{array}{l}\text { white-footed } \\
\text { mouse }\end{array}$ & $\mathbf{x}$ & & & 1.0 \\
\hline & Coopers hawk & & $x$ & & 0.2 \\
\hline & $\operatorname{mink}$ & & $\mathbf{x}$ & & $1.0^{\circ}$ \\
\hline & robin & & $x$ & & 0.2 \\
\hline & osprey & & $x$ & & $0.3^{3}$ \\
\hline
\end{tabular}

See Appendix b.

2 A CF of 1.0 was applied to Hls for each contaminax for exh species having a home range $\leq 4$ ha (10 acres); other CFs are equal to the ratio of contaminated land to the area of the waste coomplex. CFs for wide ranging species equal the raio of contaninmed area to the area of the home range isee lext and Appendix B for discussion of CFs).

3hese species feed near or in streams. ponds. and aquatic areas. Correction factors for these species are discussed in the lext (Section 7.4) 


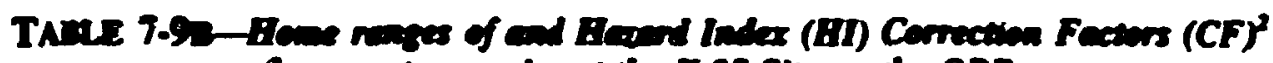

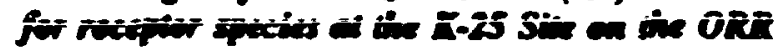

\begin{tabular}{|c|c|c|c|c|}
\hline 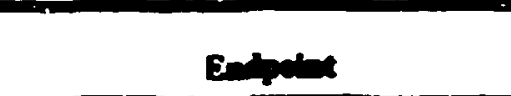 & Rexisures & (5id ecta) & $\underset{\text { (S0 ecrea) }}{>25 \mathrm{~lm}}$ & $\begin{array}{c}\text { Conrection } \\
\text { Facter }\end{array}$ \\
\hline $\begin{array}{l}\text { Thremened and Endmagered Indisma } \\
\text { Wedinds } \\
\text { Recreasional Wildlife } \\
\text { Agriculurnal } \\
\text { Biodiversity }\end{array}$ & 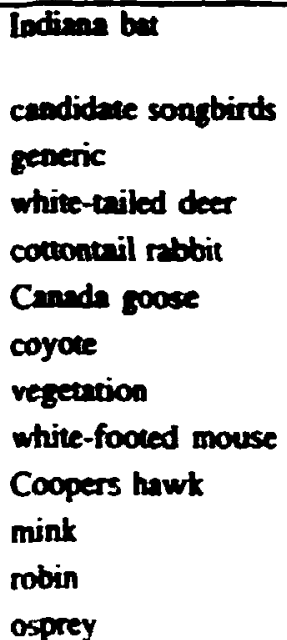 & $\begin{array}{l}\mathbf{x} \\
\mathbf{x} \\
\mathbf{x} \\
\mathbf{x} \\
\mathbf{x} \\
\mathbf{x} \\
\mathbf{x}\end{array}$ & $\begin{array}{l}\mathbf{x} \\
\mathbf{x} \\
\mathbf{x} \\
\mathbf{x} \\
\mathbf{x}^{\prime} \\
\mathbf{X}^{\prime}\end{array}$ & $\begin{array}{l}1.0 \\
1.0 \\
1.0 \\
0.1 \\
1.0 \\
0.04 \\
0.02 \\
1.0 \\
1.0 \\
0.1 \\
10.5 \\
1.0 \\
0.01\end{array}$ \\
\hline
\end{tabular}

I See eppendix B.

2 A CF of 1.0 was applied to Hls for each contaminara for each species having a home ranes $\leq 20 \mathrm{ha}$ ( 50 acres): outer CFs are equal to the ratio of contaminaxed area to the urea of the home range (see lext and Appendix B for discussion of CFs).

3 These species feed near or in strams, ponds, and aquacic areas. Correction factors for these species are discussed in the text (Section 7.4)

TABLE 7-9C-Home Ranges of and Hazard Index (HI) Correction Factors (CF) for recepeor species a $X-10$ on the $O R R$

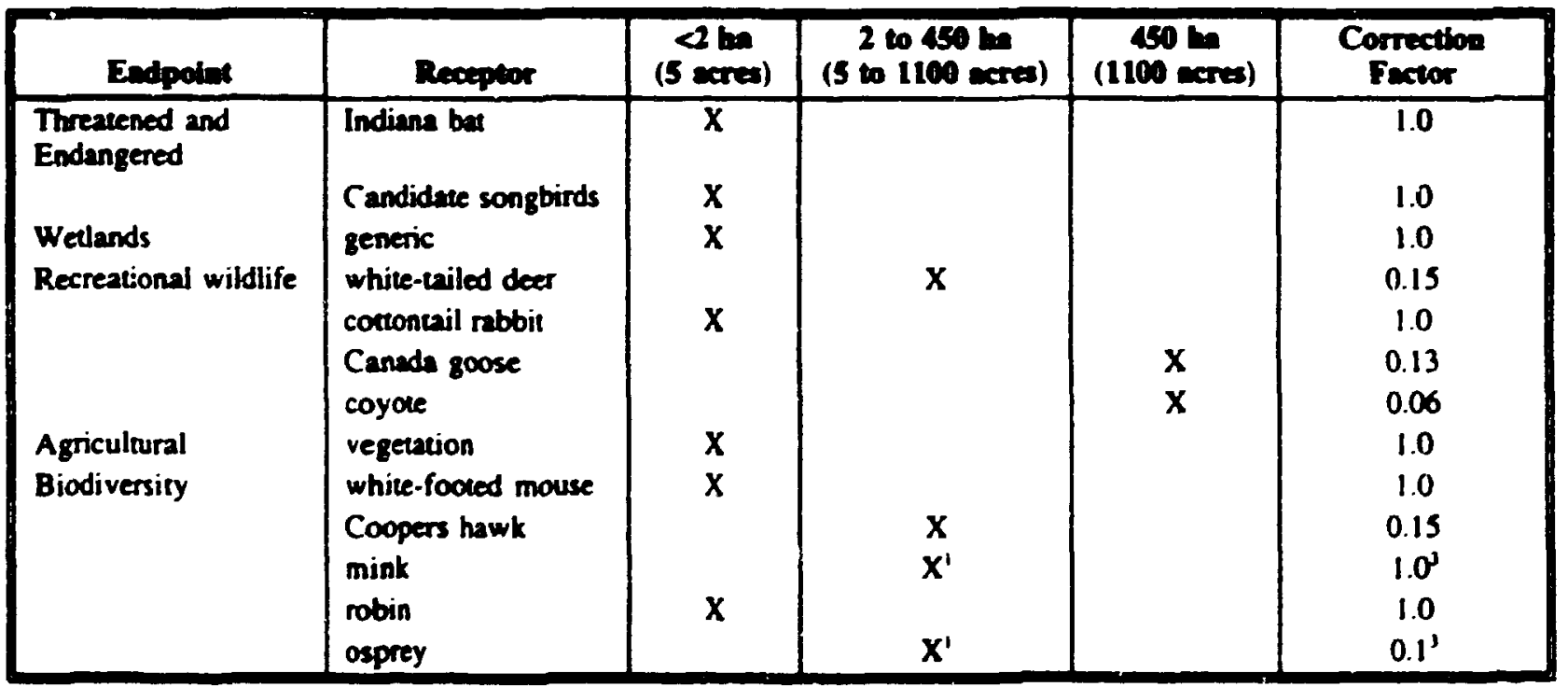

See Appendix 8

- A CF of 1.0 was applied to HIs for each contaminant for each species having a home range $\leq 2$ ha ( 5 acres); othet CFs are equal co the ratio of coneaminated land to the area of the waste complex. CFs for wide rangong species equad the ratio of contaminated area to the area of the home range (see text and Appendix B for discussion of CFs).

These species feed near $O$ in streams. ponds. and aquate areas. Correrrion factors for these species are discussed in ine lext (Section 7.4 ) 


$$
\text { nat? }
$$

Figure 7.3 
Figure 7-4 
for which the loss of an individual is considered a significant rist to the population. other endpoints wore assumed to be at risk only at 'the scale represented by the fraction of the terrestrial, aquatic, or wetland environments the ORR that are contaminated or in waste sites. As reported in the source term data base, the fraction of contaminated terrestrial environment on the ORR is about $1.5 \%$.

\subsection{Contaminant Hazard Assessments}

\subsubsection{Baseline}

The next step in the ecological risk assessment generated Hls that were representative of potential risk and that e!tiunated the level of effects fron. exposure to iontaminants.

\subsubsection{Y-12 Plant}

Baseline uncorrected HIs for terrestrial recepturs exposed to the maximum source concentrations at the $\mathrm{Y}-12$ site were greater than the criteria limit of 1 for 10 of 22 organic contaminants with benchmarks, and 23 of 28 inorganic chemicals with benchmarks. Exposure to the maximum concentrations of radionuclides resulted in HIs for all receptors of about $3 E+9$ : radiological exposure was dominated by exposure to ${ }^{\text {Sh}} Y$ and ${ }^{14} \mathrm{Ce}$ in soils.

The dominant organic contaminants responsible for producing a risk to receptors exposed to the maximum concentrations in soil or water were PCBs and pesticides.

Of the 20 radionuclides to which terrestrial receptors could potentially be exposed, only ${ }^{14} \mathrm{Ce} .{ }^{24} \mathrm{Cm}$, ${ }^{91} \mathrm{Sr}$, and ${ }^{\circ} \mathrm{Y}$ resulted in HIs greater than 1 for all species.

Exposures of terrestrial species to average soil and water concentrations of contaminants at the site were calculated for those contaminants whose maximum concentrations resulted in HIs grester than I (table 7-10a). About $40 \%$ of the HI values were above I but below $10.52 \%$ were above 10 but below 1000 , and $8 \%$ still above 1000 (versus $11 \%$ for the maximum). The radiological dose to receptors remained the same. despite the much lower average dose from ${ }^{90} \mathrm{Sr}$ and ${ }^{244} \mathrm{Cm}$; the total dose was predominantly from ${ }^{-} Y$, whose maximum and average soil concentrations were the same (table 7-10a).

Exposure of aquatic organisms to the maximum concentrations of chemical contaminants in surface water at the $\mathrm{Y}-12$ site resulted in HIs over 1 for PCBs, phenol, toluene, vinyl chloride, benzene hexachloride, and $\mathrm{Mg}, \mathrm{K}$, and $\mathrm{Na}$. Exposure of benthic macroinvertebrates to the maximum sediment pore-water concentrations (calculated from sediment concentrations) resulted in Hls over 1 for benzo(a)anthracene, BEHP. methylene chloride, vinyl chloride, and 24 inorganic contaminants

Hazard indices resulting from exposure of aquatic organisms to the average surface water concentrations were still more that 1 for all of the organics except toluene and all of the inorganic sontaminants (table 7-11a). Only exposure to the average concentration of vinyl chloride resulted in an $\mathrm{Hl}$ over $\mathrm{I}$ for benthic macroinventebrates in the sediment pore water (table 7-11a). Hazard indices for benthic macroinvertebrates exposed to the average sediment concentrations were still more than 1 for 20 inorganic chemicals (versus 24 for maximum sediment concentrations).

Exposure of aquatic organisms to the maximum radionuclide concentrations in the water and sediments resulted in HIs exceeding I only for macroinverebrates exposed to ${ }^{\circ 0} \mathrm{Sr}$. There were no HIs greater than 1 for aquatic organisms exposed to the average sediment concentrations (table 7-12a).

\subsubsection{K-25 Site}

Baseline hazard indices for terrestrial receptors exposed to the maximum source concentrations at the K-25 Site were greater than the criteria limit of 1 for 22 of 23 inorganic contaminants with benchmarks.

Of the 14 radionuclides to which terrestrial receptors could potentially be exposed, only

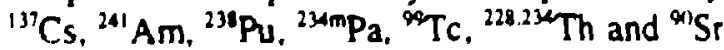
resulted in HIs greater than I for all species. 
Exposures of terrestrial species to average soil concentrations at the site were calculated for those conianiniañis whose maximum concentrations resulted in HIs greater than 1 (table 7-10b). The HI from aluminum exposure of vegetation was still greater than 1000 because the average soil concentration remained on the order of 2+e4 (table 7-1Cb). The remaining His for inorganic contaminants vere all less than 30 . About $82 \%$ of these $H I$ values were above 1 but below 10, 15\% were above 10 but below 1000 . leaving $3 \%$ still above 1000 . The radiological dose :o receptors from exposure to average concentrations decreased slightly to about $8+e 12$ and was primarily due to exposure to $230 \mathrm{pa}$ (table 7-10b).

Exposure of aquatic organisms to the concentrations of nonradiological and radiological contaminants in surface water at the K-25 Site could not be calculated because contaminant concentrati ins in water were not provided in the source terms. Exposure of benthic macroinvertebrates to the maximum sediment pore-water concentrations (calculated from sediment concentrations) resulted in HIs over 1 for one organic chemical, BEHP, and 20 inorganic chemicals.

Hazard indices resulting from exposure of benthic macroinvertebrates to the average sediment pore-water concentrations were still over 1 for BEHP and 18 inorganic contaminants (lable 7-11b). The $\mathrm{Hls}$ for $\mathrm{B}, \mathrm{Fe}, \mathrm{Mg}_{\mathrm{g}}$, and $\mathrm{K}$. were more than 1000 , and $\mathrm{Al}, \mathrm{Cr} . \mathrm{Co}$, and $\mathrm{AB}$ had HIs greater than 100 but less than 1000 .

Exposure of benthic macroinvertebraies to the maximum and average concentrations of radionuclides in the sediment pore water resulted in Hls exceeding 1 for ${ }^{\text {") }} \mathrm{Sr}$ only (table 7-12b). Concentrations of ${ }^{\text {}} \mathrm{Sr}$ in the sediments were on the order of $10^{13} \mathrm{pCikg}$ (table 7-5b).

\subsubsection{X-10}

Baseline HIs for terrestrial receptors exposed to the maximum source concentrations at the X-10 site were greater than the criteria limit of 1 for 14 of 18 inorganic contaminants with benchmarks. There were no Hls greater than 1 for terrestrial receptors exposed to the maximum concentrations of organic contaminants.
Exposure to the meximum concentrations of radionuclides resulted in HIs for all recentors of about 1.5E+0S. The naximum rediological exposure was dominated by exposure to ${ }^{13 t} \mathrm{Cs}$ in soils.

Exposure of terrestrial species to average soil and water concentrations at the site were calculated for those contaminants whose maximum concentrations resulted in Hls greater than 1 (table 7-10c). About $73 \%$ of the $\mathrm{HI}$ values were above 1 but below 10 (versus 70\% for the maximum), 25\% were above 10 but below 1000 (versus $27 \%$ for the maximum), and about $2 \%$ were still above 1000 (versus $3 \%$ for the maximurn). Theaverage radiological dose to receptors decreased to about 100 and was primarily due to exposure to ${ }^{106} \mathrm{Ru}$ (table $7-10 \mathrm{c}$ ).

Exposure of aquatic organisms to the maximum concentrations of non-radiological contaminants in surface water at the X-10 site resulted in HIs over 1 for one organic contaminant, benzene hexachloride, and 13 inorganic contaminants.

Hazard indices resulting from exposure to the average surface water concentrations were still greater than 1 for 8 inorganic contaminants (table 7-11c).

Exposure to the average concentrations of radionuclides in the surface water or in the sediment pore water (macroinvertebrates only) did not result in any Hls exceeding 1 (table 7. 12c).

\subsubsection{Summary}

For the three facilities combined, the initial screening using average contaminant values indicated 36 contaminants resulting in $\mathrm{HI}$ values greater than 10 (i.e., severe risk from contaminants) or HI values greater than 1 (i.e. intermediate risk from contaminants) for various endpoints (tables 7-10 a, b, c; 7-11 a, b, $c$; and 7.12 a. b. c). Following the assumptions outlined in section 7.4, the approximate home range or territory size of receptors was estimated to determine the proportion that could potentially be contained within waste sites.

Of the receptors included in the analyses, only the Indiana bat, small songbirds (includimg 


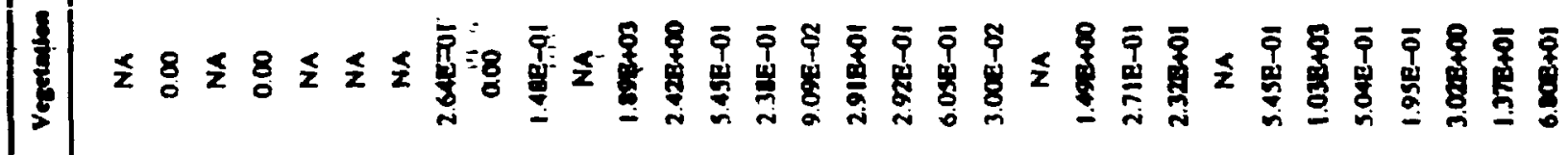

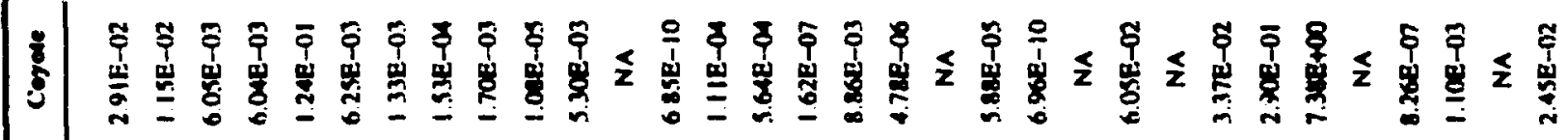

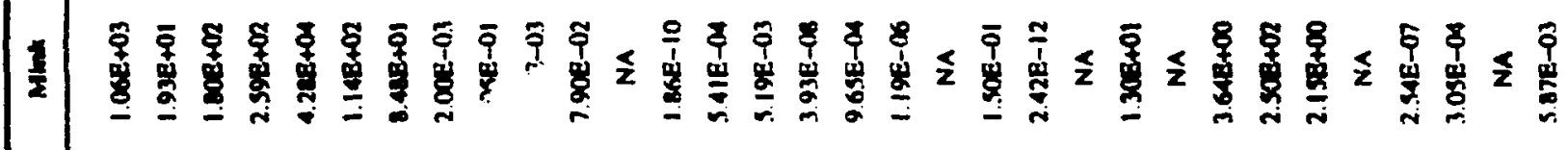

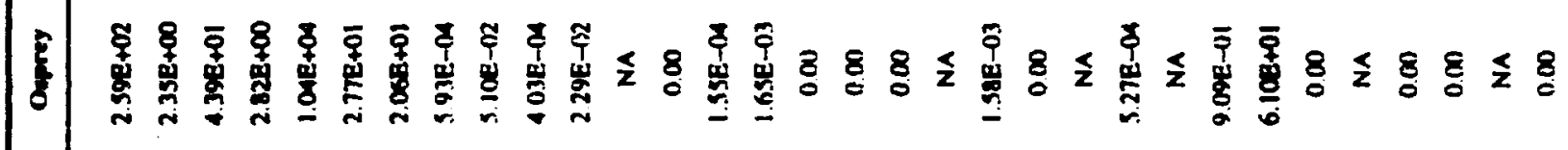

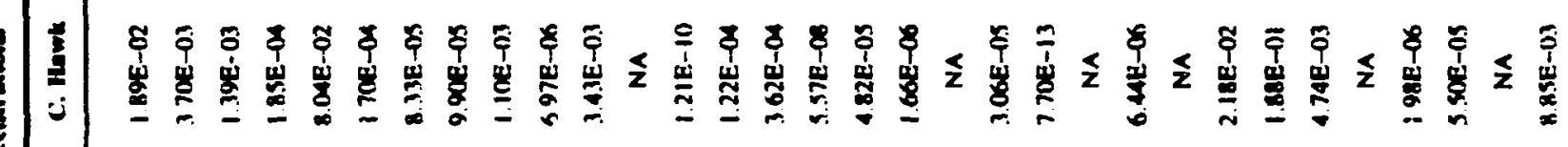

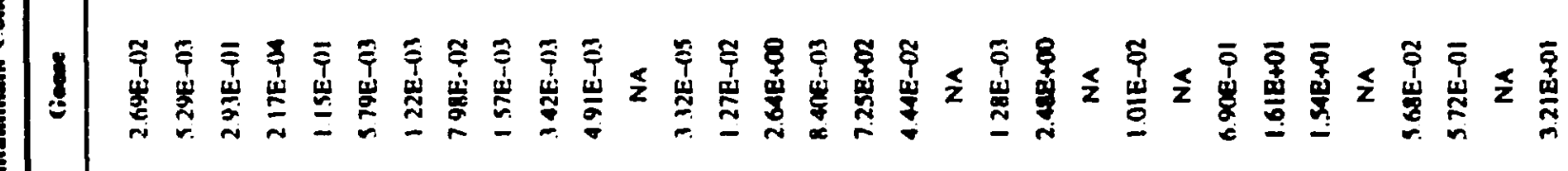

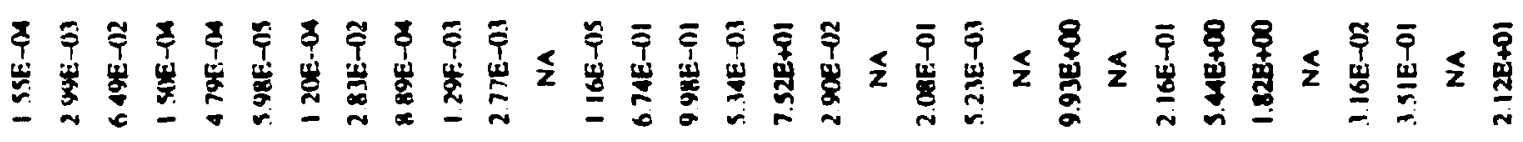

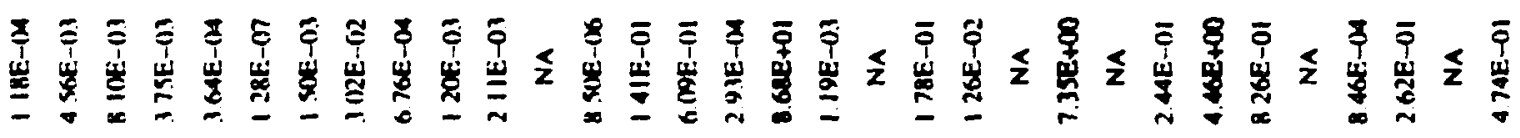

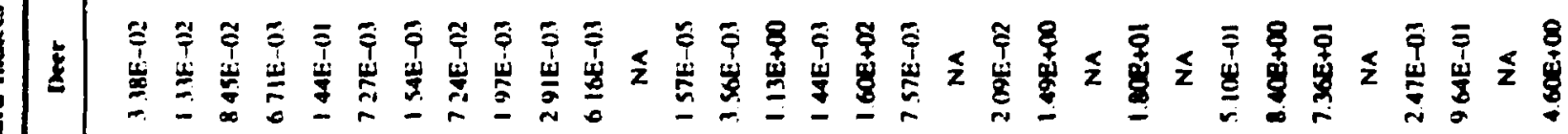

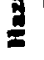

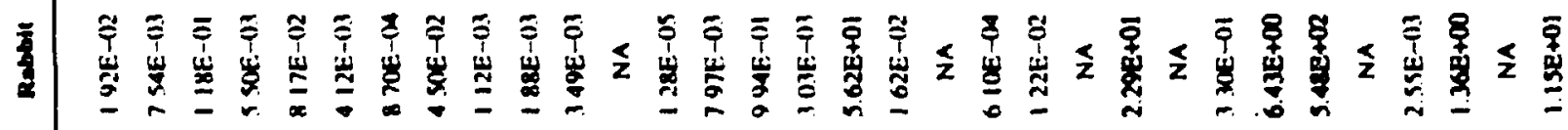

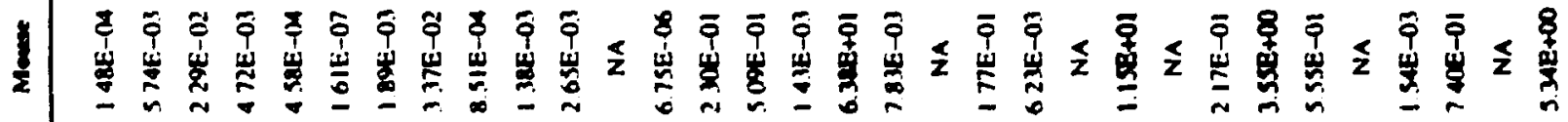

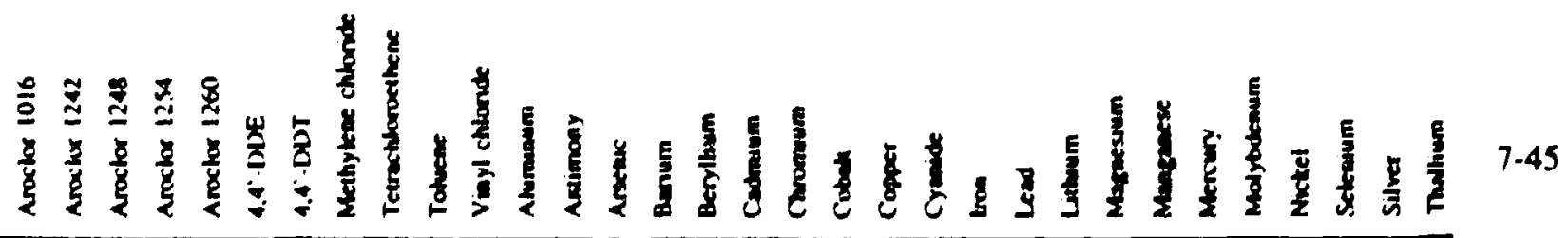


Tabte 7-10a (con't)

\begin{tabular}{|c|c|c|c|c|c|c|c|c|c|c|c|}
\hline \multicolumn{12}{|c|}{ 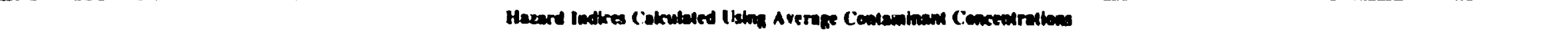 } \\
\hline & Mouse & Rebait & Ineer & Ind. Bm & Resun & Come & C. Hawk & Omprey & Mima & Cogete & Veretiulos \\
\hline Venedivin & $187 \mathrm{E}-\mathrm{O}) 1$ & 39KE-01 & $1.7|E-0|$ & 2 |9F-02 & $7 \mid 9 E-01$ & $1.09 E+\infty 0$ & $188 E-05$ & 0.00 & $1.29 \mathrm{E}-0 \mathrm{~s}$ & $5298-105$ & $4.002-01$ \\
\hline $2 \max$ & 5 S.7E-102 & $1006-0 \mid$ & | 6.1E-01 & $998 E-02$ & $5596-02$ & $2.776-01$ & $2.818-94$ & $3600-01$ & $1.406+\infty 0$ & $9.11 \mathrm{E}-04$ & $5.28 \mathrm{e}-01$ \\
\hline & $2536-0$ & $2005-01$ & $223 E-12$ & $4.328-0]$ & $185 E=0$ & $5,735-01$ & $2,218=-05$ & nom. & 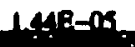 & 6018_- $=5$ & \\
\hline \multicolumn{12}{|c|}{ 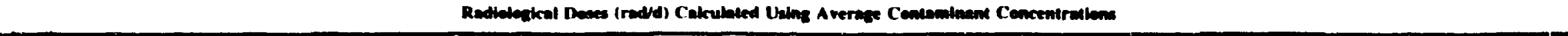 } \\
\hline & Manse & Robbh & Deer & Ind. Bat & Redin & Come & C.Hawk & Oeprey & Mhat & Coyole & Vequatim \\
\hline Cerimen 141 & $223 \mathrm{E}+07$ & $221 \mathrm{E}+07$ & 2.2.3E+07 & $22.1 \mathrm{E}+07$ & 2. 2.1E+07 & $22.3 E+07$ & $2.2 ?=07$ & 2.2.3E $\nrightarrow 177$ & $2.23 \mathrm{E}+07$ & $2.23 \mathrm{E}+07$ & $2.24 \mathrm{E}+01$ \\
\hline Cunum 244 & $235 E+02$ & $7.25 E+02$ & $725 \mathrm{SE}+02$ & $725 E+02$ & 125E+102 & $72 S E+02$ & $725 \mathrm{E}+02$ & ; 2.5e+02 & $7.25 \mathrm{E}+02$ & $7.25 E+02$ & $8.31 \mathrm{e}+0.2$ \\
\hline Suromivim 90 & $477 E-08$ & $477 E-08$ & $477 \mathrm{E}-08$ & $477 E-0 B$ & $4778-08$ & 4.77e-06 & $4.77 E-96$ & $4.77 E-\infty$ & $4.77 \pi-08$ & $4.77 \mathrm{E}-00$ & $9.01 \mathrm{E}-0.3$ \\
\hline Yanem.90 & $281 E+\infty 8$ & $281 E+07$ & $281 E+04$ & $2.81 E+06$ & $281 E+08$ & $281 E+0 B$ & $281 E+18$ & $2.31 E+00$ & $2.81 E+06$ & $2.81 \mathrm{E}+08$ & 2.85e+013 \\
\hline Toen dosere & $30.3 E+00$ & $30.3 E+\infty$ & $30.35+48$ & $30.3 E+08$ & $3018+08$ & $3.03 E+06$ & $1.0 .3 E+0$. & $3.03 E+06$ & $1.038+00$ & $3.03 \mathrm{E}+0$ & $3.058+a 1$ \\
\hline Radioforica & $1038+10$ & $303 \mathrm{E}+02$ & $3031 E+09$ & $303 E_{102}$ & $3038+02$ & 1031E4:92 & $1018+02$ & $3038+09$ & $10 m:+19$ & $3 m^{2}+02$ & Inoting \\
\hline
\end{tabular}


TAB1.F. 7-10B-Baseline Average llazard Indices for K25 Terrestrial Organisms

\begin{tabular}{|c|c|c|c|c|c|c|c|c|c|c|c|}
\hline \multicolumn{12}{|c|}{ 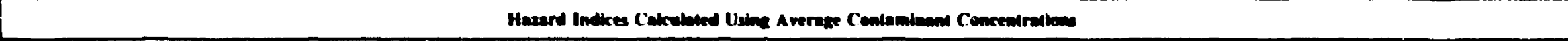 } \\
\hline & Manis & Reanen & Deer & Ind. An & Rebita & Geace & C.Hawk & Oaprey & Mina & Coycle & Vequetiben \\
\hline Beezoratpyreac & $1045-01$ & $202 E-131$ & ||$S E-(1) \mid$ & $278 E-02$ & TAIE-OI & $53 \mid \mathrm{E}-01$ & Q 9SE-(0S & om & $7.86 E-06$ & $27.38-04$ & S C9E-0.) \\
\hline ВЕHP & NA & NA & NA & NA & NA & NA & NA & NA & NA & NA & $7.97 \mathrm{E}-02$ \\
\hline Di-a.beryl phenalate & 9 HE-115 & $1 \operatorname{art}-14$ & $1,17 E-1)$ & $424 F-09$ & S I9E-OII & B 806:-01 & $21.5 \mathrm{E}-(1) 9$ & 0.00 & $104 E-\infty 9$ & $3.95 \mathrm{E}-08$ & $8.02 R-0.5$ \\
\hline Absomonsm & NA & NA & NA & NA & NA & NA & NA & NA & NA & NA & $2.140+03$ \\
\hline Amamony & 2 3,E-OS & $441 E-05$ & S AIE-OS & $29.3 \mathrm{E}-0.3$ & $401 E-0 S$ & I 14E-104 & $4192-10$ & 0.00 & $6.41 E-11$ & $2.26 \mathrm{E}-19$ & $1.362+00$ \\
\hline Arsenax & $267 E-01$ & 9 ЗIE-0.? & $407 E-0.3$ & $\mid 62 E-01$ & $794 E-01$ & $149 E-02$ & $284 E-m$ & $n$ & $2.52 \mathrm{E}-0 \mathrm{a}$ & S.8nE- -07 & $647 \mathrm{E}-01$ \\
\hline Bmen & 7 MYE-0I & $1.442+00$ & $1648+00$ & $885 E-01$ & $1.45 E+00$ & $3.84 E+\infty 0$ & $2.27 E-06$ & $0, \infty$ & $3.05 E-07$ & $1.16 E-0.9$ & $345 \mathrm{E}-01$ \\
\hline Berylliven & $90 \mathrm{EE-104}$ & | 92E-013 & Y IUE-OM & $1.868-1) 4$ & $3.39 \mathrm{E}-0.3$ & 5 IIE- (\}$)$ & IS.TE-O & $n(x)$ & $2.49 E-09$ & $1.0 .98-07$ & $5.77 \mathrm{e}-02$ \\
\hline Cadrumm & $1.158+00$ & $1.01 E+00$ & $2.898+00$ & $1.578+00$ & $1.36 E+100$ & $1.31 E+01$ & 8. $70 \mathrm{E}-07$ & $\mathbf{0 . 0 0}$ & $1.74 E-06$ & $5.892-10.5$ & $5.24 \mathrm{E}-01$ \\
\hline Onamen & $2 \sin E-02$ & $5.31 E-02$ & $247 E-02$ & $3.89 E-03$ & $947 E-112$ & $|45 E-0| \mid$ & $5.4 E-(X)$ & 0.00 & $187 \mathrm{E}-017$ & $1 \sin 20$ & $9.32 \mathrm{E}-01$ \\
\hline Coben & NA & NA & NA & NA & NA & NA & NA & NA & NA & NA & $3502-01$ \\
\hline Copper & S.2AE+10 & 107E- 02 & $1008+100$ & $8.998+100$ & $1.05 E+01$ & 6 GOE- -112 & 1 99E-OK & 000 & S.9E-07 & $1.66 \mathrm{e}-0.03$ & $1.618+00$ \\
\hline troe & NA & NA & NA & NA & NA & NA & NA & NA & NA & NA & $4.428+100$ \\
\hline Lead & $1.468+01$ & $2.92 E+01$ & $2.28 E+01$ & $9.35 E+\infty 0$ & $1.2 \pi E+01$ & $129 \mathrm{E}-112$ & $3.97 E_{-125}$ & $n(n)$ & $1.21 \mathrm{E}-0.5$ & $4.70 \mathrm{E}-\mathrm{M}$ & $3468-01$ \\
\hline Linkman & NA & NA & NA & NA & NA & NA & NA & NA & NA & NA & $9.208+\infty 0$ \\
\hline Magnesium & $101 E-01$ & $4(6 \mid F-0)$ & $707 E-(0)$ & $345 \mathrm{E}-01$ & $297 \mathrm{E}-01$ & $9.89 \mathrm{E}-01$ & 1.59E-05 & 0.00 & $4.14 E-06$ & 1 2.5E-04 & NA \\
\hline Manonese & $2.11 E+00$ & $3.87 E+00$ & $5.002+00$ & $2.702+00$ & $3.28 \mathrm{E}+00$ & $9.10 \mathrm{E}+00$ & I 378.-09 & 000 & $2.32 \mathrm{E}-1 \mathrm{6}$ & $12 \mathrm{E}-0 \mathrm{~S}$ & $1.38 \mathrm{e}-01$ \\
\hline Merceny & $195 E-0.3$ & $1.92 \mathrm{E}+\infty 0$ & $258 E-01$ & 2 9OE- 03 & 6. $37 E-0.3$ & $5 \triangle 0 E-02$ & $1608-05$ & 0.00 & 7 ste-04 & 2 59R-02 & $3.618+\infty 0$ \\
\hline Molyodenuma & NA & NA & NA & NA & NA & NA & NA & NA & NA & NA & 9.998-01 \\
\hline Nictel & $222 E-03$ & $3685-03$ & $157 \mathrm{E}-\mathrm{O})\}$ & $122 E-03$ & 4 S6E-02 & $819 E-02$ & $2898-\infty 6$ & 000 & $.067 \mathrm{E}-08$ & 1.19E-16 & $2.82 \mathrm{E}-01$ \\
\hline Selemenom & 100E-01 & $5626-011$ & $1996-01$ & $1008-01$ & $\mid 45 E-01$ & $2.37 E-01$ & $2.2 \mathrm{NE}-0 \mathrm{~S}$ & 0.00 & $1.26 \mathrm{e}-0.08$ & $4.53 E-04$ & 1.258400 \\
\hline Sulver & NA & NA & NA & NA & NA & NA & NA & NA & NA & NA & $7.32 \mathrm{E}-0 \mathrm{I}$ \\
\hline Voadium & 5 OSE-01 & $1.072+00$ & $4(6) E-1) 1$ & 5 QOE- -12 & $1.948+00$ & $2.94 \mathrm{E}+00$ & S. OSE-0S & 0.00 & $1.47 E-06$ & $1.42 \mathrm{E}-04$ & $1.168+00$ \\
\hline $\operatorname{zin}$ & $|+Z E-0|$ & $27|E-0|$ & ||$Q E-1||$ & 2 SWE-DI & $|4,1 \mathrm{E}-0|$ & 7 ||E-0| & $1.49 E-04$ & 000 & $3.9 .3:-03$ & | 45E-0. & $1.348+00$ \\
\hline zirooming & $2158-01$ & (n):-1) & $124 E-1) 1$ & $2255-03$ & M.9F-131 & $2098+09$ & $1009-01$ & 0.00 & $3,26 a-n$ & $1.68 \mathrm{E}=0$. & NA \\
\hline
\end{tabular}


Table 7.10b (cont'd)

\begin{tabular}{|c|c|c|c|c|c|c|c|c|c|c|c|}
\hline \multicolumn{12}{|c|}{ 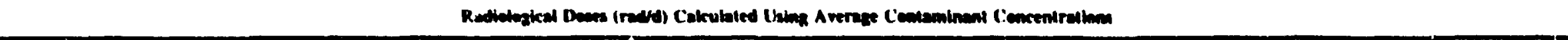 } \\
\hline & Mmone & Resant & Deer & Ind. Ben & Roming & Game & C:Hawh & Inprey & Mmank & Coyeve & Vepinani \\
\hline A.nerncium-241 & $76(E+0)$ & $761 E+00$ & $761 E+00$ & 7.61t:+10) & $761 E+10$ & $761 E+00$ & $761 E+(0)$ & T GIE+DO & $7.618+100$ & $761 E+(D)$ & $5.10 e_{402}$ \\
\hline Cesmm 117 & $577 E+02$ & $577 \mathrm{E}+02$ & $577 E+02$ & $\{77 E+02$ & $577 E+02$ & $577 \mathrm{E}+02$ & $577 E+(12$ & $5.77 \mathrm{E}+02$ & $977 E+02$ & $377 E+132$ & $5938+12$ \\
\hline Pheromoun 238 & 3 ONE +00 & $304 E+00)$ & $304 E+(10)$ & $3(M E+\infty)$ & $30 \mathrm{ME}+100$ & $30 \mathrm{alit}+(x)$ & $30 \mathrm{ME}+\mathrm{CO}$ & $30 \mathrm{CE}+00$ & 3 MAE $+\infty$ & 3 MEE +00 & 1.37e+03 \\
\hline Prounctmum 2.4MM & $776 E+11$ & 77 GE+11 & $776 E+11$ & 7.76E+11 & $776 E+11$ & $7160+11$ & $7765+11$ & $7.76 \mathrm{E}+11$ & $7.76 E+11$ & $776 E+11$ & $7.77 \mathrm{E}+11$ \\
\hline Stromemenn- 80 & $572 E+O M$ & $676 E+04$ & $5.72 \mathrm{E}+04$ & $572 E+1 M$ & $5.73 \mathrm{E}+04$ & $1.0 \mathrm{ME}+05$ & $572 E+04$ & $5.72 \mathrm{E}+104$ & $3.72 E+04$ & $572 E+04$ & $1.0010+05$ \\
\hline Techeocivein-40 & $5 \sec -04$ & $152 \mathrm{E}+10$ & 9.58E-04 & $588 E-04$ & $1.25 E-12$ & $68.3 E+10$ & 5.58E-14 & $5.58 E-M$ & $3.588-04$ & $362 E-1 M$ & $2.44 \mathrm{e}-03$ \\
\hline Thanum-228 & $200 E+03$ & $200 E+05$ & $2.00 E+05$ & $200 E+05$ & $2.00 E+05$ & 2.00E+115 & $2.00 E+05$ & $200 \mathrm{Ne}+0 \mathrm{~S}$ & $2.00 e+05$ & $2.008+05$ & $2.808+06$ \\
\hline Thonem-2.30 & $1096-02$ & $100+-02$ & | $09 E-02$ & IDOE- -22 & I O9E-02 & 1 ose-02 & I (ABE-12 & 1 (19)-02 & $1.09 e-02$ & $1098-02$ & $2.002+106$ \\
\hline Nhanum 2 K & 1 XEE+07 & [ 9XE+1)] & | 96E+07 & $196 E+07$ & 196E+07 & $196 \mathrm{EE}+107$ & | 96E+107 & 1 W6E+07 & $1.66+07$ & $1.96 E+07$ & $7718+\infty$ \\
\hline Tow dose & $7.76 E+11$ & $776 E+11$ & $7.76 E+11$ & $776 E+11$ & $7.76 \mathrm{E}+11$ & $7.76 E+11$ & $7.76 E+11$ & $7.76 \mathrm{E}+11$ & $7.768+11$ & $7.76 E+11$ & $7.77 \mathrm{E}+11$ \\
\hline tholoractuls & $2 \times 5+x_{2}$ & $1262+12$ & $77^{8}+12$ & $2768+12$ & $2768+12$ & $2768+12$ & $276 \%+12$ & $2368+12$ & $2 \pi 68+12$ & $2768+12$ & $2 \pi:+12$ \\
\hline
\end{tabular}

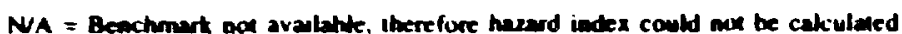


TABLE 7-10C-Baseline Average Hazard Indices for X-10 Terrestrial Onganisms

\begin{tabular}{|c|c|c|c|c|c|c|c|c|c|c|c|}
\hline \multicolumn{12}{|c|}{ 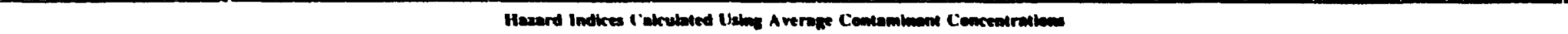 } \\
\hline & Manse & Renade & Deer & Ind. Bat & Roungin & Cienese & C: Hawk & Oaprey & Mhin & Corewe & Vesotimas. \\
\hline Atumasem & NA & NA & NA & NA & NA & NA & NA & NA & NA & NA & $6.628 \ln _{03}$ \\
\hline Benwm & $104 E+\infty$ & $2.01 E+00$ & $2.31 E+\infty 0$ & $1.2 .3 \mathrm{E}+00$ & 2.018 .00 & $5.29 \varepsilon+\infty$ & $360 E-02$ & $165 \mathrm{E}-01$ & $5.19 \mathrm{E}-01$ & $5.56 E-02$ & $4.72 \mathrm{E}-01$ \\
\hline Beryihum & $222 \mathrm{E}-0 \mathrm{~A}$ & $292 \mathrm{E}-14$ & $516 E-134$ & $177 \mathrm{E}-04$ & $232 \mathrm{E}-1 \mathrm{M}$ & A IIE-0A & 2.RME-MA & $4.81 E-03$ & 1.85E-02 & $444 E-04$ & NA \\
\hline Cadmum & $7.318+00$ & $6.602+00$ & $1.88 E+01$ & $1.02 \mathrm{E}+01$ & $8.84 \mathrm{~B}+00$ & $8.498+01$ & $1.07 E-02$ & $4.228+01$ & $6.398+01$ & $4.01 E-01$ & $3.3 \operatorname{man} 00$ \\
\hline Omumum & $194 \mathrm{E}-02$ & $40 \mathrm{ONE}-02$ & $193 \mathrm{E}-02$ & $322 \mathrm{E}-0.1$ & $7.08 E-02$ & | OOE-0| & S. $40 \mathrm{E}-04$ & $9.38 \mathrm{E}-0.3$ & $? .62 \mathrm{E}-02$ & $8.39 \mathrm{E}-04$ & $7.000-01$ \\
\hline Copper & 1 46E-02 & $432 E-05$ & $|B| E-0.3$ & $1 / 6 E-1) 2$ & $1.52 E-02$ & $6008 E-05$ & $14.1 \mathrm{E}-0.3$ & $1.78 E-0.3$ & I. SSE-01 & 6.57E-0. & NA \\
\hline Lead & 1. $7 \mathrm{me}+\infty$ & $2.338+00$ & $\triangle 11 E+\infty 0$ & $1.41 E+00$ & $56.3 E-01$ & $5.39 \mathrm{E}-04$ & $3.77 E-04$ & $3,10 \mathrm{e}-02$ & $7.63 \mathrm{E}+02$ & $3.538+\infty 0$ & NA \\
\hline Lintivm & NA & NA & NA & NA & NA & NA & NA & NA & NA & NA & $2.69: 401$ \\
\hline Magneswm & 7 59E-O1 & $1.168+00$ & $1.78 E+00$ & $867 \mathrm{E}-01$ & 7 S.SEE-0I & $2.488+00$ & I.6.1E-02 & $6 \mathrm{BOE}-01$ & $2.728+\infty 0$ & $2.558-02$ & NA \\
\hline Monegerese & $1292+\infty$ & $2.362+\infty 0$ & $3.062+\infty 0$ & $1.65 \mathrm{E}+00$ & $2.00 \mathrm{~g}+00$ & $598 \mathrm{E}+00$ & $2.07 E-02$ & $6.722+00$ & 2.758+01 & $3208-02$ & $2.052-01$ \\
\hline Mencury & $S|A E-0|$ & $5.118+02$ & $687 E+01$ & 7 70E-01 & $1.69 \mathrm{E}+00$ & | $448+0 \mid$ & $442 E-0\}$ & 0.00 & $2.018+00$ & $6.018+00$ & 9.600000 \\
\hline Nickel & $201 \mathrm{E}-02$ & $13 \mathrm{E}-02$ & $124 \mathrm{~F}-02$ & I IIE-02 & 4. 12E-01 & $7 / 1 \mathrm{E}-(1) 1$ & $592 \mathrm{E}-04$ & $4.6 .5 \mathrm{E}-02$ & | 95E. 12 & $1018-04$ & $2.559+00$ \\
\hline Scheanum & $200 E-01$ & $2 \sim 4 E-01$ & 4 SAE-01 & $|605-01|$ & $3.65 E-012$ & $64 \mathrm{HE}-112$ & $4.52 \mathrm{E}-02$ & $6.27 \mathrm{~B}+100$ & $1.538+02$ & $4.17 \mathrm{E}-01$ & NA \\
\hline Vandmen & 4 BoE-01 & $1.01 E+\infty 0$ & $4.42 \mathrm{E}-01$ & $585 E-02$ & $1.8 .1 \mathrm{E}+\infty$ & $2.788+00$ & $4 x[-0.3$ & 4.39E-02 & $1608-0 \mid$ & $7318-0.3$ & $1.098+00$ \\
\hline $2 x$ & 1 12E-02 & $\mid$ SME-0| & $238 E-01$ & $|46 E-0|$ & $814 E-102$ & 4.04E-011 & $2.74 E-M$ & $306 E-01$ & $1.268+\infty 0$ & $1.12 \mathrm{E}-03$ & $7718-01$ \\
\hline & $2112+00$ & $1518 \times 00$ & $182 \mathrm{~g}+00$ & 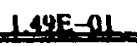 & $8 \times 2+m$ & $1258+01$ & $9,201=-12$ & $3698=01$ & Wham & $|A 38=0|$ & NA \\
\hline
\end{tabular}

\begin{tabular}{|c|c|c|c|c|c|c|c|c|c|c|c|}
\hline \multicolumn{12}{|c|}{ 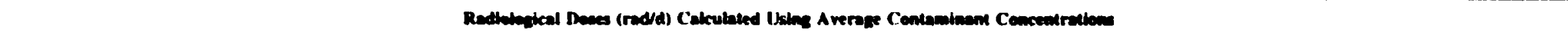 } \\
\hline & Mnere & Reman & Deer & Ind. An & Reala & (ieme & C.Hawt & Ouprey & Minar & Cegren & Venperion \\
\hline Cesum-137 & 8 IIE+00 & 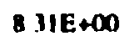 & $8.11 E+\infty$ & Q ME+OO & X.31E+(x) & 8.31E+100 & A. $31 E+10$ & $8.31 E+\infty$ & $8.31 E+00$ & $8.31 E+100$ & $8.54++\infty 0$ \\
\hline Cotan 60 & $275 E-01$ & $27 S E-01$ & $275 E-01$ & $275 \mathrm{E}-01$ & 2.79E-01 & $275 E-01$ & $2.7 \mathrm{SE}-01$ & $275 E-01$ & $2.75 E-01$ & $275 \mathrm{e}-01$ & $2 . m \mathrm{e}-01$ \\
\hline Rullesoum-106 & $100 E+02$ & $100 E+02$ & $100 x+02$ & 1 OOE+02 & $100 E+02$ & $100 E+02$ & $1.00 E+02$ & $1.002+02$ & $1,00 \mathrm{E}+\mathrm{m}$ & $100 \mathrm{E}+02$ & $1.038+12$ \\
\hline Strominen 90 & $\triangle O O A+C O$ & A OXENDO & $400 E+100$ & 4 OXE+(00 & $400 E+100$ & $4.00 E+(00$ & $400 E+00$ & $4.002+00$ & $4.00 \mathrm{E}+00$ & $4.002+100$ & $7.369+00$ \\
\hline Total dose & | I3E+02 & I I.3E+02 & I I.1E+02 & $1,1, E+112$ & 1.1.3E+102 & | |,.3E+02 & 1.1.3E+02 & 1. 1.1.E+02 & 1.1.3E+02 & | | YE+02 & $1.202+02$ \\
\hline ברים & $14120+03$ & $128+03$ & $1,128+01$ & 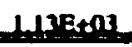 & $1,138+03$ & $1,128+03$ & 1,128403 & $11^{2} 8+03$ & $1+19: 40$ & ll12:40m & $1.20 \mathrm{ten}$ \\
\hline
\end{tabular}




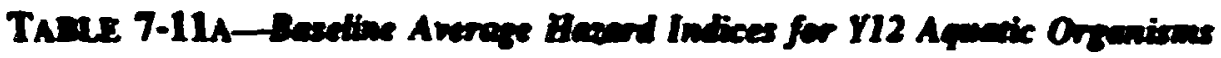

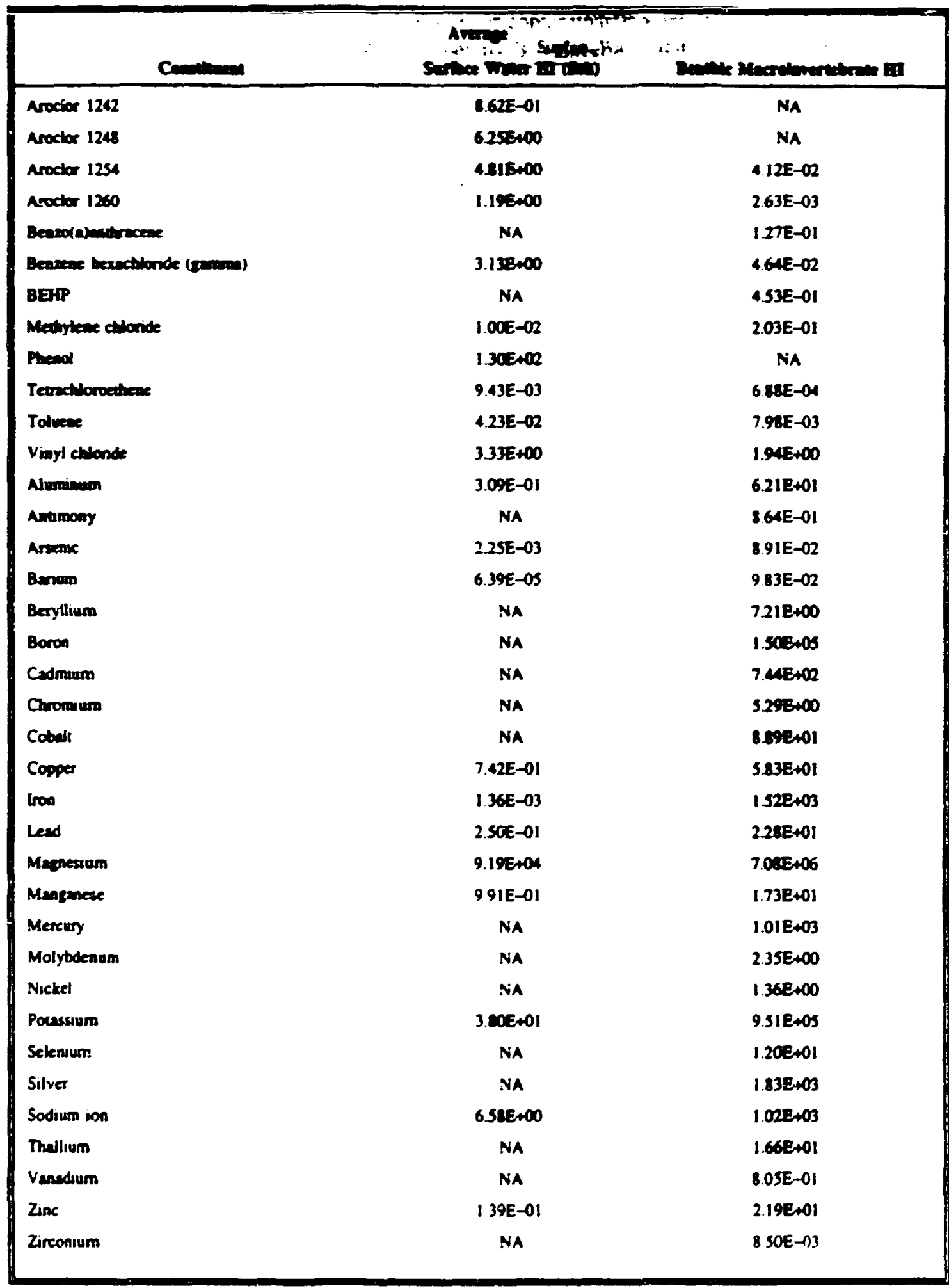

$N / A=$ Benchmet nor aveslable, therefore hazand index could not be calculated 
TABuE 7-11B-Baselime Average Herend Indices for K25 Agmatic Organisus

\begin{tabular}{|c|c|c|}
\hline Cencibout & $\begin{array}{l}\text { Averes } \\
\text { (and) }\end{array}$ & 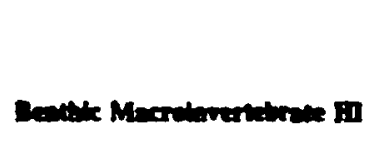 \\
\hline BEHP & NA & $8.47 \mathrm{E} * 00$ \\
\hline Alunisum & NA & $2.7 \times 2+02$ \\
\hline Arsenic & NA & 7.45E-02 \\
\hline Beriam & NA & $2.65 E-02$ \\
\hline Deryliam & NA & 4.86E-01 \\
\hline Baroa & NA & $381 E+03$ \\
\hline Codasiun & NA & $627 \varepsilon+01$ \\
\hline Chromiun & NA & $1.402+02$ \\
\hline Cobelt & NA & $126=102$ \\
\hline Copper & NA & $3.03 E+102$ \\
\hline Iros & NA & $1.90 E+03$ \\
\hline Lead & NA & $8.25 E+00$ \\
\hline Mapresium & NA & $7.048+06$ \\
\hline Marpanese & NA & 1. $\mid 4 E+01$ \\
\hline Mercury & NA & 5.95E +01 \\
\hline Malytudesom & NA & $1.39 E+\infty 0$ \\
\hline Nictel & NA & I.8TE+OI \\
\hline Potastium & NA & $6.64 E+06$ \\
\hline Selenum & NA & $5.72 E+\infty 0$ \\
\hline Silver & NA & $1.392+02$ \\
\hline Vanedium & NA & $1.07 E+\infty 0$ \\
\hline Zinc & NA & $9.8 \mid E+0\}$ \\
\hline
\end{tabular}

$N / A$ = Beachonert not available, thesefore hazerd index could not be calculated 


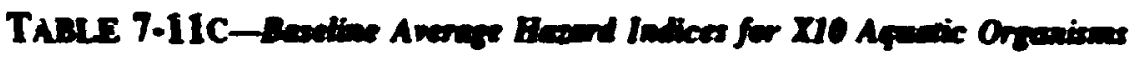

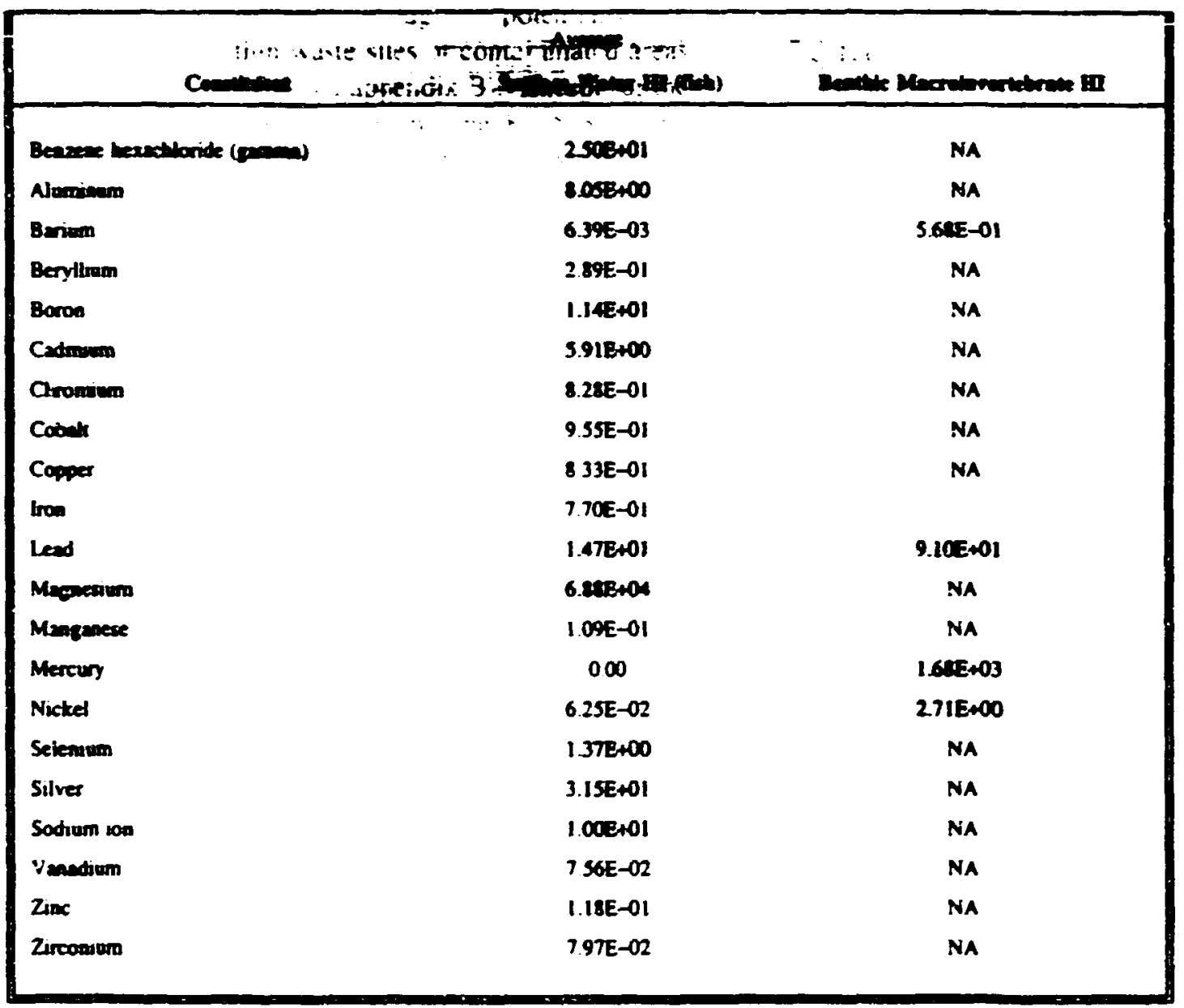

N/A = Benchrant not available. therefore hazard index could not be calculated 
TABL.E. 7-12A-Baseline Average Internal and External Radiological Doses for Y12 Aquatic Organisms (rad)

\begin{tabular}{|c|c|c|c|c|c|}
\hline & External & Internal Plants & $\begin{array}{c}\text { Inlernal } \\
\text { Invertebratea }\end{array}$ & Intermal Fath & Toternal Muakrals \\
\hline Curium-244 & $0 . \overline{00}$ & $\overline{0(0)}$ & 7.57E-05 & 0.00 & $\overline{\mathbf{0 . 0 0}}$ \\
\hline Strontium-9) & $0 .(x)$ & $0 .(x)$ & $7.846:-117$ & 0.000 & $0 .(x)$ \\
\hline Tunal dose & 0.00 & $0 .(x)$ & $4.64 \mathrm{E}-0.5$ & 0.00 & $0 .(x)$ \\
\hline
\end{tabular}

TABLE 7-12B--Baseline Average Internal and External Radiological Doses for K25 Aquatic Onganisms (nad/d)

\begin{tabular}{|c|c|c|c|c|c|}
\hline & External & Internal Ptants & $\begin{array}{c}\text { Internal } \\
\text { Invertebrates }\end{array}$ & Internal Frh & Internad Muskrats \\
\hline Cesium-137 & 0.00 & 0.00 & $2.00 \mathrm{e}-05$ & 0.00 & 0.00 \\
\hline Plutonium-238 & 0.00 & 0.00 & $1.45 E-04$ & 0.00 & 0.00 \\
\hline Strontiuni-90 & 0.00 & $0 .(0)$ & $1.23 \mathrm{E}+(x)$ & 0.00 & 0.00 \\
\hline Technecium-99 & 0.00 & 0.00 & $.3 .83 \mathrm{E}-02$ & 0.00 & 0.00 \\
\hline Tutal doses ( rad/d) & $0 .(x)$ & $0 .(x)$ & $1.23 \mathrm{E}+06$ & 0.100 & 0.00 \\
\hline
\end{tabular}

TABLE 7-12C-Baselime Average Internal and Extermal Rediological Dases for X10 Aqmatic Organisms (rudd)

\begin{tabular}{|c|c|c|c|c|c|}
\hline & External & Internal Planta & $\begin{array}{c}\text { Internal } \\
\text { Invertebrates }\end{array}$ & Internd Diah & Internad Muakrnt: \\
\hline Cesium-137 & $9.86 \mathrm{E}-0.5$ & $7.236-(0.3$ & 0.00 & $3.62 \mathrm{E}-02$ & $5.10 \mathrm{E}-02$ \\
\hline Coball-on) & $6.71 E-(1) 4$ & $7.82 E-(1) 2$ & 0.10 & $7.82 \mathrm{E}-03$ & $1.54 E-(1) 2$ \\
\hline Simntium-9) & $7.12 \mathrm{E}-10$ & $7.125-(1) 7$ & $0 .(\mathrm{x})$ & $7.12 \mathrm{E}-(\mathbf{9 9}$ & $3.13 \mathrm{E}-106$ \\
\hline Total choses (rad/d) & $7.69 \mathrm{~F}-04$ & 8.55E-(1)2 & 0.00 & $4.401:-112$ & $6.6 .35-02$ \\
\hline
\end{tabular}


cardidate species), the cotton tuil rabbit. the dee: inwuse, equatic species. and mink have horne ranges sinall enough to poventially live

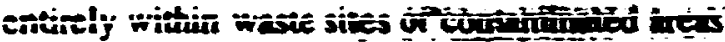

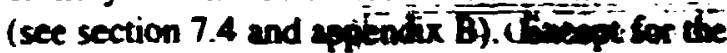
coyote for the Y-12 Ptant, the K-25 Sice, and $X-10$, and for the Canada goose at $X-10$, other ieriestrially based receptors have home nages greater than an individual typical waste site but less than the total area inclusive of most waste sites or the waste complex. The coyote home range is greater than the waste complex of each facility. and the estimated home range of the Canada goose is greater than the waste complex at X-10. Based on the assumptions discussed in section 7.5, appropriate correction factors were applied to Hls in tables ?-10 a, b. c: 7-11 a, b. $\mathrm{c}$ and $7-12 \mathrm{a}, \mathrm{b}, \mathrm{c}$ to estimate severity of risks to endpoints which occupy waste sites or contaminated areas for the three sets of source terms (tables 7-92,b,c). Risks were considered modere.: for HIs from 1 to 10 and severe for Hls greater than 10. No correction factor was used for receptors with home ranges or temitories less than a representative waste site. or for aquatic organisms or vegetation. As discussed in section 7.5. no correction factor was used for mink at the $Y-12$ Plant or $X-10$ or for the Indiana bat, which could occur only at the $Y-12$ Plant. For all other receptors at the Y-12 Plant except the coyoce, a correction factor of 0.2 was used. For all other receptors at X-10 except the coyore and Canada goose. a correction factor of 0.15 was used. For the remaining receptors, a correction factor was determined by dividing the total area in all waste sites or contaminated streams and ponds by home range to approximate the percentage of contaminated home range. See appendix B for further discussion of correction factors.

Some contaminants may be highly localized, but data are lacking for theis areal distribution. For example, of the contaminants which the analyses indicate result in moderate to severe riske, source terms for cyanide and copper represent less than 0.006 ha ( .02 acres) of contaminated land (appendix B). Source terms for other soil contaminants range from 0.07 ha $(0.2$ acres) to 68 ha $(170$ acres). Although data for most contaminants were reported for only some of the total area in waste sites, the data were assumed to be representative. The averaged source terms used in the risk analysis were, therefore. assumed to be present in all waste sites or contuminated areas (appendix B).

\section{Is.iAi Y-iz Fiant.}

Threatened and Endanrered Species. Risks to some threatened and endangered species would be moderate or severe if individuals occupy waste sites or contaminated areas (table 7-13a). Potentially severe risks would be present from cadmium and the sum of radioactive contaminants for the endangered Indiana bas and candidate songbirds. Risks woul' also be severe to the candidate songbirds from thallium and to the candidate Bewick's wren from lead Potentially moderate risks would be present from these and other contaminants to all listed and candidare wildlife species (table 7-13a). There is no suitable babitat for candidate plant species in or near the contaminated or waste sites at the Y-12 Plant included in the analyses. Although the analyses indicated potential risks to species. a site-specific survey of individual waste sites for occurrences of threatened and endangered species would be necessary to determine if there are actual risks.

75.1.4.2 Wethnds Risks to wetlands receptors (e.g. nonbenthic aquatic life and benthic macroinvencbrates) would be severe from 18 contaminants in waste ponds and streams and moderate from an additional 9 contaminants (table 7-13b). The total area of wetlands affected by contaminants at the $Y-12$ Plant is un:vailable but is assumed to be proportional to the total area of contaminated water at the Y.12 Plant, which is about 40 to 80 ha (100 to 200 acres) or about one-third to onehalf of the surface area of watei in streams. embayments, and conds on the ORR.

\subsection{Recreational Species. For some} recreasional species occupying waste sites or contaminated areas, risks from $\mathrm{Cd}, \mathrm{Pb}, \mathrm{Hg}$. $\mathrm{Ti}$. and toeal radioactive contaminants would be severe (lable 7-13c). Additional moderate risks would also be possible from manganese and selenium. Risks to individuals that do not occupy waste sites or contaminated areas would be negligible.

75.1.4.4 Aerriculture. Aluminum, $\mathrm{Cd}, \mathrm{Li}$. Hg. Ag. Ti, and total radiological contaminants would pose severe risks to vegetation (e.g. hay or timber) growing in waste sites or 
TABLE 7.13A-Basctine podential riskn' to threatened, endengered and candidane species' that .

\begin{tabular}{|c|c|c|c|}
\hline \multirow[b]{2}{*}{ Combanmant } & \multirow[b]{2}{*}{ Indtane bet } & \multicolumn{2}{|c|}{ Candidale Soogbints' } \\
\hline & & resident & migraxt \\
\hline Cadmium & $\mathbf{S}^{\mathbf{s}}$ & $\mathbf{s}$ & $\mathbf{S}$ \\
\hline Lead & $\mathbf{M}$ & $\mathbf{S}$ & M \\
\hline Mangarese & M & $\mathbf{M}$ & $\mathbf{M}$ \\
\hline Mercury & & $\mathbf{M}$ & M \\
\hline Thallium & & $\boldsymbol{s}$ & $\mathbf{S}$ \\
\hline Radiological & $\mathbf{s}$ & $\mathbf{S}$ & $\mathbf{S}$ \\
\hline
\end{tabular}

1 Risks based on assumprions discussed in Section 7.4 .

: The candidate hellbender and peddlefish only occur in the river reservoirs for which no source term data were available. No candidare plank species habila is in waste sites or contaminated areas.

${ }^{\prime}$ Candidace songtinds are Bewick's wren and Bxhman's sparrow. Rists were estimated from risks to the robin.

- $M=$ moderace. $S=$ severe.

Note: Rists to individuals that do not occupy waste sites are negligible. Waste sites and contaminated areas associated with $Y-12$ account for less than 1.5\% of the land area and one third to one half of the streams and ponds on the ORR 


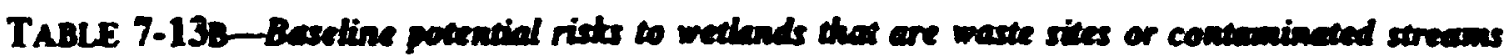
and seationents on the Y-12 Site.

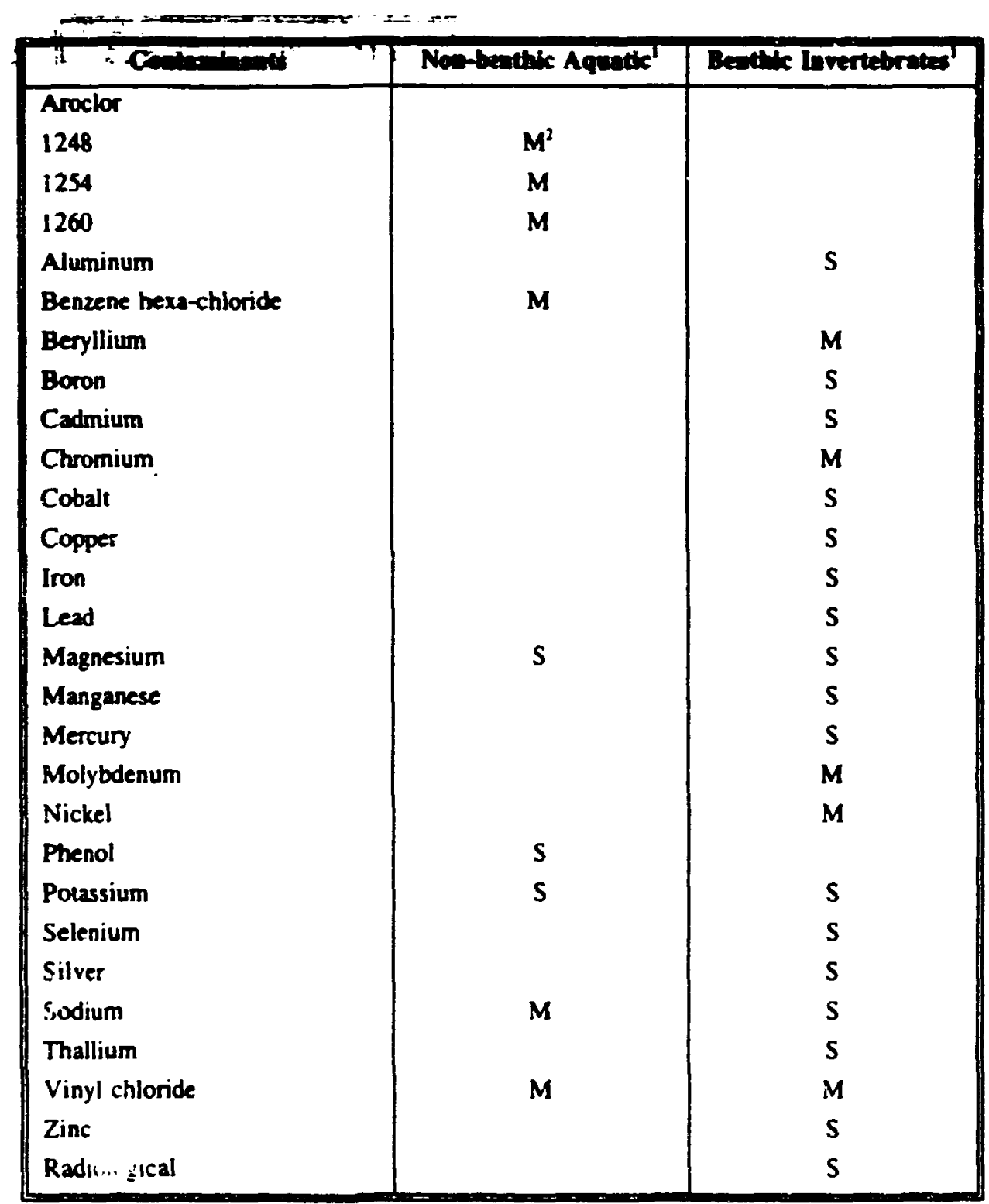

- Based on EPA Water Quality Criteria (Suler et a! 1992). We assume that benthic invertebrates are exposed to pore water concentrations while other wetland (aquatic) organisms are exposed to surface water.

: $M=$ moderale. $S=$ severe.

Nole: Sourse terms were not available for other wetiands; therefore we assume nsks to other wetlands are negligible. 
TABLE 7-13C-Basetine marimum potential risks to recreanional wildife that occuppy waste sites or contaminated areas on the Y-12 Site.

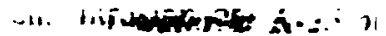

\begin{tabular}{|c|c|c|c|c|}
\hline & $\begin{array}{c}\text { Cottontall } \\
\text { Rabbit }\end{array}$ & $\begin{array}{c}\text { White-talled } \\
\text { Deer }\end{array}$ & Cande Goose & Coyote \\
\hline Cadmium & $S^{\prime}$ & S & S & \\
\hline Lead & $S$ & $\mathbf{M}$ & & \\
\hline Manganese & $\mathbf{M}$ & $\mathbf{M}$ & $\mathbf{M}$ & \\
\hline Mercury & $\mathbf{S}$ & S & $\mathbf{M}$ & $\mathbf{M}$ \\
\hline Selenium & $\mathbf{M}$ & & & \\
\hline Thallium & $\mathbf{S}$ & $\mathbf{M}$ & $\mathbf{M}$ & \\
\hline Radiological & $\mathbf{S}$ & $\mathbf{S}$ & $\mathbf{S}$ & $S$ \\
\hline
\end{tabular}

' $\mathbf{M}=$ moderate. $\mathbf{S}=$ severe

Nore: $R$ s.ts to individuals that do not orcupy waste sites or contaminated areas are negligible.

TABLE 7-13D-Baseline potential risks to hay and timber that grow on waste sites or contaminated areas on the Y.12 Sice.

\begin{tabular}{|l|c|}
\hline Contaminant & Vegetation \\
\hline Aluminum & $\mathbf{S}^{\prime}$ \\
Antimony & $\mathrm{M}$ \\
Cadmium & $\mathrm{S}$ \\
Iron & $\mathrm{M}$ \\
Lithium & $\mathrm{S}$ \\
Mercury & $\mathrm{S}$ \\
Selenium & $\mathrm{M}$ \\
Silver & $\mathrm{S}$ \\
Thallium & $\mathrm{S}$ \\
Radiological & $\mathrm{S}$ \\
\hline
\end{tabular}

I $M=$ moderate. $S$ = severe.

Note: No hay is harvested from contaminated areas, and timber is not grown on the ORR for commercial harvest. Therefore. baseline risks to agriculture and timber production are negligible. 


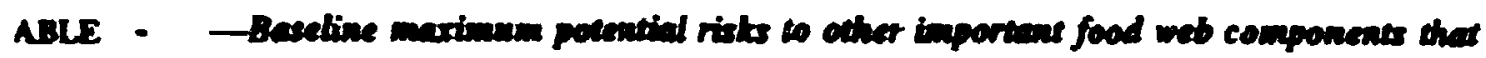
accupg waste sites or combinivated aress on the Y.12 Site.

\begin{tabular}{|c|c|c|c|c|c|}
\hline sin naser & "Mom & $\begin{array}{l}\text { Cooper's } \\
\text { Hewt }\end{array}$ & Osprey & Mhat & Robha \\
\hline Aroclor & & & & & \\
\hline 1016 & & & $S^{\prime}$ & $S$ & \\
\hline 1242 & & & & $\mathbf{S}$ & \\
\hline 1248 & & & $\mathbf{S}$ & $\mathbf{S}$ & \\
\hline 1254 & & & & $\mathbf{S}$ & \\
\hline 1260 & & & $S$ & $S$ & \\
\hline DDE & & & $\mathbf{M}$ & $\mathbf{S}$ & \\
\hline DDT & & & $\mathbf{M}$ & $\mathbf{S}$ & \\
\hline Cadmium & $\mathbf{S}$ & & & & $\mathbf{S}$ \\
\hline Lead & S & & & $\mathbf{S}$ & $\mathbf{M}$ \\
\hline Magnesium & & & & $\mathbf{M}$ & \\
\hline Manganese & $\mathbf{M}$ & & $\mathbf{S}$ & $\mathbf{S}$ & $\mathbf{M}$ \\
\hline Mercury & & & & $\mathbf{M}$ & \\
\hline Thallium & $\mathbf{M}$ & & & & $\mathbf{M}$ \\
\hline Zinc & & & & M & \\
\hline Radiological & $\mathbf{S}$ & 5 & $\mathbf{S}$ & $\mathbf{S}$ & $\mathbf{S}$ \\
\hline
\end{tabular}

I $M=$ moderate. $S$ = severe.

Note: Risks to individuals that do not occupy waste sites and contaminated areas are negligible. 
contaminated areas (table 7-13d). Similarly, Sb, Fe, L, and S., would pose monerate risks to vegetation. Hay is not harvested in waste sites or other contaminated areas; therefore, potential risks to agriculture on the ORR are negligible. Similarly, trees are not grown for timber harvest on the ORR, and risks to forestry would be negligible.

\subsubsection{Public Londs. Because risks to} receptor species in the food web were assumed to be negligible unless receptors occupy waste sites or contaminated areas and because Clark Center Park is more than $1.6 \mathrm{~km}$ ( 1 mile) from the nearest waste sites, risks to public lands would be negligible for food web components with small home ranges. Wide-ranging species such as coyote, hawks, deer, and geese could be foraging in waste sites or contaminated areas and also foraging in public lands. Therefore, this endpoint could experience risks comparable to those for other endpoints because source terms for the impounded river were not included, risks to fish in public access areas downstream from Y-12 were not estimated.

\subsubsection{Biodiversity. Risks to overall} biodiversity of the forest ecosystem on the reservation would be negligible because waste sites and contaminated areas reported in the source term data base occupy only about $1.5 \%$ of the total land area. Risks to receptors in stream ecosystems and associated wetlands and floodplains could be substantial, potentially affecting as much as one-half of these areas (see section 7.4). As there are for other endpoints, there could be risks to some receptors important to biodiversity in waste sites. In addition to the receptor species discussed previously, Aroclor (all five forms). DDE, DDT, Cd, PI, Mn, and total radiological contaminants pose pots,ntially severe risks, and $\mathrm{Mg} . \mathrm{Hg}$, and $\mathrm{Zn}$ pose potentially moderate risks to other wildlife that could occupy waste sites (table 7-13e). The kingfisher and great blue heron, two birds that feed exclusively on aquatic life in streams and embayments, could feed exclusively in contaminated streams and experience risks similar to those estimated for the osprey (Landrum et al. 1993).

The Y-12 facility occupies less than $5 \%$ of the ORR, and public roads and utility and railroad rights-of-way occupy an additional small fraction. These disturbed sites provide

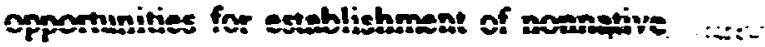

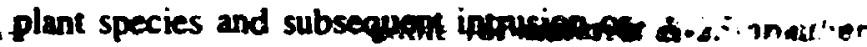
expansion of populations of these phissoinfaripils. surrounding narive plant communities.

\subsubsection{K-25 Site}

\subsection{Threntened and Endingered}

Species. Risks to some threatened and endangered species would be moderate or severe if individuals occupy waste sites (table 7-14a). Potentially severe risks to the candidate songbirds would be present from exposure to copper, lead, and the sum of radioactive contaminants and for the Indiana bat from radioactive contaminants. Potentially moderate risks would be present from these and other contaminants to candidate bird species (table 7-14a). No suitable habitat for candidate plant species exists in or near the contaminated or waste sites at the K-25 Site. Although the analyses indicated potential risks to species, a site-specific survey of individual waste sites for occurrences of threatened and endangered species would be necessary to determine if there are actual risks.

7.5.1.5.2 Wetlands. No source term data for water were included in the source terms for the K-25 Site. Risks to benthic macroinvertebrates in wetlands would be severe from 14 contaminants in waste ponds and streams and moderate from an additional 6 contaminants (table 7-14b). The total area of wetlands affec $:-t$ by the K-25 Site was not known, but it is assumed to be proportional to the total area of contaminated stream sediment at the K-25 Site reported in the source term data base, which is about 2.6 ha (6.5 acres) or less than 1\% of the area of water in streams. embayments, and ponds on the ORR. Only 0.3 ha ( 0.8 acres) of the total is stream environment; the remainder is waste ponds.

\subsection{Recreational Species. For some} recreational species occupying waste sites or contaminated areas, risks from lead and total radioactive contaminants would be severe (table 7-14c). Additional moderate risks would also be possible from $\mathrm{Be}, \mathrm{Cd}, \mathrm{Mn}, \mathrm{Hg}$, and Se. Risks to individuals that do not occupy waste sites or contaminated areas would be negligible. 


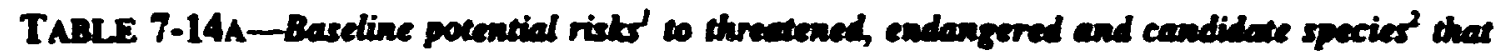

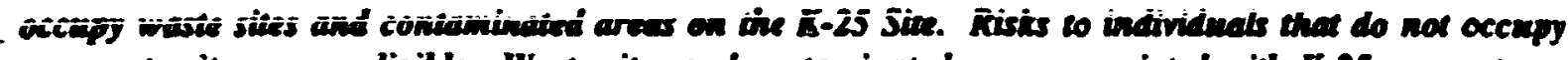
weste sites are nogligible. Waste sites and contanimated aress associnted with K-25 account for less than $1.5 \%$ of the ORR

\begin{tabular}{|c|c|c|c|}
\hline \multirow[b]{2}{*}{ Contaminant } & \multirow[b]{2}{*}{ Indiann Bat } & \multicolumn{2}{|c|}{ Caodidnte Somgbirds' } \\
\hline & & Rexident & Migrant \\
\hline Barium & & $\mathbf{M}^{\prime}$ & \\
\hline Cadmium & & $\mathbf{M}$ & \\
\hline Copper & & $\mathbf{S}$ & $\mathbf{M}$ \\
\hline Lead & & $\mathbf{S}$ & $\mathbf{M}$ \\
\hline Manganese & & $\mathbf{M}$ & $\mathbf{M}$ \\
\hline Vanadium & & $\mathbf{M}$ & $\mathbf{M}$ \\
\hline Radiological & $\mathbf{s}$ & $\mathbf{S}$ & $\mathbf{S}$ \\
\hline
\end{tabular}

' Risks based on assumptions discussed in Section 7.4.

'The candidate hellbender and paddlefish only occur in the rivet reservoirs for which no source term data were available. No candidate plant species habitat is in waste sites or contaminated areas.

${ }^{3}$ Bewick's wren and Bachman's sparrow represented by the robin in our analyses

- $M=$ moderaic. $S$ = severe 


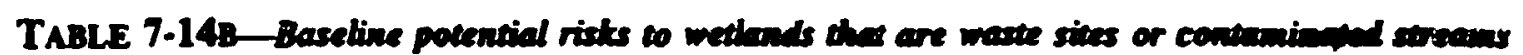

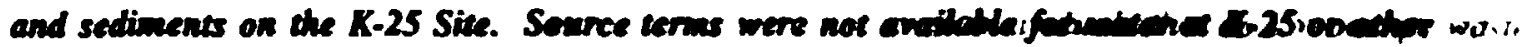

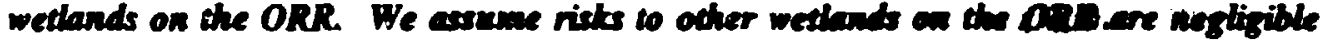

\begin{tabular}{|c|c|}
\hline Contaningonts & Dendelc Invertubrates' \\
\hline Aluminum & $S^{2}$ \\
\hline BEHP & $\mathbf{M}$ \\
\hline Boron & $\mathbf{S}$ \\
\hline Cadmium & $\mathbf{S}$ \\
\hline Chromium & $\mathbf{S}$ \\
\hline Cobalt & $\mathbf{S}$ \\
\hline Copper & $\mathbf{S}$ \\
\hline Iron & $\mathbf{S}$ \\
\hline Lead & $\mathbf{M}$ \\
\hline Magnesium & $\mathbf{S}$ \\
\hline Manganese & $\mathbf{S}$ \\
\hline Mercury & $\mathbf{S}$ \\
\hline Molybdenum & $\mathbf{M}$ \\
\hline Nickel & $\mathbf{M}$ \\
\hline Potassium & $\mathbf{S}$ \\
\hline Selenium & $M$ \\
\hline Silvet & $\mathbf{S}$ \\
\hline Vanadium & M \\
\hline Vinc & $\mathbf{S}$ \\
\hline Radiological & $\mathbf{S}$ \\
\hline
\end{tabular}

Based on EPA Water Quality Criteria (Suter et al. 1992). We assume that benthic invertebrates are exposed to pore water concentrations while other wetland (aquatic) organisms are exposed to surface water.

: $M=$ moderate. $S$ = severe 


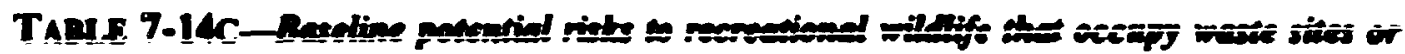

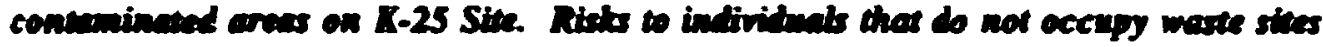
or conteminned areas are negligible

\begin{tabular}{|c|c|c|c|c|}
\hline & Cottonend Rabsin & White-taned Deer & Canodn Goose & Coyocie \\
\hline Barium & $\mathbf{M}$ & & & \\
\hline C.mium & $\mathbf{M}$ & & $\mathbf{M}$ & \\
\hline Lead & $\mathbf{S}$ & $\mathbf{M}$ & & \\
\hline Manganese & $\mathbf{M}$ & & $\mathbf{M}$ & \\
\hline Mercury & M & & & \\
\hline Vanadium & $\mathbf{M}$ & & & \\
\hline Radiological & $\mathbf{S}$ & $\mathbf{S}$ & $\mathbf{S}$ & $\mathbf{S}$ \\
\hline
\end{tabular}

' $M=$ moderate. $S=$ severe.

TABLE 7-14D-Baseline potential risks to hay and timber that grow on waste sites or contaminated areas on K-25 Site. No hay is harvested from contominated areas, and timber is not grown on the ORR for commercial harvest. Therefore, baseline rists to agriculture and timber production are negligible

\begin{tabular}{|l|c|}
\hline \multicolumn{1}{|c|}{ Contaminants } & Vegetation \\
\hline Aluminum & $\mathbf{S}^{\mathbf{1}}$ \\
Antimony & $\mathrm{M}$ \\
Copper & $\mathrm{M}$ \\
Iron & $M$ \\
Lithium & $M$ \\
Mercury & $M$ \\
Selenium & $M$ \\
Vanadium & $M$ \\
Zinc & $M$ \\
Radiological & $M$ \\
\hline
\end{tabular}

$M=$ moderace. $S=$ severe 


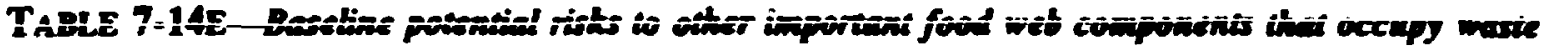

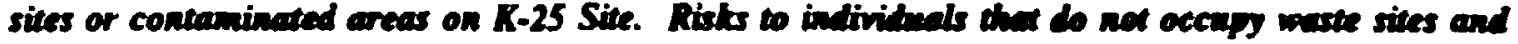
contaninated areas are megligisle

\begin{tabular}{|l|c|c|c|c|}
\hline & Moase & Cooper's Hank & Oaprey & Mink \\
\hline Cadmium & $M^{\prime}$ & & & \\
Copper & $M$ & & & \\
Lead & S & & & \\
Manganese & M & & & \\
Radiological & S & S & S & S \\
\hline
\end{tabular}

' $M=$ moderate. $S=$ severe

7.5.1.5.4 Arriculture. Aluminum and total radiological contaminants would pose severe risks to vegetation (e.g., hay or timber) growing in waste sites or contaminated areas (table 7-14d). Similarly, Sb, Cu, Fe, Li, Se, V, and $\mathrm{Zn}$ would pose moderate risks to vegetation. Hay is not harvested from waste sites or other contaminated areas; therefore. potential risks to agriculture on the ORR are negligible. Similarly, trees are not grown for timber harvest on the ORR, and risks to forestry would be negligible.

\subsection{Public Lands. Because risks to} receptor species in the food web were assumed to be negligible unless receptors occupy waste sites or contaminated areas, risks to public lands would be negligible for terrestrial food web components with small home ranges. Wide-ranging species such as coyote, hawks, deer, and geese could be foraging in waste sites or contaminated areas and also foraging in public lands. Therefore, this endpoint could experience risks comparable to those for other endpoints. Because source terms for the impounded river were not included, risks to fish in public access areas near the K-25 Site were not estimated.

7.5.1.5.6 Blodiversity. Risks to overall biodiversity of the forest ecosystem on the reservation would also be negligible because waste sites and contaminated areas reported in the source term data base occupy only about $1.5 \%$ of the rotal land area. Risks to receptors in stream ecosystems and associated wetlands and floodplains would be negligible because of the smail area of stream habitat affected $[<0.3$ ha ( 0.7 acres)]. As there are for other endpoints, there could be risks to some receptors important to biodiversity in waste sites. In addition to the receptor species discussed previously, $\mathrm{Pb}$ and total radiological contaminants pose potentially severe risks, and $\mathrm{Cd}, \mathrm{Cu}$, and $\mathrm{Mn}$ pose potentially moderate risks to other food web components that could occupy waste sites (table 7-14e).

\section{$7.5 .1 .6 \times-10$.}

\subsection{Threatened and Endangered}

Species. Risks to some threatened and en Jangered species would be moderate or severe if individuals occupy waste sites (table 7-15a). Potentially severe risks would be present from exposure to $\mathrm{Al} . \mathrm{Li}, \mathrm{Hg}$, and i.ie sum of radioactive contaminants for candidate plant species (e.g., tall larkspur). Risks would also be severe from the sum of radioactive contaminants to the candidate songbirds. Potentially moderate risks would be present from these and other contaminants to birds and plants (table 7-15a). There is no suitable habitat for the Indiana bat on or near the contaminated areas or waste sites at X-10. Although the analyses indicated potential risks to species, a site-specific survey of individual waste sites for occurtences of threatened and endangered species would be necessary to determine if there are actual risks. 


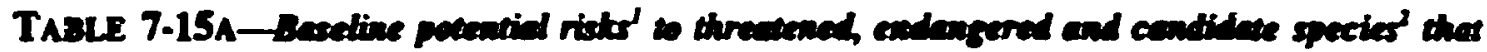

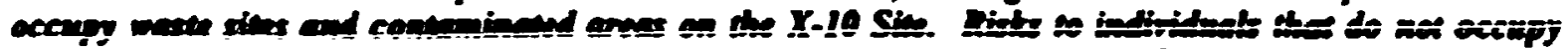

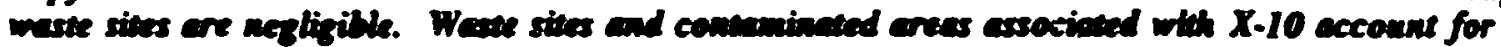
Less then 15\% of the ORR

\begin{tabular}{|c|c|c|c|}
\hline \multirow[b]{2}{*}{ Compingert } & \multicolumn{2}{|c|}{ Condilate Somplintor } & \multirow[b]{2}{*}{ Cardidate Plant Spectes" } \\
\hline & Reatiden & Mignt & \\
\hline Aluminum & & & $\mathbf{S}^{3}$ \\
\hline Barium & $\mathbf{M}$ & $\mathbf{M}$ & \\
\hline Cadmium & $\mathbf{M}$ & $\mathbf{M}$ & $\mathbf{M}$ \\
\hline Llithium & & & $\mathbf{S}$ \\
\hline Mmanganese & $\mathbf{M}$ & $\mathbf{M}$ & \\
\hline Mercury & $\mathbf{M}$ & & $\mathbf{S}$ \\
\hline Nickel & & & $\mathbf{M}$ \\
\hline Vanadium & $\mathbf{M}$ & & $\mathbf{M}$ \\
\hline Zirconium & $\mathbf{M}$ & $\mathbf{M}$ & \\
\hline Radiological & $S$ & $\mathbf{S}$ & $\mathbf{S}$ \\
\hline
\end{tabular}

' Risks based on assumptions discussed in Section 7.4

: The candidate hellbender and paddiefish only occur in the river reservoirs for which no source term data were available. No suitable habitat for the Indiana bat is found in waste sites or concaminared areas a X-10.

'Candidate songbirds are Bewick's wren and Bxhman's sparrow. Risks were estimated from risks to the robin.

- Tall larkspur represented by generic vegecacion. These risks are the same as for the timber and agricultural endpoints

" $M=$ moderate, $S=$ severe.

TABLE 7-15B-Baseline potential risks to wetlands that are waste sites or contaminated streams and sediments at X-10. Source terms were not available for other wetlands; therefore we assume risks to ocher wettands are negligible

\begin{tabular}{|c|c|c|}
\hline Contaninants & Non-Beathic Aquntic' & Benthic Invertebrates' \\
\hline Aluminum & $\mathbf{M}^{2}$ & \\
\hline Benzene hexa-chloride & $\mathbf{S}$ & \\
\hline Boron & $\mathbf{S}$ & \\
\hline Cadmium & $\mathbf{M}$ & \\
\hline Lead & $\mathbf{S}$ & $\mathbf{S}$ \\
\hline Magnesium & $\mathbf{S}$ & \\
\hline Mercury & & $\mathbf{S}$ \\
\hline Nickel & & $M$ \\
\hline Selenium & $\mathbf{M}$ & \\
\hline Silver & $\mathbf{S}$ & \\
\hline Sodium & $\mathbf{S}$ & \\
\hline
\end{tabular}

- Based on EPA Water Quality Critena (Suter et al. 1992). It was assumed that benthic invertebrates are exposed to pore water concentrations while other wetland (aquatic) organisms are exposed to surface water.

$\mathrm{M}=$ muderate. $\mathrm{S}$ = severe. 
TABLE 7-15C-Baseline maximum potential risks to recreational wildife that occupy maste sites or contaninated areas at X-10. Rists to individuals that do not occupy waste sites or

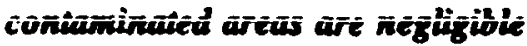

\begin{tabular}{|l|c|c|c|c|}
\hline & Cottontail Rabbit & White-Tailed Deer & Canada Goose & Coyote \\
\hline Cadmium & $\mathbf{M}^{\mathbf{3}}$ & $\mathrm{M}$ & $\mathrm{S}$ & \\
\hline Mercury & $\mathrm{S}$ & $\mathrm{S}$ & $\mathrm{M}$ & \\
\hline Zirconium & & & $\mathrm{M}$ & \\
\hline Radiological & $\mathrm{S}$ & $\mathrm{S}$ & $\mathrm{S}$ & $\mathrm{S}$ \\
\hline
\end{tabular}

' $M=$ moderate. $S$ = severe.

TABLE 7-15D—Baseline potential risks to other important food web components that occupy waste sites or contaminated areas at X-10. Risk to individuals that do not occupy waste sites and contaminated areas are negligible

\begin{tabular}{|c|c|c|c|c|c|}
\hline & Monse & Cooper's Hawt & Osprey & Mink & Rabin \\
\hline Barium & $\mathbf{M}$ & & & & \\
\hline Cadmium & $\mathbf{M}$ & & & $\mathbf{S}$ & $\mathbf{M}$ \\
\hline Lead & $\mathbf{M}$ & & & $\mathbf{S}$ & \\
\hline Magnesium & & & & $\mathbf{M}$ & \\
\hline Manganese & $\mathbf{M}$ & & & $\mathbf{s}$ & \\
\hline Mercury & & & & $\mathbf{M}$ & \\
\hline Selenium & & & & $S$ & \\
\hline Zinc & & & & $\mathbf{M}$ & \\
\hline Zirconium & $\mathbf{M}$ & & & $\mathbf{M}$ & $\mathbf{M}$ \\
\hline Radiulogical & $S$ & $\mathbf{S}$ & $S$ & $s$ & $s$ \\
\hline
\end{tabular}

Baseline potential risks to hay and tinber that grow on wase sites or contaninated areas are the same ar for pegetation shown in Table 7.16a. No hay is harvested from conlaninated areas, and imber is not grown on the ORR for commercial havest. Therefore, baseline rists to agriculuere and timber production are nigliptble

$M=$ moderate, $S=$ severe. 
75.1.6.2 Wetinnds Risks to wetlands receptors (e.g., nonbenthic amuatic life and benthic macroinvertebrates) would be severe from 7 contaminants in waste ponds and streams and moderate from an additional 4 contaminants (table 7-15b). The total area of wetlands affected by $X-i 0$, is not known but is assumed to be proportional to the total area of streams and ponds at $\mathrm{X}-10$ as estimated in section 7.4. This area is about 5 to 20 ha ( 12 1050 acres) or less than $2 \%$ of the area of water in streams, embayments, and ponds on the ORR.

\subsection{Recreational Species. For some} recreational species occupying waste sites or contaminated areas, risks from cadmium. mercury, and total radioactive contaminants would be severe (table 7-15c). Additional moderate risks would also be possible from zirconium. Risks to individuals that do not occupy waste sites or contaminated areas would be negligible.

75.1.6.4 Agriculture. Aluminum, $\mathrm{Li}, \mathrm{Hg}$. and total radiological contaminants would pose severe risks to vegetation (e.g., hay or timber) growing in waste sites or contaminated areas (table 7-15a). Similarly, Cd, Ni and V u ould pose moderate risks to vegetation. Hay is not harvested in waste sites or other contaminated areas; therefore, potential risks to agriculture on the ORR, are negligible. Similarly, trees are not grown for timber harvest on the ORR and risks to forestry would be negligible.

\subsection{Public Lands. As for the $Y-12$} Plant and the K-25 Site, risks to public lands would be negligible for terrestrial food web components with small home ranges but could exisı for wide-ranging species such as coyote. hawks, deer, and geese foraging in waste sites or contaminated areas and in public lands. Therefore, this endpoint could experience risks comparable to those for other endpoints. Because source terms for the impounded river were not included, risks to fish in public access areas near X-10 could not be estimated.

7.5.1.6.6 Blodiversity. As at the $Y-12$ Plant and the K-25 Site, risks to overall biodiversity of the forest ecosystem on the reservation would be negligible because waste sites and contaminated areas reported in the source term data hace ocrupy only ahon! !.ST of the tost land area. Risks to receptors in stream ecosystems and associated wetlands and floodplains would be negligible because of the small area of stream habitat affected [5 to 20 ha (12 to 50 acres)]. As there are for other endpoints, there could be risks to some receptors important to biodiversity in waste sites. In addition to the receptor species discussed previously, Cd, Pb, Mn, Se, and total radiological contaminants pose potentially severe risks, and $\mathrm{Ba}, \mathrm{Mg}, \mathrm{Hg}_{\mathbf{g}}, \mathrm{Zn}$, and $\mathrm{Zr}$ pose potentially moderate risks to other food web components that could occupy waste sites (table 7-15d).

\subsection{Cumulative Assessment}

\subsubsection{On-Site Baseline}

\subsubsection{Risk from Contaminants}

For 33 contaminants, Hls suggest potential risks to organisms inhabiting waste sites and contaminated streams (table 7-16). Of these contaminants, $\mathrm{Sb}, \mathrm{Li}$, and $\mathrm{Ti}$ pose risks only to vegetation. Other contaminants pose risks only to aquatic biota (benzene hexachloride, BEHP, $\mathrm{B}, \mathrm{Cr}, \mathrm{Co}, \mathrm{Mo}$, phenol, $\mathrm{K}, \mathrm{Na}$, and vinyl chloride). Aluminum. $\mathrm{Cd}, \mathrm{Cu}, \mathrm{Pb}, \mathrm{Mg}, \mathrm{Hg}$, Se, $\mathrm{Ti}, \mathrm{V}, \mathrm{Zr}$, and total radiological contaminants pose potential risks to many endpoints occupying waste sites and contaminated strearns. Some of the waste sites are highly developed areas that do not provide suitable habitat for most organisms. Actual risks associated with these sites are probably lower than indicated by the HIs. Waste ponds, however, are probably used by wildlife and waterfowl: for these organisms current exposures may be substantial. Contaminated streams flow through relatively undisturbed regions of the ORR, and risks to aquatic bioka and wildlife that feed on fish in these streams may also be substantial. For all of the sites, a future scenario involving closure of the ORR facilities without restoration would result in reoccupation of all waste sites by plants and animals; risks similar to those indicated in tables $7-13,7-14$, and $7-15$ would then be expected. 
TABLE 7-16-Comparative summang of potential an-site cumblative rists' to ecoloxical endpoinsts from baseline on the ORR. Rists are for endpoints which occupy waste sites and conduininated areas for which source terms were available?

\begin{tabular}{|c|c|c|c|c|}
\hline Source of Ret & $Y \cdot 12$ & K-25 & $\mathbf{X}-10$ & ORR \\
\hline Construction" & & & & \\
\hline Aluminum & W.F & WF & E,W.F.? & E,W,F \\
\hline Antimony & $\mathbf{F}$ & $\mathbf{F}$ & & $\mathbf{F}$ \\
\hline Arockor & W.B.P & & & W.B.P \\
\hline Barium & & $\mathbf{E}$ & ER,B & E,R.B \\
\hline Benzene hexecloride & WP & & W.P & $\mathbf{W}, \mathbf{P}$ \\
\hline BEHP & & $\mathbf{W}$ & & $\mathbf{W}$ \\
\hline Beryllium & $\mathbf{w}$ & & & $\mathbf{w}$ \\
\hline Boron & $\mathbf{w}$ & $\mathbf{w}$ & W.P & $\mathbf{W . P}$ \\
\hline Cadmium & E.W.R,F.B & E.W.R.B & E.W,R.F.P.B & E.W.R.F.P.B \\
\hline Chromium & $w$ & $\mathbf{w}$ & & $\mathbf{w}$ \\
\hline Cobalt & $\mathbf{w}$ & $\mathbf{w}$ & & $\mathbf{w}$ \\
\hline Copper & & E.W.F.B & & E.W.F,B \\
\hline DDE & B & & & B \\
\hline DDT & B & & & B \\
\hline Iron & W.F & $\mathbf{W . F}$ & & W.F \\
\hline Lead & E.W.R.B & E.W.R.B & W.P.B & E.W,R,P.B \\
\hline Lithium & $\mathbf{F}$ & $\mathbf{F}$ & E.F & E.F \\
\hline Magnesium & W.B.P & E.W & W.P.B & E,W.F.B \\
\hline Mangarese & E.W.R.B & W.R.B & E,B & E,W,R.B \\
\hline Mercury & E.W.R.F.B & W.R.F & E,W,R,F.B & E.W.R.F.B \\
\hline Molybdenum & $\mathbf{w}$ & $\mathbf{w}$ & & $w$ \\
\hline Nickel & w & $\mathbf{w}$ & E.WF & E.W.F \\
\hline Phenol & $\mathbf{W . P}$ & & & $\mathbf{W}, \mathbf{P}$ \\
\hline Potassium & W.P & $\mathbf{w}$ & & W.P \\
\hline Selenium & W.R.F & $\mathbf{W}, \mathbf{F}$ & W,P,B & W.R.F.P.B \\
\hline Silver & $\mathbf{W}, \mathbf{F}$ & $w$ & W,P & W,F,P \\
\hline Sodium & $\mathbf{W}, \mathbf{P}$ & & $\mathbf{W}, \mathbf{P}$ & $\mathbf{W}, \mathbf{P}$ \\
\hline Thallium & E,W,R,F,B & & & E.W.R.F.B \\
\hline Vanadium & & E.W.R.F & E,F & E.W.R.F \\
\hline Vinyl chloride & $\mathbf{W}, \mathbf{P}$ & & & $\mathbf{W . P}$ \\
\hline Zine & W,B & $\mathbf{W}, \mathbf{F}$ & B & W.F.B \\
\hline Zirconium & & & E.R.B & E,R.B \\
\hline Radiological & E.W.R.F & E.W.R.F.B & E.R.F.B & E,W,R,F,B \\
\hline
\end{tabular}

1 Only those contaminants are listed which could pose severe or moderate risks to some endpoints. Risks could be severe from at least one contaminant for each endpoint (see Tables 7-16.7-17.7-18).

2 Risks to endpoints which do nol occupy waste sites or contaminated areas are assumed to be negligible (see Section 7.4)

' These are short-term risks. Long-term risks could be reduced with successful restoration of appropriate habitat.

- Ecological endpoints: $E=$ threatened, el,dangered. and candidate species: $W=$ wetlands: $R=$ recreational fish and wildlife: $F=$ agriculture and forestry: $P=$ public land (fish); and $B=$ biodiversity (only for receptors nor included under other endpoints) 
TABUE 7-17-Ciomparison of Source Term Concentumions of Elements in Soil with Natmally Occuring Concentrutions (pros)

\begin{tabular}{|c|c|c|c|c|}
\hline Contandment & $\begin{array}{c}\text { Source Term } \\
\text { Concentration } \\
(Y-12, K-25, X-10)\end{array}$ & $\begin{array}{c}\text { Ave Backyroud } \\
\text { Concentrition at } \\
\text { ORR' }\end{array}$ & $\begin{array}{l}\text { Ave Coscentration } \\
\text { for Endern US.'? }\end{array}$ & $\begin{array}{l}\text { Range of Natarally } \\
\text { Occurring } \\
\text { Concentration' }\end{array}$ \\
\hline Aluminum & $\begin{array}{l}16800 \\
19000 \\
58800\end{array}$ & $9430-38500$ & 33000 & $7000->100000$ \\
\hline Artimony & $\begin{array}{l}14 \\
47 \\
-\end{array}$ & $0.08-0.3$ & 0.52 & $<1-8.8$ \\
\hline Barium & $\begin{array}{l}132 \\
192 \\
262\end{array}$ & $17-107$ & 290 & $10-1500$ \\
\hline Beryllium & $\begin{array}{l}1.0 \\
0.6\end{array}$ & $0.43-1.6$ & 0.55 & $<1-7$ \\
\hline Boron & $\begin{array}{c}\ddot{2} \\
\ddot{2} \\
(80)^{3}\end{array}$ & $2-12$ & 31 & $<20-150$ \\
\hline Cadmium & $\begin{array}{c}97 \\
2 \\
11\end{array}$ & $\mathbf{N A}^{*}$ & $\mathrm{NA}^{3}$ & NA \\
\hline Chromium & $\begin{array}{c}24 \\
79 \\
59 \\
(1310)\end{array}$ & $15-50$ & 33 & $1-1000$ \\
\hline Cobalt & $\begin{array}{l}17 \\
10 \\
\cdots\end{array}$ & 3.19 & 6 & $<0.3-70$ \\
\hline Copper & $\begin{array}{c}2 \\
107 \\
--\end{array}$ & $5-27$ & 13 & $<1-700$ \\
\hline Iren & $\begin{array}{c}16500 \\
49100 \\
--\end{array}$ & $13000-53000$ & 14000 & $100-100000$ \\
\hline Lead & $\begin{array}{l}30 \\
38 \\
--\end{array}$ & $12-33$ & 14 & $<10-300$ \\
\hline Lithium & $\begin{array}{l}52 \\
20 \\
59\end{array}$ & $3-36$ & 17 & $<5-140$ \\
\hline Magnesium & $\begin{array}{l}1400 \\
2100 \\
5210\end{array}$ & $413-3840$ & 2100 & $50-50000$ \\
\hline Manganese & $\begin{array}{l}908 \\
563 \\
34 i\end{array}$ & $126-1330$ & 260 & $<2-7000$ \\
\hline
\end{tabular}




\begin{tabular}{|c|c|c|c|c|}
\hline Contanimant & $\begin{array}{c}\text { Source Teria } \\
\text { Coenceatration } \\
(Y \cdot 12, K-25, X \cdot 10)\end{array}$ & $\begin{array}{c}\text { Ave Bectrowad } \\
\text { Concentration at } \\
\text { ORR! }\end{array}$ & $\begin{array}{l}\text { Ave Concemination } \\
\text { for Eextern U.S. }\end{array}$ & $\begin{array}{l}\text { Rance of Naturnlly } \\
\text { Occurrtus } \\
\text { Coscenturation? }\end{array}$ \\
\hline Mercury & $\begin{array}{c}343 \\
1 \\
320\end{array}$ & $0.05-0.28$ & .081 & $0.01-3.4$ \\
\hline Molybdenum & $\begin{array}{c}1 \\
2 \\
- \\
(17)\end{array}$ & $1.2-3^{6}$ & .32 & $<3-15$ \\
\hline Nickel & $\begin{array}{c}22 \\
31 \\
283\end{array}$ & 7.27 & 11 & $<-700$ \\
\hline Potassium & $\begin{array}{c}3160 \\
1570 \\
17200\end{array}$ & $301-3960$ & 12000 & $50-37000$ \\
\hline Selenium & $\begin{array}{c}17 \\
7 \\
-- \\
(126)\end{array}$ & $0.4-0.8$ & 0.3 & $<0.1-3.9$ \\
\hline Silver & $\begin{array}{c}31 \\
2 \\
--\end{array}$ & ND & NA & NA \\
\hline Sodium & $\begin{array}{c}81 \\
- \\
2600\end{array}$ & $337-435$ & 2500 & $500-50000$ \\
\hline Thallium & $\begin{array}{c}76 \\
\cdots \\
\cdots \\
(1590)\end{array}$ & $0.06-0.5^{7}$ & NA & NA \\
\hline Vanadium & $\begin{array}{l}24 \\
64 \\
61\end{array}$ & $28-67$ & 43 & $<7-300$ \\
\hline Zinc & $\begin{array}{l}41 \\
106 \\
60\end{array}$ & $37-149$ & 40 & $<5-2500$ \\
\hline Zirconium & $\begin{array}{c}4 \\
10 \\
92\end{array}$ & NA & 220 & $<20-2000$ \\
\hline
\end{tabular}

'Watkins et al., 1993

'Shacklette and Boerngen 1984

'Source term concentrations for sediment on the ORR was more than 10 times source term concentrations for soil only for these elements. All other source terni concentrations for sediments were about the same or less than soil source term concentrations.

${ }^{4} \mathrm{ND}=$ nor detected.

' $N A=$ not available.

" Not detectable in $97 \%$ of sites

'Not detectable in $87 \%$ of samples. 
Determining cumulative risks to endpoints that do not occupy waste sites is problematic. Data were not adequate to determine the contaminant levels across the rese:- ation. Moreover, many of the inorganic contaminants (e.g., metals) included in the analyses are known to occur in scils throughout the United States at concentraticns greater than or equal to concentrations in the ORR source term data base (table 7-17). Intensive sampling of soils throughout the ORR to determine reservationwide background levels of contaminants also indicates that concentrations of many contaminants in the source term data base were similar to background levels (table 7-17). Therefore, some of the source term data may reflecr naturally occurring concentrations rather than centamination. Even when background levels are known, interpretation of HIs for inorganic substances is often difficult because most analytical techniques do not distinguish between chemical frrms that are available for uptake by organisms (e.g., dissolved in soil pore water or loosely bound to particles) and those that are biologically unavailable (e.g.. insoluble salts.)

It was not possible to definitively determine either the fraction of inorganic substances in the source term data base actually attributable to contamination or the fraction of those substances biologically available to organisms living on the reservation. However, evaluation of existing data on ORR background levels permits some tentative conclusions. Ranges of concentrations for $\mathrm{Al}$ (except at X-10), B, Co, Fe, Be, Na (except at X-10), Mg, Mn, Mo, K, $V$, and $\mathrm{Zn}$ throughnut the ORR are greater than or equal to the average source term data for the individual elements (table 7-17). Therefore, risks from these elements due to waste sources are probably negligible. At present, no data for zirconium are available for the ORR, but the mean concentration for the eastern United States is much greater than source terms for zirconium on the ORR (table 7-17). On the other hand, source terms for $\mathrm{Sb}, \mathrm{Ba}, \mathrm{B}$ (in sediment), Cd, Cr, Cn (at K-25), $\mathrm{Li}, \mathrm{Mg}$ (at $\mathrm{X}-10$ ), $\mathrm{Hg}, \mathrm{Mo}$ (in sediment), Ni (at X-10), K, Se, $A_{g}$, and $\mathrm{Tl}$ wre generally more than 10 times greater than background levels. Lead and cobalt source terms were somewhat higher than average ORR concentrations. Because of the high toxicity of lead and the uncertainty associated with background variability, risks from lead from waste sources may be present.

Despite difficulties in interpreting HIs. cumulative risks from available source term and benchmark data are adequate to conpare altematives. Because of the relatively small fraction of the terrestrial portion of the ORR that is in waste sites, potential risks to :errestrial endpoints except for endangered and threatened species would be negligible.

Although available data are not adequate to accurately determine the fraction of water and sediment on the ORR (excluding the impounded rivers) that is contaminated, it is i robably substantial (e.g., one-third to one-half of all stream area). Therefore, potential risks to (1) wetlands, (2) recreational fish, and (3) biodiversity could also be substantial. Risks to parks and public lands would be negligible. however, because most recreational fishing in these areas takes place only on the impounded rivers. Because no restoration activities are included in the baseline case, habitat disturbance/fragmentation risks would also be negligible.

\subsubsection{Risks from fragmentation and other noncontaminant degradation of biodiversity}

Large, undisturbed, and protected blocks of natural landscape are becoming more important for protection of biodiversity. The URK is a large block of relatively undisturbed primarily native hardwood forest ecosystem, interspersed with ecologically sensitive cedar barrens and river bluff habitats. The surrounding landscape is a highly fragmented mosaic of pastures, cropland, forest, urban, and suburban areas (table 7-18).

$\mathrm{Y}-12, \mathrm{~K}-25$, and $\mathrm{X}-10$ facilities together occupy less than about $15 \%$ of the ORR, and public roads and utility and raiıroad rights-ofway occupy an additional small fraction. 1 
TABLE 7-18-Land use in the four county area surrounding but not including the ORR, which is considered to be $80 \%$ in native forest vegetation with the remainder in facilities, roads, and rights-of-way'

\begin{tabular}{|l|l|l|l|l|l|}
\hline & Cropland & Pasture & Forest & Other & Total \\
\hline $\begin{array}{l}\text { 1000s of ha } \\
\text { (acres) } \\
\text { percent }\end{array}$ & $30(75)$ & $54(133 ;$ & $177(437)$ & $72(177)$ & $332(822)$ \\
9 & 16 & 53 & 22 & \\
\hline
\end{tabular}

' Derived from Censıs of Agriculture. Volume I Geographic Area Series, Part 42: Tennessee State and County Data. U.S. Department of 1: mmerce. Bureau of the Census. 1987; and Tennessee Statistical Abstracts 1992/1993. The University of Tennessee, Knoxville, Center for Business and Economic Research. 1993.

These disturbed sites provide s.pportunities for establishment of nonnative plant species and subsequent intrusion or expansion of populatiors of these species into surrounding native p'arit communities.

\subsubsection{Off-Site}

Contaminants from waste sites are transported off the reservation in streams leaving the ORR. After leaving the ORR, East Fork Poplar Creek, the largest of the contarininated streams, travels a short distance through the city of Oak Ridge before reentering the ORR. . Ill contaminated streams enter the impounded river at the boundary of the ORR. Transport of contaminarts from waste sites off the reservation through ingestion by wide-rangilis wildlife such as Canada goose, coyjute, and white-tailed deer is probably not a major mode of off-site transport. Of the three classes of contaminants (organics, inorganics, and radioactive elements) migrating from wasic sites into nearby streams, the major source of radionuclides in the region would be the ORR. Therefore, regional (off-site) cumulative risks for radionuclides would be the same as on-site risks. At the time of the analyses, no regional data for organics or metals were available, although the $\mathrm{Y}-12$ sites is known to be the principal source of mercury in East Fork Poplar Creek. Cumulative risks for the region of influence could not be estimated. 


\section{CHAPTEK 8ิ: KŌCKY FLATS PLANT}

The Rocky Flats Plant (RFP) lies in northem Jefferson County, approximately $25 \mathrm{~km}$ (16 miles) northwest of Denver. RFP and its buffer zone occupy 2652 ha (6550 acres) of former rangeland on broad, relatively gently sloping alluvial fans immediately east of the Front Range of the Rocky Mountains. Elevations on the site range from $1722 \mathrm{~m}$ (5650 ft) in the east to 1890 $\mathrm{m}(6200 \mathrm{ft})$ at the westem boundary. The continental climate is characterized by cold winters, moderately warm summers, and relatively low precipitation (an average of $38 \mathrm{~cm}$ or 15 in. per year). The growing season typically lasts from mid-May through late September. RFP soils tend to be fairly deep. well-drained clay, cobbly clay, and sandy loams of moderate to low permeability. Most of the RFP facilities lie within a centrally located, fenced industrial area of approximately 156 ha (384 acres). The buffer zone has several relatively minor developments such as holding ponds, gravel pits, a target range, a salvage yard, and a sanitary landfill, but for the most part the buffer zone is characterized by vegetation representative of tall grass prairie, short grass plains, lower montane, and foothill ravine regions. These communities in turn support wildlife typical of similar areas all along the foothills of the Front Range. Housing developments are encroaching into rangelands adjoining the northeast, east, and southeast perimeter of the buffer zone. Non-DOE industrial facilities are located near the southem bourdary, whereas clay and gravel pit operations are found along the western boundar;. Public lands near the site include Boulder Coun'y Open Space land adjoining the northern boundary and the Standley Lake Recreation Area to the east.

The surface waters at RFP provide natural and man-made habitat supporting aquatic communities characteristic of the semiarid foothills region where prairie and mountains meet. RFP surface waters are small in scale, and many contain water only intermittently, a natural condition in headwater streams due to a highly seasonal distribution of precipitation and snow melt. Aquatic ecosystems on the site consist primarily of holding ponds, farm ponds, ditches, springs, and three iniermittent creek systems of the South Platte River drainage. Small wetland areas are associated with many of these surface waters. The three principal creek systems (Rock Creek, Walnut Creek, and Woman Creek) generally flow eastward across the site as shown in figure 8-1. Several impoundments of small to moderate size lie within these creek basins. Although intermittent surface runoff supplies some of the water to these aquatic ecosystems, perennial groundwater discharges through seeps and springs are more important in maintaining stable, long-lived aquatic habitits on the site. Small wetlands and areas of riparian habitat occur along streams and around springs and seeps.

More cetailed descriptions of the environmental characteristics of the site and surrounding environs may be found in the Baseline Biological Characterization (DOE 1992) and the Final EIS for the RFP site (DOE 1980).

Most of the contaminated sites are associated with the central industrial area and the holding ponds downstream of the industrial area. Particularly important sites include the solar evaporation ponds and contaminated soils associated with these ponds and other waste facilities. In addition, almost one third of the surface soils of the RFP site and buffer zone, approximately 810 ha (2000 acres), is contaminated with low concentrations of plutonium and americium. Based on the source-term data (appendix B) usec in this assessment, a total of 982 ha (2420 acres) of soil and 17.4 ha (42.9 acres) of surface water (and associated sediments) within the REP site boundaries are contaminated by at least one contaminant. Moreover, another 552 ha (1360 acres) of off-site reservoirs and their sediments are contaminated by low levels of radionuclides: 


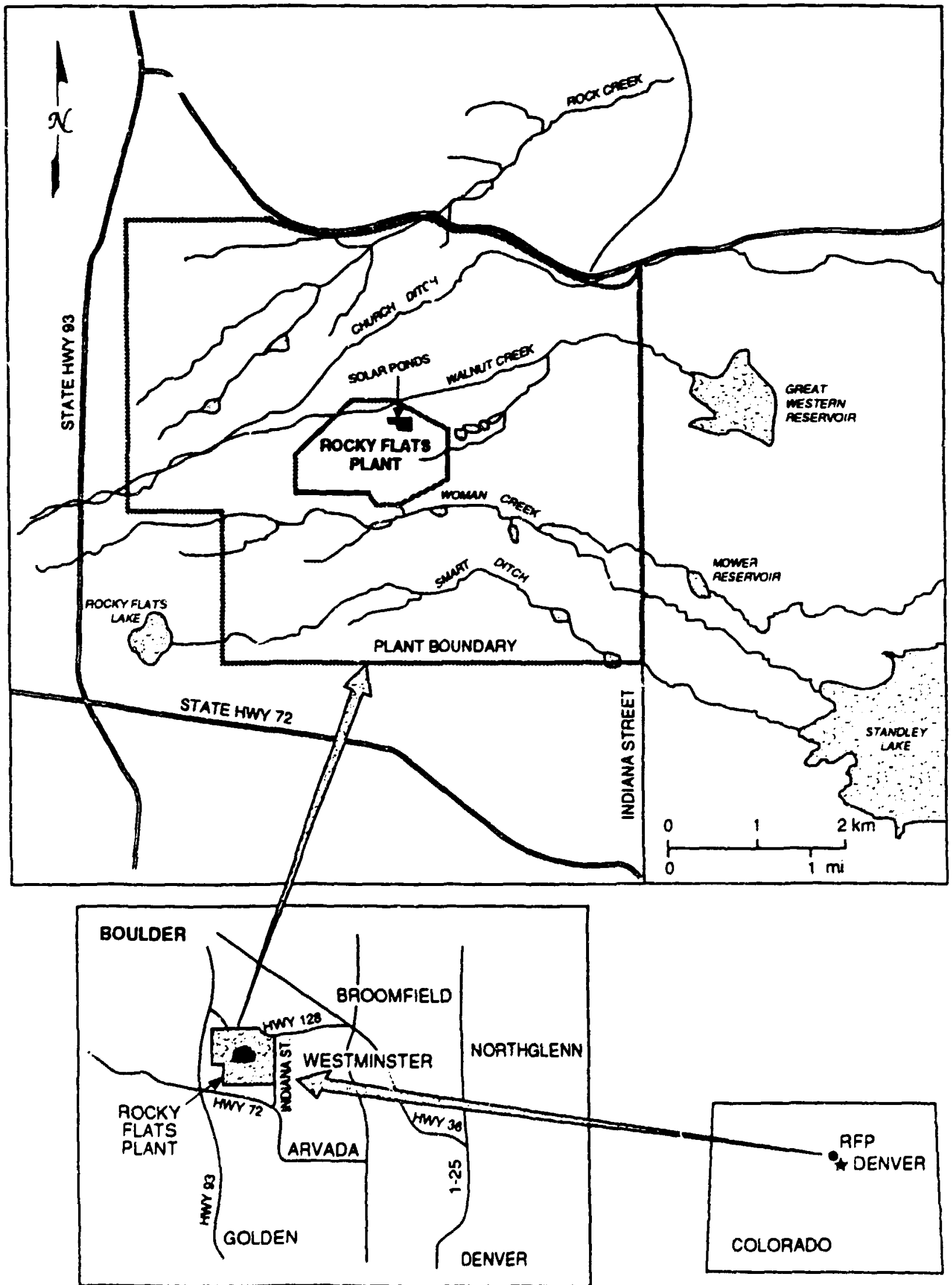


the 84-ha (210 acres) Great Western Reservoir, 465-ha (1150 acres) Standley Lake, and 3.6-ha (8.9 acres) Mower Reservoir.

\subsection{ECOLOGICAL ENDPONTS AND SPECIES DISTRIBUTION}

The ecological endpoints and representative receptors chosen for the Rocky Flats reservation are described in this chapter. In summary, at least five federally listed threatened, endangered, or candidate species of plants or animals are possible residents or visitors on the reservation; wetlands are found in swales, ditches, and ponds, along the streams, and in topographic depressions; recreational wildlife species are present but hunting is not allowed; and agricultural practices are prohibited. No public areas occur within the reservation, but public open land adjoins the northern boundary and a recreational area lies near the southeastern boundary. Vegetation and wildlife (i.e., biodiversity) are typical of that found in the surrounding area.

Vegetation representative of tall grass prairie, short grass plains, lower montane, and foothill ravine regions dominates most of the RFP reservation outside the highly disturbed central industrial area. These vegetation communities in turn support wildlife typical of the foothills of the Front Range. Most of the few non-riparian trees growing on the site were planted. Springs, streams, and holding ponds support small wetlands. Recreational fish are found in some of the holding ponds, and recreational wildlife are present, but neither hunting nor fishing is allowed on the reservation. Agriculture is not permitted on the reservation. No public lands occur on the reservation, but limited public land does occur adjacent to the reservation boundary. Four federally listed and candidate species are known to reside, visit, breed, or over-winter on or in the vicinity of the site. Several other listed or candidate species could possibly find suitable habitat on the reservation. Important species groups of concem for conservation of biodiversity include native vegetation, deer. rodents, jackrabbits, and wintering and migratory birds and wildlife.

Determining risks to endpoints requites (1) defining distribution and composition of endpoints and (2) selecting representative receptor species. The distribution of endpoints must be known in order to determine both exposure pathways for contaminants and risks to endpoints from construction.

For purposes of determining risk of exposure to contaminants, distribution of endpoints is considered to be either ubiquitous (i.e., more or less uniformly distributed throughout the reservation or region), discrete (i.e., located in one clearly identified location), or discontinuous (i.e., found in several locations within a limited area or areas). Risks to ubiquitous endpoints are assumed to be related to the total surface area affected by contaminant exposure or by disturbance from remidiation. Risks to discontinuous and discrete endpoints are detennined if their locations are known to be within contaminated areas or within areas affected by remedial activities or contaminant exposures.

Ubiquitous endpoints on the RFP reservation include endangered species, recre'tional wildlife, and certain components of biodiversity (table 8-1). On the other hand, wetlands, federally listed candidate and threatened species, and other elements of biodiversity and recreational wildlife exhibit discontinuous distributions. The distribution of endpoints for agricultural production and public lands (off-site only) can best be described as discontinuous and discrete. respectively. Locations of endpoints were determined from existing maps and publications.

Endpoints can be represented by many different receptors. The following sections describe endpoints on the RFP reservation and receptors selected for our analyses. 
TABLE 8-i-Distribution of Endpoints and Receptors on the Rocky Flats Plant Reservation

\begin{tabular}{|l|l|l|}
\hline \multicolumn{1}{|c|}{ Ubiquitous } & \multicolumn{1}{|c|}{ Discontinuous } & \multicolumn{1}{c|}{ Discrete } \\
\hline $\begin{array}{l}\text { Foraging Federally listed } \\
\text { species (peregrine falcon, bald } \\
\text { eagle, Preble's jumping mouse) }\end{array}$ & $\begin{array}{l}\text { Possible resident, Federally listed } \\
\text { and candidnte species (Ute lady's- } \\
\text { tresses) }\end{array}$ & $\begin{array}{l}\text { Prairie dog colonies, one } \\
\text { component of biodiversity } \\
\text { Recreational wildife (rabbit, } \\
\text { deer, mallard) }\end{array}$ \\
$\begin{array}{l}\text { Wetlands (benthos, fish, and } \\
\text { riparian vegetation along streams) } \\
\text { biodiversity not included in the } \\
\text { above (coyote, meadowlark, } \\
\text { vegetation) }\end{array}$ & & \\
\hline
\end{tabular}

\subsubsection{Threatened and Endangered Species}

\subsubsection{Receptors}

Four federally listed and candidate species have been known to occur at least occasionally at RFP: the endangered peregrine falcon (Falco peregrinus) and bald eagle (Haliaeetus leucocephalus) and the candidate ferruginous hawk (Buteo regalis) and Preble's meadow jumping mouse (Zapus hudsonius preblei). The endangered black-footed ferrat (Mustela nigripes), a threatened flowering species, the Ute lady's-tresses (Spiranthes diluvialis), and five other candidate species have not been observed but could possibly occur on the reservation on the basis of what appears to be the presence of potentially suitable habitat. Prairie dog colonies on the reservation are considered too small to support even one black-footed ferret, however (EG\&G 1991). The candidate species are the Colorado butterfly plant (Gaura neomexicana var. coloradensis), swift fox (Vulpes velox), white-faced ibis (Plegadus chichi), mountain plover (Charadrius montanus), and long-billed curlew (Numenius americanus). Table 8-2 lists those threatened, endangered, and candidate species that occur or may occur on the reservation. For purposes of this assessment, the bald eagle, peregrine falcon, Preble's meadow jumping mouse, and, because of the special interest expressed by the U.S. Fish and Wildlife Service, the Ute lady's-tresses, were selected as the receptors representing the threatened and endangered species endpoint.

\subsubsection{Distribution}

Candidate Preble's meadow jumping mice have been captured from three of the major drainages on the reservation: the Walnut Creek, Rock Creek, and Woman Creek drainages, usually in moist sites within $30-60 \mathrm{ft}$ of a stream channel (Stoecker 1992). Shrubby riparian vegetation dominated the mouse habitat, in particular coyote willow, indigo bush, and westem snowberty, with dense forbs, tall grasses, and sedges usually growing nearby. This type of habitat amounts to a very small fraction of the reservation. Food items include seeds of grasses and other plants, berries, insects, and fungus (EG\&G 1991). The distribution of this species would be considered discontinuous.

Occasionally, the endangered bald eagle has been observed to soar over the reservation during winter or, as a migrant, during spring and fall. Although individuals a!so have occasionally been seen perching on utility poles in the northeast comer of the reservation, none have been observed roosting or actively hunting prey within the reservation (DOE 1992). These large birds of prey generally prefer large bodies of water with trees for perching nearby. Although these conditions are not met on the reservation, Great Western Reservoir, only about $0.5 \mathrm{~km}$ ( 0.3 mile) east of the reservation, and Standley Lake, about 
TABLE 8-2-Federally Listed Threctened, Endangered, And Candidate Species on the Rocky Flats Pland

\begin{tabular}{|c|c|c|}
\hline Species & Common Name & Status' \\
\hline \multicolumn{3}{|c|}{ BRDS } \\
\hline Haliaeetus leucocephalus & Bald eagle & $\mathbf{E}$ \\
\hline Falco peregrinus & Peregrine falcon & $\mathbf{E}$ \\
\hline Buteo regalis & Fernuginous hawk & C2 \\
\hline Lanius Iudovicianus & Loggerhead shrike & $\mathrm{C} 2$ \\
\hline Plegadis chihi & White-faced ibis & $\mathrm{C} 2^{3}$ \\
\hline Charadrius montanus & Mountain plover & $\mathrm{C}^{3}$ \\
\hline Numenius americanus & Long-billed curlew & $\mathrm{C}^{3}{ }^{3}$ \\
\hline \multicolumn{3}{|c|}{ MAMMALS } \\
\hline Mustela nigripes & Black-footed ferret & $\mathbf{E}^{3}$ \\
\hline Zapus hudsonius preblei & Preble's meadow jumping mouse & C2 \\
\hline Vulpes velox & Swift fox & $\mathrm{C} 2^{3}$ \\
\hline \multicolumn{3}{|c|}{ PLANTS } \\
\hline Spiranthes diluvialis & Ute lady's-tresses & $T^{3}$ \\
\hline Gaura neomexicana var. coloradensis & Colorado butterfly plant & $C 2^{3}$ \\
\hline
\end{tabular}

' Endangered and threacened wildlife and planes, 50 CFR 17.11 and 17.12. July 15. 1991: Endangered and threatened wildlife and plants: candidate review. S6 FR 58804 - 58836 . November 21. 1991.

2 $E=$ endangered. $T=$ threatened. $C 2=$ candidate under revieu.

' Not ubserved at RFP. but knowrt from region and potential habitat identified on site. 
$1.9 \mathrm{~km}$ ( 1.2 miles) east, appear to satisfy these preferences, given reports of roosting bald eagles at these reservoirs (Uppendahl 1990). If available. fish usually make up most of their diet. However, if freezing of reservoir surfaces prevent preying on fish in the winter, the eagles may infrequently feed on carrion or small mammals on the RFP reservation. The nearest known nest is $\mathbf{4 0} \mathrm{km}$ ( 25 miles) from RFP. This species is considered to have a ubiquitous distribution when it is present on the reservation.

The nearest suitable nesting habitat of the endangered peregrine falcon (cliffs and river gorges) is approximately $8 \mathrm{~km}(5$ miles $)$ southwest of the reservation (EG\&G 1991). The reservation is, however, well within the hunting range of the peregrine falcon, and these birds have been observed on occasion to fly over, pursue prey, and perch on the reservation (DOE 1992). Their diet consists primarily of other birds and, secondarily, smal! rodents. Like the bald eagle, the peregrine falcon's distribution on the reservation is considered to be ubiquitous when it occurs at all.

A terrestrial orchid, the threatened Ute lady'stresses, has not been found on the reservation. The presence, however, of apparently appropriate habitat in the form of moist, grass-dominated swales and wetland edges supporting cattails, rushes, and sedges, in concert with the location of known populations a few kilometers north and south of the reservation (EG\&G 1991), argued for its inclusion in this assessment. If present. this orchid would have a discontinuous distribution.

\subsubsection{Wetlands}

\subsubsection{Receptors}

Wetlands on and in the vicinity of the reservation, including riparian woodiand, rularshes, and wet meadows, support a variety of wetland vegetation, aquatic life, and wildlife. Witland plants on the site include watercress, sandbar willow, cottonwood, cattails, rushes, and sedges. Twenty-three species of waterfowl and shorebirds, of which the mallard is most abundant, make use of reservation wetland resources to satisfy their requirements for shelter, food, and breeding habitat (DOE 1992). Because species-specific toxicity benchmarks for most wetland-dependent organisms are limited, benthic macroinvertebrates and fish were selected as generic receptors representative of the wetland endpoint. The mallard ilso was selected as a representative wetland receptor.

\subsubsection{Distribution}

Several wetland types are distributed discontinuously throughout the reservation according to wetland maps prepared by the U.S. Fish and Wildlife Service (FWS 1975) and studies conducted by the U.S. Army Corps of Engineers and EG\&G (1990). These wetlands are mostly associated with open holding reservoirs and ponds, numerous intermittent streams, and hillside seeps. Total measured wetlands on the reservation amount to 43 ha (107 acres) (EG\&G 1990), or approximately 1.6\% of the entire reservation area. In addition. approximately $26 \mathrm{~km}(85,000$ linear $\mathrm{ft})$ of wetland occur along intermittent stream courses. Altogether, about $3.6 \%$ of the reservation is in one kind of wetland (including open water) or another. East of the reservation, but potentially under its influence another 63 ha (156 acres) of aerial wetlands and $4.3 \mathrm{~km}(14,200 \mathrm{ft})$ of linear wetlands occur (EG\&G 1990). Most of these wetlands ( 57 ha or 140 acres) are associated with the Great Westem Reservoir.

\subsubsection{Recreational Fish and Wildife}

\subsubsection{Receptors}

Although the entire reservation is closed to the public, the buffer zo.e supports or is periodically visited by several recreationally desirable species of fish and wildlife. Among these are mule deer. white-tailed deer, elk, desert cottontail, black-tailed jackrabbit, coyote, raccoon, Canada goose, mallard, bufflehead, largemouth bass, green sunfish, and white sucker (DOE 1992). For the assessment of the RFP reservation, the mule deer, jackrabbit, coyote, and mallard, along with fish in general, were chosen as receptors representative of the recreational fish and wildlife endpoint. To maintain conservatism in the analysis, all of these receptors are considered to be year-round residents; at RFP, this is certainly a reasonable assumption, since even the 
mallard is common on the reservation throughout the year.

\subsubsection{Distribution}

The mule deer, jackrabbit, coyote, and mallard are assumed to have ubiquitous distributions. Fish on the reservation exhibit a discontinuous distribution defined principally by perennial water bodies such as holding ponds.

\subsubsection{Agricultural Production}

\subsubsection{Receptors}

Although once a part of the vast area of open rangeland dominating this region in the past, the reservation is now off-limits to agriculture of any kind. This endpoint, therefore, will not be considered further.

\subsubsection{Parks and Other Public Lands}

\subsubsection{Receptors}

As pointed out in the introduction to this chapter, no public lands overlap the site, and the only designated public lands near the site are the Boulder County Open Space land adjoining the northern boundary of the reservation and the Standley Lake Recreation Area $1.9 \mathrm{~km}(1.2$ miles) is the east. Maximum risks to these endpoints were assumed to be equivalent to those calculated for the same food web components (receptors) within the reservation boundary in the case of the adjacent Boulder County Open Space land. This holds true for Standley Lake as well since it was included in the total area of contamination used to calculate HIs for the various receptors.

\subsubsection{Distribution}

Each of these public lands is considered to have a discrete distribution.

\subsubsection{Biodiversity}

\subsubsection{Receptors}

Because (1) the RFP site occupies an ecological and topographical transition zone including elements of both the prairie and Front Range foothills, and (2) most of the reservation outside the fairly small incustrial area is relatively undisturbed (especially when compared with the continuing development of surrounding lands), this reservation represents an important reservoir of biodiversity in the region. In particular, the reservation exhibits diverse plant communities including tall and short grass prairie. small stands of riparian woodlands, marshes and other small wetlands, prickly pear and yucca uplands, and ravine uplands supporting wild plum, chokecherry, and hawthorn. These plant communities in turn support, directly or indirectly, diverse arthropod, amphibian, reptile, bird, and mammal communities. Recent sampling at RFP identified 1232 taxa of plants and animals, including 768 species of terrestrial and aquatic plants, 300 taxa of terrestrial animals, and 164 tara of aquatic animals (DOE 1992). All of the receptors already identified for the preceding threatened and endangered, wetland, and recreational fish and wildlife endpoints are also important elements of the reservation's food webs and, ultimately. biodiversity. Other receptors selected for this assessment of risks to biodiversity are the prairie dog, the meadowlark, coyote, and vegetation.

\subsubsection{Distribution}

The two prairie dog colonies on site exhibit discrete distributions, one paralleling about 700 $\mathrm{m}(2300 \mathrm{ft})$ of the northeast boundary (the greater part of this colony is actually outside the reservation boundary), the other just south and west of the east gate. The fish and benthic macruinvertebrates have discontinuous distributions defined by wetlands, streams, and man-made impoundments, whereas the meadowlark and vegetation are assumed to have ubiquitous distributions (table 8-1).

\subsection{Constituents of Potentual CONCERN}

The constituents of potential soncem at Rocky Flats include inorganic, organic, and radioactive contaminants (table 8-3). The most prevalent radionuclides, according to relative average concentrations, are ${ }^{241} \mathrm{Am}$ and ${ }^{\circ 0} \mathrm{Sr}$, whereas $\mathrm{Al}$, $\mathrm{Ba}, \mathrm{Be}$, cyanide ion, $\mathrm{Pb}, \mathrm{Mn}$; $\mathrm{Afg}$; and $\mathrm{Zn}$ are the 
TABLE 8-3-Maximum and Average Soil Concentrations on the Rochy Flass Plant [mg/kg dry weight (for chemical constiments) or pCillg dry weight (for madionuclides)]

\begin{tabular}{|c|c|c|c|}
\hline Constituent & $\begin{array}{c}\text { Maxinenam } \\
\text { Coscentration }\end{array}$ & Constitureat & $\begin{array}{c}\text { Avernoc } \\
\text { Concentration }\end{array}$ \\
\hline Acelone & $2.60 E+01$ & & $7.46 \mathrm{E}-01$ \\
\hline Aroclor 1254 & $5.40 \mathrm{E}+01$ & Arocior 1254 & $5.40 E+01$ \\
\hline Aroclor 1260 & $1.60 E+03$ & Arocior 1260 & $7.47 E+\infty 0$ \\
\hline BEHP & $1.40 \varepsilon+03$ & BEHP & $4.70 \varepsilon+00$ \\
\hline 2-butanone & $3.90=-01$ & Di-n-butyl phthalate & $2.70 E+00$ \\
\hline Carbon disulfide & $1.90 E+01$ & Tohuene & $2.76 E+01$ \\
\hline Carbon tetrachloride & $1.00 E-01$ & Aluminum & $1.18 E+04$ \\
\hline 1.2-dichloroethane & $1.10 \mathrm{E}-01$ & Antimony & $3.96 E+01$ \\
\hline di-n-butyl phthalate & $2.70 E+00$ & Arsenic & $1.2 \pi E+01$ \\
\hline Ethyl benzene & $7.80 \mathrm{E}-01$ & Barium & 3.24E:01 \\
\hline Methylene chloride & $1.30 E-01$ & Beryllium & $1.97 \mathrm{E}+1,3$ \\
\hline 4-methyl-2-pentanone & $6.80 \mathrm{E}-02$ & Chromium & $9.0=-02$ \\
\hline 1.1.1-trichloroethane & 2.50E-01 & Copper & $6.53 E+01$ \\
\hline Trichlorethylene & $1.50 \mathrm{E}-01$ & Cyanide ion & $8.70 E+\infty 0$ \\
\hline Xylene & $3.30 E+00$ & Iron & $2.82 E+04$ \\
\hline Aluminum & $1.76 E+04$ & Lead & $1.31 \mathrm{E}+01$ \\
\hline Antimony & $3.96 \mathrm{E}+01$ & Magnesium & $2.32 E+03$ \\
\hline Arsenic & $3.70 E+01$ & Manganese & $3.36 \mathrm{E}+02$ \\
\hline Barium & $5.30 E+02$ & Mercury & $9.66 \mathrm{E}+00$ \\
\hline Beryllium & $1.97 \mathrm{E}+03$ & Nickel & $2.81 E+01$ \\
\hline Boron & $2.77 \mathrm{E}+\infty 0$ & Vanadium & $5.49 \mathrm{E}+01$ \\
\hline Chromium & $7.56 \mathrm{E}+01$ & Zinc & $7.51 \mathrm{E}+01$ \\
\hline Copper & $7.36 \mathrm{E}+01$ & Americium-241 & $2.47 \mathrm{E}+08$ \\
\hline Cyanide ion & $8.70 E+\infty 0$ & Strontium-90 & $9.76 E+13$ \\
\hline Iron & $1.23 \mathrm{E}+05$ & & \\
\hline Lead & $8.69 E+01$ & & \\
\hline Magnesium & $3.87 E+03$ & & \\
\hline Manganese & $5.51 E+02$ & & \\
\hline Mercury & $1.14 \mathrm{E}+02$ & & \\
\hline Nickel & $2.81 E+01$ & & \\
\hline Vanadium & $6.00 E+01$ & & \\
\hline Zinc & $1.73 E+02$ & & \\
\hline Americium-241 & $5.92 \mathrm{E}+11$ & & \\
\hline Plutonium-238 & $1.34 \mathrm{E}+03$ & & \\
\hline Plutunium-239 & $2.05 E+0 ?$ & & \\
\hline Radium-226 & $1.60 \mathrm{E}+03$ & & \\
\hline Strontium-90 & $9.76 E+13$ & & \\
\hline Uranium-234 & $2.20 \mathrm{E}+03$ & & \\
\hline Uranium-235 & $3.30 \mathrm{E}+02$ & & \\
\hline Uranium-238 & $450 E+05$ & & \\
\hline
\end{tabular}


TABLE 8-4-Maximan and Average Weter Concentrations or the Rocky Flats Plant [mg/L (for chemical constituents) or $\mathrm{PCi} / \mathrm{L}$ (for radionuclides)]

\begin{tabular}{|c|c|c|c|}
\hline Constibered & Madionan Concentration & Condituent & A verage Coscentration \\
\hline Acetone & $2.90 E-02$ & Acetone & S.75E-03 \\
\hline Aldrin & $6.00 E-02$ & BEHP & $1.86 E-02$ \\
\hline Ammonia & $5.00 \mathrm{E}-01$ & Di-n-butyl phthalate & $1.85 E-03$ \\
\hline BEHP & $6.50 E-01$ & Phenol & $6.44 E-02$ \\
\hline Benzene & $2.46 \mathrm{E}-03$ & Toluene & $2.82 E-03$ \\
\hline Bromoform & $2.13 E-03$ & Aluminum & $4.21 E-01$ \\
\hline 2-butanone & $1.30 E-02$ & Antimony & $6.70 E-02$ \\
\hline Butylbenzylphthalate & $3.00 E-03$ & Arsenic & $1.30 E-02$ \\
\hline Carbon disulfide & 4.00E-03 & Barium & $1.02 E-01$ \\
\hline Carbon tetrachloride & $7.00 E-03$ & Beryllium & $3.90 \mathrm{E}-03$ \\
\hline Chlorobenzere & $6.00 E-03$ & Cadmium & $3.94 \mathrm{E}-01$ \\
\hline Chloroform & $1.00 E-02$ & Chromium & $1.09 E-03$ \\
\hline Diazinon & $2.80 E-03$ & Cobalt & $1.85 E-03$ \\
\hline 1.I-dichloroethane & $1.10 E-02$ & Copper & $1.47 \mathrm{E}-02$ \\
\hline 1.2-dichloroethane & $3.00 E-03$ & Cyanide ion & $1.36 E+03$ \\
\hline 1.I-dichloroethene & $2.38 E-03$ & Iron & $6.84 E-01$ \\
\hline trans-1,2-dichloroethylene & $3.00 E-03$ & Lead & $3.58 \mathrm{E}-03$ \\
\hline di-n-butyl phthalate & $2.00 E-02$ & Magnesium & $4.48 E+01$ \\
\hline di-n-octylphthalate & $1.60 E-02$ & Manganese & $9.68 E-02$ \\
\hline Ethyl benzene & $3.12 E-03$ & Mercury & $2.03 \mathrm{E}-01$ \\
\hline 2-hexanone & $8.46 E-03$ & Mclybdenum & $6.00 E-03$ \\
\hline Methylene chloride & $7.90 \mathrm{E}-02$ & Nickei & $6.92 E-02$ \\
\hline 4-methyl-2-pentanone & $3.10 E-02$ & Potassium & $3.67 E+00$ \\
\hline 2-methyiphenol & $2.40 E-02$ & Silver & $6.71 E-03$ \\
\hline n-nitrosodiphenylamine & $3.00 E-01$ & Sodium & $1.95 E+02$ \\
\hline n-nitrosodipropylamine & $3.90 E+00$ & Thallium & $7.58 \mathrm{E}-03$ \\
\hline Parathion-ethyl & $2.00 \mathrm{E}-02$ & Vanadium & 3.13E- 02 \\
\hline Phenol & $2.00 E+00$ & Zinc & $2.57 \mathrm{E}-01$ \\
\hline Simazine & $6.00 E+\infty 00$ & Americium-241 & $2.42 \mathrm{E}-02$ \\
\hline Simetryn & $6.40 \mathrm{E}-[0]$ & Strontium-90 & $7.44 E+10$ \\
\hline Tetrachlorethene & $1.40 \mathrm{E}-02$ & & \\
\hline Toluene & 1.50E-02 & & \\
\hline 1.1-trichlorethane & $2.96 \mathrm{E}-03$ & & \\
\hline 1.1.1-trichloroethane & $6.00 E-03$ & & \\
\hline Trichlorethylene & $2.60 \mathrm{E}-02$ & & \\
\hline Vinyl acetate & $8.37 E-03$ & & \\
\hline Xylene & $3.00 \mathrm{E}-03$ & & \\
\hline Aluminum & $7.39 E+01$ & & \\
\hline Antimony & $\because 44 E-02$ & & \\
\hline Arsenic & $1.40 \mathrm{E}-02$ & & \\
\hline Barium & $1.05 E+00$ & & \\
\hline Beryllium & $1.30 \mathrm{E}-\Omega 1$ & & \\
\hline Cadmium & $6.43 \mathrm{E}+00$ & & \\
\hline Chloride & $7.63 \mathrm{E}+02$ & & \\
\hline Chromium & $9.50 E-172$ & & \\
\hline Cobalt & $8.00 E-122$ & & \\
\hline Copper & $|.40 \mathrm{E}-0|$ & & \\
\hline Cyanide ion & $9.65 \mathrm{E}+103$ & & \\
\hline
\end{tabular}


Table $8-4$ (cont'd)

\begin{tabular}{|c|c|c|c|}
\hline Constituent & Maximin Coscentration & Constivient & Average Coscentration \\
\hline Acetone & $2.90 E-02$ & Actione & $5.75 E-03$ \\
\hline Flouride & $7.30 \mathrm{E}+01$ & & \\
\hline Iron & $7.72 \mathrm{E}+01$ & & \\
\hline Lead & $1.30 E-01$ & & \\
\hline Lithium & $2.60 E+01$ & & \\
\hline Magnesium & $1.81 E+02$ & & \\
\hline Manganese & $4.25 E+00$ & & \\
\hline Mercury & $2.00 \mathrm{E}+00$ & & \\
\hline Molybdenum & $5.00 E-01$ & & \\
\hline Nickel & $8.20 E-01$ & & \\
\hline Nitrate & $1.60 E+03$ & & \\
\hline Nitrite & $7.50 E+01$ & & \\
\hline Potassium & $3.76 \mathrm{E}+02$ & & \\
\hline Selenium & $2.83 E-02$ & & \\
\hline Silver & $4.46 \mathrm{E}+00$ & & \\
\hline Sodium & $2.44 E+03$ & & \\
\hline Sulfate & $7.36 \mathrm{E}+02$ & & \\
\hline Thallium & $2.10 E-02$ & & \\
\hline Tin & $2.03 E-01$ & & \\
\hline Vanadium & $3.13 E-01$ & & \\
\hline Zinc & $4.21 \mathrm{E}+00$ & & \\
\hline Americium-24I & $8.60 E+00$ & & \\
\hline Cesium 137 & $1.00 \mathrm{E}-01$ & & \\
\hline Plutonium-239 & $6.70 \mathrm{E}+02$ & & \\
\hline Radium-226 & $6.20 \mathrm{E}+00$ & & \\
\hline Radium-228 & $7.90 E+00$ & & \\
\hline Strontium-90 & $1.20 E+11$ & & \\
\hline Tritium & $1.05 E+03$ & & \\
\hline Uranium-234 & $2.60 \mathrm{E}+03$ & & \\
\hline Uranium-235 & $1.00 E+02$ & & \\
\hline Urarium-238 & $3.90 E+03$ & & \\
\hline
\end{tabular}


TABLE 8-5-Maximum and Average Sediment Concentrations on the Rocky Flats Plant [mg/kg (for chemicals) or PCikg (for redionuclides)]

\begin{tabular}{|c|c|c|c|}
\hline Constituent & Madinan Concestirntion & Constituent & Average Concentration \\
\hline Acenapthene & $4.50 E+00$ & Acetone & $4.70 E-02$ \\
\hline Acetone & $4.70 E-02$ & Phenol & $7.40 E+\infty 0$ \\
\hline Ammonia & $1.35 E+02$ & Tolvene & $1.00 E-03$ \\
\hline Atrazine & $1.00 E+01$ & Aluminum & $2.50 E+03$ \\
\hline 2-butsnone & $2.00 \mathrm{E}-\mathrm{m}$ & Barium & $7.70 E+01$ \\
\hline 4-chloro-3-methyl phenol & $7.90 E+10$ & Cadmium & $8.06 E+01$ \\
\hline 2-chlorophenol & $7.70 E+(6)$ & Chromium & $7.36 E+00$ \\
\hline 1,4-dichlorobenzene & $4.00 E+00$ & Copper & $7.36 E+01$ \\
\hline 2.4-dinitrotoluene & $3.50 E+\infty 0$ & Cyanide ion & $3.20 E+03$ \\
\hline Methylene chloride & $5.00 E-03$ & Iron & $1.28 \mathrm{E}+04$ \\
\hline n-nitrosodiphenylamine & $3.70 E-01$ & Lead & $1.26 E+01$ \\
\hline Phenol & $7.40 E+00$ & Magnesium & $3.81 E+03$ \\
\hline Pyrene & $4.60 E+\infty 0$ & Manganese & $1.34 \mathrm{E}+02$ \\
\hline Tetrachloroethane & $1.30 \mathrm{E}-01$ & Mercury & $2.00 E+00$ \\
\hline Toluene & $1.00 E-03$ & Nickel & $6.97 \mathrm{E}-02$ \\
\hline 1,2,4-trichlorobenzene & $4.30 E+00$ & Silver & $8.93 \mathrm{E}-02$ \\
\hline Aluminum & $1.00 E+04$ & Sodium & $7.78 \mathrm{E}+02$ \\
\hline Barium & $1.54 \mathrm{E}+02$ & Thallium & $7.00 \mathrm{E}+00$ \\
\hline Cadmium & $1.08 \mathrm{E}+02$ & Vanadium & $1.98 \mathrm{E}+01$ \\
\hline Chloride & $1.12 \mathrm{E}+04$ & Zinc & $8.47 \mathrm{E}+01$ \\
\hline Chromium & $1.47 E+01$ & Americium-241 & $6.71 E+08$ \\
\hline Copper & $9.60 E+01$ & Strontium-90 & $1.00 E+13$ \\
\hline Cyanide ion & $3.20 E+03$ & & \\
\hline Iron & $2.13 E+04$ & & \\
\hline Lead & $2.61 \mathrm{E}+01$ & & \\
\hline Lishium & 4.30E+ +11 & & \\
\hline Magnesium & $1.37 \mathrm{E}+04$ & & \\
\hline Manganese & $2.08 \mathrm{E}+02$ & & \\
\hline Mercury & $2.00 E+00$ & & \\
\hline Nickel & $1.65 E+01$ & & \\
\hline Nitrate & $1.30 \mathrm{E}+04$ & & \\
\hline Nitrite & 4.70E+02 & & \\
\hline Silver & $2.12 \mathrm{E}+01$ & & \\
\hline Sodium & $3.13 E+04$ & & \\
\hline Sulfate & $6.95 E+03$ & & \\
\hline Sulphide & $5.60 \mathrm{E}+01$ & & \\
\hline Thallium & $7.00 E+00$ & & \\
\hline Vanadium & $3.96 E+01$ & & \\
\hline Zine & $1.01 E+02$ & & \\
\hline Americium-241 & $3.00 E+01$ & & \\
\hline Cesium-137 & 9.0OE+02 & & \\
\hline Plutonium-239 & $1.90 E+04$ & & \\
\hline Sirnnium-90 & $1.20 \mathrm{E}+14$ & & \\
\hline Vra $\mathrm{m}-234$ & $9.50 E+02$ & & \\
\hline Uransum-238 & $1.00 F+103$ & & \\
\hline
\end{tabular}


most important inorganics based on their prevalence and/or toxicity. The principal organics are acetone, polychlorinated biphenyl (PCBs), bis(2-ethylhexyl)phthalate (BEHP), and toluene.

Maximum and average concentrations of chemical and radio'ogical constituents in soil, surface water, and sediment were determined from the source terms provided by PNL (tables $8-3,8-4$, and 8-5). Determination of these average and maximum concentrations required that certain assumptions be made with regard to data interpretation and compensation for data gaps. Appendix B describes the methodology used to develop the source terms (contaminant concentrations) for input into the exposure and risk assessment.

\subsection{EXPOSURE ASSESSMENT}

Estimating contaminant exposure for representative receptor species on the reservation involves knowledge of the number and kinds of individual organisms exposed to wastes, the amount of time spent in waste areas, and the amount of contaminant uptake. Because sitespecific home ranges, behavior patterns, and habitat requirements at Rocky Flats are not well known, an initial assessment for contaminant exposure was conducted using maximum known contaminant concentrations of each contaminant in each medium (i.e., soil, water, and sediment). Even though only a few individuals of certain species with small home ranges (e.g., small birds and mammals) could reside within contaminated areas for most of their lives, and even fewer individuals could contact the most contaminated areas, in this initial screening, these maximum concentrations, where available, were applied to all receptor species to identify the worst-case potential contaminants. Contaminants that did not pose a risk to any of the receptor species from exposure to the maximum values were not considered further. If exposure to the maximum concentrations of contaminants posed a risk to organisms, however, then the average concentrations of those contaminants were estimated and used in the assessment to determine the most probable and reasonable exposure and risk.
This nsk assessment estimates the risk to vegetation, terrestrial wildlife, and aquatic organisms from chronic exposure to radiological and nonradiological contaminants [refer to appendix $A$ for a more detailed discussion of methods]. It is desirable in exposure analysis to consider all ecological endpoints and their corresponding species. However, due to (1) limited availability of exposure sensitivity data for many species (e.g., threatened and endangered species) and (2) presumed similarities in exposure risk (e.g., similarly sized raptors feeding on the same prey), representative organisms for each endpoint were chosen for evaluation. A food web was developed that includes receptor species representing the endpoints (figure 8-1). Where data were available, conservative estimates of exposure and risk were made by selecting receptors that are (1) most sensitive to contaminants or habitat alteration, (2) most likely to experience additional risk because of bioaccumulation or larger body size, or (3) at greatest risk because of rarity. Other abundant species on the reservation were included as important prey cornponents of the foodweb, such as mice and insects (risk estimates were not determined for insects).

The primary exposure routes for terrestrial wildlife species are exposure to external radiation and ingestion of food (including soils for some species) and water. Table 8-6 lists the body weights and consumption rates for the representative species. With respect to herbivore species, the jackrabbit and prairie dog are assumed to feed exclusively on the vegetative parts of plants, whereas the mule deer is assumed to eat $80 \%$ vegetation and $20 \%$ fruits and seeds. The diet of the $m-$. idrd duck is assumed to consist of $100 \%$ fruits. On the basis of a review of the literature, the percentages of prey items consumed by omnivores and predators were also estimated (table 8-6; figure 8-2). The mouse is assumed to eat $20 \%$ fruits and seeds and $80 \%$ insects; the meadowlark. 70\% fruits and seeds and $30 \%$ insects: the peregrine falcon, $80 \%$ meadowlark and $20 \%$ mice; the bald eagle, $30 \%$ fish, 50\% mallards, and 20\% jackrabbits; and the coyute, $30 \%$ mice, $40 \%$ jackrabbits, and $30 \%$ prairie dogs. Insects are assumed to eat $100 \%$ plant tissue. 
Except for the raptors and coyote, all species are assumed to purposely or incidentally ingest soil while eating. grooming. or preening (table 8-6). The soil ingestion rate $\left(Q_{2}\right)$ for black-tailed jackrabbits is $6.3 \%$ of the dry-matter intake (Arthur and Gutes 1988); the mule deer soil ingestion rate is $1.35 \%$ of the dry-matter intake (Arthur and Alldredge 1979). The soil ingestion rates for the mouse and mallard are $2 \%$ and $8.2 \%$ of the dry-matter intake, respectively (Beyer et al. 1991). Because published values of soil ingestion rates were not found for the meadowlark, it was conservatively estimated to be $10 \%$ of the dry-matter intake.

The estimated daily rates of food and water consumption $\left[Q_{v},\left(Q_{F}, Q_{H}\right), Q_{w}\right.$, respectively] for each representative species were calculated from allometric regression equations that are based on the weight of the organism (EPA 1988) (appendix A). These equations are based on the combined measurements for laboratory animals, livestock, and selected wildlife and bird species.

Because details of the behaviors and habitat requirements of most of the representative wildlife species are not weli known, it is assumed that all species, except the bald eagle and the peregrine falcon, spend $100 \%$ of their time on the reservation. Thus, all representative species, except the two raptors, are considered to be year-round residents at Rocky Flats. Therefore, the fraction of contaminated vegetation, fruit, prey, soil, and water consumed $\left(F_{v}, F_{f}, F_{H}, F_{5}, F_{w}\right.$, respectively) is set at $100 \%$ (table 8-6). The bald eagle and peregrine falcon are present on or near the reservation only about six months or less each year (DOE 1992), and thus their values are set at $50 \%$.

Contaminant concentrations in vegetation, the first level in the foodchain, are estimated 'rom source-term concentrations in the soils using published element- or chemical-specific soil-to-plant transfer factors (Baes et al. 1984; Travis and Arms 1988) (table 8-7). Transfer factors for inorganic chemicals are available for both the vegetative and fruiting parts of plants (Baes et al. 1984); however, the transfer factors for organic chemicals do not make this distinction (Travis and Arms 1988). Moreover, :he methodology used to predict contaminant concentrations in vegetation does not make a .... distinction between different plant types or species. Therefore, all species ingest "generic" vegetation containing contaminant concentrations derived from soil concentrations by the use of transfer factors.

Transfer factors for contaminants of concem are used to predict concentrations in the tissues of terrestrial mammalian receptors from consumption of vegetaticn, soil, and water (collectively termed $B_{\mathrm{b}}$ ) (Baes et al. 1984; Travis and Arms 1988) (table 8-7). Data on transfer factors from vegetation or soil to insects and earthworms are very limited in the literature. Therefore, the concentration in insects was derived from vegetation concentrations, and a default, conservative one-to-one transfer between vegetation and insects was assumed. Fish bioconcentration factors were applied to estimate the concentrations of contaminants in fish tissue for consumption by the bald eagle (Droppo, et al. 1989; and Strange and Peterson 1989) (table 8-7). The rationale and limitations for applying these transfer factors are discussed in appendix $A$.

The consumption rates and the benchmark limits or no-observable-adverse-effects level (NOAEL) values are typically reported in wet weights, whereas the vegetation and soil concentrations are usually reported in dry weights. Therefore, conversion factors were app!ied to account for this difference. The concentration conversion factor for wet to iry weight for the vegetative parts of plants on Rocky Flats is assumed to be 0.91 [the lower end of the range of water content for hay grasses (Suter 1993)]. The conversion factor for the fruiting parts of plants on Rocky Fiats was assumed to be 0.17 (Morrison 1959). The conversion factor for soils was assumed to be 0.98 , based on the conversion factor for soils in southwest Idaho (Rope et al. 1988).

For the baseline assessment of Rocky Flats, the concentrations of radionuclides in animal tissues and the resulting doses were not decay-corrected. Doses are estimated for existing conditions and not for some point in the future. The primary radionuclides of concem, ${ }^{241} \mathrm{Am}$ and ${ }^{\text {x) }} \mathrm{Sr}$, have relatively long half-lives (432 and 29 years, respectively), so this assumption is not unreasonable. The radionuclide-concentration 
TABLE 8-6-Bady Weights and Consumption Rates" for Terrestrial Species' on the Rocky Flats Plant

\begin{tabular}{|c|c|c|c|c|c|c|c|c|c|}
\hline Parnositer & 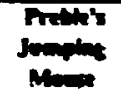 & 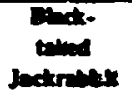 & Priste & Derr & 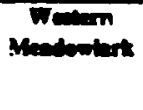 & Mannd & Pupese & m & $\cos n$ \\
\hline Bady weidhe BW (kg) & $190 E-02$ & $2.2 \pi \mathrm{E}+00^{\circ}$ & $1.19 E+00$ & $1.10 E+102$ & $9 \pi 7 E-02$ & I. IfE+C & 83सE-01' & $4.50 \mathrm{E}+00$ & $160 E+01$ \\
\hline 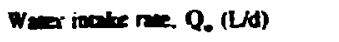 & $6.40 E-03$ & $1.83 E-01$ & $1.26 E-01$ & 1.4SE 400 & $2.24 E-02$ & $1.25 \mathrm{E}-0 \mid$ & $1.13 E-01$ & 35:E-01 & 7.TJE-OI \\
\hline 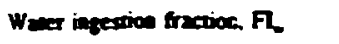 & $100 E+\infty$ & $100 E+\infty$ & $1.005+\infty 0$ & $100 E+00$ & $1.00 E+\infty 0$ & $1.00 E+\infty 0$ & S.00E-01 & $5.00 E-01$ & $1.00 E+\infty$ \\
\hline Sull inate race. Q. (tet) & S.ISE-0S' & $9.32 E-03^{\circ}$ & $1.63 E-06$ & 3.0NE-OT & S.OSE-OK & S.6AE-05 & 0.00 & 0.00 & 0.00 \\
\hline Soil iegersion fraction, $\mathbf{F}$. & $1.00 E+\infty$ & $1.00 E+\infty 0$ & $1.00 E+\infty 0$ & $1.00 E+\infty$ & $1.00 E+\infty 0$ & $1.00 E+\infty 0$ & 0.00 & 0.00 & 0.00 \\
\hline Vequetrion inate res, Q. fice/d) & 0.03 & $1.59 E-01^{\prime}$ & $1.63 \mathrm{E}-04$ & 2.13E+00 & 0.00 & 0.00 & 0.00 & 0.00 & 0.00 \\
\hline Vequation ingertion fraction. FI. & 0.00 & $1.00 E+\infty 0$ & $1.006+\infty$ & $1.00 E+\infty$ & 0.00 & 0.00 & 0.00 & 0.00 & 0.00 \\
\hline 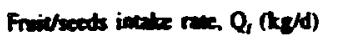 & $8.20 E-\operatorname{cis}$ & 0.00 & 0.00 & $5.32 E-01$ & 7.35E-05 & $7.41 E-02$ & 0.00 & 0.00 & 0.00 \\
\hline Frritseeds ingescion fruction. Fh, & $100 E+\infty$ & 0.00 & 0.00 & $1.00 E+\infty 0$ & $1.00 E+\infty 0$ & $1.00 E+\infty 0$ & 0.00 & 0.00 & 0.00 \\
\hline 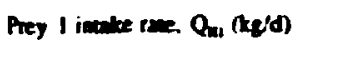 & $\begin{array}{l}3.28 E-03 \\
\text { (insects) }\end{array}$ & 0.00 & 0.00 & 0.00 & 3.15E-03 & 0.00 & $\begin{array}{l}\text { I. 29EE-0R } \\
\text { (mice) }\end{array}$ & $\begin{array}{c}\text { 643E-02 } \\
(\text { fish })^{\circ}\end{array}$ & $\begin{array}{l}\text { 1.75E-01 } \\
\text { (nice) }\end{array}$ \\
\hline Prey 1 ingertion fraction. $F_{1,1}$ & $1.00 E+\infty$ & 0.00 & $\mathbf{c . 0 0}$ & 0.00 & $1.00 E+00$ & 0.00 & SOOE-01 & $5.00 E-01$ & $1.00 E+\infty$ \\
\hline Prey 2 incribe rece. $Q_{\text {en }}$ (ke/d) & $0 \infty$ & 0.00 & 0.00 & 000 & 0.00 & 0.00 & $\begin{array}{c}5.14 E-02 \\
\text { (meadomiartu) }\end{array}$ & $\begin{array}{l}\text { 1.20E-02 } \\
\text { (rablite) }\end{array}$ & $\begin{array}{l}\text { 2.34E-0l } \\
\text { (rabtist) }\end{array}$ \\
\hline Prey 2 ingestion fraction, $F_{100}$ & 0.00 & 0.00 & 0.00 & 0.00 & 0.00 & 0.00 & $5.00=-01$ & $5.00 E-01$ & $1.00 E+\infty$ \\
\hline Prey 3 iscalce me. $Q_{n o}(k e / d)$ & 0.00 & 0.00 & 0.00 & 0.00 & 0.00 & 0.00 & 0.00 & 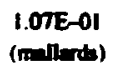 & $\begin{array}{l}\text { 1.75E-01 } \\
\text { (pripie dog) }\end{array}$ \\
\hline Prey 3 ingestion fraction. $F T_{\text {no }}$ & 0.00 & 0.00 & 0.00 & 0.00 & 0.00 & 0.00 & 0.00 & $S .00 E-\cap 1$ & $1.00 E+00$ \\
\hline
\end{tabular}

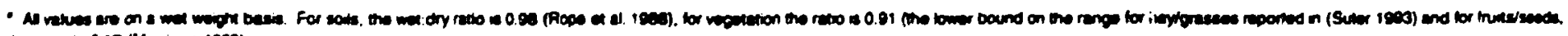
the ritio is 0.17 (Nomion tese).

- Water and food consumption rates were computed by methods in EPA 1988 (Table 4-8) unless oiherwise noted.

- Whivake 1972

- Bun et al. 1976.

- Whitiver 1988

- Anderson ea al. 1984

- Westem Bird 3anding Asunciation 1984

- Terres 1990

- Terres 1930

1 Brown a al. 1208

- Burt et al. 1976

1 The moste soil ingestion rate is 29 of dry vegeterion intalce (Beyer at as. 191 ).

- The soil ingestion rwe of the jackrabbis is $63 \%$ (Arthur et al. I9s8)

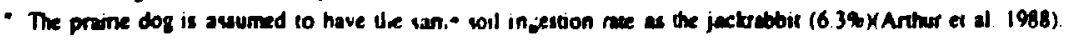

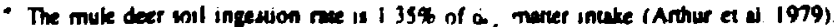

- The meadiowlort soil ingeation race is asumed to $t \cdot 10 \%$ of dry maner inclke.

- The maliard sol ingestion race is $8.2 \%$ of dy mertes intake (Beyer et $\mathrm{d}$. 1991).

- The blact-uiled jecknbbit ingeatuon mite is 199 Jday wet woiph (Amold and Reynolds 1943).

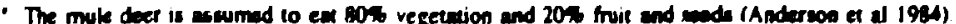

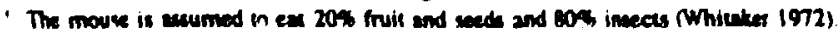

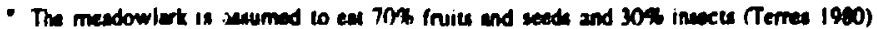

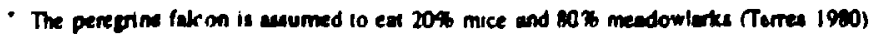

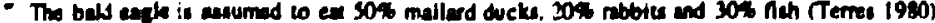

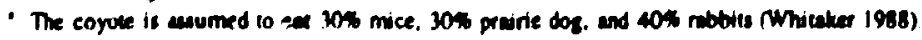




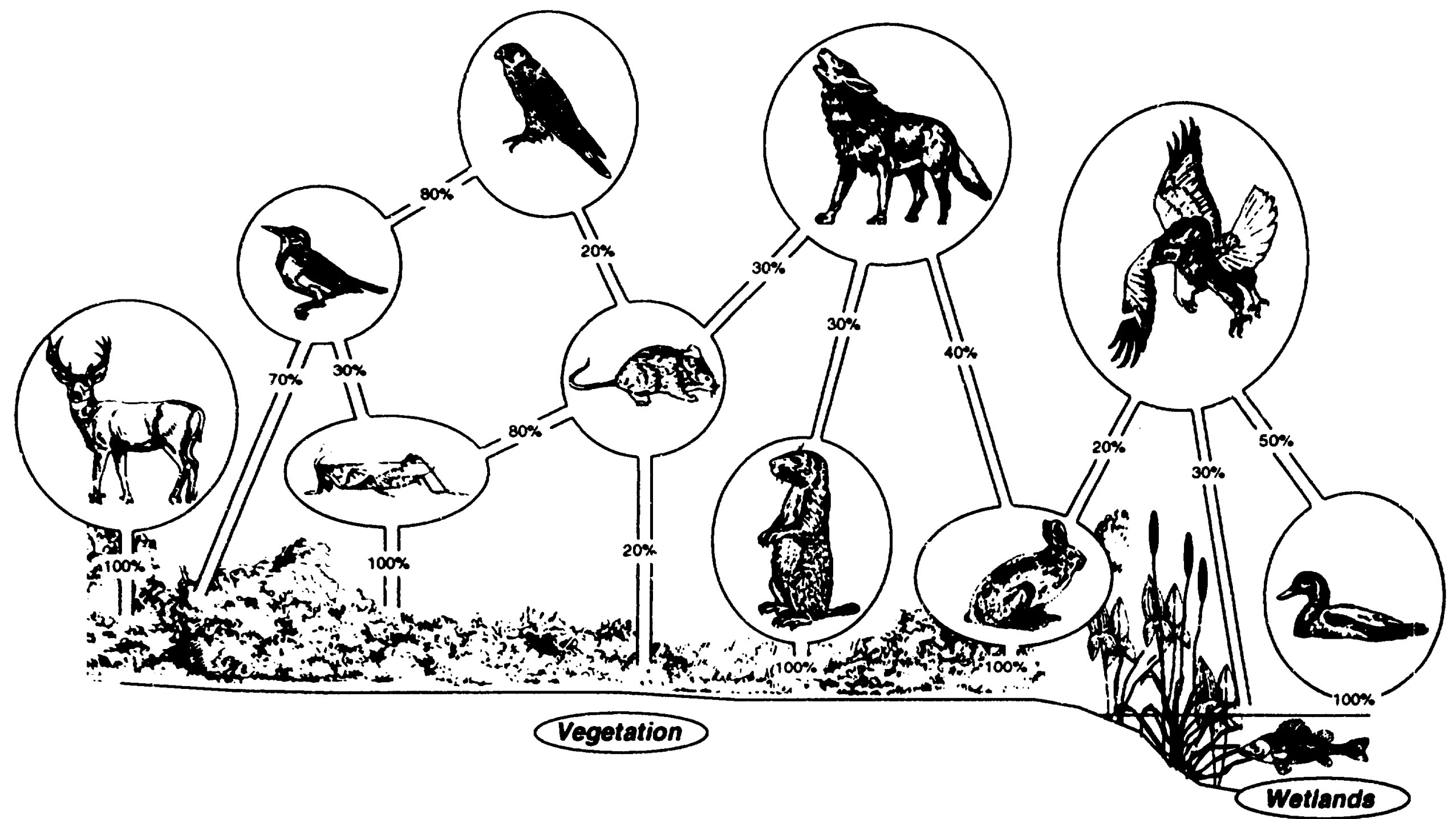

FIGUAE 8-2. REPRESENTATION OF THE TERRESTRIAL FOOD WEB OF THE ROCKY FLATS RESERVATI.SN 
TABle 8-7-Soil to Vegetation, Soil to Fruit and Plant to Beef Transfer Factors, and Fish Bioconcentration Factors for Constituents of Concasn at the Rocks Flats Plant

\begin{tabular}{|c|c|c|c|c|}
\hline Ceandinest & $\begin{array}{l}\text { Fid Diecencentindiea } \\
\text { Facter }\end{array}$ & $\begin{array}{l}\text { Soll to Vegetedian } \\
\text { Trander Facter }\end{array}$ & $\begin{array}{l}\text { Sall E Frat } \\
\text { Tranter Facter }\end{array}$ & 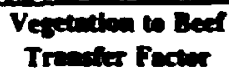 \\
\hline Acensoptiene & $6.46 E+02$ & $2.16 E-01$ & $2.16 E-01$ & $2.00 E-04$ \\
\hline Acetone & $3.89 E-01$ & $5.33 \mathrm{E}+01$ & $5.33 \mathrm{E}+01$ & $1.44 E-08$ \\
\hline Aldrin & 3.14E+03 & $7.14 \mathrm{E}-01$ & $7.14 E-01$ & $2.51 E-05$ \\
\hline Aroclor 1254 & $2.30 \varepsilon+04$ & 2.2SE-02 & $225 E-02$ & $1.00 E-02$ \\
\hline Arocior 1260 & $1.60 \varepsilon+05$ & $2.25 \mathrm{E}-02$ & 2.25E-02 & $1.00 E-02$ \\
\hline Auraine & $\mid .31 E+01$ & $4.03 \mathrm{E}+00$ & $4.03 E+00$ & $1.26 E-06$ \\
\hline BEHP & $1.19 E+07$ & $4.37 E-02$ & $4.3 \pi \mathrm{E}-02$ & $3.16 E-03$ \\
\hline Benzene & $2.41 E+01$ & $2.37 E+00$ & $2.3 \pi E+00$ & $3.16 E-06$ \\
\hline Bromoform & $4.31 E+01$ & $1.63 E+00$ & $1.63 r+00$ & $6.03 E-06$ \\
\hline 2-butancone & 9.5IE-DI & $2.63 \mathrm{E}+01$ & $2.63 E+01$ & 4.90E-0B \\
\hline Burythenzylphatualate & $3.54 E+03$ & $5.70 E-02$ & $5.70 E-02$ & $2.00=-03$ \\
\hline Carbon disalficle & I. $.95 E+01$ & $2.70 E+00$ & $2.70 \varepsilon+00$ & 2.51E-06 \\
\hline Cabon retractioride & $1.70 \varepsilon+01$ & $9.32 E-01$ & 9.32E-0I & $1.59 E-05$ \\
\hline Chlorobenzese & $6.45 E+02$ & $9.32 E-01$ & $9.32 E-01$ & I.S9E-OS \\
\hline Chloroform & $1.85 E+01$ & $2.70 E+00$ & $2.70=+00$ & $2.51 E-06$ \\
\hline 2-chlorophenol & $6.40 E+00$ & $2.07 E+00$ & $2.07 E+00$ & $3.98 E-06$ \\
\hline Dinzicon & $4.63 E+02$ & $2.46 E-01$ & $2.46 E-01$ & $1.58 E-04$ \\
\hline 1.4-dichlorobenzene & $6.00 E+01$ & $4.20 \varepsilon-01$ & $4.20 E-01$ & $6.31 E-05$ \\
\hline 1.I-dichloroethane & $1.35 E+01$ & $3.53 E+00$ & $3.53 E+00$ & $1.58 E-06$ \\
\hline 1.2-dichloroethane & $2.00 E+00$ & $5.26 \mathrm{E}+00$ & $5.26 E+00$ & $7.94 E-07$ \\
\hline 1,I-dichloroethene & $1.47 E+01$ & $2.37 \mathrm{E}+00$ & $2.37 E+00$ & $3.16 E-06$ \\
\hline trans-1.2-dichlorvethylene & $1.36 \mathrm{E}+00$ & $2.37 E+00$ & $2.37 E+00$ & $3.16 E-06$ \\
\hline di-n-butyi phehalate & $1.07 E+04$ & $3.82 E-02$ & $3.82 E-02$ & $3.98 E-03$ \\
\hline di-n-octylptuthalate & $1.87 \mathrm{E}+07$ & $1.86 \mathrm{E}-04$ & $1.86 \mathrm{E}-04$ & $3.985++1) 1$ \\
\hline 2.4-dinitrotoluene & $1.95 \mathrm{E}+01$ & $2.70 \Sigma+00$ & $2.70 E+00$ & $2.51 E-06$ \\
\hline Exhy! benzene & $1.46 E+02$ & $4.92 \mathrm{E}-01$ & $4.92 \mathrm{E}-01$ & $4.79 E-05$ \\
\hline 2-hexanone & $6.59 E+00$ & $6.17 F+00$ & $6.17 E+00$ & $6.03 E-07$ \\
\hline Methylene chloride & $5.74 E+00$ & $6.86 E+00$ & $6.86 E+00$ & $5.01 E-07$ \\
\hline 4-methyl-2-pentanone & $2.08 E+10 n$ & $7.84 \mathrm{E}+00$ & $7.84 E+00$ & $3.98 E-07$ \\
\hline 2-methylphenol & $1.85 \mathrm{E}+01$ & $2.85 E+00$ & $2.85 E+\infty 0$ & $229 F-\infty 6$ \\
\hline n-nitrosodiphenylamine & $1 .+1 E+02$ & $6.25 E-01$ & $6.25 E-01$ & 3.16E-OS \\
\hline n-nitrosoo.propylamine & $7.99 E+00$ & $5.33 E+00$ & $5.33 E+00$ & $7.76 E-07$ \\
\hline Parahion ethyl & 4.63E+02 & $2.46 E-01$ & $246 E-01$ & $158 E-04$ \\
\hline Phenal & 7.57E+00 & $3.26 \mathrm{E}+00$ & $5.26 \mathrm{E}+20$ & $7.94 \mathrm{E}-07$ \\
\hline Pyrene & $2.80 E+03$ & $3.35 E-02$ & $3.35 \mathrm{E}-02$ & $5.01 E-03$ \\
\hline Simazine & 3.6.EE-01 & $3.87 E+01$ & $3.87 E+01$ & $2.51 E-08$ \\
\hline Simetryn & $6.69 \mathrm{E}-01$ & $3.87 E+01$ & $3.87 E+01$ & $25 I E-08$ \\
\hline Tetrachloroethane & $3.90 E+01$ & $2.07 E+00$ & $2.07 E+\infty 0$ & $3.98 E-06$ \\
\hline Tetrechlorethene & S.S7E+01 & 4.20E-01 & $4.20 E-01$ & $6.30 E-05$ \\
\hline Tuluene & $6.99 E+01$ & $1.07 E+00$ & $1.07 E+00$ & 1.26E-05 \\
\hline 1,2.4-1richlombenzene & $1.09 E+03$ & $127 E-01$ & $1.27 \mathrm{E}-01$ & S.01E-04 \\
\hline 1.1.trichlorethane & 6.69E-OI & $3.87 \mathrm{E}+01$ & $3.87 \mathrm{E}+01$ & $2.51 E-08$ \\
\hline 1,1,1-Irichloroethase & $9.00 \mathrm{E}+00$ & $1.39 E+100$ & $1.39 \mathrm{E}+100$ & $7.94 E-06$ \\
\hline Trichlorethylene & $3.79 E+11$ & $1.59 \mathrm{E}+100$ & $1.59 \mathrm{E}+00$ & $6.31 E-06$ \\
\hline Vinyl acetale & 1. $34 \mathrm{c}+00$ & $1.47 \mathrm{E}+101$ & $1.47 E+01$ & $1.35 E-07$ \\
\hline Xylene & $1.77 E+02$ & $548 E-01$ & $S 48 E-01$ & 3 98E-05 \\
\hline Aluminum & $1,00 E+(0)$ & $400 E-03$ & $6.50 \mathrm{e}-04$ & $1.50 \mathrm{E}-03$ \\
\hline Antimony & $1.00 E+C 0$ & $2.00 \mathrm{E}-01$ & $3.00 E-02$ & $1.002-03$ \\
\hline Arsenic & 1. $() E+00$. & $4.00 E-02$ & $6,00 e_{-13}$ & $2.00 E-03$ \\
\hline Barium & $4.002+00$ & I.SOE-OI & $6.50 e-04$ & $1.508-04$ \\
\hline Beryllium & $1.90 E+01$ & $1.00 \mathrm{E}-02$ & $1.508-03$ & $1.002-03$ \\
\hline Bornn & $2.20 R-01$ & $4.00 E+100$ & $2.00 \mathrm{E}+00$ & $8.002-04$ \\
\hline Cadmium & $2.002+102$ & $5,50 \mathrm{e}-01$ & $1.50 \mathrm{e}-01$ & $5.502-04$ \\
\hline
\end{tabular}


Table $8-7$ (cont'd)

\begin{tabular}{|c|c|c|c|c|}
\hline Constivese & 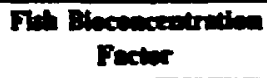 & 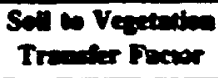 & 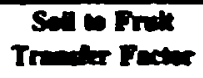 & 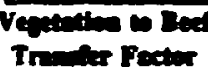 \\
\hline Crromiur & $2.00 E+01$ & $7.502-03$ & $4.50 E-03$ & $5.50=-03$ \\
\hline Cobalt & $5.00 E+01$ & $2.00=-02$ & $7.00 \mathrm{E}-03$ & $2.005-02$ \\
\hline Copper & $5.00 E+01$ & $4.00 E-01$ & $250 E-01$ & $1.00=-02$ \\
\hline Cranide iva & 3.79E-O1 & S.4IE 01 & S.4IE+01 & $1.41 E-\infty$ \\
\hline Lon & $1.00 \varepsilon+02$ & $4.00 t-03$ & $1.00 E-03$ & $2003-02$ \\
\hline Lead & $1.00 E+02$ & 4.5OE-02 & $9.00 \mathrm{E}-03$ & $3.00 E-04$ \\
\hline Lithium & $5.00 E-01$ & $2.50=-02$ & $4.00=-03$ & $1.00=-02$ \\
\hline Magnesiom & $S .00 E+01$ & $1.00 E+00$ & $5.50 E-01$ & $5.00=-03$ \\
\hline Manganese & $4.00 E+02$ & $2.502-01$ & $5.00 E-02$ & $4.00=-04$ \\
\hline Mercury & $2.00 \mathrm{E}+05$ & $9.00 E-01$ & $2.00 \leq-01$ & $250=01$ \\
\hline Molybdeaum & $1.00 E+0 \mid$ & $2 S 0 E-01$ & $6.005-02$ & $6.00 E-03$ \\
\hline Nicked & $1.00 E+02$ & $6.00 \sum-2$ & $6.00 E-02$ & $6.002-03$ \\
\hline Ponassium & $1.00 E+03$ & $1.00 E+\infty$ & $5502-01$ & $2.00 \mathrm{E}-02$ \\
\hline Selemiun & $1.70 E+02$ & $2.502-02$ & $2.505-02$ & $1.50 E-02$ \\
\hline Sitver & $2.30 \varepsilon+00$ & $4.00 E-01$ & $1.00=-01$ & $3.00=-03$ \\
\hline Sodium & $1.00 E+02$ & $7.50=-02$ & $5.5 n E-02$ & $5.50 E-02$ \\
\hline Sulphide & NA & $1.50 E+00$ & $1.50 E+00$ & $1.00 E-01$ \\
\hline Thalliam & $1.00 E+04$ & $4.00 E-03$ & $4.00 E-04$ & $4.00 E-02$ \\
\hline Tia & $3.00 E+03$ & $3.00 E-02$ & $6.00 E-03$ & $8.00 E-02$ \\
\hline Vanadiura & $1.00 E+01$ & $5.50 E-03$ & $3.00=-03$ & $2.50 E-03$ \\
\hline Zinc & $2.00 E+03$ & $1.50 E+\infty 0$ & $9.002-01$ & $|.00 E-0|$ \\
\hline Americium-241 & $2.50 E+01$ & $5.50=-03$ & $3.00=-02$ & $3.50 E-06$ \\
\hline Cesium- 137 & $2.00 E+03$ & 8.0NE-02 & $3.00=-02$ & $2.00 E-02$ \\
\hline Plutonium-238 & $3.50 E+00$ & $4.50 E-04$ & $4.50 E-0 S$ & $5.00 E-07$ \\
\hline Plutonium-239 & $3.50 E+100$ & $4.50 E-04$ & $4.50 \mathrm{E}-0 \mathrm{~S}$ & $5.00 E-07$ \\
\hline Redinm-226 & $5.002+01$ & $1.500-02$ & I.SOE-03 & $2.50 \varepsilon-04$ \\
\hline Radium-228 & $5.00 E+01$ & 1. $F \tilde{C E-02}$ & $1.50 E-03$ & $2.508-04$ \\
\hline Strontiurn-90 & $3.00 E+01$ & $2.50 E+00$ & $2.50 E-01$ & $3.00 E-04$ \\
\hline Trieium & $1.00 E+100$ & $1.00 E+\infty 0$ & $1.00 E+00$ & $1.00 E+00$ \\
\hline Uranium-234 & $2.00 E+00$ & $8.50 E-03$ & $4.00 \mathrm{E}-03$ & $2.00=-04$ \\
\hline Uranium-235 & $2.00 \varepsilon+100$ & 8. $50 E-03$ & $4.00 E-03$ & $2.00 E-04$ \\
\hline Urani_m-238 & $2.00 E+00$ & 8. $50 \mathrm{E}-03$ & $4.002-03$ & $2.00 E-04$ \\
\hline
\end{tabular}

NA $=$ Trunsfer factor could not be calculined.

Seurce: For organics. the transfer factors were calculated from capustions in Travis and Ams (1988) using K, values from the Superfund Chemucal Daulu Matrix (1991). For inorganics and radionuclides, the transfer fecters werc caken from Beas at al. (19M). The $K$, for cyanide was taken from MePAs and the tranefer factors were calculated from equetions in Travis and Ams (1988). 
source terms were decay-corrected by PNL to the time of disposal or release. Estimated dose to icrrestrial receptors was based not only on the radionuclides themselves, but on all short-lived daughter products as well.

Aquatic organisms considered in the assessment include benehic macroinvertebrates and a generic fish species. For radiological analyses, emergent vegetation (i.e., cattails) and muskrats are also included. All aquatic organisms, except for benthic macroinvertebrates, are exposed to contaminants in surface water. Benthic macroinvertebrates are assumed to be exposed only to the sediment pore-water for calculation of internal radiation dose and exposure to chemicals. The extemal radiation dose from exposure to surface water was calculated for all organisms.

\subsection{Contaminant Effects Assessment}

Two pathways are used to determine the effects of contaminant exposure (chapter 8.3) on ecologicai endpoint receptors. For terrestrial receptors, consumption rates of contaminated food and water are compared with toxicological benchmarks. For aquatic receptors, contaminant soncentrations in water or sediment pore water are compared with chemical-specific aquatic benchmarks. To quantify risk to terrestrial receptors exposed to organic and inorganic contaminants, the daily consumption rates of contaminated food and water, normalized to boily weight (in units of $\mathrm{mg} / \mathrm{kg} / \mathrm{d}$ ), were compared to the NOAEL benchmark (mg/kg/d). For purposes of this assessment, the resulting ratio is termed the hazard index (HI). Ratios greater than 1 are considered to pose a potential risk to organisms but do not necessarily indicate the severity of the effect(s). However, it is reasonable to assume that the higher the ratio. the greater the risk of adverse effects. Dose to terrestrial receptors, including vegetation, from internal and external exposure to radionuclides was also determined from calculated tissue concentrations and soil concentrations, respectively. Doses that exceeded $0.1 \mathrm{rad} / \mathrm{d}$ were considered to pose a potentially unacceptable risk (HI $\geq 1$ ) to terrestrial organisms (IAEA 1992). Methods used in calculate exposure and risk are described in appendix $A$.
Toxicological benchmarks for terrestrial organisms, excluding vegetation, were obtained from Opresko et al. (1993) (table 8-8). For representative receptor species that were not listed in the data base, extrapolation techniques were employed to obtain the chronic NOAEL by adjusting for differences in body weight between the receptor and a test organism. If a NOAEL was available for a laboratory test species, the NOAEL for a receptor species could be estimated by extrapolation. Many of the NOAEL benchmarks were derived by extrapolation from small mammal laboratory data (Opresko et al. 1993). There were a few contaminants, however, for which no wildlife toxicity data were found. For these cases, wildlife NOAELs were extrapolated from human non-carcinogenic toxicity data listed in the MEPAS constituent data base, and normalized to the "stardard man" body weight of $70 \mathrm{~kg}$. Thus, for our purposes, wildlife species that weigh less than $70 \mathrm{~kg}$ would have a higher benchmark than a human being would have; wildlife species weighing more than $70 \mathrm{~kg}$ would have lower benchmarks.

Literature sources for inorganic terrestrial phytotoxicity (vegetation) benchmarks were summarized and reported by Suter and Futrell (1993) (table 8-8). Where applicable, the lowest source concentration in a soil medium that produced phytotoxically excessive effects was chosen from the database. Several benchmarks were derived from experiments using nutrient solutions. However, uncertainty values were not applied to these data to account for differences in growth media. A methodology for deriving phytotoxicity benchmarks for organic constituents was developed by Eskew and Babb (1992) (table 8-8).

Risks to aquatic organisms from exposure to organic and inorganic contaminants in water and sediments (pore-water) were calculated by comparing the water or sediment pore-water concentrations with the chemical-specific aquatic benchmark (Suter et al. 1992) (table 8-8). To determine internal dose to aquatic plants, fish, and muskrats from exposure to radionuclides, the surface water concentrations were multiplied by radionuclide and organism-specific (internal) dose conversion factors to produce a daily dose in rads (Killough and McKay 1976). To deternine the internal dose to benthic 
macroinvertebrates and other bottom-dwelling organisms (e.g., fish larvae) from exposure to radionuclides, the sediment pore-water concentrations were multiplied by radionuclide and organism-specific (internal) dose conversion factors to produce a daily dose. The external dose to all organisms was determined by multiplying the surface water concentration by the external radionuclide-specific dose conversion factor. Combined internal and extemal doses greater than $1 \mathrm{rad} / \mathrm{d}$ are considered to pose a potential risk to aquatic organisms (i.e., a HI equal to or greater than 1; NCRP 1991).

Although it is reasonable to assume that many species are exposed to contaminants only some of the time and that contaminant concentrations are not as high as maximum values, an initial screening assessment was conducted using the maximum concentrations of each contaminant on-site to identify worst-case potential contaminants. Following this initial screening. average concentrations were used to represent more realistic exposures for contaminants and receptors that did not pass the initial screening.

Estimating realistic exposures for all endpoints on the reservation is impossible because data are lacking or incomplete in regard to numbers of individuals actually exposed to wastes, amount of time spent in waste areas, and actual amounts of contarininants ingested. In some cases, for example, benchmarks were lacking: consequently. HIs could not be calculated and risks could not be assessed. Specific home ranges, behavior, and habitat requirements of many of the representative species at RFP are not well known or they vary widely, and only a few species with small home ranges (e.g., very small mamnials and small birds) may reside within a contaminated area for most of their lives.

For contaminant and receptor combinations that did not pass the average concentration screening, an attempt was made to further define expostire risks by comparing the home range sizes of receptor species with the potential fraction of the home range that could be contaminated.

Receptor species at RFP have home ranges or territories that range from small [e.g.. I ha (about 2.5 acres) or less for very small animals such as the prairie dog. mouse. and certain aquatic species] to thousands of hectares for the peregrine fakon and coyote (table 8-9). Small species generally have home ranges small enough to be contained within waste sites or other contaminated areas. Other species may have such large home ranges that the waste sites would represent only a relatively small part of the area the species would occupy, if the waste sites were used at all.

To further interpret results of this risk analysis, the following assumptions concerning the contribution of waste sources to receptors are made.

1. For most of the DOE sites assessed in this PEIS, correction factors based on the ratio of the total contaminated area to the home range of terrestrial receptors iwere developed. These factors were applied to the HIs calculated for the average concentrations screening to produce a more reasonable or effective $\mathrm{HI}$. This was done for this assessment as well; home ranges and ratios (correction factors) are presented in table 8-9. However, because the estimate of total contaminated area used in determining exposures is so large, only one receptor species selected for this assessment (the coyote, estimated minimum home range of $2100 \mathrm{ha}$ ) has an estimated minimum home range larger than the reservation's estimated total contaminated area of 980 ha of soil. Published estimates of home ranges for one other species, the endangered peregrine falcon, vary from 65 to 31,000 ha (160 to 77,000 acres) (Brown and Amadon 1968. Schoener 1968). Although the nearest suitable nesting habitat of the peregrine falcon (cliffs and river gorges) is approximately $8 \mathrm{~km}(5$ miles $)$ southwest of the reservation (EG\&G 1991), the reservation is well within hunting range of the falcon, and these birds occasionally fly over. pursue prey, and perch on the reservation (DOE 1992). Thus, for this avian receptor a home range centered on the nearest nesting 
TABLE 8-8 Criteria Benchmarks for Terrestriat and Aquatic ${ }^{b}$ Species at the Rocky Flawi Plant (NOAELs listed in mg/kg/d for terrestrial

benchmarks or $\mathrm{mg} / \mathrm{L}$ for aquatic benchmarks)

\begin{tabular}{|c|c|c|c|c|c|c|c|c|c|c|c|}
\hline renowisuen & Jempin & 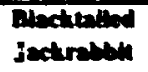 & Praluie Dose & Mats Doer & Meadowlart & Matland & $\begin{array}{l}\text { Poropolas } \\
\text { Fulece }\end{array}$ & Bald Bande & Coyore & Vegeration & Aquede \\
\hline Acenepilictex & NA & NA & NA & NA & NA & NA & NA & NA & NA & $1.28 \mathrm{~F}+02$ & T.97E-01 \\
\hline Natone & 2OAEम01 & $1.86 E+01$ & 6.6SE+C0 & $1.47 E+00$ & $1.53 E+01$ & $6.67 E+00$ & $7.49 E+00$ & $4.27 E+00$ & $2.80 E+00$ & 9.6SE+01 & $2.3 \% E+01$ \\
\hline Aroctox ISSA & $1.53 \mathrm{E}-01$ & $6.05 E-02$ & $6.92 E-02$ & 1.39E-02 & $2.92 E+00$ & 1.5SE:+00 & $1.746+100$ & $9.92 \mathrm{E}-01$ & $2.52 E-02$ & |.0OE+01 & $5.20 E-04$ \\
\hline Aroclor 1360 & $1.57 E+\infty 00$ & 1.19E-02 & $2.92 \mathrm{E}-0.3$ & $6.46 \mathrm{E}-04$ & $9 .|2 E-0|$ & $2.9 .1 E-03$ & $1.29:-03$ & $1.87 \mathrm{~F}-03$ & $1.23 \mathrm{E}-03$ & NA & $2.10 E-03$ \\
\hline BEHP $\because$ & $\mathbf{N A}$ & NA & NA & NA & HA & NA & NA & NA & NA & $1.40 E+01$ & I.OUE-04 \\
\hline Bearexx " & $0.00 E+100$ & $4.60 E+100$ & $1.60 \mathrm{t}+\infty 0$ & $3.08 E-01$ & $1.8 .3 \mathrm{E}+00$ & $1.675+00$ & $1.87 E+00$ & $1.07 E+00$ & $6.995-(1)$ & NA & 2.10:-02 \\
\hline Brompiors & NA & NA & NA & NA & NA & NA & NA & NA & NA & NA & NA \\
\hline 2-butevere- & $2+1 E+(1) 1$ & 1.72E.+1)1 & $0.12 E+(x)$ & $1.35 E+100$ & $|.4| k+0 \mid$ & $0.14 E+100$ & $6.89 E+00$ & $3.93 \mathrm{E}+00$ & $2.37 t+(x)$ & NA & NA \\
\hline 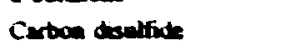 & NA & NA & NA & NA & NA & NA & NA & NA & NA & NA & $1.00 E+03$ \\
\hline 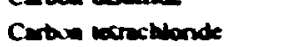 & $1.885-01$ & |. 32E-01 & $4.72 \mathrm{E}-02$ & I.04E-U2 & $1.09 \mathrm{E}-01$ & $4.74 E-02$ & $5.32 E-02$ & $3.0 .1 \mathrm{E}-02$ & $1.94 \mathrm{E}-02$ & $5.60 E+01$ & $6.50 E-02$ \\
\hline Crike benese & NA & NA & NA & NA & NA & NA & NA & NA & NA & NA & $\mid .65 E-01$ \\
\hline avoran nom & 2. 38E+01 & $1.68 E+01$ & $5.99 t+00$ & $0.28 E-01$ & $1.38 E+01$ & $0.00 \leqslant+00$ & $3.20<+\infty 00$ & $1.82 E+00$ & $1.19 \mathrm{E}+100$ & NA & B. $40 t+00$ \\
\hline 1.1 -inchi rrocthane & NA & NA & NA & NA & NA & NA & NA & NA & NA & $8.602-01$ & $1.59 t+00$ \\
\hline 1.2-decturecthane & $1.95 E+00$ & $1.38 k+\infty 0$ & $4.92 E-01$ & $1.09 E-01$ & $1.1 .3 E+\infty 0$ & $4.94 E-01$ & $5.54 E-01$ & $3.168-01$ & $2.07 E-01$ & $3.40 E-01$ & $1.10 E+01$ \\
\hline 1.1 decturathere & NA & NA & NA & NA & NA & NA & NA & NA & MA & NA & 4.47E-01 \\
\hline aress-1,2-dxchloroethylene & NA & NA & NA & NA & NA & NA & NA & NA & NA & NA & NA \\
\hline a-obocyl phethaline & $4.93 E+01$ & $1.79 E+02$ & $1.24:+01$ & $2.74 E+\infty 0$ & $1.29 \mathrm{E}-02$ & $3.64 E-0.3$ & 6.3.31 0.3 & $3.61 E-03$ & $3.22 \mathrm{E}+100$ & $1.41 \mathrm{E}+04$ & $2.20 t-01$ \\
\hline 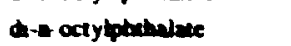 & NA & NA & NA & NA & NA & NA & NA & NA & NA & NA & $310 \mathrm{E}-01$ \\
\hline Estyl bewsence & NA & NA & NA & NA & NA & NA & NA & NA & NA & NA & $4.40 E+02$ \\
\hline 2-1texuroue & NA & NA & NA & NA & NA & NA & NA & NA & NA & NA & $1.26 E+0.3$ \\
\hline Mexhytere chlonde & 1.5AE+01 & $1006+0 \mid$ & $3.85 t+00$ & $8.60 \mathrm{E}-01$ & 8.95E +00 & $3.906+00$ & 4.38E+10 & $2.50 E+00$ & $1.64 E+00$ & $5.601+00$ & $4.100-01$ \\
\hline 4-matiyl-3-penumacer & 1.32E+01 & 9. $32 E+100$ & 3.3.3E+ +00 & $7.35 E-01$ & $7.65 E+00$ & $3.33 E+\infty 0$ & $3.74 E+\infty 0$ & $2.13 E+00$ & $1.40 E+00$ & NA & $1.59 \mathrm{E}+03$ \\
\hline 2- wedily yphenal & NA & NA & NA & NA & NA & NA & NA & NA & Ni & NA & $740 E+01$ \\
\hline 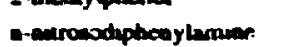 & NA & NA & NA & NA & NA & NA & NA & NA & NA & NA & $4.00 t+01$ \\
\hline Phenal & NA & NA & NA & NA & NA & NA & NA & NA & NA & NA & $2.30:-04$ \\
\hline Preac & NA & NA & NA & NA & NA & NA & NA & NA & NA & $1.28 E+02$ & NA \\
\hline Terectlbroechure & NA & NA & NA & NA & NA & NA & NA & NA & NA & NA & $1.30 E+01$ \\
\hline 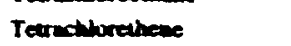 & $1.63 E+00$ & $5.92 E+00$ & 4.|IE-0| & $9.08 E-02$ & $9.45 E-01$ & $4.12 \mathrm{E}-01$ & $4.62 E-01$ & $2.63 \mathrm{E}-01$ & $1.73 E-01$ & $\mid .57 E+01$ & $3.108-01$ \\
\hline Toheace & S.89t+01 & 4.10E+01 & $|.48 E+0|$ & $3.28 E+00$ & $3.4\{E+0\}$ & $1.49 E+01$ & $1.67 E+01$ & $9.52 E+00$ & $6.24 E+10$ & $9.70 E+00$ & $2.60 \mathrm{E}-02$ \\
\hline 1.1.1 michbroethane & NA & NA & NA & NA & NA & NA & NA & NA & NA & $6.102+00$ & $2.51 E-01$ \\
\hline Inclubed ylewe & $175 E+02$ & $1.40 E+02$ & 4.99E+01 & $1.10 E+01$ & $9.45 E-01$ & S.UNE+01 & $5.62 E+01$ & $3.20 E+01$ & $2.10 E+01$ & $6.702-01$ & $5.76 E+00$ \\
\hline Vioyl xreine & NA & NA & NA & NA & NA & NA & NA & NA & NA & NA & $1.03 E+02$ \\
\hline$x$ yloee & $1.32 \mathrm{E}+03$ & $9.32 E+02$ & $3.33 E+02$ & $7.35 \mathrm{E}+01$ & $7.65 E+02$ & $3.33 E+02$ & 3.74E+02 & $2.13 \mathrm{E}+02$ & $1.40 \mathrm{E}+02$ & $2.40 \mathrm{E}+01$ & $2.68 \mathrm{E}+\infty 0$ \\
\hline Alomingm & MA & NA & NA & NA & NA & NA & NA & NA & NA & $8.002+00$ & 8.70E-02 \\
\hline Amoucay & 1.31E+04 & 1.35E+O4 & $3.31 E+03$ & $7.31 E+02$ & $7.61 E+03$ & $3.31 E+03$ & $3.72 E+03$ & $2.12 \mathrm{E}+03$ & $1.39 E+03$ & $5.00 E+00$ & $1.90 E+\infty 0$ \\
\hline Arseax & $1.11 \mathrm{E}-0 \mid$ & $4.55 \mathrm{E}+00$ & $1.62 E+00$ & $0.09 E-01$ & $6.41 E-02$ & $1.63 \mathrm{E}+100$ & $3.10 E+00$ & $1.77 E+00$ & $1.16 E+\infty 0$ & $1.505+01$ & $9.32 \mathrm{E}-01$ \\
\hline Benom & $1.3 S E+\infty$ & 9.51E-01 & $3.39 E-01$ & $7.50 E-02$ & $7.80 \mathrm{E}-01$ & $3.40 \mathrm{E}-01$ & $3.82 E-01$ & $2.18 E-01$ & $1,43 \mathrm{E}-01$ & $3.002+02$ & $2.03 \mathrm{E}+01$ \\
\hline Derylliman & $1.43 E+\infty 0$ & $1.01 E+\infty$ & $3.596-01$ & $7.94 \mathrm{E}-02$ & $8.26 E-01$ & $3.600-01$ & $4.04 E-01$ & $2.31 E-01$ & $|.51 E-0|$ & $1.002+01$ & $3.00 E-03$ \\
\hline Barca & NA & NA & NA & NA & NA & NA & NA & NA & NA & NA & $7.00 \mathrm{E}-03$ \\
\hline Cadranas & $2 . S 4 E-02$ & $|.21 E-0|$ & $6.40 E-03$ & $1.42 E-03$ & $1.32 k-01$ & S.7SE-02 & $2.60 \mathrm{E}-03$ & $1.51 \mathrm{E}-03$ & $2.69 E-03$ & $3.00 E+00$ & $1.102-03$ \\
\hline aromosons & 6. $34 E+00$ & $4.48 E+\infty 0$ & $1.60 E+00$ & 3.5.3E-0I & $3.67 E+100$ & $1.005+00$ & $1.80 E+00$ & $1.02 F+\infty 0$ & $6.71 E-01$ & $7,50 \mathrm{E}+0 \mathrm{t}$ & $1.10 E-02$ \\
\hline
\end{tabular}

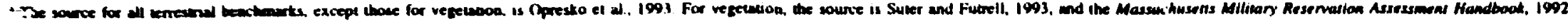

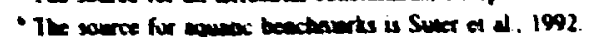


Table 8-8 (con't)

\begin{tabular}{|c|c|c|c|c|c|c|c|c|c|c|c|}
\hline Cenotinesex & Meraplase & 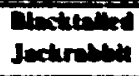 & Praint Dos & Mats Dor & Moadowbert & Mayand & Promertase & Dan Ianele & Coyose & Verectandea & Aquende \\
\hline Cobed & NA & NA & NA & NA & NA & NA & NA & NA & Nh & $2.50 \mathrm{E}+01$ & $4.40 \mathrm{E}-03$ \\
\hline Copper & $1.98 E-01$ & $3.61 E+\infty 0$ & $9.31 E-01$ & 2.06E-01 & $6.30 E+01$ & $2.74 E+01$ & $2.49 E+01$ & $|, 42 E+0|$ & $3.92 \mathrm{E}-01$ & $6.002+01$ & $1.20 \mathrm{e}-02$ \\
\hline Cyende ion & 2.85E +01 & $2.09 E-02$ & $7.18 E+00$ & 2.10E-02 & $1.65 E+01$ & $1.206 ;+\infty 0$ & $8.09 E+100$ & $6.11 E-02$ & $4,002-02$ & NA & $5.202-03$ \\
\hline Iron & NA & NA & NA & NA & NA & NA & NA & NA & NA & $1.00 E+04$ & $1.002+\infty 0$ \\
\hline Lead & 7.66-03 & S.AE-0\} & 1.936 .03 & $4.27 \mathrm{E}-0 \mathrm{4}$ & $1.46 \mathrm{E}-02$ & $\left|17 E_{+}+0\right|$ & $|.32 \mathrm{E}+0|$ & $7.51 E+00$ & B.HE-04 & $1.00 E+02$ & $3.20 \mathrm{E}-03$ \\
\hline Lethingm & NA & NA & NA & NA & NA & NA & NA & NA & NA & $2.00 E+00$ & NA \\
\hline Mapresm & $2.53 E+02$ & $4.18 E+02$ & 6. $34 E+01$ & $1.40 E+101$ & $1,46 E+02$ & $6.36 E+01$ & $7.14 E+01$ & $4.07 E+01$ & $2.67 E+(01$ & NA & $1.602-04$ \\
\hline Marence & $2.10 k+00$ & $4.46 E-02$ & $5.4 \mathrm{E}=01$ & $1.20 k-01$ & $1.25 E+00$ & $5.46 E-01$ & $6 .|| E-0 \mid$. & $3.494-01$ & $2.29 \mathrm{E}-01$ & I.506t03 & $1.10 E+\infty$ \\
\hline Meniury & | SSE+OI & $8.78 E-03$ & $6.92 E-03$ & 1.72E-02 & $2.92 E+0 \mathrm{U}$ & $2.8 .3 E-02$ & $6.8|E-0|$ & 3.88E-01 & $3.27 \mathrm{E}-02$ & $3.00 x-01$ & $1.30=-03$ \\
\hline Malybdeaum & NA & NA & NA & NA & NA & NA & NA & NA & NA & $2.00 E+00$ & $3.60 \mathrm{E}-01$ \\
\hline Nactel & 6. $32 E+01$ & $4.502+01$ & $\mid .61 E+01$ & 3.5SE+OU & $3.82 \mathrm{E}+100$ & $1.67 E+00$ & $1.87 k+\infty$ & $1.07 E+10$ & $6.75 E+00$ & $1.001+02$ & $1.60 E-01$ \\
\hline Powasom & NA & NA & NA & NA & NA & NA & NA & NA & NA & NA & $1.30 \mathrm{e}-04$ \\
\hline Seleaven & $0.04 E-02$ & $2.41 E-01$ & $1.67 E-02$ & $3.70 \mathrm{E}-03$ & 2.29E-01 & $1.00 E-01$ & $1.12 E-01$ & $6,40 \mathrm{~g}-02$ & 7.03E-(1)3 & $1.002+00$ & $3.90=-02$ \\
\hline Sulver & NA & NA & NA & NA & NA & NA & NA & NA & NA & $2.00 t+00$ & $2.00 E-04$ \\
\hline Soctum & NA & NA & NA & NA & NA & NA & NA & NA & NA & NA & $4.008-01$ \\
\hline nulbern & $2.64 E-02$ & I BGE-02 & $0.65 E-03$ & $1.47 E-03$ & $1.53 \mathrm{E}-02$ & $6.67 E-03$ & $7.49 \mathrm{E}-0.3$ & $4.27 E-03$ & $2.00 \mathrm{E}-03$ & $1.000+00$ & $6.40 \mathrm{E}-02$ \\
\hline$\pi$ & NA & NA & NA & NA & NA & NA & NA & NA & NA & S.0OE+01 & NA \\
\hline Vandum & $2.49 \varepsilon-01$ & $7.81 E-02$ & $6.26 E-02$ & I. $396-02$ & $|4| E-0 \mid$ & $6.28 E-02$ & $7.05 E-02$ & $4.02 \mathrm{E}-02$ & $2.63 \mathrm{E}-02$ & S.00Es+01 & $4.102-12$ \\
\hline $2 \operatorname{sac}$ & $2.56 E+01$ & $1.81 E+01$ & 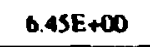 & $1.43 E+\infty 0$ & $1,48 \mathrm{E}+01$ & $0.47 E+(00$ & $7.26 E+00$ & $4.14 E+\infty 0$ & $2.71 E+\infty 0$ & $7.00 E+101$ & $1.102-01$ \\
\hline
\end{tabular}

NA $=$ Beactront son evoulabte. 
habitat and large enough to excompess the entire RFP reservation, that is, approximately $20,000 \mathrm{ha},(49,000$ acres) was assumed. On the basis of this estimate, a correction factor of 0.049 was calculated (table 8-9).

2. The endargered bald eagle presents a rather different situation. This large bird of prey soars over the reservation during winter or, as a migrant, during spring and fall. Thus far, none have been observed mosting or actively hunting prey within the reservation (DOE 1992). These birds generally prefer large bodies of water because their preferred prey is fish. Although these conditions are not wholly met on the riservation, Great Westem Reservoi:; only about $0.5 \mathrm{~km}(0.3$ mile) east of the reservation, and Standley Lake, about $1.9 \mathrm{kin}$ (1.2 miles) east, appear to satisfy these preferences, especially given reports of roosting bald eagles at these reservoirs (Uppendahl 1990). Nevertheless, this analysis treats these birds as potential residents of the contaminated areas for the following reasons. First, if frozen reservoirs prevent preying on fish in the winter, the RFP reservation may prove to be an attractive source of carrion. small mammals, or sther birds for the eagles to feed on. Second, Standley Lake and Great Western Reservoir are contaminated by some of the pollutants originating at RFP; thus these birds presumably would incur some exposure whether or not they feed on the reservation. Third, the reported home range of the bald eingle is between 500 and 800 ha (1200 - 2000 acres) (Terres 1980), so any eagle in the general area would probably find the reservation, and more particularly. the contaminated area, sufficiently large to attract and support it. Fourth, the RFP reseivation may represent a refugium for many potentiai prey species that are probably already undergoing considerable disturbances in surrouding batint from agricuftural and industrial practices as weil as residential development. For these reasons, the appropriate correction factor is considered to be 1.0 (table 8-9).

3. For all other terrestrial endpoint receptors at RFP, minimum home ranges are smaller than the estimated total contaminated area. Thus, no correction factor (i.e., a correction factor of 1.0) was applied to the calculated HIs in tables 8-10 through 8-13 to determine the effective HIs used to characterize risk (see tables 8-14a through 8-14d). In other words, receptor species with minimum home rarges of about 980 ha or less (table 8-9) could receive as much exposure as the average screening of this analysis indicates.

4. The contaminated area actually varies with different contaminant species, but lacking sufficient contaminant-specific distribution data, the estimated total area of 980 ha of contaminated soil and 17 ha of contaminated surface waters and wetlands is assumed to apply to each contaminant. Frposure of biota living completely outside the $38 \%$ of the reservation that is contaminated is limited to contaminants that have moved from waste sites in dust. water, anc by movement of contaminated wildlife. Although some contaminants possibly occur in measurable concentrations outside waste sites, for the most part there are no source terms or measurement data for them and it is assumed thcy are minor compared with the amounts and concentrations in the waste sites.

5. Although the threatened Ute lady'stresses have not been ohserved on the reservation itself, this terrestrial orchid is included in this assessment because of its known proximity (a few kilometers north and south of the reservation) and the identification of potentially suitable 
habitat along swales and the edges of wetlands within the reservation.

6. Wetland and aquatic receptors (fish, benthic invertebrates, and plants) are assumed to be fuliy exposed to contaminants measured in aquatic habitat (i.e., creeks, ponds, and associated wetlands) outside the solar evaporation ponds in the central industrial area, but not in the solar ponds themselves, because reported contaminant concentrations and other water quality and habitat conditions in these small waste ponds would be unlikely to support most aquatic life. Consequently, the actual exposures and risks incurred by aquatic receptor species are likely to be considerably lower than indicated by the HIs shown in table 8-14a through 8-14d and discussed in chapter 8.5.

7. Grazing livestock are not allowed onto the RFP reservation. Risks to this resource would occur only if livestock were allowed to graze in contaminated areas.

\subsection{Contaminant Hazard Assessment}

\subsubsection{Baseline}

The next step in the ecological risk assessment generates HIs that are representative of potential relative risks from exposure to contaminants. Baseline hazard indices (HIs) for terrestrial receptors exposed to the maximum source concentrations exceeded 1 for 15 out of 19 inorganic contaminants (for which benchmarks were available), and 6 out of 17 organic contaminants. Exposure to the maximum concentrations of radionuclides resulted in HIs for all receptors of about 5E+07. Radiological dose was dominated overwhelmingly by exposure to ${ }^{\text {n }} \mathrm{Sr}$ in soils.

Exposure of terrestrial species to average soil and water concentrations at the site were calculated for those contaminants whose maximum concentrations resulted in HIs greater than 1 itable 8-10). Because ${ }^{\text {90 }} \mathrm{Sr}$ concentrations were so much higher than concentrations of other radionuclides, and average ${ }^{9} \mathrm{Sr}$ concentrations could not be estimated, the Hs for all species exposed to the average concentrations of radionuclides were effectively the same as the His for species exposed to the maximum concentrations. ${ }^{90}$ Sr concentrations in the snil thus remained the dominant radionuclide contributing to the total dose for all species.

About $60 \%$ of HI values for all species-contaminant combinations were between' and 10 (versus 49\% for the maximum); 35\% were about 10 but below 1000 (versus $43 \%$ for the maximum), and about 5\% vere still above 1000 (versis $8 \%$ for the maximum).

Exposure of aquatic organisms to the maximum concentrations of non-radiological contaminants in surface water resulted in HIs over $\mathbf{1 0 0 0}$ for the organics BEHP and phenol. No other organic contaminants resulted in HIs greater than 1. Hazard indices also exceed 1000 for aquatic organisms exposed to the maximum concentrations of cyanide ion, $\mathrm{Cd} . \mathrm{Mg}, \mathrm{Hg} . \mathrm{K}$, $\mathrm{Ag}$, and $\mathrm{Na}$ in the surface water. Exposure of aquatic biota to $\mathrm{Be}, \mathrm{Cr}, \mathrm{Co}, \mathrm{Cu}, \mathrm{Fe}, \mathrm{Pb}, \mathrm{Mn}, \mathrm{Mo}$, $\mathrm{Ni}$, and $\mathrm{V}$ resulted in HIs less than 100. Many of the contaminants that appear hazardous to surface water organisms also posed risks to bottom-dwelling organisms. Exposure of benthic macroinvertebrates to the maximum sediment pore-water concentrations (calculated from sediment concentra :ons) resulted in HIs over 1000 for the same contaminants that resulted in HIs over 1000 for surface water dwellers, except for phenol, $\mathrm{K}$ and $\mathrm{Hg}$.

Compared with maximum exposure HIs, there was a 37\% decrease in the number of contaminants with HIs greater than I for aquatic organisms exposed to average concentrations (table 8-12). Hazard indices were still over 1000, however, for cyanide ion, $\mathrm{Mg}$ and $\mathrm{K}$. The HIs for benthic inacroinvertebrates exposed to the average pore-water concentrations were generally within the same order of magnitude as the HIs for maximum exposures, except for $\mathrm{Na}$ and Ag. whose HIs for average exposures decreased by 2 to 3 orders of magnitude. respectively (table 8-12).

Exposure to the maximum. concentrations of radionuclides in the surface water or in the sediment pore-water (macroinvertebrates only) resulted in extremely high HIs (or doses) for all 


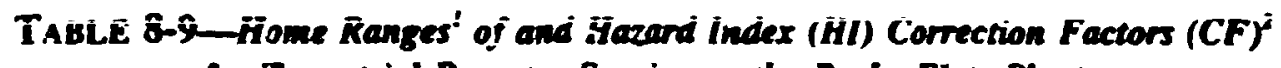
for Terrestrial Receptor Species on the Rochy Flat Plant

\begin{tabular}{|c|c|c|c|}
\hline \multirow[b]{2}{*}{$\begin{array}{l}\text { Receptor } \\
\text { Species }\end{array}$} & \multicolumn{2}{|c|}{ Home Range' (ha) } & \multirow{2}{*}{$\begin{array}{l}\text { Correction } \\
\text { Factor }\end{array}$} \\
\hline & $\leq 980 \mathrm{ha}$ & $>980$ ha & \\
\hline Mes dow jumping mouse & $\frac{x}{(0.08-: . .)}$ & & 1.0 \\
\hline Black-?ailed jackrabbit & $\frac{X}{(7.3-160)}$ & & 1.0 \\
\hline Prairie dog & $\begin{array}{c}X \\
(2.4-2.8)\end{array}$ & & 1.0 \\
\hline Coyote. & & $\begin{array}{c}X \\
(2100-8000)\end{array}$ & 0.47 \\
\hline Mule deer & $\begin{array}{c}X \\
(39 \cdot 3400)\end{array}$ & & 1.0 \\
\hline Westem meadowlark & $\begin{array}{c}x \\
(1.2-6.1)\end{array}$ & & 1.0 \\
\hline Mallard duck & $\begin{array}{c}X \\
(4.0)\end{array}$ & & 1.0 \\
\hline Bald eagle & $\underset{(520-940)}{X}$ & & 1.0 \\
\hline Peregrine falcon & & $\begin{array}{c}X \\
(65-31,000)^{3}\end{array}$ & 0.049 \\
\hline Vegetation & $\begin{array}{c}x \\
(<0.1)\end{array}$ & & 1.0 \\
\hline
\end{tabular}

'Anderson and Wailmo 1984: Brown and Amadon 1968: Bun and Grossenheider 1976 Bekoff 1977: Chapman and Feldhamer 1982: Chapman et al. 1980: Clark et al. 1971. Lim 1987: Schoener 1966: Terres 1980.

'L'nless otherwise noted, the minimum home range was used to calculate HI correction factors. A CF of 1.0 was applied to HIs for each contaminant for each species having home range $\leq 980$ ha.

'A home range of 20,000 ha was used to calculate the correction factor. 
TABlE 8-12-Baseline Hazand Indicies for Terrestrial Organisms on the Rocky Flats Plant

\begin{tabular}{|c|c|c|c|c|c|c|c|c|c|c|}
\hline \multicolumn{11}{|c|}{ 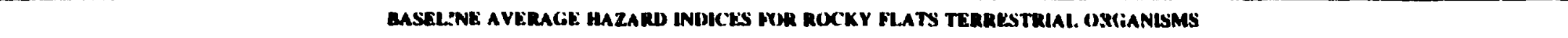 } \\
\hline \multicolumn{11}{|c|}{ 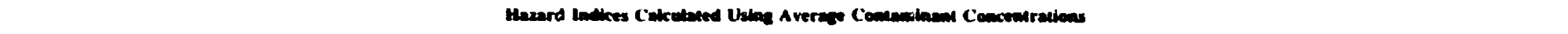 } \\
\hline & Prean's Jumerime & Masch & Pralue & $\begin{array}{l}\text { Mule } \\
\text { Doer }\end{array}$ & $\begin{array}{l}\text { Wealers } \\
\text { Mewanterth }\end{array}$ & Mallard & $\begin{array}{l}\text { Perearime } \\
\text { Pistem }\end{array}$ & and Enang & Coyade & Vegertulloes \\
\hline Acetoere & 9.4E-02 & I. Sat - - OI & $3.41+01$ & 4 (34:-01 & $604 E-02$ & $0.41 t-112$ & 5.2.ti us & $3.75 E-155$ & 49 14: 14: & 7586.03 \\
\hline Aroike 1254 & 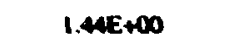 & A.87E+CO & $1.10=60$ & 2.60E+100 & $1000: 01$ & $: 73 !: 01$ & $52 b t-186$ & 6475.05 & $428+0$. & $5.29 E+00$ \\
\hline Aruclos 1200 & 1 Mat-02 & $3 .+2 E+\infty 0$ & $3.62 \mathrm{E}+00$ & $7.92 E+\infty 0$ & 4 A4:-02 & $1.26 E+01$ & 385E W4 & 5 10: 03 & (22t: 02 & NA \\
\hline BEHP & NA & NA & NA & NA & NA & NA & NA & NA & N.I & $324 t-1) 1$ \\
\hline Dn-abeyl phatialue & $2916-04$ & Y. .4AE-05 & $5.20 x-04$ & 4 xat: 149 & $1.24 E+100$ & $2.47 k+10$ & 1 44t-122 & $3.91 \mathrm{k}+01$ & $176 t-05$ & $1796:$ : 14 \\
\hline Tolvese & 3.25E-U2 & $4.77 E-02$ & $1.13 \mathrm{E}-01$ & $1675-01$ & $2346-02$ & $2.98 t-102$ & 1 15t:-1)5 & $1.600-114$ & $2.20 \mathrm{t} \cdot \mathrm{us}$ & $2.79:+100$ \\
\hline Almonemanon & NA & NA & NA & NA & NA & NA & NA & NA & $\boldsymbol{A}^{\wedge} \mathbf{H}^{*}$ & Adbasfito3 \\
\hline 4 SBE-OS & & & & & & & & & $e^{\circ}$ & \\
\hline Anseax & $\cos 2-01$ & I. B6E-02 & $1.94-02$ & $2.1 \mathrm{EE}-02$ & $1.12 E+60$ & 3.79k-02 & 2.4SE-OM & 3.48E-04 & $5.48 E-04$ & 8.30E-01 \\
\hline Denvinas & $2.096-01$ & $4.7|E-U|$ & $8.62 \mathrm{E}-01$ & $1.31 E+\infty 0$ & $2.48 \mathrm{E}-01$ & $4.79 t-61$ & $1.81 \mathrm{E}-132$ & $3.218-02$ & $3.46 E-02$ & 6.35E:-02 \\
\hline Benjitum & $4.41 E+\infty 0$ & $9.12 E+\infty 0$ & 3.87E+00 & $1.11 E+01$ & $1.20 E+01$ & $2.57 E+01$ & $7.316 \mathrm{GH}$ & $3.97 \mathrm{E} \cdot 03$ & $3.396-03$ & $1.93 E+02$ \\
\hline Cadriman & $5.22 \varepsilon+\infty 0$ & $2.53 E-01$ & $6.52 E+00$ & $1.13 E+0 \mid$ & $6.85 E-J I$ & $i .25 k-01$ & $1.01 E+01$ & $3.82 E+02$ & $7.07 E+r 0$ & 0.100 \\
\hline Cromerama & $1.02 \mathrm{E}-0.04$ & $1.10 E-W$ & $1.04 \mathrm{k}-0$. & $2.2 \%=04$ & $1.92 E-64$ & $3.19 \mathrm{E}-61$ & $4.12 \mathrm{E}-05$ & $1.94 E-04$ & $7.86 k-05$ & 1.18E-'J] \\
\hline Cobalk & NA & NA & NA & NA & NA & $N A$ & NA & NA & NA & 0100 \\
\hline Copper & $8.30 E+\infty 0$ & 7. J9E-0I & $1.61 E+00$ & $2.39 E+\infty 100$ & $1.27 \mathrm{E}-12$ & $1.7+E-02$ & 4.i3E- os & AIIE-OM & $3.406-03$ & $1.07 E+00$ \\
\hline Cyande un & I.71E+01 & $6.70 E+03$ & 2.38E+01 & $3.03 E+03$ & 1.95E+01 & $2.07 E+C 1$ & $1.14 E+\infty 1$ & $9.50 E+02$ & $1,64 E * 03$ & NA \\
\hline troe & NA & NA & NA & NA & NA & NA & NA & NA & NA & $2.76 E+00$ \\
\hline Lead & $9.10 E+00$ & $1.67 E+01$ & 1.25E+01 & $3.32 E \star 01$ & $4.995+00$ & S. I7E- 43 & 1.85E-0S & 354:-194 & 2.15E-01 & $1.24 \mathrm{E}-01$ \\
\hline мирестих & $6.31 E-01$ & $3.40 E-01$ & $2.17 E+\infty 0$ & $3.16 E+100$ & 6.24E-01 & $4(606-(1) 1$ & $4.26 \mathrm{E}-02$ & 4. 37E-01 & $8.25 \mathrm{E} \cdot 02$ & NA \\
\hline Manesese & $263 E+\infty 0$ & $1.50 E+\infty$ & $2.90 E+00$ & I.32E^01 & $2.20 E+\infty 0$ & $3.23 E+\infty 0$ & $1.07 k-02$ & 8.02t.-01 & $2.09 t-112$ & $2.20 k-01$ \\
\hline Mercury & 3.00E-102 & Q.9UE+01 & $7.50 E+01$ & $9.62 E+\infty 0$ & 2.14k-02 & $3.09 E+\infty 0$ & $2.05 k-02$ & $7.47 \mathrm{E}+102$ & S.07t:-01 & $3.168+01$ \\
\hline Matyouteanom & NA & NA & NA & NA & NA & NA & NA & NA & NA & 0.00 \\
\hline Nonitud & $3.2 \cup E-03$ & $5,02 E-03$ & $6.68 \mathrm{k}-03$ & $1.17 \mathrm{E}-02$ & $5.04-02$ & $9.43 \mathrm{E}-02$ & $2.52 \mathrm{E}-03$ & 4.90E-02 & S.03E-(04 & $2.75 E-01$ \\
\hline sulver & NA & NA & NA & NA & NA & NA & NA & NA & NA & 0.00 \\
\hline Thellowo & 9.67E-02 & 1.28E-02 & | 2IE-OI & 2.0uE-OI & IIAE UI & $|20 \mathrm{E}-\mathrm{U}|$ & $6.88 \pi-02$ & $1.27 E+02$ & I.31E-01 & 0.00 \\
\hline Vanadum & T.0SE- -01 & $3.11 E+\infty$ & $4.46 E-01$ & $1.56 E+\infty 0$ & $1.95 \mathrm{E}+100$ & $4.18 E+C 0$ & 3.02t:-02 & $8.71 E-02$ & $3.82+52$ & $1.008+00$ \\
\hline $2 x$ & $2.245: 4$ & $415 \mathrm{k}-0 \mid$ & $100 \mathrm{~s}+0$ & 1,55900 & $1055-01$ & 170401 & 252503 & $g 9 \mid F-(0)$ & $10 \%-0 p$ & $1055+0$ \\
\hline
\end{tabular}


TABLE 8-11-Baseline Average Radiological Doses for Terrestrial Organisms on the Rocky Flats Plant

\begin{tabular}{|c|c|c|c|c|c|c|c|c|c|c|}
\hline \multicolumn{11}{|c|}{ 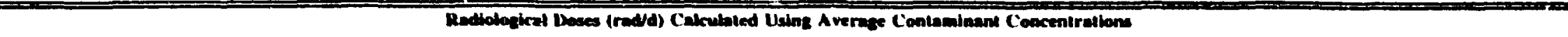 } \\
\hline & $\begin{array}{c}\text { Pretbir's bumpine } \\
\text { Mouse }\end{array}$ & Ji-itrabbil & $\begin{array}{l}\text { Pralirie } \\
\text { Dewe }\end{array}$ & $\begin{array}{l}\text { Mulk } \\
\text { Deer }\end{array}$ & Meadowlart & Mallard & Pereprine bakeen & Balt Enale & Coycle & Vezetation \\
\hline Americinum-241 & $104 E+(x)$ & $104 E+\infty$ & $104 E+\infty 0$ & i. $(24 E+1 X)$ & $1.04 E+(x)$ & $1.04 E+60$ & $104 E+(x)$ & $1.04 E+(X 0)$ & $1(41:+1)$ & 1 HEE+(x) \\
\hline Stromimango & $S S 3 E+06$ & $5.53 \mathrm{E}+(\mathbf{6}$ & $\$ \$ 3 E+C 6$ & $5.54 E+06$ & $5.53 E+106$ & $S .5 \mathrm{EE}+166$ & S.S.3E+HO & $5.53 E+06$ & 5 S.1E+16 & I $84 E+(1)$ \\
\hline Totel dose & $553 E+106$ & S S.JE+U6 & $5.53 E+06$ & $5.54 E+166$ & $5.53 E+16$ & $5.5 .1 E+06$ & $5.5] E+(x)$ & $5.53 E+166$ & 5 S.EE+1(t) & $184 t+07$ \\
\hline Radiulogenal HI & $5.53 E+07$ & $5.53 E+07$ & $5.53 E+07$ & S.SAE+OT & $5.53 E+07$ & $5.53 E+07$ & $5.53 E+117$ & $5.5,3 E+07$ & $5.53 E+07$ & $1.84 E+08$ \\
\hline
\end{tabular}


TABLE 8-12-Baseline Average Hozard Indices for Aquatic Onganirmes an the Recty Flet Pland

\begin{tabular}{|c|c|c|}
\hline \multicolumn{3}{|c|}{ A vernge } \\
\hline Constituent & $\begin{array}{c}\text { Surface Water } \\
\text { HI } \\
\text { (Fish) }\end{array}$ & $\begin{array}{c}\text { Benthic } \\
\text { Macroinvertebrate } \\
\text { HI }\end{array}$ \\
\hline Acetone & $2.42 \mathrm{E}-04$ & $3.45 E-01$ \\
\hline BEHP & $6.20 \mathrm{E}+01$ & NA \\
\hline Di-r-butyl phthalate & $6.85 E-03$ & NA \\
\hline Phenol & $2.80 \mathrm{E}+02$ & $1.02 E+05$ \\
\hline Toluene & $1.08 \mathrm{E}-01$ & $7.67 \mathrm{E}-03$ \\
\hline Aluminum & $4.84 E+00$ & $1.92 E+01$ \\
\hline Antimony & $3.53 E-02$ & NA \\
\hline Arsenic & $1.39 E-02$ & NA \\
\hline Barium & $5.02 E-03$ & $9.47 \mathrm{E}-02$ \\
\hline Beryllium & $1.03 E+00$ & NA \\
\hline Cadmium & $3.58 E+02$ & $1.13 \mathrm{E}+04$ \\
\hline Chromium & $9.91 E-02$ & $7.87 E-01$ \\
\hline Cobalt & $4.21 E-01$ & NA \\
\hline Copper & $1.23 \mathrm{E}+00$ & $1.75 E+02$ \\
\hline Cyanide ion & $2.62 E+05$ & $1.10 E+06$ \\
\hline Iron & $6.84 E-01$ & $5.12 E+02$ \\
\hline Lead & $1.12 \mathrm{E}+00$ & $4.38 E+00$ \\
\hline Magnesium & $2.80 \mathrm{E}+05$ & $5.29 E+06$ \\
\hline Manganese & $8.80 \mathrm{E}-0$. & $1.87 \mathrm{E}+00$ \\
\hline Mercury & $1.56 \mathrm{E}+02$ & $1.545+02$ \\
\hline Molybdenum & $1.67 \mathrm{E}-02$ & NA \\
\hline Nickel & $4.32 E-01$ & $2.90 \mathrm{E}-03$ \\
\hline Potassium & $2.83 E+04$ & NA \\
\hline Silver & $3.36 \mathrm{E} \div 01$ & $9.93 \mathrm{E}+00$ \\
\hline Sodium & $4.06 \mathrm{E}+02$ & $2.49 \mathrm{E}+02$ \\
\hline Thallium & $1.18 \mathrm{E}-01$ & $7.29 \mathrm{E}-02$ \\
\hline Vanadium & $7.63 E-01$ & $4.83 \mathrm{E}-01$ \\
\hline Zinc & $234 \mathrm{sm}$ & Loxsint \\
\hline
\end{tabular}

NA = Benchmark not available, therefore hazard index could not be calculated. 
TABlE 8-13-Baseline Maximum Radiological Doses for Terrestrial Organisms on the Rocky Flats Plant

\begin{tabular}{|c|c|c|c|c|c|c|c|c|c|c|}
\hline \multicolumn{11}{|c|}{ 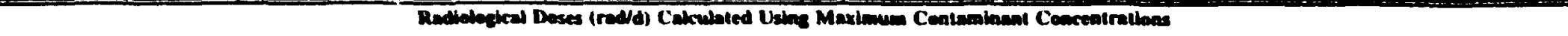 } \\
\hline & $\begin{array}{c}\text { Preble's } \\
\text { Jumpines Mouse }\end{array}$ & Jackrabuli & $\begin{array}{l}\text { Privik } \\
\text { Dese }\end{array}$ & Mule beer & Meadowlark & Mallerd & $\begin{array}{l}\text { Pereprias } \\
\text { Palcun }\end{array}$ & $\begin{array}{l}\text { Dald } \\
\text { baple }\end{array}$ & Coyole & Vezetintion \\
\hline Americiuan-241 & $2.50 E+03$ & $250 E+03$ & $2.506+03$ & $2.50 E+03$ & $2.50 E+03$ & $2.5 \mathrm{SCE}+03$ & $2.506+03$ & $2 . \sin +03$ & $2.5 x+03$ & $3.36 \mathrm{E}+(1) .3$ \\
\hline Cesingo- 137 & S. 32E-13 & I.521: 11 & |OSE-11 & 3.70E-10 & $1.86 \mathrm{E}-12$ & |.04E-11 & $4.71 \mathrm{E}-12$ & S.35E-09 & $6.42 E-11$ & 000 \\
\hline Ptmoaium-238 & $833 E-07$ & ४.3.3E-07 & $83.32: 07$ & 8.J., 07 & $833 E-07$ & $8.13 E-07$ & $8.3 .3 E \cdot 47$ & A.3.3E-07 & H.J3E 07 & 4 צx: U7 \\
\hline Phemoniven-23y & $7.65 E-03$ & $7.65 E-0.3$ & 7.65E-03 & $2.65 \mathrm{E} \cdot 0.3$ & $7.655-0.3$ & $2.65 E-03$ & $7.65 E-0.3$ & 7.6.3E-0.3 & 7.65t: U. & Y.YYE-0. \\
\hline Radiuar 226 & $2.13 E-04$ & $213 E-14$ & $2.13 \mathrm{E}$ Q4 & $213 E-1) 4$ & 2.13E-14 & $213 \mathbf{E}$ O4 & $2.13 E-134$ & $2.13 \mathrm{E}-04$ & $2.13 \mathrm{E}-14$ & $244 E$ US \\
\hline Radiuna-228 & $9.44 E-13$ & $270 E-11$ & I SOE 11 & $6 \sin E \cdot 10$ & 3.30E-12 & | MAE II & $8.16 E-12$ & $2.6 .3 \mathrm{E}-10$ & $1.14 k: 10$ & $\theta(x)$ \\
\hline Strommentso & S S3E+W6 & $5.53 E+06$ & S.53E+06 & $5.94 E+166$ & $5.53 E+06$ & S.5. $. E+106$ & $5.53 E+06$ & $5.53 F+06$ & $5.53+1 \times$ & $1.44+07$ \\
\hline Tritiven & 1. $22 E-\infty$ & $4.92 \mathrm{E}-\mathrm{u}$ & $3396-08$ & $1.20 \mathrm{E}-06$ & $6.02 E-09$ & $3.36 \mathrm{E} \cdot 08$ & $1.52 E \cdot 08$ & $5.69 E-048$ & $2.04 \mathrm{E}-07$ & () (x) \\
\hline Ureniman-234 & $1.658-06$ & $1.67 E-06$ & $1.668-06$ & $2.238 \cdot 06$ & $165 E-06$ & $1.66 E-06$ & $1.6 .5 \mathrm{E}-1 \mathrm{~K}$ & $1.68 \mathrm{E}-0.06$ & $1.75 E-06$ & $588 E-16$ \\
\hline Uranimen-235 & $6.47 E-06$ & $6.47 E-36$ & $647 E-1 \times 6$ & $6.49 E-16$ & $6475-06$ & $6.47 E-106$ & $6.478 \cdot 06$ & $6.47 E-106$ & $6.47 E-106$ & $7.10 \mathrm{e}-06$ \\
\hline Ursainom-238 & $2.05 \mathrm{E}-02$ & $2.06 E-02$ & 2.05E 02 & $2.56 E 02$ & 2.05E-02 & $2.06 E-02$ & $2.03 E-02$ & 2.03E-02 & $2.066-02$ & $2.18 E-02$ \\
\hline Towl dose & $5.53 E+06$ & $5.33 E+06$ & $5.53 E+06$ & $554 E+106$ & $5.53 E+106$ & $5.53 E+(66$ & $5.53 E+06$ & S.53E+06 & $5.53 E+106$ & $1.84 E+07$ \\
\hline Ratiolopical HI & $5.53 E+07$ & S.53E+07 & $5.53 \mathrm{E}+07$ & S.SAE+07 & $5.53 E+07$ & $5.53 \mathrm{E} \times 07$ & $5.53 \mathrm{E}+07$ & $5.53 E+07$ & $5.538+07$ & $1.84 E_{+0}$ \\
\hline
\end{tabular}




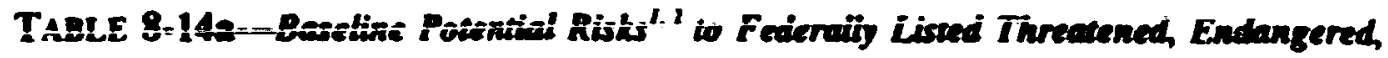
and Candidate Species That May Reside, Feed, or Drink in the Imunediate Vicinity of Contaminated Soils, Sedinents, or Woters on Rocky Flats Plane?.

\begin{tabular}{|c|c|c|c|c|}
\hline Costaminant & $\begin{array}{l}\text { Jumping } \\
\text { Mouse }\end{array}$ & $\begin{array}{l}\text { Bald } \\
\text { Enople }\end{array}$ & $\begin{array}{l}\text { Peregrine } \\
\text { Falcon }\end{array}$ & $\begin{array}{c}\text { Ute's Lody's } \\
\text { Treases }\end{array}$ \\
\hline Aroclor 1254 & $\mathbf{M}$ & & & $\mathbf{M}$ \\
\hline Di-n-butyl phthalate & & $\mathbf{S}$ & & \\
\hline Toluene & & & & $\mathbf{M}$ \\
\hline Aluminum & & & & $\mathbf{S}$ \\
\hline Antimony & & & & $\mathbf{M}$ \\
\hline Beryllium & $\mathbf{M}$ & & & $\mathbf{S}$ \\
\hline Cadmium & $\mathbf{M}$ & $\mathbf{S}$ & & \\
\hline Copper & $\mathbf{M}$ & & & $\mathbf{M}$ \\
\hline Cyanide ion & S & $S$ & & \\
\hline Iron & & & & $\mathbf{M}$ \\
\hline Lead & $\mathbf{M}$ & & & \\
\hline Manganese & $\mathbf{M}$ & & & \\
\hline Mercury & & $\mathbf{S}$ & & $\mathbf{S}$ \\
\hline Thallium & & $\mathbf{S}$ & & \\
\hline Vanadium & & & & $\mathbf{M}$ \\
\hline Zinc & & & & $\mathbf{M}$ \\
\hline Radiologic dose & $\mathbf{S}$ & $\mathbf{S}$ & $\mathbf{S}$ & $\mathbf{S}$ \\
\hline
\end{tabular}

'Potential risks based on assumptions discussed in Section 8.4.3.

${ }^{2} \mathrm{M}=$ moderate risk. where $\mathrm{HI}$ is equal to or greater than 1.0. but less than $10: \mathrm{S}=$ severe risk. where $\mathrm{HI}$ is equal to or greater than 10

'Risks to individuals that are not in the immediate vicinity of the contaminated resources are negligible. Contaminated sites and contaminated waters account for $38 \%$ and $100 \%$ of the surface area and water resources, respectively, on the Rocky Flats Plant 
TABLE 8-14b-Baseline Potential Risks' to Wetlands on the Racky Flate Plont

\begin{tabular}{|l|c|c|}
\hline \multicolumn{1}{|c|}{ Contaminant } & Benthos & Fish \\
\hline BEHP & S & S \\
Phenol & S & M \\
Aluminum & & M \\
Beryllium & S & S \\
Cadmium & S & M \\
Copper & S & S \\
Cyanide ion & S & \\
Iron & M & M \\
Lead & S & S \\
Magnesium & M & \\
Manganese & S & S \\
Mercury & & S \\
Potassium & M & S \\
Silver & S & S \\
Sodium & S & M \\
Zinc & & S \\
Radiological dose & & \\
\hline
\end{tabular}

$' M=$ moderate risk. where $H I$ is equal to or greaser than 1.0 , but less than $10 ; S=$ severe risk, where $H I$ is equal tc or greater than 10 .

'Based on EPA Water Quality Criteria (Suter et al. 1992). We assume that benthic invertebrates are exposed wo port water concentrations while other wetland (aquaric) organisms are exposed to surface waset. 


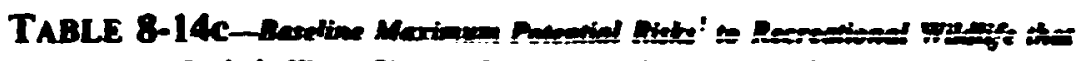

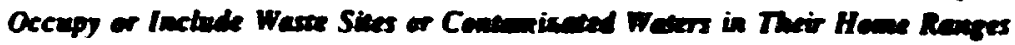
on the Rach Flas rian

\begin{tabular}{|c|c|c|c|}
\hline Contaminant & Jackrabbit & Mule Deer & Mallard \\
\hline Aroclor 1254 & $\mathbf{M}$ & $\mathbf{M}$ & \\
\hline Aroclor 1260 & $\mathbf{M}$ & $\mathbf{M}$ & $\mathbf{s}$ \\
\hline Di-r-butyl phthalate & & & M \\
\hline Barium & & M & \\
\hline Beryllium & $\mathbf{M}$ & $\mathbf{s}$ & $\mathbf{s}$ \\
\hline Cadmium & & $\mathbf{s}$ & \\
\hline Copper. & & $\mathbf{M}$ & \\
\hline Cyanidc ien & S & $\mathbf{S}$ & $\mathbf{s}$ \\
\hline Lead & $\mathbf{S}$ & $\mathbf{S}$ & \\
\hline Magnesium & & $\mathbf{M}$ & \\
\hline Manganese & $\mathbf{S}$ & $\mathbf{S}$ & $\mathbf{M}$ \\
\hline Mercury & $\mathbf{S}$ & $\mathbf{M}$ & $\mathbf{M}$ \\
\hline Vanadium & $\mathbf{M}$ & M & M \\
\hline Zine & & M & \\
\hline Radiologic dose & $\mathbf{s}$ & $\mathbf{s}$ & $\mathbf{s}$ \\
\hline
\end{tabular}

$' M=$ moderate risk. where $\mathrm{HI}$ is equal to or greater than 1.0. but less than $10: S=$ severe risk. where $\mathrm{HI}$ is equal to or greater than 10 . 


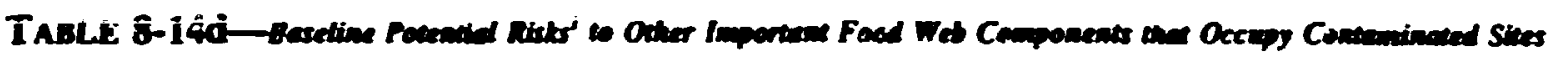

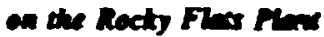

\begin{tabular}{|c|c|c|c|c|}
\hline Contaminant & Prairie Dog & Coyote & Mescowlert & Vegetation \\
\hline Aroclor 1254 & $\mathbf{M}$ & & & M \\
\hline Aroclor 1260 & $\mathbf{M}$ & & & \\
\hline Di-n-butyl phthalate & & & M & \\
\hline Toluene & & & & M \\
\hline Aluminum & & & & $\mathbf{S}$ \\
\hline Antimony & & & & $\mathbf{N}$ \\
\hline Arsenic & & & M & \\
\hline Beryllium & $\mathbf{M}$ & & s & $\mathbf{s}$ \\
\hline Cadmium & $\mathbf{M}$ & M & & \\
\hline Copper & $\mathbf{M}$ & & & $\mathbf{M}$ \\
\hline Cyanide ion & $\mathbf{S}$ & $\mathbf{S}$ & $\mathbf{S}$ & \\
\hline Iron & & & & $\mathbf{M}$ \\
\hline Lead & $\mathbf{S}$ & & $\mathbf{M}$ & \\
\hline Magnesium & $\mathbf{M}$ & & & \\
\hline Manganese & $\mathbf{M}$ & & $\mathbf{M}$ & \\
\hline Mercury & $\mathbf{S}$ & & & $\mathbf{S}$ \\
\hline Vanadium & & & M & $\mathbf{M}$ \\
\hline Zinc & $\mathbf{M}$ & & & $\mathbf{M}$ \\
\hline Radiologic dose & $\mathbf{s}$ & $\mathbf{s}$ & $\mathbf{s}$ & $\mathbf{s}$ \\
\hline
\end{tabular}

$' \mathrm{M}=$ moderale risk. where $\mathrm{HI}$ is equal to or greater than I.0, but leas than 10; $\mathrm{S}$ = severe risk, where $\mathrm{HI}$ is equal to or greater than 10. 
anpesio organisms exposed to "Sr. Exposure to average concentrations resulted in substantially the same HIs for the same reasons stated above for terrestrial receptors (table 8-13).

From the initial suite of 92 constituents of concern. the two-stage screening process using maximum and then average coniaminant values yielded 27 contaminants producing $\mathbf{H I}$ values equal to or greater than I (i.e., resresenting at least an intermediate risk from coniaminants) for at least one endpoint receptor, as shown in tables 8-10 through 8-13). Of these, 20 contaminants produce $\mathrm{HIl}$ values of 10 or greater (i.e., severe risk) for one or more endpoint receptors. A few contaminant - species combinations restilted in HIs in the thousands. and. indeed, HIs as high as $1.8 \mathrm{e}+8$ for terrestrial organisnis and $9.0 \mathrm{e}+6$ for aquatic organisms were calculated for radionuclides. Because these radionuclide values are not credible this matter will be addressed in more detail below. Otherwise, inorganics (primarily trace elements) most commoniy exceeded HI values of one, followed by organic compounds.

The incomprehensibly high $\mathrm{HI}$ values $\left(-10^{6}-10^{8}\right)$ calculated for radiation exposures to all receptors are almost entirely due to one radioactive contaminant. "Sr. And yet even ponds designed and used on the reservation specifically for containment of contaminated water and sediments appear to support relatively healthy aquatic communities, including, for example, largemouth bass. This fact alone demonstrates that the calculated HI values for radionuclides are not credible. Moreover, examination of the source term data base (Worksheer "B") reveals ${ }^{n 0} \mathrm{Sr}$ concentrations higher than $1.8 \mathrm{pC} \Omega \mathrm{L}$ in surface waters and $0.1 \mathrm{pCV} / \mathrm{g}$ in sediments. To put this in perspective, continual exposure of fish to a conecntration of $1.8 \mathrm{pCi} / \mathrm{h}$ would produce a $\mathrm{HI}$ (rads per day) of only $5.5 \mathrm{e}-7$, or about 14 orders of magnitude below the $\mathrm{HI}$ calculated in this assessment.

On the other hand. it was found that concentrations of strontium metal in the water of solar evaporation ponds within the central industrial complex were up to six times the concentrations found off-site and elsewhere on the reservation. Similarly, solar pond sediments exhibited elevated s:rontium metal concentrations faboit thice times ithe incan concentration reported for the western U.S., but well within the range of concentrations reported for this region (Shacklette and Boerngen 1984)]. However, only if all strontium metal in these solar ponds were assumed to be "Sr would the magnitude of HIs reported in this document be feasible. Backcalculations indicate that is exactly what happened sometime early in the data gathering process for calculation of source terms. Based on examination of the evidence available, it is therefore concluded that $\mathrm{Sr}$ does not pose undue risks to receptor species outside of the solar ponds, but, because it cannot be ascertained for certain that considerable quantities of ${ }^{20} \mathrm{Sr}$ do not exist in the solar ponds themselves, we have recorded the His for total radionuclides in this EIS to indicate possible relative risk to any organism residing in, or otherwise using these ponds, however unlikely that may be. Even without "Sr, the HI of 2900 (i.e., highly "severe" risk) for ${ }^{201}$ Am-effects on aquatic invertebrates would sill be cause for concern. but a similar examination of the available data on ${ }^{241} \mathrm{Am}$ indicates that this particular $\mathrm{HI}$ is also probably incorrect. Based on soil data, however. the ${ }^{24 !} \mathrm{Am} \mathrm{HIs}$ of 1.0 (representing the threshold for moderate risk) for all terrestrial wildlife do appear potentially valid.

Following the assumptions outlined in Section 8.4. the approximate home range or territory size of receptors was determined to calculate the proportion of their range that could potentialiy encompass contaminated lands or surface waters (table 8-9). Because of the large extent of the area assumed for this analysis to be contaminated [i.e. 980 ha $(2400 \mathrm{ac})$ of contaminated soil and virually all reservation surface waters and wetlands. plus off-site. but downstream. reservoirs (570 ha or $[400 \mathrm{ac})]$. only two receptor species exhibit minimum horre ranges larget than the postulated contaminated area. These are the coyote ( 2100 he home range) and the peregrine fakon (20,000 ha home range).

\subsubsection{Threatened and Endangered Species}

As shown in table 8-14a, all four Federally listed threatened, endangered, or candidate species used as receptors in this assessment are subject to Hls greater then 1, although radionuclides ( ${ }^{\circ} \mathrm{Sr}$ and 
${ }^{241}$ Am! were the only contaminnnts generating such 2 hazard index for the peregrine fakcon. Six contaminants (radioruclides, three metals. and one organic) all pose severe risks to the bald eagle if it should forage and drink regularly on the reservation. The Preble's meadow jumping mouse (a candidate species) incurs severe risks from cyanide and radiation exposure, and moderate risks from six other contaminants (five metals and one organic). Finally, a total of 11 contaminants exhibit HIs greater than one with respect to a federally listed threatened plant, the Ute lady's-tresses. Four of these contaminants (Al, Be. Hg. and radionuclides) pose severe risks. Although by these analyses, individuals of these species utilizing contaminated areas would presumably dic. a site specific analysis using individual waste sources and actual occurrences of threatened and endangered species would be necessary to determine actual risks.

\subsubsection{Wetlands}

Risks to wetlano receptors (e.g., benthic macroinvertebrates and fish) that might receive contamination from the waste sites are shown in table 8-14b. Potential risks to benthic invertebrates are considered severe for 11 contaminants and moderate for three, while potential risks to fish residing in wetlands are severe for 10 contaminants and moderate for five.

It should be noted, however that the aqueous concentrations of some contaminants $(\mathrm{Mg}$ and $\mathrm{K}$ in particular) that result in severe risk ratings for fish and/or benthic macroinvertebrates only moderately exceed average background concentrations and are well within the range of consentrations reported ior natural waters (Bowen 1979). The benchmarks used in this analysis ray well be based on test species that are unusually sensitive to these contaminants, thereby resulting in the severe risk ratings. Magnesium and K. therefore, almost cernainly do not represent severe risks to aquatic life at the concentrations used in this analysis.

\subsubsection{Recreational Wildlife}

Table 8-14c summarizes risks to recreationally desirable species at RFP. Baseline average His for recreational cerrestrial species as represcnted

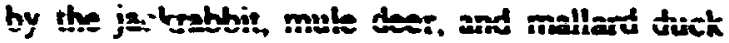
exseeded unity for 15 different contaminants. including trace metals, cyanide ion. PCBs (Aroclor 1254 and 1260), and radionuclides. Moreover, based on this assessment. five of the contaminants pose severe risks to jackrabbits. four would produce severe risks to mallards, and six contaminants would put deer at severe risk.

\subsubsection{Agriculume and Timber Production}

Although once a part of the vast area of open rangeland dominating this region in the past, the reservation is now off limits to agriculture of any kind. This endpoint, therefore, was not a factor in this assessment.

\subsubsection{Parks and Other Public Lands}

No public lands overtap the site, and the only designated public lands near the site are the Boulde- County Open Space land adjoining the northem boundary of the reservation and the Standley Lake Recreation Area to the east. Maximum porential risks to receptors in this endpoint, therefore, are assumed to be equivalent to those calculated for similar food web components (receptors) within the reservation boundary in the case of the adjacent Boulder County Open Space land, but also for the Standley Lake area as well since it was included in the total irea of contamination used to calculate Hazard Indices for the various receptors. Thus cables 8-11 and 8-12 and the remarks in this section concerning these tables represent the maximum potential risks to receptors in these public lands. Most probably. however, contaminant levels in these public lands are far below those reported for contaminated areas in the reservation: consequently actual risks to receptor species on public lands are almost certainly much lower than the values reported for on-site receptors.

\subsubsection{Biodiversity}

Table 8-14d summarizes the baseline potential risks to four food web components selected as representative receptor species for the biidiversity endpoint. It should be understood. however, that all of the other receptor species evaluated in this assessment (and many that were 
not considered in this assessment 2t al!) are also important elements of biodiversity as RFP.

Each of a total of 19 contaminants pose moderate or severe risks to one or more of the biodiversity endpoint receptor species selected for this analysis: the prairie dog. coyote. meadowlark, and vegetation. With respect to the prairie dog. four contaminants (cyanide, lead. mercury, and radionuclides) resulted in severe risks, and eight contaninants produced moderate risks. Cyanide and radiologic exposure result in severe risks to the coyote and meadowlark as well. The coyote incurs a moderate risk from cadmium, while the meadowlart is subject to a severe risk from beryllium exposure and moderate risks from four metals and one organic compound (di-n-butyl phthalate). Finally, four contaminants (aluminum, beryllium. mercury. and radiologic exposure) are seen to be severe risks for vegetation, while six ocher contaminants pose moderate risks.

\subsubsection{Conclusions}

Based on the assumptions and calculations used in this assessment, cerrain contaminants at cerrain locations pose moderate to severe risks from a large suite of contaminants to selected receptor species (depending on the particular contaminant) in the endangered species, wetlands, recreational wildlife. and biodiversity endpoint calegories. Under some circumstances, receptor species on (wo nearby public lands may incur risks. Table 8-15 shows which individual contaminants pose risks to one or more receptor species in the six endpoints.

The HI values generated by this analysis should nor be viewed as absoluce measures of risk; they represent estimated relative potensial risks to be used for comparative purposes only, and should be understood only in that sense. For numerous reasons discussed earlier, many of these HIs are likely to prove to be highly conservative. The actual areas of ecologically hazardous levels of contamination. for example. are probably far smaller for most contaminants than assumed in this analysis; consequently exposures and risks incurred by most aquatic and terrestrial organisms not in the immediate areas of contamination would likely be far less than indicated by these indices of relative risk (harard intines). The value of tilese inazand indices. rather. lies in their usefulness as tool: that can provide decisionmakers and other i.ierested persons information needed to compare or rank relative risks among the many contaminants occurring within a given DOE facility. and among the various DOE facilities.

\subsection{Habitat Disturgance/ Fragmiantation Assescaisnt}

\subsubsection{Baseline}

Although nearly $88 \%$ (approximately 2300 ha or 5800 acre) of the reservation is relatively undisturbed by construction and operation of the Rocky Flats Plant facilities (about 320 ha or 790 acre). all or nearly all of the reservation prior to construction of the plant was used as grazing range for livestock. Even though the reservation is hardly a perfect example of the montane-prairie transition ecosystem that once dominated the region, the non-developed and largely recovered buffer zone nevertheless presents a reasonably good semblance of the former undisturbed ecosystem, and supports many of the structural and functional elements necessary to the persistence of such an ecosystem. Moreover, the value of this buffer zone to regional biodiversity and aesthetics continually increases as similar land succumbs on an almost daily basis to agricultural. industrial, and residential development. As long as this buffer zone is secured from such development, the baseline condition (or no-action altemative) will have litule direct effect on habitat in terns of disturbance or fragmentation beyond the limited damage already done by past construction and operations.

\subsection{Cumulattve assessmeat}

\subsubsection{On-SHe}

\subsubsection{Baseline}

As many as 26 contaminants present at RFP have been identified on the basis of this analysis as potential hazards ( $\mathrm{Hls} \geq \mathrm{l}$ ) to the well-being of certain endpoint recepior species of local ecosystems including four federally listed 


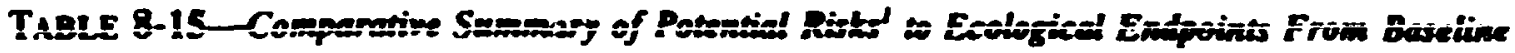
and ARAR Altermatives on the Rochy Flats Plant. Risks ane for eadpoins which occupy of use convaminated land andlor waters'

\begin{tabular}{|c|c|c|}
\hline Soarce of Rist & $\begin{array}{l}\text { Endpolines" - No-Action } \\
\text { (Beseline) }\end{array}$ & $\begin{array}{c}\text { Escipaims - ARAR (to be } \\
\text { provided) }\end{array}$ \\
\hline $\begin{array}{l}\text { Construction } \\
\text { Aroclor 1254 } \\
\text { Aroclor } 1260 \\
\text { BEHP } \\
\text { Cyanide ion } \\
\text { Di-n-butyl phathalate } \\
\text { Phenol } \\
\text { Toluene } \\
\text { Aluminum } \\
\text { Antimony } \\
\text { Arsenic } \\
\text { Barium } \\
\text { Beryllium } \\
\text { Cadmium } \\
\text { Copper } \\
\text { Iron } \\
\text { Lead } \\
\text { Magnesium } \\
\text { Manganese } \\
\text { Mercury } \\
\text { Potassium } \\
\text { Silver } \\
\text { Sodium } \\
\text { Thallium } \\
\text { Vanadium } \\
\text { Zinc } \\
\text { Radiologic dose }\end{array}$ & $\begin{array}{l}\text { E.R.B } \\
\text { R.B } \\
\text { W } \\
\text { E.W.R.B } \\
\text { E.R.B } \\
\text { W } \\
\text { E } \\
\text { E.W B } \\
\text { E. B } \\
\text { d } \\
\text { R } \\
\text { E.W.R.B } \\
\text { E.W.R.B } \\
\text { E.W.R.B } \\
\text { E.W.B } \\
\text { E.W.R.B } \\
\text { W.R.B } \\
\text { E.W.R.B } \\
\text { E.W.R.B } \\
\text { W } \\
\text { W } \\
\text { W } \\
\text { E } \\
\text { E.R.B } \\
\text { E. W.R.B } \\
\text { E.W.R.B }\end{array}$ & \\
\hline
\end{tabular}

'Only those contaminants are listed which our analyses showed could pose severe or moderate risks to some endpoints.

'Risks to endpoints which do not include known comaminated areas within their ranges are assumed to be segligible (see Section 4.4 J).

'These are short-lerm risks. Longterm risks could be reduced with successful restoration of approprime habitas.

- Ecological endpoints: $E$ = threatened. endangered. and candidace species: $W=$ wetlands; $R=$ recreaional fish and wildife; $F$ a agriculuure and timioer production; $P$ = parks and other pubtic lands; 8 a biodivensity (only for recepers not included under other endpoints) 
threatened, endangered, and candidate species, recreationally desirable fish and wilalife, and other elements of biodiversity. More specifically, 17 contaminants refresenting all three contamisant classes (organics, inorganics. and radionuclides) pose moderate to severe risks to one or more federaliy listed species and wetland receptor species. Similarly, 15 contaminants represent potentially moderate to severe risks to recreational wildlife. and a total of 19 contaminants could pose moderate or higher risks to other important elements of biodiversity. With the exception of radionuclides. the cyanide ion represents severe risks to the most receptor species (ten of 13 species). followed in importance by the metals $\mathrm{Be}, \mathrm{Cd} . \mathrm{Pb}$. and $\mathrm{Al}$. On the basis of closer examination of other evidence available (see discussion in chapter 8.5.1), these estimates of risks from radionuclides appear to be far 100 excessive. and, in fact, radionuclides as a class are probably of little consequence to any organisms not residing in the immediate vicinity of a few small waste sites. Moreover, certain other contaminants that apeear to represent moderate or severe risks to some receptors occur at concentrations comparable to, or even well below, background concentrations reported for the western United States (chapter 8.5.1). Table 8-15 summarizes which contaminants pose moderate or severe risks to one or more receptor species in four of the six endpoints that occur on-site.

Neither agricultural and timber production, nor public lands, occur on the reservation, but public lands do occur off-site where they may possibly be affected by small amounts of RFP-generated contaminants (see chapter $\mathbf{8 . 7 . 2}$ below).

\section{7 .2 OLfSite}

\subsubsection{Baseline}

Some of the contaminants found on the RFP reservation (mostly radionuclides) are known to occur in relatively low concentrations in three downstream reservoirs where they possibly, but not likely, affect offsite terrestrial and aquatic receptors using these reservoirs. Even though these reservoirs were included in the cumulative area of "contaminated waters" used in this assessment, the available data on contaminan levels in these reservoirs (indicating very low concentrations of contaminants) strongly suggest that rerrestrial and aquatic life would not in face. be adversely affected. In the unlikely event these contaminants eventually should be found to exert some degree of stress on resident organisms. then cumulative effects of these contaminants and other external stresses. including physical disturbances such dredging. and other sources of pollutants such as runoff from agricultural. residential, and industrial development in the watersheds. would be expected to be greater than if RFP-generated contaminants acted alone.

Other possible mechanisms for contaminant transport off-site are contaminant ingestion by widely ranging wildlfife (e.g.. migratory birds and coyotes), and wind-borne dust. Neither mechanism would likely be as important at Rocky Flats as hydrologic transpon of contaminants. 


\section{CHAPTER 9: PORTSHOUTH GASEOUS DIFFUSION PLANT}

The Portsmouth Gaseous Diffusion Plant (PORTS) occupies about 400 ha (1000 acres) of a 1620-ha [4000-acre: 6.2-km $\mathrm{km}^{2} \quad\left(6.3-\mathrm{mi}^{2}\right]$ reservation in sparsely populated Pike County. Ohio. The primary orocess at Portsmouth, since beginnia 8 operation in 1954, has been separating uranium isotopes by way of a gaseous diffusion cascade. The reservation is about $1.6 \mathrm{~km}$ (1 mile) east of the Scioto River Valley at an elevation approximately $36.6 \mathrm{~m}$ (120 ft) above the Scioto River floodplain [162 m (530 ft) above mean sea level] (figure 9-1). The areas of the plant not occupied by buildings and roads are mowed grassy fieids with a few wooded areas. The surrounding DOE land is pasture; oid fields; upland and bottomland hardwood forest and pine forest; second-growth hardwood forest dominated by white oak and red oak, with some hickory; and scrub thicket. Much of the site was logged in 1977. Cattle graze selected portions of open pasture and forest. Land surrounding the Portsmouth Reservation. except for the Scioto River floudplain, is marginal farmland and densely forested hills. The floodplain is farmed extensively, particularly with row crops such as com and soybeans. Hillsides and terraces are commonly used for cattle grazing. Currently, there are no systematic programs to monitor or characterize ecological resources at Portsmouth. However, a work plan (DOE 1993) is being prepared to characterize the environmental setting and to determine ecological effects from the release of contaminants. Information in this repon was drawn from Rogers et al. (1988); ERDA (1977a and b); and Saylor et al. (1990).

The Portsmouth Reservation lies within the Scioto River drainage basin at the headwaters of two smal! tributaries to the Scioto River-Little Beaver Creek and Big Run Creek. The Scioto River is a major tributary of the Ohio River. Both groundwater and surface water are drained from the reservation by this network of tributaries (DOE 1993). Little Beaver Creek drains the northern portion sf Portsmouth; shortly after leaving the reservation it flows into Big Beaver Creek which also receives nunoff directly from the nontheastern portion of the plant. Big Beaver Creek flows to the Scioto River. Storm water is drained from the southern portion of Portsmouth via the South Holding Pond, which overflows to Big Run Creek, and from the southwest, central, and westem portions of the plant via holding ponds, drainage dit ihes. and intermittent unnamed tributaries to the scioto River.

The reservation itself is characterized by (1) the fenced centrally located production and waste storage area [about $40 \mathrm{c}$ ha $(1000$ acres)] surrounded by grasses and herbaceous dicots that are mowed throughout the growing season, (2) several small pine plantations and extensive oid field and second-growth hardwoods loakhickory) north and east of the plant. (3) pastureland used partly for grazing of cattle south and north of the plant, (4) bottomland mixed hardwoods along the creeks, and (5) upland mixed hardwoods along the westem border of the reservation. No federally listed threatened, endangered, or candidate species of plants, or animals are known to inhabit the Porsmouth Reservation. Wetland swales and ditches and emergent wetlands occur primarily along streams, in topographic depressions, and along roads. In addition, small wetland areas formed around holding ponds are utilized by migratory waterfowl. Recreational fish [e.g.. longear sunfish (Lepomis megaloris) and smallmouth bass (Micropterus dolomieu)] occur in downstream segments of Little Beaver Creek. Although hunting is not allowed, several recreational wildlife species are present. Imporant species groups of concern for conservation of biodiversity at Portsmouth include songibirds, raptors, deer, fox, bats, amphibians, fish, and vegetation.

\subsection{ECOLOGICAl ENDPONTSS AND SPECRES DistrRBution}

Endpoints can be represented by many different receptors. The ecological endpoints and receptors chosen for the Portsmouth Reservation 


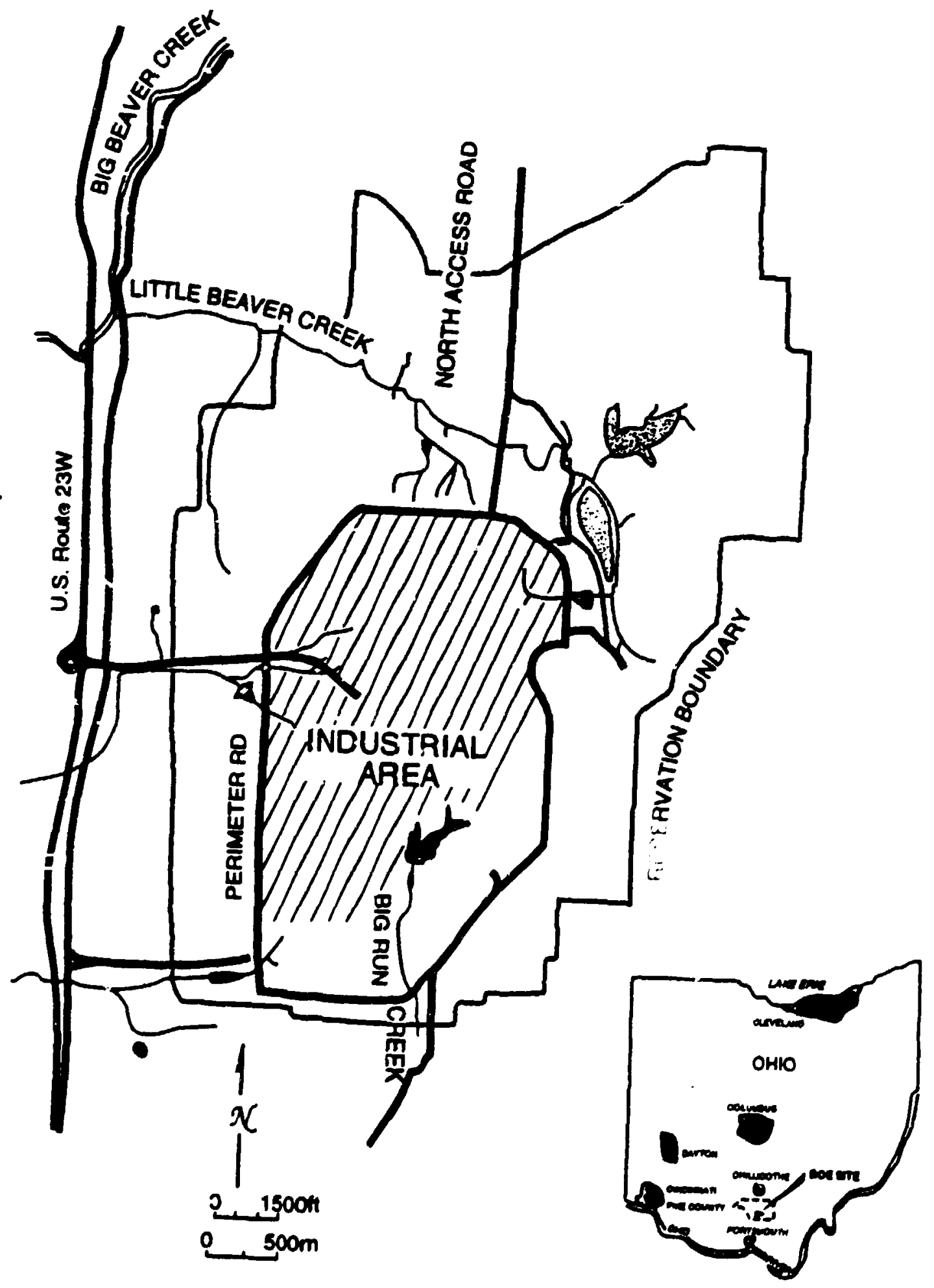


ecological risk assessment are described in this section of the report. In summany, currently, no fecierally listed threatened, endangered, or candidate species of plants or animals are known to occur on the reservation: wetlands are found in swales, ditches, and ponds, along the streams, and in lopographic depressions; recreational wildlife species are present but hunting is not allowed: grazing is limited to specific areas; no public areas occur on the reservation; and the vegetation and wildlife (i.e., biodiversity) are typical of that found in the su.tounding area.

Determining risks to endpoints requires (1) defining distribution and composition of endpoints and (2) selecting receptor species. The distribu:ion of endpoints must be known in order to determine both exposure pathways for contaminants and risks to endpoints from construction.

For purposes of determining risk of exposure to contaminants, distribution of endpoints is considered to be either ubiquitous (i.e., more or less uniformly distributed throughout the reservation or region); discrete (i.e., located in one clearly identified location); or discontinuous ii.e., found in several locations within 1 limited area or areas). Risks to ubiquitous endpoints are assumed to be related to the total surface area dffected by contaminant exposure or by discurbance from construction. Risks to discontinuous and discrete endpoints are determined if their locations are known to be within contaminated areas or within areas affected by remediation-related construction or contaminant exposures.

Ubiquitous endpoints include: recreational wildlife and certain components of biodiversity (table 9-1). Wetlands, agriculture and forestry, and the oniy federally listed species (if present) exhibit discontinuous distributions. Locations of endpoints were determined from existing maps and publications.

Endpoints can be represented by many different receptors. The following sections describe endpoints on the Portsmouth Reservation and receptors selected for these analyses.

\subsubsection{Threatened and Endangered Species}

\subsubsection{Receptors}

The geographic range of the federally listed endangered Indiana bat (Myotis sodalis) encompasses the Portsmouth Reservation. Although the Indiana bat is not known to inhabit the reservation, it was selected as representative of a federally listed threatened, endangered, or candidate species under the Endangered Species Act that may at least forage on the reservation. Currently, no federally listed or candidate species are known to occur at Portsmouth.

\subsubsection{Distribution}

The Indiana bat has been reported in the Portsmouth area (Houlberg et al. 1992). As do most bats, the Indiana bat lives in caves and feeds on flying insects. At the time of this report, no caves were known to exist on Portsmouth. However, the site may provide suitable frraging habitat. Foraging habitat for one colony of Indiana bats ranged from 1.5 ha (3.6 acres) in early summer to 4.5 ha $(11.2$ acres) after young bats are flying (Humphrey et al. 1977). In the summer, these bats forage for insects in the upper woodland canopy (Thomson 1982). They prefer mature riparian woodland, with dead trees for shelter, along small to medium-sized streams.

\subsubsection{Wetlands}

\subsubsection{Receptors}

Representative wetland organisms include minnows and other small fish species, benthic invertebrates, and wetland vegetation such as cattails and rushes. For this assessment, benthic invertebrates and fish were selected as the receptors representative of reservation wetlands.

\subsubsection{Distribution}

The extent of wetlands on the reservation is unknown. A wetland survey was completed in 1993 for Quadrant III of the Portsmouth 


\begin{tabular}{|l|l|l|}
\hline \multicolumn{1}{|c|}{ Ubiquitous } & \multicolumn{1}{|c|}{ Discontinuous } & Discrete \\
\hline $\begin{array}{l}\text { Recreational wildlife (fish. } \\
\text { rabbit, and deer) }\end{array}$ & $\begin{array}{l}\text { Wetlands (fish, benthic invertebrates. } \\
\text { and vegetation) }\end{array}$ & \\
$\begin{array}{l}\text { Components of biodiversity } \\
\text { not included above (bats, } \\
\text { mice. songbirds, raptors, } \\
\text { foxes, and insects) }\end{array}$ & $\begin{array}{l}\text { Agricultural and timber production } \\
\text { (vegetation) }\end{array}$ & $\begin{array}{l}\text { Threatened and endangered species } \\
\text { (Indiana bat, if present) }\end{array}$ \\
\hline
\end{tabular}

Reservation Manual for Identifying and Delineating Jurisdictional Wetlands. This survey delineated wetland swales and ditches, emergent wetlands on alluvial soils, and nine wetland areas. Wetland swales exist adjacent to many roads in Quadrant III and are identified by cattails and other vegetation. Emergent wetlands and wetland areas are identified by hydric soils. They occur primarily along streams and topographic depressions in Quadrant III (DOE 1993). Holding ponds located around the reservation also provide wetland habitat for muskrats and migrating waterfowl. These wetlands and the receptors chosen to represent them exhibit discontinuous distributions. For purposes of this assessment. the wetlands are considered to be under the influence of the waste sites.

\subsubsection{Recreational Fish and Wildlife}

\subsubsection{Receptors}

Several recreationally desirable animals occur on the Portsmouth Reservation, although the reservation is closed to public access. Fish (particularly those of the catfish and sunfish families), the cottontail rabbit, and the white-tailed deer were selected for this assessment as representative of the recreational fish and wildife at the reservation. The data araifable for fish are not specific to species of interest; therefore. the assessment is limited to risks to fish as a class.

\subsubsection{Distribution}

Little Beaver Creek is the largest stream on the Portsmouth Reservation. It drains the northem and northeastern part of the site before discharging into Big Beaver Creek upstream of the reservation. Little Beaver Creek has intermittent flow throughout the year. Nevertheless, populations of spotred bass, northern hog sucker, longear sunfish, and several darter species are commonly found at sites a short distance downstream from all Portsmouth inputs. Recreationally desirable fish (e.g., sunfish, bass, and crappie) are also found in Big Beaver Creek and, of course, in the Scioto River. Game mammals and birds that occur on the reservation include the eastem cottontail rabbit (Sylvilogus floridanus), white-tailed deer (Odocoileus virginianus), and the bobwhite quail (Colinus virginianus). The fish have a discontinuous distribution, whereas both mammalian species are considered to be ubiquitous in distribution. 


\subsubsection{Agricultural or Timber Production}

\subsubsection{Receptors}

Although cattle are allowed to graze on the Portsmouth Reservation, under normal circumstances they do not have access to contaminated sites. Therefore, vegetation (representing grass and planted pines), but not cattle. was selected for this assessment as the endpoint receptor representative of agricultural production.

\subsubsection{Distribution}

Much of the land on which Portsmouth was constructed was originally cropland. The area within the perimeter road not occupied by buildings and roads is mowed grassy fields. A few wooded areas also exist. The DOE property surrounding the perimeter road supports pasture, old fields, upland and bottomland mixed hardwoods and pine forest, second-growth hardwoods, and scrub thicket. Much of the site was logged in 1977. This assessment considers only vegetation on or adjacent to the contaminated sites.

\subsubsection{Parks and Other Public Lands}

\subsubsection{Receptors}

Except for Wayne National Forest. no likely receptors in terms of parks and public lands were identified for this assessment.

\subsubsection{Distribution}

There are no parks or public lands on the reservation. The land surrounding the reservation is mostly privately owned croplands. Wayne National Forest is adjacent to the Portsmouth property on the east and southeast. The Brush Creek State Forest is about $1.6 \mathrm{~km}$ ( 1 mile) southwest of the property and west of the Scioto River.

\subsubsection{Blodiversity}

\subsubsection{Receptors}

Ecosystems of the reservation and environs underwent substantial alteration with the arrival of the first European settlers. Virgin forest and the complex plant and animal communities it supported no longer exist in the area. What woodland exists is fragmented, and current practices in land management on the reservation (e.g., mowing and gazing) prevent the establishment of truly climax communities. Even so, the fragmented and disturbed terrestrial systems support a variety of plant and animal communities.

Except for cattle. all of the animals and plants used as representative of the other endpoints discussed above are considered as representative elements of area biodiversity and. therefore, are used in this assessment of impacts on biodiversity (i.e., the mouse. rabbit, deer, robin, bat, hawk, fox, vegetation, aquatic invertebrates, and fish). Note that for this assessment aquatic organisms are assumed to be absent from the actual waste sites.

\subsubsection{Distribution}

All but two of the selected receptors representative of the area's biodiversity are considered to have ubiquitous distributions. Fish and benthic invertebrates have discontinuous distributions.

\subsection{Contaminants of Poitentul CONCERN}

The contaminants of potential concem at Portimouth include radionuclides and inorganic and organic contaminants. The primary radionuclides are ${ }^{28} \mathrm{U}$ and ${ }^{20} \mathrm{Tc}$; the primary inorganics are $\mathrm{Al}, \mathrm{As}, \mathrm{Ba}, \mathrm{Cd} . \mathrm{Cu}, \mathrm{H}_{\mathrm{g}}$ and $\mathrm{Pb}$; the primary organic contaminants are polychlorinared biphenyls (PCBs), vinyl chloride and benzo(a)pyrene. 
Maximum and average concentrations of chemical and radiological contaninants in soil. surface water, and sediment were determined from the source terms provided by PNL (tables 9-2, 9-3 and 9-4 respectively) and compared to toxicological benchmarks. Determination of these average and maximum concentrations required that certain assumptions be made with regard to data interpretation and compensation for data gaps. Appendix A describes the methodology used to develop the source terms for input into the exposure and risk assessment.

\subsection{Exposure Assessment}

Where available for Portsmouth, the maximum concentrations of each contaminant in each medium (i.e.. soil, water, and sediment) were used to identify the worst-case porential contaminants. Contaminants that did not pose a risk to any of the receptor species from exposure to the maximum values (when compared to toxicological benchmarks, see chapter 9.4) were not considered further. If exposure to the maximum concentrations of contaminants posed a risk to organisms, then the average concentrations of those contaminants were estimated and used in the assessment to determine the most probable and reasonable exposure and risk.

Estimating contaminant exposure for receptor species on the reservation also depends on knowing the amount of time species spend in waste areas and the amount of contaminants ingested. Because specific home ranges aid habits of many of the receptor species on Portsmouth are not well known, an initial screening assessment for contamitiant exposure was conducted using conservative assumptions. Even though only a few species with small home ranges (e.g.. small mammals, and birds) could reside within contaminated areas for most of their lives and even fewer individuals could contact areas of inaximum concentrations (see chapter 9.4 for discussion of home ranges). the conservative assumptions were applied routinely.

The risk assessment (appendix A) estimates the risk to vegetation, terrestrial wildlife, and aquatic organisms from chronic exposure to radiological and nonradiological contaminants. In these exposure analyses, the ecological endpoints and their receptor species were sossidered. However. due to limited availability of sensitivity data for many species (e.g., threatened and endangered species) and to similarities in exposure risk (e.g., similarly sized receptors feeding on the same prey). representative organisms for each exdpoint were chosen for evaluatioa. A food web was developed tha includes receptor species representing the endpoints (figure 9-2). In all cases in which dota were available, conservative estimnes of exposure and risk were made by selecting receptors that are either (1) most sensitive to contaminants or habitat alteration. (2) most likely to experience additional risk because of bioaccumulation or larger body size, or (3) at greatest risk because of rarity. Other abundant species on the reservation were included as important prey cormponents of the foodweb. such as mice and insects (risk estimates were not determined for insects).

The primary exposure routes for terrestrial wildlife species are exposure to external radiation and ingestion of food (including soils for some species) and water. Table 9-5 lists the body weights and consumption rates for the representative species. The cow is assumed to feed exclusively on the vegetative parts of plants. The cottontail rabbit and white-tailed deer are assumed to eat $50 \%$ vegetation and $50 \%$ fruits and seeds. On the basis of a review of the literature, the percentage of prey items consumed by omnivores and predators was estimated (table 9-5; figure 9-2). The mouse and robin are assumed to eat $70 \%$ fruitseeds and $30 \%$ insects; the red-tailed hawk eats $80 \%$ mice and $20 \%$ rabbits; and the red fox eats $70 \%$ inice and $30 \%$ rabbits. The bat is assumed to eat $100 \%$ insects. and the insects are assumed to eat 100\% vegetative plant parts.

All species are assumed to purposely or incidentally ingest soil while eating. grooming. or preening except for the bat, hawk, and red fox (table 9-5). The soil ingestion rate (Q) for cottontail rabbits was assumed to be the same as that reponted for the jackmabit, $6.3 \%$ of the dry-matter intake (Arthur and Gates 1988). The whise-tailed deer soil ingestion rate is asumed to be the same as that reported for the mule deer. 1.35\% of the dry-maner intake (Arthur and 


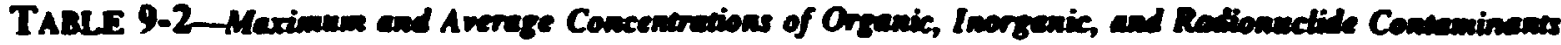

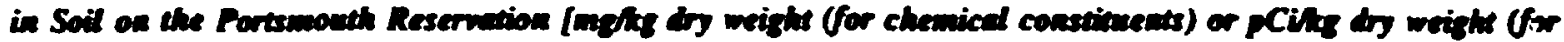
refionmefives)]

\begin{tabular}{|c|c|c|c|}
\hline Comatiment & 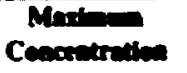 & 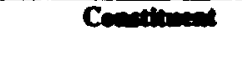 & Averes Concendratien \\
\hline Acenspetrene & $1.20 E+00$ & Acenaptiese & $208 E-02$ \\
\hline Acenapthylene & $7.10 \varepsilon-03$ & Anthracese & $6.605-02$ \\
\hline Acetone & $3.90 E-01$ & Aroclor 1260 & $1.50=-01$ \\
\hline Anthracene & $1.80 E+00$ & Bescodalendracene & $1.52 E-01$ \\
\hline Aroctor 1254 & $2.10 E-01$ & Bescolalpyiene & $1.14 E-0 \mid$ \\
\hline Aroctor 1260 & $2.00=+03$ & Benwic acid & $2.50 \varepsilon-01$ \\
\hline Bendene & $5.10 E-03$ & BEHP & $5.20 \Sigma-02$ \\
\hline Benzoralanthrecene & $1.50 c+\infty 0$ & Foornothene & $2.49 E-01$ \\
\hline Benzola)pyiere & $3 . \pi E+\infty$ & Preanothere & $1.79 E-01$ \\
\hline Benzo(b) Mlooranthene & $4.00 E+\infty 0$ & Trichloroethene & $4.06 E-01$ \\
\hline Benzo(ghi)perylexe & $2.50 E+00$ & Viayl chloride & $8.92 E-01$ \\
\hline Benzo(k)fluormanthene & $3.00 E+\infty 0$ & Aluminisin & $1.16 E+04$ \\
\hline Benzoic acud & $8.40 E-01$ & Anumony & $6.60 E+\infty 00$ \\
\hline BEHP & I.00E+02 & Arsenic & $3.35 E+01$ \\
\hline Bromodichloromechane & $790 E-03$ & Berium & $6.98 E+01$ \\
\hline 2 -burasose & $1.80 E-02$ & Codminam & $1.00 . E+\infty 0$ \\
\hline Buyl benzyl phathalaxe & $2.70 E-02$ & Cromimg & $1.34 E+01$ \\
\hline Carbon disulfide & $1.20 E+00$ & Cobale & $1.58 E+01$ \\
\hline Chlorobenarne & $5.00=-03$ & Coppe & $2.07 E+01$ \\
\hline Chloroform & $6.25 E-01$ & Cyanide ion & $3.20 \varepsilon+00$ \\
\hline Chloromethane & $6.60 E-02$ & Iroa & $3.43 E+04$ \\
\hline 4-chloro-3-methylpotenol & $4.60 E-01$ & Lead & $3.78 E+0 !$ \\
\hline 2-chlorophenol & 8. $50 E-01$ & Mapresium & 7.34E+03 \\
\hline Chryene & $7.06 E+00$ & Manganese & $3.24 E+02$ \\
\hline Dibenzofurm & $6.60=-01$ & Mercury & $1.71 E+\infty 0$ \\
\hline Dibenzo(s.h)anthracene & 6. $10 E-01$ & Nictel & $5.7|E+0|$ \\
\hline 1.2-dichlorobenzene & $3.50 \mathrm{E}-01$ & Potescium & $1.42 E+03$ \\
\hline 1.A-dichlorobenzene & $2.40 E-01$ & Selenium & $7.80 E+00$ \\
\hline 1.1-dichloroethane & $2.05 E-01$ & Silver & $6.56 E+00$ \\
\hline 1.1-dichloroethene & $3.302-03$ & Sodiun ion & $1.69 E+02$ \\
\hline cis-1.2-dichioroecthene & $3.80 e-03$ & Thallium & $1.305+00$ \\
\hline Irans-1.2-dichlorcethene & $1.70 E-03$ & Vanadium & $3.94 E+01$ \\
\hline 1.1-dichloroethylene & $5.88 E-02$ & Zinc & $4.78 E+01$ \\
\hline 2-trans-dichloroethylene & $1.44 E+00$ & Technecium-99 & $2.44 E+02$ \\
\hline 2.4-dichlorophenol & $2.40 E-01$ & & \\
\hline $4,4-D O T$ & $1.60 E-02$ & & \\
\hline 2.4-diaitrotoluene & $2.00 E-01$ & & \\
\hline Diethyl phehalate & $1.80 E-01$ & & \\
\hline Dimethyl phthalete & $4.30=-03$ & & \\
\hline Di-n-buryl phthalase & $3.50 E-01$ & & \\
\hline Di-n-octylphthalme & $2.20 \mathrm{E}-02$ & & \\
\hline Ethylbenzene & $2.30=-03$ & & \\
\hline Fluoranthene & $1.30 E+01$ & & \\
\hline Flworene & i. $40 E+00$ & & \\
\hline Freon & $3.59 \mathrm{E}+\infty 0$ & & \\
\hline indenor $(1.2 .3-\mathrm{cd}$ )pyrene & $2.10 \mathrm{E}+00$ & & \\
\hline Methylene chloride & $|32 E-0|$ & & \\
\hline 2-methylnapshylene & $6.602-01$ & & \\
\hline 2-mathylphenol & $8.502-01$ & & \\
\hline Nepthalene & $5.002-01$ & & \\
\hline 4-nituophenol & $3.102-01$ & & \\
\hline n-nitrosodi-n-propyl & $=002-01$ & & \\
\hline
\end{tabular}


TABLE 9.2 (conthend)

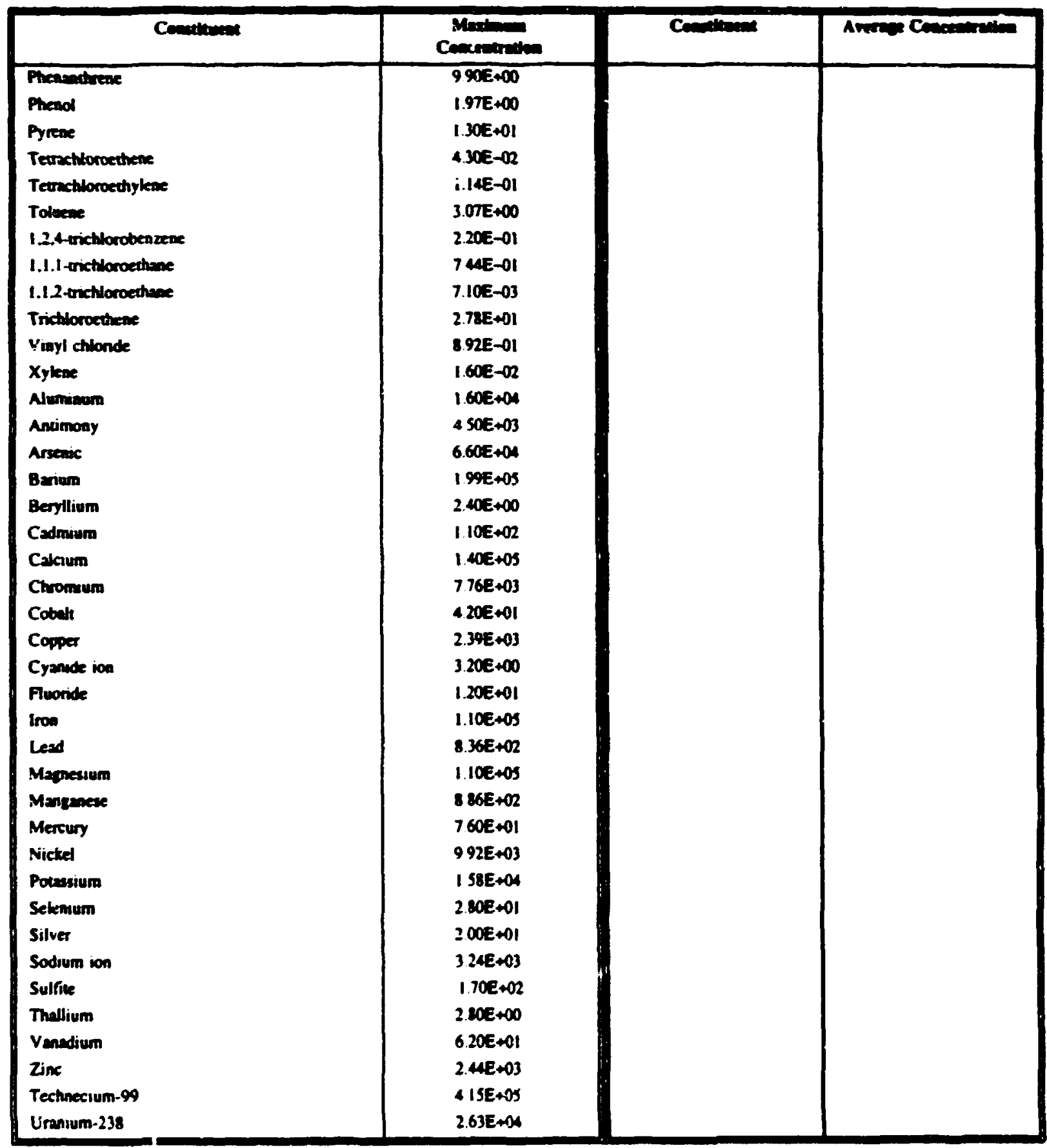




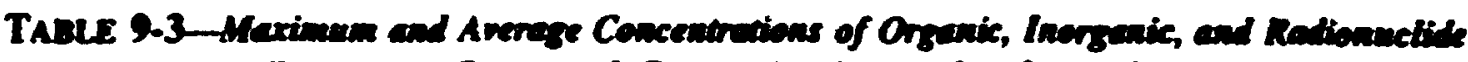

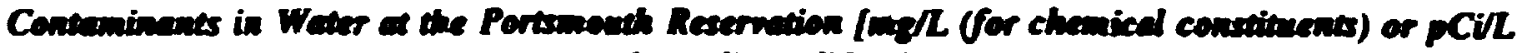
(for malionucliates)!

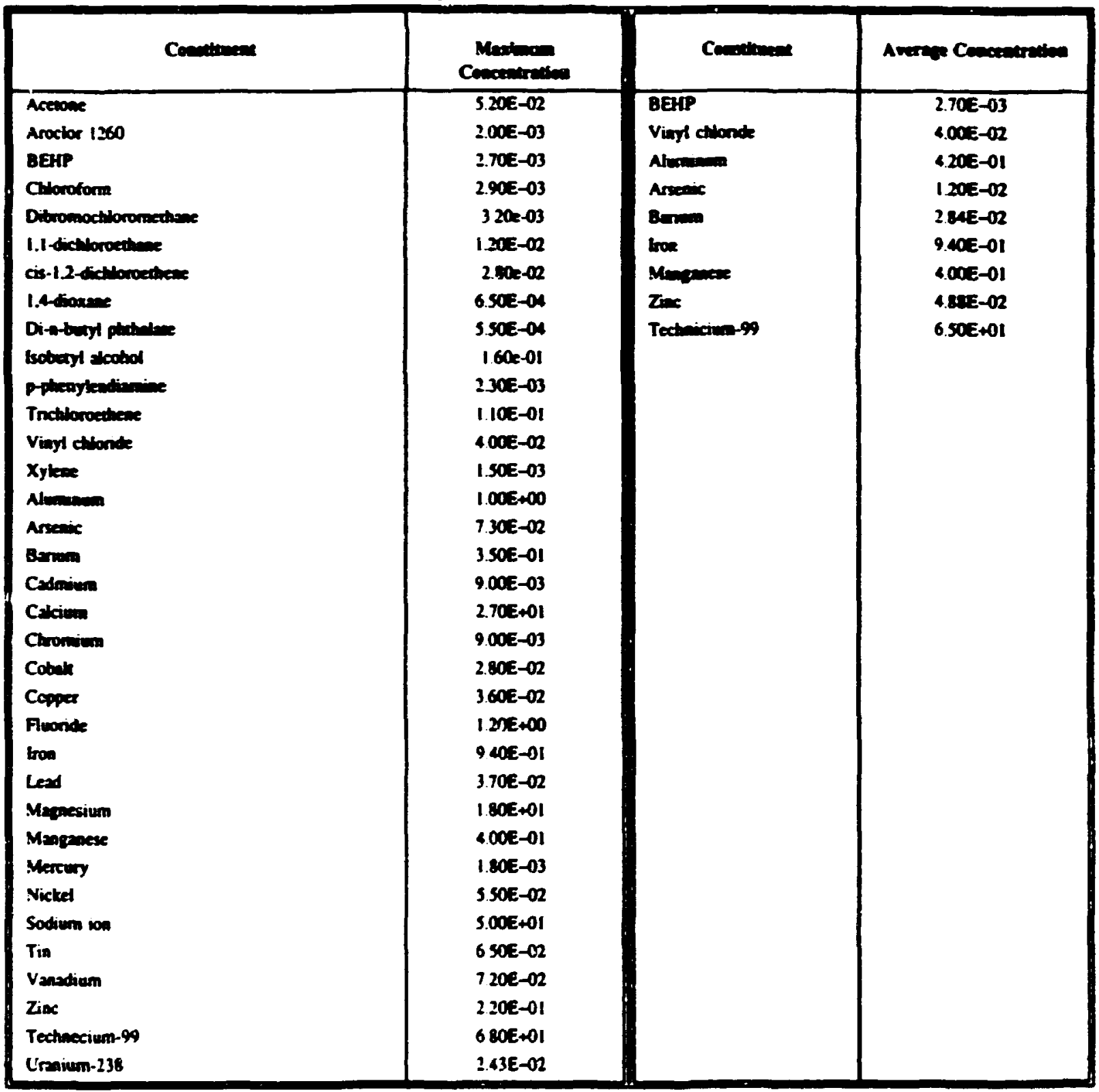

9-9 


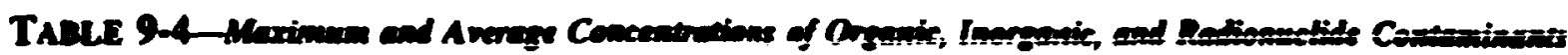

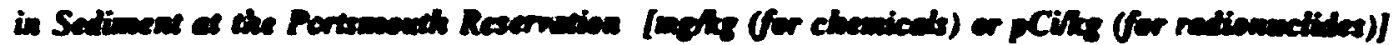

\begin{tabular}{|c|c|c|c|}
\hline 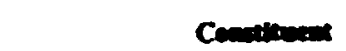 & 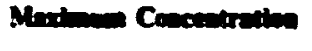 & Conomenese & Averes Conctinesten \\
\hline 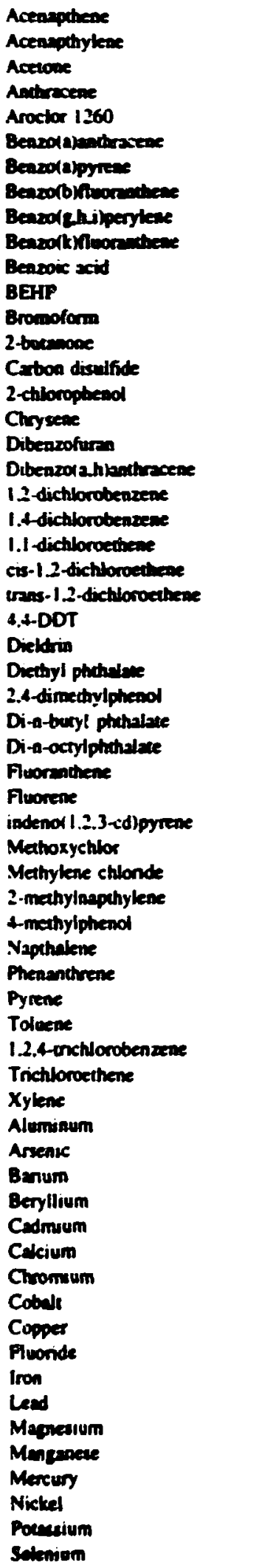 & 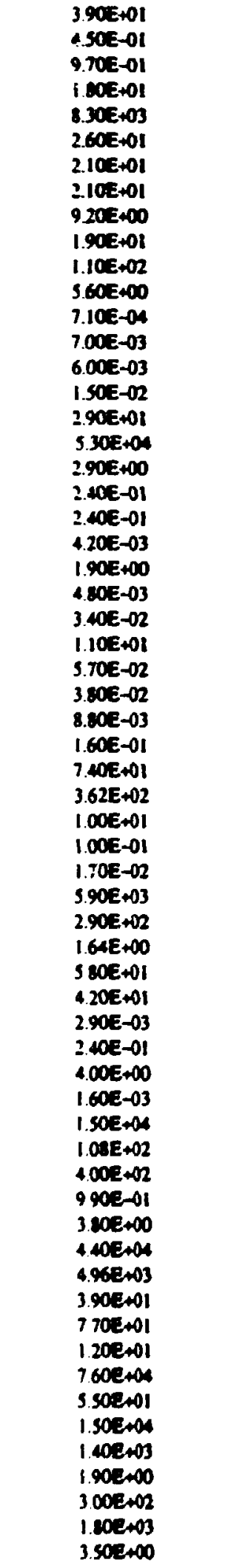 & 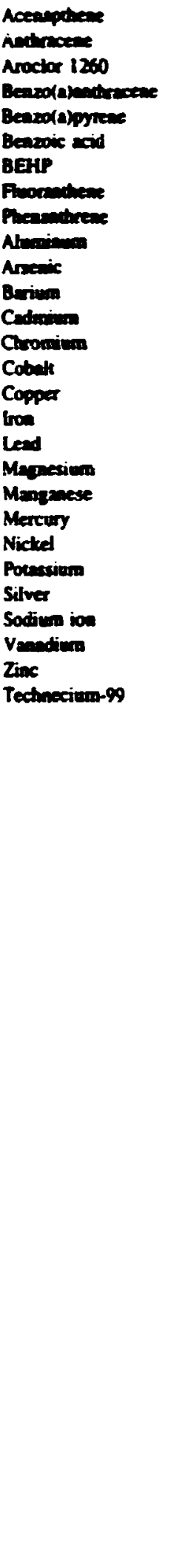 & $\begin{array}{l}1.22 E+01 \\
2.13 E+00 \\
3.8 \% E+02 \\
3.23 E+00 \\
1.75 E+00 \\
1.33 E-01 \\
3.11 E+00 \\
9.83 E+00 \\
9.70 E+00 \\
1.43 E+03 \\
5.8 \% E+00 \\
1.96 E+02 \\
2.04 E+00 \\
4.18 E+01 \\
1.34 E+01 \\
1.28 E+00 \\
2.94 E+04 \\
2.11 E+01 \\
360 E+03 \\
+.86 E+02 \\
9.71 E-01 \\
130 E+02 \\
1.02 E+03 \\
760 E+00 \\
8.20 E+01 \\
3.34 E+01 \\
3.60 E+02 \\
1.50 E+05\end{array}$ \\
\hline
\end{tabular}


Talle 9-4 (con't)

\begin{tabular}{|c|c|c|c|}
\hline 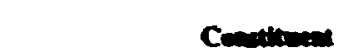 & 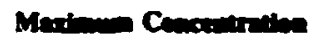 & 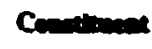 & 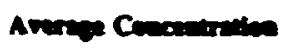 \\
\hline 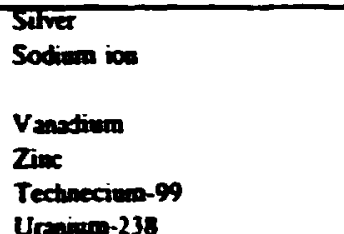 & $\begin{array}{l}\text { T.10E201 } \\
2.30 E+02 \\
8.10 E+01 \\
8.30 E+02 \\
4.61 E+15 \\
2.00 E+04\end{array}$ & & \\
\hline
\end{tabular}




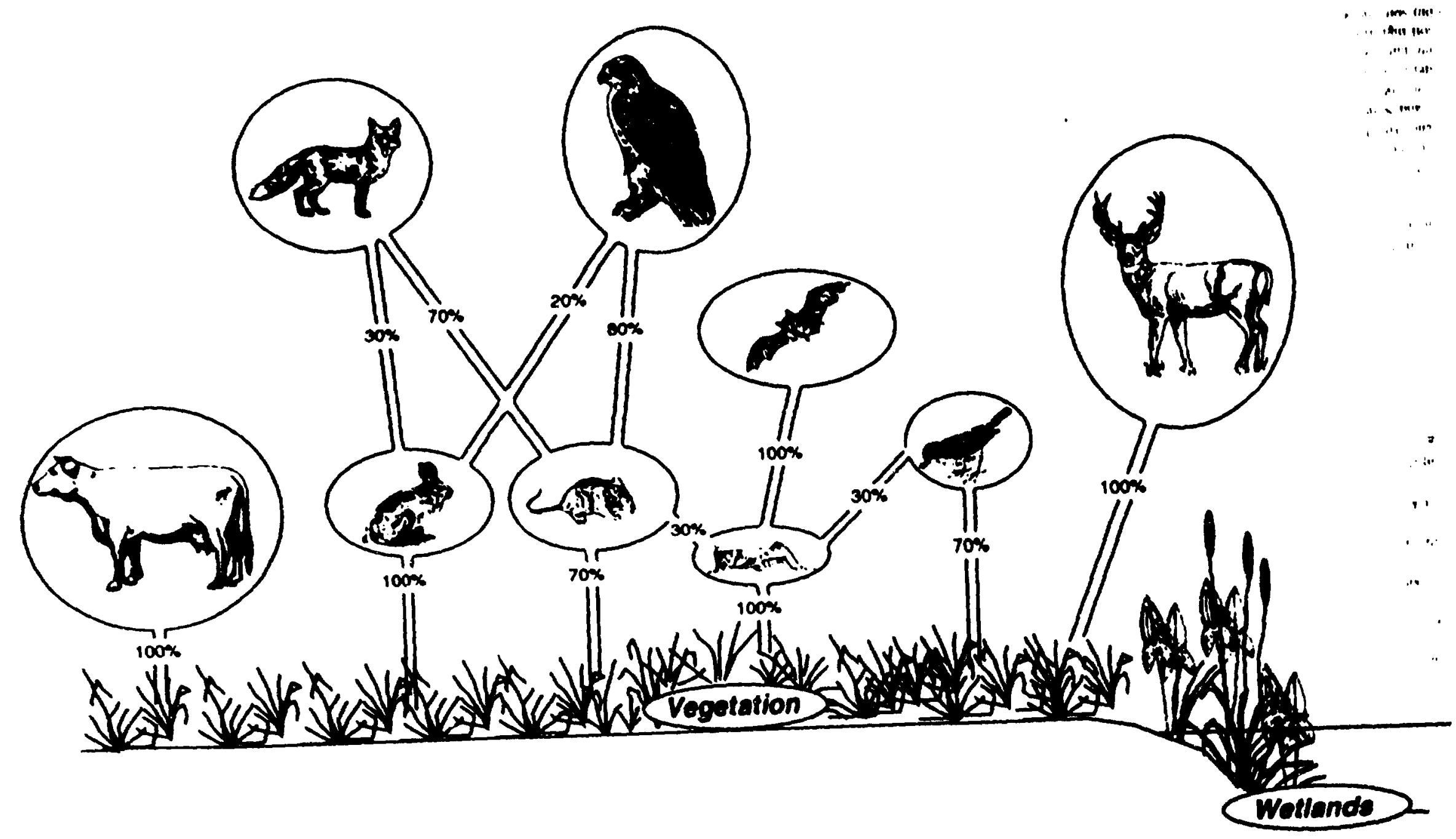

FIGUAE 9-2. REPRESENTATION OF THE TERRESTAIAL FOOD WEB OF THE PORTSMOUTH RESERVATION 
Alldredge 1979). The soil ingestion rates for the cow and mouse are 7\% and 2\% of the dry-mutter intake. respectively (Mayland et.af. 1977 and OHEA 1991). Since published values of soil ingestion rates were not found for the robin, it was conservatively estimated to be $10 \%$ of the dry-mater intake.

The estimated daily rates of food and water consumption $\mathbf{Q}_{\text {. }} Q_{\text {r }}$ or $Q_{\text {* }}$ and $Q_{\text {. }}$ respectively) for each receptor species were calculated from allometric regression equations that are based on the weight of the organism (EPA 1988) (appendix A). These equenions are based on the combined measurements for laboratory animals, livestock, and selected wildlife and bird species.

Because information on the specific habits and behaviors of most of the recepror wildlife species at Portsmouth is not well known, it is assumed that all species spend $100 \%$ of their time on the reservation. Therefore. the fraction of contaminated vegetation, fruit, prey. soil. and water consumed (F, $F_{\text {, }}, F_{\text {H, }}, F_{\text {, }}$ and $F_{\text {. }}$. respectively) is set at 100\% (table 9-5).

Contaminant concentrations in vegetarion, the first level in the foodchain. are estimated from source-term concentrations in the soils using published element-, or chemical-specific soil-toplant transfer factors (Baes et al. 1984; Travis and Arms 1988) (table 9-6). Transfer factors for inorganic chernicals are available for both the vegetarive and fruiting parts of plants (Baes et al. 1984): however, the transfer factors for organics do not make this distinction (Travis and Arms 1988). The methodology used to predict contaminant concentrations in vegetation does not make a distinction between different plant types or species. Therefore, all species ingest "generic" vegetation containing contaminant concentrations derived from soil concentrations by the use of transfer factors.

Transfer factors for contaminants of concem are applied to predict concentrations in the tissues of terrestrial man'malian receptors from consumption of vegetation, soil, and water (collectively termed $B_{b}$ ) (Bees et al. 1984: Travis and Arms 1988) (table 9-6). Den on transfer factors from vegetation or soil to insects and earthworms are very limited in the liternoure.
Therefore, the concentration in insects was derived from vegetarion concentrations, and a defauth, conservative one-to-one trensfer between vegetation and insects was assumed. The rationale and limitations for applying these transfer factors are discussed in appendix B.

The consumption rates and the beachmak lienit or no-observable-adverse-effect level (NOAEI) values are typically reported in wet weights. whereas the vegetation and soil concenturations are typically reported in dry weights. Therefore. conversion factors were applied to accoun for this difference. The wet- to dry-weigh concentration conversion factor for the vegetative parts of plants a Portsmouth was assumed to be 0.32 (the average for meadow fescue, Kentucky bluegrass, wild bromegrass, and orcherd grass (Morrison 1959). The wet- to dry-weight concentration conversion factor for the fruting parts of planes a Portsmouth was assumed to be 0.17 (Morrison 1959). The wet- to dry-weight concentration conversion factor for soils was assumed to be 0.90 (Solid Wastes: Engineering Principles and Management Issues 1977).

For the base-line asseasment of Portsmouth, the concentrations of radiomuclides in animal tissues and the resulting doses were not decay-corrected. The doses are estimated for the current situation and not for some point in the future. The primary radionuclides of concern. ${ }^{23} \mathrm{U}$ and $\mathrm{Tc}$, have long half-lives (4.5 $\times 10^{\circ}$ and $2.12 \times 10^{5}$, respectively) so this assumption is reasonable. The radionuclide concentrations in the source terms were decay-corrected by PNL to the time of disposal or release. To estimate dose to terrestrial receptors, all short-lived daughter products were included.

Aquatic organisms considered in the assessment included benthic macroinvertebrates and a generic fish species. For rediological analyses, emergent vegetation (i.e., cattails) and muskrats were included as well. All aquatic organisms. except for benthic macroinvertebrates, are exposed to contsminants in surface water. Benthic macroinver ebraics are assumed to be exposed only to the sediment pore weter for calculation of intemal radiation dose and exposure to chemicals. The external radietion dose from exposure to surface water was calculeced for all organisms. 


\begin{tabular}{|c|c|c|c|c|c|c|c|c|}
\hline 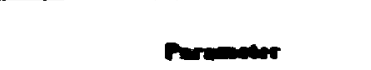 & 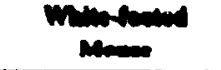 & 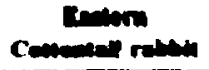 & Dow & con & andons & 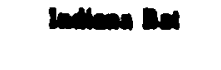 & Dostrand thom & Dan \\
\hline 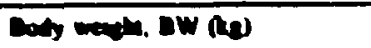 & $200=-42$ & $1.190200 \mathrm{r}$ & $56.5 E+011^{\prime}$ & 4.00E+00 & $7.50 t-02^{1}$ & 7.xes $-03^{\circ}$ & 1.104: wap & $6.0012 \times 00^{10}$ \\
\hline 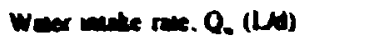 & a.cos- -13 & $\mid$ |Ak:-10| & $2616+10$ & $1.2 .1 E+01$ & $1+3 E-02$ & $2.200-03$ & $|+||t-0|$ & A SIE-114 \\
\hline 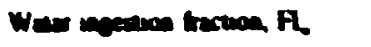 & $1.005 \times 10$ & I oxt.tw & $10 x: 00$ & $100 \mathrm{x}+0 \mathrm{x}$ & $1001+100$ & $1: 0 x+60$ & j oxying & 1 cont+ou \\
\hline 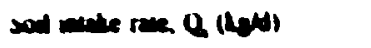 & $4.205-10 "$ & 1 24t:-01" & SUth:-0." & $|-100-0| \omega \mid$ & $3 \pm 74-14=$ & $0(x)$ & 000 & $\mathbf{0 0 0}$ \\
\hline 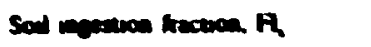 & 100EN00 & $1000:+00$ & 1 on: & 1.00titw & $1.00 x+\infty 0$ & vow & 000 & 0.00 \\
\hline 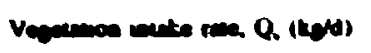 & 0,0 & $3136-020$ & $7.916-0111$ & $7.47 t+100$ & 000 & 000 & 0.00 & 000 \\
\hline 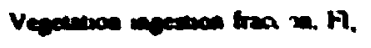 & 000 & $100 x+100$ & $1.000+00$ & $1000+101$ & o.uns & ow & 000 & 0.00 \\
\hline 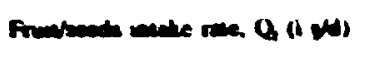 & $3.36-0.34$ & $37 x-\infty$ & T YIE-OI & $\mathbf{0} 0$ & $3000-0]^{n}$ & $\mathbf{0 0 0}$ & 0.00 & 000 \\
\hline 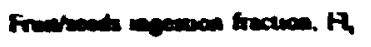 & $100 \leq-\infty$ & $1006+00$ & I 00:+10 & 0.00 & 1000 itwo & n.w0 & 000 & 000 \\
\hline 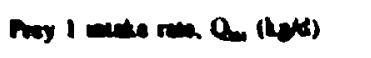 & $140 E-03$ (nemets) & 0.00 & 0.00 & 000 & $2 s(x-01$ (miscts) & I . Met-01 (manats) & $7028-100$ (muxe) & $|\operatorname{xet}-0| 01 "(\max )$ \\
\hline 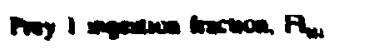 & IOOENOD & 000 & o.ou & 000 & $100 x+\infty 0$ & $1006+00$ & $1.00 k+\infty 0$ & $100 x+\infty$ \\
\hline 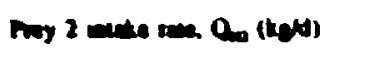 & 000 & 0.0 & 0.00 & 0.00 & o(x) & 0.00 & $1.906 x-02$ (robous) & $1000-02$ (rbenis) \\
\hline 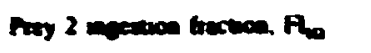 & 000 & 0.00 & 0.00 & 0.00 & 0.00 & 000 & $1000+00$ & $1.006+00$ \\
\hline 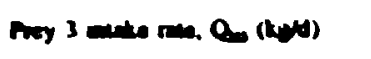 & 000 & 0.00 & 000 & 0.00 & 010 & 000 & 0.00 & 0.00 \\
\hline 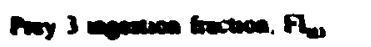 & 0.00 & 0.00 & 0.00 & $0 . \mathbf{m}$ & 000 & 0.00 & 000 & 0.10 \\
\hline
\end{tabular}

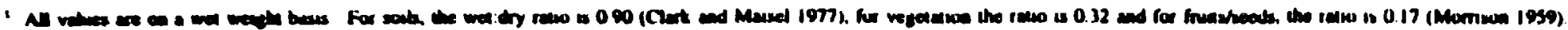

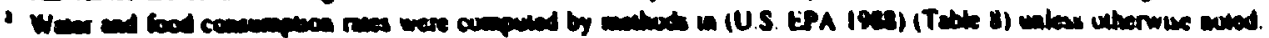

- Lectey a el ises

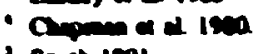

sim iogi.

- U.S. EPa lise

T $T=0$

- 7.

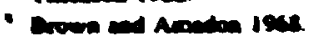

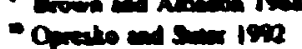

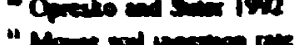

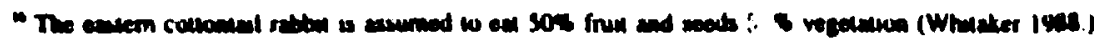

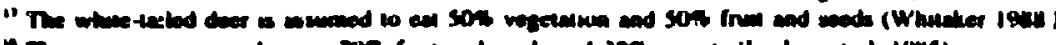

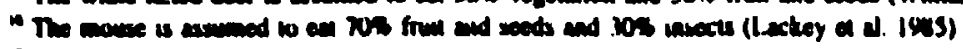

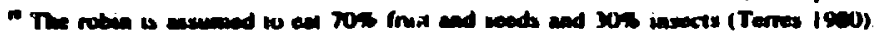

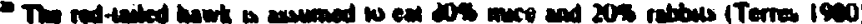

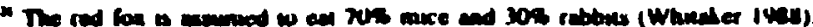

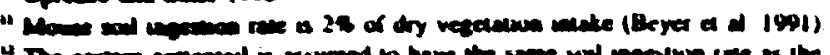

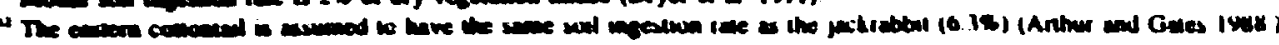

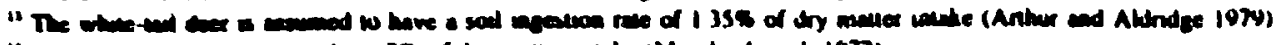

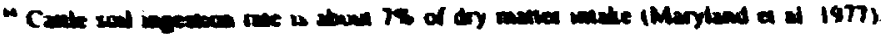

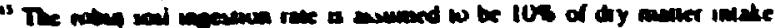




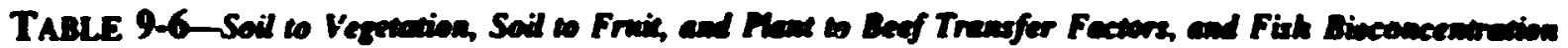

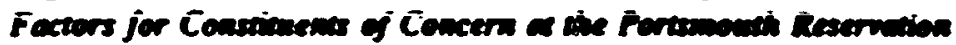

\begin{tabular}{|c|c|c|c|c|}
\hline Cantivent & 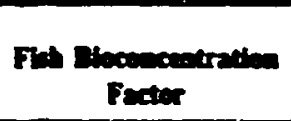 & 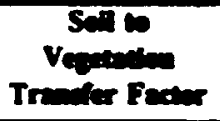 & Trim & 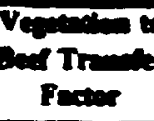 \\
\hline Aceaspothene & $6.46 E+02$ & $2.16 E-01$ & $2.162-01$ & $2.005-04$ \\
\hline Acensphylene & $3.01 E+02$ & $2.16 E-0 t$ & $2.16 E-01$ & $200=-04$ \\
\hline Acetwe & $3.89 E-01$ & $5.33 E+01$ & $5.33 E+01$ & $1.44 E-6$ \\
\hline Anthracene & $1.42 E+03$ & $9.71 E-02$ & $9.71 E-02$ & 7. SAE-04 \\
\hline Arocior 1254 & $2.30 E+04$ & $2.24 E-02$ & $2.24 E-\sqrt{2}$ & $1.00 \leq-02$ \\
\hline Arocior 1260 & $1.60 E+C 5$ & $2.24 E-02$ & $2.24 E-12$ & $1.00 E-02$ \\
\hline Beavene & 2.41E+01 & $2.3 T E+00$ & $237 E+00$ & $3.16 E-06$ \\
\hline Beasor(a)anthrecene & $1.1 T E+0.4$ & $1.97 E-02$ & $1.97 \mathrm{E}-02$ & $1.265-02$ \\
\hline Benzodapyrene & $2.38 E+04$ & $1.32 E-02$ & $1.32 E-02$ & 2S1E-02 \\
\hline Beazo(b)fivoranthene & $2.38 E+04$ & $1.195-02$ & $1.195-02$ & $3.02 E-02$ \\
\hline Bearorghilperylene & $\mathbf{N A}$ & $6.09 E-03$ & 9.55E-02 & $6.70 E+04$ \\
\hline Beakaxk)ficorandhene & $2.38 E+04$ & $1.195-02$ & $3.02 E-02$ & 2.38E $\leadsto 4$ \\
\hline Benzoic axid & 1.S5E•01 & $3.09 E+00$ & $3.09 E+00$ & $2.00 E-06$ \\
\hline BEHP & I.19E+07 & $4.37 E-02$ & $\therefore: ? E-02$ & $3.16 E-03$ \\
\hline Bromodichloromethane & $2.97 \mathrm{E}+01$ & $2.37 \mathrm{E}+00$ & $2.37 E+00$ & $3.16 E-06$ \\
\hline 2-butranate & 9.5IE-0I & $2.63 E+01$ & $2.63 E+01$ & $4.90=-08$ \\
\hline Butyl benzyl phathalate & 3.S4E+03 & $5.70 E-02$ & $5.70 \Sigma-02$ & $2.00 E-03$ \\
\hline Carton disulfide & I.95E +01 & NA & NA & NA \\
\hline Chlorobenzene & 6.45E +02 & $9.32 E-01$ & $9.32 E-01$ & $1.58 E-05$ \\
\hline Chloroform & $1.85 E+01$ & $2.70 E+00$ & $2.70 E+00$ & $2.51 E-06$ \\
\hline Chloromethane & $3.10 E+00$ & $1.15 E+01$ & i.ISE+01 & $2.04 E-07$ \\
\hline t-chloro-3-methylphenol & NA & $6.25 E-01$ & 0. $25 E-01$ & $3.16 E-05$ \\
\hline 2-chlorophenol & $6.40 E+00$ & 2.07E+00 & $2.07 E+00$ & $3.98 E-06$ \\
\hline Chrysene & $1.08 E+04$ & $1.97 E-02$ & $1.97 E-02$ & $126 E-02$ \\
\hline Dibenzol ah)anthrecene & $1.13 E+0 S$ & $6.78 E-03$ & $6.78 E-03$ & $7.94 E-02$ \\
\hline Dibromochloromethane & NA & $2.07 \mathrm{E}+00$ & $2.07 E+00$ & $3.98 E-06$ \\
\hline 1.2-dichlorobenzene & $8.90 E=01$ & $4.20 E-01$ & $4.20 \mathrm{E}-01$ & $6.31 E-05$ \\
\hline 1.t-dinthlorobenzene & $6.00 E+01$ & $4.20 \mathrm{E}-01$ & $4.20 E-01$ & $6.31 E-O S$ \\
\hline 1,1-dichloroethane & I.35E +01 & $3.53 E+00$ & $3.53 E+00$ & $1.58 E-06$ \\
\hline 1.1-dichloroethene & $1.47 E+0 \mid$ & $2.3 \pi E+\infty 0$ & $2.37 E+00$ & $3.16 E-06$ \\
\hline 1.1-dichloroethylene & $1.47 \mathrm{E}+01$ & $3.35 E+00$ & $3.35 E+00$ & $1.73 E-06$ \\
\hline 2-trans-dichloroethylene & NA & $2.37 E+00$ & $2.37 E+00$ & $3.16 E-06$ \\
\hline 2.4-dichlorophenol & $3.405+01$ & $4.79 \varepsilon-01$ & $4.79 \varepsilon-01$ & S.01E-OS \\
\hline f.+DDT & $2.98 E+04$ & $7.74 E-03$ & $7.74 E-03$ & $6.31 E-02$ \\
\hline 2.4-dinutrololuene & $1.95 E+01$ & $2.70 \varepsilon+00$ & $2.70 \varepsilon+00$ & $2.51 E-06$ \\
\hline 1.4-dioxane & $5.98 E-01$ & S.55E+01 & S.55E+01 & $1.35 E-08$ \\
\hline Dreldria & $4.87 E+03$ & $8.50 E-02$ & $8.50 E-02$ & $1.00 E-03$ \\
\hline Duechyl phchalace & $+36 E-01$ & $5.48 E-01$ & $5.48 E-01$ & $3.985-05$ \\
\hline 2.4-dimethylphenol & $1.50 t+1) 2$ & $1.39 E+00$ & $1.39 \varepsilon+00$ & $7.94 \mathrm{E}-06$ \\
\hline Dimethyl phinalace & 57 & $2.37 E+00$ & $2.3 \pi 5+00$ & $3.165-06$ \\
\hline Di-n-butyl phchalase & $1.07 E+04$ & $3.82 E-02$ & $3.82 E-02$ & 3.9aE-03 \\
\hline Di-n-octylphehalace & $1.8 \pi E+07$ & $1.865-04$ & $1.86 E-04$ & 3.905 .01 \\
\hline Edhylbencene & 146 & $5.48 E-01$ & $5.48 E-01$ & 3.98E-OS \\
\hline Fluorantixene & $3.12 E+03$ & $5.700-02$ & $5.705-02$ & $2.005-03$ \\
\hline Fluorem: & $7.13 E+02$ & $1.44 E-01$ & 1.44E-01 & $4.02 E-04$ \\
\hline indenor . 2.3-cad pyrene & S.13EAOA & $6.692-03$ & $6.692-03$ & $8.13 E-02$ \\
\hline Isobun I alcohol & 2.23 & NA & NA & NA \\
\hline Mesionychlor & $8.30 \varepsilon+03$ & $6.51 E-02$ & $6.510-02$ & $1.58 \mathrm{E}-03$ \\
\hline Medhylene chlonds & $5.74 E+00$ & 6.802000 & 6.860000 & $5.01 E-07$ \\
\hline 2-methylaspthylens & S.0SE+02 & NA & NA & NA \\
\hline 2-methylphenol & $1.85 E+01$ & NA & NA & NA \\
\hline 4-- ethylphend & $1.72 E+01$ & NA & NA & NA \\
\hline
\end{tabular}


TABLE 9-6 (continned)

\begin{tabular}{|c|c|c|c|c|}
\hline Cowethenent & 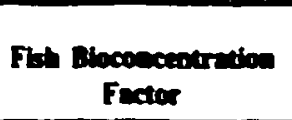 & $\begin{array}{c}\text { Sod to } \\
\text { Vejetion } \\
\text { Trencer Fedor }\end{array}$ & $\begin{array}{l}\text { Soll to Proth } \\
\text { Trumer } \\
\text { Pecoes }\end{array}$ & $\begin{array}{l}\text { Vespendon to } \\
\text { Ded Traeder } \\
\text { Fector }\end{array}$ \\
\hline Tapthalene & $1.68 E+02$ & $3.22 \mathrm{E}-01$ & $3.32 \mathrm{E}-01$ & $1.00=04$ \\
\hline 4-inurophenol & $1.26 E+02$ & $3.095+00$ & $3.09 E+00$ & $2.00 E-06$ \\
\hline Phenanthrene & $1.44 E+03$ & $9.71 E-02$ & $9.71 \mathrm{E}-02$ & $7.94 E-04$ \\
\hline Phenol & $7.57 E+\infty 0$ & $5.26 E+0 C$ & $5.26 E+00$ & $7.94 E-07$ \\
\hline Pyrere & $2.80 E+03$ & $3.35 E-02$ & $335 E-02$ & $5.01 E-03$ \\
\hline Tetrachloroethene & $5.57 E+01$ & $4.20 \mathrm{E}-01$ & $4.20 E-01$ & $6.31 E-05$ \\
\hline Tetrachloroethylene & $5.57 E+01$ & NA & NA & NA \\
\hline Toluene & $6.99 E+01$ & $1 . C T E+\infty 0$ & $1.07 E+\infty 0$ & $1.26 E-05$ \\
\hline 12.4-trichlorobenzene & $1.09 E+03$ & $1.27 \mathrm{E}-01$ & $1.27 \mathrm{E}-01$ & S.01E-04 \\
\hline 1.1.1-trxchloroethane & $9.00 E+00$ & 1.39E+00 & 1.39E+C0 & $7.94 E-06$ \\
\hline 1.1.2-enchloroethane & $3.90 E+01$ & $2.07 E+\infty 0$ & $2.07 E+\infty 0$ & $3.98 E-06$ \\
\hline Tnchloroethene & $3.79 E+01$ & $1.59 E+00$ & 1.59E+00 & $6.31 E-06$ \\
\hline Vinyl chloride & $6.59 E+00$ & $6.01 E+\infty 0$ & $6.01 E+00$ & $6.31 E-07$ \\
\hline Xylene & $1.77 E+02$ & $5.48 E-01$ & $5.48 E-01$ & 3.98E-05 \\
\hline Alumunum & $1.00 E+00$ & $4.00 \varepsilon-03$ & $6.50 E-04$ & $1.50 E-03$ \\
\hline Antumony & $1.00 E+00$ & $2.00 E-01$ & $3.00 E-102$ & $1.00 E-03$ \\
\hline Arsenic & $1.00 E+00$ & $4.00 E-02$ & $6.00 \varepsilon-03$ & $2.00 E-03$ \\
\hline Banum & $4.00 E+00$ & $|.50 E-0|$ & $1.50 \varepsilon-02$ & 1.50E-04 \\
\hline Beryllium & $|.90 E+0|$ & $1.00 \varepsilon-02$ & $1.50 E-03$ & $1.00 \varepsilon-03$ \\
\hline Cadmum & $2.00 E+02$ & $5.50 E-01$ & $1.50 \mathrm{E}-01$ & $5.50 E-04$ \\
\hline Calcium & 0.00 & $3.50 E+00$ & $3.50 E-01$ & $7.00 E-04$ \\
\hline Chromium & $2.00 E+01$ & $7.50 E-03$ & $4.50 E-03$ & $5.50 z-03$ \\
\hline Cobalt & $5.00 E+01$ & $2.00 E-02$ & $7.00 E-03$ & $2.00 E-02$ \\
\hline Copper & $S .00 E+01$ & $4.00 E-01$ & 2.50E-01 & $1.00 E-02$ \\
\hline Cyanide ion & $3.79 E-01$ & $S .42 E+01$ & $5.60 E-01$ & $1.41 E-08$ \\
\hline Fluoride & $1.00 E+01$ & NA & NA & NA \\
\hline Iron & $1.00 E+02$ & $4.00=-03$ & $1.00 E-03$ & $2.00 E-02$ \\
\hline Lead & $1,00 E+02$ & $4.50 E-02$ & $9.00 E-03$ & $3.00 E-04$ \\
\hline Magnesium & $5.00 E+01$ & $100 E+00$ & $5.50 E-01$ & $5.00 E-03$ \\
\hline Manganese & $4.00 E+02$ & 2.50E- $\Omega 1$ & $5.00 E-02$ & $4.00 E-04$ \\
\hline Mercun & $2.00 E+05$ & $9.00 E-01$ & $2.00 E-01$ & $2.50 E-01$ \\
\hline Nickel & $1.00 E+02$ & $6.00 \Sigma-02$ & $6.00 E-02$ & $6.00 E-03$ \\
\hline Potassium & $1.00 E+03$ & $1.00 \Sigma+\infty 0$ & $5.50 \mathrm{E}-01$ & $2.00 E-02$ \\
\hline Selenium & $1.70 E+02$ & $2.50 E-02$ & $2.50 E-02$ & $1.50 E-02$ \\
\hline Silver & $2.30 E+00$ & $4.00 E-0 I$ & $1.00 E-01$ & $3.00 E-03$ \\
\hline Sodium ion & $1.00 E+02$ & $7.90 \varepsilon-02$ & $5.50 E-02$ & 3.50E-02 \\
\hline Thallium & $1.00 E+04$ & $4.00 E-03$ & $4.00 E-04$ & $4.00 E-02$ \\
\hline Tin & $3.00 E+03$ & $3.00 \mathrm{E}-02$ & $6.00 E-03$ & $8.00 E-02$ \\
\hline Vanadium & $1.00 E+01$ & $5.50 E-03$ & $2.50 E-03$ & $2.50 \mathrm{E}-03$ \\
\hline Zinc & $2.00 E+03$ & $1.50=400$ & $1.005-01$ & $1.00 E-01$ \\
\hline Technecium-99 & $2.50 E+01$ & $5.50 \mathrm{E}-03$ & $3.00 E-102$ & $3.50 E-06$ \\
\hline Uransum-238 & $1.00 E+00$ & $1.00 \varepsilon-02$ & $4.00 E-03$ & 7.50E-r4 \\
\hline
\end{tabular}

NA = Transfer factor could not be calculated.

Sourca: For organics, the cansfer factors were calculaced from equations in Travis and Arms (1988) using $K$, values from the Superficad Chemical Doia Mouru (|99|). For inorganics and radionuclides. the transfer factors were taken from Baes et al. (1984). The $K$, for cyanide was iaken from MEPAS and the transfer factors were calculated from equations in Travis and Ams (1988). 


\subsection{Contammant Efrects Assessmiant}

Two pathways are used to determine the effects of contaminant exposure (chapter 9.3) on ecological endpoint receptors. For terrestrial receptors, consumption rates of contaminated food and water are compared with toxicological benchmarks. For aquatic receptors, contaminant concentrations in water or sediment pore water are compared with chemical-specific aquatic benchmarks.

To quanıfy risk to terrestrial receptors exposed to organic and inorganic contaminants, the daily consumption rate of contaminated food and water, normalized to body weight (in units of $\mathrm{mg} / \mathrm{kg} / \mathrm{d}$ ), was compared to the NOAEL benchmark (mg/kg/d). Ratios greater than $I$ are considered to pose a potential risk to organisms but do not necessarily indicate the severity of the effect(s). However, it is reasonable to assume that the higher the ratio, the greater the risk of adverse effects. Dose to terrestrial receptors, including - igetation, from intemal and external exposure to radionuclides was also determined from calculated tissue concentrations, respectively. Doses that exceeded $0.1 \mathrm{rad} / \mathrm{d}$ were considered to pose a potential risk to terrestrial organisms (IAEA 1992). Methods used to calculate exposure and risk are described in appendix $B$.

Toxicological benchmarks for terrestrial organisms, excluding vegetation, were obtained from Opresko and Suter (1992) (table 9-7). For representative receptor species that were not listed in the data base. extrapolation techn:ques were employed to obtain the chronic NOAEL by adjusting for differences in body weight between the receptor and a test organism. If a NOAEL was available for a laboratory test species, the NOAEL for a receptor species could be calculated. Many of the NOAEL benchmarks were derived by extrapolation from small mammal laboratory data (Opresko and Suter 1992). No wildlife toxicity data were found for a few contaminants. For these cases, wildlife NOAELs were extrapolated from human noncarcinogenic toxicity data (i.e., RfD's) listed in the MEPAS constituent data base, normalized to the "standard man" body weight of $70 \mathrm{~kg}$. Thus, for this report, wildlife species that weigh less than $70 \mathrm{~kg}$ would have a higher benhmark than humans, and the opposite wruld be true for wildtife speries we ighing more then $70 \mathrm{~kg}$.

Literature sources for inorganic terrestrial phytotoxicity benchmarks were summarized and reported by Suter and Futrell (1993). Where applicable, the lowest source concentration in a soil medium that prodized phytotoxically excessive effects was chosen from the data base. Several benchmarks were derived from experiments using nutrient solutions. However, uncertainty values were not applied to these data to account for differences in growth media. A methodology for deriving phytotoxicity benchmarks for organic constituents was developed by Eskew and Babb las cited in the MMR Air National Guard Risk Assessment Handbook (1992)].

Risks to aquatic organisms from exposure to organic and inorganic contaminants in water and sediments (pore water) were calculated by comparing the water or sediment pore-water concentrations with the chemical-specific aquatic benchmark (Suter et al. 1992). To determine internal dose to aquatic plants, fish, and muskrats from exposure to radionuclides, the surface-water concentrations were multiplied by radionuclide and organism-specific aquatic (internal) dose conversion factors to produce a daily dose in rads (Killough and McKay 1976). To determine the intemal dose to benthic macroinvertebrates and other bottom-dwelling organisms (e.g., fish larvae) frotn exposure to radionuclides, the sediment pore-water concentrations were multiplied hy radionuclide and organism-specific aquatic (internal dose) conversion factors to produce a daily dose. The external dose to all organisms was determined by multiplying the surface-water concentration by the exiemal radionuclide-specific dose conversion factor. Combined internal and external doses greater than $1 \mathrm{rad} / \mathrm{d}$ are considered to pose a potential risk to aquatic organisms (NCRPM 1991).

For contaminants and receptors that did not pass the average concentration sciersing (chapter 9-3), an attempt was made to further define exposure risks by comparing the home range sizes of receptor species with the porential fraction of the home range that is contaminated. 
Receptor species at Portsmouth have home ranges or territories which range from small [e.g., one ha ( 2.5 acres) or less for very small animals such as the robin, mouse, and certain aquatic species] to hundreds of hectares for hawks and foxes (table 9-8). Snuall species have home ranges small enough to be contained within individual waste sites. Some species have such large home ranges that the waste sites would comprise only a part of the area they would occupy, if the waste sites were used at all. To further interpret results of this risk analysis. the following assumptions are made about contaminant exposure to receptors.

1. Burrowing small mammals, insects, and vegetation are known to move radiological contaminants from buried waste where it is presumably redistributed on the surface through the food chain, excrement, and soil dust (Arthur 1982; Markham 1987; Arthur and Markham 1983). The same is probably true for nonradiological contaminants. Because the waste sites are the original sources of contaminants, and data are lacking for contaminant levels outside of the waste sites, it is assumed that source terms outside waste sites are negligible.

2. It is assumed that species with home ranges of less than 10 ha ( 25 acres) (table $9-8$ could receive as much exposure as the average screening in these analyses indicates.

3. For wider-ranging species, exposure may be less than the average screening indicates. Thus, for species with home ranges equal to or greater than the contaminated area of 40 ha (100 acres), it is assumed that the effective exposure is proportional to the ratio of the contaminated area to the area of the waste complex [i.e., about 400 ha (1000 acres)]. This ratio (i.e., $40 / 400=0.10$ ) was applied as a correction factor to the calculated HIs presented in table 9-9 for the red fox, white-tailed deer, and red-tailed hawk to determine the effective HI. Because sufficient contaminant-specific distribution data are unavailable, an area of $\mathbf{4 0}$ ha (100 acres) is assumed for each contaminant.

4. About 2.5\% of the surface area of Portsmouth is waste sites. Exposure of biota living in the other 97.5\% of the reservation is limited to contaminants that have moved from waste sites in dust and from contaminated wildlife and plants. Although this contamination may be measurable, source terms are lacking; thus, it is assumed that the concentrations are negligible compared with the amounts and concentrations in the waste sites. Exposures could be higher if, for instance, the sole source of contaminants is a waste pond used as the only source of drinking water. However, for Portsmouth it is assumed that contaminants in soil, water, and sediment are evenly distributed among media.

5. Except for threatened and endangered species, for which the loss of an individual is considered a significant risk to the population, it is assumed other endpoints are at risk only at the small end of the home range scale represented by the 2.5\% of the Portsmouth Reservation that is in waste sites.

6. Contaminated wetlands are waste ponds. It is assumed that aquatic biota receive the average exposure to contaminants if they occur in waste ponds. Similarly, it is assumed that bioca in other wetlands are not exposed to contaminants.

7. Grazing livestock are not allowed into contaminated sites. Risks to livestock would be applicable only if livestock were allowed to graze in waste areas. 


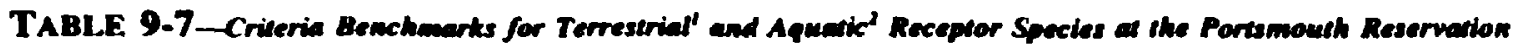
(NOAELs lised in meftefd for lorrestried benchments or mall for aquetic benchmarts)

\begin{tabular}{|c|c|c|c|c|c|c|c|c|c|c|}
\hline $\operatorname{mon}$ & Whaterad moser & 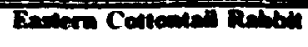 & Whine-tad buer & $\operatorname{Com}$ & Ixibat den & Tols & 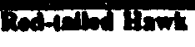 & Red Pax & Verotedien & ande \\
\hline Toen $=0$ & NA & NA & Th & NA & NA & Nh & NA & Nh & $7.216+02$ & 7.97:=01 \\
\hline Acempatytem & NA & HA & NA & NA & NA & NA & NA & NA & $1.28 \mathrm{E}+02$ & NA \\
\hline Anetoone & $244 E+01$ & $6.65 E+00$ & $184 E+00$ & $9.56 E-01$ & 3.63E+01 & $1.67 E+01$ & $0.31 E+00$ & $3.884+60$ & NA & $2.37 \mathrm{E}+01$ \\
\hline Antravere & NA & NA & NA & HA & NA & NA & NA & MA & $1.28 E+02$ & $1.200-03$ \\
\hline Noction I2S4 & $|+| E-0 \mid$ & $+3+4 t-02$ & $1736-02$ & $2.22 E-01$ & $2.10 E-01$ & $3.19 E+\infty 0$ & $1.20 E+\infty 0$ & I SCE-02 & |.00E^0| & 5.20E-04 \\
\hline Aracion 1200 & $1+60+100$ & $2.92 \mathrm{E}-03$ & $8.005-04$ & $4202-04$ & $2.17 E+\infty 0$ & $9.96 E-01$ & $2.77 \leq-03$ & $1.70 \mathrm{e}-03$ & NA & $2.108-03$ \\
\hline Deanex & SIIE+00 & $1.66 E+00$ & $4.59 E-01$ & 2.39E-01 & $9.086+00$ & $4.18 E+00$ & i suti+00 & $9.706-01$ & NA & $2.108-02$ \\
\hline 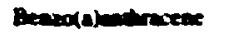 & NA & NA & NA & NA & NA & NA & NA & NA & $1.26 \mathrm{E}+02$ & $6.500-04$ \\
\hline Denololprose & 2 HE -02 & $665 E-03$ & | $84 E-0\}$ & $9.56 E-\infty$ & $3.63 \mathrm{E}-02$ & $1.67 E-02$ & $6.31 E-03$ & B.RBE -03 & 1.2BE+02 & $2.996-03$ \\
\hline Beavolofinormplese & NA & NA & NA & NA & NA & NA & NA & NA & $128 E+02$ & NA \\
\hline Beneari acid & NA & NA & NA & NA & NA & NA & NA & NA & NA & $1.262+00$ \\
\hline Nertip & NA & NA & NA & NA & NA & NA & NA & NA & $1.402+01$ & $3.002-01$ \\
\hline 2 twonesere & $225 E+01$ & $612 E+00$ & 169E+00 & $8.80 \mathrm{E}-01$ & 3.34E+01 & $1.54 E+01$ & $5.81 E+100$ & $3.57 E+\infty 0$ & NA & NA \\
\hline 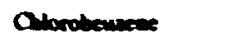 & NA & NA & NA & NA & NA & NA & NA & NA & NA & [.65E-0] \\
\hline Oabroform & $220 E+01$ & $5.996+10$ & 2BAE-01 & $408 E-01$ & 3.27E+01 & $1.508+01$ & $5.68 E+100$ & $1.668+00$ & NA & $8.405+00$ \\
\hline Anyoces & NA & NA & $\mathbf{N A}$ & NA & NA & NA & NA & NA & $1.28 E+02$ & NA \\
\hline 1.1 dichloroetione & HA & NA & NA & NA & NA & NA & NA & NA & $8.602-01$ & I.SPEnO0 \\
\hline 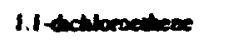 & $2.20 E+00$ & S.99E-01 & |. OSE-01 & $8.61 E-02$ & $3.27 E+\infty 0$ & $1.505+\infty 0$ & S.08E-0\} & $1.492-01$ & NA & $4.472-01$ \\
\hline 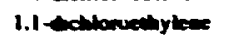 & $2201 * 00$ & S.99E-0! & $1.65 E-01$ & $0.61 E-02$ & $3.27 E * 00$ & $1.50 E+00$ & $5.60 \mathrm{e}-01$ & $3.49 \mathrm{E}-01$ & NA & NA \\
\hline Dreyl prature & NA & NA & NA & NA & NA & NA & NA & NA & MA & 100E+00 \\
\hline 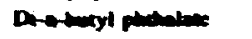 & +.SSE+O1 & $12+E+01$ & $3.43 E+00$ & 8.0se-04 & $6.78 E+01$ & $1.41 E-02$ & $5.365-03$ & $7.23 \mathrm{E}+00$ & $1.48 E+04$ & $2.200-02$ \\
\hline 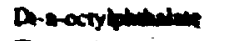 & NA & NA & NA & Nh & NA & NA & NA & NA & NA & $3.100-01$ \\
\hline Anorinicere & NA & NA & NA & NA & NA & NA & NA & NA & $1.288+02$ & $320 \div-02$ \\
\hline Monyles cting & $1+3 E+01$ & $3895+60$ & $107 E+00$ & $5.60 E-01$ & $2.13 E+01$ & $9.78 E+00$ & $3.69 E+00$ & $2.27 E+\infty 0$ & $3.60 \mathrm{E}+00$ & $+100-11$ \\
\hline Pumber: & NA & NA & NA & NA & NA & NA & $N A$ & NA & $1.28 E+02$ & $1.105-01$ \\
\hline nnal & NA & NA & NA & NA & NA & NA & NA & NA & NA & $2300-04$ \\
\hline Prease & NA & NA & NA & NA & NA & NA & NA & NA & 1.2858+02 & NA \\
\hline 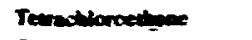 & I SIE+00 & +||$E-0 \mid$ & $1.13 E-0 \mid$ & $5.300-02$ & $2.24 E+00$ & $1.03 E+100$ & 390E-01 & $2.39 \mathrm{E}-01$ & |.57Eн01 & S. $100-01$ \\
\hline Tolasere & S +SE+0I & 1. $48 E+01$ & $4.10 E+100$ & $2.13 E * 00$ & 8. 105401 & 3.73E +01 & I.4IE+0I & $8.65 E+00$ & $9.70 e+\infty 0$ & $2600-02$ \\
\hline 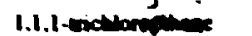 & S SSE+01 & $2.33 k+01$ & $043 E+00$ & $3.35 E+\infty 0$ & $1.27 E_{+02}$ & S.8SE+01 & $2.21 E+01$ & $1.36 E+01$ & $6.10 e+00$ & 2SIE-OI \\
\hline 1.12 - noclibere & NA & NA & NA & NA & NA & NA & NA & NA & NA & | 30E+01 \\
\hline Tnctionocitain & $162 E+02$ & $4.995+01$ & $1.38 E+0 \mid$ & $7.17 E+\infty 0$ & $2.40 E+02$ & $1.11 E+02$ & $474 E+01$ & 2.91E+01 & $6.7000-01$ & $5760+00$ \\
\hline 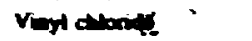 & $3.18 E-01$ & $8.65 E-02$ & $2.396-02$ & $1.24 E-02$ & $4.72 E-01$ & $2.17 E-01$ & $8.21 \mathrm{E}-02$ & $5048-02$ & NA & $9500-04$ \\
\hline xylane & $1.22 E+03$ & $3.33 E+02$ & $9.12 E+01$ & $478 E+01$ & $1.82 E+03$ & $8.36 z+02$ & $3.165+02$ & $1.94 E+02$ & $2.402+01$ & $2618 \times 00$ \\
\hline Almosing & NA & NA & NA & NA & NA & NA & $\mathbf{N A}$ & NA & $1.005+00$ & $1704-02$ \\
\hline Ansimony & 1.21E+04 & $3.31 E+03$ & $9.13 E+02$ & $4.75 E+02$ & $1.81 E+04$ & 8.31E+0. & $3.14 E+03$ & $1.93 E+03$ & $5.000+\infty 0$ & $1000+00$ \\
\hline Nisencis & $1.02 E-01$ & $1.62 E+00$ & $7.60 \mathrm{E}-01$ & $3.960-01$ & $|.52 E-0|$ & $7.008-02$ & $1.54 E+00$ & 1.602400 & $1.502+01$ & $0328-01$ \\
\hline nom & $1256+00$ & $3.39 \varepsilon-01$ & $9.37 E-02$ & $4.825-02$ & $1.85 E+00$ & $8.52 E-01$ & $3.22 \mathrm{E}-01$ & $1.988-01$ & $5.000+02$ & 203801 \\
\hline Derylm & 1.32E<00 & $3.59 E-01$ & $9.92 E-02$ & 5.16E-02 & $1.96 E+00$ & $9.02 E-01$ & $3.41 E-01$ & $2.09 \varepsilon-01$ & $1.002+01$ & $380 x-03$ \\
\hline Oniminin & 2 3SE-02 & $1.26 E-02$ & $1.77 E-03$ & $3.39 E-04$ & $3.505-02$ & $1.61 \mathrm{E}-02$ & $3.44 E-02$ & $1.38 E-03$ & $3.002+00$ & $1,100-03$ \\
\hline Ondinen & $S B O E+\infty O$ & $1.605+00$ & $4.4|E-0|$ & $2.30 \mathrm{a}-01$ & $8.72 E+\infty$ & $4.01 E+00$ & $1.52 E+00$ & $9.31 \mathrm{E}-01$ & $7.502+01$ & $1108-02$ \\
\hline Coowen & MA & NA & NA & NA & NA & NA & NA & NA & $2.50 E+01$ & $4402-03$ \\
\hline Conpres & $183 E-01$ & $2.21 E+01$ & $2.57 E-01$ & $3.17 E \star 00$ & $2.72 \mathrm{E}-01$ & $1.25 \mathrm{E}-01$ & $2.602+01$ & 1.290001 & $6.000 * 01$ & $1200-02$ \\
\hline Orand & $2.604 E+01$ & 7 IAE + 00 & $2.63 \mathrm{E}-02$ & $1.37 E-02$ & $3.92 E+01$ & $1.005 \times 01$ & $0.02 E+\infty 0$ & 5.55E:-02 & NA & $5202-03$ \\
\hline
\end{tabular}

' The sounce for all terrestrial benchmarks except those for vegetation is Opresko et al. 1993. For vegetation, the snurce is Suter and Futrell 1993 and the Massachusetts Military Reservation Risk Assessment Handbook, 1992.

: The surce for aquatic benchmarks in Suter et al. 1992. 


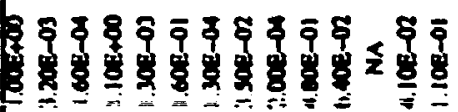

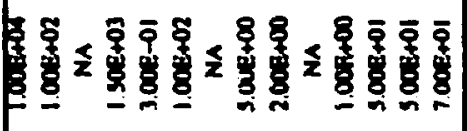

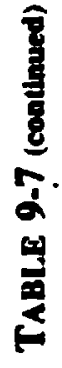

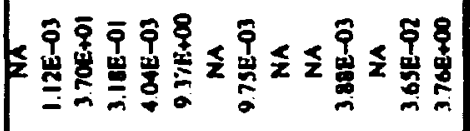

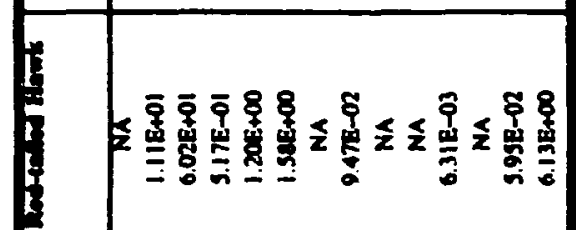

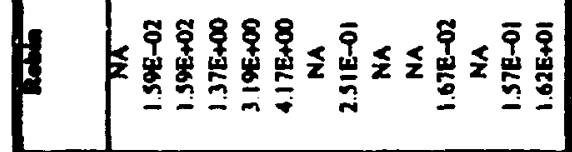

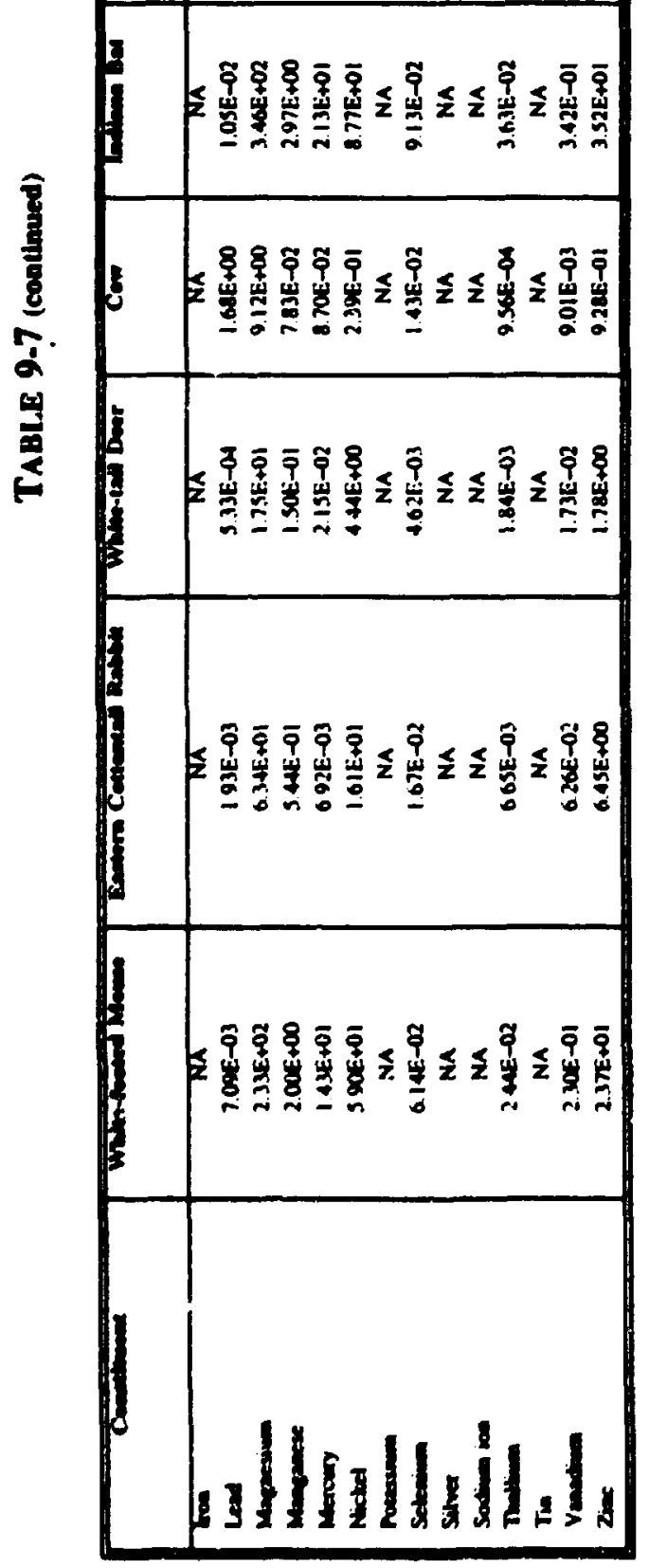




\section{Contaminant Hazard Asstssmdent}

The next step in the ecological risk assessment generates His tha are representative of potential risk and that estimate the level of effects from exposure to contaminants. Risk to terrestrial and aquatic receptors from contamination at the Portsmouth Reservation was modeled. For terrestrial receptors, hazard indices (HIs) were generated from maximum and average contaminant concentrations for chemical constituents and maximum and average doses were generated for radiological constituents. For aquatic receptors, maximum and average doses were generated for chemical constituents and for radiological constituents.

\subsubsection{Baseline}

From the initial suite of 102 contaminants of concern, the two-stage screening process using maximum and then average contami.sant values yielded 26 contaminants producing HIs equal to or greater than 1 (i.e., representing at least a moderate risk from contaminants) for at least one terrestrial or aquatic endpoint receptor as shown in tables 9-9, 9-10, 9-11, and 9-12. Hazard indices of radionuclides did not exceed one. Following the assumptions outlined in chapter 9.4, the approximate home range or territory size of receptors was determined in order to calculate the proportion of their range that could potentially encompass contaminated lands or surface water.

Four of the endpoint receptors included in the analyses, the white-footed mouse, the cottontail rabbit, the Indiana bat, and the American robin, occupy small enough areas (table 9-8) to potentially live their lives entirely within a contaminated area [e.g., less than 10 ha $(25$ acres)l. Vegetation obviously can occupy small areas. The remaining terrestrial receptor species, the red fox, the white-tailed deer, and the redtailed hawk, have home ranges generally larger than the areas of the waste sites but less than the area of the waste complex and, therefore, require application of a correction factor to their average HIs to produce a more meaningful, effective HI. Aquatic receptors (fish, invertebrates, muskrats, and vegetation) are assumed to be fully exposed to contaminants measured in aquatic habitat.

\subsubsection{Threatemed and Endangered Species}

As shown in table 9-13a, four inorganic contaminants pose moderate risk to Indiana bats that may forage near the contaminated sites. The $\mathrm{HI}$ for $\mathrm{Pb}$ is 9 and the HIs for $\mathrm{Cu}, \mathrm{Mg}$. and $\mathrm{Mn}$ are less than 2. However, Indiana bats are not known to live or forage on the Portsmouth Reservation. A site-specific analysis of individual waste sources and a survey to determine occurrence of bats or other threatened and endangered species would be necessary to determine actual risks.

\subsubsection{Wetlands}

Risks to wetlands receptors (e.g., benthic macroinvertebrates and fish) that might receive contamination from the waste sites are shown in table 9-13b. For purposes of this analysis, wetlands included most holding ponds but not creeks, ditches, swales, or other potentially contaminated wetlands because surface area data necessary for the analysis were lacking. Benthic macroinvertebrates (e.g., fly larvae, caddisflies, mayflies, stoneflies, snails, and beetles) would incur moderate and severe risks from 3 organic contaminants and 15 inorganic contaminants (probably mostly from the sediment pore water). There is less risk to fish from the inorganic contaminants but severe risk from vinyl chloride if fish inhabit the holding ponds.

\subsubsection{Recreational Wildife}

Table 9-13c summarizes risks to recreationally desirable species on the Portsmouth Reservation. Base-line average HIs for terrestrial species (i.e., the eastem cottontail rabbit and the white-tailed deer) exceeded one for six contaminants. However, only lead posed severe risk to the rabbit. Fish in contaminated waters (table 9-13b) would incur severe risks from vinyl chloride and moderate risks from BEHP and aluminum.

\subsubsection{Agriculture}

Cattle are not allowed to graze in waste areas; therefore, potential risks to livestock are negligible. Vegetation, in the form of grass and planted pines, would incur a severe risk from exposure to aluminum and moderate risks from seven inorganic contaminants (table 9.13d). 


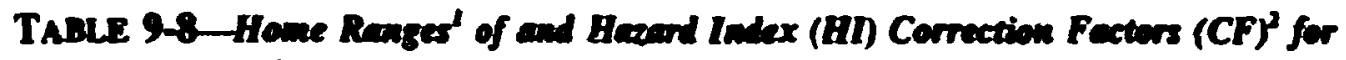

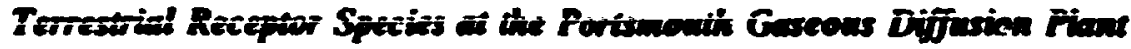

\begin{tabular}{|c|c|c|c|}
\hline \multirow[b]{2}{*}{ Receptor Species } & \multicolumn{2}{|c|}{ Howe Range (ha) } & \multirow[b]{2}{*}{ Correction Fector } \\
\hline & $<10$ & $\geq 10$ but $<400$ & \\
\hline White-footed mouse & $X(0.2-0.6)$ & & 1.0 \\
\hline Eastem cottontail rabbit & $X(1.0-2.8)$ & & 1.0 \\
\hline Indiana bat & $X(1.5-4.5)$ & & 1.0 \\
\hline Red fox & & $X(260-520)$ & 0.1 \\
\hline White-tailed deer & & $X(60-520)$ & 0.1 \\
\hline American robin & $X(0.1-2.0)$ & & 1.0 \\
\hline Red-tailed hawk & & $X(130-420)$ & 0.1 \\
\hline Vegetation & $X(<0.1)$ & & 1.0 \\
\hline
\end{tabular}

'Bun and Crossenheider 1976: Chapman et al. 1980. Smith 1991: Schoener 1966.

'A CF of 1.0 was applied to HIs for each contaminant for each species having a horre range less then 10 ba (25 acres). Other CFs were besed on a ratio of area of contaminated land and water [i.e., $40 \mathrm{ha}$ (100 acres)] to the tocal area of the waste complex [i.e., $400 \mathrm{ha}$ (1000 acres)]. 


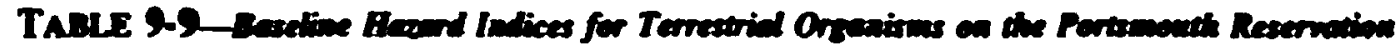

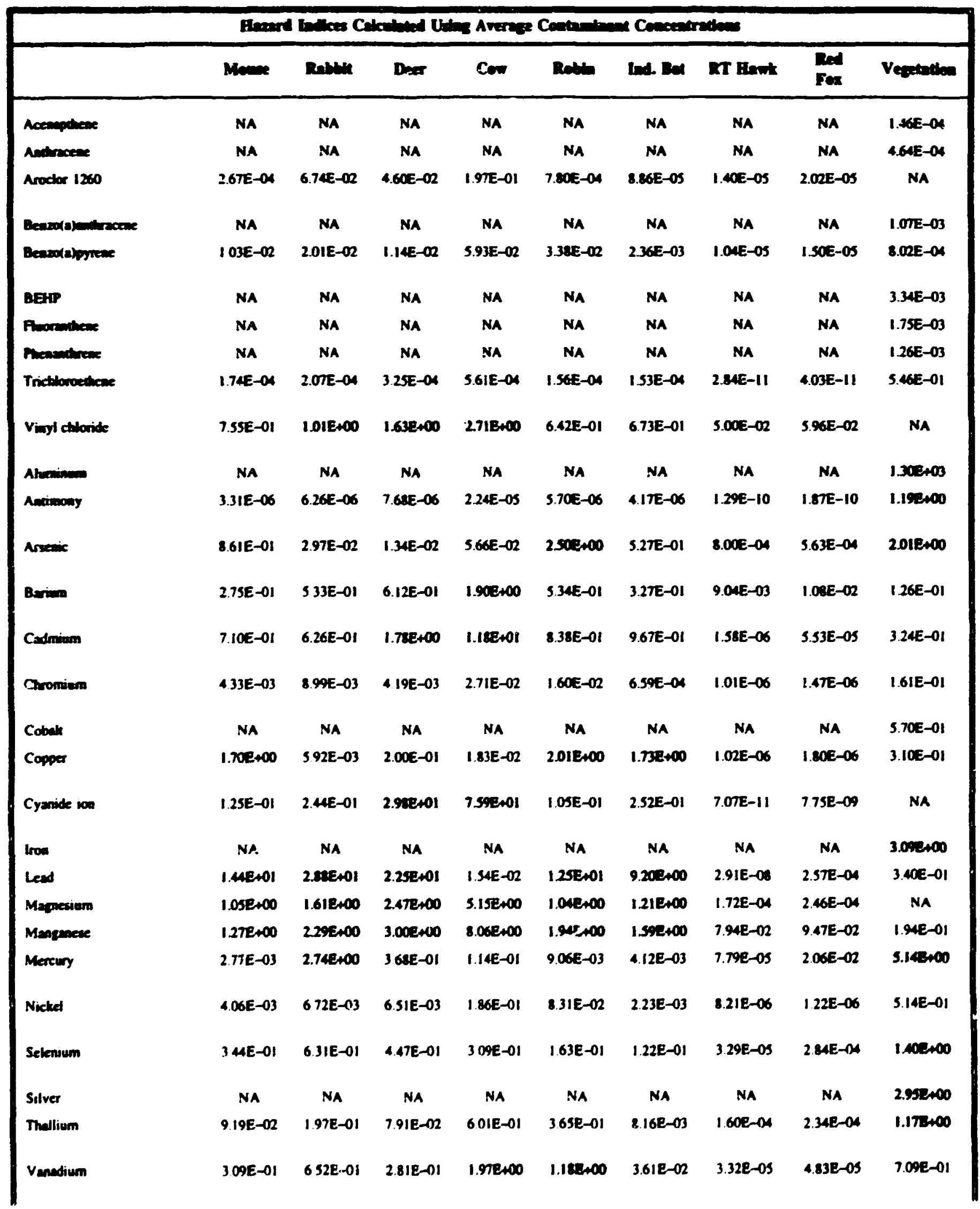




\begin{tabular}{|c|c|c|c|c|c|c|c|c|c|}
\hline \multicolumn{10}{|c|}{ 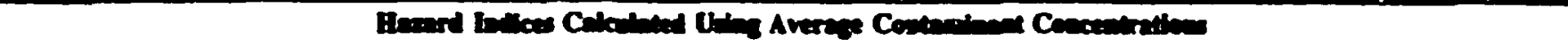 } \\
\hline & Mure & Reven & Dex & Con & 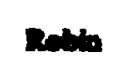 & Int Det & MT Rint & Pex & 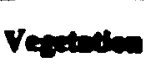 \\
\hline $\operatorname{zix}$ & 6SIE-OR & $123 E-0 \mid$ & I.9IE-01 & $4.85 E-01$ & $6.53 E-02$ & I.16E-0I & $1.07 \mathrm{E}-03$ & $1.34 E-03$ & 6.|SE-01 \\
\hline
\end{tabular}

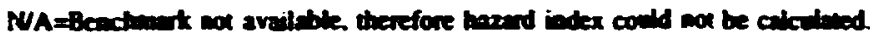




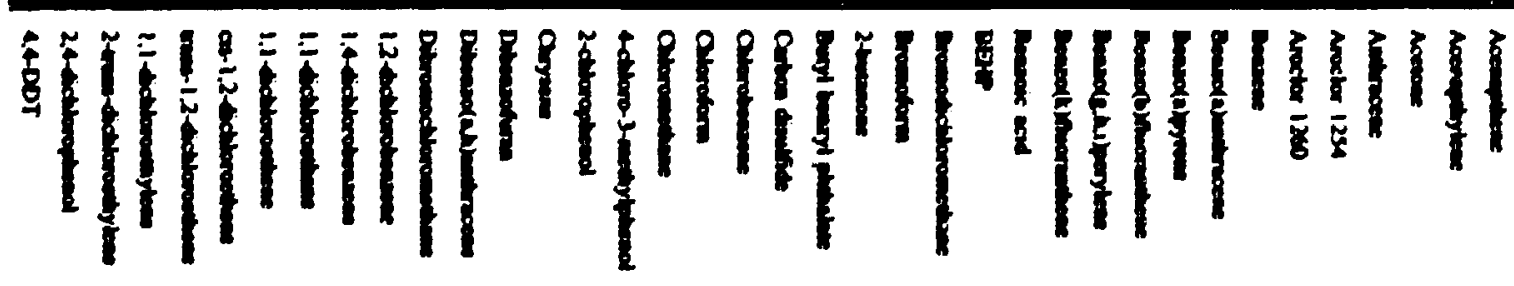

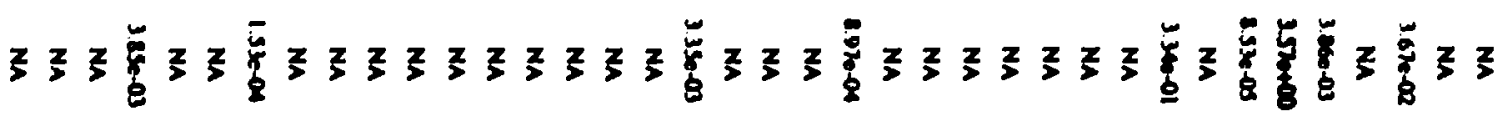

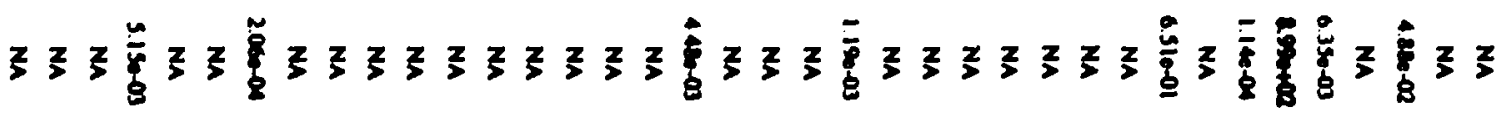

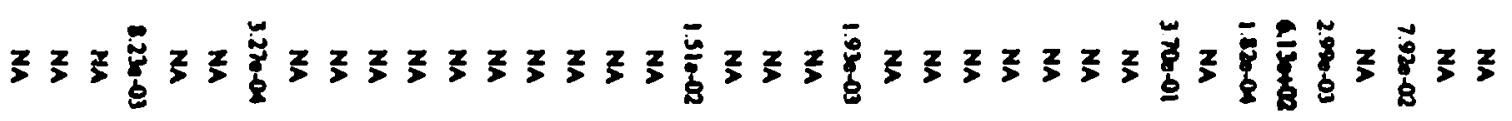

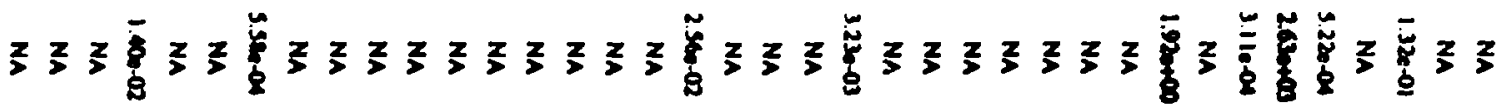

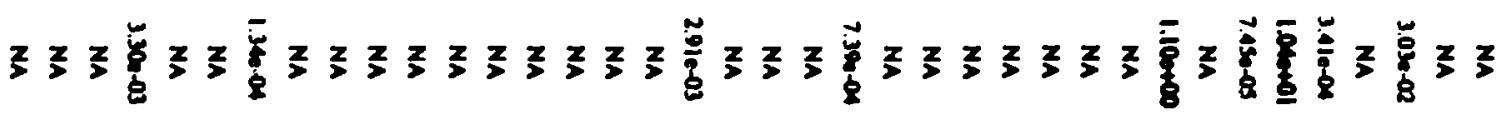

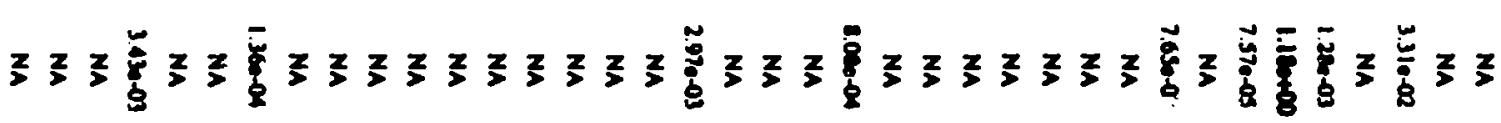

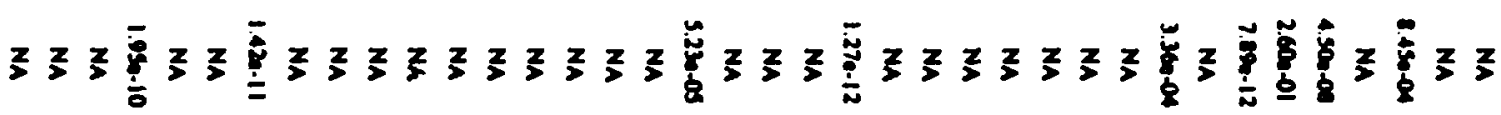

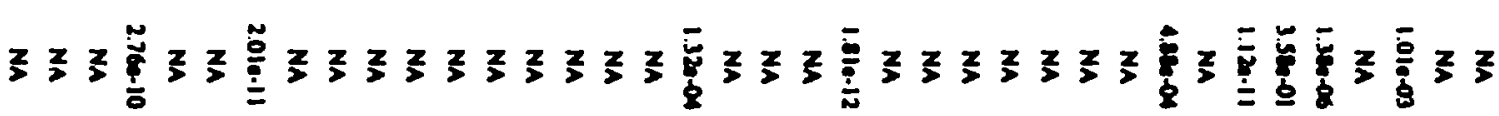

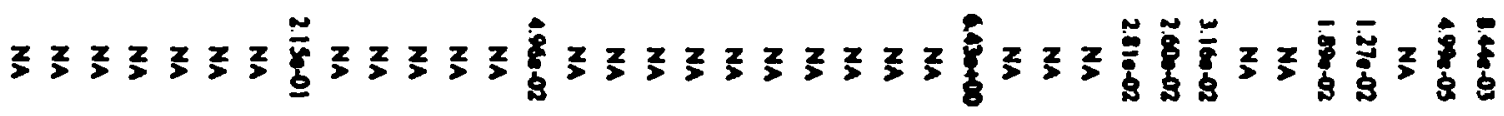




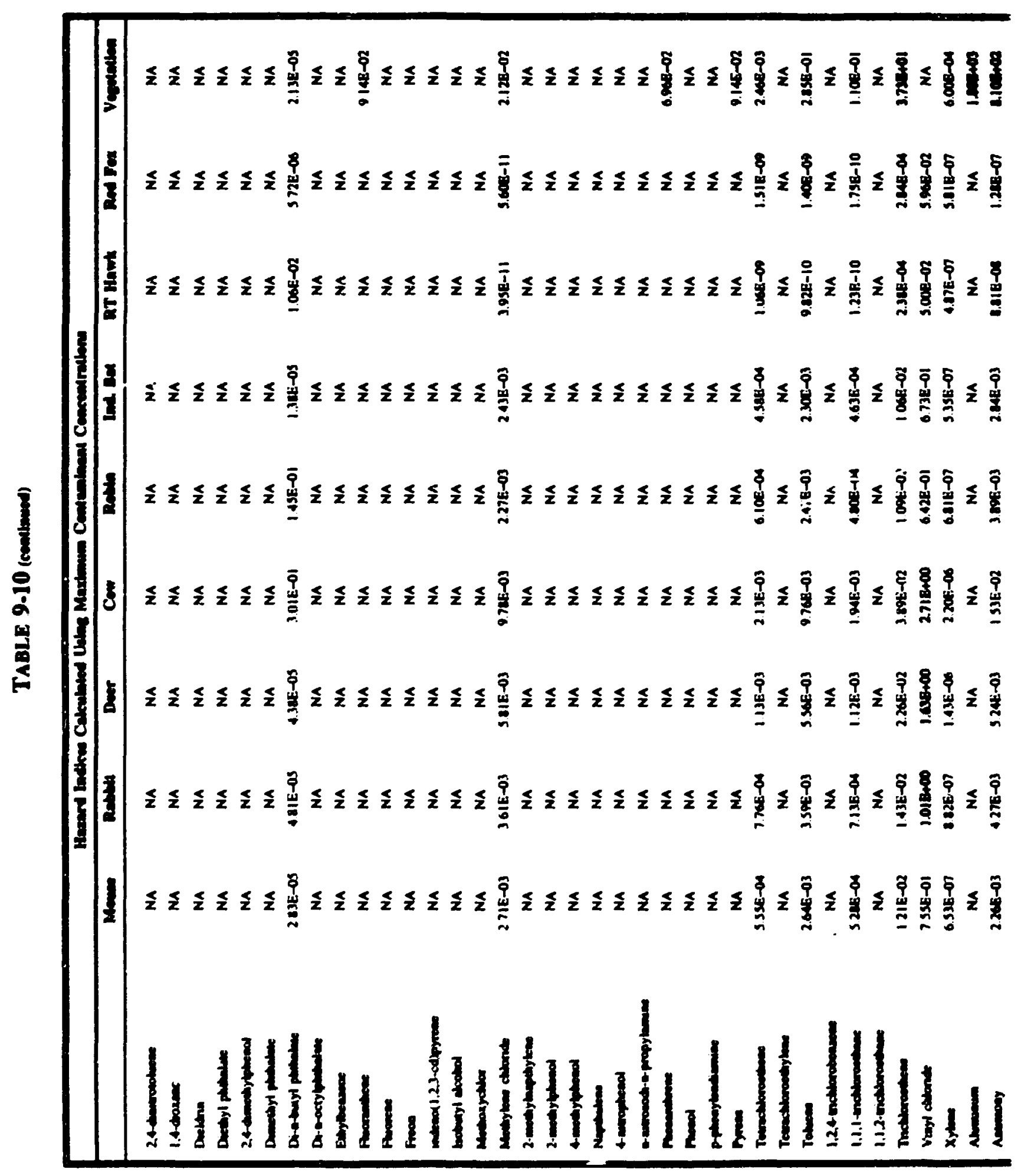




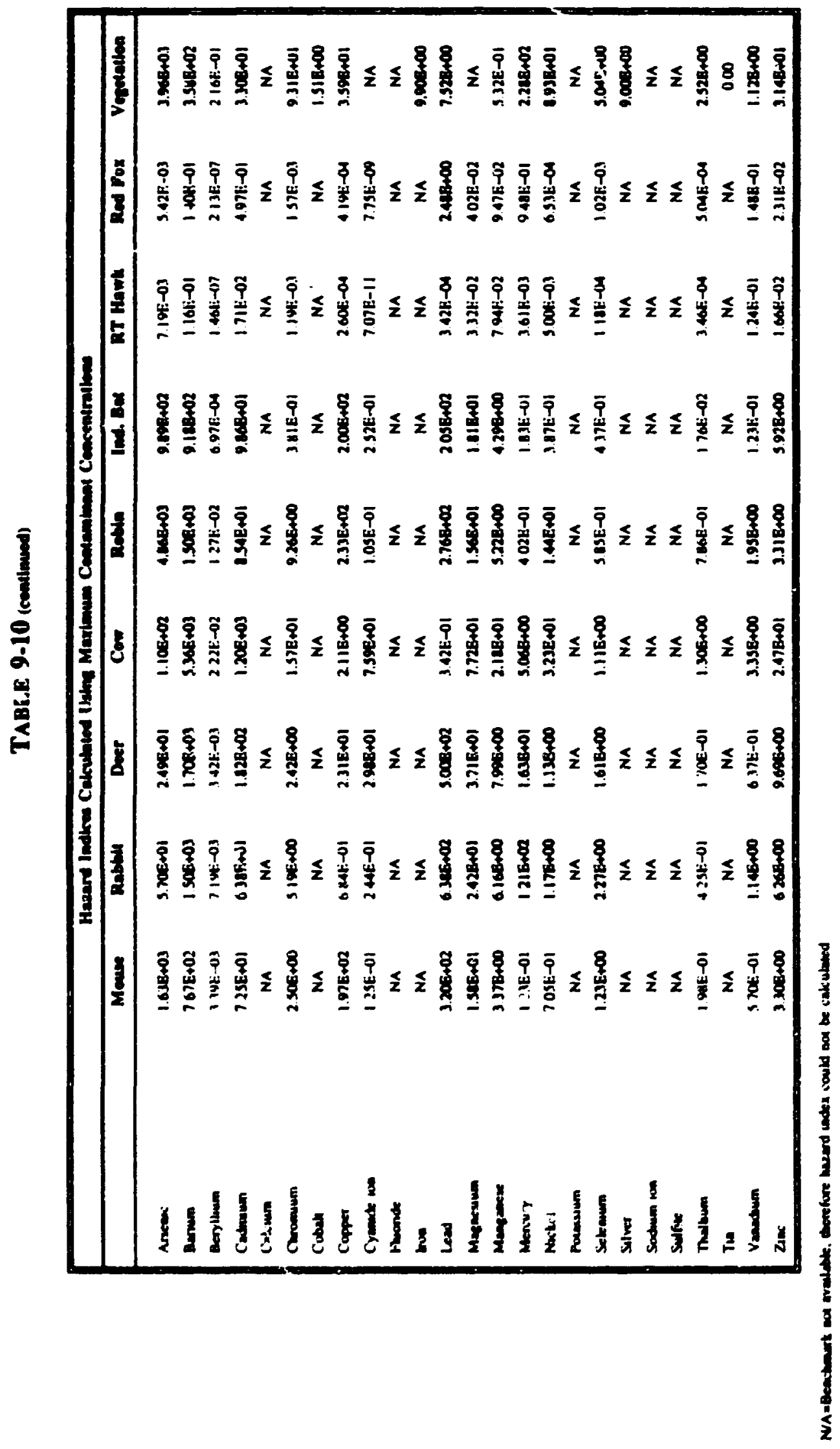




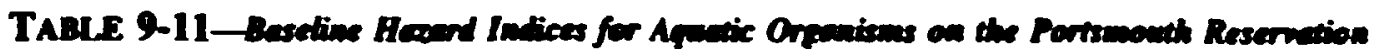

\begin{tabular}{|c|c|c|}
\hline Compinatest & $\begin{array}{l}\text { Averase } \\
\text { Sulios Wext } \\
\text { III (f-d) }\end{array}$ & 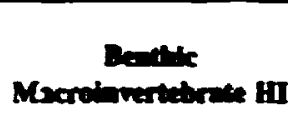 \\
\hline Acenpotiene & NA & $7.82 E-01$ \\
\hline Andurcoene & NA & $8.23 E-01$ \\
\hline Aroctar 1260 & NA & $4603+01$ \\
\hline Beasod (a)andhrucease & NA & $1.618 \times 00$ \\
\hline Beano(a)pyreace & NA & I.S9E-CI \\
\hline BEHP & $9.005+00$ & $8238+00$ \\
\hline Fluorendiene & NA & $3.87 \mathrm{E}-01$ \\
\hline Plienomithese & NA & $279 E-01$ \\
\hline Vingl chloride & $421 \mathrm{E}+01$ & NA \\
\hline Aluminum & $453 E+00$ & 3.395 .01 \\
\hline Arsearc & $1.29 \varepsilon-02$ & $3.16 E-02$ \\
\hline Brriur: & $1.39 E-03$ & $1.61 E-01$ \\
\hline Cadrul & NA & $2858+02$ \\
\hline Chrom & NA & $4.4 \times B+00$ \\
\hline Cobak & NA & $6.7+8+01$ \\
\hline Copper & NA & $1.028+01$ \\
\hline Iron & $9.40 E-01$ & $1.183 * 03$ \\
\hline Lead & NA & $7348 \times 00$ \\
\hline Magnesium & NA & $5.003+06$ \\
\hline Manganese & $3.64 E-01$ & $6203+00$ \\
\hline Mereury & NA & T.4TE+01 \\
\hline Nicked & NA & S.43E+00 \\
\hline Pocsssium & NA & $1.42 E+06$ \\
\hline Silver & NA & 8.44B*02 \\
\hline Sodium ion & NA & $2632+01$ \\
\hline Vanadium & $\mathbf{N A}$ & 8.15E-01 \\
\hline Zinc & $4+3 E-01$ & 8.18E+01 \\
\hline
\end{tabular}

N/A = Benchmark nox available. therefore hazard index could not be calculated.

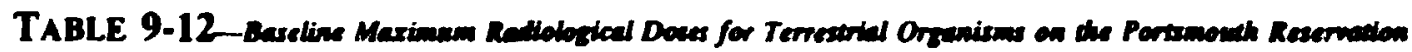

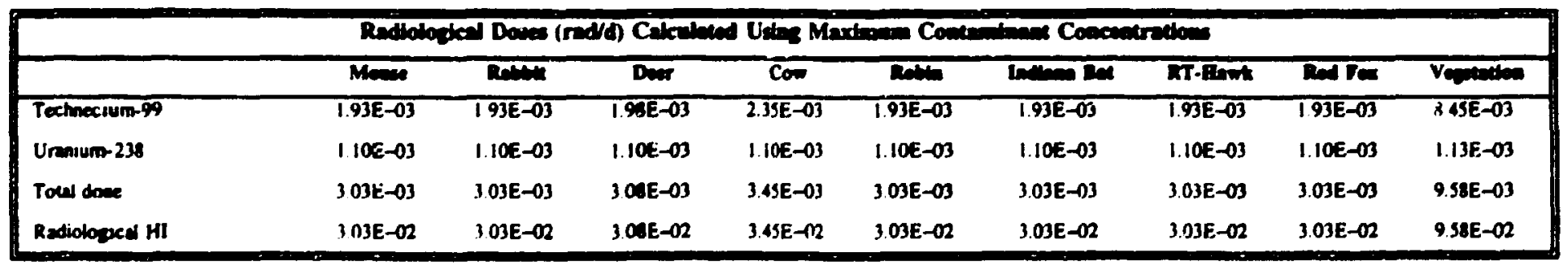




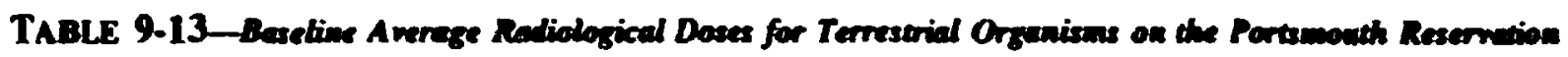

\begin{tabular}{|c|c|c|c|c|c|c|c|c|c|}
\hline & Mane & Rnimin & Deer & $\mathrm{Cem}$ & Datur & Inen $2 x$ & RT-Bunt & Dad Fea & Veratedo \\
\hline Technecinam-99 & $1.13 E-\infty$ & $1.13 E-06$ & $1.17 E-\infty$ & I.4IE-06 & $1.13 E-06$ & $1.13 E-06$ & $3.36 E-07$ & $3.37 E-07$ & $4.9 E-\infty$ \\
\hline Toul dose & i. $13 \mathrm{E}-06$ & $1.13 E-06$ & $1.17 E-\alpha E$ & $1.41 E-06$ & $1.13 E-06$ & $1.13 E-06$ & $3.36 E-07$ & $3.37 E-07$ & 4 A.E-O \\
\hline Radiolopical HI & $1.13 \mathrm{E}-\mathrm{OS}$ & $1.13 \mathrm{E}-0 \mathrm{~s}$ & 1.1TE-0S & $1.41 E-05$ & $1.13 E-05$ & 1.13E-OS & $3.36 E-06$ & $3.37 \varepsilon-06$ & $456-\infty$ \\
\hline
\end{tabular}


Potentially adverse effects, however, would be limited to the relatively small areas (totaling less than $32 \mathrm{ha}$ ) within and around the waste sites. With respect to aluminum, however, the geometric mean concentration for soils in the eastern United States $(33,000 \mathrm{mg} / \mathrm{kg})$ reported by Shacklette and Boemgen (1984) is greater than the $11,600 \mathrm{mg} / \mathrm{kg}$ average concentration used in this assessment. Therefore, it is quite possible that the extremely low benchmark $(8.0 \mathrm{mg} / \mathrm{kg}$ ) used in this assessment represents a plant species unusually sensitive to aluminum and that would not grow in most soils found throughout the United States, including those at Portsmouth.

\subsubsection{Public Lands}

There are no parks or public lands on the Portsmouth Reservation. State and private recreation areas are all more than $16 \mathrm{~km}$ (10 miles) in various directions from the Portsmouth Reservition. Wayne National Forest is adjacent to the reservation on the east and souteast.

\subsubsection{Biodiversity}

As noted previously, biodiversity on and around the reservation reflects modern human activities. The original forests have given way to agriculture (crops and cattle) and second-growth forest. Nevertheless, the area supports desirable ecological communities that could be affected by harmful contaminants on the reservation, as indicated in table 9-13e (see, aiso, tables 9-13a, $b, c$, and d). The mouse, robin, and bat incur moderate risks from each of several contaminants, whereas lead poses potentially severe risk to the mouse and robin. Hazard indices for the red-tailed hawk and red fox are less than one; therefore, risks to these elements of biodiversity are considered negligible.

\subsection{Habitat Disturbance ASSESSment}

The natural mesophytic and oak-hickory forests that dominated Ohio before the arrival of Europeans have given way to managed agriculture and timber production and residential and industrial development. Although the reservation and environs are substantially altered ecosystems, they nevertheless support fairly rich plant and animal communities that are typical of murh of rural Ohio and Kentucky today.

\subsubsection{Baseline}

About 400 ha (1000 acres) or $25 \%$ of the reservation possesses little or no habitat value to wildlife because of the presence of waste sites, production areas, and ancillary facilities. The base-line altemative loes not, by definition, include any additional disturbance from restoration activities. Thus, no additional risks to plant or animal habitat are anticipated as a result of the base-line alternative.

\subsection{Cumulattve Assessment}

\subsubsection{On-Site}

B ssed on the assumptions and calculations used in this assessment, the base-line altemative clearly poses moderate to severe risks from a suite of contaminants to selected receptor species in the endpoint categories, particularly wetlands. Table 9-14 shows which contaminants pose risks to one or more receptor species in five of the six endpoints. Public recreation lands and parks do not occur on the reservation; hence, no adverse effects on this endpoint would be expected.

For 25 contaminants, HIs suggest potential risks to organisms inhabiting waste sites. Of these contaminants, four pose potential risks to federally listed threatened, endangered, or candidate species (table 9-13a); 19 pose potential risks to species in wetlands; six pose potential risks to recreational wildlife species (table 9. 13c): eight pose potential risks to vegetation; and six pose potential risks to important food web compoitents and species important to biodiversity (table 9-13e).

\subsubsection{Off-Site}

Determining cumulative risks to endpoinis and receptors that do not occur at waste sites is more problematic. Data were not available to determine reservation-wide or regional contaminant levels. For some contaminants, it is possible that the source terms reflect naturallycccurring concentrations rather than contamination (e.g., aluminum, see chapter 9.5.1). Even when background levels are known, interpretation of hazard indices for inorganic substances is often difficult because most analytical rechniques do not distinguish between 
TABLE 9-13A-Baseline Potential Risks' to Federally Listed Threatened, Endangered, or Candidate Receptor Species ${ }^{2}$ that Occupy Waste Sites on the Portsmouth Reservation

\begin{tabular}{|l|c|}
\hline \multirow{2}{*}{ Contaminant } & Receptor \\
\cline { 2 - 2 } & Indiana Bat ${ }^{2}$ \\
\hline Copper & $\mathbf{M}^{3}$ \\
Lead & $\mathbf{M}$ \\
Magnesium & $\mathbf{M}$ \\
Manganese & $\mathrm{M}$ \\
\hline
\end{tabular}

'Potential sisk based on assumptions described in Section 9.4. Risks to individuals that do not occupy waste sites are negligible. Waste sites account for about 2.5\% of the surface area of the Portsmouth Reservation.

'The Indiana bat has been reponed in the Portsmouth area (Houlberg et al. 1992); however, suitable habitat (i.e., caves) does not exist on the Portsmouth Reservation and the bat is not expected to be an inhabitant of the reservation.

${ }^{3} \mathrm{M}=$ moderate risk, where $\mathrm{HI}$ is equal to or greater than 1.0. but less than 10; $\mathbf{S}=\mathbf{s e}$ 'rre risk. where HI is equal to or greater than 10 .

\section{TABLE 9-13B-Baseline Potential Risks' to Wettands Associated With Waste Sites' on the Portsmouth Reservation}

\begin{tabular}{||l|c|c|}
\hline \multirow{2}{*}{ Contaminant } & \multicolumn{2}{|c|}{ Receptor } \\
\cline { 2 - 3 } & Fish & Benthic Invertebrates \\
\hline Aroclor 1260 & & $\mathbf{S}$ \\
Benzo(a)anthracene & & $\mathrm{M}$ \\
BEHP & $\mathbf{M}^{3}$ & $\mathrm{M}$ \\
Vinyl chloride & $\mathrm{S}$ & \\
Aluminum & $\mathrm{M}$ & $\mathrm{S}$ \\
Cadmuim & & $\mathrm{S}$ \\
Chromuim & & $\mathrm{M}$ \\
Cobalt & & $\mathrm{S}$ \\
Copper & & $\mathrm{S}$ \\
Iron & $\mathrm{S}$ \\
Lead & & $\mathrm{M}$ \\
Magnesium & & $\mathrm{S}$ \\
Manganese & & $\mathrm{M}$ \\
Mercury & & $\mathrm{S}$ \\
Nickel & $\mathrm{M}$ \\
Potassium & & $\mathrm{S}$ \\
Silver & & $\mathrm{S}$ \\
Sodium ion & & $\mathrm{S}$ \\
Zinc & & $\mathrm{S}$ \\
\hline
\end{tabular}

'Pocential nisk based on assumpeions described in Section 9.4.

${ }^{2}$ For purposes of this analysis, wetlands included holding ponds but not creeks. ditches, swales or other potentially contaminated wetlands because surface area dala were lacking.

${ }^{\prime} M=$ moderale risk, where $H I$ is equal to or greater than 1,0 , but less than $10 ; S=$ severe risk, where $H I$ is equal to or greater than 10 . 
TABLE 9-13C-Baseline Potential Risks' to Recreational Wildife That Occupy Waste Sites on the Portamonth Reaprontion

\begin{tabular}{|l|c|c|}
\hline \multirow{2}{*}{ Contaminant } & \multicolumn{2}{|c|}{ Receptor } \\
\cline { 2 - 3 } & Eestern Cottontail Rabbit & White-tailed Deer \\
\hline Vinyl chloride & $\mathbf{M}^{2}$ & \\
Cyanide ion & & $\mathbf{M}$ \\
Lead & $\mathrm{S}$ & $\mathbf{M}$ \\
Magnesiurr & $\mathbf{M}$ \\
Manganese & $\mathbf{M}$ & $\mathbf{M}$ \\
Mercury & $M$ & \\
\hline
\end{tabular}

'Pocential risk based on assumptions destribed in Section 9.4. Risks to individuals that do not occupy waste sites are negligible and overall risks to populations of wildlife on the reservation are negligible. Wasse sites account for about $2.5 \%$ of the surface area of the Ponsmouth Reservation.

${ }^{2} M=$ moderate risk. where $H I$ is equal to or greater than 1.0 , but less than $10: S=$ severe risk, where $H I$ is equal to or greater than 10.

\section{Table 9-13d-Baseline Potential Risks' to Vegetation² on the Portsmouth Reservation}

\begin{tabular}{|l|c|}
\hline \multirow{2}{*}{ Contaminant } & Receptor \\
\cline { 2 - 2 } & Vegetation \\
\hline Aluminum & $\mathbf{S}^{\mathbf{3}}$ \\
Antimony & $\mathbf{M}$ \\
Arsenic & $\mathbf{M}$ \\
Iron & $\mathbf{M}$ \\
Mercury & $\mathbf{M}$ \\
Selenium & $\mathbf{M}$ \\
Silver & $\mathbf{M}$ \\
Thallium & $\mathbf{M}$ \\
\hline
\end{tabular}

'Potential risk based on assumptions described in Section 9.4. Risks to populations that do not occupy waste sites are negligible. Terrestrial waste sites account for about $2 \%$ of the surface area of the Portsmouth Reservation.

${ }^{2} V$ egetation includes grasses and pine.

$' M=$ moderate risk, where $\mathrm{HI}$ is equal to or greater than 1.0 , but less than $10: \mathrm{S}=$ severe risk. where $\mathrm{HI}$ is equal to or greater than 10 . 
TABLE 9-13E-Baseline Potential Risks' to Important Food Web and Biodiversity Components That Occupy Waste Sites on the Portsmonth Rescrmation

\begin{tabular}{|l|c|c|c|c|c|}
\hline \multirow{2}{*}{ Contaminant } & \multicolumn{5}{|c|}{ Receptors } \\
\cline { 2 - 6 } & Mouse & American Robin & Bats & Red-tailed ${ }^{2}$ Hawk & Red Fox \\
\hline Arsenic & & $\mathbf{M}^{3}$ & & & \\
Copper & $M$ & $M$ & $M$ & & \\
Lead & $\mathrm{S}$ & $\mathrm{S}$ & $\mathrm{M}$ & & \\
Magnesium & $\mathrm{M}$ & $\mathrm{M}$ & $\mathrm{M}$ & & \\
Manganese & $\mathrm{M}$ & $\mathrm{M}$ & $\mathrm{M}$ & & \\
Vanadium & & $\mathrm{M}$ & & & \\
\hline
\end{tabular}

'Potential rist based on assumptions described in Section 9.4. Risks to individuals that do not occupy waste sites and rists to populations are negligible. Waste sites account for about $2.5 \%$ of the surface area of the Portsmouth Reservation.

'Baseline average hazard indices for the red-tailed hawk and the red fox are all below 1 indicating negligible risk to these biodiversity endpoint receptors. ${ }^{\prime} M=$ moderate risk, where $\mathrm{HI}$ is equal to or greater than 1.0, but less than 10: $\mathrm{S}=$ severe risk, where HI is equal to or greater than 10 . 
chemical forms that are available for uptake by organisms (e.g., dissolved in soil pore water or loosely bound to particles) and those that are biologically unavailable (e.g., insoluble salts).

The waste sites are mostly highly developed areas that do not provide suitable habitat for many organisms. Thus, actual risks associated with these sites are probably lower than indicated by the HIs. However. for biota that live in (e.g. macroinvertebrates) or use the wetlands (e.g. waterfowl in punds), contaminant exposure may be substantial. Exposure of benthic macroinvertebrates to average sediment porewater concentrations resulted in Hls over one for 15 inorganic contaminants. Risk to receptors was greatest from inorganic contaminants (21 with HIs greater than 1). Organic contaminants (4 with HIs greater than 1) posed a risk mainly to receptors in wetlands. Risks from radionuclides were negligible (all His less than 1). An alternative that involves closure of the
Portsmouth facility without restoration might result in reoccupation of the waste sites by plants and animals: risks similar to those indicated in tables 9-13a, b, c, d, and $e$ would then be expected.

The only currently known mechanism for off-site transport of contaminants from the waste sites is via ingestion by wide ranging wildlife (e.g.. migratory waterfowl or deer). Of the three classes of contaminants in waste sites (i.e.. organics, inorganics, and radionuclides), the only source of radionuclides in the region would be the Portsmouth Reservation waste sites. Therefore, any regional (off-site) cumulative risks from radionuclides would be the same as on-site risks which are considery negligible (i.e., HI less than 1). At the time of our analyses no regional date for organics or inorganics were available, and cumulative risks off-site could not be estimated. 
TABLE 9-14-Comparative Summary of Alternatives for Onsite Risto' to Ecological Endpoints" on the Portrmouth Resemation

\begin{tabular}{|c|c|c|}
\hline \multirow[b]{2}{*}{ Source of Rist } & \multicolumn{2}{|c|}{ Endpoints" } \\
\hline & Boseline & ARAR $^{5}$ \\
\hline Construction' & & \\
\hline Aroclor 1260 & $\mathbf{w}$ & \\
\hline Benzo(a)anthracene & $\mathbf{W}$ & \\
\hline BEHP & $\mathbf{W}$ & \\
\hline Vinyl chloride & $\mathbf{W}, \mathbf{R}$ & \\
\hline Aluminum & $\mathbf{W}, \mathbf{F}$ & \\
\hline Antimony & $\mathbf{F}$ & \\
\hline Arsenic & F, B & \\
\hline Cadmium & $\mathbf{w}$ & \\
\hline Chromium & $\mathbf{W}$ & \\
\hline Cobalt & $\mathbf{w}$ & \\
\hline Copper & E, W, B & \\
\hline Cyanide ion & $\mathbf{R}$ & \\
\hline Iron & $\mathbf{W}, \mathbf{F}$ & \\
\hline Lead & $E, W, R, B$ & \\
\hline Magnesium & E, W, R, B & \\
\hline Manganese & $E, W, R, B$ & \\
\hline Mercury & $\mathbf{W}, \mathbf{R}, \mathbf{F}$ & \\
\hline Nickel & $\mathbf{w}$ & \\
\hline Potassium & $\mathbf{w}$ & \\
\hline Selenium & $\mathbf{F}$ & \\
\hline Silver & $\mathbf{W}, \mathbf{F}$ & \\
\hline Sodium ion & $\mathbf{w}$ & \\
\hline Thallium & $\mathbf{F}$ & \\
\hline Vanadium & $\mathbf{B}$ & \\
\hline Zinc & $\mathbf{w}$ & \\
\hline
\end{tabular}

'Only those contaminants are listed which our analyses showed could pose severe or moderate risks to some endpoints.

${ }^{2}$ Risks are for endpoints associated with waste sites or contaminated waters. Otherwise, risks to endpoints are assumed to be negligible.

These are short-lerm risks. Long-lerm risks could be reduced with successful restoration of appropriate habitat.

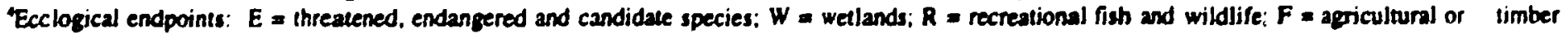
production: $P=$ parts and other public lands, and $B=$ biodiversity.

'Source terms for altematives were unavailable for this ecological risk assessment. 


\section{CHAPTER 10: COMPARISON OF ALTERNATIVES}

Programmatic altermatives for environmental restoration are described in Chapter 4 of the DOE Implementation Plan for the PEIS. Under the No Action altemative, DOE would undertake no further remedial actions at ER sites. Although this alternative is not censistent either with DOE policy or with CERCLA, it provides a baseline of potential impacts for comparison to other altematives. Altemative 1 , which reflects DOE's current ER program. emphasizes compliance with applicable laws and regulations. The principal laws in question include CERCLA, the Resource Conservation and Recovery Act (RCRA), and the Atomic Energy Act (AEA). These laws are implemented in facility-specific agreements negotiated with Federal, state, and local regulatory agencies. Environmental standards specified in other regulations, termed Applicable or Relevant and Appropriate Requirements (ARARs), are often adopted as remedial action goals. The use of ARARs as remedial action goals emphasizes reduction of local public risks from residual contamination. but may involve unrealistic assumptions about future land use and also fails to account for risks to remedial action workers and risks related to transportation of contaminated material.

Under Alternative 2, likely future land use would be given explicit emphasis early in the site evaluation process to better reflect potential risks which are likely to occur. The PEIS Implementation Plan describes three "bounding land use" options. For unrestricted land use. contaminant exposures associated with all six major human exposure pathways (groundwater for drinking, surface water, air inhalation, atmospheric deposition, soil ingestion, and direct radiation) would be reduced to levels that would permit any future land use. For "somewhat restricted land use," groundwater would not be remediated, and future land use would be restricted to activities not involving the use of groundwater as drinking water. For "totally restricted land use," only the minimum remediation performed to stabilize contamination and prevent future spread. Only future land uses consistent with prevention of public access (e.g., hazardous waste management facilities, m:litary test facilities) would be permitted.
Under Altemative 3, remedial and waste management worker and remedial waste transportation risks would be equally emphasized with the risks to a site's surrounding population. Remedial actions that would result in greater risks than posed by the current contamination would not be implemented, even though ARARs might have to be waived. Feasible future land uses and necessary engineering or institutional controls at each site would be determined by the condition of the site following completion of remediation.

Under Altemative 4, alternatives 2 and 3 would be combined to emphasize both early evaluation of likely future land uses and minimization of worker and transportation risks.

Estimates of (1) degrees of reduction in human health risk and (2) areas of land disturbed for each alternative were developed by PNL. These results were used to roughly compare the ecological benefits and impacts caused by implementation of each altemative at INEL. Femald, Rocky Flats, Hanford, and Oak Ridge. Analyses of health risk reductions were not performed for Portsmouth, consequently, no comparisons can be made for that site.

Several assumptions were required to extrapolate the human health risk results to ecological risks. First. radionuclides were selected as reference contaminants. Estimates of the aggregate radiological doses for all radionuclide sources on ech reservation were calculated for on-siie workers, the off-site public, and for a farm family residing on the site. It was assumed for our analysis that (1) radionuclide risk reduction would be qualitatively similar to reductions in risks from chemical contaminants, and (2) reductions in exposure of on-site farmers would be qualitatively similar to reductions in risk to on-site biota.

Table 10-1 presents results of these analyses. It is apparent from this table that most of the above altematives are quite similar with respect to ecological risk reductions and disturbance impacts. The No Action alternative and the Totally Restsricted Land Use alternative involve 
little or no contaminant risk reduction and also lipte or no hahitat disturhance. All of the other altematives involve large (2-4 orders of magnitude or more) reductions in contaminant risks and similar degrees of habitat disturbance. With the exception of Rocky Flats, the areas disturbed were estimated to be on the order of 500 acres or less. These values represent $1 \%$ or less of the total areas of large reservations such as INEL. Hanford. and Oak Ridge. From a complex-wide programmatic perspective, none of the environmental remediation alternatives appear to have major ecological consequences. Impacts of land use changes associated with opening up these reservations for residential, agricultural, or commercial development would likely be much greater than the impacts of any of the remediation alternatives examined in this report.

On a facility-specific level, there may be substantial differences between the altematives. For smaller sites. (e.g., Rocky Flats and Fernald), contaminated areas requiring remediation may be a much larger fraction of the total facility area than is the case on large facilities. Differences between removal-oriented and land-use oriented remediation approaches could be substantial for these facilities. For example, the disturbed areas of Rocky Flats listed in Table 10-1 range from 6\% for the Totally Restricted Land Use altemative to $26 \%$ for the ARAR altemative. Moreover, ecological impacts of restoration activities that disturb equal areas can vary significantly depending on the remediation technology employed. Although the immediate ecological impacts of soil removal/remediation are large (i.e., complete destruction of all ecological resources on the site), the long-term impacts may be small if the site is properily restored. Capping involves an initially similar degree of disturbance. but the potential for ecological restoration is severly limited because of the need to insure integrity of the cap.

For any facility, the ecological importance of the specific areas selected for remediation (e.g., wetlands, habitat for endangered species) must be evaluated prior to any action. These determinations would best be addressed in facility-specific assessments. If adequate facililty-specific data on contaminant distributions and biological resource distributions are availabte, the technical approsch employed in this renort can be directly applied to facility-leve! assessments.

\subsection{UNCERTAINTTES}

The results presented in Table $10-1$ are predicated on several key assumptions. The assumption that exposures to an on-site farmer are similar to exposures to biota was necessitated because the ARAM model used to calculate risk estimates for the various alternatives does not permit direct calculation of ecological exposures. Reductions in exposures to farmers eating vegetables grown en contaminated soil or consuming beef/milk from cattle grazing on contaminated pastures would be expected to be similar to reductions in exposure to wildlife consuming natural vegetation growing on the same soil. However, farmers might drink treated tapwater or be exposed to well-water that is not consumed by wildlife and they may not ingest surface water at all. The farm scenario is, therefore. less realistic for the surface-water pathway than for the soil pathway. However, for INEL and Fernald, no surface-water remediation is included in any of the altematives and so for those sites the difference between surface-water exposure to farmers vs. wildlife is unimportant.

Radionuclides were used as reference contaminants because (1) radiological doses due to different isotopes are summed to caluclate human exposures in the same way they are summed to calculate ecological exposures (this is not true for cancer risk estimates for chemical carcinogens), and (2) the environmental transport of radionuclides is similar to the transport of many chemical contaminants. This assumption could produce misleading estimates of ecological risk reductions if (1) chemical contaminants are the dominant source of ecological risks, and (2) the remediation alternatives emphasize radionuclides over chemical contaminants. The results in chapters 4-9 suggest that chemical contaminants may, in fact, often be of more concem than radionuclides, but insufficient information was available to evaluate whether the remediation alternatives preferentially emphasize radionuclides. 
TABLE 10-1-Ecological Rists and Benefits of ER Alarnatives

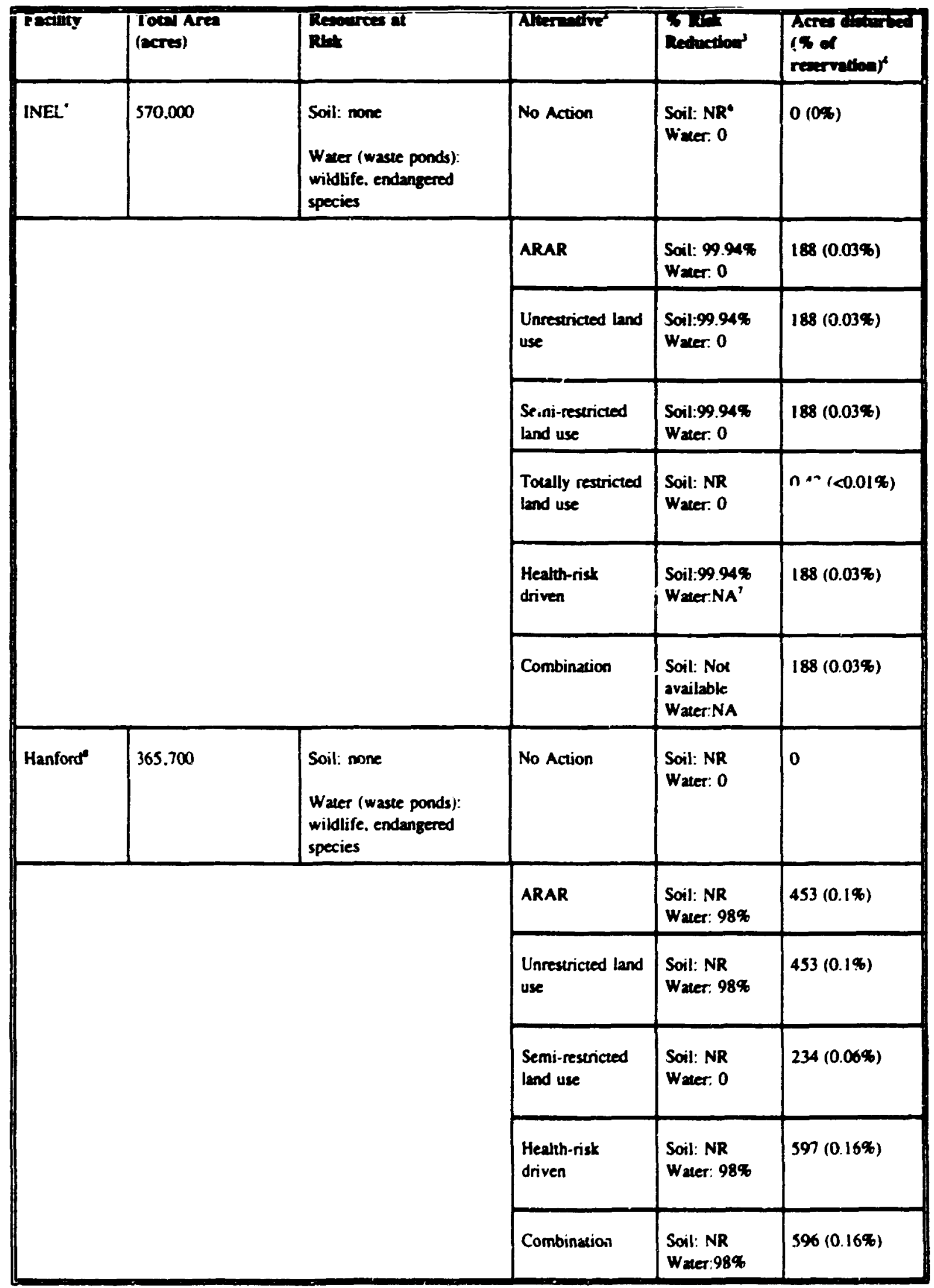


TABLE 10-1 (contineed)

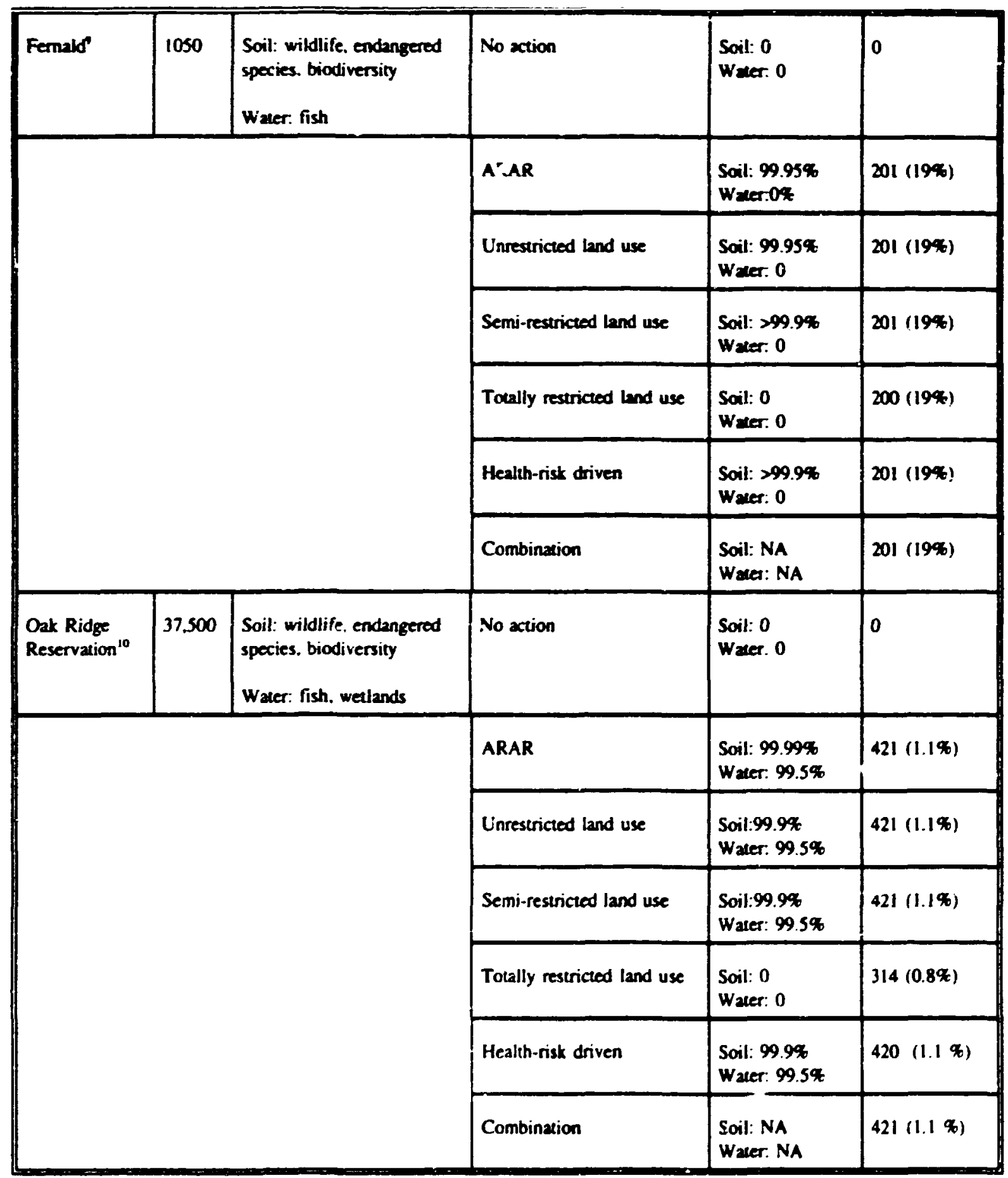


TARLE $10-1$ (comtinned)

\begin{tabular}{|c|c|c|c|c|c|}
\hline Rocky Flexs" & 6550 & $\begin{array}{l}\text { Scil: wildife. } \\
\text { endengered species. } \\
\text { biodiversity } \\
\text { Waer wethands }\end{array}$ & No action & $\begin{array}{l}\text { Soil: } 0 \\
\text { Werer. } 0\end{array}$ & 0 \\
\hline & & & ARN. & $\begin{array}{l}\text { Soil-59.99\% } \\
\text { W wer. }>99.99 \%\end{array}$ & $1695(26 \%)$ \\
\hline & & & Unrestricted land use & $\begin{array}{l}\text { Soil: } 99.9 \% \\
\text { Wreer. } 299.9 \%\end{array}$ & \\
\hline & & & Serni-restricted land use & $\begin{array}{l}\text { Soil: } 99.9 \% \\
\text { Wmer. } 299.9 \%\end{array}$ & $1694(26 \%)$ \\
\hline & & & Restricted land use & $\begin{array}{l}\text { Soil: } 0 \\
\text { Waver: } 0\end{array}$ & $373(6 \%)$ \\
\hline & & & Health-risk driven & $\begin{array}{l}\text { Soil: }>99.9 \% \\
\text { Wmer. }>99.9 \%\end{array}$ & NA \\
\hline & & & Combination & $\begin{array}{l}\text { Soil: NA } \\
\text { Water. NA }\end{array}$ & $1694(26 \%)$ \\
\hline
\end{tabular}

'Resources at risk are defined separzely, by principal exposure medium. Resources were determined to be "at risk" if (1) the are present on the facility and possibly present in known contaninated areas, and (2) comparison of estimated contaninant concensations to regulatory criteria or other toxicological benchmarts indicates a moderate or severe risk to organisms inhabiting contaminated areas.

'Alternatives are defined in the PEIS Implementation Plan.

${ }^{3} q$ reduction in contaminant exposure, as approximated by $q$ reduction in risk to on-sile farmers. Radionuclides were used ans reference contaminants.

\% of total facility area either temporarily or permanently disturbed by remedial activities. Estimates inchude adjustments for access roads and soil borrow areas.

'major areas of INEL containing contaminated soil (e.g. the Radioactive Waste Management Complex) are already heavily disturbed and provide poor habitat for terrestrial biota, hence, terrestrial resources are not at risk. Contaminated waste ponds are utilized by wildlife. hence these resources are considered to be at risk for purposes of the PEIS. None of the remediation alternastves for INEL inclide remediation of waste ponds

"NR $=$ no resources at risk

'NA = no estimate available

- major areas of Hanford containing contaminated soil are already heavily disturbed and provide poor habitat for lerrestrial biola, hence. lerrestrial resources are not at risk. Conkaminaled waste ponds are utilized by wildlife. hence chese resources are considered to be at risk for purposes of the PEIS.

'Wildlife have free access 10 contaminated areas: aquatic resources at risk include waste ponds and statutory wetlands. None of the remediation alternatives for fernald include remediation of waste ponds or wetlands.

19This facility has many widely-dispersed contaminated areas: wildlife have free access to many of these. Contamineted aquatic resources include hoth on-site waste ponds and on- and off-site streams.

"Wildlife have free access to some contaminated areas. Small wetlands are widely dispersed over the sice. 
Additional uncertainties limiting this assessment include (1) the validity of source-term estimates, (2) the actual distribution of receptor species on the facilities relative to sites where contamination is present. (3) the unknown degree of conservatism of the transfer coefficients and toxicity benchmarks used in the hazard assessment. The first two uncertainties can be addressed in facility-specific assessments that focus on optimizing the balance between remediation and habitat preservation tased on reservation-wide distributions of contaminants and ecologiral resources. The third uncertainty is a function of the state-of-the-science of environmental toxicology. It can be reduced by performing (1) periodic updates of the toxicological data base as new information becomes available from the scientific community. and (2) field studies at the DOE facilities to generate site-specific exposure and effects data. Such studies are now being performed at many DOE facilities to support CERCLA Baseline Ecological Risk

Assessments. 


\section{CHAPTER 11: REFERENCES}

Arthur, W. J. $1982 . \quad$ Radionuclide concentrations in vegetation at a solid waste disposal area in southeastem Idaho. J. Envir. Qual. 11:394-399.

Arthur, W. J., and A. W. Alldredge. 1979. Soil Ingestion by Mule Deer in North Central Colora:.. J. Range Management 32:67-71.

Adams, L. E., D. H. Janke, and P. T. Dickman. 1979. Annual repon-1978 environmental surveillance report of the INEL radioactive waste management complex. TREE-1357.

Anderson, A. E., and O. C. Wallmo. 1984. Odocoileus hemionus. No. 219. Mammalian Species. The American Society of Mammalogists.

Anderson, S. H., and H. H. Shugart. 1974. Habitat selection of breeding birds in an east Tennessee deciduous forest. Ecology 55:828-837.

Amold, J. F., and H. G. Reynolds, 1943. Droppings of Arizona and Antelope Jackrabbits and the "pellet census." J. Wildlife Manage. 7:322-327.

Arthur, W. J., and O. D. Markham. 1983. Small mammal, soil burrowing as a radionuclide transport vector at a radioactive waste disposal area in southeastern Idaho. J. Environ. Qual. 12:117-122.

Arthur, J. W. III, and D. H. Janke. 1986. Radionuclide concentrations in wildlife occurring at a solid radioactive waste disposal area. Northwest Sci. 60(3): .

A:thur, W. J., J. W. Connelly, D. K. Halford. and T. D. Reynolds. 1984. Vertebrates of the Idaho National Engineering Laboratory, DOEЛD-12099. National Technical Information Service, Springfield, Virginia.

Arthur, W. J. III, and R. J. Gates. I988. Trace Element Intake via Soil Ingestion in
Pronghoms and in Black-Tailed Jackrabbits. J. Range Manage. 41:162-166.

Arthur, W. J., O. D. Markham. C. R. Groves, and B. L. Keller. 1987. Radionuclide export by deer mice at a solid radioactive waste disposal area in southeastem Idaho. Health Phy. 52(1):45-53.

Baes, C. F. III, R. D. Sharp, A. L. Sjoreen, R. W. Shor. 1984. A Review and Analysis of Parameters for Assessing Transport of Environmentally Released Radionuclides through Agriculture. ORNL-5786, Health and Safety Research Division, Oak Ridge National Laboratory, Oak Ridge, Tennessee.

Baver, B. H., B. A. Branson, and S. T. Colwell. 1978. Fishes of Paddy's Run Cresk and the Dry Fork of the Whitewater River, Southwestem Ohio. Ohio J. Sci. 78(3): 144-148.

Bekoff, M. 1977. Canis latrans. No. 79. Mammalian Species. The American Society of Mammologists.

Bekoff, M. 1982. Coyote. Chapter 20 In: Chapman, J. A. and G. A. Feldhamer (eds). Wild Mammals of North America. pp 447. 452.

Beyer, N., E. Conner, and S. Gerould. 1991. Survey of Soil Ingestion by Wildlife. Report cn work funded by U.S. EPA and supervised by Ruth Miller, OPPE.

Blaustein, A. R. and D. B Wake. 1990. Declining amphibian populations: a global phenomenon? TREE (Trends in Ecology and Evolution) 5:203-204.

Bowen, H. J. M. 1979. Environmental Chemistry of the Elements. Academic Press, New York.

Boyle, J. W., R. Blumberg, S. J. Conter, G. S. Hill, C. R. Kerley, R. H. Ketelle, R. L. Kroodsma, D. W. Lee, R. C. Martin, R. D. Roop. D. N. Secora, W. P. Staub, R. E. 
Thoma. 1982. Environmental analysis of the operation of Oak Ridge National Laboratory (X-10 site). ORNL-5870.

Bradburn, D. M. and E. H. Rosenbalm. 1984. Resource management plan for the U.S. Department of Energy Oak Ridge Reservation. Vol. 6. Appendix F: Forest management. ORNL-6026N6.

Bradbum, D. M. 1977. Forest management plan, ERDA Oak Ridge Reservation: 1976-1980. ORNL/TM-5833.

Brown, L., and D. Amadon. 1968 . Eagles, Hawks, and Falcrns of the World. Vol.2. County Life Books, Hamlyn Publishing Group, Ltd. Hamlyn House, Feltham, Middlesex, Greiu Britain.

Brown, L., and D. Amadon. 1968. Eagles, Hawks, and Falcons of the World. Country Life Books. Hamlyn Pub!ishing, Middlesex, Great Britian.

Burt, W. H., and R. P. Grossenheider. 1976. A Field Guide to the Mammals. Third edition. Houghton Mifflin Company, Boston.

Chapman, J. A., and G. A. Feldhamer (eds.). 1982. Wild Mammals of North America. The Johns Hopkins University Press, Baltimore. p. 129.

Chapman, J. A., J. G. Hockman, and M. M. Ojeda C. 1980. Sylvilagus floridanus. Mammalian Species, No. 136: pp 1-8. American Soc. Mammalogists.

Cheater, M. 1992. Alien Invasion. Nature Conservancy Magazine. SepuOct: 24-29.

Cholewa, A. F., and D. M. Henderson. 1984. A survey and assessment of the rare vascular plants of the Idaho National Engineering Laboratory site. Great Basin Nat. 44:140-144.

Clark, T. W., R. S. Hoffman, and C. F. Nadler. 1971. Mammalian Species: Cynomys leucurus. No. 7: 1-4. American Society of Mammalogists.
Connelly, J. W., and O. D. Markham. 1983. Movements and radionuclide concentrations of sage grouse in southeastem Idaho. J. Wildlife Manage. 47(1):169-177.

Council on Environmental Quality (CEQ). 1993. Incorporating biodiversity considerations into environmental impact analysis under the National Environmental Policy Act. CEQ, Exectitive Office of the President, Washington.

Cunningham, $M$. and L. Pounds. 1991. Resource Management Plan for the Oak Ridge Reservation. Vol. 28: Wetlands on the Oak Ridge Reservation. ORNLNERP-5.

Cunningham, M., L. Pounds, S. Overholster, P. Parr, and L. Edwards. (1992 DRAFT). Resource Management Plan for the Oak Ridge Reservation. Rare plants on the Oak Ridge Reservation. ORNLNERP-DRAFT REPORT.

Cushing, C. E. (ed :. 1991. Hanford Site National Environmental Policy Act (NEPA) Characterization. PNL-6415 Rev. 4, UC-600. Pacific Northwest Laboratory, Richland, Washington.

Dale, V. H., L. K. Mann, R. J. Olson, D. W. Johnson, and K. C. Dearstone. 1990. The long-term influence of past land use on the Walker Branch forest. Landscape Ecology. 4:211-224

Droppo, J. G., Jr., D. L. Strenge, J. W. Buck, B. L. Hoopes, R. D. Brockhaus, M. B. Walter, and G. Whelan. 1989. Multimedia Environmental Pollutant Assessment System (MEPAS) Applications Guidance. Volume I-User's Guide. Richland. Washington: Pacific Northwest Laboratory. PNL-7216, Vol. 1. 
EG\&G Rocky Flats, Inc. 1991. Threatened and Fndangered Species Eyaluation, Rocky P'ant Site. U.S. Department of Energy Rocky Flats Plant, Golden, Colorado.

EC\&\&G Rocky Flats, Inc. 1990. Wetland Assessment Rocky Flats Site. Golden, Colorado.

Eskew and Babb. 1992. Massachusetts Military Reservation Air National Guard Risk Assessment Handbook. Draft report. Advanced Sciences, Inc., Oak Ridge, Tennessee.

Facemire, C. F., S. I. Guttman, D. R. Osbome, and R. H. Sperber. 1990. Biological and Ecological Site Characterization of the Feed Materials Production Center. U.S. Department of Energy, Oak Ridge Operations Office, Oak Ridge, Tennessee.

Fielder, G. F. Jr., S. R. Ahler, and B. Barrington. 1977. Historic sites reconnaissance of the Oak Ridge Reservation, Oak Ridge, Tennessee. ORNL/TM-581I.

Fitzner, R. E., and R. H. Gray. 1991. The status, distribution, and ecology of wildlife on the U.S. DOE Hanford site: a historical overview of research activities. Environmental Monitoring and Assessment 18:173-202.

Gray, R. H., and W. H. Rickard. 1989. The protected area of Hanford as a refugium for native plants and animals. Environmental Conservation 16:251-216.

Green, J. S., and J. T. Flinders. 1980. Brachylagus idahoensis. Mammalian Species \# 125. Amer. Soc. Mamm.

Halford, D. K., O. D. Markham, and R. L. Dickson. 1982. Radiation doses to waterfowl using a liquid radioactive waste disposal area. J. Wildlife Manage. 46(4):905-914.

Hermanson, J. W., and T. J. O'Shea. 1983. Antrozous pallidus, Mammalian Species. The American Society of Mammalogists.
Houlberg. L. M., L. A. Eaton, J. A. Martin, E.

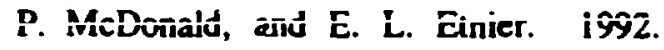
Applicable or Relevant and Appropriate Requirements (ARARs) for Remedia! Actions at the Portsmouth Gaseous Diffusion Plant. A Compendium of Environmental Laws and Guidance. Martin Marietta Energy Systems, Inc. POEF/ER4533.

Humphrey, S. R., A. R. Richter, and J. B. Cope. 1977. Summer Habitat and Ecology of the Endangered Indiana Bat, Myotis sodalis. Joumal of Mammalogy, 58/3: pp. 334-346.

Ibraham. S., and T. Culp. 1989. Plutonium distribution and oxidation states in a reactor leaching ponds system. Health Phys. $57(4) 607-614$.

Intemational Atomic Energy Agency (IAEA). 1992. Effects of lonizing Radiation on Plants and Animals at Levels Implied by Current Radiation Protection Standards. Vienna. IAEA Technical Report Series No. 332.

International Atomic Energy Agency (IAEA). 1982. Generic Models and Parameters for Assessing the Environmental Transfer of Radionuclides from Routine Releases. Safety Series No. 57., Vienna, Austria.

Janke, D. H., and J. W. Arthur. 1985. Radionuclide transport by cotto ttail rabbits at a radioactive waste disposal area. Northwest Sci. 59(3):180-184.

Killough, G. G., and L. R. McKay. 1976. A Methodology for Calculating Radiation Doses from Radioactivity Released to the Environment. ORNL-4992. Environmental Sciences Division Publication No. 660. Oak Ridge National Laboratory, Oak Ridge. Tennessee.

Kroodsma, R. 1992. Memo to Linda Mann, Aligust 18, 1992. 
Kroodsma, R. 1987b. Edge effect on breeding

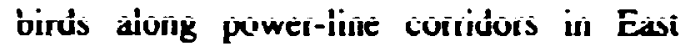
Tennessee. Am. Mid. Nat. 118: 275-283.

Kroodsma, R. 1987a. Resourc: Management Plan for the Oak Ridge Reservation. Vol. 24: Threatened and endangered animal species. ORNL/ESH-1/V24.

Kunz, T. H., and R. A. Martin. 1982. Plectotus townsendii. Mammalian Species \# 175.

Lackey et al. 198j.

Lim, B. K. 1987. Lepus townsendii. No. 288. Mammalian Species. The American Society of Mammologists (includes discussion of L. californicus).

Markham, O. D. 1987. Summaries of the Idaho National Engineering Laboratory Radioecology and Ecology Program research projects. DOE/D-12111.

Markham, O. D., and D. K. Halford. 1985. Effects of decreased effluents irom nuclear fuel reprocessing on ${ }^{137} \mathrm{Cs}$ concentrations in wildlife. Northwest Sci. 59(3).180-184.

Markham, O. D., D. K. Halford, S. K. Rope, and G. B. Kuzo. 1988. Plutonium, Am, Cm, and $\mathrm{Sr}$ in ducks maintained on radioactive leaching ponds in southeastem Idaho. Health Phys. 55(3):517-524.

Markham, O. D., D. K. Halford, and R. D. Auter.rieth. 1980 . Strontium-90 concentrations in pronghom antelope bones near i nuclear fuel reprocessing plant. Health Phys. 38(?):811-816.

Markharn, O. D., and D. K. Halford. 1982. Radionuclites in mouming doves near a nuclear facility complex in southeastem Idaho. Wilsun Bull. 94:185-197.

Markham, O. D., and R. C. Morris (eds.). 1991. Sunımaries of the Idaho National Engineering Laboratory radioecology and ecology program environmental restoration and waste management related research. DOE ID- 12124.
May, R. M. 1992. How many species inhabit ìne carưt? Scieniific nmer. Oci: 42-46.

Mayland, H. F., G. E. Shrewmaker, and R. C. Bull. 1977. Soil ingestion by cartle grazing crested wheatgrass. J. Range Manage. 30:264-265.

McBride, R., W. R. French, A. H. Dahl, and J. E. Detmer. 1978. Vegetation types and surface soils of the Idaho National Engineering Laboratory site. IDO-12084.

McCance, R. M., Jr., and J. F. Burns (eds.). 1984. Ohio Endangered and Threatened Vascular Plants. Ohio Department of Natural Resources, Columbus, Ohio.

McCracken, G. F. 1988. Who's endangered and what can we do? Bat Conservation International. 6: 5-9.

McNabb, B. K. 1963. Bioenergetics and the determination of home range size. Amer. Nat. 8(94):133-140.

Millard, J. B., F. W. Whicker, and O. D. Markham. 1990. Radionuclide uptake and growth of barn swallows nesting by radioactive leaching ponds. Health Phys. 58(4):429-439.

Morris, R. C. 1992. Bounding ecological risk assessments on the INEL. INEL. Radiological and Environmental Sciences Laboratoiy, Idaho Falls, Idaho (unpublished).

Morrison, F. B. 1959. Feeds and feeding: A Handbook for the Student and Stockman. Morrison Publishing Co., Clinton, Iowa.

Moseley, R., and C. Groves. 1992. Rare. Threatened and Endangered Plants and Animals of Idaho. Conservation Data Center, Nongarne and Endangered W:Idlife Program, Idaho Devartment of Fish and Game.

National Council on Radiation Protection and Mezsurement. 1991. Effects of Ionizing Radiation on Aquatic Organisms. NCRP 109. 
Nehlsen, W., J. E. Williams, and J. A. Lichatowich. !O90!. Paciffe silmon at ithe crossroads: stocks at risk from Califomia, Oregon, Idaho, and Washington. Fisheries. 16: $4-21$.

Nowak, R. M., and J. L. Paradiso. 1983. Walker's Mammals of the World. The Johns Hopkins University Press, Baltimore. pp. 583-585.

O'Gara, B. W. 1978. Antilocapra umericana. Mammalian Species \#90. Amer. Soc. Mamm.

Ohio Environmental Protection Agency (OEPA). 1982. Comprehensive Water Quality Report for the Lower Mainstem of the Great Miami River (River Mile 92.5-0.9) Montgomery, Warren, Butler, and Hamilton Counties, Ohio: Final Draft. Div. Wastewater Poll. Control, Columbus, Ohio.

Opresko, D. M., B. E. Sample, and G. W. Suter II. 1993. Toxicological Benchmarks for Wildlife. ES/ER/TM-86. Oak Ridge National Laboratory, Oak Ridge, Tennessee.

Opresko, D. M., and G. W. Suter II. 1992. Toxicological benchmarks for wildlife. Oak Ridge National Laboratory, Oak Ridge, Tennessee (unpublished).

Pacific Northwest Laboratory. 1989. Multimedia environmental Pollutant (Assessment System (MEPAS) Pacific Norinwest Laboratories (PNL), Richiand. Washington.

Parr, P. D. and J. W. Evans. 1992. Resource Management Plan for the Oak Ridge Reservation. Vol 27: Wildlife management plan. ORNISNERP-6.

Pounds, L. R., P. D. Parr, and M. G. Ryon. DRAFT. 1993. Oak Ridge National Environmental Research Park natural areas and reference areas: Oak Ridge Reservation environmentally sensitive sites containing special plants, animals, and communities. ORNL/NERP-8.
Reynolds, T. D. 1993. Summary of telephone coniversatioñs dưring i 993 from Linda Mann, research associate, Environmental Sciences Division, Oak Ridge National Laboratory. Written summary validated by T. Reynolds. INEL Ecologist, January 11, 1994.

Reynolds, T. D., J. W. Connelly, D. K. Halford, and W. J. Arthur. 1986. Vertebrate fauna of the Idaho National Environmental Research Park. Great Basin Nat. 46:513-527.

Reynolds, T., and W. J. Arthur. 1983. Preliminary report of biological intrusion studies at the Idaho National Engineering Laboratory Subsurface Disposal Area. pp. 14-20, Idaho National Engineering Laboratory Radioecology and Ecology Programs 1983 Progress Report. DOE/ID. 12098 National Technical Information Service, Springfield, Virginia.

Reynolds, T. 1979. The impact of loggerhead shrikes on nesting birds in a sagebrush environment. Auk 96:798-800.

Rogers, J. G., et al. 1988. Environmental Surveillance of the U.S. Department of Energy Portsmouth Gaseous Diffusion Plant and Surrounding Environs During 1987, ES/ESH-4/V4, POEF-1180, pp. 1, 2. $8,9,71,73$.

Rogers, J. G., et al. 1989b. Portsmouth Gaseous Diffusion Plant Site Environmental Report for 1988, ES/ESH-8/V4, POEF2010, Martin Marietta Energy Systems, Inc., Oak Ridge, Tennessee, and Paducah, Kentucky, May.

Rope, S. K., W. J. Arthur III, T. H. Craig, and E.H. Craig. 1988. Nutrient and trace elements in soil and desert vegetation of southern Idaho. Env. Monit. Assess. 10:1-24. 
Rope, R. C., and C. S. Stahly. 1993. Chap. 5. Riotic resources. pn. 1-28. In: Environmental Resource Document, Idaho National Engineering Laboratory, April, Issue No. 001 .

Sackschewsky, M. R., D. S. Landeen, J. L. Downs, W. H. Rickard, and C. I. Baird. 1992. Vascular plants of the Hanford site. WHC-EP-0554. Westinghouse Hanford Company, Richland, Washington.

Saylor, R. W., D. G. Jernigan, B. D. Lasley, M. A. Mitckes, L. K. Mann, S. M. Schexnayder, M. Schweitzer, W. P. Staub, V.R. Tolbert, J.W. Van Dyke, J. P. Witherspoon, and A. K. Wolfe. 1990. Data package for the Atomic Vapor Laser Isotope Separation (AVLIS) plant environmental impact statement. ORNL/TM-11482.

Schoener, T. W. 1968. Sizes of feeding territories among birds. Ecology 49:123141.

Severson, K. M., M. May, and W. Hepworth. 1968. Food preferences, carrying capacities and forage competition between antelope and domestic sheep in Wyoming's Red Desert. Sci. Monogr. 10. Agr. Exp. Sta. University of Wyoming, Laramie.

Shacklette, H. T., and J. G. Boerngen. 1984. Element concentration in soils and other surficial materials of the conterminious United States. US Geological Survey Professional Paper 1270. US Govt. Printing Office, Washington.

Smith, W. P. 1991. Odocoileus virginianus. Mammalian Species, No. 388: pp 1-13. American Soc. Mammalogists.

Stoecker, R. E. 1992. Reporn of Findings: Survey for Preble's Jumping Mouse, Rocky Flats Buffer Zone. ESCO Associates, Inc., Boulder, Colorado, and EG\&G Rocky Flats, Inc., Golden, Colorado.

Strenge, D. L., and S. R. Peterson. 1989. Chemical Data Bases for the Multimedia Environmental Pollutant Assessment System
(MEPAS): Version 1. PNL-7145. Battelle Memorial Institute, Richland: Washington

Suter, G. W., II. 1991. Screening level risk assessment for off-site ecological effects in surface waters downstream from the I.S. Department of Energy Oak Ridge Reservation. ORNL/ER-8. Oak Ridge National Laboratory, Oak Ridge, Tennessee.

Suter, G. W. II, M. A. Futrell, and G. A. Kerchner. 1992. Toxicological Benchmarks for Screening of Potential Contaminants of Concern for Effects on Aquatic Biota on the Oak Ridge Reservation, Oak Ridge, Tennessee. ORNL/ER-139, Environmental Sciences Division, Oak Ridge National Laboratory. Oak Ridge, Tennessee.

Suter, G. W. II, and M. A. Futrell. 1993. Toxicological Benchmarks for Screening Potential Contaminants of Concem for Effects on Terrestrial Plants. Unpublished draft report. Oak Ridge National Laboratory, Oak Ridge, Tennessee.

Suter, G. W. II. 1993. Ecological Risk Assessment. Lewis Publishers, Chelsea, MI. 538 pp.

Suter, G. W. II, M. G. Will and C. Evans. 1993. Toxicological benchmarks for screening potential contaminants of concern for effects on terrestrial plants. ES/ER/TM85. Oak Ridge National Laboratory (ORNL/ER), Oak Ridge, Tennessee.

Suter, G. W. II, and L. W. Barnthouse. 1993. Assessment Concepts. Chapter 2. In: G. W. Suter II (ed.) Ecological Risk Assessment, Lewis Publishers, Boca Raton, Florida.

Terborgh, J. 1989. Where have all the birds gone? Princeton Univ. Press, Princeton, iNew Jersey. 
Terres, J. K. 1980. The Audubon Society Encyclopedia of North American Birds.

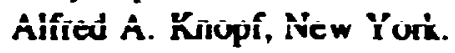

Thomson, C. E. 1982. Myoris sodalis. Mammalian Species, No. 163: pp 1-5. American Soc. Mammalogists.

Till, J. E., and H. R. Meyer, eds. 1983. Radiological Assessment. NUREG/CR3332. ORNL-5968.

Tkachyk, J. W., K. C. Wright, and R. N. Wilhelmsen. 1990. Annual report-1989 environmental monitoring for EG\&G Idaho facilities at the Idaho National Engineering Laboratory. EGG-2612.

Travis, C., and A. D. Arms. 1988. Bioconcentration of organics in beef, milk, and vegetation. Environ. Sci. Technol. 22(3):271-274.

Tumer, 3. E. 1986. Atoms, Radiation and Radiation Protection. Pergamon Press, New York.

U. S. Department of Energy (DOE). 1985. Depirtment of Energy National Environmental Research Parks. DOE/ER0246.

U.S. Environmental Protection Agency. 1988. Recommendations for and documentation of biological values for use in risk assessment. EPA 600/6-87/008. U. S. Environmental Protection Agency, Washington.

U.S. Fish and Wildlife Service (FWS). 1980 and 1984. National Wetlands Inventory Maps: Antelope Butte, Atomic City, Big Southem Butte, Big Lost River Sinks. Circular Butte, Circular Butte 3SE, Circular Butte 3NW, Circular Butte 3NE, Circular Butte 3SW, Circular Butte NW, Kettle Butte NW, Kettle Butte SW, Little Butte, Little Butte NE, Little Butte NW, Little Butte SW, Little Lost River Sinks, Middle Butte, Monteview, Richard Butte, Scott Butte, Snaky Canyon, and Terreton 7.5 in. quadrangles. U. S. Fish and Wildlife Service, Reston, Virginia.
U.S. Department of Energy (DOE). 1993. Baseline Ecological Risk Assessment Wioripian for Fortsmouth Giaseous Diffusion Plant, Piketon. Ohio. DOE/OR/12-1163 \& D3.

U.S. Environmental Frotection Agency (EPA). 1988. Recommendations for and Documentation of Biological Values for use in Risk Assessment. EPA600/6-87/008. Washington.

U.S. Department of Energy (DOE). 1992. Baseline Characterization of the Terrestrial and Aquatic Habitats at Rocky Flats Plant. Final Report. Golden, Colorado.

U.S. Department of Energy (DOE). 1992. Draft Site Wide Characterization Report. Femald Environmental Management Project Remedial Investigation and Feasibility Study. Vol. 4. DOE Fernald Field Office. Fernald. Onio.

U.S. Energy Research and Development Administration (ERDA). 1977b. Portsmouth Gaseous Diffusion Plant Expansion, Piketon, Ohio, Vol. 2 of 2 , $1549 / 22$, pp. B-6 through B-15, B-17 through B-57, B-59 thorugh B-62, B-64, B79.

U.S. Energy Research and Development Administration (ERDA). 1977a. Portsmouth Gaseous Diffusion Plant Expansion, Piketon, Ohio, Vol. 1 of 2. $1549 / \mathrm{Vl}$, pp. 2-10, 2-12, 2-224, 2-225, 2 298. 2-300, 2-301, 2-302, 2-305, 2-306, 2 $319,2-321$.

U.S. Fish and Wildlife Service (FWS). 1975. National Wetlands Inventory. Lafayette. Colorado and Golden, Colorado quadrangles. Denver, Colorado.

Uppendahl, M. L. 1990. Winter Raptor Nesting Survey at Rocky Flats Plant and Surtounding Area, Golden, Colorado. Letter to Scott McGlochin. Rocky Flats Plant, :... . M. L. Uppendahl, Advanced Sciences. Inc., Lakewood, Colorado. 
Watkins, D. R., et al. 1993. Final Report on the BAckground Soil Characterization Project at the Oak Ridge Reservation, Oak Ridge, Tennessec. Volume 1-Results of Field Sampling Program. DOE/ORN1-1175/VI.

Westem Bird Banding Association. Monograph No. 1. 1984. Eldon Publishing. Arizona.

Whitaker, J. O. 1988. The Audubon Society Field Guide to North American Mammals. Alfred A. Knopf, New York.

Wilson, E. O. (ed.) 1988. Biodiversity. National Academy Press, Washington.

Woodruff, R. K., and R. W. Hanf (eds.). 1992. Hanford Site Environmental Report for Calendar Year 1991. PNL-8148 UC-602. Pacific Northwest Laboratory, Richland, Washington. 


\section{APPENDIX A: EXPOSURE AND EFFECTS ASSESSMENT METHODOLOGY}

\section{A.1 EXPOSURE ASSESSMENT}

The baseline (no-action) exposure assessment focuses on chemical stresses and any existing physical stresses to the endpoints as a result of preremediation activities. Baseline exposures to chemical stresses were assessed from the current, existing contaminant profile in the environmental media in which organisms may be exposed. Physical stresses are defined in terms of alteration or destruction of ecosystems during and after remediation. The baseline (no-action) assessment of contaminant exposures involves the following tasks: (1) determining representative receptor species composition and distribution within the ecological endpoints, (2) defining the contaminant transport and exposure pathways from the sources to the biotic receptors. (3) determining the average and maximum contaminant levels in the media to which the receptors are exposed, (4) calculating the daily intake or tissue concentrations of contaminants from each exposure pathway for each receptor, and (5) characterizing the risks to each receptor for each contaminant by comparing the total daily intake or exposure of a contaminant to the contaminant-specific benchmark (figure A-1). Assessment of ecological exposures associated with remediation alcematives involves ( 1 ) reassessment of residual contaminant exposures, and (2) evaluation of habitat disturbance (Appendix B).

Exposure scenarios were determined for each of the representative receptors for all ingestion-related pathways (e.g., food and water consumption; grooming or preening) and for extemal exposure. Inhalation exposures were not included because (1) air concentrations of contaminants were not available, and (2) preliminary calculations showed that risks from inhalation are minor compared to risks from food and water ingestion. To determine how contaminants are transferred through components of successive trophic levels within terrestrial ecosystems, a food web was formulated for each reservation and used to assess contaminant ingestion by terrestrial receptors.

The fate and transport model used for the human health risk assessment by Oak Ridge National Laboratory is the Multimedia Environmental Pollutant Assessment System (MEPAS) (Pacific Northwest Laboratories, 1989). MEPAS was developed to prioritize contaminated waste sites based on their potential hazard to the public. The assessment framework for MEPAS addresses the migration, fate, exposure and human health impact from radionuclides and chemical contaminants, accounting for complex chemical processes and intermedia transfer among the atmospheric, groundwater, surface water, and overland runoff pathways. MEPAS-derived contaminant concentrations in surface water were used as exposure estimates for aquatic receptors. Soil-to-plant and plant-to-animal transfer coefficients were used to translate MEPAS-derived soil concentrations into food-chain exposures to terrestrial receptors.

The primary exposure routes for terrestrial vegetation is root uptake from soil. Published soil-to-plant transfer factors were be applied to obtain concentrations of radionuclides, organics. and inorganics in the vegetative parts of plants and concentrations of radionuclides and inorganic chemicals in fruits (Baes et al. 1984; Travis and Arms 1988). Travis and Arms (1988) reported that for organic chemicals, the bioconcentration factors for vegetation were inversely proportional to the square root of the octanot-water partition coefficient. This transfer factor takes into 
account all exposure routes responsible for the contaminant burden measured in plant tissues. Transfer factors do not take into account. however. the bioavailability of a chemical in the soil, the biodegradation rate, weathering factors. or chemical transformations within the tissues. Therefore, the transfer factor is conservative in that it does not factor for these loss mechanisms. The equation used to estimate concentrations of contaminants in vegetation is:

$C_{v}=C_{s} * T F$,

where

$C_{v}=$ concentration in vegetation (vegetative or fruits) (mg/kg: pCi/kg dry weight).

$\mathrm{C}_{\mathrm{s}}=$ concentration in soils $(\mathrm{mg} / \mathrm{kg}$; pC.ivkg dry weight),

TF = soil to plant transfer factor (vegetative or fruits) $=$ concentration in vegetation (unitless).

The primary exposure routes for terrestrial wildlife species are ingestion of food, external exposure to radionuclides, and drinking water. The incidental ingestion of soils is also considered for some herbivorous species such as deer. mice. and rabbits. The daily intake of a nonradiological contaminant by ingestion is estimated by the following equation:

intake $=\left[\left(\mathrm{C}_{\mathrm{V}} * \mathrm{Q}_{\mathrm{v}}\right) \mathrm{FI}_{\mathrm{v}}+\left(\mathrm{C}_{\mathrm{S}} * \mathrm{Q}_{\mathrm{s}}\right) \mathrm{FI}_{\mathrm{s}}+\left(\mathrm{C}_{\mathrm{W}} *\right.\right.$ $\left.\mathrm{Q}_{w}\right) \mathrm{FI}_{*}+\left(\mathrm{C}_{\mathrm{f}} * \mathrm{Q}_{\mathrm{f}}\right) \mathrm{FI}_{\mathrm{f}}+\left(\mathrm{C}_{\mathrm{H}} * \mathrm{Q}_{\mathrm{H}}\right) \mathrm{FL}_{\mathrm{h}} \mathrm{l} / \mathrm{BW}$.

where

intake = daily intake of contaminated sourc: ( $\mathrm{mg} \mathrm{kg}^{-1}$ day $^{-1}$ ),
$C_{v}=$ concentration in vegetation (vegetative parts of plants) $(\mathrm{mg} / \mathrm{kg}$ wet weight).

$C_{s}=\quad$ concentration in soils $(\mathrm{mg} / \mathrm{kg}$ wet weight),

$\mathrm{C}_{\mathrm{w}}=\quad$ concentration in water $(\mathrm{mg} / \mathrm{L})$,

$\mathrm{C}_{\mathrm{H}}=\quad$ concentration in (prey) $(\mathrm{mg} / \mathrm{kg}$ wet weight).

$C_{P}=$ concentration in fruits, nuts, or seeds (mg/kg wet weight),

$Q_{v}=\quad$ consumption rate of vegetation by animal (kg/day),

$Q_{t}=\quad$ consumption rate of fruits, nuts, or seeds (kg/day)

$Q_{s}=\quad$ consumption rate of soils by animal (kg/day).

$Q_{w}=$ consumption rate of water by animal (Lday),

$Q_{H}=\quad$ consumption rate of prey by animal (kg/day).

$\mathrm{FI}_{\mathrm{vs}, \mathrm{whS}}=$ fraction of source ingested or inhaled that is contaminated (unitless),

$\mathrm{BW}=$ body weight of the organism $(\mathrm{kg})$.

Typical consumption rates of food sources and water were obtained from the literature, where available, or determined from calculations by using allometric regression equations based on the body weight of the organism (Opresko and Suter 1992; EPA 1988;).

The contaminated fraction (FI) of each food source ingested was estimated for each organism based on the animals home range, time spent on the reservation, and the amount of food and water consumed from contaminated areas.

To determine the exposure of tertestrial organisms to radionuclides. tissue concentrations were estimated by using the following equation: 
$C_{A}=B_{B}\left[\left(C_{V} * Q_{v}\right) F_{v}+\left(C_{s} * Q_{s}\right) F_{S}+\left(C_{w} *\right.\right.$ $\left.\left.\mathrm{Q}_{W}\right) \mathrm{FL}_{*}+\left(\mathrm{C}_{1} * \mathrm{Q}_{1}\right) \mathrm{FI}_{\mathrm{H}}+\left(\mathrm{C}_{\mathrm{H}} * \mathrm{Q}_{\mathrm{H}}\right) \mathrm{FL}_{\mathrm{w}}\right]$.

where

$C_{A}=$ concentration in animal tissue ( $\mathrm{pC} i / \mathrm{kg}$ or mg/kg wet weight),

$\mathbf{B}_{\mathbf{8}}=$ plant to muscle transfer factor (day/kg).

The other variables were defined in Eq. (A.2); the units for concentration in food sources and drinking water containing radionuclides are $\mathrm{pCi} / \mathrm{kg}$ or $\mathrm{pCi} / \mathrm{L}$, respectively. The plant-to-muscle transfer factors for inorganics and radionuclides can be obtained from various literature sources, such as Baes et al. (1984), and for organic compounds, the biotransfer factor can be estimated by using allometric regression equations (Travis and Arms 1988). Travis and Arms (1988) found that the biotransfer factor for organic chemicals in muscle tissue (and milk) was directly proportional to the octanol-water partition coefficient. Although the muscle biotransfer factor was originally derived for cattle. as a reference herbivore, it can be applied to other animals that are consumed as food. Even though ( 1 ) the amount of dry matter ingested per body weight of the animal, (2) the fraction assimilated by muscle, and (3) turnover rate differ among species, the relationship between food ingested and concentration in muscle should not vary substantially among species (IAEA 1982). The transfer factor can also be applied to ingestion of water and soil. However, the chemical forms of the contaminant in soils and water may be different from that in meat, and care should be taken when applying these transfer factors. Biotransfer from food to muscle for organic chemicals assumes that fresh meat is 25\% fat (Travis and Arms 1988). Although some predators ingest the whole organism, it is assumed that bone will not be digested. Thus, concentrations in an organism ingested whole are expected to be similar to those in muscle tissue.
Contaminant-specific fish bioconcentration factors (BCFs) were used to estimate the concentration of contaminants in fish tissue for consumption by fish-eating receptor organisms. The BCF is simply the ratio of literature-derived measurements of contaminant concentrations in fish tissue to corresponding contaminant concentrations in ambient surface water.

The internal dose to terrestrial organisms from exposure to radionuclides is estimated by converting the concentrations in organisms [Eq. (A.3)] to an internal whole-body dose rate for alpha-, beta- and gamma-emitting radioisotopes (IAEA 1982; Tumer 1986):

dose $(\mathrm{rad} /$ year $)=0.01867\left(\mathrm{E}_{\mathrm{i}}\right)\left(\mathrm{C}_{\mathrm{i}}\right)$.

where

$E_{i}=\quad$ average energy of decay $(\mathrm{MeV})$ for isotope $i$ (includes all short-lived daughter products),

$C_{1}=\quad$ concentration of radionuclide in the organism ( $\mathrm{pCi} / \mathrm{g}$ wet weight),

This relatively simple dose estimation of a semi-infinite absorbing medium assumes that the radionuclide is distributed uniformly throughout the organism.

To estimate external ground dose from gamma radiation and skin dose from beta radiation, the soil concentration can be substituted for the organism concentration in $\mathrm{Eq}$. (A.4) (IAEA 1982).

Exposure of aquatic organisms may occur via several pathways: (1) direct ingestion of water and sediments, (2) foliar or root uptake by aquatic plants, (3) indirect exposure via uptake through the food chain, and (4) external exposure from contaminated water and sediments. Chronic exposures of aquatic organisms to contaminants in surface water and sediments were determined for fish and benthic macroinvertebrates, and radionuclide exposures 
are determined for wetland emergent plants and muskrats, as well. Because muskrats are semiaquatic, estimated radiation doses, which are based on criteria established for strictly aquatic species that spend the entire lives submerged in water, are conservative.

Exposures of bottom-dwelling fish, benthic macroinvertebrates, and fish larvae were determined from the sediment pore-water concentrations. Organisms that reside on or in the sediments are primarily exposed to chemicals in the pore-water. If pore-water measurements are not available, they can be estimated for organic chemicals by using the following equation (Suter 1991):

$P=S /\left(K_{\text {aw }}\right)(F)$

where

$P=$ pore-water concentration $(\mathrm{mg} / \mathrm{L})$

$\mathrm{S}=$ sediment concentration $(\mathrm{mg} / \mathrm{L})$

$\mathbf{K}_{\mathrm{ow}}=$ octanol-water partition coefficient,

$F=0.01$, the assumed organic fraction of the sediments.

It was assumed that equilibrium partitioning occurs between the organic matter in the sediments and the pore-water. The $\mathrm{K}_{\text {ow }}$ is used in place of the organic matter-water partitioning coefficient $\left(K_{\alpha}\right)$ because $K_{\kappa}$ values are not generally available. The organic fraction of the sediments was conservatively assumed to be $1 \%$, unless otherwise known. For radionuclides and inorganic chemicals. the $K_{d}$ can be substituted for the $K_{n w}$ and the organic fraction of the sediments in the denominator can be omitted.

Internal and extemal chronic radiation doses to aquatic organisms from exposure to water were estimated by applying published dose conversion factors derived from generic bioaccumulation factors for freshwater fish, invertebrates. plants. and muskrats (Killough and McKay 1976). inte.nal radiation doses for combined alpha, beta. and gamma energies of a radionuclide are estimated by the following equation:

intemal radiation dose $(\mathrm{mrad} / \mathrm{year})=$ exposure concentration ( $\mathrm{pCi} \mathrm{L}$ ) $\mathrm{x}$ intemal dose conversion factor (mrad/year per $p C i l$ ).

The extemal dose from exposure to gamma rays. or both gamma rays and beta particles in water. were calculated in the same way, except that the external dose conversion factor is used.

The estimated daily rates of food and water consumption ( $Q_{r}$ or $Q_{m}$, and $Q_{n}$. respectively) for each representative species were calculated from allometric regression equations that are based on the weight of the organisms (EPA 1988.) These equations (Table A-1) are based on the combined measurements for laboratory animals, livestock. and selected wildlife and bird species.

\section{A.1.1 Uncertainties in Model Predictions}

All models used to predict the fate and effects of contaminants on the environment are inherently uncertain. At best, they can only approximate the real-world situation. Model predictions contain many potential sources of errors. Major sources include (1) improper parameter estimation (or parameter bias), (2) improper model formulation (or model bias), and (3) stochastic effects due to random measurement and sampling errors or natural variability (Till and Meyer 1983).

The models used to estimate doses to receptor organisms are limited by the lack of site-specific data for model parameters. Most of the reservations considered in the PEIS lack sufficient environmental databases to allow detailed and specific predictions of contaminant exposures. Transfer factors and dose conversion factors are not determined on a site-specific hasis, even though these parameters are the most variable and exhibit the most uncenainty. Consumption rates, body weights, and behaviors 
TABLE A-1 - Allometric Equations for Estimating Water Consumption (C in Ud) and Food Consumption (F in kg/d) from Data on Bady Weight (U.S. EPA 1988

\begin{tabular}{|c|c|c|}
\hline Animal Group & Allemetric Equation & $r^{2}$ \\
\hline \multicolumn{3}{|c|}{ Water Comaresption Rates } \\
\hline All species combined & $C=0.11 \mathrm{wm}$ & 0.93 \\
\hline Primares & $C=0.09 W^{09 m s}$ & 0.95 \\
\hline Laborztory mammals & $C=0.10 w^{0} \mathrm{rm}$ & 0.88 \\
\hline Chickens & $C=0.13 w^{07 s s 5}$ & 0.74 \\
\hline \multicolumn{3}{|c|}{ Food Consumption Rates } \\
\hline All species combined & $F=0.065 w_{0} \times 19$ & 0.95 \\
\hline Laboratory mammals & $F=0.056 W^{0011}$ & 0.87 \\
\hline Rabbits & $F=0.041 w^{0}$ & 0.73 \\
\hline Chickens & $F=0.075$ wores & 0.97 \\
\hline
\end{tabular}

of representative species are also generally nor site-specific, however, these values are much less variable and exhibit less overall uncertainty. The consistent use of the same contaminant- and organism-specific parameters for all reservations permits comparisons between reservations on a relative scale. Because most of the parameters used in the models are conservative (i.e., they represent the upper-most value on the range of pu.sible values), the models can be used to identify contaminants that clearly pose negligible risks to exposed organisms.

There are additional uncertainties conceming the fate and effects of radionuclides and toxic contaminants that are cuncarty unaccounted for even in site-specific assessment models. These include antagonistic or synergistic interactions between chemicals and influences of environmental coriditions such as $\mathrm{pH}$, temperature, and redox potential on contaminant mobility, bioavailability, or toxicity. Although potentially significant to site-specific assessments, these uncertainties are unlikely to affect estimates of the relative risks of broadly defined programmatic altematives such as those addressed in the PEIS.

\section{A.2 EFfects ASSESSMENT}

Characterization of ecological effects from contaminant exposures begins with an evaluation of the toxicity effects data that are relevant to the particular contaminants and species of interest. Aquatic and terrestrial chemical effects databases for the primary contaminants that occur at representative DOE reservations have been compiled and consist of toxicological benchmark concentrations to which the exposure concentration is compared (Suter et al. 1992: Suter et al. 1994; Opresko et al. 1994). If the exposure concentration exceeds the benchmark. there is considered to be a risk that the contaminant may adversely affect the population (or individual organisms in the case of threatened or endangered species) organism and would require further measurement and evaluation. 
However, if the benchmark is greater than the exposure concentration, no adverse effects to populations are expected to occur and further assessment is not necessary. The ratio of the exposure concentration to the benchmark is termed the hazard index (HI). In evaluating the total exposure to an organism from multiple contaminants, the individual HIs for each contaminant are summed together to account for potential additive effects. Although several HIs may be less than 1 and individually would not be expected to pose any adverse effects, the sum of the HIs could be greater than one, potentially posing cumulative adverse effects. (The media concentrations considered are at or above background concentrations, so the sum of His greater than 1 would not include exposures to natural trace elements in the environment.) Cumulative impacts to endpoints from exposure to contaminants are discussed in Chapter 3.

For radionuclides, the available evidence indicates that a combined intemal and external chronic dose rate from all radionuclides of no greater than 1 rad per day to the most sensitive aquatic species or the maximally exposed individuals in a population would not measurably affect aquatic populations (NCRP 199!). For terrestrial organisms, the upper dose limit is set at $100 \mathrm{mrad}$ per day (IAEA 1992). If the total dose received from all exposure parhways and radionuclides exceeds the limit (i.e., the $\mathrm{HI}$ is greater than 1), there is a risk that the contaminant may adversely effect the population (or individual organism in the case of threatened or endangered species) and would require further measurement and evaluation.

The aquatic benchmarks choser: from the chemical effects data base are, in order of priority, the (1) Environmental Protection Agency (EPA) Ambient Water Quality Criteria from the state in which the reservation is located, if availahle, (2) Environmental Protection Agency (EPA) National Ambient Water Quality (.iteria for Protection of Aquatic Life (NAWQC), where available; or (3) the lowest effective concentration $\left(E_{20}\right)$ test results for fish and invertebrates reported in the literature (Suter et al. 1992). The latter benchmart may be lower than the NAWQC for various reasons and is thus considered to be more conservative. The NAWQC benchmarks are set at limits that are intended to protect most of the aquatic species most of the time (Suter et al. 1992). Thus, lower benchmark values should offer even more protection. The rationale for the selection of benchmarks for specific chemicals will be discussed in the reservation-specific reports.

The benchmarks for determining effects in terrestrial species from exposure to chemicals is the chronic no-observed-adverse-effects level (NOAEL) in units of milligrams per kilogram per day. The $\mathrm{HI}$ is detennined by comparing the benchmark NOAEL with the daily intake of a contaminant per unit body weight of the animal. The information on the toxicological effects of chemicals on wildlife is limited; most toxicity studies are conducted on laboratory animals and may only report the acute $\mathrm{LD}_{90}$ (the dose at which the contaminant is lethal to $50 \%$ of the organisms), the LOAEL (lowest-observedadverse-effects level), or a subchronic NOAEL. For receptor organisms that are not listed in the data base or for which the chronic NOAEL is not available, extrapolation techniques that use uncertainty factors and adjust for differences in body weight (BW) are employed to estimate the chronic NOAEL for wildlife species from laboratory animal data or other wildlife species within the same phylogenetic class (Opresko et al. 1994). If a NOAEL is available for a laboratory test species (NOAEL), the NOAEL for a receptor species (NOAEL, can be calculated according to the following equation (Opresko et al. 1994):

NOAEL $_{r}=$ NOAEL $_{1}^{*}\left(B W_{/} \mathrm{BW}_{\mathrm{p}}\right)^{1 /}$.

If the body weight of the test species is not reported, a more conservative approach can be taken that does not adjust for differences in body size. A multiplicative factor of 0.1 is applied to account for intraclass differences (e.g., from quail to hawk), and a factor of 0.05 is applied to

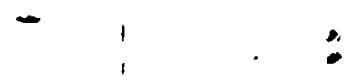

A-6 
account for interclass differences (e.g. mammal to bird) (EPA 1989). A factor of 0.1 is used to extrapolate from the LOAEL or a subchronic (NOAEL) study to the NOAEL (Opresko et al. 1994).

Literature sources for inorganic terrestrial phytotoxicity benchmarks were summarized by Suter et al. (1994). Where applicable, the lowest source concentration in a soil medium that produced phytcioxically excessive effects was chosen from the database. Several benchmarks were derived from experiments using nutrient solutions. However, uncertainty values were not applied to these data to account for differences in growth media. A methodology for deriving phytotoxicity benchmarks for organic consituents was developed by Eskew and Babb (Air National Guard Risk Assessment Handbook 1992). The organic fraction of the soil is the primary factor in determining bioavailability of organic compounds to plant roots. Therefore, estimated critical concentrations (mg/kg wet weight) for soil were calculated from experimental data on the uptake of compounds from nutrient solution or vapor phase by using octanol-water partitioning coefficients $\left(K_{\text {ow }}\right)$ to estimate the distribution of compounds between the solution phase (soil pore water) and the solid phase (organic soil particles). Assumptions used to derive toxicity benchmarks were (1) a soil organic content of $1 \%$. (2) a bulk soil density of $1.3 \mathrm{~g} / \mathrm{cm}^{3}$, and (3) a soil water content of $18 \%$. Uncertainty factors were applied to adjust the data from acute to chronic effects and from $50 \%$ inhibition of growth to lowest toxic effect levels.

\section{A.3 Postremedial Assessment}

For the baseline (no-action) risk assessment, the only environmental stressors considered are exposures to chemical contaminants and radionuclides. For the postremedial assessments, habitat disturbance resulting from each respective remedial altemative action (Appendix B), as well as the associated exposure to residual contaminart levels, were considered (figure A-1). Contaminants that do not elicit effects in the baseline assessment are not expected to cause effects after remediation, assuming that contaminant loading into the environment remains the same or is reduced afier remediation.

Descriptions of remedial alternatives were supplied by PNL. These descriptions contain estimates of the reduction in contaminant inventory expected from each alternative, as well as estimates of the total area disturbed. The resultant environmental concentration at a given location should be directly proportional to the release rate from a particular source (although, depending on the environment, this may occur over a relatively long period of time). It follows that if the release rate were reduced by a given amount by remediation, the environmental concentration will be reduced proportionately. Therefore. the percentage reductions of contaminants from each source were directly applied to the contaminants in the media of interest to determine the degree reduction of the HIs. In the case of multiple sources of a particular contaminant, attempts were made to eliminate those not contributing to the environmental concentrations by examining the transport pathways from the sources to all potential receptors. Once the major contributing sources of a particular cortaminant were identified, the average percentage reductions were applied to the envirormental concentrations. 


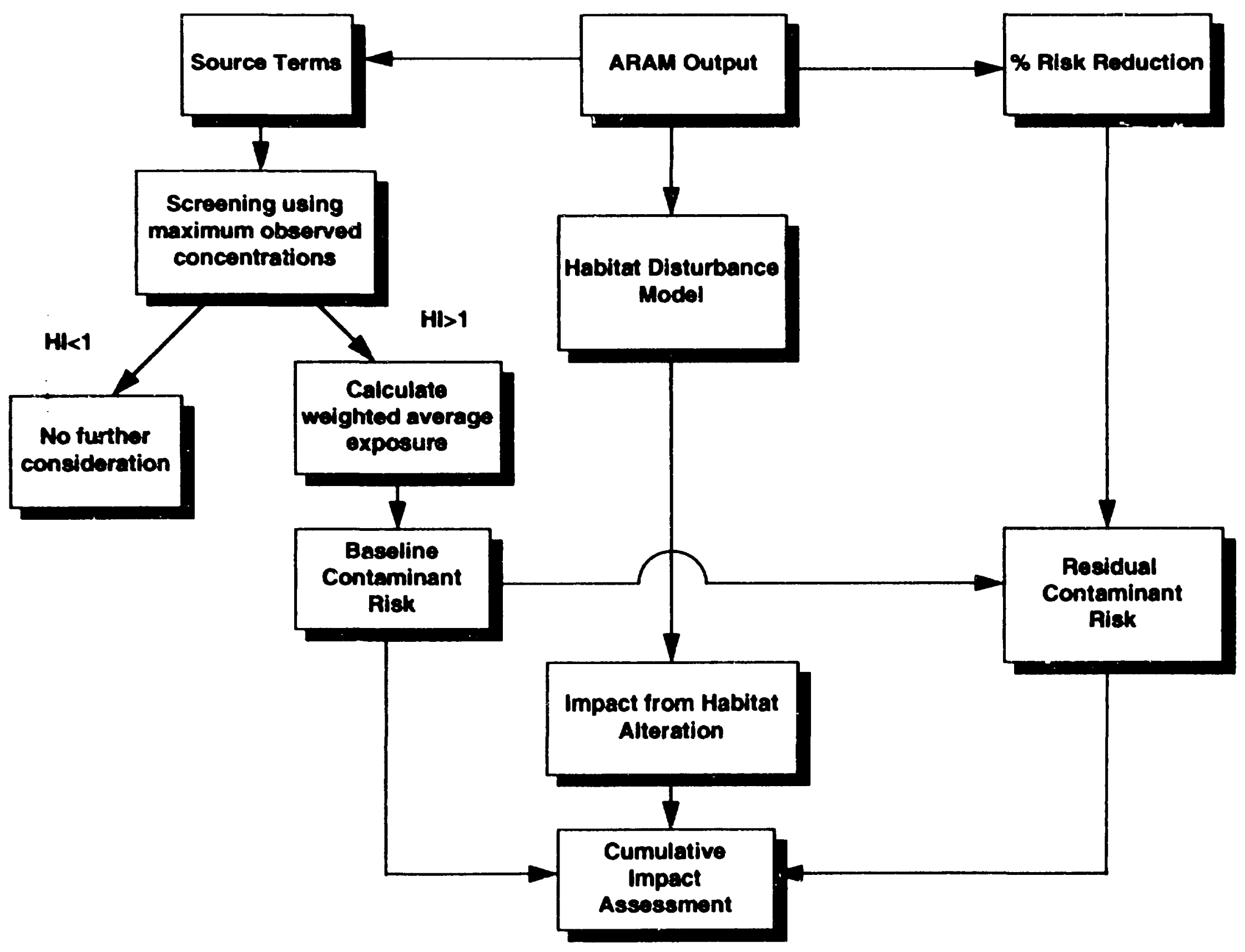




\section{APPENDIX B: GENERATION OF HAZARD HNICES, HOME RANGE ESTIMATES, EXPOSURE CORRECTION FACTORS, AND HABITAT DISTURBANCE ESTIMATES}

\section{B.1 INTRODUCTION}

This appendix describes the methodologies used to (1) develop hazard indices and (2) calculate habitat disturbance caused by remedial actions. This information is needed to determine how DOE ER activities will affect ecological resources at DOE facilities. In sections $B .2$ and B.3 of this appendix, the methodology for generating ER PEIS scurce terms is explained. Section B.4 discusses determination of home ranges for potentially exposed organisms. Section B.5 explains the habitat disturbance calcrilations.

\section{B.2 INITLAL HaZARd SCREENING}

\section{B.2.1 ER PEIS Data b'ases}

Source terms used for the ecological risk assessment were derived from the ER PEIS source term data base developed hy Tacitic Northwest Laboratory (PNL). Six contaminated media types are included in the data base: solid waste, contaminated soil, liquid containment structures, groundwater, facilities, and surface water. Groups of data are further associated by site names within reservation operable units.

The ecological risk assessment focused on soil and surface water: groundwater was addresse orily to the exient that, through linkages to surface water, it influe aced surface water quality. The initial stagc of source term generation, then, is one of determining which data are appropriate for the ecological risk assessment. Table B-1 lists assumptions made during source term developmeni.

\section{B.2.2 Data Screening Based on Sitewide Maxima}

Generation of ER PEIS hazard indices is a twostep process. The first stage is a conservative screening assessment based on the absolute maximum contamination levels possible across each reservation. In the second stage a more realistic estimation of contaminant exposi:re is attempted. This task presents several difficulties, some of which will be discussed later. Figure BI describes the process by which hazard indices are generated.

The information compiled for a given facility can list many different concentrations for the same contaminants in the same medium at different spatial locations. For example, ${ }^{238} U$ could be found in soil at several different sampling locations on a reservation, and each one of these sampling locations could have different surface area associated with it. In the initial screening stage, the absolute sitewide maxima for each combination of cortamirant and medium is determined. These maxima are used as inputs to the exposure and effects assessment models described in appendix $A$. Cor aminants shown to have a negligible risk und $r$ these extremely conservative assumptions are eliminated from further assessment. Remaining contarrirants are analyzed using the methods described in the next section.

\section{B.3 AREA-A Veraged HAZARD SCREENING}

\section{B.3.1 roncentration Averaging Scheme}

Source terms orted by PNL are generally representative samples collected at known sites of contam : Ion and are not representative of reservation- de levels of contamination. Knowledge of the areas occupied by burial grounds or other contamination sources was used 
io develop a schénte for estimating the contaminant exposures within these contaminated areas. Where possible, based on knowledge of the local ecosystems, surface water used solely for drinking was treated separately from surface water that provides aquatic habitat.

The averaging scheme is shown in figure B-2. In this hypothetical case, data are available for contaminated sites $A, B$, and C. A weighted mean contaminant exposure is calculated by (1) averaging all of the contaminant measurements within each area, and (2) computing an overall mean from the site means, each weighted by its area.

The weighted mean applies only to the fraction of a reservation within which samples have been collected. It is assumed that contamination of the remainder of each reseryation is negligible compared to contamination of the areas that have been characterized. Exposure estimates for receptor species are corrected to account for (1) the fraction of an individual organism's horne range that might include contaminated sites, and (2) the fraction of the total range of receptor species or community types occupied by contaminated sites.

The source term data base does not include area estimates for all contaminated sites. Estimates of the total contaminated area on each reservation were adjusted to account for the fraction of contaminated sites for which areas were provided. If, for example, surface areas are provided for $50 \%$ of the contaminated sires at a particular reservation, all known surface areas are summed and then multiplied by two to compensate for the missing data.

\section{B.4 HOME R.NGES OF RECEPTOR SPECIES}

For contaminants and receptors for which detailed analysis was required, an attempt was made to further define contaminant exposures by comparing the home range sizes of receptor species with the potential fraction of the home range that was contaminated.

Receptor species at the six DOE reservations have home ranges or territories which range from

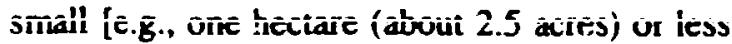
for very small animals such as songbirds and mice] to very large [e.g., thousands of hectares (acres) for some bats and coyotes (table B-2)].

Food webs of receptor species were developed for each DOE reservation (appendix A). An effort was made to include prey species, game mammals, birds, and predators in these food webs. Also, where possible, receptor species were selected that were common to multiple DOE sites and that included state and federally listed, threatened, endangered, and candidate species for each of the six sites.

Species home ranges may vary from reservation to reservation depending on food availability. Larger home ranges are typically found in the arid western reservations where animals must forage over greater distances to find sufficient food.

Table B-2 lists the bird and mammal receptor species used for the six DOE reservations, their home ranges, and the sources of the data. Where data were lacking, home ranges for birds were estimated based on regression of home range size as a function of body weight [i.e., $Y=-1.16+$ $1.19 X$, where $Y=\log _{10}$ area (acres) and $X=$ $\log _{10}$ body weight (grams); $r^{2}=.65$ with 94 observations in the sample size]. Generally, home range area was assumed to be circular or square. In some cases however, (e.g., some bats, mink, osprey), home range is reported as a linear stream distance or as a distance of linear travel to feeding areas.

Home range data were used to further define exposure risks by comparing the home range sizes of receptor species with the potential fraction of the home range that is contaminated.

\section{B.4.1 Theoretical Basis for Estimating Correction Factors}

The following discusses the theoretical basis for applying correction factors to the calculated risks (i.e., HIs). The DOE reservations described in the ER PEIS have numerous contaminated areas will not spend all of their time in a contaminated (e.g., burial grou.ds, scrap yards, contaminated ponds and streams) yet many animals and birds area. Thus, it is imponant to determine the 
TABLE B-1-Assun :ptions Madr in the Firyt Stnge of Source Term Gerestion

\begin{tabular}{|c|c|}
\hline General & $\begin{array}{l}\text { - When isotopes are not specifically stated, uranium is assumed to } \\
\text { be }{ }^{24} \mathrm{U} \text {, plutonium is assumed to be }{ }^{23 \%} \mathrm{Pu} \text {, and strontium is } \\
\text { assumed to be }{ }^{\text {*) }} \mathrm{Sr} \text {. } \\
\text { Measurements not associated with specific contaminants will not } \\
\text { be used (e.g., gross alpha and total suspended solids). }\end{array}$ \\
\hline Solid Waste & $\begin{array}{l}\text { - Solid waste sources will be considered only if surface soils } \\
\text { surrounding the solid waste sto.age areas have become } \\
\text { contaminated. }\end{array}$ \\
\hline Contaminated Soil & $\begin{array}{l}\text { - Only contamination in the top } 2 \mathrm{ft} \text { of surface soil will be used, } \\
\text { bec zuse it is assumed that deeper soils do not contribute to } \\
\text { contaminant exposure to biota. }\end{array}$ \\
\hline Liquid Containment Structures & $\begin{array}{l}\text { - Liquid containment structures (LCS) will be considered only if } \\
\text { biota could use water contained in the structure for habitat or } \\
\text { drinking water. }\end{array}$ \\
\hline Groundwater & Groundwater contamination will not be considered. \\
\hline Surface Water & $\begin{array}{l}\text { - Surface water and sediments will be treated as separate media. } \\
\text { Where appropriate. the surface water category will be divided } \\
\text { into water used solely for drinking and water used for aquatic } \\
\text { habitat. }\end{array}$ \\
\hline
\end{tabular}




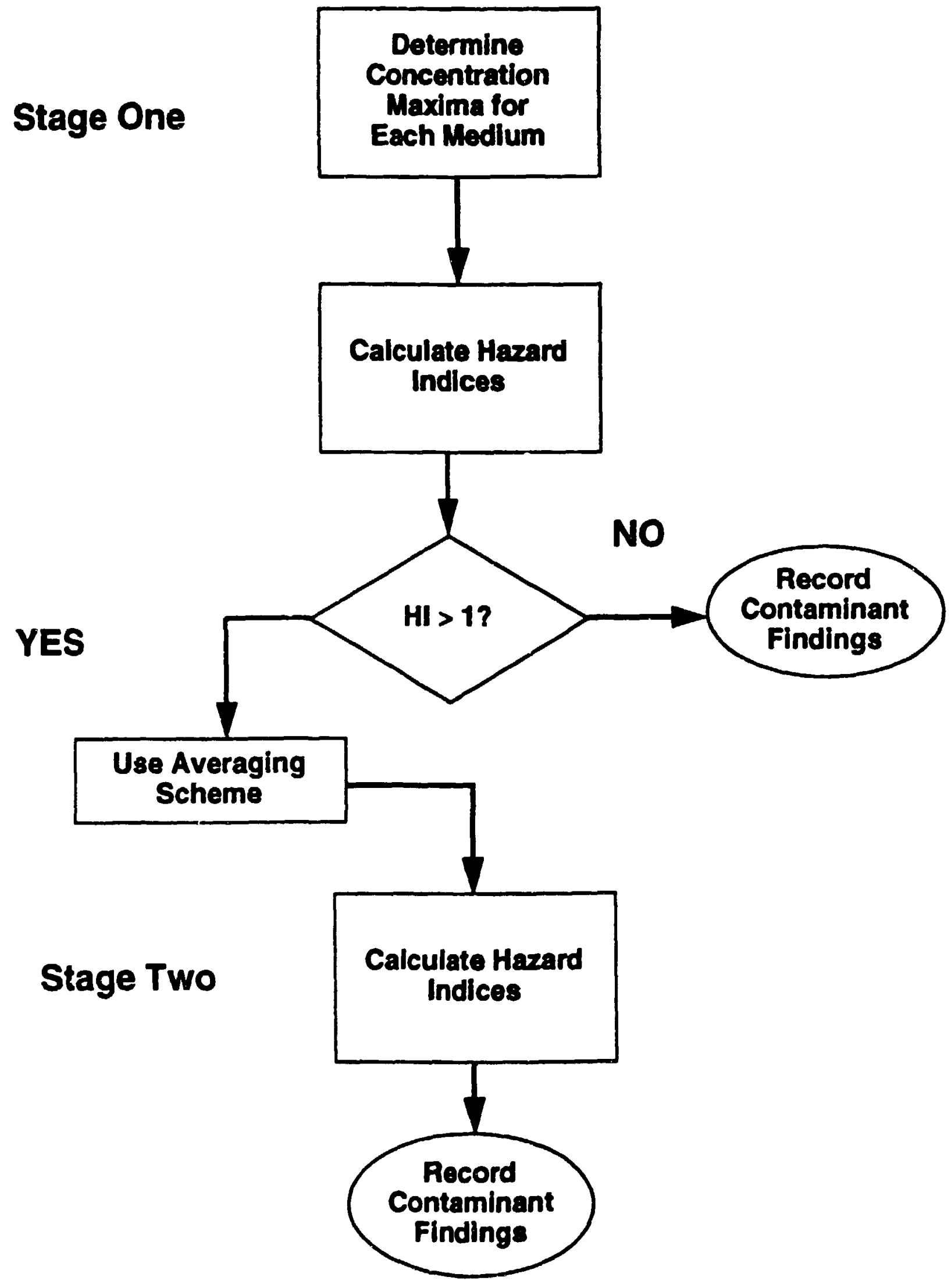




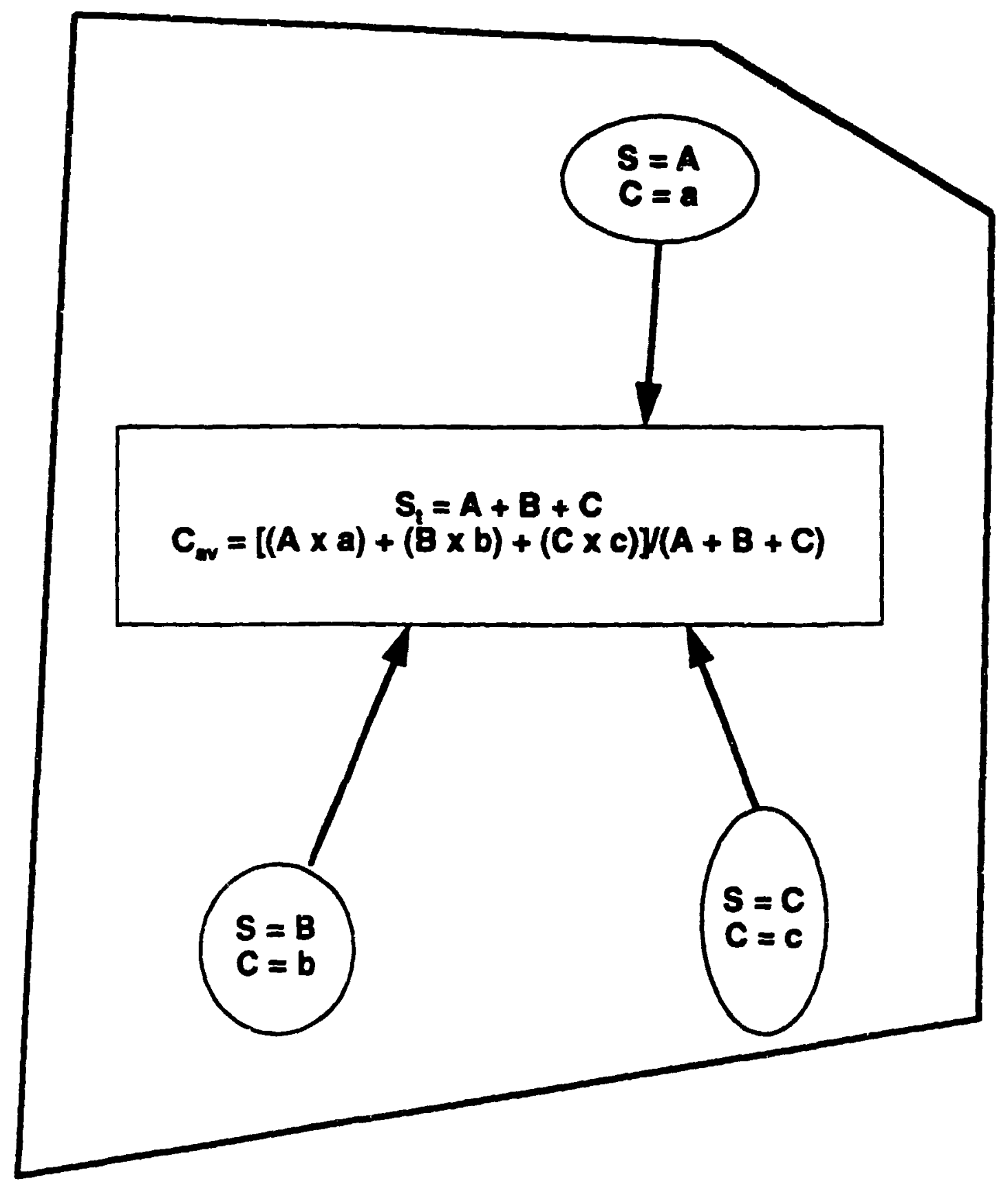
$\mathbf{S}=$ surface area
$S_{i}=$ total surface area
$\mathbf{C}=$ contaminant concentration
$C_{w}=$ wolghted average contaminant concentration




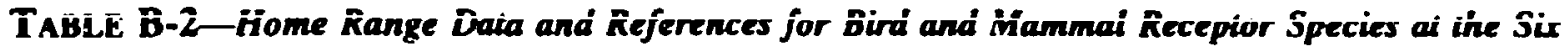
DOE Reservations'

\begin{tabular}{|c|c|c|}
\hline Receptor Species & $\begin{array}{l}\text { Home Range } \\
\text { hectares (acres) }\end{array}$ & References \\
\hline $\begin{array}{l}\text { American robin } \\
\text { (large generic songbird) }\end{array}$ & $\begin{array}{l}0.24(0.6) \mathrm{HN} \\
0.1-0.24(0.2-0.6) \mathrm{RF} \\
4(10) \mathrm{N}, \mathrm{OR}\end{array}$ & $\begin{array}{l}\text { Terres 1980; based on } \\
\text { regression of home range size } \\
\text { as a function of body weight } \\
\text { (Schoener 1968) }\end{array}$ \\
\hline Bald eagle & $\begin{array}{l}5500(14.000) \mathrm{HN} \\
520-940(1300-2300) \mathrm{RF} \\
1200(3000) \mathrm{IN}\end{array}$ & $\begin{array}{l}\text { Based on regression of home } \\
\text { range size as a function of body } \\
\text { weight (Schoener 1968); Terres } \\
1980\end{array}$ \\
\hline Canada goose & $\begin{array}{l}980(2400) \mathrm{HN} \\
500(1200) \text { OR }\end{array}$ & $\begin{array}{l}\text { Fitzner and Gray 1991: based } \\
\text { on regression of home range } \\
\text { size as a function of body } \\
\text { weight (Schoener 1968) }\end{array}$ \\
\hline Cooper's hawk & $230(560) \mathrm{OR}$ & Schoener 1968 \\
\hline Ferruginous hawk & $\begin{array}{l}7200(18,000) \mathrm{HN} \\
210(520) \mathrm{DN}\end{array}$ & $\begin{array}{l}\text { Fitzner and Gray 1991: based } \\
\text { on regression of home range } \\
\text { size as a function of body } \\
\text { weight (Schoener 1968) }\end{array}$ \\
\hline Loggerthead shrike & $\begin{array}{l}8(20) \mathrm{HN} \\
2(5) \mathrm{IN}\end{array}$ & $\begin{array}{l}\text { Schoener 1968; based on } \\
\text { regression of home range size } \\
\text { as a function of body weight } \\
\text { (Schoener 1968) }\end{array}$ \\
\hline Mallard duck & $\begin{array}{l}4(10) \mathrm{RF} \\
170(410) \mathrm{IN}\end{array}$ & $\begin{array}{l}\text { Based on regression of home } \\
\text { range size as a body weight } \\
\text { (Schoener 1968) }\end{array}$ \\
\hline Osprey & $200(507)) O R$ & $\begin{array}{l}\text { Based on regression of home } \\
\text { range size as a function of body } \\
\text { weight (Schoener 1968) }\end{array}$ \\
\hline Peregrine falcon & $\begin{array}{l}2600(\hat{\mathrm{u}} 400) \mathrm{HN} \\
65-31,000(160-77,000) \mathrm{RF}\end{array}$ & $\begin{array}{l}\text { Brown and Amadon 1968: } \\
\text { based on regression of home } \\
\text { range size as a function of brdy } \\
\text { weight (Schoener 1968) }\end{array}$ \\
\hline Sage giouse & $\begin{array}{l}8(20) \mathrm{HN} \\
350-410(880-1000) \mathrm{IN}\end{array}$ & $\begin{array}{l}\text { Based on regression of home } \\
\text { range size as a function of body } \\
\text { weight (Schoener 1968): } \\
\text { Connelly and Markham 1983 }\end{array}$ \\
\hline Small generic songbird & $0.24(0.6) \mathrm{NN}, \mathrm{OR}$ & $\begin{array}{l}\text { Based on regression of home } \\
\text { range size as a function of body } \\
\text { weight (Schoener 1968) }\end{array}$ \\
\hline Red-tailed hawk & $190-240(480-1000)$ FN & $\begin{array}{l}\text { Brown and Amadon 1968; } \\
\text { Schoener } 1968\end{array}$ \\
\hline Western meadowlark & $1.2-6.1(3.0-15) \mathrm{RF}$ & Terres 1980 \\
\hline
\end{tabular}


TABLE $\overline{\mathrm{B}}-\overline{\mathbf{z}}$ (continued)

\begin{tabular}{|c|c|c|}
\hline Receptor Species & $\begin{array}{l}\text { Home Range } \\
\text { hectares (acres) }\end{array}$ & References \\
\hline Black-tailed jackrabbit & $\begin{array}{l}20(49) \mathrm{HN} \\
7.3-160(18.0-400) \mathrm{RF} \\
16-20(40-50) \mathrm{IN}\end{array}$ & $\begin{array}{l}\text { Chapman and Feldhamer 1982; } \\
\text { Chapman et al. 1980; Lim 1997 }\end{array}$ \\
\hline Coyote & $\begin{array}{l}8800(22.000) \mathrm{HN} \\
2100-8000(5100-20,000) \mathrm{RF} \\
4100(10,000) \mathrm{WN} \\
1000-6800(2500-16.800) \text { OR }\end{array}$ & $\begin{array}{l}\text { Fizner and Gray 1991: Bekoff } \\
\text { 1977; Bekoff 1982; ORR staff } \\
\text { cbservation }\end{array}$ \\
\hline Eastern cottontail rabbit & $\begin{array}{l}1.0-2.8(2.5-6.9) \mathrm{FN} \\
2-6(5-15) \mathrm{OR}\end{array}$ & $\begin{array}{l}\text { Chapman et al. 1980; McNabb } \\
1963\end{array}$ \\
\hline $\begin{array}{l}\text { Generic mouse (as in various species } \\
\text { of Peromyscus) }\end{array}$ & $0.12-2.4(0.3-6)$ IN, OR & McNabb 1963 \\
\hline Great Basin pocket mouse & $0.2(0.5) \mathrm{HN}$ & Nowak and Paradiso 1983 \\
\hline Indiana bat & $\begin{array}{l}1.5-4.5(3.7-11) 0.82 \mathrm{~km} \text { linear } \\
\text { stream distance FN OR }\end{array}$ & $\begin{array}{l}\text { Thomson 1982: Humphrey et } \\
\text { al. } 1977\end{array}$ \\
\hline Mink & $\begin{array}{l}8-20(20-49) \text { OR } \\
2-5 \mathrm{~km} \text { linear strean distance }\end{array}$ & $\begin{array}{l}\text { Chapman and Feldhamer 1982; } \\
\text { Linscombe et al. 1982: ORR } \\
\text { staff observation }\end{array}$ \\
\hline Mule deer & $\begin{array}{l}3000(7400) \mathrm{HN} \\
36-240(90-600) \mathrm{RF}\end{array}$ & $\begin{array}{l}\text { Anderson and Wallmo 1984; } \\
\text { Burr and Grossenbeider } 1976\end{array}$ \\
\hline Pallid bat & $\begin{array}{l}196.000(485.000) ; 25 \mathrm{~km} \\
\text { foraging distance } \mathrm{HN}\end{array}$ & Hermanson and O'Shea 1383 \\
\hline Prairie dog & $2.4-2.8(5.9-6.9) \mathrm{RF}$ & Clark et al. 1971 \\
\hline Preble's meadow jumping mouse & $0.08-1.1(0.19-2.7) \mathrm{RF}$ & Whitaker 1972 \\
\hline Pronghorn antelope & $300-2300(740-5700)$ IN & O'Gara 1978 \\
\hline Pygmy rabbit & $2(5)$ IN & Green and Flinders 1980 \\
\hline Red fox & $260-520(640-1300) R F$ & Burt and Grossenheider 1976 \\
\hline Townsend's big-eared bat & $\begin{array}{l}2-14,000(5-35,000) ; 64 \mathrm{~km} \\
\text { foraging distance } \mathrm{IN}\end{array}$ & Kunz and Martin 1982 \\
\hline White-footed mouse & $0.2 .06(0.5-1.5)$ OR RF & Burt and ürossenheider 1976 \\
\hline White-tailed deer & $60-520(150-1300) R F$ & $\begin{array}{l}\text { Burt and Grossenheider 1976; } \\
\text { Smith 1991 }\end{array}$ \\
\hline
\end{tabular}

HN = Hanford Reservation: FN = Femald Environmental Management Project: IN $\approx$ Idaho National Engineering Labnratory: OR = Oak Ridge Reservation: $R F=$ Rocky Flats Plant; $P M=$ Portsmouth Reservation. 
proportion of contaminated area to the total area of an animal's or bird's home range or territory. Waste sites and adjoining contaminated areas are usually clustered in waste area groups or operable units. On large reservations such as ORR. INEL, and Hanford, waste sites are generaily concentrated near major facilities or groups of facilities. We refer to the area containing most of the contaminated sites as the "waste complex." At facilities where a small proportion of waste sites are widely dispersed, a representative waste complex was defined which contained most of the waste sites. The relationships between a waste complex, individual waste sites or contaminated areas, and home ranges of various species of wildlife are shown in figure B-3. This conceptual relationship was used to develop correction factors for hazard indices in order to produce more realistic estimates of risks to receptors.

For purposes of this programmatic risk assessment, all waste sites are assumed to be the same size and randomly distributed throughout the waste complex. This may not be a realistic assumption as waste sics range in size and often their distribution is clumped. It is also assumed that the area surrounding waste sites within the waste complex is suitable habitat for wildlife.

As shown in figure B-3, some species have home ranges small enough to be entirely within waste sites. For these species no correction factor was used. For species with home ranges larger than a representative waste site but smaller than the entire waste complex, a correction factor is used that is equal to the ratio of the sum of the area of the individua! waste sites divided by the total area of the waste complex. For species with home ranges larger than the waste complex, a correction factor is used that is equal to the ratio of the sum of the area of the individual waste sites divided by the area of the home range or territory.

\section{B.5 Habitat Disturbance.}

Remedial activities can cause adverse impacts on plant and animal communities through (1) the removal and treatment of soil or sediment, and (2) the building of roads. decontanination facilities. and other infrastructure associated with remediation. For the ER PEIS, a stochastic analysis of habitat disturbance risks was performed using the @RISK software package. a supplement to the Lotus $\mathrm{i}-2-3$ spreadsheet program.

Information on the areas expected to be disturbed by remedial activities is derived from the Analysis of Remedial Alternatives Model (ARAM) output for each reservation. Site codes provided in ARAM are cross-referenced to site codes, site names, and site areas contained in the source rerm data base. For each remediation alternative, the specific sites to be remediated are identified from the ARAM output and the areas of those sites are extracted from the source term data base.

It is unlikely that the entire area of each site will be disturbed. For example, a $100-\mathrm{m}^{2}$ trench may have significant contamination throughout only $80 \%$ of its area. It is assumed that only this $80 \%$ will be disturbed by remediation. There is no way, however, to determine from the ER PEIS source term data the exact fraction of each site that might require remediation. Therefore, the @RISK program is used to generate probability distributions of disturbance fractions for each site. A triangular distribution with a minimum of $50 \%$ disturbance, a maximum of $100 \%$, and a mode of $90 \%$ is used to generate these estimates.

Roads, buffer zones, and storage facilities are generally constructed at remediated sites. It is assumed that the amount of habitat disturbance from these sources is directly proportional to the area to be remediated.

In many instances, remediation activities will require that some volume of clean soil be used to fill in pits created when contaminated soil is taken to remediation or waste management facilities. Borrow pits either on- or off-site must be excavated to provide this soil. The general tern "off-site effects" is used to describe the impacts of these activities as they relate to habitat disturbance. The percentage of each remediated site requiring clean soil from a borrow pit is assumed to be a function of surface 


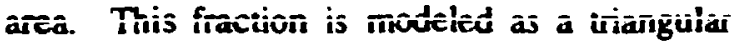
probability distribution with a minimum of $50 \%$, a maximum of $100 \%$, and a mode of $80 \%$. When borrow pits are constructed, the surface area affected is expected to be somewhat less than the actual surface area requiring borrowed soil because pits are likely to be dug deeper to generate the necessary volumes of soil. The area estimates are therefore adjusted by an additional area ratio hiving a minimum value of $10 \%$, a maximum of $100 \%$, and a mode of $50 \%$.

The total area of habitat disturbed is summed over all of the remediation sites included in the
ÁRिìi ouipui. In most cases, the sites inciuded in this output represent a sample of all of the sites at a reservation requiring remediation. To scale up the habitat disturbance estimates to the reservation level, it is assumed that the sites ircluded in the ARAM analysis are representative of the full suite of contaminated sites. For example, if $20 \%$ of the known contaminated sites at a reservation are included in the ARAM output, the total area disturbed is adjusted by a factor of five. 


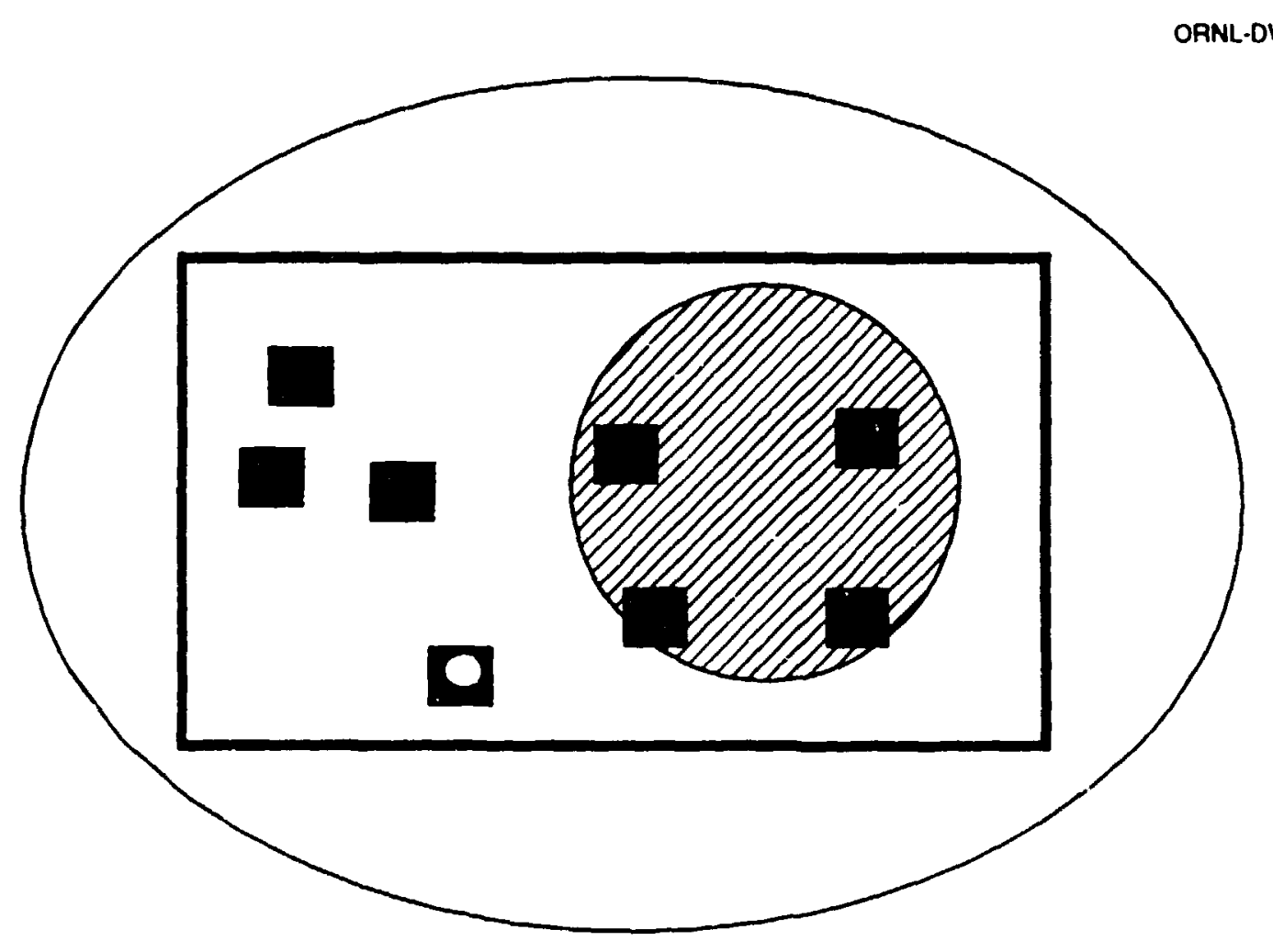

$\square$ Waste complex (Y acres)

- Typical (representative) waste site (X acres)

Small home range $(<X$ acres); Correction Factor $(C F)=1$

$\oslash$ Intermediate home range (more than $X$ but less than $Y$ ); CF $=\underline{\text { sum } X}$

$O$ Large home range (more than $Y$ ); $C F=\frac{\text { sum } X}{\text { home range }}$ 